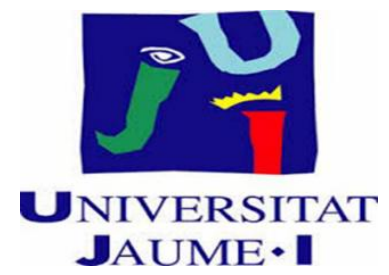

Título de la tesis:

\title{
LA LEGÍTIMA EN EL DERECHO ESPAÑOL
}

Presentada por Hilario Mondragón Martín

Dirigida por: Dr. Prof. Federico Arnau Moya

Enero de 2019 


$$
-2 \text { - }
$$




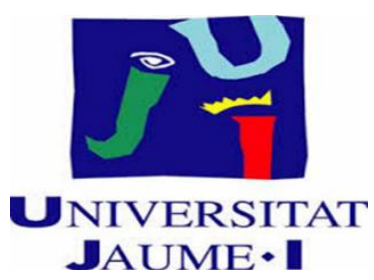

Programa de Doctorado en Derecho

Escuela de Doctorado de la Universitat Jaume I

Título de la tesis: LA LEGÍTIMA EN EL DERECHO ESPAÑOL

Memoria presentada por Hilario Mondragón Martín para optar al grado de doctor por la Universitat Jaume I

Doctorando: Hilario Mondragón Martín - Director de la tesis: Dr. Federico Arnau Moya Firma original:

Firma original:

Castellón de la Plana enero de 2019 
Financiación recibida por el doctorando para la investigación realizada:

- Contrato predoctoral: P. INVESTIGADOR EN FORMACIÓN con la Universitat Jaume I. Financiación recibida a través de la Generalitat Valenciana y UNIÓN EUROPEA Fondo Social Europeo.

- Subvenciones para estancias en centros de investigación fuera de la Comunidad Valenciana: Universitat Jaume I, UNIÓN EUROPEA Fondo Social Europeo, Generalitat Valenciana. 


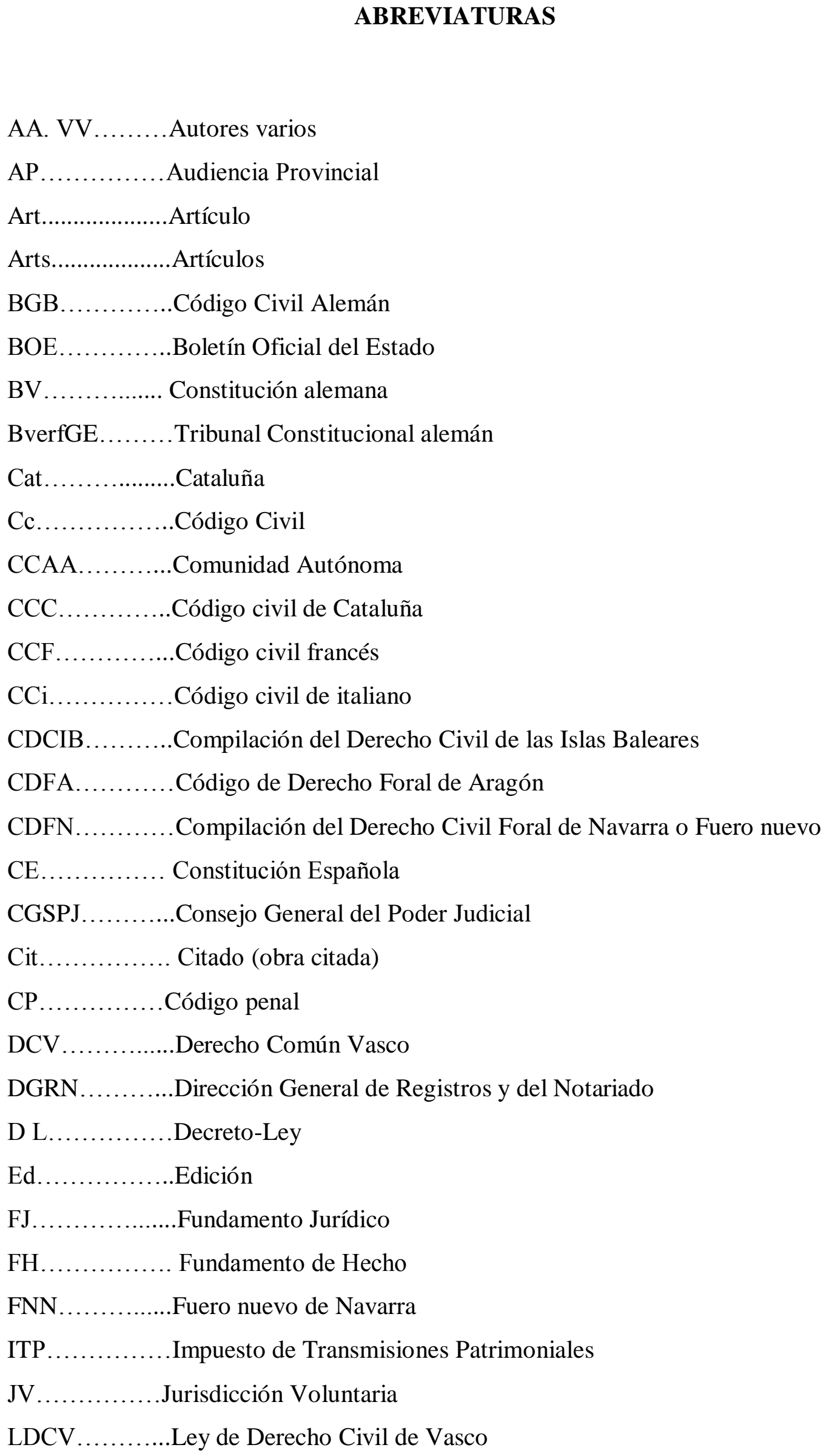


LDFV ............Ley de Derecho Foral Vasco

LEC...............ey Enjuiciamiento Civil 1/2000, de 07 de enero

Loc............. Lugar citado

PACS............Pacto Civil de Solidaridad

Pág..............Página

RISD...........Reglamento del Impuesto de Sucesiones y Donaciones

SAP .............Sentencia de la Audiencia Provincial

STC............Sentencia Tribunal Constitucional

SS AP..........Sentencias de la Audiencia Provincial

SS ...............Siguientes

STS...........Sentencia Tribunal Supremo

SSTS.......... Sentencias del Tribunal Supremo

TCA...........Tribunal Constitucional alemán

Tit.............Título

TSJ............Tribunal Superior de Justicia

STSJ.......... Sentencia del Tribunal Superior de Justicia

SSTSJ......... Sentencias del Tribunal Superior de Justicia

TPO...........Transmisiones Patrimoniales Onerosa

Vol.............Volumen 


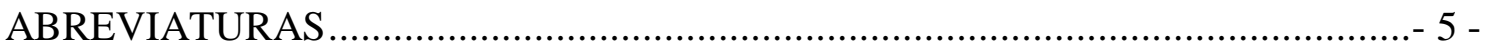

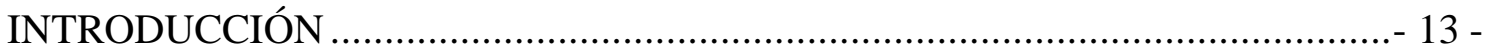

CAPITULO I EVOLUCIÓN HISTÓRICA DE LA LEGÍTIMA............................. 18 -

1.1. LA SUCESIÓN EN ROMA …............................................................ 18 -

1.1.1 La legítima en las XIII Tablas .......................................................... 20 -

1.1.2 La Lex Furia Testamentis ................................................................. 23 -

1.1.3. La Lex Voconia ....................................................................... 25 -

1.1.4. Lex Falcidia de Legatis........................................................................ 26 -

1.1.5. Destino de los legados en época romana ............................................. 31 -

1.1.6. La legítima como protección a la familia con Justiniano ....................... 33 -

1.2. LA LEGÍTIMA EN EL FUERO JUZGO................................................ 37 -

1.3. LA CUARTA FALCIDIA CONTENIDA EN LAS PARTIDAS .................. 38 -

1.4. LAS LEYES DE TORO …............................................................ 40 -

1.5. LA RESERVA LEGAL HASTA LA CODIFICACIÓN …............................. 41 -

1.6. LA LEGÍTIMA EN LA CODIFICACIÓN ESPAÑOLA …........................... 43 -

CAPÍTULO II. LA LEGÍTIMA EN LA ACTUALIDAD ...................................... 48 -

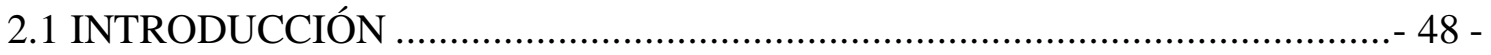

2.2. NATURALEZA JURÍDICA DE LA LEGÍTIMA ......................................... 51 -

2.2.1. La naturaleza jurídica de la legítima................................................ 52 -

2.2.2. La facultad del pago de la legítima en metálico .................................... 62 -

2.2.3. Computación, imputación y colación de la legítima ...............................- 70 -

2.3. LA LEGÍTIMA COMO INSTITUCIÓN DE ORDEN PÚBLICO ....................- 79 -

2.4. INTANGIBILIDAD DE LA LEGÍTIMA .................................................. 81 -

2.4.1. La intangibilidad cualitativa............................................................. 84 -

2.4.2. La intangibilidad cuantitativa ................................................................ 87 -

2.4.3. La acción de reducción .................................................................... 89 -

2.4.4. La acción de complemento .............................................................. 91 -

2.4.5. El derecho de representación ............................................................. 94 -

2.5. LOS LEGITIMARIOS EN EL CÓDIGO CIVIL ............................................. 97 -

2.5.1. La legítima de los hijos y descendientes..................................................... 99 -

2.5.2. Los ascendientes como legitimarios ...................................................... 101 -

2.5.3. La legítima del cónyuge viudo ............................................................- 103 -

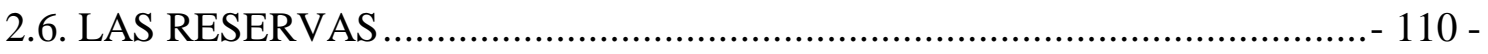

2.6.1. La reserva lineal ................................................................................ 110 -

2.6.2. El derecho de reversión o retorno sucesorio .............................................. 115 -

2.6.3. La reserva viudal ...................................................................................... 119 - 
2.7. LA PÉRDIDA DE LA LEGÍTIMA: DESHEREDACIÓN E INDIGNIDAD ..- 126 -

2.8. LA DESHEREDACIÓN ..................................................................... 131 -

2.8.1. La desheredación parcial y condicional .............................................. 133 -

2.8.2. La desheredación injusta............................................................... 136 -

2.8.3. Causas de desheredación de los hijos y descendientes ......................... 138 -

2.8.4. Causas de desheredación de los padres y ascendientes ......................... 145 -

2.8.5. Causas de desheredación del cónyuge viudo ........................................ 149 -

2.8.6. La reconciliación ............................................................................ 155 -

2.9. LA INDIGNIDAD PARA SUCEDER ................................................ 158 -

2.9.1 Las causas de indignidad ............................................................. 158 -

2.9.2. Las reformas de las causas de indignidad ......................................... 164 -

2.10. LA PRETERICIÓN........................................................................ 175 -

2.10.1. La preterición intencional ........................................................... 178 -

2.10.2. La preterición no intencional o errónea ............................................ 183 -

2.10.3. La preterición mixta de hijos o descendientes: simultánea y sucesiva .- 193 -

2.11. LA ACEPTACIÓN DE LA HERENCIA ................................................. 196 -

2.11.1. La aceptación pura y simple .......................................................... 197 -

2.11.2. La aceptación a beneficio de inventario y el derecho a deliberar ........- 205 -

2.11.3. Los efectos del beneficio de inventario ............................................. 210 -

2.12. LA REPUDIACIÓN............................................................................. 213 -

2.12.1. La repudiación de la legítima ......................................................... 213 -

2.12.2. La repudiación y el impuesto de sucesiones ....................................... 219 -

2.13. LA LEGÍTIMA ESTRICTA AFECTADA POR LA POR LA LEY 41/2003, DE

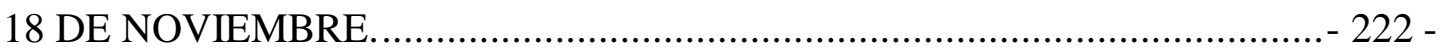

2.14. LAS CAUTELAS DE OPCIÓN COMPENSATORORIA: CAUTELA SOCINI$225-$

3.1 INTRODUCCIÓN AL DERECHO FORAL ESPAÑOL ............................. 236 -

3.2. LA LEGÍTIMA EN ARAGÓN.............................................................. 239 -

3.2.1. La legítima colectiva................................................................. 240 -

3.2.1. Los legitimarios en el CDFA ...................................................... 244 -

3.2.3. Intangibilidad de la legítima............................................................... 245 -

3.2.4. Intangibilidad cuantitativa de la legítima............................................ 246 -

3.2.5. Intangibilidad cualitativa de la legítima.............................................. 250 -

3.2.6. Las cautelas de opción compensatoria.............................................. 253 -

3.2.7. La prohibición de gravar la legítima................................................. 256 -

3.2.8. Usufructo viudal en Aragón ...........................................................- 258 -

3.2.9. La desheredación con causa legal..................................................... 259 -

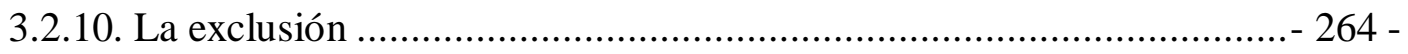


3.2.11. Error en el motivo o en la causa ...................................................... 268 -

3.2.12. La preterición en Aragón ..............................................................- 270 -

3.2.13. Acción de complemento de la legítima........................................... 275 -

3.3. LA LEGÍTIMA EN EL PAÍS VASCO ….......................................... 276 -

3.3.1. El Fuero nuevo. Aparición de la legítima ........................................... 278 -

3.3.2. El derecho sucesorio vigente en el País Vasco .................................... 279 -

3.3.3. La cuota de legítima y los legitimarios ................................................ 280 -

3.3.4. El cónyuge viudo o el superviviente de la pareja de hecho .................... 281 -

3.3.5. El Título II de la Ley $5 / 2015$ de 25 de junio de 2015 .......................... 282 -

3.3.6. La troncalidad en la Ley $5 / 2015$..................................................... 285 -

3.3.7. La intangibilidad de la legítima en el País Vasco ................................ 287 -

3.3.8. La preterición y la desheredación...................................................... 289 -

3.3.9. La libertad de testar en el Valle de Ayala ............................................. 292 -

3.4. LAS LEGÍTIMAS EN EL DERECHO FORAL DE NAVARRA ............... 293 -

3.4.1. El usufructo de fidelidad ............................................................... 297 -

3.4.2- La preterición en Navarra ............................................................. 299 -

3.4.3. La desheredación y la exclusion en Navarra....................................... 300 -

3.4.4. El mantenimiento de la casa en Navarra ........................................... 303 -

3.4.5. El pacto o contrato sucesorio .......................................................... 304 -

3.4.6. Naturaleza jurídica de la legítima en Navarra ....................................... 306 -

3.5 LA LEGÍTIMA EN EL DERECHO FORAL DE CATALUÑA .................. 308 -

3.5.1. La legítima de los descendientes .................................................. 311 -

3.5.2. La legítima de los ascendientes .................................................... 311 -

3.5.3. La cuantía y el cómputo de la legítima ............................................. 312 -

3.5.4. La legítima como pars valoris ....................................................... 314 -

3.5.5. La intangibilidad de la legítima ...................................................... 314 -

3.5.6. La inhabilidad en Cataluña .......................................................... 315 -

3.5.7. La preterición ........................................................................... 318 -

3.5.8. Las causas de desheredación del Código civil de Cataluña ...................- 320 -

3.5.9. LA LIBERTAD DE TESTAR. ARTÍCULO 421-1 CCC ..................... 328 -

3.6. LAS LEGÍTIMAS EN EL DERECHO FORAL DE GALICIA ................... 329 -

3.6.1. El Derecho foral gallego en la codificación......................................... 331 -

3.6.2. Antecedentes recientes del Derecho foral gallego.............................. 332 -

3.6.3. La legítima en el Derecho foral gallego............................................. 334 -

3.6.4. Naturaleza jurídica de la legítima en Galicia ...................................... 335 -

3.6.5. Los legitimarios en el sistema gallego ............................................. 337 -

3.6.6. Los descendientes ....................................................................... 338 - 


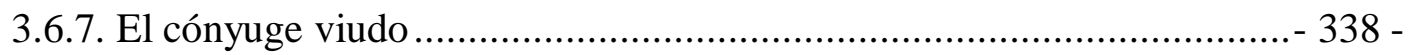

3.6.8. Los pactos sucesorios ................................................................ 341 -

3.6.9. Causas de desheredación.................................................................... 343 -

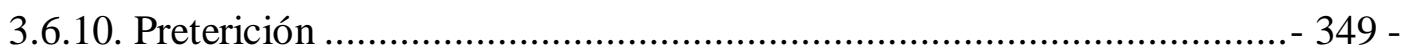

3.7. LAS LEGÍTIMAS EN EL DERECHO FORAL DE BALEARES ..............- 353 -

3.7.1. Las legítimas en Mallorca y Menorca .................................................... 354 -

3.7.2. Naturaleza jurídica de la legítima en Mallorca y Menorca.................... 356 -

3.7.3. Atribución y forma de pago de la legítima en Mallorca y Menorca ......- 356 -

3.7.4. La intangigilidad de la legítima........................................................ 362 -

3.7.5. La desheredación y sus causas en Mallorca y Menorca ........................ 362 -

3.7.6. La preterición en Baleares.................................................................. 364 -

3.7.7. La legítima en Ibiza y Formentera..................................................... 367 -

3.7.8. Los legitimarios en Ibiza y Formentera. Cuantía ................................... 368 -

3.7.9. El cónyuge viudo .......................................................................... 370 -

3.7.10. La desheredación en Ibiza y Formentera ............................................ 371 -

3.7.11. La desheredación ....................................................................... 372 -

CAPÍTULO IV .............................................................................. 375 -

4.1. DERECHO FRANCÉS .................................................................... 375 -

4.1.1. La codificación francesa ................................................................ 375 -

4.1.2. La adquisición de la herencia ipso iure ................................................ 376 -

4.1.3. Las legítimas en el Derecho francés .................................................... 377 -

4.1.4. La reforma de la legítima por la ley de 23, de julio de 2006 ................. 378 -

4.1.5. La reserva a los distintos reservatarios o legitimarios .......................... 379 -

4.1.6. La preterición y la desheredación en el Derecho civil francés................ 381 -

4.1.7. El artículo 909 del Code francés ......................................................... 382 -

4.2. DERECHO ANGLOSAJÓN ................................................................ 384 -

4.2.1. La decadencia del Civil law ........................................................... 385 -

4.2.2. Legítimas dentro del Derecho anglosajón............................................ 386 -

4.2.3. La provisión de la familia y dependientes ............................................ 389 -

4.2.4. La provisión para la familia anglosajona y el derecho de alimentos

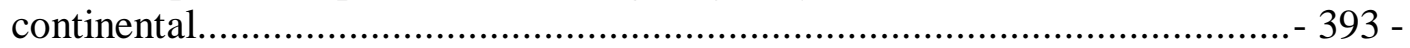

4.2.5. Diferencias con el Derecho español ................................................... 396 -

4.3. LA LEGÍTIMA EN ALEMANIA Y AUSTRIA ....................................... 398 -

4.3.1. Los legitimarios en el BGB ........................................................ 400 -

4.3.2. La reforma de 2010 en Alemania .................................................... 401 -

4.3.3. El principio de solidaridad en el BGB alemán ..................................... 403 -

4.3.4. El cónyuge viudo en el Derecho alemán ........................................... 404 - 
4.3.5. La preterición en el Derecho alemán ...................................................- 406 -

4.3.6. La legítima en el Derecho austriaco ................................................ 407 -

4.3.7. La desheredación en Alemania y Austria ............................................ 408 -

4.3.8. Los cuidadores del testador y la legítima.......................................... 414 -

4.3.9. La aceptación de la herencia ipso iure ............................................... 415 -

4.4. LA SUCESIÓN EN EL DERECHO ITALIANO ......................................... 416 -

4.4.1. La aceptación o repudiacion de la herencia .......................................... 419 -

4.4.2. Administración de apoyo en Italia Amministratore di sastengo ............ 422 -

4.4.3. La legítima en el Código civil italiano de 1942 .................................. 423 -

4.4.4. La porción disponible .................................................................. 425 -

4.4.5. La sucesión universal y la sucesión particular ..................................... 427 -

4.4.6. Intangibilidad de la legítima........................................................... 427 -

4.4.7. Las causas de desheredación e indignidad ............................................ 428 -

4.4.8. Parientes afectados por la colación....................................................... 434 -

4.4.9. Diferencias con el Derecho común español ........................................... 437 -

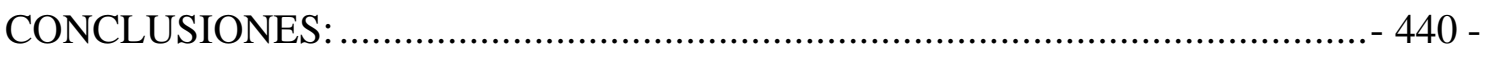

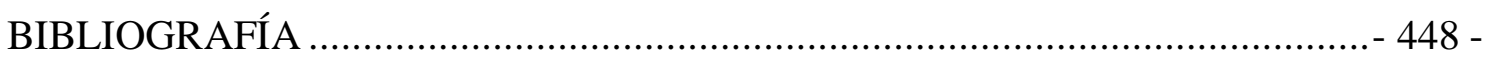

TABLA DE JURISPRUDENCIA ............................................................ 469 -

1. Tribunal Supremo: ............................................................................. 469 -

2. Audiencia Provincial ................................................................................... 471 -

3. Tribunal Superior de Justicia ................................................................. 473 -

4.Dirección General de los Registros y del Notariado .................................. 473 - 
- 12 - 


\section{INTRODUCCIÓN}

Es sonada la discrepancia existente, entre los autores, por lo que a la extinción o permanencia de la legítima, en lo que al Derecho español se refiere. Aportando cada sector los argumentos propios para avalar su postura. El argumento utilizado en la mayoría de las opiniones favorables o contrarias a la permanencia del sistema legitimario, sobretodo en el Derecho común, siempre brilla por la ausencia de datos subjetivos que afiancen la postura escogida. Estimo que solamente con un estudio del cuándo, el cómo y el porqué de la legítima se podra dotar de un calado suficiente, al planteamiento de la permanencia, minoración o supresión, del sistema legitimario actual en el Código civil.

Cuándo surge la legítima interesa conocerlo para tratar de verificar los motivos que impulsaron a su nacimiento, pero también sus errores y sus aciertos. Al conocer como surgió la legítima nos desvelará su verdadera finalidad, la fuerza de esta institución y su fiabilidad. Hasta puede que nos indique el camino de llegar al porqué de la legítima. Evidentemente en los motivos del surgimiento o nacimiento del sistema legítimario, bajo mi opinión, es donde reside la clave para poder tener una idea, más o menos acertada, sobre la permanencia o supresión de la portio debita. Al conocer los motivos de su creación estimo que se podrá identificar y valorar a los que resultaron beneficiados con su aparición y poderlos comparar con la situación actual.

Esta tesis como nucleo del sistema legitimario del Código civil, tal como ha sido configurado por el legislador tiene en cuenta lo que la doctrina y la jurisprudencia han establecido al respecto durante los últimos años. Las conclusiones que efectuaré al final de este trabajo de investigación relativa al mantenimiento, modificación o supresión de la 
legítima tomarán como modelo el Código civil. El recorrido por el sistema legitimario, dispuesto en el Código civil, lo justifico a los solos efectos de conocimiento de la institución dentro del ordenamiento español. Adviertase que de la legítima, además de su nacimiento originario, también interesa saber como surgío en España, así como su expansión a los distintos Derechos civiles forales, que también componen el ordenamiento español.

Por lo que respecta al Derecho foral y al de algunos países europeos de nuestro entorno cultural, simplemente trataré de encontrar en ellos, más que su comparación institucional con nuestro Derecho civil común, su acercamiento o alejamiento de nuestros sistemas legitimarios o bien su libertad dispositiva post mortem. Mi intención es buscar en estos sistemas jurídicos novedades dignas de ser incorporadas, en su caso, a una hipotética reforma del Derecho de sucesiones del Código civil español. Para ello analizaré Derechos como el navarro o como parte del País Vasco que parten de una mayor libertad de disposición para los testadores, es decir, una casi total libertad de distribución de sus bienes para después de su muerte. También analizaré otros ordenamientos como el anglosajon (Inglaterra, Estados Unidos, etc.) que rozan la absoluta libertad dispositiva para al testador. Estos sistemas atienden más al individuo que a la familia y ya anticipo que el único freno para el testador son unos derechos similares a los conocidos en el continente como derecho de alimentos entre parientes.

La naturaleza de la legítima va intrínsecamente unida al concepto y modelo de familia y dentro de esta del parentesco con total independencia de la necesidad que tenga el titular del derecho a ella. En cambio el derecho de alimentos entre parientes, si bien es una obligación impuesta por la ley, atendiendo a la proximidad del parentesco al igual que la legítima. Sin embargo los alimentos requieren necesidad del alimentista como requisito indispensable para que produzca sus efectos. Por lo tanto los alimentos 
requieren parentesco y necesidad, mientras que la legítima únicamente requiere parentesco y produce sus efectos cuando muere el causante y no antes, por mucha necesidad que tenga el legitimario. La legítima y el derecho de alimentos son dos instituciones paralelas con algunas similitudes y muchas diferencias, que por mucho que se prolonguen nunca se pueden encontrar.

Tambien me atrevo a anticipar que las voces que proclaman la extinción de la legítima justifican su postura, en la mayoría de los casos, en la evolución del modelo de familia, cuya motivación encuentra apoyo en el mayor poder adquisitivo de los legitimarios actuales (hijos y decendientes), en comparación con los de décadas anteriores. Evidentemente la mayor esperanza de vida del disponente/causante aumenta también la edad en que sus principales legitimarios adquirirán su correspondiente legítima, es decir, legitimarios menos necesitados los actuales que los anteriores. Pero precisamente como hemos dicho antes, la legítima no obedece a situaciones de mayor o menor necesidad económoca, simplemente atiende a la existencia de parentesco entre legitimario y causante. Por lo tanto la evolución de la familia, en ese sentido, no tiene porque afectar a la naturaleza de la legítima.

Con respecto a la mayor esperanza de vida no se pueden desatender sus nuevas consecuencias en que una de las más visibles es el "testador vulnerable". Simplemente con mirar el Código de circulación se puede comprobar las restricciones que tiene el conductor a partir de los 65 años, debido a que sus reflejos van en disminución progresiva conforme avanza su edad. Me sorprende que a la misma edad el mismo legislador conceda al mismo individuo libertad para testar y restricción para conducir, cuando son palpables los daños que pueden producir, tanto el testador como el conductor carente de reflejos, a terceras personas. Este es el tema que 
justifica el indagar en aquellos ordenamientos que han tenido en cuenta la vulnerabilidad del testador debido al cambio social (mayor ingreso de ancianos en los geriatricos) y a su mayor esperanza de vida, que en ocasiones va acompañado de deterioros o debilitamiento del sistema cognitivo.

La obra se va a dividir en cuatro capítulos. En el primero de ellos indagaré sobre los motivos que dieron lugar al nacimiento de la legítima en la antigua Roma. Se hace necesario también el paso por la Edad Media española para contestar la evolución de la figura en los distintos reinos. Finalmente analizaré cuales de aquellas distintas concepciones de la legítima fueron tenidas en cuenta para su regulación en el Código civil. El Cápitulo segundo pretende ser un estudio sobre aquella parte del Derecho de Sucesiones que tiene especial incidencia en el ámbito del Código civil. Así pues, analizaré la naturaleza de la legítima; la intangibilidad de la misma en sus aspectos cuantitativos y cualitativos; también incidiré en las distintas clases de legitimarios así como en la porción que les corresponde. Asimismo, las figuras de la desheredación y la indignidad para suceder. Finalmente, la preterición, la aceptación de la herencia y la repudiación.

En el Capítulo tercero, efectuaré un estudio, en menor profundidad al realizado en el Código civil, en los distintos Derechos forales españoles. Finalmente, en el cápitulo cuarto analizaré, de manera mucho menos exhaustiva, aquellas particularidades que presentan algunos de los ordenamientos jurídicos de nuestro entorno cultural en materia de legítimas. 


\section{CAPITULO I EVOLUCIÓN HISTÓRICA DE LA LEGÍTIMA}

\subsection{LA SUCESIÓN EN ROMA}

La sucesión en Roma tenía como base, desde la época de la Ley de las XII Tablas, a la familia agnaticia o civil. Dicha familia comprendía a todas las personas en la línea masculina bajo la patria potestad del pater familias hasta el sexto grado. El parentesco agnaticio se transmitía únicamente a través de la línea de los varones con independencia del vínculo sanguíneo que los unía. El vínculo que unia a las personas que formaban una familia era la sujeción a la potestad de un paterfamilias. A diferencia de la anterior, la familia cognaticia o consanguínea basada en los vínculos de la sangre es posterior en el tiempo y se transmitía a través de la línea de las mujeres. En Roma tenían, en una misma persona, que reunirse tres condiciones indispensables, para ser titular de determinados derechos jurídicos sobre cosas o sobre personas: ser libre, ser romano y ser paterfamilias ${ }^{1}$. Sólo el valor que tenían estas condiciones podía transmitirse por vía hereditaria.

La sucesión tenía como propósito la permanencia y continuidad de la familia agnaticia o civil ${ }^{2}$. De tal manera, que fallecido el pater familias, sin

${ }^{1}$ GAMBOA URIBARREN, B.: "Mujer y sucesión hereditaria en Roma", en Mujeres y Derecho, pasado y presente: I Congreso multidisciplinar de Centro-Sección de Bizkaia de la Facultad de Derecho (coord. J. Astola Madariaga), 2008, págs. 1 a 2. Nos dice este autor que, en Roma para formalizar negocios jurídicos, como pueda ser la formalización de un testamento válido, además de los tres requisitos expuestos en el texto se debía de poseer capacidad de obrar. El autor mantiene que las relaciones familiares en la Roma antigua eran completamente distintas a como se puedan entender hoy en día. Basta con decir que el Estado, sólo reconocía al paterfamilias, es decir, no se reconocía a los hijos de la familia que se encontraban bajo la potestad absoluta del padre. Todos sus descendientes legítimos por línea masculina estaban sometidos a su potestad, como jefe de la familia y en consecuencia formaban una familia a las órdenes de un jefe.

${ }^{2}$ ARIAS RAMOS, J. Y ARIAS BONET J.: Derecho romano, vol. II, $17^{\mathrm{a}} \mathrm{ed,} \mathrm{Editoriales} \mathrm{De}$ Derecho Reunidas, Madrid, 1984, pág. 829, pone de manifiesto el autor que la condición de heredero necesario, heres suus, no es el vínculo de la sangre, sino la potestad que ejerce el paterfamilias sobre los demás. En el caso de un adoptado por este, tiene la condición de heredero necesario, pero carece de ella, el hijo biológico emancipado o la hija casada. Se refiere a las clases de herederos BETANCOURT SERNA, F.: Derecho romano clásico, $3^{\text {a }}$ ed. Universidad de Sevilla, Sevilla, 2007, pág. 487. 
otorgar testamento, se llamaba a la sucesión, en primer lugar, a los herederos sobre los que tenía potestad el fallecido, es decir, hijos, hijas y la esposa in manu (sometida al marido) que con el fallecimiento se convertían en sui iuris (personas de derecho propio con capacidad para manejar sus propios asuntos). Durante la vida del padre eran alieni iuris (bajo el derecho ajeno incapaces de manejar sus propios asuntos). Estos herederos legítimos independientes no tenían necesidad de aceptar la herencia y no podían repudiarla, es decir, la institución de herederos sólo tenía cabida cuando no existían sui heredes (descendentes de primer grado) del causante. En caso contrario continuaba la familia agnaticia. El término "familia" deriva de familius, que define al grupo o conjunto de individuos y bienes (res mancipi) bajo la potestad del paterfamilias. Precisamente los bienes patrimoniales res mancipi, eran los bienes heredables ${ }^{3}$.

El propio término familias (derivado de famulus) se refiere también al conjunto de personas y bienes subordinados al paterfamilias, concretamente a los bienes res mancipi que integran el patrimonio, y de los que se pretende la continuidad familiar, por lo que estas reses mancipi se definen como los bienes que se heredan. Por lo tanto, el vínculo que une a la familia civil o agnaticia es el "paterfamilias" y muerto este y designado por él su sucesor, la familia permanecía igualmente unida y bajo la tutela de su heredero. En el supuesto de no haberse efectuado dicha designación, ni existir herederos "sui heredes" (herederos necesarios), se permite a los

Manifiesta que desde la Ley de las XII Tablas hasta la primera época clásica (año 40, a. C.) se distinguía entre herederos necesarios o heredes sui et necesariiy herederos voluntarios o heredes voluntarii o extranei.

${ }^{3}$ Mollá Nebot, M.A.: Usufructo de pecunia. Aplicación a los fondos de inversión desde la ley de jurisdicción voluntaria, Dykinson, Madrid, 2015, pág. 39. 
pertenecientes a la misma "gens" o familia-gentiles, agnados o adrogados adquirir la potestad de paterfamilias y con ello apoderarse de la misma ${ }^{4}$.

\subsubsection{La legítima en las XIII Tablas}

En el primitivo Derecho romano la libertad de testar era prácticamente absoluta. En la Ley de las XII Tablas se recoge, sin apenas límites, la libertad de testar. Esta libertad de testar significaba que el testador podía disponer como quisiera de sus bienes para después de la muerte, sin estar vinculado a beneficiar como herederos ni siquiera a sus hijos ${ }^{5}$. Una libertad que se materializa con legados y donaciones e incluso con desheredaciones a favor de los parientes del fallecido, con la consecuencia que dejaba a estos últimos desprotegidos. La legítima romana constituye un límite a la falta del deber protector en que puede incurrir el paterfamilias sobre sus parientes más íntimos ${ }^{6}$. Esta protección para evitar la preterición de los familiares más íntimos, no se verá materializada hasta llegado el Derecho Pretorio, que trasformará la reserva formal en reserva legal. Con la influencia ejercida por el cristianismo, con Justiniano, se cambia el concepto parental de la familia, que pasa de ser agnaticia a cognaticia o consanguínea por virtud del matrimonio. Aumentando sus vínculos parentales y con ello aparece la legítima como institución, entre el año 536

\footnotetext{
${ }^{4}$ BERNAD MAINAR, R.: Derecho romano: curso de derecho privado romano, Universidad Católica Andrés Bello, 2001, pág. 582. "Si muere intestado y sin herederos suyos, tenga la familia el agnado más próximo. Si no existen agnados, tengan la familia los gentiles".

${ }^{5}$ VAliño ArCos, A.: La aemulatio en el Derecho romano, Instituto de Historia del Derecho, Santiago de Chile, 2002, pág. 362.

${ }^{6}$ Betancourt Serna, F.: Derecho romano clásico, $3^{\mathrm{a}}$ ed. Universidad de Sevilla, Sevilla, 2007. pág. 505. La Ley de las XII Tablas sólo denominaba de manera expresa como herederos a las personas que a tiempo de fallecimiento del paterfamilias se hallaban bajo su patria potestad. De ahí que se hable de sucesión legítima y de legitimarios que eran precisamente los llamados a la sucesión intestada, por estar bajo potestad del paterfamilias.
} 
y el 542, d. $C^{7}$. A partir de Justiniano queda fijado el circulo cognaticio y después el agnaticio, con las Novelas 118 y 127.

No se puede olvidar, que para el grueso de la población plebeya la tradición, la costumbre, el Derecho natural y la religión marcaban las pautas a seguir a la hora de trasmitir sus posesiones ${ }^{8}$. En cambio para la sociedad patricia, el negocio jurídico del testamento, constituía una herramienta mucho más útil para la transmisión patrimonial ${ }^{9}$. Además, el carácter formal y estricto del testamento hacía necesario contratar los servicios de un jurista para que tuviera efectividad ${ }^{10}$.

En Derecho romano se toma como punto de partida a la libertad de otorgamiento post mortem de que disponía el testador, la Época Arcaica, (800-500 a. C.), cuya sanción constaba en las XII Tablas. La única exigencia que se le imponía, en dicha época, al paterfamilias, a la hora de designar a sus sucesores era la obligación de mencionar en su testamento a

${ }^{7}$ BERNAD MAINAR, R.: "La porción legítima en la familia del Derecho romano", Revista Crítica de Derecho Inmobiliario, núm. 757, 2016, pág. 1766. Las fechas 536 y 542, d. C., se refieren a la entrada en vigor de la Novela 18 y 115 respectivamente. Conviene aclarar que los romanos entendían el AS, bien como un tipo de moneda o bien como un todo, es decir, la masa hereditaria era conocida como un AS. El As era dividido en doce partes de onza cada una: As /12= una onza = una parte de la herencia; una onza, parte $\mathrm{x}$ $12=$ un todo = un AS = una herencia. En el caso que nos ocupa, si el As lo dividimos entre $4(12 / 4=3)$ tres onzas $=1 / 4$ que, la Lex falcidia, reserva a determinados herederos.]

${ }^{8}$ MAIOFER, W.: "El Derecho natural como Derecho existencial", Anuario de Filosofía del Derecho, núm. 9, 1962, pág. 9. "recuérdese de nuevo, aquella común sabiduría de los antiguos, para la que hay un Derecho más alto que la ley, un Derecho natural, un Derecho divino, en resumen, un Derecho supralegal, respecto del cual la injusticia es injusticia, aun cuando revista forma de ley".

${ }^{9}$ CASTÁN PÉREZ GÓMEZ, S.: "Reflexiones sobre el origen de las sucesiones en Roma. El testamentum calatis comitiis y su relación con la sucesión intestada", Ridrom, núm. 11, 2013, págs., 284 a 286. Una sociedad en que la mayoría de individuos estaban sometidos a un cabeza de familia, con la suma añadida, de la diferencia de clases. Se trata simplemente de aclarar que la oportunidad de materializar determinados negocios jurídicos, como pudiera ser hacer un testamento, sólo estaba a disposición de muy poca gente.

${ }^{10}$ V AliÑo ArCOS, La aemulatio... op. cit., pág. 360. 
los sui heredes (descendientes inmediatos que se encuentran bajo su patria potestad y que se convierten en sui iuris con su muerte). Habría que mencionarlos tanto para instituirlos herederos como para desheredarlos, de lo contrario el testamento devenía nulo y se abría la sucesión legal ${ }^{11}$.

La libertad de testar otorgada por las XII Tablas, no es pacifica la postura doctrinal entre los romanistas. Si bien existe común acuerdo entre ellos de asociar la libertad de testar al Derecho romano, parte de ellos, encuadran dicha libertad de disposición en los orígenes del pueblo romano. En cambio otros se limitan a relacionar la primitiva libertad dispositiva de testar con el Derecho romano sin precisar su vigencia. Otro sector pone como comienzo y consagración de la precitada libertad de disposición, al texto Decenviral. Aquí cabria incidir en la reconstrucción de la Ley de la XII Tablas. Ello implicaría que de su contenido indirecto solamente se conozca a través de referencias de juristas muy posteriores a su existencia. Además se refrenda lo anteriormente citado sobre la poca certeza de lo escrito en dicho Código ${ }^{12}$, la propia discusión sobre la fecha inicial de la plena libertad de disposición en Roma ${ }^{13}$.

\footnotetext{
${ }^{11}$ Polo Arévalo E. M.: "Concepto y Naturaleza Jurídica de la Legítima en Derecho Sucesorio Español: precedentes y actualidad”, Ridrom, núm. 10, 2013, pág., 332.

${ }^{12}$ Sobre la libertad de testar hay autores que la fijan en la Ley de las XII Tablas. Otros autores la datan con anterioridad a las mismas. No obstante, hay que puntualizar que el texto de las XII Tablas no se ha conservado y el contenido de las mismas ha sido reconstruido a través de manifestaciones de autores clásicos.

${ }^{13}$ BARrio Gallardo, A.: El largo camino hacia la libertad de testar. De la legítima al derecho sucesorio de alimentos, Dykinson, Madrid, 2012, págs. 55 a 59. Este autor confirma lo que mantenía Castán Pérez-Gómez acerca de la poca certitud de los contenidos de las XII Tablas:"(...) no se trata de un documento histórico cuyo original se haya conservado, sino de una reconstrucción, ya que el texto fidedigno posiblemente se perdiera con el saqueo que padeció Roma en torno al 390 a. C. Ello implica que el acceso a su contenido sea necesariamente indirecto y sólo lo conozcamos a través de las citas y referencias de juristas y literatos romanos posteriores".
}

La discrepancia acerca de la datación de la libertar de disposición en Roma se tiene, por una parte, en autoridades en la materia como Vallet de Goytisolo, Ortega Pardo, Lasarte Álvarez, entre otros, que han preferido mantener una "indefinición convenientemente 
Agonizando la República se dictaron nuevas protecciones de la "portio debita mínima" correspondiente a los herederos, así como una justificación motivada para el caso de desheredación. Con base a ello nace la "querella inofficiosi testamenti" asegurando al heredero una parte mínima de la herencia. En caso contrario este tenía acción para interponer, la citada querella durante el plazo de cinco años desde la apertura de la sucesión para declarar inoficioso el testamento. En el supuesto de prosperar la acción se anulaba dicho testamento y se abría la sucesión intestada. Se entendía en la época que si un padre cometía semejantes atrocidades, de desheredar o preterir a un hijo de manera injusta, contradecía el "officium pietatis". Se admitía como ficción jurídica una supuesta demencia del testador, que como consecuencia, anulaba todo lo dispuesto por el supuesto demente $^{14}$. Son varios los pasos hasta llegar a configurar una legítima en sentido similar al moderno. Hasta que se consolida el concepto de cuota reservable se van utilizando diversos mecanismos, como la "querella inoficiosi testamenti”, estipulado en las Leyes Furia, Voconia y Falcidia.

\subsubsection{La Lex Furia Testamentis}

Esta Ley constituye la primera limitación a la capacidad de disposición post mortem. De fecha de promulgación desconocida si bien algunos autores sitúan su aparición entre finales del s. III y principios del s. II a.

calculada" sobre el inicio de la libre disposición en Roma. Mientras que X. O'callaghan Muñoz encuadra en las XII Tablas, el comienzo de la libertad de legar, pero no hace lo mismo, con la de disponer, en el texto Decenviral. De otra parte, otros expertos en la materia como Castán Tobeñas, Ragel Sánchez, Ribera Fernández, Algaba Ros, si que sitúan la libertad de disposición en la Ley de las XII Tablas.

La opinión de BARRIO Gallardo, es que la libre disposición de los bienes de una persona fue notoriamente posterior a las XII, Tablas, coincidiendo, probablemente, con el período expansionista republicano que se iniciaba a comienzos del siglo III a. C.

${ }^{14}$ GONZALEZ LÓPEZ, R.:” El pulso entre heredero y legatario propiciado por la voluntas testatotiris, la victoria de la cuarta falcidia", Anuario de la Facultad de Derecho, (Universidad de Alcalá) núm. 6, 2013, págs. 147 a 161. 
$\mathrm{C}^{15}$. Concretamente establece que sobre los parientes consanguíneos, más próximos al testador (hasta el $6^{\circ}$ grado), todo aquel apartado del parentesco cognaticio (excepto el cónyuge viudo) no puede adquirir, por legado o cualquier otro título, más de 1000 ases $^{16}$. De esta medida general quedaban exceptuados los miembros de la familia cognaticia del disponente. Por lo que todo apunta, a que el fundamento de esta Ley era proteger a los familiares del testador contra extraños ${ }^{17}$. Tampoco se impedía, con la medida impuesta, que el causante hubiera igualmente, dividido su patrimonio con porciones inferiores a 1000 ases $^{18}$. La Ley no pudo cumplir su objetivo de proteger al heredero, no pudo evitar el fraude de ley, puesto que con un conocimiento exhaustivo de la legalidad y por medio de los legados se seguía burlando la Lex Furia testamenti ${ }^{19}$.

\footnotetext{
${ }^{15}$ Señala CASINOS MORA, F.J.: La prescripción de la hereditatis petitio, Dykinson, Madrid, 2008, pág. 19, que no existe fecha exacta de la promulgación de dicha Ley. Ello hace pensar que, de haberla sabido Gayo, la hubiera escrito y, el autor citado, no hubiera manifestado la inexistencia de fecha de promulgación de la Lex Furia.
}

${ }^{16}$ DuPLÁ MARÍn, M. T.: El proceso de recepción de la quarta falcidia romana en el Derecho civil catalán, Bosch, 2013, pág. 423.

${ }^{17}$ Barrio Gallardo, A.: El largo camino..., op. cit, pág. 119. Confirma "que nadie podía recibir de otro más de mil ases en concepto de legado. Ahora bien, de esta proscripción general quedaban exceptuados, de nuevo, ciertos parientes, en concreto la familia cognaticia del testador. Circunstancia que, a mi juicio, abona la tesis de que toda esta legislación, tardo-republicana, se dictó fundamentalmente con vistas a proteger a la familia del testador frente a disposiciones efectuadas por éste, en favor de extraños".

\footnotetext{
${ }^{18}$ RAGEL SÁNCHEZ, L.F.: Encuadre de la materia a estudiar en la intangibilidad cualitativa de la legítima, en La Cautela Gualdense o Socini y el artículo 820.3. ${ }^{\circ}$ del Código Civil, Dykinson, Madrid 2004, pág. 80."Para esto se promulgó la ley Furia, en la cual se prohibía que, excepto ciertas personas, los legatarios y donatarios a causa de muerte recibieran más de mil ases. Pero no se consiguió lo que se quería, porque el que tenía un patrimonio, por ejemplo, de cinco mil ases, podía consumir todo su patrimonio instituyendo cinco legatarios con mil ases cada uno".
}

${ }^{19}$ GONZÁLEZ LÓPEZ, “El pulso entre heredero...”, op. cit., pág. 155. 


\subsubsection{La Lex Voconia}

Promulgada, la Ley Voconia, el año 169 a. C. con posterioridad a la Lex Furia Testamenti, con la intención de corregir y limitar los legados impuestos por los testadores. No pudiendo superar estos, a lo recibido por el heredero. En adelante si podían igualarlo, es decir, el valor de los legados podía ser igual a la herencia, como cuota máxima, de la masa hereditaria. La ley no permitía heredar a las mujeres y, por lo tanto los testadores se valían de la sustitución fideicomisaria para no dejar desprotegidas a su esposa e hijas. Para lograrlo tenían que dejarse los bienes en manos de un tercero, con supuesta buena fe, con el gran riesgo de que, el citado tercero, acabara haciendo suyos dichos bienes. Cuyo argumento era el cumplimiento que le imponía la Ley que se viene analizando $^{20}$. Por lo tanto, esta Ley limitaba la capacidad de la mujer para poder ser instituida heredera ${ }^{21}$. A partir de la abolición de esta Ley Voconia en el siglo I, d. C., las mujeres alcanzaron mayor capacidad de obrar y la

\footnotetext{
${ }^{20}$ ORTUÑo PÉREZ, M. E.: Contribuciones al derecho romano de sucesiones y donaciones Dykinson, 2015, pág. 57. Es una Ley, la Voconia, que pretende poner límites a la capacidad sucesoria de la mujer. No se puede ver como frenadora de la libre disposición testamentaria, sino que limitando la capacidad sucesoria de la mujer, anulaba su capacidad patrimonial y con ello, debilitaba su progresiva autonomía. Su verdadero objetivo, era frenar la independencia que estaba adquiriendo la mujer respecto del hombre y se pensó que promulgando esta Ley Voconia, la mujer, volvería a ser dependiente totalmente de su marido o padre. A nivel de sucesión, pretende conservar la institución de herederos y la eficacia del testamento manteniendo que nadie pueda recibir, en concepto de legado, más que lo recibían los herederos. Adviértase que con esta Ley se sigue favoreciendo, que simplemente se instituyan mayor número de legatarios, a fin de no superar ninguno de ellos los 1000 ases.

${ }^{21}$ Para MCClintock, A.: "Un analisi giuridica della lex Voconia" Teoria e storia del dirito privato, núm. 10, 2017, págs. 1 a 4. El carácter antifeminista que tenía la Ley Voconia: "Molti studiosi hanno ritenuto che la lex Voconia avesse uno scopo 'antifemminista' inteso a prevenire un potere femminile finanziato da ingenti patrimoni Studi più recenti hanno fortemente ridimensionato questo approccio sostenen do che $\mathrm{i}$ romani non si erano mai sentiti realmente minacciati dalle donne". (La traducción al castellano sería: Muchos estudiosos han considerado que la lex Voconia tenía un objetivo 'antifeminista' para evitar que el poder femenino se financiara con grandes activos. Estudios más recientes han reducido en gran medida este enfoque al afirmar que los romanos nunca se habían sentido realmente amenazados por las mujeres).
} 
capacidad de poder heredar de manera legal. Lo podían hacer en iguales condiciones que los varones e incluso podían tener bienes propios $^{22}$. En definitiva, la citada Ley tuvo como finalidad mantener las costumbres romanas y no impidió la desprotección del cónyuge sobreviviente ${ }^{23}$.

\subsubsection{Lex Falcidia de Legatis}

El trasfondo de esta Ley, protectora de los herederos, era impedir la desmesurada utilización de los legados con la consecuente reducción del caudal hereditario. Como freno a esta tendencia se promulgó la Lex Falcidia de Legatis, que limitaba la capacidad de disposición del testador. El objetivo, de dicha limitación, era que los legados no dañaran al heredero y que pudiera peligrar la aceptación de la herencia y con ello, la eficacia del testamento. La protección al heredero, que brindaba esta Ley, ocultaba la intención de gravar con una tasa el incremento patrimonial que recibía el heredero de su causante ${ }^{24}$.

No se puede hablar de trabas a la plena libertar de otorgamiento post mortem. La mención, exigida en la XII Tablas de sus herederos, con el propósito de desheredarlos, antes citada. Se entiende como una reflexión más que una traba a la libertad de disponer que tenía el testador a la hora de

\footnotetext{
${ }^{22}$ Como dicen Chamocho CANTUdo M.A. y RAmos VÁzQuez, I.: "La herencia de la antigüedad: De las relaciones de trabajo en Roma hasta los sistemas gremiales de cofradías y hermandades medievales", en Introducción jurídica a la historia de las relaciones de trabajo, Dykinson, Madrid, 2013, pág. 46, es cierto que las mujeres podían heredar con las mismas condiciones que lo hacían los varones, pero también es cierto que, "mientras estuvieran casadas in manus, la administración de dichos patrimonios pasaba al marido. En cambio los bienes propios revertían a sus manos en caso de divorcio o viudedad. Pudiendo en este caso administrarlos ellas mismas, lo que da lugar a una nueva figura de mujer trabajadora capaz de gestionar sus propios negocios".

${ }^{23}$ Véase PÉREZ EsCOLAR, M.: "Sucesión intestada del cónyuge supérstite. Perspectiva histórica del Derecho Romano a la época de las Recopilaciones", Revista Crítica de Derecho Inmobiliario, núm. 686, noviembre-diciembre 2004.

${ }^{24}$ OrtuÑo PÉREZ, M.E.: "Limitación de la capacidad de testar", en Contribuciones al Derecho romano de sucesiones y donaciones, Dykinson, Madrid 2015, pág. 80.
} 
instituir herederos. En cambio, en la "Lex Falcidia de legatis" (40, a. C. $)^{25}$ devenía nulo todo acto que contrariara lo en ella dispuesto ${ }^{26}$. En esta Ley sí que se encuentran verdaderas trabas a la libertad de disponer post mortem. Mandaba que nadie pudiera cargar su herencia con legados y ello significaba que había que dejar libre un cuarto de la masa hereditaria. Por lo tanto, se hace una reserva de una parte alícuota consistente en un cuarto de la herencia para los herederos. En el supuesto de rebasarse dicho límite por el testador tenían obligación los legatarios de restituir a los herederos instituidos en el testamento, hasta alcanzar el cuarto de la herencia que les quedaba reservado por la Ley. Teniendo ello también aplicación en las sucesiones " $a b$ intestato"

Se ha hablado hasta ahora de la Lex Falcidia, como limitadora de los legados, por lo menos en su etapa inicial. En cambio con el Senadoconsulto Pegasiano, la cuarta falcidia, también podía afectar a los fideicomisos. Así también es aplicable a los fideicomisos abintestato gracias a Antonino Pío. Finalmente, tampoco se libraron las donaciones mortis causa, de la reducción citada, con Séptimo Severo. Esta Ley continuó en vigor hasta la época de Justiniano como límite a toda institución que pudiera perjudicar al heredero $^{28}$. Prueba de ello es el Capítulo quinto de la Novela cinco, donde

\footnotetext{
${ }^{25}$ BARrio Gallardo, “El largo camino...,” op. cit., pág. 91.

${ }^{26}$ Olis RobledA, S.J.: "La nulidad del acto jurídico" Gregorian Biblical BookShop. 1964, pág. 310. La Lex Falcidia, señala este autor, su entrada en vigor en el año 714, desde la fundación de Roma o del año 40 a. C. La referida Ley anulaba todo acto que se dispusiera en contrario a su espíritu. Se le atribuye la autoría, de ahí su nombre, a Publio Falcidio. Se conocía también como "Ley perfecta". Postura, la citada, que es compartida por BARRIO GALLARDO A.: El nacimiento del common law en el bajo Medievo en El largo camino hacia la libertad de testar. De la legítima al derecho sucesorio de alimentos, T. II, Dykinson, 2012, págs. 119 a 123. Matizando al respecto que sin duda lo más importante, de esta Ley es que,"cierra el ciclo a la libertad de testa y es el anticipo de la legítima que hoy conocemos".

${ }^{27}$ GONZÁLEZ LÓPEZ,” El pulso entre heredero y legatario...," op. cit. págs.155 a157

${ }^{28}$ GONZÁLEZ LÓPEZ,” El pulso entre heredero y legatario...," loc. cit. pág. 157.
} 
se dispone que de ingresar alguien en un monasterio y haber entregado todo su patrimonio a dicha institución, sin haber testado con anterioridad al ingreso o tuviera hijos, a los cuales no les hubiera respetado su legítima parte, se detraerá de dicho patrimonio destinado al monasterio, la cuarta parte (cuarta falcidia) del haber hereditario ${ }^{29}$. También existen otros autores que afirman la inserción de esta cuarta falcidia, en los Códigos Justinianeos $^{30}$. Si bien lo hacen en base a la nueva concepción de la familia que tenía Justiniano, al sustituir el parentesco civil agniticio por el consanguíneo condicionado al matrimonio debido a la influencia ejercida por el cristianismo en todo el Imperio ${ }^{31}$.

Más que lo que engloba, la propia Lex Falcidia, sin dejar de atender a su importancia, aporta datos relevantes al propósito de conocer las causas

\footnotetext{
${ }^{29}$ BuEno Delgado, J.A.: "Derecho fiscal", en Hacia un derecho administrativo, fiscal y medioambiental romano, III, (coord. A. Fernández Buján y G. Gerez Kraemer), Dykinson, Madrid, 2016, págs. 516 a 517.

${ }^{30}$ Sahagún de la Marfa y de Quintana J.: Curso de Ampliación de Derecho Civil Español, Imprenta Hispana de Vicente Castaños, 1857, pág. 239. Este autor, refrenda lo expuesto anteriormente, al mantener que la Lex Falcidia fue introducida en los Códigos de Justiniano. También Consideraba que esta Ley es igualitaria frente a testador, legatarios y herederos, es decir, no discrimina a ninguno de los citados. Beneficia a los herederos, al reservarles una parte de la herencia que no podía gravarse con legados, en beneficio de los legatarios dispone que la herencia se aceptara y no fuese destruido el testamento arrastrando con él, a los legados. Si bien con anterioridad a la entrada en vigor de la citada Ley, los legatarios tenían que llegar a acuerdos con los herederos/s con el fin de que la herencia no fuese repudiada por estos. En beneficio del testador, no hay duda al respecto, de que sus últimas voluntades eran cumplidas y se disponía de sus bienes, según su voluntad y no según la voluntad de la Ley en la sucesión legal.

${ }^{31}$ BERNAD MAINAR, "La porción legítima...", op. cit., pág. 1766. Confirma este autor lo expuesto manifestando que: la legislación justinianea consagrará una nueva concepción familiar tras abandonar definitivamente el parentesco civil agnaticio, adopta únicamente la consanguinidad. Pero la adopta bajo la condición del matrimonio. Ello debido a la influencia que el cristianismo mantenía en todo el Imperio, una vez que se instala como religión oficial. Con ello se pretende fortalecer las relaciones entre parientes basadas en un modelo familiar unido por vínculos de solidaridad, lo que contribuirá de sobremanera: "a la consolidación de la institución de la legítima mediante la conservación de algunos de sus precedentes legislativos y la incorporación de novedades significativas en aspectos tales como su cuantía, relación de beneficiarios legitimarios-, o las justas causas para desheredar (Novelas 18 del 536 d.C. Y 115 del año 542 d.C., respectivamente)".
} 
que provocaron dicha reserva legal, es decir, lo que propició la implantación de una reserva legal para determinados familiares del testador. Ello encuentra la causa en las XII Tablas, al establecerse allí la libertad de disponer post mortem, también se le concedió al testador una importante libertad para legar, de la que como ya se ha apuntado anteriormente, con frecuencia se abusaba. Se cargaban las herencias con legados, hasta el extremo, que a los herederos no les merecía la pena aceptarla $^{32}$. En respuesta a ello se dictaron las tres Leyes citadas (lex Furia, lex Voconia y la lex Falcidia de legatis) la última fue la más relevante de las tres. ${ }^{33}$. Cataluña tiene mucho que decir a este respecto, ya que como dice su jurisprudencia "hunde sus raíces en el Derecho romano"34.

\footnotetext{
${ }^{32}$ La STSJ de Cataluña de 07/01/2010 (RJ 2010\4869), F.J. 5º al explicar el fundamento de la cuarta falcidia, no deja de refrendar lo expuesto en el texto sobre la Ley Falcidia y sus predecesoras: "En su origen -como nos permitimos recordar en las SS TSJC 15/1998 de 18 jun. ( RJ 1998, 10057) y 14/1999 de 21 jun. ( RJ 2000, 8028) -, la institución romana de la cuarta falcidia (Lex Falcidia de legatis del 40 a. C.), que sucedió a otros intentos fallidos de limitar la facultad del testador para realizar legados caso de las leyes Furia y Voconia, que también abarcaron las donaciones por causa de muerte (Gayo, II.225 y 226)-, tenía por objeto incentivar al heredero para aceptar la herencia gravada con legados con el fin de evitar que, por su renuncia, se produjera la total ineficacia del testamento y de todas las disposiciones particulares contenidas en él, declarando para ello, sin que el testador pudiera disponer otra cosa (ius publicum), en un primer momento, la nulidad de los legados que superasen las 3/4 partes (dodrans) del activo hereditario y, después -por influencia del derecho pretorio-, un derecho (exceptio doli) del heredero testamentario a la cuarta parte de la aestimatio de la cosa legada, por cuya virtud podía accionar para evitar el fraude a la reserva legal. Lo cierto es que, en el derecho romano clásico, la cuarta falcidia se acabó reconociendo también en los fideicomisos (senadoconsulto Pegasiano) y en los ab intestatos (rescripto de Héctor), y sus efectos se extendieron, de forma gradual, a toda suerte de disposiciones patrimoniales mortis causa, tanto a las donaciones como, en general, a las demás mortis causa capiones".
}

${ }^{33}$ Gottlieb Heineccius, J., "Elementos del Derecho Romano según el orden de las instituciones", $3^{\text {a }}$ Ed., Imprenta de Pedro Sanz y Sanz, 1842, Traducción de José de Vicente y Carabantes, págs.193 a 198. La Lex Voconia. (año 169, a C.) Curiosa esta Ley que prohibió instituir herederos a las mujeres, prohibió que a ningún legatario le llegara más, que lo que le llegaba al heredero. No tuvo tampoco éxito en cumplir su cometido. La Lex Furia (año 200, a C.) prohibió, que a ningún legatario se le pudieran asignar más de mil ases, con excepción de los parientes, y en el supuesto de pasarse el testador tenía 
La Ley Falcidia, que además de limitar los legados mediante la asignación de una cuota para el heredero garantizaba los mecanismos de protección y cumplimiento necesarios para su efectividad. Para conseguirlo fija, como se ha dicho, un tope para los legados en que no podían superar las tres cuartas partes de la herencia y en caso de exceder se establecía la reducción excedente y proporcional entre los distintos legatarios. Se trata de verdaderas obligaciones propias del Derecho público sin límite alguno de cantidad ${ }^{35}$.

En líneas generales, la Lex Falcidia, guarda o reserva alguna porción de bienes a determinados herederos. Reserva un cuarto del " $A s$ " a los herederos y, por lo tanto, el testador no puede disponer de ese cuarto ( 3 onzas) de su herencia. Visto lo expuesto, en principio, se puede equiparar a lo que se entiende hoy por legítima. La Lex Falcidia es el antecedente, más que el nacimiento de la legítima dentro de un ordenamiento jurídico. Si bien hay que distinguir que las Leyes Furia y Voconia iban destinadas contra el legatario, mientras que la Lex Falcidia iba contra el testador. Limitándole con ello su testamento, si bien, esta limitación sólo duró hasta

que restituirlos. Disponía, dicha Ley, el inconveniente que el testador podía repartir su herencia en legados no superiores a 1000 ases.

${ }^{34}$ La SAP de Barcelona (Secc. $1^{\text {a }}$ ) de 29/04/2014 (Tol. 4.374.667), con alusiones a la ya citada anteriormente STSJ de Cataluña de 07/01/2010, en su FJ $3^{\circ}$ también hace referencia a lo expuesto en el texto, acerca de la Lex Falcidia, en cuanto a su finalidad y procedencia. Como dice la STSJ. "Catalunya es una institución que hunde sus raíces en el Derecho Romano y que tiene como principal finalidad incentivar la aceptación por el heredero de la herencia excesivamente gravada con legados, cuyo origen, con precedentes en la 'Lex Furia' y en la 'Lex Voconia', se encuentra en la 'Lex Falcidia' del tribuno Publio Falcidio por la cual se dispuso que el testador no podía legar más de tres cuartas de la herencia, pues la restante cuarta parte, debía quedar íntegra para el heredero. La precitada STSJ de Cataluña se hace eco de estos orígenes y señala que: "tenía por objeto incentivar al heredero para aceptar la herencia gravada con legados, con el fin de evitar que, por su renuncia, se produjera la total ineficacia del testamento y de todas las disposiciones particulares contenidas en él" y recuerda que es una institución que siempre se ha considerado vigente en Cataluña y que en la actualidad se encuentra regulada en el Libro IV del Código Civil de dicha CCAA".

${ }^{35}$ GONZÁLEZ LÓPEZ R, “El pulso entre heredero...”, op. cit., pág. 156. 
que este pudo excluirla de su testamento, en los casos en que el heredero no era legitimario. De coincidir en la misma persona, la cualidad de heredero y de legitimario, no podía ser excluida la citada Lex Falcidia ${ }^{36}$.

La Lex Falcidia facultaba al heredero a retener bienes para en caso de liberalidad testamentaria poder pagarse su propia cuarta parte. El cálculo tenía efectos desde el momento de fallecimiento del causante, sin contar lo ganado o perdido con posterioridad, sólo las deudas, cargas y gravámenes e incluso los gastos de funeral, entierro y aceptación de herencia. Tras estas operaciones los herederos, reservadas sus cuartas partes, repartian el resto de manera proporcional a la voluntad del testador entre los distintos legatarios $^{37}$. Justiniano, en su Novela 18 con el objetivo de mejorar la reserva legal o legítima introduce cambios aumentando la porción de la reserva en proporción al número de legitimarios. Si estos legitimarios no pasaban de cuatro percibían un tercio de la herencia y si se sobrepasaba este número, la legítima, se aumentaba a la mitad de la masa hereditaria ${ }^{38}$.

\subsubsection{Destino de los legados en época romana}

La proliferación de los legados en Roma tiene su razón en la prohibición de instituir herederos a ciertos colectivos de personas. En primer lugar a las personas jurídicas, los herejes y apóstatas, los póstumos, las mujeres, en vigor esta última prohibición desde la Lex Voconia (169 a. C) ${ }^{39}$. Por lo tanto, es lógico que, frente a tal prohibición se tuviera que

\footnotetext{
${ }^{36}$ Según manifestaciones de VAllet DE Goytisolo, J.:" Deslinde de la reducción de disposiciones testamentarias que mengüen la legítima", en artículos 806 a 857 del Código Civil, Tomo XI (dir. M. Albadalejo), Edersa, Madrid, 2004, las Leyes Furia y Voconia "iban dirigidas al legatario a quien le producían una incapacitas", mientras que la Falcidia se refería al testador, limitándose su "testamenti factio".

${ }^{37}$ GONZÁLEZ LóPEZ, “El pulso entre heredero...”, op. cit., págs. 156-157.

${ }^{38}$ Llamas y Molina, S.: Comentario crítico, jurídico, literal, a las ochenta y tres Leyes de Toro, $3^{\mathrm{a}}$ ed., tomo I, Imprenta y Librería de Gaspar y Roig editores, 1853, pág. 319.

${ }^{39}$ GAmbOA URIBARREn, B.: “Mujer y sucesión hereditaria en Roma...”,op. cit., pág. 29.
} 
recurrir a los legados, para poder dejar bienes a los templos y a quienes la Ley prohibía su designación en el testamento ${ }^{40}$. En tal caso era el instituido heredero, el que entregaba los legados a los legatarios. No se verá hasta el Derecho justinianeo, con la piae causae, cambios en el aspecto de poder otorgar disposiciones testamentarias a favor de personas inciertas ${ }^{41}$.

Tras ser declarado el cristianismo religión oficial del Imperio romano, cumpliendo con los preceptos de caridad, beneficencia y de amor al prójimo que preconiza esta religión. Es bastante frecuente que sus fieles dejen sus bienes o parte de ellos a la institución a la que pertenecen, es decir, a la iglesia católica. Para su propio beneficio o bien para otras instituciones a ella adscritas, como pudieran ser oratorios, capillas, hospitales casas de acogida y otros destinados a piae causae, que proclamaban el nombre de algún santo. Ello desembocaba en lagunas

\footnotetext{
${ }^{40}$ Señala VALiÑo ARCOS, "Protección de las...", op. cit., pág. 361, "Las personas inciertas como las personas jurídicas no pueden heredar, pues sobrevivirían al testador y sus futuros componentes no podrían ser conocidos por este. Se trata de la precaución práctica de que las personas jurídicas tienen grandes patrimonios. Especialmente el pueblo romano y el fisco podían ser herederos".

${ }^{41}$ También el vigente Código civil sigue el criterio de anular la disposición testamentaria a favor de personas inciertas y el 772, recoge la manera en que el testador debe de designar al heredero. Así la SAP de Valencia (Secc. 8 ${ }^{\text {a }}$ ) de 20/10/2010, (JUR

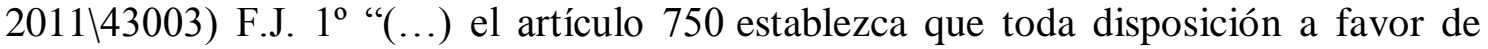
persona incierta será nula, a menos que por algún evento pueda resultar cierta, expresando el artículo 772.1 del mismo texto legal, que el testador designará al heredero por su nombre y apellido, añadiendo en el apartado 2 que aunque el testador haya omitido el nombre del heredero, si lo designare de modo que no pueda dudarse quien sea el instituido valdrá la institución. En relación a esta cuestión se ha de decir que no es necesaria la inicial determinación del heredero en su plena individualidad, pero sí que, de una manera u otra, el favorecido sea inequívocamente determinable, esto es, que el testamento contenga los datos o circunstancias precisos para llegar a una precisa identificación, de manera que no exista duda razonable de que se trata de la persona a la que el testador quiso favorecer. En cualquier caso, sí que ha de puntualizarse que no es indispensable que el testador piense en una persona determinada, con tal que sea determinable, esto es, puede ser heredero un sujeto cuya individualidad se desconoce por el momento, pero que puede ser averiguada en el futuro, con ayuda de las circunstancias que señale. La jurisprudencia entendió que se trataba de institución de persona cierta en los siguientes casos: $1^{\circ}$ ) La persona que fuese " director" de cierta sociedad cultural (...)".
} 
jurídicas y prohibiciones como las expuestas de otorgar disposiciones testamentarias en favor de personas inciertas. Justiniano lo soluciona con una ficción dotando de personalidad a Jesucristo, la Iglesia Católica, santos, ángeles, etc. De esta manera estas instituciones adquieren capacidad jurídica y de obrar, por lo que ya pueden intervenir en el tráfico jurídico. Ya pueden disponer de patrimonio, contratar y aceptar herencias entre otros supuestos. En definitiva, las iglesias, conforme a sus estatutos sociales son las encargadas de la administración de los bienes destinados a Jesucristo, ángeles, mártires y otras figuras de similar naturaleza ${ }^{42}$.

En la Novela 139, del año 530, se regula acerca de las herencias y legados que se dejan para causas pías. El Capítulo 9 recoge acerca de las herencias y legados otorgados a Jesucristo o a los santos. Ante tal supuesto, lo heredado o legado en su nombre lo recibe la iglesia de la localidad del domicilio del testador. Cuando el favorecido por herencia o legado es un santo, lo recibía la iglesia que lo albergaba. Ello, junto a la validez que otorga este Emperador a las herencias, legados y fideicomisos a favor de Jesucristo, santos, iglesias, arcángeles, etc. ${ }^{43}$

\subsubsection{La legítima como protección a la familia con Justiniano}

\footnotetext{
${ }^{42}$ Señala BuENo DELGADO, J. A.: "El régimen económico y fiscal del estamento clerical, en la legislación justinianea", en Hacia un Derecho administrativo, fiscal y medioambiental romano III, (coords. A. Fernández Buján, G. Jerez Kraemer), Dykinson, Madrid, 2016, pág. 503, apoyándose en BLANCH; (cita 62) Régimen jurídico de las fundaciones en derecho romano, Madrid 2007, p. 183, "el cristianismo vino a fomentar y a dar cauce legal a un latente espíritu de fraternidad y solidaridad entre los ciudadanos del Imperio Romano, y así, lo cierto es que desde su reconocimiento oficial surgieron numerosas fundaciones benéficas cristianas".

${ }^{43}$ Bueno Delgado, "Derecho fiscal...", op. cit., págs. 504 a 506. "Al reconocerles capacidad, las corporaciones autorizadas colegios, sociedades, u otras cualquiera con esos nombres, pueden tener, siguiendo el modelo de la República, bienes comunes, caja común, y apoderado o síndico por medio del que, como en la República, haga y trate lo que deba hacer y tratar en comunidad".
} 
La legítima se convierte en una figura jurídica de protección a la familia con las modificaciones legislativas introducidas por Justiniano. El Derecho promulgado por el citado Emperador tiene tendencia a limitar la libertad de disposición post mortem manifestada en las XII Tablas. Las reformas que llevó a cabo este Emperador romano consistieron en la implantación de un sistema legitimario material y con protección a los herederos de herencias dañosas mediante la aceptación, de las mismas, a beneficio de inventario. También abordó el tema de las legítimas en sucesivas ocasiones. Así, con la publicación de la Novela $18^{44}$ (año 536) y con la Novela 115 (año 541) que era complementaria de la primera ${ }^{45}$. Destacar de la Novela 115 la disposición por la cual era preciso que lo dejado al legítimario en pago de su legítima fuera dejado bajo el título de heredero, caso contrario el testamento devenía nulo, aunque la cuantía fuera la legal, pero amparada bajo otro título distinto al de heredero. Disposición que con posterioridad recogerán las Partidas (Ley 5, Tit. 8, P. $\left.6^{\mathrm{a}}\right)^{46}$

La Novela 18, Capítulo I, determina la cuantía de la legítima, por lo que distingue el número de hijos. De tener el causante cuatro, o menos hijos, la parte que se les debía reservar, era de un tercio del total de la

\footnotetext{
${ }^{44}$ Rivas MartíneZ, J.J.: "Derecho de sucesiones. Común y Foral", tomo. II, Vol. I, 4a ed., Dykinson, 2009, pág. 1799. Además de situar la legítima en la Novela 18, aporta, este autor, sobre la Novela 115, la obligación del testador de dejar la legítima de descendientes y ascendientes por institución de herederos.

${ }^{45}$ SÁNCHEZ-VENTURA MORER, I.: "Limitación de la responsabilidad a los bienes de la herencia por una de las deudas que conforma el haber hereditario" Revista Crítica de Derecho Inmobiliario, núm. 757, 2016, pág. 3280. La conocida y temida "confusión de patrimonios", que suponía y supone la aceptación de una herencia, era y es ejecutable sobre los bienes de la propia herencia y sobre los del que la ha aceptado. Agotados los primeros, contra este supuesto perjuicio en herencias de dudosa solvencia, estableció, Justiniano, la facultad de poder aceptar la herencia, separarla de su propio patrimonio frente a los acreedores de la misma.

${ }^{46}$ VAllet De Goytisolo, J.: "Comentarios al Código civil y Compilaciones Forales", tomo XI, $2^{\text {a }}$ ed (dir. M. Albadalejo), Revista de Derecho Privado, Madrid 1982, pág. 210.
} 
herencia. En cambio, si el número de hijos era superior a cuatro se reservaba la mitad de la masa activa. También mantiene el citado texto legal que el testador tenía que reservar un cuarto de la herencia a descendientes que no fueran hijos legítimos y ascendientes con derechos hereditarios $^{47}$. Tras quedar establecida la parte que correspondería a los distintos legitimarios, la manera que tenían para impugnar el testamento que no respetaba la legítima era por medio de la "Querella inofficiosi testamenti $^{\text {,48 }}$

Más que instaurar el derecho legitimario, esta Novela18 adecua la porción legítima heredada en función del número de sujetos legitimarios, ya que con anterioridad a esta constitución, era una cuarta parte, la reservada a herederos sin tener incidencia el número de hijos ${ }^{49}$. En consecuencia, la porción de que disponía libremente el testador era de los tres cuartos restantes de la masa hereditaria. Por lo tanto, las Novelas $18 \mathrm{y}$ 115, suponen la plena existencia de un sistema legitimario, con la prohibición de la desheredación sin justa causa ${ }^{50}$. Se entienden por causas

\footnotetext{
${ }^{47}$ Cerdé Jimeno, J.: “Costumbres jurídicas en las Pithiusas”, Dykinson, 2011, pág. 21.

${ }^{48}$ Polo ARÉvalo E. M.: “Concepto y Naturaleza Jurídica de la Legítima en Derecho Sucesorio Español: precedentes y actualidad”, Ridrom, núm. 10, 2013, pág., 343. La querella inofficiosi testamenti, era el medio de que disponía el legitimario preterido (olvidado) o desheredado de impugnar el testamento bien demandando su anulación total o parcial que por medio de la actio ad supplement, podia solicitar el complemento de legitima al que tenía derecho. Esta última acción citada, según la autora, evitó tras su implantación definitiva en época de Justiniano, muchas impugnaciones de testamentos, al permitir que el legitimario recobrara su derecho sin tener que anular el testamento que conllevaba la puesta en marcha, según épocas, de la sucesión abintestato.

${ }^{49}$ Destacable el paso que se da con Justiniano, de pasar de una legítima estricta, a una legítima flexible. Esta flexibilidad entre la reserva legal y el número de legitimarios anterior y posterior a Justiniano respectivamente, se refleja con posterioridad en distintos ordenamientos como el italiano, entre otros, que irán apareciendo a lo largo de este trabajo.
}

${ }^{50}$ DonAT, J.: Las leyes civiles en su orden natural, Tomo III, Imprenta de José Taulo, Barcelona, 1841. pág. 229. Este autor distingue dos clases de causas para poder desheredar a un legitimario. La primera es todo lo que atente contra los padres como atentar contra la vida de estos. La segunda, todo aquello que excite su indignación, 
de desheredación, todas aquellas que atraigan la ingratitud de los padres. Se llegaron a fijar 14 causas de desheredación de los descendientes en la Novela 115 trasladándose este mismo régimen a las Siete Partidas y con posterioridad sirvieron de base a la confección del Código civil español de $1889^{51}$.

También cabe entender por ingratitud, las causas que no sean conformes con un deber para con dichos progenitores y atraigan la cólera de éstos, sobre sus hijos: el atentado contra la vida, maltrato, injuria y la falta generalizada de prestar atención a los padres, teniendo posibilidad de prestarla a nivel económico o moral.

Llegado este punto cabe preguntarse qué razón hizo llegar a Justiniano a tomar tal decisión, es decir, la implantación de las legítimas (tal como hoy se conocen) y la regulación de la desheredación. En la propia Novela 18 se puede obtener la respuesta. Es evidente que, con anterioridad, la lex Falcidia, limitaba la reserva legal a un cuarto de la herencia para los herederos del causante, por lo tanto, este disponía de tres cuartos, de sus bienes, a su antojo. No obstante parece ser, que no era suficiente la reserva para frenar los abusos cometidos por los testadores para con sus familiares íntimos. Dicho de otra manera, trata de evitar Justiniano, con la implantación en la Novela 18 "De las legítimas", la injusticia acaecida sobre los hijos con el anterior sistema de reservas. Por lo que respecta a la

como por ejemplo provocar la indignación de un padre dedicándose el hijo a una profesión deshonesta.

${ }^{51}$ BARCELÓ DOMÉNECH, J.: "La desheredación de los hijos y descendientes por maltrato de obra o injuria graves de palabra", Revista Crítica de Derecho Inmobiliario, núm. 682, marzo-abril, 2004. Por lo que a la desheredación se refiere, mantiene este autor, que no se necesitaba con anterioridad a Justiniano, de motivación alguna, simplemente el requisito era expresar en su testamento: "que desheredaba a...". 
Novela 115 limitaba la facultad del testador prohibiendo la preterición y la desheredación injusta ${ }^{52}$.

Con el Emperador Justiniano, no sólo se asienta el momento en el que surge la legítima actual, sino que marca el verdadero cambio en el derecho sucesorio que demandaba la evolución familiar y social en base al cambio surgido de la agnación primitiva a la cognación experimentado por la familia en época imperial. Una etapa de transición que, la doctrina científica situa entre el 451(a.C), hasta la época Justinianea del 527, d.C) ${ }^{53}$. La legítima romana de los descendientes y ascendientes constituyó una pars hereditatis, hasta el extremo que no se consideraba satisfecho el derecho del legitimario si su portio debita se le había dejado en el testamento por cualquier otro concepto, como pudiera ser legado, donación o fideicomiso. En cambio, el resto de legitimarios sí que podían recibir su legítima parte por cualquier otro título ${ }^{54}$. De ahí que la legítima dejada a los legitimarios distintos de los ascendientes y descendientes (hermanos del testador) pueda ser conceptuada como pars o quota bonorum ${ }^{55}$.

\subsection{LA LEGÍTIMA EN EL FUERO JUZGO}

Tras la caída del Imperio Romano, el Liber iudiciorum (Lex visigothorum, Lex Gótica, Codex visigothorum) actúa como transmisor del sistema jurídico romano. En el siglo XIII es traducido del latín al romance

\footnotetext{
${ }^{52}$ Cerdá Jimeno, “Costumbres jurídicas...”, op. cit., pág. 386.

${ }^{53}$ FILIPPI, M. C.: "Sucesión ab instestato en la ley de las XII tablas", Anuario de Derecho Civil, núm.7, 2012, pág. 121.

${ }^{54}$ BERNAD MAINAR, “La porción legítima...”, op. cit, pág. 1767.

${ }^{55}$ POLO ARÉVAlo, “Concepto y Naturaleza...”, op. cit. págs. 335 y 336. "La Novela 18 salvaguarda en su inciso final la parte de la herencia que les correspondía a la personas que podían atacar el testamento por inoficioso por medio de la querella inofficiosi testamento. El testador debía reservar una cuarta parte se sus bienes para descendientes ilegítimos y ascendientes que fueran herederos civiles o pudieran recibir los bienes como bonorum possessores- los hermanos del testador y los hermanos de padre-, aunque fueran de distinta madre".
} 
con el nombre de Fuero Juzgo. De dicha manera se convierte en uno de los sistemas que contribuyen a la imposición en el Derecho castellano del modelo de legítima romana, la cual limitaba la libertad de disposición por parte del testador, hasta los cuatro quintos del haber hereditario ${ }^{56}$.

El Codex visigothorum se separa de la configuración romana, de la legítima, disponiendo que de los hijos fuesen todos los bienes del padre, a excepción de la quinta parte, ya que dicha porción se le permitía, dejarla a favor "de su alma o de extraños". Dicho de otra manera, podía disponer de un quinto, de sus bienes, para satisfacer su voluntad y los cuatro quintos restantes, les correspondían a sus hijos. Estas cuatro quintas partes de la masa hereditaria se dividían en tres partes, de las que dos correspondían a los hijos, por igual y la tercera parte puede el padre otorgarla como mejora, a cualquiera de sus hijos ${ }^{57}$.

\subsection{LA CUARTA FALCIDIA CONTENIDA EN LAS PARTIDAS}

El Libro de las Leyes responde a un cuerpo legal redactado por la Corona de Castilla entre 1252 y 1284 durante el reinado de Alfonso X con el objetivo de conseguir la uniformidad jurídica en el Reino. Hacía el siglo IV recibió su actual nombre de las Siete Partidas o simplemente Partidas

\footnotetext{
56 De BARRón ARniches, P.: "El pacto de renuncia a la legítima futura", Cedecs, Barcelona, 2001, pág. 32.

${ }^{57}$ Llamas y Molina, S.: Comentario crítico, jurídico, op. cit., pág. 320. Pone como referencia a lo expuesto, la Ley $1^{\text {a }}$, Tít. 5 , Lib. $4^{\circ}$ del Fuero Juzgo, referente al tema aquí tratado, por poner un ejemplo: un testador que tiene tres hijos y un patrimonio de $500 €$. La primera operación que debía hacer con arreglo al Fuero Juzgo era dividir 500 entre 5 con un resultado de 100; $(500 / 5=100)$ por lo tanto disponía de 100 para su libre disposición y de los 400 restantes $(500-100=400)$ tras dividirlos entre tres $(400 / 3=133,33)$. Dispone de dos partes, es decir, 133,33 x2 $=266,67$ para repartirlos entre sus tres hijos $(266,67 / 3=88,89) 88,89 €$ para cada uno y el tercio restante $(133,33)$ usarlo en concepto de mejora entre sus hijos. En consecuencia, puede mejorar, con dicho tercio, al que estime de sus hijos, a uno, varios o a todos mejorarlos por igual ya que de la mejora de ese tercio, dispone el padre para con sus hijos.
} 
debido al número de secciones en que está dividida la obra. La Partida XI es la que recoge del Derecho de Justiniano las sucesiones ${ }^{58}$.

La Partida XI, Tit. XI, Ley I, contiene lo referente al límite de la cuantía de los legados la "cuarta falcidia". De consumir el testador todos sus bienes en legados y donaciones, de manera que no quedara nada para el heredero. Este podía, en tal caso, reducir a cada legatario la cuarta parte de su legado y con ello formar su cuarta falcidia. En el supuesto de no llegar a cubrir el heredero su cuarta parte deberá quitar proporcionalmente a cada uno lo que le falte para completarla. De coincidir en la misma persona el derecho a cuarta falcidia y legítima, es decir, si el instituido heredero es a la vez descendiente o ascendiente del causante. En este caso deberá, el heredero detraer su legítima, pero no, la cuarta falcidia de los legados ${ }^{59}$.

Si bien es cierto que podía entenderse una cierta similitud entre falcidia y legítima, ya que ambas figuras tratan de hacer una reserva por medio de la Ley ${ }^{60}$. Es decir, ambas eran reservas legales, y también cuartas partes de reserva, pero son instituciones completamente distintas en lo que a su fundamento se refiere ${ }^{61}$. La legítima está vinculada exclusivamente al parentesco y la falcidia no. Sólo son legitimarios los descendientes,

${ }^{58}$ CAMACHO Clavijo, S.: El testamento revocatorio. La reorganización de la sucesión mediante la revocación testamentaria, Marcial Pons, Madrid, 2015, pág. 48.

${ }^{59}$ DíAZ GonZÁLEZ F.J.: "El derecho de sucesiones en los primeros manuales de Derecho español: el caso de la ilustración del Derecho Real de España de don Juan Salas Bañuls (II)," Anuario de la Facultad de Derecho-Universidad de Alcalá, núm. 5, 2012, págs. 347 y 348.

${ }^{60}$ El parecido entre ambas instituciones, falcidia y legítima, podría ser la explicación que, según Montagud i EstRagues, T.: "El testamento inoficioso en las Partidas y sus fuentes", Anuario de historia del Derecho español, núm. 62, 1992, pág. 258 y 302, algunos glosadores de la Edad Media, utilizaran indistintamente el término falcidia para referirse a la legítima. El propio autor pone como referencia "Lo Codi 635, al regular en que forma el padre o el abuelo pueden hacer testamento entre sus hijos, al menos en la cuota que determina la Falcidia, que significa la portio debita al hijo".

${ }^{61}$ ESQUIROL GIMÉNEZ, V.: "La prohibició de la quarta falcídia: exigència de manifestació expressa per part del testador”, Indret, núm. 1, 2011, pág. 10. 
ascendientes y cónyuge del causante. En cambio, el derecho a la falcidia se adquiere por ser heredero y no por parentesco. De ahí, que puedan coincidir ambos derechos en una misma persona. El espíritu de ambas instituciones es muy diferente ya que el fundamento de la falcidia, como se ha dicho, era incentivar la aceptación de la herencia por parte del heredero poco favorecido por las disposiciones testamentarias, para evitar que su repudiación a la herencia afectara a la eficacia de los legados ${ }^{62}$.

El Tit. XI, de la Ley III recoge el tiempo que debe transcurrir para que el heredero pueda detraer su cuarta parte (Falcidia). La cuantificación de los bienes del causante debe ser efectuada al tiempo de fallecimiento de este, y es en ese tiempo, cuando el heredero debe sacar las partes. Si después se acrece o se reduce, el daño o beneficio producido corresponde al heredero, dejando de participar en las ganancias o pérdidas patrimoniales los legatarios.

Excepcionalmente en Ley IV se recogen los legados que no están sujetos a reducción de la cuarta falcidia. Son los dejados por parte del testador para obras piadosas, como pueda ser la iglesia, hospitales, etc., los otorgados en virtud de testamento militar y conforme a la Ley VI, los legados de cosa identificada o determinada en cuya causa testamentaria se prohíba su enajenación. El heredero para tener derecho a deducir su cuarta parte ha de hacer necesariamente inventario de la herencia ${ }^{63}$.

\subsection{LAS LEYES DE TORO}

Interesa esta legislación del siglo XVI, en particular, por tratar de armonizar el vigente Derecho civil de la época, entre otras, la materia de sucesiones. Las novedades que aporta este texto legal, al sistema

\footnotetext{
${ }^{62}$ ESQUIROL JiMÉNEZ, “La prohibición...”, op. cit., pág. 10.

${ }^{63}$ DíAZ GonZÁlez F. J.: “E1 Derecho de sucesiones...”, op. cit., pág. 348.
} 
legitimario, es muy importante ya que regula por primera vez, dentro del Derecho español, la mejora de origen germánico de manera detallada. El testador, en base a las Leyes de Toro podía dejar una parte de sus bienes (mejora) a uno o varios de sus legitimarios, por supuesto respetando la legítima corta entre ellos ${ }^{64}$.

Lo que al tema presente aporta la citada Ley, se puede resumir en el inmenso rechazo que provocaba en aquella sociedad el hijo de clérigo. Llevándolo hasta el extremo de no poderle dejar su madre, ni siquiera por razón de alimentos, ninguna cosa. El argumento a esta negación, está en que los alimentos son debidos al que los necesita, y por ser su hijo un necesitado de ellos, su madre, se los podía conceder, pero no por el hecho de ser hijo de clérigo ${ }^{65}$. También coinciden otros autores en este mismo aspecto $^{66}$.

\subsection{LA RESERVA LEGAL HASTA LA CODIFICACIÓN}

La legítima desde Roma hasta la codificación española ha sufrido las siguientes variaciones:

\footnotetext{
${ }^{64}$ DE BARRón ARMiches P.: El pacto..., op. cit., pág. 321. Pone de manifiesto, esta autora, el paralelismo que existe entre el pacto de mejora de las Leyes de Toro y el pacto de renuncia a la herencia futura. El testador, en este último caso, pacta con el legitimario una renuncia a la legítima de éste a la muerte de aquel. A cambio de cierta compensación que recibe el legitimario en vida del testador.

${ }^{65}$ Llamas y Molina, Comentario crítico, jurídico..., op. cit., págs. 177-180.

${ }^{66}$ Álvarez Posadilla, Comentarios a las Leyes de Toro..., op. cit. pág. 101. Dos importantes preguntas se hace a sí mismo el autor:

"¿Por razón de alimentos podrá la madre dejar alguna cosa al hijo de clérigo, fraile, etc.? Su propia respuesta es," un no rotundo, en base a que los alimentos sólo son debidos a los que los necesitan tanto si son hijos de clérigo como si no lo son."

"¿Se les puede dejar a los hijos de clérigo el quinto $1 / 5$ de sus padres con pretexto de alimentos? Ni con el pretexto de los alimentos se les puede dejar el quinto y ello en base a que la mayor parte de las veces el quinto no será suficiente para cubrir dichos alimentos, pero es por la circunstancia personal del individuo y no por precedente sentado para todo hijo de clérigo."
} 
- Derecho romano, Lex Falcidia: reserva un cuarto a herederos.

- Justiniano:

○ Reserva de un tercio (1/3) para legítimas, si hay cuatro o menos legitimarios.

- Reserva de un medio (1/2) para legítimas, si hay más de cuatro legitimarios.

- Derecho germánico- visigodo:

○ Cuatro quintos (4/5) reservados para pagar legítimas.

○ Un quinto (1/5) para libre disposición.

- No admitía una legítima para los ascendientes, si bien eran llamados a la sucesión intestada a falta de descendientes legítimos.

- Fuero Real:

- Recoge la reserva de los cuatro quintos (4/5) visigodos.

○ No permite que se acumule en un mismo descendiente el tercio de mejora y el quinto de libre disposición.

- Siete Partidas: (Partida Sexta)

○ Un tercio (1/3) de reserva si concurren cuatro o menos legitimarios.

○ Un medio (1/2) si concurren más de cuatro hijos o descendientes legítimos.

- Un tercio (1/3) para los ascendientes en defecto de descendientes.

- Leyes de Toro: (Restauran el sistema de quintos visigodo)

- Cuatro quintos (4/5) para legítima de descendientes. 
○ Un quinto (1/5) para libre disposición.

- Posibilidad de mejora de tercio (1/3) y quinto (1/5).

○ Dos tercios es la legítima de los ascendientes a falta de descendientes.

\subsection{LA LEGÍTIMA EN LA CODIFICACIÓN ESPAÑOLA}

La reforma de la legislación civil española comienza con la propuesta de revisión de la legislación existente hasta aquellos momentos. Hecha, la citada proposición, a las Cortes de Cádiz a finales de 1810, por el diputado liberal y eclesiástico D. José Espiga y Gadea, proposición que sería aprobada por dichas Cortes en febrero de $1811^{67}$. Dentro de la época de la codificación, en España se pueden encontrar distintos proyectos de Código Civil, incluso algunos de gran utilidad para la confección del de 1851 del que, este último, será la principal fuente del definitivo y convertido en la ley de 1889. El proyecto de 1851 es un punto de confluencia de labor doctrinal desarrollado, en épocas anteriores tanto en España como fuera de ella $^{68}$. Este proyecto es conocido como el proyecto de Código civil de García Goyena o proyecto isabelino.

Cabe destacar sobre este proyecto, que mantiene a los ascendientes y descendientes legítimos, dentro de los herederos forzosos. Con respecto a la porción que ha de reservarse, su acogida a la de los cuatro quintos. Por lo tanto, un quinto para libre disposición en el supuesto de tratarse de descendientes, reduciéndose a los dos tercios, si se trata de un solo

\footnotetext{
${ }^{67}$ Peset Reig M.: "Análisis y Concordancias del Proyecto de Código Civil de 1821", Anuario de Derecho civil, Vol. 28, núm. 1, 1975, págs. 83-85.

${ }^{68}$ BARÓ PAZOS J.: "La Codificación del Derecho Civil en España, 1808-1889". Universidad de Cantabria, 1993, pág. 18. Este autor mantiene: que la no promulgación del proyecto de 1851, fue debido "a su carácter unitario y afrancesado". Matizando lo dicho, con la oposición de la iglesia, la no concordancia con el derecho foral y la regulación del derecho de propiedad entre otros matices.
} 
descendiente. La legítima de los ascendientes es de dos tercios y de tratarse de uno sólo se reduce a la mitad, ello todo a falta de descendientes (artículos 641, 642 y 646 del proyecto de 1851) ${ }^{69}$. Fue un Proyecto mal recibido en las regiones con Derecho foral, ya que alteraba o suprimía instituciones de dichas zonas. Así en Cataluña, por ejemplo, se alteraba la legítima, la enfiteusis, el censo, entre otras instituciones, es decir, el proyecto encerraba un sistema rígido de legítimas, artículo 642. Además se posicionaba contrario a la libertad de disposición post mortem $^{70}$.

Bajo la iniciativa del entonces Ministro de Gracia y Justicia, ÁLVAREZ BUGALLAL, S..$^{71}$, la codificación española recibió un nuevo impulso, cuando mediante el Real Decreto de 2 de febrero de 1880 se nombró y se reestructuró la Comisión General de Codificación, con el fin de proceder a la confección de un Código Civil. Este Real Decreto además de mejorar la organización de la Comisión agrega un vocal por cada región foral $^{72}$. Tuvo que ser otro Ministro de Gracia y Justicia, D. Francisco Silvela, el 7 de enero de 1885, el que propusiera de nuevo al Senado realizar un proyecto de ley de bases para confeccionar un Código civil

\footnotetext{
${ }^{69}$ SÁnChEZ Román, F.: La Codificación Civil en España, Sucesores de Rivadeneira. Impresores de la Real Casa, Madrid, 1890, pág. 22.

${ }^{70}$ BARÓ PAZOS, J.: "El Derecho civil de Cataluña ante el proceso codificador español”, Glossae: European Journal of Legal History, núm. 12, 2015, pág. 125. Manifiesta el autor, que hubo reacción por parte de Cataluña en contra del Proyecto de 1851, "Pero entiéndase bien; reacción no significa oposición contundente de Cataluña frente al proyecto redactado. Incluso hubo letrados catalanes, integrantes de círculos liberales, que se manifestaron a favor de aspectos concretos del proyecto, como el sistema rígido de legítimas y, simultáneamente en contra de la libertad de testar. Y desde amplios sectores de Cataluña cercanos al liberalismo, se intentó en todo momento, que sus instituciones peculiares formasen parte del Código, o que al menos se contemplase un régimen excepcional que permitiese el mantenimiento, por razones socio-económicas, de estas instituciones con arraigo en la sociedad".

${ }^{71}$ SENAdO DE EsPaÑa (000013344) [ÁLVAREZ BUGALLAL, Saturnino. Ministro de Gracia y Justicia y Diputado a Cortes] (1880-1881)

${ }^{72}$ LASSO GAITE, J. F.: “Crónica de la Codificación en España. El procedimiento civil”. Reimpresión, Imprenta Nacional del Boletín Oficial del Estado, Madrid 1999, pág.132.
} 
precisamente sujeto a dichas bases aprobadas por ambas Cámaras. El dictamen de la discusión parlamentaria se sancionaba el día 11 de mayo de 1888, por la Corona dando lugar a la ley de esta fecha, fundamento legal supremo del llamado Código Civil ${ }^{73}$.

Ya en la elaboración del Código civil hubo discrepancias con el artículo $806 \mathrm{Cc}^{74}$. Respecto a si se debía implantar la legítima o la libertad de testar, es decir, hubo discusión parlamentaria con el contenido del precepto último citado, a la hora de dictar las bases para la confección del Código civil $^{75}$. Sólo puedo pensar, frente a este planteamiento, que si a fecha anterior a la promulgación del Código civil de 1889, y ello era en el siglo XIX, los juristas y políticos ya discutían por la mal llamada libertad de testar y la permanencia de las legítimas, no se trata en absoluto la abolición o permanencia de las legítimas, de una demanda social que requiere la actual sociedad ${ }^{76}$. La familia española característica de la Edad

${ }^{73}$ SÁnchez Román, La Codificación Civil..., op. cit. pág.43.

74 ARTí́culo 806 CC. Legítima es la porción de bienes de que el testador no puede disponer por haberla reservado la ley a determinados herederos, llamados por esto herederos forzosos.

75 VAllet De Goytisolo J. B.: "Significado Jurídico-Social de las Legítimas y de la Libertad de Testar" Anuario de Derecho Civil, 1967, págs. 14-16. Este autor afirma sobre las discrepancias aludidas en el texto, entre D. L. Alonso Martínez, como defensor de la implantación de la legítima en el futuro y debatido Código civil español. En cambio, D. Gumersindo de Azcarate y Menéndez (1840-1917), entre otros, como defensores de la libertad de testar dice que "robustece la autoridad paterna, garantiza el acierto sobre la elección del heredero o en la distribución de la herencia, estimula la cooperación y el esfuerzo de los hijos, conserva la familia evitando su liquidación, mantiene el espíritu y las tradiciones familiares, es escuela de cumplimiento de los deberes familiares, de los que se inviste el heredero". Para Alonso Martínez el más decisivo argumento a favor de la conservación de las legítimas fue: "que no es justo y bueno en sí, un sistema que permita enriquecer a un extraño a expensas de la familia".

${ }^{76}$ En el ordenamiento español, teniendo plenas facultades mentales, no hay precepto vigente que restrinja la libertad para que una persona pueda otorgar testamento. Incluso puede decidir libremente si hace o no hace testamento, o lo hace cerrado o abierto o bien decide no ir a la notaria y realizar un testamento ológrafo. Por lo expuesto, no encuentro traba alguna a la libertad de poder testar. Otra cosa muy distinta es las distintas restricciones que determinadas personas, con legitimarios han de tener en cuenta si otorgan testamento y que previene la Ley para sus legitimarios. Frente a este 
Media, anterior a la recepción del Derecho romano y canónico, es un grupo parental o consanguíneo. La familia moderna española es una familia (de normal el matrimonio y sus hijos) que se moldea a la imagen de la familia romana, es decir, de carácter patriarcal. En la que impera, de manera tajante, el cabeza de familia y ello va a proseguir hasta muy avanzado el siglo XIX. Durante toda la Edad Moderna, perdura en líneas generales lo dispuesto en las Siete Partidas, si bien con las aclaraciones de las Leyes de Toro y ligeras modificaciones ${ }^{77}$.

supuesto, sólo tendría cabida la restricción para otorgar post mortem, determinados testadores sus bienes (los que tengan legitimarios) el resto tienen toda la libertad. tanto para otorgar testamento como para otorgar su patrimonio tanto en vida como con posterioridad a su muerte a quien por conveniente estimen. La prueba que acredita lo expuesto es que en el supuesto de concederse la mal llamada libertad de testar los testadores sin legitimarios se quedarían exactamente igual como están ahora. Por lo tanto, demostradas las inexistentes restricciones en España para testar, las restricciones para otorgar bienes post mortem, para los testadores con cargas familiares se tendrían que denominar, de ésta manera y no como se le denomina en muchas ocasiones cuando el testador con cargas familiares ha de proceder a reservar cierto número de bienes para sufragar a sus legitimarios la parte que por Ley les corresponde.

${ }^{77}$ GACTO FERNÁNDEZ, E.: "El marco jurídico de la familia castellana: Edad Moderna", Deposito de Investigación de la Universidad de Sevilla, 1984, pág., 41. Apunta este autor que esta estructura familiar es en la que se asientan la Siete Partidas. Se repite de manera literal el derecho implantado por Justiniano. 


\section{CAPÍTULO II. LA LEGÍTIMA EN LA ACTUALIDAD}

\subsection{INTRODUCCIÓN}

Nuestra actual legítima es el fruto de una evolución histórica que nace en el Derecho romano pasando por una marcada influencia germánica cuya trayectoria acaba en la codificación francesa. Este modelo francés es recogido por la mayor parte de los ordenamientos jurídicos pertenecientes a la familia del Derecho romano. Si bien entre ellos se pueden distinguir marcadas diferencias en cuanto a los legítimarios, la cuota de legítima y su naturaleza jurídica ${ }^{78}$. La legítima existe con independencia de que haya o no testamento. Cualquiera que haya sido el cauze sucesorio por el cual se ha deferido la herencia tanto si ha intervenido el testador o ha sido por disposición legal. Son las maneras de suceder denominadas testamentaria e intestada $^{79}$. Siendo esta última de carácter supletorio o dispositivo, que causa efecto únicamente en defecto de negocio jurídico privado válido que ordene la sucesión. Existiendo tres tipos de sucesores legales o legítimos: los parientes del testador, el cónyuge supérstite y el Estado ${ }^{80}$. Estas tres categorías de sucesores se asientan precisamente en el parentesco, el matrimonio o la nacionalidad ${ }^{81}$.

La apertura de la sucesión intestada, legítima o legal se articula en base a llamamientos cuya efectividad se produce en unos, cuando hay defecto de los otros. Es preferente el llamamiento que se hace a la línea recta

\footnotetext{
${ }^{78}$ BERNAD MAINAR, "la porción legítima...", op. cit., pág. 1766.

${ }^{79}$ IRURZUN GOICOA, D.: “¿Qué es la legítima para el Código Civil español? (Búsqueda de su concepto, naturaleza y caracteres)", Revista Crítica de Derecho Inmobiliario, núm. 759, enero 2017, pág. 2526.

${ }^{80}$ DíEZ PiCAZo, L. y Gullón, A.: Sistema de Derecho civil, Vol. IV, tomo $2^{\circ}$ (Derecho de Sucesiones), 12 ed, Tecnos, Madrid, 2017, pág. 210.

${ }^{81}$ Lasarte Álvarez, C.: Derecho de sucesiones. Principios de Derecho civil, $10^{\mathrm{a}}$ ed, Marcial Pons, Madrid, 2015, pag. 239.
} 
descendiente de ahí que los hijos y sus descendientes sucedan a sus padres y ascendientes. Los hijos del finado heradan siempre por derecho propio dividiendo la herencia entre ellos a partes iguales, sin perjuicio de la legitima (1/3 en usufructo) que le correspone al cónyuge supérstite ${ }^{82}$. La sucesión legal o abintestato no afecta en absoluto a la cuantía variable que en usufructo le concede el Código civil al cónyuge supérstite en calidad de legitimario $^{83}$. El llamamiento a descendientes que no sean hijos tiene lugar por derecho de representación. En defecto de la línea descendiente la ley llama a los ascendientes que heredan, padre y madre por iguales partes. En el supuesto de haber fallecido alguno de ellos hereda el superviviente toda la herencia. En defecto de padres del causante son llamados los ascendentes más próximos en grado. En el supuesto de existir cónyuge viudo del causante tiene que respetarse la cuota usufructuaria (la mitad de la herencia) que le otorga el artículo 837.1 Cc. El llamamiento al cónyuge viudo se antepone a los colaterales y finalmente es llamado el Estado (o Comunidad Autónoma) en defecto de cónyuge y parientes dentro del cuarto $\operatorname{grado}^{84}$.

Por lo que respecta a los legitimarios en la sucesión testada en el Derecho español, si bien algunos Derechos forales se decantan por el principio de plena libertad de disposición post mortem (Navarra y parte del País Vasco donde rige el Fuero de Ayala), en la mayor parte de ellos se reconoce la institución de la legítima. Se reputan legitimarios en el Derecho

\footnotetext{
${ }^{82}$ LaSARTE Álvarez, Derecho de sucesiones..., op. cit., pág. 240.

${ }^{83}$ LASARTE ÁlVAREZ, C.:" Concurrencia de hijos de anterior matrimonio y cónyuge supérstite en la sucesión intestada", Revista Crítica de Derecho Inmobiliario, núm. 734, 2012, pág. 3290. Por aplicación del artículo 834 Cc al viudo le corresponde en usufructo un tercio de la herencia si concurre a la sucesión con hijos o descendientes propios y del causante, siempre que el viudo no se encuentre separado judicialmente o de hecho (Ley 15/2015, de 2 de julio de la Jurisdicción Voluntaria). En el supuesto de concurrir a la sucesión con ascendientes su cuota alcanzará en usufructo a la mitad de la herencia.
}

${ }^{84}$ DíEZ- PiCAZO y Gullón, Sistema de derecho civil..., op. cit., págs. 213 y 214 
común, Mallorca y Menorca a los descendientes, ascendientes y al cónyuge viudo. En cambio, en Cataluña, Ibiza y Formentera, Vizcaya donde rige el Fuero de Ayala, no es legitimario el cónyuge viudo. En Aragón sólo son legitimarios los descendientes, mientras que en Galicia no son legitimarios los ascendientes pero si que lo son los hijos y descendientes y el cónyuge supérstite, pero lo son en calidad de usufructuarios ${ }^{85}$.

La cuota legitimaria encuentra entre los distintos Derechos españoles un cierto equilibrio: mientras que legislaciones como el Derecho común; Baleares; País Vasco (donde no rige el Fuero de Ayala) reconocen una cuota variable de la porción de legítima. En cambio Cataluña, Aragón y Galicia mantienen una cuota fija de legítima. Respecto de la naturaleza jurídica que presenta la cuota de legítima en los ordenamientos españoles, constatamos diversidad de configuraciones. Así el Derecho común mantiene la legítima como pars hereditatis, con determinadas reservas al poderse reputar como pars bonorum ${ }^{86}$. En Cataluña y Galicia la legítima constituye un derecho de crédito, es decir, pars valoris. En Aragón, Mallorca y Menorca la legítima se compone de una porción de bienes- pars bonorum-. Se considerera la legitima en Ibiza, Formentera y en parte de Vizcaya (donde no rige el Fuero de Ayala) un derecho de crédito garantizado con un gravamen real que afecta a todos los bienes de la herencia - pars valoris bonorum ${ }^{87}$.

\footnotetext{
${ }^{85}$ BERNAD MAINAR, "la porción legítima...”, op. cit., pág. 1794.

${ }^{86}$ BERROCAL LANZAROT, A. I.:"El maltrato psicológico como justa causa de desheredación de hijos y descendientes", Revista Crítica de Derecho Inmobiliario, núm. 748, marzo, 2015, pág. 929. Señala la autora la gran discusión doctrinal al respecto de este tema. Siendo considerada por unos autores como cuota sobre los bienes de la herencia - teoría de la pars bonorum- o bien como otros, que la consideran como- pars hereditais- que en este caso estaría sujeta al pago de las deudas. Otra corriente doctrinal considera al legitimario como acreedor de los herederos y, en su caso, de los legatarios y donatarios a quienes puede reclamar el complemento de lo que le falta recibir en concepto de de legítima mediante la reducción de atribuciones (Art. 820 Cc).

${ }^{87}$ BERNAD MAINAR, “la porción legítima...”, op. cit., pág. 1795.
} 


\subsection{NATURALEZA JURÍDICA DE LA LEGÍTIMA}

En el Capítulo I ya se ha hecho alusión a la naturaleza protectora que mantiene la legítima, con respecto a los familiares más allegados del causante. Tales efectos son lo que encuadra la legítima dentro del Derecho natural, es decir, por propia naturaleza un padre o madre quiere lo suyo para sus familiares más cercanos. Las referencias históricas expuestas en el Capítulo I permiten afirmar la restricción a la libertad de otorgamiento post mortem que supone la institución de la legítima. Una restricción impuesta por el legislador al causante para beneficiar a sus familiares más cercanos ${ }^{88}$. Cabe destacar una legítima inicial nacida dentro del ordenamiento jurídico romano y de una reserva germánica, que hibridadas por su mutua influencia reciproca desembocan en el ordenamiento jurídico francés, que a su vez sirve como referencia, para confeccionar la legítima española. Una legitima que califican algunos autores como "moderna" $"$. La expresión "haberla reservado..." que hace el artículo $806 \mathrm{Cc}$ es uno de tantos término que corroboran la influencia germánica que recoge la institución de la legítima ya que la expresión se corresponde más con la reserva germánica que con la legítima romana ${ }^{90}$.

${ }^{88}$ Lasarte Álvarez, C.: Derecho de sucesiones. Principios de Derecho civil, $10^{\mathrm{a}}$ ed, Marcial Pons, Madrid, 2015, pags. 163.

Esta teoría también la defienden entre otros:

VAlLET DE Goytisolo, J.: “Comentarios...”, op. cit., pág. 2.

Díez Picazo, L. y Gullón, A.: Sistema de Derecho civil, Vol. IV, tomo $2^{\circ}, 7^{\mathrm{a}}$ ed (Derecho de Sucesiones), Tecnos, Madrid, 1997, pág. 461.

${ }^{89}$ Bernad MAINAR, La porción legítima..., op. cit., pág., 1770. "Tertium genus”, con este término latino, que significa a mitad de camino entre una cosa y otra, califica el autor el resultado de la fusión entre la legítima romana y la reserva germánica.

${ }^{90}$ O'CAllaghan Muñoz, X.: Compendio de Derecho Civil, tomo 5, Edersa, Madrid 2004, leción 12, pág. 1. 
2.2.1. La naturaleza jurídica de la legítima

Respecto a la naturaleza jurídica de la legítima la doctrina ha planteado la existencia de su configuración de acuerdo con sus distintas modalidades de pago. Esta confusión doctrinal que gira en torno a la naturaleza de la legítima está en parte originada por el carácter transaccional de la Codificación civil española ${ }^{91}$. La transacción operaba entre la legítima del Derecho de Castilla, donde el legitimario era heredero y la legítima foral donde, como se ha dicho anteriormente, los distintos Derechos forales presentaban distintas modalidades con respecto al pago de la legítima ${ }^{92}$.

Entre las explicaciones que la doctrina dispone para definir la naturaleza de la legítima, ninguna como la consideración que le otorga el propio Código civil en su artículo 806, cuando la define como una "porción de bienes" de la herencia de la cual el testador no puede disponer. El derecho a la porción de todos y cada uno de los bienes de la herencia lo tiene el legitimario desde el momento de la apertura de la sucesión y no al proceder a su cálculo ${ }^{93}$. Esta porción de bienes ha de verse con cierta desconfianza ya que el propio artículo 806 , contra su propia literalidad,

\footnotetext{
${ }^{91}$ Con respecto a la regulación de las legítimas en el Código civil Perez EsCOLAR, M.: "Sucesión intestada y legítima del cónyuge supérstite en el Código civil español. Revsión de fundamentos y planteamiento de futuro", Anuario de Derecho Civil, Vol. 60, núm. 4, 2007, pág. 1641 y ss.; Puig Brutau, J.: Fundamentos de Derecho Civil, III, Madrid, 1964, págs. 14 y 15; Albaladejo García, M. Curso de Derecho Civil, V, Derecho de sucesiones, Bosch, Barcelona, 1989, pág. 372.

92 Señala Torres GARcíA, T. F. y Domínguez Duelmo A.: “ La legítima en el Código civil (I) en Tratado de legítimas (coord. T. F. Torres García), Atelier, Barcelona, 2012, pág. 25. El artículo 267 del Fuero Nuevo de Navarra, Artículo 243 LDF de Galicia o el artóculo 451 del CCCat.

${ }^{93}$ De PABlo Contreras, P.: "Los herederos forzosos y su porción jurídica" en Curso de Derccho civil, (Coord. M. A. Pérez Álvarez), Colex, Madrid, 2008. pág. 280.
} 
llama herederos (sucesores universales) a los legitimarios a quienes ha reservado antes una porción de bienes ${ }^{94}$.

La naturaleza de la legítima ha de analizarse desde el sentido de qué, en virtud de qué y cómo recibe el legitimario su legítima. Se puede contestar a este planteamiento con cuatro teorías que después se ampliaran: la legítima como pars hereditatis, que entiende que el legitimario es heredero ${ }^{95}$. La legítima como pars valoris, en que se estima que el legítimario es acreedor teniendo un derecho personal de crédito frente a la herencia, para recibir su legítima. La legítima como pars valoris bonorum, que es una titularidad sobre parte del valor de los bienes heredables. La legítima como pars bonorum, es la admitida por la mayor parte de la doctrina y jurisprudencia ${ }^{96}$. Considera a la legítima como una parte de los bienes relictos recibidos por cualquier título por el legítimario, sin perjuicio de que en ciertos casos reciba el valor económico de su parte ${ }^{97}$. Se asegura

${ }^{94}$ IRURZUN GOICOA, ¿Qué es la legítima...?”, op. cit., pág. 2518.

${ }^{95}$ PeÑA BERnALDO DE QUIRÓS, M.: "La naturaleza de la legítima" Anuario de derecho civil, vol. 38, núm. 4, 1985, págs. 849 y ss.; FuENMAYOR CHAMPÍN, A.: "Intagibilidad de la legítima", Anuario de Derecho Civil, Vol. 1, 1948, págs. 46 y ss.; ORTEGA PARDO, G.: "Heredero testamentario y heredero forzoso", Anuario de Derecho Civil, Vol. 3, núm. 2, 1950, págs.. 322 y ss.

${ }^{96}$ Se admite el pago de la legítima como pars bonorum, entre otros, por VALLET DE Goytisolo, J.B.: "Observaciones en torno a la naturaleza de la legítima", Anuario de derecho civil, vol. 39, num. 1, 1986, pág. 3; DIEZ- PICAZO, L y GuILLÓN BALLESTEROS, A.: Sistema de Derecho civil, vol. 3, 7. a ed., Madrid, 1997, pág. 461; ACEDo PENCO, A.: Derecho de Sucesiones. El testamento y la herencia, Dykinson, Madrid, 2014, pág. 158. Este autor manifiesta la tendencia jurisprudencial a entender la legítima como pars bonorum, o como pars hereditatis, pero rechaza siempre que sea un «derecho decrédito»-pars valoris-, o que se trate de un «derecho real de realización de valor sobre los bienes de la herencia. En cambio RocA - SASTRE MuncuniLl, L. M.: "Naturaleza jurídica de la legítima", Revista de Derecho Privado, vol. 26, 1944, pág. 185, si bien niega la legítima como parte de la herencia, parece inclinarse más por considerar su pago como pars valoris bonorum.

${ }^{97}$ CuCurull Poblet, T.: El protocolo familiar mortis causa, Dykinson, Madrid, 2015, pag. 182. La conclusión de que la legítima en el Código civil es una pars bonorum la extrae la autora de la mera lectura del Código Civil. En su artículo 806 se refiere a ella como "la porción de bienes" (art. $806 \mathrm{CC}$ ). Tambien se plantea la autora acerca de la modificación por la Ley 11/1981, de 13 de mayo, del artículo 841 del Código Civil si 
al legitimario que no responderá de las deudas del causante y que puede recibir su parte por medio de cualquier título, es decir, puede recibir su legítima por medio de herencia, legado o donación (Art. $815 \mathrm{Cc})^{98}$.

En cambio en el momento actual se han superado las teorías que atribuían a la legítima la naturaleza de pars hereditatis, que ha de satisfacerse necesariamente con bienes hereditarios. Admitiendose que todos los bienes hereditarios están afectos al pago de la legítima y aunque esta ha de pagarse con bienes hereditarios, pero en determinados supuestos el pago de la legítima no necesariamente ha de realizarse con bienes que formen parte de la herencia, razón por la cual la legítima es una pars valoris bonorum (parte del valor de los bienes hereditarios) ${ }^{99}$. La descripción de las cuatro posibilidades de pagar la legítima serían ${ }^{100}$ :

1. Pars hereditatis: El beneficiario de la legítima es un heredero, y por tanto, tiene derecho a participar de la herencia en una parte alícuota bruta de la misma ${ }^{101}$. En este caso la legítima ha de satisfacerse con

habría modificado o no la naturaleza de la legítima. A su entender no varía, puesto que dicho artículo emplea la palabra "adjudicar", en cuanto a los bienes hereditarios se refiere, se trata de una operación particional realizada por el testador o el contador partidor expresamente autorizado. Por tanto "no modifica la naturaleza de la legítima, como pars bonorum.

${ }^{98}$ Torres García, T. F. Y Domínguez Duelmo A.: "La legítima en el Código civil (I) en Tratado de legítimas (coord. T. F. Torres García), Atelier, Barcelona, 2012, pág. 25.

En este mismo sentido también se pronuncia la STS de 28/09/2005 (RJ 2005\7154), F.J.3 "Del mismo modo, el legitimario que hubiera recibido íntegramente la legitima por herencia, legado o donación, carece del derecho a reclamarla como heredero forzoso, independientemente del título de su atribución por el causante, pues no ha sido favorecido por una delación legal inmediata y directa".

99 Busto Lago; M.: Derecho de Sucesiones, (coord.. R. Bercovitz Rodríguez- Cano) Tecnos, Madrid 2009, pág. 418.

${ }^{100}$ NúÑEZ NúÑEZ, M.: La sucesión intestada de los parientes colaterales, Dykinson, Madrid, 2007, pág. 51.

101 Señala VAllet De GoYtisolo, “Comentarios...", op. cit. pág. 8 explica los motivos según la Ley de Bases (Bases 1, 15 y16) ante la contraposición de las palabras de la definición contenida en la Ley y el contenido normativo claro que la reglamenta hay que 
bienes hereditarios ${ }^{102}$. El legitimario para recibir la legítima como

Pars hereditatis ha de ser investido como heredero, es decir, con la consecuente atribución de una cuota de la herencia que comportaría el activo y el pasivo de la misma ${ }^{103}$. Con ello se estaría excluyendo al

atenerse al contenido resultante. Sin embargo el contenido del artículo 806 Cc queda desmentido por los artículos 636, 808, 815, 821, 829 y 1056 Cc.

102 Prueba de la profunda discusión sobre la materia es la Resolución de 15 de septiembre de 2014, de la RDGRN 15/09/2014 (RJ 2014\4742) F.J. 30. "En la actualidad es pacífica, en doctrina y jurisprudencia, la consideración de la legítima como una pars bonorum» o en su caso «pars hereditatis". "En la jurisprudencia, el Tribunal Supremo conceptúa la legítima como una «pars hereditatis», en cuanto los legitimarios son herederos y cotitulares directos del activo hereditario. No cabe su exclusión de los bienes hereditarios salvo supuestos excepcionales y en los términos de conformidad expresados. La Sentencia de 8 de mayo de 1989, en la estela de pronunciamientos anteriores, dice que la legítima es cuenta herencial y ha de ser abonada, precisamente, con bienes de la herencia, dado que los legitimarios son cotitulares directos del activo hereditario y no se les puede excluir de los bienes hereditarios, salvo en hipótesis excepcionales (artículos 829, 838 y 840 y párrafo segundo del artículo 1.056 del Código Civil) e incluso, en tal caso, sujetos a su regla especial".

${ }^{103}$ DíEZ PiCAZO y Gullón, Sistema de derecho civil..., op. cit., pág.155. Señalan que de los preceptos 806 y $808 \mathrm{Cc}$ se desprende que el el gitimario es un heredero-legatario y que su llamamiento lo realiza la Ley, pero no a una cuota de bienes concretos sino a una cuota de patrimonio hereditario que comporta activo más pasivo. Esta conclusión deja de tener credibilidad a la vista de los preceptos 815 y $818 \mathrm{Cc}$ donde se dice que el heredero forzoso puede recibir por cualquier título la legçitima. Estas discordancias entre los primeros artículos y los segundos son las que han aflorado diversas opiniones doctrinales al respecto.

También VAllet de Goytisolo, "Comentarios al Código...", op. cit. págs. 9 y 10, apoya esta postura en base a la prohibición de disponer que recoge el artículo $806 \mathrm{Cc}$ y desmienten los artículos $815 \mathrm{Cc}$. Este precepto autoriza a pedir el complemento de legítima cuando el testador haya dejado por "cualquier título" menos bienes al legitimario de los que por legítima le corresponden.

La jurisprudencia se pronuncia en similar sentido a la doctrina:

Señala la STS de 26/04/1997 (Tol. 5.119.575) F. J. $3^{\circ}$, la repercusión que tiene para el legitimario la atribución de la herencia como pars hereditatis, ya que se hace cargo del pasivo de de la herencia en su parte proporcional: “(...) esta calificación de la legítima como "pars hereditatis", parte alícuota del caudal hereditario con todo su activo y su pasivo, no impide que el testador pueda disponer de alguno de los bienes de la herencia en su totalidad a favor de un legitimario o de otra persona siempre que se respete la legítima de sus herederos forzosos y ésta se pague con bienes de la herencia".

La STS 17/01/2001 (Tol. 63.745) F. J. $3^{\circ}$ distingue la manera en que recibe su parte el legitimario, resaltando el nombramiento del legitimario como heredero y precisamente por ello adquire su legítima como pars hereditatis: "Ante todo, es preciso recordar que 
legitimario de recibir su parte como legatario o donatario. Si bien la doctrina jurisprudencial no acaba de ser pacífica a este respecto ${ }^{104}$.

2. Pars valoris. Por medio de la legítima sus titulares adquieren un derecho en dinero líquido y relicto proporcional al valor de la herencia, que es determinado al momento de la muerte del causante $^{105}$. El legitimario no es ni heredero ni legatario, simplemente mantiene un derecho de crédito sobre la herencia ${ }^{106} . \mathrm{El}$

la madre, como legitimaria (artículos $807,2^{\circ} ; 809$, último inciso y 810 , primer párrafo, segundo inciso, del Código civil) fue nombrada heredera en testamento y al percibir la tercera parte de la herencia, adquiere su legítima como pars hereditatis (pars bonorum) en el sentido de que recibe la legítima como cuota de la herencia que recae sobre los bienes que la integran, concepto que le dieron las sentencias de 31 de marzo de 1970, 8 de mayo de 1989, 27 de febrero de 1997 y 26 de abril de 1997: la legítima es parte de los bienes de la herencia, que recibe el legitimario por cualquier título; en el presente caso, por título de heredera y sobre aquella cuota no puede recaer gravamen ni limitación (artículo 813 del Código civil)".

${ }^{104}$ STS de 20/07/2012 (Tol. 2.654.655) F. J. $2^{\circ}$ se pronuncia, la presente sentencia, a la falta de definición jurisprudencial unánime acerca de la nomenclatura de la legítima que recibe el titular del derecho: "Frente a esta posición, la sentencia de Primera Instancia, que es confirmada en Apelación, y con una base bien documentada doctrinalmente, eleva el grado de la cuestión debatida al referirla al ámbito, más complejo y dogmático, de la dialéctica doctrinal existente en torno a la condición de herederos forzosos de los legitimarios. De esta forma, aunque considera que la cuestión no está del todo definida jurisprudencialmente, ya como pars hereditatis, o como pars bonorum, se inclina por admitir la condición de herederos de los legitimarios aun cuando no fueren instituidos en el testamento por este título. Para concluir que, en todo caso, ya sea por aceptación de la herencia o del legado el acto de disposición resulta innegable y comporta una previa adquisición de los derechos hereditarios".

105 MenÉndez Mato, J. C.: El Legado de la Legítima Estricta en el Derecho Común Español, Dykinson, Madrid, 2012, pág. 33.

${ }^{106}$ STS de 18/07/2012 (Tol. 2.635.443) F. J. 4º. El derecho que mantiene el legitimario sobre una parte alícuota de la herencia pars hereditatis, pasar a tenerlo como pars valoris, es decir, como acreedor de la misma. Ello ocurre cuando el legitimario deja de ser atribuido heredero por parte del testador. Lo permite el artículo $841 \mathrm{Cc}$ en determinados supuestos. De no darse el mandato del precepto $841 \mathrm{Cc}$ se vulneraría el artículo 1061, que dispone la igualdad en la partición hereditaria. En el punto $1^{\circ} \mathrm{del} \mathrm{F}$. J. $4^{\circ}$ la STS entiende: "En el segundo submotivo se preguntan las recurrentes si la contadora partidora podía pagar con efectivo metálico ajeno a la herencia, por ser la legítima una pars hereditatis y no una pars valoris. La asignación de todos los bienes de la herencia a uno de los interesados, con la obligación de pagar las legítimas a los demás, transforma la condición de estos en la de titulares de un derecho de crédito. Esta decisión vulnera asimismo el Art. $1061 \mathrm{CC}$, porque habiendo tres inmuebles en la herencia pudo respetarse el principio de equidad. No se dieron los requisitos que el Art. 
heredero estará obligado a pagar al legitimario su parte, como un crédito cualquiera de la herencia ${ }^{107}$. Es prácticamente unánime la doctrina actual al considerar a la legítima gallega como pars valoris. Ello en base a los artículos 240, 243,244, 249, 251.3 LDCG $^{108}$. También en Cataluña la legitíma consiste en una pars valoris y no en un derecho a los bienes de la herencia conforme a los artículos 4511, 451-15.1, y 451-5 CCCat $^{109}$. Como se ha visto al comenzar este Capítulo también otros autores son coincidentes en la manera en que Galicia y Cataluña consideran el pago de las legítimas como pars valoris $^{110}$.

841 CC posibilita el pago de la legítima en metálico". En el punto $2^{\circ}$, con referencia a la autorización para conmutar: “(...) porque según la doctrina, dicha autorización convierte al legitimario en un acreedor, que recibe la condición de legatario de crédito en la herencia donde esta posibilidad se ha establecido. Esta consecuencia es la que deriva de las normas que permiten esta conmutación. La configuración legal de la legítima en este caso impide la infracción del art. $841 \mathrm{CC}$, porque es la propia ley la que produce el cambio de naturaleza de la posición del legitimario en la herencia".

${ }^{107}$ Torres GarcíA, y Domínguez Luelmo, La legítima en el Código civil (I)..., op . cit, pág. 26.

107 Señala MenÉndez MATO, J. C.: El Legado de la Legítima... op. cit., pág. 31, dos conclusiones acerca de lo expuesto en el texto: "la primera, en cuanto que los legitimarios pueden recibir su cuota de legítima mediante cualquier título: herencia, legado o donación inter vivos. La segunda -no menos relevante y fundada en la anteriorse basa en el hecho de que si el patrimonio hereditario resultase negativo, después de haber descontado las deudas del difunto, la responsabilidad de los legitimarios frente a las deudas restantes será diferente según hayan sido llamados a su legítima en concepto de herederos o de legatarios".

108 García Rubio M. P., Nieto Alonso, A. Y Herrero Oviedo, M.: Tratado de legítimas, (coord. T.F. Torres García), Atelier, Barcelona, 2012, págs.. 206 y 207.

109 VAquer Aloy, A: Tratado de legítimas, (coord. T.F. Torres García) Atelier, Barcelona, 2012.

${ }^{110}$ BERNAD MAINAR, “la porción legítima...”, op. cit., pág. 1794.

También la jurisprudencia refrenda la manera en que se consideran las legitimas en Galicia. Asi la SAP de A Coruña (S. 4") de 17/06/2016, (JUR $2016 \backslash 183848$ ) F.J. $3^{\text {o }}$ "En efecto, la legítima de los descendientes de $2 / 3$ partes del haber relicto del causante constituida por el tercio de legítima estricta y por el tercio de mejora- en los términos del art. 808 del CC ( LEG 1889, 27 ) , se reduce a la cuarta parte del valor del haber hereditario líquido conforme al art. 243 de la LDCG. Por otra parte, deja de concebirse como "pars bonorum", es decir como porción de bienes de la herencia, que faculta 
3. Pars bonorum. Es la asignación a los titulares de la legítima de una cuota líquida de los bienes hereditarios que se les ha detraído previamente las cargas y las deudas de la misma contraídas por el testador en vida ${ }^{111}$, es decir, no se incluyen las impuestas en el testamento $^{112}$. El legatario de parte alícuota y a la vez legitimario se diferencia del heredero en que el primero no se subroga ni en los derechos ni en las obligaciones del causante y el segundo sí. Esta interpretación encuentra su apoyo en los artículos 815, 818 y 819 Cc. Como ya se ha apuntado anteriormente el Código civil de Aragón, así resulta de los artículos 497 a 502 CDFA, Mallorca y Menorca por virtud de la Ley 8/1990, que así lo refleja en su Exposición de

activamente al legitimario para instar la partición judicial de la herencia, para convertirse en un "pars valoris", esto es en un simple valor del caudal relicto del causante, que confiere al legitimario un derecho de crédito, al que se refiere el art. 249.1 de la mentada Disposición General”.

Reafirma lo expuesto para Cataluña la SAP de Barcelona (S $1^{\text {a }}$ ) de 28/03/2013, (JUR 2003\199937), F. J. $3^{\text {o } ~ " A ~ l o ~ d i c h o ~ c a b e ~ a n ̃ a d i r ~ q u e ~ l a ~ l e g i ́ t i m a ~ e s ~ u n a ~ p a r s ~ v a l o r i s ~ y ~ p o r ~}$ ello el legitimario es un acreedor del heredero para la reclamación de una cuarta parte del valor de los bienes hereditarios, de un valor patrimonial concreto y nunca de un futurible (ex artículo $350,366.3^{\circ}$ y concordantes del CdeS)".

Tambien coincide LORA-TAMAYO, I. Y PÉREZ RAMOS, C.: Cuestiones prácticas sobre herencias para especialistas en sucesiones, El Derecho S.A., Madrid, 2016, págs. 235 y 238 que, en Aragón, Mallorca y Menorca, la legítima es pars bonorum.

${ }^{111}$ La SAP de Guipúzcoa (S. 2 ${ }^{\text {a }}$ ) de 01/12/2017 (Tol. 6.533.403) F.J. 2 ${ }^{\text {o }}$, distingue al legatario de parte alícuota del heredero en que el primero no es deudor de las cargas y obligaciones de la herencia como lo es el segundo: "Ello es evidente a juicio del Tribunal toda vez que el legatario de parte alícuota es un copropietario junto con los herederos o coherederos de la masa patrimonial por tener derecho a percibir una pars bonorum, y debe percibir de los bienes que integran dicha masa lo que les corresponde con arreglo a los criterios de igualdad y proporcionalidad, diferenciándose el legatario de parte alícuota de los herederos, en tanto que aquél no es deudor personal de las cargas y obligaciones de la herencia, ya que no se subroga en los derechos del causante".

112 MenÉndez Mato, J. C.: El Legado de la Legítima..., op. cit., pág. 34. 
Motivos $^{113}$. También se adhieren estos Derechos a esta forma de pagar su legítima.

4. Pars valoris bonorum. Esta expresión tiene dos significados diferentes, cuando se refiere a legítimas: por una parte se trata de una legítima abonable en metálico cuya fijación es a la muerte del disponente. Por otra parte se trata de una cuota líquida del valor de los bienes de caudal relicto, que representa una parte alícuota del valor de la herencia ${ }^{114}$. Cuando la legítima adquiere tal calificativo, recoge la base que concede el Código civil en los artículos 821 a 829 de que pueda pagarse la legítima en metálico, incluso extrahereditario. Desde la reforma que la Ley 11/1981, introduce en los artículos 841 y ss del Código civil, el citado derecho de pago en metálico, con ello se convierte en pars valoris bonorum ${ }^{115}$. Por consiguiente, el derecho que tiene el legitimario es sobre el valor dinerario del patrimonio de que se compone la herencia, es decir, tiene derecho a una fracción del valor del patrimonio hereditario. Como ya se apuntaba al comienzo de este Capítulo Ibiza, Formentera y Vizcaya en la parte que no rige el fuero de Ayala contemplan la legítima como una pars valoris bonorum, en el resto del País vasco existe una amplia libertad de disposición post mortem $^{116}$.

113 PARra LuCÁn, M. A. y BARrio Gallardo, A.: Tratado de legítimas, (coord. T.F. Torres García), Atelier, Barcelona, 2012, pág. 381.

Corrobora lo expuesto para Mallorca y Menorca VILA RIBAS, C.: Tratado de legítimas, (coord. T.F. Torres García), Atelier, Barcelona, 2012, pág. 393.

${ }^{114}$ MenÉndez Mato, J. C.: El Legado de la Legítima ..., op. cit., pág. 34.

115 Torres García, y Domínguez Luelmo, La legítima en el Código civil..., (I) op. cit, pág. 26.

${ }^{116}$ BERNAD MAINAR, "La porción legítima...”, op. cit., pág. 1794. En el territorio vasco en que no rige el Fuero de Ayala, conforme a los artículos 53, 56 y 58 de la LDFV, sin perjuicio de lo dispuesto para la troncalidad, "se defiere a los hijos, incluso los adoptivos, y demás descendientes y, en su defecto, a los padres y demás ascendientes. Se configura como una porción del caudal neto relicto a pagar con los bienes del mismo 
El tema tratado no deja de ser un tema "controvertido", puesto que conforme a los artículos 808 y 809 Cc la legítima se contempla como pars hereditatis. Pese a la poca concreción de estos preceptos, el primero entiende la legítima de los descendientes como las dos terceras partes del caudal hereditario, es decir, "partes de la herencia". Lo mismo ocurre con el segundo, el cual se refiere a la legítima de los padres o ascendientes, disponiendo que constituye la mitad de la masa hereditaria, si concurren en

(pars valoris bonorum). No obstante, el testador podrá distribuir libremente los bienes que integran la sucesión forzosa entre los sucesores comprendidos en cada una de las líneas, o elegir a uno solo de ellos".

Afirma Granados de Asensio, D. M.: Legítima Vasca VS. Legítima del Código Civil, Notaría Abierta, 2016 que la legitima vasca se configura como un valor económico al configurarla como valor económico, ya que el art. 48.1 LDCV vigente desde el 3 de octubre de 2015 dispone "La legítima es una cuota sobre la herencia, que se calcula por su valor económico y que el causante puede atribuir a sus legitimarios a título de herencia, legado, donación o de otro modo". Esta afirmación también se desprende por el mismo autor en la Ponencia presentada el 2 de marzo 2016, en la Jornada celebrada en la Diputación Foral de Gipuzkoa titulada: "La legítima en la ley 5/2015 de Derecho Civil Vasco: sus caracteres".

Señala Galicia AizPURUA, G.: "En torno a la revisión de las legítimas: casos vasco y estatal", Indret, núm. 4, 2017, la nueva tendencia del Derecho vasco, con respecto al pago de la legítima. "Se ha descartado su conversión en un simple derecho de crédito y, por el contrario, se ha preservado su tradicional configuración como una pars bonorum pagadera en bienes relictos. No obstante, se han sentado algunas notables excepciones a esta regla general. La más importante de ellas consiste en la posibilidad de que el causante autorice al heredero (legitimario o extraño) a que proceda a su pago con dinero extraherencial...".

También coincide con la manera de pagar la legitima en Ibiza y Formentera MUNAR BernAt, P. A.: La legitima en el Derecho civil de las Islas Baleares, Tratado de legítimas, (coord. T.F. Torres García), Atelier, Barcelona, 2012, pág. 333.

En el mismo sentido se pronuncia la SAP de Baleares (S 3 ${ }^{\text {a }}$ ) de 21/02/2001, (AC 2002\46) F.J. $1^{\circ}$ afirma que la legítima en Ibiza y Formentera tiene naturaleza jurídica de: "No existe duda de que la legítima en Ibiza y Formentera tiene la naturaleza de «pars valoris bonorum». Así se deducía del art. 81 de la antigua Compilación ( RCL 1961, 574, 625; NDL 2909) en el que se establecía el principio de que el legitimario tenía derecho a que se le abonara su legítima en bienes de la herencia salvo disposición distinta del testador o pacto en contra entre heredero y legitimario; y así se deduce de la regulación que de la legítima se contiene en los arts. 81 y 82 de la actual Compilación ( RCL 1990, 2762; LIB 1990, 118 y LIB 1991, 44) . La exposición de motivos de la Ley de 28 de junio de 1990 (RCL 1990, 1768 y LIB 1990, 103), coincidiendo con los comentaristas de la antigua Compilación la califica como «pars valoris bonorum qua in specie heres solvere debit". 
solitario y un tercio si lo hacen con el viudo/a del hijo o descendiente. En ambos casos se refiere a partes de la herencia, es decir, pars hereditatis ${ }^{117}$. En cambio son una minoría los autores que aceptan la teoría del pago de la legítima como pars valoris ${ }^{118}$. Hecho que al igual que la discrepancia doctrinal acerca de la naturaleza del pago de la legítima también resalta la jurisprudencia en la STS de 08/05/1989 (RJ 1989\3673) ${ }^{119}$.

La Jurisprudencia del Tribunal Supremo refrenda lo expuesto hasta el momento en la STS de 26/04/1997(RJ 1997\3542) y STS de 18/07/2012 (RJ 201218364) tras entender y aceptar la legítima, en el ordenamiento español, como pars hereditatis. Por lo que debe de ser abonada con bienes de la herencia. Pero debe hacerse teniendo presentes las excepciones previstas en los artículos $829,838,840,841$ y el párrafo $2^{\circ}$, del 1056. 2 Cc. Por lo tanto, existe una parte alícuota de la masa hereditaria, con todo su

${ }^{117}$ Admiten esta forma de entender el pago de la legítima: FERNÁNDEZ DOMINGO J.I.: Derecho de sucesiones, Reus, Madrid, 2010, pág. 114; PEÑA BERNALDO DE QuIRÓs, M.: "La naturaleza de la legítima", Anuario de Derecho civil, vol. 38, núm. 4, 1985, pág. 849; ORTEGa PARDO, G.: " Heredero testamentario y heredero forzoso" Anuario de derecho civil, vol. 3, núm 2, 1950, pág. 321; GARRIDO DE PALMA, V. M.: "Visión notarial de la legítima”. Revista de Derecho Notarial, Madrid, 1971, pág. 515.

118 Roca GuILlamón, J.: "Delegación fiduciaria de la facultad de distribuir y mejorar: notas al artículo 831 del Código Civil, Ley 41/2003" en Libro homenaje al profesor Manuel Albaladejo García (coord. J. M. González Porras, F. P. Méndez González), vol. 2, 2004, págs. 4286 y ss.

119 STS de 08/05/1989 (RJ 1989\3673) F. J. 5º "La solución que se dé a la cuestión planteada en el motivo depende de la postura que se adopte acerca de la naturaleza de la legítima definida en el artículo 806 del Código Civil como «porción de bienes de que el testador no puede disponer por haberla reservado la Ley a determinados herederos, llamados por esto herederos forzosos»; la doctrina científica no se muestra unánime en esta cuestión pues mientras unos autores, partiendo de la expresión «herederos forzosos» que utilizan los artículos 806 y 807 del citado Código, entienden que se trata de una «pars hereditatis», una parte alícuota del caudal hereditario con todo su activo y su pasivo, otros la consideran como "pars bonorum», dada la definición del artículo 806, con la consecuencia de que el legitimario participa de todos los bienes de la herencia y ha de ser satisfecha, excepto en los casos legalmente establecidos, con bienes de la misma formando el legitimario parte de la comunidad hereditaria en tanto la herencia se halle pendiente de liquidación; finalmente, un grupo de autores que puede calificarse de minoritario la califica de "pars valoris», simple derecho de crédito, de carácter personal y pagable en dinero". 
activo y todo su pasivo como pago de la legítima. Lo dicho, no impide, que el testador disponga de alguno de sus bienes de manera completa, es decir, sin dividirlos a favor de un legitimario o de algún otro. Siempre, claro está, respetando lo que les corresponde a los que ostentan su respectivo derecho a legítima y esta legítima se pague con bienes de la herencia sin olvidar el principio de equidad $^{120}$.

\subsubsection{La facultad del pago de la legítima en metálico}

${ }^{120}$ STS de 26/04/1997 (RJ 1997\3542) F. J. 3º "Esta Sala acepta aquella tesis según la cual la legítima es «pars hereditatis» (...) establece que en nuestro Ordenamiento, por tener dicha institución (la legítima) la consideración de "pars hereditatis" y no de "pars valoris", es cuenta herencial y ha de ser abonada con bienes de la herencia, porque los legitimarios son cotitulares directos del activo hereditario y no se les puede excluir de los bienes hereditarios, salvo en hipótesis excepcionales -arts. 829, 838, 840 y párrafo 1. ' del artículo 1056 del Código Civil”.

En el sentido de no vulnerar el principio de equidad del artículo $841 \mathrm{CC}$ se pronuncia la STS de 18/07/2012 (RJ 2012\8364), F. J. 4. "En el segundo submotivo se preguntan las recurrentes si la contadora partidora podía pagar con efectivo metálico ajeno a la herencia, por ser la legítima una pars hereditatis y no una pars valoris. La asignación de todos los bienes de la herencia a uno de los interesados, con la obligación de pagar las legítimas a los demás, transforma la condición de estos en la de titulares de un derecho de crédito. Esta decisión vulnera asimismo el Art. 1061 CC, porque habiendo tres inmuebles en la herencia pudo respetarse el principio de equidad. No se dieron los requisitos que el Art. 841 CC posibilita el pago de la legítima en metálico. $2^{\circ}(\ldots)$ Las recurrentes entienden que esta autorización convierte en un crédito la legítima pars hereditatis. Y desde el análisis puramente teórico llevan razón, porque según la doctrina, dicha autorización convierte al legitimario en un acreedor, que recibe la condición de legatario de crédito en la herencia donde esta posibilidad se ha establecido. Esta consecuencia es la que deriva de las normas que permiten esta conmutación. La configuración legal de la legítima en este caso impide la infracción del art. 841 CC , porque es la propia ley la que que produce el cambio de naturaleza de la posición del legitimario en la herencia.

Tambien la SAP de Burgos (S. 2) de 11/12/2016 (AC 2007\1050) F.J. $4^{\circ}$ se pronuncia en el mismo sentido. “(...) el Tribunal Supremo en STS de 26 de abril de 1997 ( RJ 1997, 3542) , se ha decantado por la concepción de la legítima como «pars heredatis», que ha de ser abonada con bienes de la herencia, ya que los legitimarios son cotitulares directos del activo hereditario, y no se les puede excluir de los bienes que lo integran, salvo en los supuestos expresamente previstos (artículos 829, 839 y 840.1 del Código Civil”". 
Lo dispuesto en el artículo $841.1 \mathrm{Cc}^{121}$ es una facultad y no un deber que se les impone a los herederos, porque según el artículo $842 \mathrm{Cc}$ el heredero que ha de pagar las legítimas tiene opción para pagarlas con dinero o con bienes de la herencia, pero carece de la facultad de elección quien ha de cobrarla. En este caso la legítima pasa de ser una pars hereditatis (una parte de la herencia pagable con los bienes de esta) a ser una pars valoris (un derecho de crédito que se puede pagar con bienes o con dinero, incluso, de fuera de la herencia) ${ }^{122}$. Dicho lo anterior preceptúa el artículo 843 Cc la necesidad de aprobación por parte del Secretario judicial o Notario, en defecto de acuerdo particional de todos los hijos y descendientes, en los supuestos de partición contemplados en el artículo 841 y $842 \mathrm{Cc}^{123}$. El artículo $842 \mathrm{Cc}$ (facultad de conmutación) se puede entender como una excepción a lo dispuesto en el artículo $841 \mathrm{Cc}$ que condiciona la efectividad de la voluntad del testador a la decisión del adjudicatario $^{124}$.

\footnotetext{
${ }^{121}$ Artículo 841.1 Cc. "El testador, o el contador-partidor expresamente autorizado por aquél, podrá adjudicar todos los bienes hereditarios o parte de ellos a alguno de los hijos o descendientes ordenando que se pague en metálico la porción hereditaria de los demás legitimarios".

122 Señala CuCurull PoBlet, T.: El protocolo familiar mortis causa, Dykinson, Madrid, 2015, pág. 183. "En conclusión, apriori, la legítima debe ser satisfecha con los bienes relictos. No obstante, y de forma excepcional, podría ser considerada como una pars valoris bonorum, ya que permitiría que ésta fuese satisfecha en metálico".
}

Véase Vallet de Goytisolo, Comentarios..., op. cit. pag. 489 y ss. Refiriendose al artículo $841 \mathrm{Cc}$ "es aplicable en caso de pluralidad de bienes sin conexión alguna (...) parte de la posibilidad de adjudicar a uno solo incluso todos los bienes hereditarios, con la contrapartida de pagar en metálico las porciones de los demás".

${ }^{123}$ El artículo 843 del Código civil ha sido modificado por la Ley 15/2015, de Jurisdicción Voluntaria, quedando en su nueva redacción de la siguiente manera: "Salvo confirmación expresa de todos los hijos o descendientes la partición a que se refieren los dos artículos anteriores requerirá aprobación por el Secretario judicial o Notario".

${ }^{124}$ LaCAlle SERER, E., SANMARTín ESCRICHE F. y APARICIO URTASUM, C.: Sucesiones y Herencias, $1^{\text {a }}$ ed, Tirant Lo Blanch., Valencia, 2008, pág. 324.

Véase JuRAdO JURADO, J.J.: "Resumen de resoluciones de la dirección general de los registros y del notariado", Revista Crítica de Derecho Inmobiliario, núm. 765, enero 
Así pues la facultad de pago en metálico de la legítima puede ser concedida por el testador a alguno de sus herederos de pagar las legítimas en metálico. Facultad que el referido heredero autorizado puede rechazar de acuerdo con el artículo $842 \mathrm{Cc}$. El artículo $844 \mathrm{Cc}$ establece el plazo de un año para que se comunique a los perceptores de la decisión de pago en metálico. El pago se tendrá que efectuar en plazo de otro año más. Transcurrido el plazo sin haberse efectuado el pago caducará la facultad conferida y se repartirá la herencia de acuerdo a las disposiciones generales sobre partición $^{125}$.

Otra excepción al pago con bienes de la herencia lo constituye el artículo 1056 Cc en atención a la conservación de la empresa familiar o al interés de su familia que faculta al testador para que disponga el pago en metálico de las legítimas incluso con efectivo extrahereditario. Así como el aplazamiento para efectuar el pago, siempre que no superen los cinco años

2018, pág. 357. En el supuesto de este expediente, más que una facultad de pago de legítima en metálico, lo que ha dispuesto la testadora es una orden, y aunque en puridad se pague la legítima en metálico, los herederos que deben hacerlo carecen de elección y deben cumplir la voluntad de la testadora".

Así también la RDGRN de 18/07/2016 (RJ 201614601) F.J. 1º, donde en el supuesto de hecho se cuestiona la inscripción de una escritura de protocolización de operaciones particionales de herencia en la que el testador lega a sus nietas lo que por legítima estricta les corresponde y dispone que se les pague en efectivo metálico hay nombrado contador-partidor testamentario que otorga la escritura y comparecen al otorgamiento los herederos, pero no las nietas legitimarias. "El testador ha de referirse al artículo $841 \mathrm{CC}$, ya sea invocándolo numeralmente o bien refiriéndola al supuesto en él previsto, con sus propias palabras o con otras cualesquiera con sentido equivalente, aunque técnicamente sean impropias o incorrectas, o simplemente de significado distinto". Lo esencial es que resulte indudable la intención del testador de conferir una autorización que encaje con el supuesto del artículo 841. (Así lo será en los casos en que el testador designe heredero universal a uno de los descendientes legitimarios o a varios, y legue a los demás legitiamrios y mejorados la compensación que, para satisfacer sus respectivas legítimas el instituido o los instituidos deban abonarles en metálico".

${ }^{125}$ LORA-TAMAYO, I. Y PÉREZ RAMOS, C.: Cuestiones prácticas sobre herencias para especialistas en sucesiones, El Derecho S.A., Madrid, 2016, pág. 178. 
desde la muerte del causante ${ }^{126}$. Por lo tanto, siempre tiene que haber uno o varios que pague/n con dinero a los demás. Aunque del artículo 841.2 autoriza al contador-partidor dativo a que efectúe el pago en metálico de la legítima, incluso cuando el testador no hubiera dispuesto al respecto en su testamento $^{127}$. La partición efectuada por el testador en atención a la conservación de la empresa o en interés de su familia faculta para que un legitimario pueda pagar al resto de legitimarios en metálico por virtud del precitado artículo $1056 \mathrm{Cc}^{128}$. En el referido $841 \mathrm{Cc}$ ya se establece el

\footnotetext{
${ }^{126}$ Señala GARCíA ALEMANY, E.: "La sucesión mortis causa en la empresa familiar" Cuadernos de derecho y comercio, núm. Extraordinario 2017, diciembre 2017, pág. 703, para el caso que se considere que la partición impuesta por el disponente no obedece al supuesto planteado por los artículos 841 y ss Cc la cuestión no parece sencilla. Asi la La STS de 09/12/2010 (RJ 2011\1415) F.J. 6º en que el supuesto de hecho que recoge una causante que lega a tres de sus hijos la única finca de la herencia, con la obligación de pagar sus partes al resto de hermanos legitimarios sus legítimas en metálico. "La problemática se plantea en el litigio sobre la base de la corrección o incorrección de la partición efectuada por el contador-partidor, dadas las expectativas de valor, por cuestiones urbanísticas, que afectan a la finca objeto del legado". El Alto Tribunal en el F.J. $6^{\circ}$ estima: a) conservar indivisa su explotación agrícola; b) adjudicarla a quienes consideraba más aptos para gestionarla; c) usar la facultad del propio art. $1056 \mathrm{CC}$, mandando que se pagaran las legítimas de los demás en metálico. Esta interpretación razonable de la voluntad testamentaria ha sido desnaturalizada por las expectativas urbanísticas de la única finca de la herencia, pero la exclusión de dicha finca de la comunidad hereditaria, hizo que de acuerdo con lo establecido en el art. 822.2 CC , deba ser el legatario quien sufra su pérdida o deterioro, así como que también se aproveche de sus aumentos y mejoras. Otra cosa sería tanto como la consagración de la inseguridad jurídica, puesto que en cualquier momento, los legitimarios tendrían derecho a pedir la revisión de las valoraciones y de la correspondiente partición.
}

${ }^{127}$ ESPEJO LERDO DE TEJADA, M.: "El contador-partidor dativo: algunas claves sobre su escaso arraigo práctico y sobre su regulación por la Ley de Jurisdicción Voluntaria", Anuario de Derecho Civil, núm. LXX-I, enero 2017, pág. 61. Tambien la "SAP de Ciudad Real (S. 2 ${ }^{\mathrm{a}}$ ) de 29.9.2003 (JUR 2004/48042), en que efectivamente en su F. J. $3^{\text {o }}$ señala: "En efecto en aquél testamento no vino la causante a expresar su voluntad de adjudicación de cualquier tipo de bien mueble o inmueble en favor de ninguno de sus cuatro descendientes, lo que motivó que el contador partidor designado entre los herederos de mutuo acuerdo viniera a confeccionar los oportunos lotes empleando las facultades al mismo conferidas por el artículo 841 del Código Civil, en relación al artículo 1.057 del mismo cuerpo legal, (...)”.

${ }^{128}$ CREMADES GARCÍA, P.: Sucesión mortis causa de la empresa familiar: la alternativa de los pactos sucesorios, Dykinson, Madrid, 2014, pág. 41. "En el segundo párrafo del art. 1056 del Cc, se prevé la posibilidad de que en el referido reparto, la empresa se 
poder pagar un legitimario al resto con dinero, si bien este precepto no exige requisito alguno. Argumentando, sin embargo en otros preceptos la perturbación que suponía, para la empresa familiar, el pago de las legítimas con caudal relicto, es decir, pars hereditatis ${ }^{129}$.

El contador - partidor dativo ${ }^{130}$, (figura regulada en el art. 1057. $2 \mathrm{Cc}$ ) ostentará la facultad que le otorga el artículo 841 y siguientes Cc de pagar la legítima en metálico a sus titulares en los siguientes tres supuestos ${ }^{131}$ :

1. Cuando el testador le haya concedido dicha facultad de manera expresa.

adjudique a alguno o algunos de los herederos, con el pago en metálico a los demás interesados de su legítima. Este supuesto se ha detallado con la redacción dada al precepto a propósito de la reforma acaecida por la Ley 7/2003, de 1 de abril, de la sociedad limitada Nueva Empresa. Pero la referida posibilidad, que cabe cuando el objeto lo constituye una empresa, resulta incardinada dentro de la genérica forma de división de la herencia a instancias del testador, de manera que en ausencia de su manifestación de voluntad en este sentido, no puede aplicarse”.

${ }^{129}$ PARRA LUCÁN, M.A, "Legítimas, libertad de testar y transmisión de un patrimonio"Anuario da Facultade de Dereito da Universidade da Coruña, núm. 13, 2009, págs. 481-554.

${ }^{130}$ El contador-partidor dativo es una interesante novedad de la Ley de Jurisdicción Voluntaria de 1 de julio de 2015, encaminada a poner en marcha herencias estancadas por la negativa de alguno de los coherederos a proceder a su división. Esta figura viene contemplada por el artículo 1057. 2, de Código civil: "No habiendo testamento, contador-partidor en él designado o vacante el cargo, el Secretario judicial o el Notario, a petición de herederos y legatarios que representen, al menos, el 50 por 100 del haber hereditario, y con citación de los demás interesados, si su domicilio fuere conocido, podrá nombrar un contador-partidor dativo, según las reglas que la Ley de Enjuiciamiento Civil y del Notariado establecen para la designación de peritos. La partición así realizada requerirá aprobación del Secretario judicial o del Notario, salvo confirmación expresa de todos los herederos y legatarios".

${ }^{131}$ Lledó Yague, F., Monje Balmaseda, O., Herrán Ortiz, A. I., AAVV, Examen particular de las causas de indignidad en Cuaderno Teórico Bolonia I. La sucesión mortis causa, Dykinson, Madrid, 2012, pág. 130. "En cuanto a la pregunta de quién puede conceder la opción, el artículo 841 determina que podrá ser bien el testador o el contador partidor expresamente autorizado por aquél y finalmente también el contador partidor dativo, dudándose sobre esta cuestión si asimismo debe ser expresamente autorizado por el testador o si por el contrario su autorización y nombramiento provienen ex lege". 
2. Cuando el Notario o el Secretario Judicial que lo hayan nombrado le hayan concedido tal facultad.

3. Si nombrado contador-partidor por el testador en su testamento y autorizado este, a pagar en metálico la legítima a determinados titulares de la misma cuando por circunstancias el cargo ha quedado vacío (muerte, enfermedad, etc.) el contador-partidor dativo conservará la facultad de poder pagar en metálico, de que disponía su predecesor en el cargo ${ }^{132}$.

Faltaría, en todo caso, determinar aquellos legitimarios que deban recibir su legítima parte en metálico atendiendo a lo que disponen los artículos 841 y $847 \mathrm{Cc}^{133}$. En virtud del primero de los preceptos, para recibir su parte de legítima en metálico, además de legitimarios tendrán que ser herederos o legatarios de parte alícuota, puesto que el artículo 641Cc se refiere al pago en metálico de la "la porción hereditaria". Ello también se ve reflejado, aunque de manera indirecta en el otro precepto reseñado ( 845 Cc) cuando señala que dicha opción (pago en metálico) no afectará a los

\footnotetext{
${ }^{132}$ LORA-TAMAYO, I. Y PÉREZ RAMOS, C.: Cuestiones prácticas sobre herencias..., op. cit., pág. 178. Para el contador- partidor dativo poder pagar en metálico la legítima ha de conllevar la autorización incluida el cargo que ocupa y que había sido su predecesor autorizado a ello por el testador.

133 García Alemany, "La sucesión....”, op. cit., pág. 702. “La solución del artículo 847 del Código civil, sin duda, es la adecuada para los casos de patrimonio con cierta estabilidad en el valor, pero en los casos de establecimientos mercantiles con clara influencia de la coyuntura económica y capacidad de gestión del empresario, se puede producir un fluctuación del valor que perjudique a los adjudicatarios". Así la STS de 22/11/1991 (Tol. 1.728.561) F.J. $3^{\text {o } ~ " t e n i e n d o ~ e n ~ c u e n t a ~ e l ~ q u e ~ c o r r e s p o n d e ~ a ~ l o s ~ b i e n e s ~}$ que corresponda adjudicar, y a cuyo momento de adjudicación es al que ha de someterse la sustitución de equivalencia con otros bienes o en metálico que consideraba el precitado art. 842, en su párrafo segundo, en su redacción anterior a la mencionada Ley de 13 de mayo de 1981, dado que el entender lo contrario significaría vulnerar claramente el principio de equivalencia patrimonial que en todo momento ha de presidir en la actividad particional de bienes".
} 
legados de cosa específica, conforme al artículo $846 \mathrm{Cc}^{134}$. Para el pago de la legítima en los casos especiales, el artículo 841 Cc faculta al testador la posibilidad de que la legítima de los descendientes pueda ser siempre pagada en dinero, a todos menos a uno que evidentemente es quien tiene que pagar. Ello es debido a que, el precepto exige, que se puedan adjudicar todos o parte de los bienes a alguno de los hijos o descendientes, ordenándole que pague en metálico su parte al resto de legitimarios ${ }^{135}$.

La modificación del artículo 841Cc en 1981, produce que determinados legitimarios sólo ostenten un derecho de crédito, una "pars valoris" sobre la herencia. El 829 Cc referido a que la mejora, que podrá señalarse en cosa determinada ${ }^{136}$. Si su valor excede del tercio de mejora y de la parte de legítima correspondiente al mejorado, en tal caso deberá el mejorado abonar la diferencia a los demás interesados. El $822 \mathrm{Cc}$ con el legado de cosa específica y determinada sobre un derecho de habitación ${ }^{137}$.

\footnotetext{
${ }^{134}$ LORA-TAMAYO, Y PÉREZ RAMOS, Cuestiones prácticas sobre herencias..., op. cit., pág. 178.

${ }^{135}$ VAllet DE GOYTISOLO, “Comentarios...”, op. cit., pág.492. El autor se pregunta si dejando el testador un solo hijo y verios nietos puede aqhél utilizar la norma del artículo $841 \mathrm{Cc}$, adjudicando los bienes, o parte de ellos a uno de los nietos, encargándole que pague al hijo su legígima en dinero. Tengase presente que los nietos, si bien no tinen legítima, si que pueden ser mejorados por el abuelo y en consecuencia pueden recibir todo el exceso de la legitima larga respecto de la corta, como mejora. Por consiguiente los nietos deben considerarse incluidos dentro del conjunto de descendientes que contempla el artículo $841 \mathrm{Cc}$.

${ }^{136}$ Artículo 829 Cc "La mejora podrá señalarse en cosa determinada. Si el valor de ésta excediere del tercio destinado a la mejora y de la parte de legítima correspondiente al mejorado, deberá éste abonar la diferencia en metálico a los demás interesados".

137 Artículo 822 Cc "La donación o legado de un derecho de habitación sobre la vivienda habitual que su titular haga a favor de un legitimario persona con discapacidad, no se computará para el cálculo de las legítimas si en el momento del fallecimiento ambos estuvieren conviviendo en ella". Este derecho de habitación se atribuirá por ministerio de la ley en las mismas condiciones al legitimario discapacitado que lo necesite y que estuviera conviviendo con el fallecido, a menos que el testador hubiera dispuesto otra cosa o lo hubiera excluido expresamente, pero su titular no podrá impedir que continúen conviviendo los demás legitimarios mientras lo necesiten.
} 
El cambio sufrido por la legítima con la posibilidad de pago en metálico, supone una flexibilidad con la libertad de testar, frente a la rigidez existente con anterioridad a la modificación. A la doctrina no le pasó desapercibida esta modificación, y hubo crítica al respecto del cambio de naturaleza sufrido por la legítima. Ello sin atender a los motivos y si a los resultados, se advierte la flexibilidad expuesta, en la Ley 7/2003 de 1 de abril del 2003, de la Sociedad Limitada Nueva Empresa. Esta ley modifica el artículo $1056 \mathrm{Cc}$, con respecto al precedente de 1988, con el fin de mantener indivisa una empresa, podrá al que se le ha adjudicado, pagar en metálico, incluso extrahereditario, su parte al resto de legitimarios ${ }^{138}$. El citado pago puede aplazarse hasta cinco años. También la Ley 42/2003, de 18 de noviembre de 2003, sobre la Protección Patrimonial de personas con discapacidad contribuye a flexibilizar la legítima en la sustitución fideicomisaria, frente al incapacitado en virtud de resolución judicial del artículo 831 Cc. Finalmente, también se flexibiliza la legítima con ocasión de las sucesivas modificaciones de los artículos 834 y $835 \mathrm{Cc}$ efectuados por la Ley de 8 de julio de 2005 y de la Ley 15/2015. Simplificando los derechos de legítima que tiene el cónyuge supérstite ${ }^{139}$.

En la jurisprudencia del Tribunal Supremo, concretamente, en la STS de 18/07/2012 se alude al pago de la legítima con dinero. Se trata de un

El derecho a que se refieren los dos párrafos anteriores será intransmisible”.

Lo dispuesto en los dos primeros párrafos no impedirá la atribución al cónyuge de los derechos regulados en los artículos 1406 y 1407 de este Código, que coexistirán con el de habitación.

138 GARRIDO DE PALMA, V. M.: Régimen matrimonial. Sucesiones mortis causa y Estatutos sociales. Armonización con el Protocolo Familiar, Vol. IX, (coor. M. Garrido Melero y J.M. Furgado Estevill), Consejo General del Notariado, Bosch, Barcelona 2005, pág. 627 y ss.

${ }^{139}$ PARRA LUCÁN, "Legítimas, libertad de testar...", op. cit., pág. 492. Comenzó la flexibilidad de la legítima con la Ley de 13 de mayo de 1981 haciendo iguales a todos los hijos en virtud de la modificación impuesta en el artículo 807 Cc. También sufre modificación el articulo 814 Cc con respecto a la preterición. 
pago en metálico con dinero efectivo y ajeno a la herencia ya que todos los bienes de la herencia se habían asignado a uno de los llamados. Una asignación que conllevaba la obligación de pagar al resto, sus respectivas legítimas. Con tal medida se asignaba, a estos legitimarios, un derecho de crédito sobre la herencia. Con esta decisión, se ha vulnerado, por un lado, el artículo 1061 Cc no respetándose el principio de equidad, allí preceptuado ${ }^{140}$. Ello es debido a que había tres inmuebles y tres hijos. Además no se dieron los supuestos enmarcados en el artículo 841, del Cc para proceder a efectuar el pago de la legítima en metálico ${ }^{141}$.

\subsubsection{Computación, imputación y colación de la legítima}

Por cómputo de la legítima se entiende la cuantía de esta, es decir, lo que reciben los legitimarios, que no siempre es en la misma proporción, dependiendo de con quién concurran a la sucesión. Para determinar, dicho

\footnotetext{
${ }^{140}$ Artículo $1061 \mathrm{Cc}$ "En la partición de la herencia se ha de guardar la posible igualdad, haciendo lotes o adjudicaciones a cada uno de los coherederos cosas de la misma naturaleza, calidad o estirpe".
}

141 Véase la STS de 18/07/2012 ( RJ 201218364) donde en su F.J. $4^{\text {o detalla los }}$ requisitos para que se produzca el pago de la legítima en metálico: "El Art. $841 \mathrm{Cc}$ permite al testador autorizar al contador partidor o a los demás herederos efectuar el pago en metálico de las legítimas y ello cuando adjudique los bienes relictos a uno o varios de los descendientes, supuesto que concurre en el presente litigio. Hay que tener en cuenta que el testador solo atribuye una facultad a quienes reciben el caudal hereditario frente a quienes no lo reciben. Para que esta opción sea eficaz, se requiere que la partición en que se ejecute la opción autorizada por el testador, sea aprobada por los hijos o descendientes y en su defecto, debe concurrir aprobación judicial (art. $843 \mathrm{Cc}$ ). La autorización del pago de las legítimas en dinero permite al hijo obligado a pagar a optar por atribuir bienes en lugar del dinero; esta posibilidad no se puede ejercer por los legitimarios afectados por la opción, ya que el art. 842 Cc cuya infracción se ha denunciado, establece que "cualquiera de los hijos o descendientes obligados a pagar en metálico la cuota hereditaria de sus hermanos podrá exigir que dicha cuota sea satisfecha en bienes de la herencia", lo cual excluye la denunciada infracción, porque las recurrentes pretenden que se declare que son ellas quienes están capacitadas para efectuar esta elección. En consecuencia y para resumir lo dicho hasta aquí, los requisitos para que se produzca un pago en dinero de las legítimas son:

a) que el testador lo haya autorizado;

b) que estén de acuerdo en la conmutación o que se autorice judicialmente;

c) que se atribuya a los autorizados el patrimonio relicto". 
cómputo, se suma el relictum (masa hereditaria descontada las deudas y cargas no impuestas en el testamento) con el donatum (donaciones realizadas en vida del testador) ${ }^{142}$. Tal como dispone el artículo $818 \mathrm{Cc}$ que regula la fijación del montante de la legítima ${ }^{143}$. Se hace con el fin de calcular el quantum legitimario global, es decir, para calcular o determinar la legítima global ${ }^{144}$. A la operación de sumar al valor de la herencia líquida las donaciones y liberalidades equivalentes otorgadas en vida por el causante también se la denomina, de manera técnica, operación de "agregación de las donaciones" imputadas a los hijos que no tengan el concepto de mejora ${ }^{145}$. De la misma manera se pronuncia la jurisprudencia manifestando que la legítima se calcula sumando al valor del relictum el donatum $^{146}$.

${ }^{142}$ Señala SAN SEgundo MANUEL, T.: "La Legítima los conceptos de computación, atribución, imputación y colación. La acción de suplemento en la jurisprudencia del Tribunal Supremo", Revista Crítica de Derecho Inmobiliario, núm. 707, 2008, pág. 1376, que la computación es la fijación cuantitativa de la legítima que se hace calculando la cuota correspondiente al patrimonio hereditario del causante, que se determina sumando el relictum con el donatum, siguiendo los postulados del artículo 818 del Código Civil”.

143 Se refiere VAllet DE Goytisolo, J.B.: Comentarios al Código civil y Compilaciones Forales, Tomo XI, $2^{\mathrm{a}}$ ed., (Dir. M. Albadalejo García), EDERSA, Madrid, 1982, pág. 235, al articulo 818 Cc como el precepto que regula las tres cifras, con las cuales se debe proceder a hacer las operaciones aritméticas sucesivas de resta y suma, para optener la base o dividendo, para fijar el montante de la legítima.

${ }^{144}$ Mantiene RocA - SASTRE Muncunill, L.: Derecho de sucesiones, Tomo II, Boch, Barcelona, 1991, págs. 44 y 45, que el quantum legitimario global actuará de dividendo, el número de legitimarios actuará de divisor y el cociente arrojará lo que corresponde de manera individual a cada legitimario.

145 ACEDO PENCO, Dercho de Sucesiones..., op. cit., pág. 162. Se refiere a la operación de cómo se computa la legítima: sumando al valor de la herencia líquida (activo -pasivo o lo que es lo mismo los bienes dejados por el causante a su muerte menos las deudas y cargas que sobre ellos pesan) las donaciones y liberalidades equivalentes otorgadas en vida por el causante. Donaciones que no tengan el concepto de mejora tal como dispone el artículo 818 y 819 Cc en el caso de las efectuadas a los hijos.

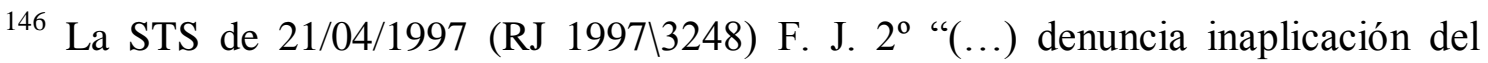
artículo 818 del Código Civil. Este precepto viene a operar en forma de computación del haber hereditario, estableciendo las bases para la determinación de la legítima, a cuyo efecto, al ser esta parte alícuota de la masa hereditaria, es preciso fijar mediante la 
El cálculo o fijación de la legítima tiene lugar conforme a los artículos 806, 818 y ss del Código civil. Se trata de adaptar las operaciones de inventario y evaluación de los bienes que han quedado a la muerte del causante. La adaptación se hace con el pertinente cálculo de la legítima colectiva o global, como grupo de bienes del haber hereditario reservado a los legitimarios ${ }^{147}$. Trata la jurisprudencia del "relictum" como el valor de los bienes y derechos a la muerte del disponente descontando las deudas ${ }^{148}$.

correspondiente prueba el líquido de la misma, que resulta de la diferencia entre el activo (suma del valor de los bienes de causante al tiempo de su fallecimiento) y el pasivo (deudas y cargas del testador hasta el momento de su muerte). El valor líquido así obtenido no es el que sirve de base a la legítima, ya que ha de agregarse a aquél, tratándose de relaciones entre herederos, como es el supuesto de autos, el importe de las donaciones de naturaleza colacionable".

${ }^{147}$ La STS de 26/06/2012 (Tol. 2.673.860) F.J. $5^{\circ}$ se refiere a los bienes del causante para la determinación del caudal relicto y del donatum: "con relación al carácter imperativo de la regulación de la legítima y en concreto, de la determinación del relictum y el donatum de la causante $\mathrm{D}^{\mathrm{a}} \mathrm{xxx}$. Al establecer el art. $659 \mathrm{CC}$ que la herencia comprende todos los bienes del causante que no se extingan con su muerte, y el art. $818 \mathrm{CC}$ que para fijar la legítima se atenderá al valor que tuvieren los bienes del causante en el momento de su fallecimiento, y excluirse los tres bienes inmuebles cuya existencia no fue alegada en el primer procedimiento, se han infringido estas disposiciones y con ello, el carácter imperativo en la norma de cálculo de la legítima". También la SAP de Oviedo (S. 6 ${ }^{a}$ ) de 24/02/2017 (Tol. 6.026.817) F.J. $2^{\circ}$ define el cómputo, la atribución, la imputación y la colación de manera clara y concisa: "El cómputo de la legítima es la fijación cuantitativa de ésta, que se hace calculando la cuota correspondiente al patrimonio hereditario del causante, que se determina sumando el relictum con el donatum. La atribución es el pago de la legítima, por cualquier título; como herencia, como legado o como donación. La imputación es el colocar a cuenta de la legítima lo que un legitimario ha recibido de su causante como heredero, como legatario o como donatario. Distinto de todo ello es la colación. Este es un tema de cálculo de legítima, cuando hay varios legitimarios y es, sencillamente, (...), la adición contable a la masa hereditaria del valor del bien donado; o, más precisamente, la agregación intelectual que deben hacer al activo hereditario los legitimarios que concurran en una sucesión con otros, de los bienes que hubieran recibido del causante en vida de éste, a título gratuito, para computarlo en la regulación de las legítimas y en la cuenta de la partición, como dice el art. 1035 del código civil (STS 24 de enero de 2008)"-

${ }^{148}$ Dispone la STS de 22/02/2006 (Tol. 843.360) F. J. $3^{\circ}$ que el relictum trata del valor de los bienes al tiempo de fallecimiento del causante, siempre que sean bienes y derechos que no se extingan con su muerte, según dispone el artículo 695 Cc. 
La imputación consiste en colocar a cuenta de la legítima los bienes y derechos que haya recibido el legitimario del causante como heredero, legatario o donatario. La donación otorgada en vida del causante a un legitimario se imputará a su legítima, salvo que sea hijo o descendiente del causante que en este caso podrá imputarse como mejora. No cabe imputar la donación a la legítima sino a la mejora o incluso a la libre disposición cuando así lo manifieste el disponente en su testamento ${ }^{149}$. Se refiere a la imputación de donaciones el artículo $819.1 \mathrm{Cc}^{150}$. Por lo tanto la imputación de la legítima supone colocar a cuenta de esta lo que ha recibido un legitimario del disponente bien como heredero, bien como legatario o bien como donatario. Su finalidad es aplicar las donaciones a las distintas partes de la herencia con el fin de determinar si hubo o no hubo inoficiosidad. Es decir, si el causante sobrepasó su libertad de atribución para disponer de manera gratuita de su patrimonio tal como dispone el artículo $836 \mathrm{Cc}^{151}$. Mantiene la misma opinión que la doctrina la jurisprudencia $^{152}$.

\footnotetext{
${ }^{149}$ Señala ACEDO PENCO, Dercho de Sucesiones..., op. cit., pág. 163 que la herencia que reciba el legitimario, a quien se haya nombrado heredero, se imputará a su legítima; pero la destinada a un extraño no legitimario será imputada a la parte de libre disposición del testador. En cambio el legado que reciba un legitimario, nombrado legatario se imputará a su legítima. De ser un extarño el que recibe el legado se imputará a la cuota de libre disposición.

${ }^{150}$ RoCa - SAStre Muncunill, Derecho de sucesiones..., op. cit., pág. 45.

151 SAn Segundo Manuel, "La Legítima...", op. cit., págs. 1377 y 1378. La jurisprudencia del TS se pronuncia al respecto de la imputación de la legítima en varias ocasiones:
}

La STS de 22/02/2006 (RJ 20061900) F.J.3 ${ }^{\circ}$ pone de manifiesto que " no tiene lugar la imputación cuando en el artículo 1037 se establece que la colación no procede, si el testador así lo dispone, salvo el supuesto de inoficiosidad; lo que hay que entender es que entonces no se imputarán las donaciones en la legítima, pero no que se prescinde de aquéllas en el inventario general de los bienes del causante para imputarlas donde resultase preciso ( SSTS de 6 de junio de 1962 y 21 de abril de 1997 [ RJ 1997, 3248] ).

Se refiere al articulo 836 Cc la STS de 21/04/1990 (RJ 1990L2762) F. J. $2^{\text {o }}$ "La doctrina científica predominante, al interpretar el precepto del artículo 818 del Código Civil, viene entendiendo que para el cálculo de la legitima, mejora y tercio de libre disposición 
La colación que regula el artículo 1035 y ss Cc es la agregación a la herencia, después de liquidadas las deudas de las donaciones hechas en vida por el disponente a favor de herederos-legitimarios que concurran a la sucesión con otros de su misma clase. Su finalidad es mantener la proporcionalidad entre las cuotas que se adjudiquen en pago de sus respectivas legítimas ${ }^{153}$. Tambien se puede definir la colación como la adición contable a la masa hereditaria que deben hacer los legitimarios que concurran en una sucesión con otros legitimarios, de aquellos bienes recibidos en vida a título gratuito del causante, para computarlo en la regulación de las legítimas el valor de las donaciones ${ }^{154}$. Del contenido de

de la herencia deben sumarse a lo relicto líquido todas las donaciones no exceptuadas de computación por razón de sus circunstancias (como pueden ser, entre otras, las remuneratorias, onerosas y modales, usuales, las de frutos y en particular algunas otras entre las que no se encuentran las del supuesto que nos ocupa), y que así se desprende de la interpretación conjunta de los artículos 808 y 818 del Código Civil, preceptos de los cuales el primero determina las cuotas que constituyen la legítima, señalando la proporción, mientras que el segundo indica el modo de determinar el montante de una de esas cuotas ideales, estableciendo la base a la que debe aplicarse aquélla, así como de la de los artículos 819 y 820 , cuya interpretación conjunta con el 818 hace palpable la evidencia de que las donaciones hechas a extraños deben ser computadas a todos los efectos, agregándose, finalmente, que, si tal y como el artículo 636 afirma, ninguno podrá dar ni recibir por vía de donación, más de lo que puede dar o recibir por testamento".

152 STS de 29/11/2012 (RJ 2013\190) F. J. 4 o "La imputación es el colocar a cuenta de la legítima lo que un legitimario ha recibido de su causante como heredero, como legatario o como donatario. A ella se refieren las sentencias citadas, de 31 de abril de 1990 SIC y 28 de septiembre de 2005 (RJ 2005, 7154). Artículo 819 del Código civil, que se refiere a la imputación de las donaciones".

Se refiere a la imputación la STS de 14/12/2015 (RJ 20061300) F. J. 17º "sostiene que se ha producido una infracción de los preceptos relacionados con la imputación de los excesos de la mejora en cosa determinada al tercio de legítima estricta (...) En efecto, las operaciones realizadas han consistido en: a) agrupar a efectos de cálculo los bienes determinados (fincas) asignados de consuno en uno y otro testamento a cada uno de los herederos para hacer efectiva la mejora, b) calcular su valor conjuntamente; c) comparar el valor global así obtenido con la suma de lo que corresponde en concepto de mejora y de legítima estricta conjuntamente a todos los herederos mejorados; d) establecer la diferencia entre las dos cantidades anteriores, globalmente calculadas para todos los herederos mejorados; e) comprobar que resulta un exceso".

\footnotetext{
${ }^{153}$ Roca - SASTRe Muncunill, Derecho de sucesiones..., op. cit., págs. 45 y 46.

${ }^{154}$ SAn SEGUNDO MANuel, “La Legítima...”, op. cit., págs. 1378 y 1379.
} 
los artículos 1035 al 1050 Cc se puede llegar a la conclusión que las donaciones realizadas en vida del disponente sean todas colacionables. Excepto lo dejado en testamento a los legitimarios salvo disposición testamentaria en contrario ${ }^{155}$, quedando a salvo las legítimas (art. 1037 Cc) $)^{156}$.

Conforme al artículo 818 Cc para fijar la legítima se atenderá al valor de los bienes que queden disponibles a la muerte del testador ${ }^{157}$. Cabe

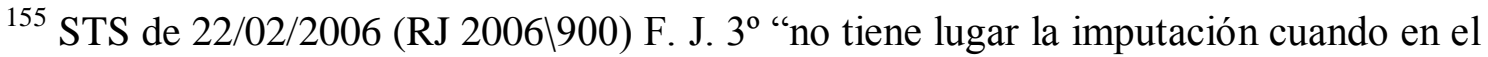
artículo 1037 se establece que la colación no procede, si el testador así lo dispone, salvo el supuesto de inoficiosidad; lo que hay que entender es que entonces no se imputarán las donaciones en la legítima, pero no que se prescinde de aquéllas en el inventario general de los bienes del causante para imputarlas donde resultase preciso ( SSTS de 6 de junio de 1962 y 21 de abril de 1997 [ RJ 1997, 3248] )”.

156 Señala ACEDo Penco, Dercho de Sucesiones..., op. cit., pág. 164, que del artículo 1037 Cc la doctrina extrae las siguientes reglas especiales: "a) lo que dejare en testamento a los legitimarios se imputará, en principio, a la parte de libre disposición; $b$ ) cuando se dejen legados de bienes concretos al legitimario se imputarán a su legítima y si no hubiera bastante, a la parte libre; $c$ ) si tal disposición testamentaria a título singular al legitimario, tampoco cupiera en la parte de libre disposición, deberá procederse a su reducción562; d) podrá el testador desigualar a hijos y descendientes mejorándolos expresamente".

157 Se refiere SAN SEGUndo MANuEl, "La Legítima...", op. cit., pág. 1736, a los artículo 808 y 818 del Cc, preceptos de los cuales el primero determina las cuotas que constituyen la legítima, señalando la proporción, mientras que el segundo indica el modo de determinar el montante de una de esas cuotas ideales, estableciendo la base a la que debe aplicarse aquélla.

La STS de 23/12/2011 (RJ 2012\301) F. J. 3 "Las donaciones válidas no forman parte del caudal relicto. Solo si debe calcularse el valor del caudal relicto al haber legitimarios, se aplicará el Art. 818 CC ( LEG 1889, 27 ) , cuyo párrafo segundo establece que una vez determinado el valor de dicho caudal, se agregará el de las donaciones colacionables. Esta operación es meramente contable y no requiere la aportación de los mismos bienes donados, sino únicamente la de su valor a los efectos de la determinación del quantum sobre el que se van a calcular las legítimas y las mejoras y va a servir de base para la reducción de las donaciones que haya que declarar inoficiosas, de acuerdo con lo que dispone el Art. $654 \mathrm{CC}$, de modo que solo han de computarse a los efectos del cálculo de la legítima y de la colación, si a ello hubiera lugar, lo que no ocurre en el presente litigio".

Tambien la SAP de Las Palmas (S. 5) de 31/03/2014 (JUR 2014\147032) F.J. $5^{\circ}$ "Este haber hereditario se configura, según el art. 818 por el valor de los bienes que queden a la muerte del causante (relictum) al que hay que agregar el de las donaciones (donatum), sobre cuyo conjunto, es decir, sobre la suma de lo dejado y de lo donado se debe 
destacar de este precepto que no establece el momento de la valoración de los bienes heredables. Su disposición trata de determinar los bienes que integran la masa hereditaria a la muerte del causante y no la valoración de los mismos. A partir de la reforma del Código civil por la Ley de 13 de mayo de 1981, por virtud del artículo 847 Cc para fijar la suma que deben recibir los legitimarios se atenderá, en el supuesto de que la legítima se pague en metálico, al momento en que se liquide esta a los interesados. Si esta valoración es legal para el pago en metálico de la legítima (artículos 841-846 Cc) no cabe duda que también lo es, para cuando la legítima se pague de otro modo ${ }^{158}$.

Por lo tanto, los bienes que componen el activo de la herencia serán los bienes y derechos que queden a la muerte del disponente, es decir, que no se extingan con su muerte (artículos 659 y $818 \mathrm{Cc}$ ). Cuya valoración tendrá lugar en el momento de la fijación o cálculo de la legítima. Al valor obtenido se le tiene que detraer el pasivo de la herencia, que son todas las deudas y cargas contraídas por el causante, que no se extingan con su muerte. Una vez deducidas, a la masa hereditaria las deudas y cargas, el resultado será: bienes relictos o caudal relicto ${ }^{159}$. Al mismo tendrán que adicionarse los bienes donados en vida por el causante y que sean colacionables. Por lo que respecta al artículo $1045 \mathrm{Cc}$ los legitimarios no

calcular el importe cuantitativo de la legitima a fin de determinar si la donación es inoficiosa".

158 Señalan Lledó Yagüe, F., Monje Balmaseda, O., Herrán Ortiz, A.. I., AAVV: Cuaderno Teórico Bolonia I. La sucesión mortis causa, Dykinson, Madrid, 2012, págs. 119 a 120, para la valoración de los bienes hereditarios, antes de la reforma operada por la Ley de 13 de mayo de 1981, "la jurisprudencia mantenía que había que atender al valor de los bienes en el momento de la muerte del causante (...). Según esta doctrina, este momento, el de la muerte del causante, servía para determinar tanto los bienes que integran el patrimonio del causante como el valor de dichos bienes".

159 Lledó Yagüe, Monje Balmaseda, Herrán Ortiz, AAVV: Cuaderno teórico Bolonia I... ”, op. cit., pág. 121. 
han de entregar las mismas cosas donadas, sino aportar su valor al momento de la evaluación hereditaria de fecha de liquidación de legítimas. La determinación de la legítima, tanto colectiva o global como individual, ha de atenderse a lo dispuesto en los artículos 808 y 809 Cc para determinar la cuota que corresponde al conjunto de legítimarios ${ }^{160}$.

Entendiendo la legítima como la define el artículo 806, Cc como una porción de bienes "pars hereditatis". No obstante el Código civil establece varias excepciones a esta consideración. La explicación se encuentra en la necesidad de buscar solución a problemas de convivencia familiar o los inconvenientes que puede provocar la división del haber hereditario. De ahí que en ocasiones, como se ha visto, se permita pagar la legítima individual como parte del haber hereditario o con bienes o derechos ajenos al mismo $^{161}$. La doctrina castellana, con anterioridad a la promulgación de Código civil ya hacía alusión a las diferentes responsabilidades de los legitimarios a la hora de hacerse cargo de las deudas del causante. Dependiendo de cómo este los hubiera instituido en su testamento, es decir, si recibían su legítima en concepto de herederos universales (quota hereditatis) o de legatarios (quota bonorum). Efectos los expuestos, que implicaba, respectivamente, hacerse o no hacerse cargo de las obligaciones del causante ${ }^{162}$.

Lo que más destaca, del cálculo de la legítima, es su carácter imperativo, ya que, como dice el Tribunal Supremo, no es posible saber si

\footnotetext{
${ }^{160}$ De PABlo CONTRERAS, Los herederos forzosos..., op. cit. págs. 308 a 310 . La legítima colectiva es la parte de los bienes que en su conjunto corresponde a todos los legitimarios de manera individual. Para el cálculo de la segunda se tendrá que tener en cuenta la renuncia a su parte de alguno de los legitimarios y el derecho de representación que lo asista.

${ }^{161}$ De PABlo CONTRERAS, Los herederos forzosos ...,op. cit., pág. 280.

${ }^{162}$ VAllet DE Goytisolo J. B.: "Observaciones en torno a la Naturaleza de la Legítima", A propósito de un trabajo de Manuel Peña Bernaldo de Quirós, Anuario de Derecho civil, 1986, pág.18.
} 
una donación es inoficiosa si con anterioridad no se ha efectuado el pertinente cálculo global o colectivo de las legítimas. ${ }^{163}$. Señala ROCA SASTRE que la computación consiste en agregar al caudal relicto líquido (deducidas las deudas y cargas) todas las donaciones hechas por el causante en vida. Es decir, donaciones en general, incluyendo las efectuadas a legitimarios y a no legitimarios, conforme dispone el artículo 818, del Código civil. Mientras que la imputación, la entiende, como el hecho de agregar al caudal relicto las donaciones hechas, en vida del causante, en favor de los legitimarios de acuerdo con el artículo 819.1, del mismo Código. La colación, dispuesta en el artículo 1035 y ss., del Código civil consiste en agregar al caudal relicto las donaciones hechas, por el causante en vida a los legitimarios cuando estos concurren con otros legitimarios buscando la "igualdad o proporcionalidad" entre ellos ${ }^{164}$.

Siendo la computación, imputación y colación operaciones de contabilidad, cada una de ellas tiene una finalidad específica. La computación y la imputación forman parte de la regulación de las legítimas, mientras que la colación es una operación de regulación de la partición hereditaria. La diferencia entre la computación, la imputación y la colación, la aportan los destinatarios de las donaciones hechas en vida del causante y dependiendo de con quién concurran a la sucesión. Entre la computación y la imputación, ambas se refieren a donaciones hechas por el causante en vida, la primera se refiere a donaciones en general y la segunda

\footnotetext{
${ }^{163}$ La STS de 26/02/2006 (Tol. 2.592.138) F.J. 5º , se refiere al carácter imperativo que tiene el cálculo de la legítima. 2Al declararse en el anterior pleito la inoficiosidad, se llevó a cabo un cálculo genérico de la legítima, ya que de otro modo, no hubiera sido posible estimarla, porque no es posible saber si una donación lesiona la legítima y por ello debe considerarse inoficiosa, si antes no se ha efectuado el cálculo global.

${ }^{164}$ RoCA - SASTRE Muncunill, L.: Derecho de sucesiones, Tomo II, Boch, Barcelona, 1991, pág. 45.
} 
sólo a las efectuadas a legitimarios ${ }^{165}$. La colación, en cambio, atiende a las donaciones tenidas en cuenta en la imputación, pero sólo en el caso de concurrir varios legitimarios a la sucesión buscando equipararlos entre sí. Por lo tanto, de concurrir un solo legitimario, no tendría sentido esta figura jurídica. Al igual que de no existir legitimarios, tampoco tendría sentido las otras dos figuras que tienen en común ser "actuaciones de adición contable". Cada una de las citadas figuras mantiene una naturaleza jurídica distinta. La computación y la imputación regulan y fijan la legítima, mientras que la colación atiende a la partición hereditaria ${ }^{166}$.

\subsection{LA LEGÍTIMA COMO INSTITUCIÓN DE ORDEN PÚBLICO}

La expresión "orden público" aparece en cinco preceptos del Código civil, en un sentido de ordenación general de la sociedad. El artículo 1.3, Cc impone para que la costumbre pueda ser aplicada en defecto de ley, que no sea contraria a la moral ni al orden público. El artículo 6.2 Cc limitativo de la eficacia de la voluntad dispositiva, siempre que no perjudique, entre otros, el orden público. El artículo 12. 2 Cc determina que las leyes extranjeras no tendrán aplicación en España, cuando contradigan el orden público. El artículo $1255 \mathrm{Cc}$ referente a los contratos, en cuanto a su

\footnotetext{
${ }^{165}$ La STS de 22/02/2006 (Tol. 843.360) F. J. $3^{\circ}$, contempla la figura de la computación referida a las donaciones con el fin de imputarlas al legitimario en el supuesto que coincidan legitimario y donatario en el mismo individuo. "El artículo 654 y los dos siguientes desarrollan la inoficiosidad de las donaciones, y así, al fallecimiento del donante, se computan las donaciones, las cuales se imputan a la legítima, si el donatario es, a su vez, legitimario, pues aquella se atribuye, amén de por otros medios, por donaciones, que, con lo que deja el donante a su muerte, sirve para su cálculo; es el " donatum ", que se suma al " relictum ", y si con este último no hay bienes suficientes para que los legitimarios perciban sus legítimas, las donaciones son inoficiosas y habrá que rescindirlas total o parcialmente para alcanzar los bienes suficientes para cubrir las legítimas, que es lo que establece el primer párrafo, inciso primero, del artículo 654 , con la significación de que, si la donación es inoficiosa, se reducirá lo que sea necesario para defender las legítimas".

166 RocA- SASTRE Muncunil, L.: Derecho de sucesiones, Tomo I, Bosch, Barcelona, 1989, pág. 46.
} 
clausulado, cuando contradigan el orden público, en tal supuesto, devendrían nulos ${ }^{167}$.

La legítima es una institución de orden público, tal como lo entiende la jurisprudencia del Tribunal Supremo ${ }^{168}$. En consecuencia el testador, no tiene disposición sobre la legítima, precisamente, por el carácter imperativo en que se ampara su regulación ${ }^{169}$. Por lo tanto, cualquier norma extranjera que contradiga a la española se considera que está alterando el orden público y en consecuencia no se aplica. La explicación a dicha protección que envuelve a la legítima, puede verse desde una perspectiva personalista o bien desde una patrimonialista.

La primera entiende la sucesión como la sustitución de la personalidad del causante en la persona del heredero e incluso en sus defectos entra a tomar parte el legislador al establecer la presunción del sentir del causante medio. Prueba de ello, son los distintos llamamientos de la sucesión intestada que son efectuados por el Código civil, bajo la presunción de la voluntad del causante de haber este, podido testar. Por lo tanto en este sistema personalista el heredero entra a formar parte de la misma personalidad jurídica que ocupaba el causante en las relaciones jurídicas. Es el sistema romanista que en tantos preceptos del Código civil se advierte. En cambio, el sistema patrimonialista concibe la sucesión como

\footnotetext{
${ }^{167}$ ARNALDO AlCUBILla, E.: La noción de orden público en el constitucionalismo español, Dykinson, Madrid, 2011, págs. 219 a 221.

${ }^{168}$ Mantiene la STS de 19/04/1963 (Tol. 4.329.527), primer Considerando que: el testador no tiene disposición sobre la legítima. No puede tomar decisiones que perjudiquen los derechos de los legitimarios. Puesto que "siendo la legítima de orden público, no puede disponer el testador, por venir impuesta por la ley ni hacer recaer gravamen ni limitación alguna sobre ella, es decir, que ha de llegar al heredero legítimo con pleno dominio sobre todos los derechos que la integran".

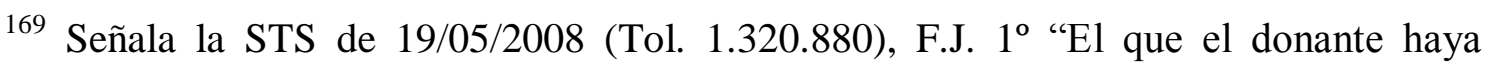
declarado no inoficiosa a la donación que hace con dispensa de colación no impide en absoluto la aplicación de las normas protectoras de la legítima por su carácter imperativo, entre ellas las de reducción de donaciones (Art. $636 \mathrm{Cc}$ )".
} 
un simple cambio de titularidad de los bienes que forman la herencia, un principio de territorialidad de carácter anglosajón, más bien basado en el modelo de familia germánico. Desde este punto de vista el heredero, no adopta la personalidad jurídica que ocupaba el causante en las relaciones jurídicas ${ }^{170}$.

\subsection{INTANGIBILIDAD DE LA LEGÍTIMA}

La intangibilidad de la legítima hace referencia a la protección de la misma. Puesto que "intangible" conforme al Diccionario de la Real Academia Española es un adjetivo, cuyo significado es "Que no debe o no puede tocarse". Según dispone el artículo $813 \mathrm{Cc}$ deja muy claro que las únicas causas por las que el testador puede privar de su legítima a los legitimarios han de estar determinadas por la Ley. Así sucede con las justas causas de desheredación (Art. 848 y ss Cc), el usufructo viudal y lo dispuesto para los hijos incapacitados judicialmente. Como se ha visto, en el epígrafe anterior, la legítima es de orden público y no puede el testador disponer de ella por venir impuesta por la Ley ni imponerle nigún gravamen, ni ninguna limitación ${ }^{171}$. Ello se debe a que las leyes imperativas y prohibitivas protegen al legitimario, no solo cuando recibe menos cuantía de la que le corresponde como legítima, sino también cuando la recibe de

\footnotetext{
${ }^{170}$ ADROHER BiOSCA, S.: "Hacia la supresión del exequátur en el espacio judicial europeo: el título ejecutivo europeo", Universidad de Sevilla, 2006, págs. 55 y 56.

${ }^{171}$ Manifiesta SAN SEGUNDO MANUEL, T.: "Intangibilidad de la legítima, infracción por acto dispositivo del causante a través de una simulación de compraventa civil", Revista Crítico de Derecho Inmobiliario, núm. 701, mayo 2007, pág.1346, que el contenido del artículo 806 Cc sirve como partida del principio de intangibilidad de la legítima al disponer este precepto que la legítima es la porción de bienes de que el testador no puede disponer por haberla reservado la ley a determinados herederos llamados por esto herederos forzosos.
} 
manera diferente a la exigible ${ }^{172}$. Corrobora lo expuesto la jurisprudencia del Tribunal Supremo ${ }^{173}$.

El término de "intangibilidad de la legítima" entra en acción, precisamente, cuando se vulneran los derechos del legitimario. El causante

\begin{abstract}
${ }^{172}$ Berrocal LANZAROT, A. I.: "El maltrato psicológico como justa causa de desheredación de hijos y descendientes", Revista Crítica de Derecho Inmobiliario, núm. 748, marzo 2015, pág, 930. En el mismo sentido se pronuncia O'CALLAGHAN MUÑOZ, Naturaleza..., op. cit., manifestando que la normativa de las legítimas es de derecho necesario por estar formada por normas imperativas sustraídas a la libre disposición tanto de los legitimarios como del disponente. RoCA- SATRSE MunCuniLl, Derecho de sucesiones..., op. cit., pág. 85, señala que al ser la legitima del Derecho común de freno o negativa que implica una limitación a la libertad de disposición de que goza el causante impera en el ordenamiento el principio de inatangibilidad de la legítima tanto en el quantum como el el quale. Esto se debe, manifiesta el autor, a la ausencia de toda noción de reserva germánica en nuestra legítima común, ya que en aquella rige una cuota pars reservata que a la muerte del causante hace traslado, por ministerio de la ley (ipso iure), a los legitimarios, por ser la legitima germánica una porción de bienes sustraída a la disponibilidad del disponente.
\end{abstract}

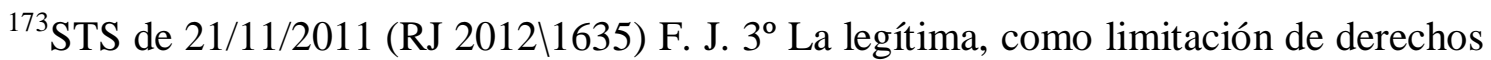
sucesorios a la facultad de disponer del causante o, como dice la sentencia de 28 de septiembre de 2005 (RJ 2005, 7154), sistema de reglamentación negativa, el sistema se califica como de reglamentación negativa, dado que la ley deja al causante disponer de sus bienes en la confianza de que va a cumplir voluntariamente, y por cualquier título, el deber de atribución (...). La STS de 21/12/2006 (RJ 2007/264) F. J. $2^{\circ}$ enjuicia un caso en que se atenta directamente por parte del testador contra la intangibilidad de la legitima de parte de sus propios legitimarios: "La pretensión de los primeros cuatro hijos se basa en que, según su posición, el causante -siempre respecto a su mitad de gananciales ya que ambos pisos lo eran-dejó sin contenido su propia herencia al haber vendido simuladamente un piso a su hija del segundo matrimonio, doña Eva y haber comprado con dinero propio otro piso a nombre de su hijo don Jose Daniel, todo ello atentando directamente el principio de intangibilidad de la legítima, en perjuicio de los cuatro hijos, demandantes, habidos del primer matrimonio".

La STS de 20/09/2005 (RJ 2005\7154) F. J. $2^{\text {o }}$ califica el sistema dispositivo del testador de reglamentación negativa por suponer el correcto cumplimiento con las legítimas: "El sistema se califica como de reglamentación negativa, dado que la Ley deja al causante disponer de sus bienes en la confianza de que va a cumplir voluntariamente, y por cualquier título, el deber de atribución)". Cambia la cosa en los ordenamientos de legítima colectiva y testamento mancomunado como el de Aragón.

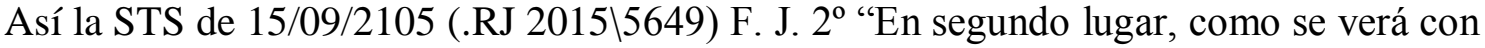
mayor detalle en el examen de los motivos tercero, cuarto y quinto del recurso, la validez de la cláusula primera del testamento resulta incuestionable, pues en ella los testadores aragoneses se acogen al testamento mancomunado instituyéndose recíprocamente como herederos universales, sin que ello comporte la vulneración de la intangibilidad cuantitativa de la legítima colectiva aragonesa, pues en tal caso se daría la reducción del haber de la institución de heredero, pero no su nulidad o supresión". 
incumple totalmente el deber de legítima, cuando no habiendo donado nada en vida al legitimario, no lo menciona el testamento, ni tan siquiera, para desheredarlo (preterición) o cuando lo deshereda sin justa causa ${ }^{174}$. La figura de la intangibilidad de la legítima pone a favor del legitimario mecanismos, para hacer valer su derecho legal, frente a una hipotética alteración en cantidad- bien total o parcial - o bien en calidad ${ }^{175}$. De ahí que se distingan dos tipos de intangibilidad de la legítima, la cualitativa y la cuantitativa $^{176}$.

${ }^{174}$ RuIZ -Rico RuIZ - Morón, J.: "Lesión de la legítima" en AAVV., Curso de Derecho Civil IV, Derecho de Familia y Sucesiones, 4ª ed., Tiran Lo Blanch, Valencia, 2009, pág. 724.

${ }^{175}$ Torres García, T.F. Y Domínguez Luelmo, A.: "La legítima en el Código civi (Il)", en Tratado de legítimas, (coord. T. F. Torres García), Atelier, Barcelona, 2012, pág. 46.

${ }^{176}$ Refrenda lo expuesto la STS de 18/10/2012 (RJ 201219722) F. J. $1^{\text {o }}$ "Materialmente, sólo podría impugnarse si se alegara y probara violación de la intangibilidad cuantitativa y cualitativa de la legítima o vulneración del principio de equidad en la correcta formación de lotes o, incluso, adjudicación indeferenciada de bienes sin concretar los tercios de libre disposición y mejora, como es el caso que contempla la sentencia de 14 de diciembre de 2005 (RJ 2006, 300)". La STS de 18/07/2012 (Tol. 2.635.443) F.J. $3^{\circ}$ distingue los dos tipos de intangibilidad de la legítima, así como sus efectos: "Se distinguen dos tipos de intangibilidad de la legítima: la cuantitativa y la cualitativa. Con el segundo tipo, la ley impide al testador imponer un gravamen al legitimario, mientras que, en virtud de la intangibilidad cuantitativa, se impide otorgar menos de lo que por legítima corresponda. El primer tipo está previsto en el art. $813.2 \mathrm{CC}$, y su incumplimiento produce la anulación del gravamen, mientras que el segundo se encuentra en el art. $815 \mathrm{CC}$ y da lugar al complemento de la legítima. Por tanto, ninguno de estas lesiones produce la nulidad. Si las recurrentes se están refiriendo a los valores de los bienes de la herencia a los efectos del cálculo de la misma, deberían haber denunciado la inaplicación del art. $815 \mathrm{CC}$ y no del art. 813, por lo que se acaba de decir. Pero, en cualquier caso, la intangibilidad afecta al causante, que no puede ni gravar al legitimario, ni dejarle menos de lo que por legítima le corresponda y abre las acciones que éste tiene para corregir las disposiciones que le perjudican. Cuando la lesión la produce la partición, no se puede hablar de intangibilidad, sino de corrección de las operaciones particionales". Así también la STS de 04/01/2012 (RJ 2013\4590) F.J. $3^{\text {o }}$ "la defensa de la intangibilidad cuantitativa de la legítima y, con ella, la pretensión de una nueva cognitio relativa a computación y valoración del haber hereditario debe realizarse, únicamente, por el marco general de la acción de suplemento de la legítima, articulo 815 del Código Civil, como base para el ejercicio de la acción de reclamación de disposiciones testamentarias que lesionen o "mengüen" la legítima y, en su caso, de la reducción por inoficiosidad de las donaciones, artículo 817 del Código Civil . Esta aplicación técnica, que deriva de nuestro sistema sucesorio, 


\subsubsection{La intangibilidad cualitativa}

El término intangibilidad cualitativa hace referencia a cuando se vulnera en calidad el derecho de los legitimarios a recibir su legítima. Conforme dispone el artículo 813. 2 Cc el testador no podrá imponer sobre la legítima gravamen, condición, ni sustitución de ninguna especie. Ello significa que los legitimarios han de poder adquirir la titularidad de los bienes que forman parte de su porción legítima en las mismas condiciones de disponibilidad en que las tenía su causante. Por lo tanto, el testador no puede establecer en su testamento límites o cargas a sus legitimarios de las cuales él, no disponía ${ }^{177}$. Así pues, existirá lesión cualitativa de la legítima aun cuando siendo la atribución en favor del legitimario de valor igual, o incluso superior al de la cuota que señala la Ley se establece alguna restricción de las señaladas en el artículo 813.2 Cc. Salvadas las excepciones allí presentes del usufructo viudal y de la sustitución fideicomisaria en favor del hijo judicialmente incapacitado ${ }^{178}$. El disponente no puede estar cumpliendo la legalidad, en el supuesto de

específica y diferenciada, no puede confundirse ni reconducirse al ámbito de la nulidad patrimonial o al de su rescindibilidad por lesión ".

${ }^{177}$ De PABLo CONTRERAS, Los herederos forzosos ..., op. cit. pág. 287.

${ }^{178}$ Corrobora lo expuesto por la doctrina la STS de 18/07/2012 (RJ 2012/8364) F. J. $3^{\text {o }}$ "1 ${ }^{\circ}$ Se distinguen dos tipos de intangibilidad de la legítima: la cuantitativa y la cualitativa. Con el segundo tipo, la ley impide al testador imponer un gravamen al legitimario, mientras que en virtud de la intangibilidad cuantitativa, se impide otorgar menos de lo que por legítima corresponda. El primer tipo está previsto en el art. 813.2 CC, y su incumplimiento produce la anulación del gravamen, mientras que el segundo se encuentra en el art. $815 \mathrm{CC}$ y da lugar al complemento de la legítima. Por tanto, ninguno de estas lesiones produce la nulidad. Si las recurrentes se están refiriendo a los valores de los bienes de la herencia a los efectos del cálculo de la misma, deberían haber denunciado la inaplicación del art. $815 \mathrm{CC}$ y no del art. 813, por lo que se acaba de decir. Pero en cualquier caso, la intangibilidad afecta al causante, que no puede ni gravar al legitimario, ni dejarle menos de lo que por legítima le corresponda y abre las acciones que éste tiene para corregir las disposiciones que le perjudican. Cuando la lesión la produce la partición, no se puede hablar de intangibilidad, sino de corrección de las operaciones particionales". 
otorgarle la nuda propiedad de bienes en pago de su legítima al legitimario y el usufructo a un tercero o al contrario ${ }^{179}$.

Como regla general a la intangibilidad cualitativa de la legítima, la Ley por virtud del segundo párrafo del artículo $813 \mathrm{Cc}$, no contempla como vulneración de la legítima el usufructo viudal. Ni tampoco se considera, que vulnere la legítima, lo preceptuado en el artículo $808 \mathrm{Cc}$ referente a los hijos o descendientes judicialmente incapacitados. El primer supuesto se deriva del derecho que asiste al cónyuge supérstite que reúna todos los requisitos legales para exigir a los grabados que se constituya su usufructo legal. El segundo supuesto procede de la Ley 41/2003, de 18 de noviembre que supone una excepción al artículo $782 \mathrm{Cc}$ que establece que las sustituciones fideicomisarias nunca pudieran gravar la legítima. En cambio autorizó a que se pueda gravar en los términos establecidos en el artículo $808 \mathrm{Cc}$ estableciendo el testador, una sustitución fideicomisaria sobre el tercio de legítima estricta ${ }^{180}$.

Se entiende por excepciones las cargas, limitaciones o sustituciones impuestas por el testador que no afectan al principio general de intangibilidad cualitativa de la legítima ${ }^{181}$. La Ley 41/2003, de 18 de noviembre ha permitido al disponente establecer una sustitución fideicomisaria sobre el tercio de legítima estricta en la que sean fiduciarios los hijos o descendientes judicialmente incapacitados y fideicomisarios el

\footnotetext{
${ }^{179}$ FuENMAYOR CHAMPÍN, A.:" Intangibilidad de la legítima” Anuario de Derecho Civil, 1948, pág. 63.

${ }^{180}$ De PaBlo ConTRERAs, Los herederos forzosos..., op. cit. pág. 289.

${ }^{181}$ RoCA - SASTRE MunCUnILl, Derecho de sucesiones..., op. cit., pág. 90.
} 
resto de legitimarios (art. 808.2 y $813 \mathrm{Cc})^{182}$. También está el caso de las llamadas cautelas socini o cautelas de opción compensatoria.

En la denominada cautela socini el causante (se desarrolla más adelante) grava la legítima, por lo general, con el usufructo universal en favor del cónyuge, ofreciendo al legitimario que acepte tal gravamen, una porción hereditaria mayor de la que por ley le corresponde. Mientras que los que no la acepten verán reducida su participación en la herencia a la legítima estricta. Disposición testamentaria, la citada, carente de regulación legal a diferencia del Derecho aragonés que en su artículo 500 CDFA si que recoge las cautelas de opción compensatoria. La solución que se ha buscado en este Derecho civil ha sido diseñar los presupuestos que acompañan a la figura: la voluntad del disponente plasmada en su testamento y la total libertad del legítimario para optar por consentir el usufructo universal viudal o bien reclamar sus derechos con la consecuente pérdida de las atribuciones que excedan de su legítima estricta ${ }^{183}$.

Otros Derechos civiles también regulan la atribución al viudo del usufructo universal por parte del testador: usufructo de regencia en Cataluña, usufructo de fidelidad en Navarra, en Galicia la Ley 2/2006, de 14 de junio dispone en el artículo 228 el pacto entre cónyuges tanto en testamento como en escritura pública ${ }^{184}$.

182 Señalan Diez PiCAZo y Gullón, Sistema de Derecho..., op. cit., pág. 182, como regla más importante a las excepciones de la intangibilidad cualitativa de la legítima, el tercio destinado a mejora de los hijos y descendientes grabado por el usufructoviudal (Art, $813 \mathrm{Cc}$ )

183 TORRES GARCÍA y DOMÍNGUEZ LuElmo, La legítima ..., op. cit., pág. 47.

${ }^{184}$ NúÑEZ MuÑIZ, M. C.: "El usufructo universal y el legado de usufructo universal: análisis particular del ejercicio y titularidad de la acción de desahucio", Revista Crítica de Derecho Inmobiliario, núm. 747, enero, 2015, pág. 435. Esta autora se refiere al Derecho civil aragonés resaltando el derecho expectante de que disponen los cónyuges durante su matrimonio e invoca el y 283.1 CDFA «El fallecimiento de un cónyuge atribuye al sobreviviente el derecho de usufructo de todos los bienes del premuerto, así 


\subsubsection{La intangibilidad cuantitativa}

Tiene lugar la intangibilidad cuantitativa de la legítima cuando se mengua, en todo o en parte, al heredero forzoso del derecho que le asiste. Con la intangibilidad cuantitativa de la legítima surge la necesidad de que el causante respete la cuantía de la legítima ${ }^{185}$. Tengase presente que el testador ha podido hacer en vida donaciones que impidan al legitimario recibir completa su legítima. Tambien puede ocurrir entre otros supuestos, que el disponente otorque legados en su testamento que agoten la parte de libre disposición de la herencia, perjudicando con ello al legitimario ${ }^{186}$.

Tal como se prevé en el artículo 815 Cc cuando dice "que se haya dejado a un heredero forzoso por cualquier título menos de la legítima que le corresponde" ${ }^{\# 187}$. Se puede dar este supuesto, en aquellos casos en que el

como los enajenados en vida sobre los que subsista el derecho expectante de viudedad, de acuerdo con lo pactado y lo dispuesto en los artículos anteriores». Tambien RUIZ RICO RUIZ - MORÓN, "Lesión de la legítima...", op. cit. págs. 743 y 744, sigue esta misma línea de opinión con respecto al artículo 820.3 Cc. Así también lo reitera la STS de 21/11/2011 (RJ 2012\1635) F.J. $3^{\text {o c }}$ es claro que la cautela socini no puede alcanzar a la legítima estricta; es decir, el causante puede poner limitaciones o prohibiciones y dar la opción al legitimario de aceptarlas o verse reducido a percibir la legítima estricta; pero ésta es intocable, intangible. Por tanto, no cabe una prohibición que la afecte y si se trata de prohibir la intervención judicial, nunca podrá impedir que la persona legitimaria acuda a los Tribunales en protección de la legítima estricta". Tambien sigue la misma línea La STS de 27/05/2010 (RJ 2010\5158) F. J. $3^{\circ}$ se refiere a la carga que supone para la intangibilidad cualitativa de la legígima la cautela socini: "La llamada comúnmente cláusula o cautela Socini así como Gualdense (por apoyarse en un dictamen emitido por el jurisconsulto italiano del S.XVI Mariano Socini Gualdense) o cláusula angélica (por atribuirse dicha fórmula a Ángelo Ubaldi) es la que puede emplear el testador para, dejando al legitimario una mayor parte de la que le corresponde en la herencia por legítima estricta, gravar lo así dejado con ciertas cargas o limitaciones, advirtiendo que si el legitimario no acepta expresamente dichas cargas o limitaciones perderá lo que se le ha dejado por encima de la legítima estricta”.

185 TORRES GARCíA Y DOMíngueZ LuElMo, La legítima ..., op. cit., pág. 50.

${ }^{186}$ DieZ PICAZO y Gullón, Sistema de Derecho..., op. cit., pág. 178.

${ }^{187}$ Señala RoCA-SASTRE MuNCUNILL, Derecho de sucesiones..., op. cit., págs. 86 y 87 que es la acción ad suplendam legítima expletoria del Derecho romano, como remedio a subsanar la atribución insuficiente del testador y así evitar los efectos destructores de la preterición o de la querella inofficiosi testamento. Ello es debido a que muchas veces la 
testador bien le asigne menos de lo que realmente le corresponde o bien aquel, reservándole su parte a este, se la vacie por medio de donaciones o legados, es decir, le reduzca su correspondiente parte ${ }^{188}$. No tendría sentido una prohibición sin restitución y en consecuencia es el propio ordenamiento el que propicia dicha restitución ${ }^{189}$. Lo hace por medio de acciones en que el legitimario dispone para proteger su integridad cuantitativa. Unas van encaminadas a la obtención de un complemento de lo atribuido por el testador y otras a la impugnación de las disposiciones inoficiosas dispuestas por el testador ${ }^{190}$. Las acciones para proteger la intangibilidad cuantitativa de la legítima se dividen en acciones de complemento conforme al artículo $815 \mathrm{Cc}$ y acciones de reducción conforme al artículo $817 \mathrm{Cc}^{191}$.

insuficiencia de legítima puede deberse a un error de valoración o a un incremento patrimonial ulterior.

${ }^{188}$ Lledó Yagüe, F., Monje Balmaseda, O., Herrán Ortiz, A.I., AAVV: Intangibilidad de la legítima, Dykinson, Madrid, 2012, págs. 124-125.

189 Señala DiEZ- PICAZO Y Gullón, Sistema de Derecho..., op. cit., pág. 178, la evidencia que supone en todos estos casos reducir las disposiciones (donaciones o legados) inter vivos o mortis causa, ya que de mantenerlas los legitimados serian perjudicados en su cuota cuantitativamente.

${ }^{190}$ Torres GARCÍA, y DOMínguez LuElmo, “La legítima en el Código civil (I)... ”, op. cit, pág. 50.

${ }^{191}$ Lledó YAGÜE, Intangibilidad de la ..., op. cit. pág. 125. La jurisprudencia se pronuncia en STS de 23/06/2015 (RJ 2015\2547) F. J. por la preterición de un heredero forzoso (814 del Código Civil), debe $3^{\circ}$ Así, en primer lugar, tal y como esta Sala ha señalado en su sentencia de 10 de diciembre de 2014 (núm. 695/2014 (RJ 2014, 6842) ), a propósito de la ineficacia testamentaria tenerse en cuenta que, pese al tenor literal del precepto, la acción que se ejercita no se incardina, en sentido técnico, en el marco de una acción de nulidad que provoque la invalidez estructural de lo ordenado por el testador sino que responde, más bien, a la dinámica de las acciones o medidas de resolución propias de la defensa de la intangibilidad cuantitativa de la legítima. De ahí que la causa de la impugnación no sea otra que la propia preterición del heredero forzoso, esto es, heredero legitimario, y que la ineficacia resultante se dirija funcionalmente a purgar los efectos que resulten lesivos de cara al derecho que le asiste al heredero preterido como legitimario del causante. La STS de 20/07/2012 (RJ 2012 19001) F. J. 4" "La desestimación del primer motivo del recurso de casación en el sentido de apreciar la plena validez de la renuncia traslativa de don Baltasar a favor de 


\subsubsection{La acción de reducción}

La acción de reducción está prevista en el artículo 817 Cc y se aplica cuando la masa hereditaria es insuficiente para cubrir la legítima colectiva y la individual ${ }^{192}$. Esta acción encuentra su razón en las donaciones realizadas en vida por el testador, que impiden al legitimario recibir completa su legítima. También puede ocurrir que aquel haya otorgado un exceso de legados en su testamento, que junto con las donaciones, superen la parte de libre disposición ${ }^{193}$. En tales casos, para que los legitimarios reciban íntegramente su parte ha de aplicarse la acción de reducción dispuesta en el artículo $817 \mathrm{Cc}^{194}$. La legitimación para interponerla, al igual que ocurre en la acción de complemento, corresponde al perjudicado. Debido a que la propia acción no presenta plazo especial de prescripción. Cabe acogerse a lo dispuesto en el artículo 1964.2 Cc, para las acciones personales que no tengan plazo personal de prescripción, es decir, de 5 años ${ }^{195}$. Una vez fijada la legítima por aplicación de los artículos 818, 819, 825 y $828 \mathrm{Cc}$, de existir disposiciones que mengüen la legítima, se tendrán

sus restantes hijos y, por tanto, de la implícita aceptación de la herencia de su hijo, hace innecesario entrar en la valoración de los restantes motivos de casación formulados, por cuanto la partición practicada por el contador-partidor no solo no se realizó conforme a la voluntad testamentaria sino que, además, infringió la intangibilidad cuantitativa y cualitativa del legitimario al vaciarla de todo contenido económico resultando, por

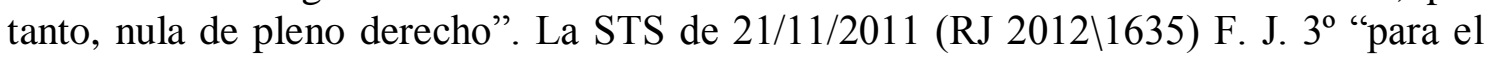
caso de que se superen en su perjuicio los límites establecidos, la facultad de ejercitar las acciones de defensa cuantitativa de su legítima, con la reclamación del complemento ( artículo 815 del Código Civil ), la reducción de legados excesivos ( artículos 817 y 820 del Código Civil y sentencia de 24 de julio de 1.986 (RJ 1986, 4619) ) o, en su caso, de las donaciones inoficiosas ( artículos 634 , 651 , 819 y 820 del Código Civil ), aunque estén ocultas bajo negocios aparentemente onerosos ( sentencia de 14 de noviembre de 1.986 (RJ 1986, 6392) )".

${ }^{192}$ De Pablo Contreras, Los herederos forzosos..., op. cit., págs. 319 a 322.

${ }^{193}$ RoCA - SASTRE MunCUnILl, Derecho de sucesiones..., op. cit., pág. 90.

${ }^{194}$ Diez PiCAZO, L. y Gullón, A.: Sistema de Derecho civil, Vol. IV, tomo $2^{\text {o }}$ (Derecho de Sucesiones), 12ª ed, Tecnos, Madrid, 2017, pág.178

${ }^{195}$ Torres GARCÍA, y Domínguez LuELmo, "La legítima en el Código civil (I)...”, op. cit., pág. 53. 
que reducir, como regla general, las disposiciones testamentarias inoficiosas o excesivas ${ }^{196}$.

Cuando es la propia institución de heredero la que está menguando las legítimas, aunque el propio Código civil no disponga de precepto especifico para ello, se puede aplicar la reducción dispuesta con carácter general en el artículo 817 Cc para las disposiciones testamentarias que perjudiquen la legítima. Así pues, en primer lugar se reducirá la institución de heredero como antes ya se apuntaba ${ }^{197}$. Si esta continuara siendo insuficiente para salvar las legítimas se reducirán los legados, por entenderse que también están comprendidos dentro de las disposiciones testamentarias a las que se refiere el precitado artículo 817 Cc. Finalmente, en el caso de que reduciendo los legados no se pudieran cubrir las legítimas se tendrían que reducir las donaciones. Es el ya citado artículo 820 Cc en su respectivo apartado $1^{\circ}$ y $2^{\circ}$ el que permite reducir o anular, si procede, las "mandas" que el testador hizo en su momento y los legados. No se puede pasar por alto, en este apartado, la incómoda reducción o división de la cosa que está impidiendo que se cubran las legítimas en su integridad. A ello dedica su contenido el artículo $821 \mathrm{Cc}^{198}$. Otro posible planteamiento sería el supuesto que recogen los artículos 654.1 y $656 \mathrm{Cc}$ en que, agotados

${ }^{196}$ Torres García, y Domínguez Luelmo, “La legítima en el Código civil (I)...”, op. cit., págs. 52 y 53.

${ }^{197}$ LASARTe, ÁLVAREZ, Derecho de sucesiones..., op. cit., pág. 216.

198 Artículo 821Cc: "Cuando el legado sujeto a reducción consista en una finca que no admita cómoda división, quedará ésta para el legatario si la reducción no absorbe la mitad de su valor, y en caso contrario para los herederos forzosos; pero aquél y éstos deberán abonarse su respectivo haber en dinero"-

"El legatario que tenga derecho a legítima podrá retener toda la finca, con tal que su valor no supere, el importe de la porción disponible y de la cuota que le corresponda por legítima".

"Si los herederos o legatarios no quieren usar del derecho que se les concede en este artículo se venderá la finca en pública subasta, a instancia de cualquiera de los interesados". 
todos los legados, no se llegan a cubrir totalmente las legítimas. En este caso tendría que procederse a reducir las donaciones que el testador hubiera hecho en vida por orden de antigüedad. Con preferencia para ser reducidas o suprimidas las más recientes a las más antiguas ${ }^{199}$.

\subsubsection{La acción de complemento}

La integridad cuantitativa de la legítima la pone de manifiesto el artículo $815 \mathrm{Cc}$ al ser el remedio a la insuficiente cuantía de la legítima. Este precepto a la vez que recoge la acción de complemento de la legítima, cancela el deber formal de tener que instituir al legítimario heredero tal como recogían las partidas del Derecho romano. Lo hace con las palabras "por cualquier título"200. Por consiguiente el legitimario parcialmente insatisfecho (sujeto activo) podrá reclamar al heredero (sujeto pasivo) lo que le falte, para tener completa su legítima ${ }^{201}$. Si de esta forma no logra

\footnotetext{
${ }^{199}$ LASARTE Álvarez, Derecho de sucesiones..., op. cit., pág. 216-217.

${ }^{200}$ VAllet de Goytisolo, J.: “Comentarios al Código...”, op. cit., pág. 209.

${ }^{201}$ LASARTE, ÁlVAREZ, Derecho de sucesiones..., op. cit., pág. 215. Coincide este autor de que se trata, al pedir en la acción de complemento, lo que le falte de su legítima al legitimario parcialmente insatisfecho. La STS de 02/10/2014 (RJ 2014\4714) F.J. 9º "No obstante, la sucesión en nuestro derecho no concede al "de cuius" una absoluta libertad en cuanto a la disposición de sus bienes por vía de testamento y por ello, entre otros, el artículo 815 del Código Civil permite ejercer la acción de complemento de legítima en los casos en que el testador no ha respetado con su disposición los derechos de los legitimarios. Así se ha entendido en este caso y por ello carece de sentido invocar el respeto de la voluntad del causante cuando la misma no ha sido respetuosa con la ley aplicable; como igualmente carece de explicación la atribución expresa a los contadores partidores de la facultad de pago en metálico de la legítima cuando, según el testamento, la legítima ya había sido satisfecha al demandante mediante una donación. Por ello el motivo ha de ser desestimado. La SAP de Madrid (S.21) de 31/05/2012 (AC $2012 \backslash 506$ ) F.J. $1^{\circ}$ Corrobora lo expuesto en el texto al mantener que para el ejercicio de la acción de complemento de legítima sólo requiere ostentar la condición de legitimario: "El cuadro rasgado" - menos de la legitima que le corresponde, todo ello al amparo de lo dispuesto en el artículo 815 del Código Civil, considerando correcta la forma de ejercitar la acción de complemento de legitima y que, aún no ostentando la condición de heredero, en su condición de legitimario se encuentra plenamente facultado para el ejercicio de las pertinentes acciones de impugnación de los actos realizados por el causante en cuanto perjudiquen sus derechos". Este caso fue llevado a casación dando el Tribunal Supremo la razón a la Audiencia Provincial de Madrid en STS de 02/10/2014 (RJ 2014l4714).
} 
completar su legítima se tendría que pasar a reducir los legados y las donaciones, tal como se ha visto en la "acción de reducción" $" 202$.

Distíngase en este punto que el legitimario consta en el testamento, lo único es que los bienes que le ha atribuido el causante no son suficientes para cubrir su legítima. El disponente ha vulnerado la intangibilidad cuantitativa de la legítima y cuyo remedio para ello es la aplicación de lo dispuesto en el artículo 815 Cc. Cosa muy distinta sería la acción de reclamación de legítima (completa) por preterición ${ }^{203}$. En muchas ocasiones la merma de legítima puede deberse a un error de valoración del testador o haber incrementado su patrimonio con posterioridad al otorgamiento del testamento. Con esta acción, ya desde el Dercho romano, se pretendía ante tales casos evitar los efectos destructores de la preterición ${ }^{204}$.

202 Diez PicAzo, L. y Gullón, A.: Sistema de Derecho civil, Vol. IV, tomo $2^{\text {o }}$ (Derecho de Sucesiones), $12^{\mathrm{a}}$ ed, Tecnos, Madrid, 2017, pág.181.

203 PANIZA FullanA, A.: La acción de complemento de legítima: concurrencia y ejercicio en El patrimonio sucesorio: Reflexiones para un debate reformista, Dykinson, Madrid, 2014, pág. 863.

204 RocA-SATRSe MunCunill, Derecho de sucesiones..., op. cit., pág. 87. Mantiene este autor que la acción de complemento de legítima es la ad supplendam legíman o expletoria del derecho romano introducida como remedio para subsanar las atribuciones insuficientes por parte del disponente al legitimario y evitar con ello destrucciones innecesarias como las provocadas por la preterición o la querella innofficiosi testamenti. La STS de 18/07/2012 (RJ 201218364) F. J. $3^{\circ}$ pone de manifiesto que el artículo 815 Cc es el remedio contra la merma de legítima: "Se distinguen dos tipos de intangibilidad de la legítima: la cuantitativa y la cualitativa. Con el segundo tipo, la ley impide al testador imponer un gravamen al legitimario, mientras que en virtud de la intangibilidad cuantitativa, se impide otorgar menos de lo que por legítima corresponda. El primer tipo está previsto en el art. $813.2 \mathrm{CC}$, y su incumplimiento produce la anulación del gravamen, mientras que el segundo se encuentra en el art. $815 \mathrm{CC}$ y da lugar al complemento de la legítima. En la misma línea la STS de 21/11/2011 (RJ 2012\1635) F.J. $3^{\text {o }}$ "La legítima, como limitación de derechos sucesorios a la facultad de disponer del causante (...) para el caso de que se superen en su perjuicio los límites establecidos, la facultad de ejercitar las acciones de defensa cuantitativa de su legítima, con la reclamación del complemento ( artículo 815 del Código Civil ), la reducción de legados excesivos ( artículos 817 y 820 del Código Civil (...)". Tambien la STS de 28/08/2005 F. J. $2^{\circ}$ " la Ley deja al causante disponer de sus bienes en la confianza de que va a cumplir voluntariamente, y por cualquier título, el deber de atribución y confiere al legitimario (artículo 763.2 del Código Civil) para el caso de que se superen en su 
Por lo que respecta a la legitimación activa para poder pedir el complemento, como se ha apuntado, sólo tiene la facultad de hacerlo el perjudicado, es decir, aquel legitimario que cuantitativamente ha visto reducida la cantidad de su correspondiente derecho ${ }^{205}$. Al ser esta acción transmisible, en el supuesto de no haberla ejercitado el propio interesado, podrán ejercitarla sus herederos conforme a lo previsto en el al artículo 16 LEC para la "sucesión procesal por muerte". También, dicha acción, conforme a los artículos 1111 y1001 Cc pueden ejercitarla los acreedores del legitimario con legitimación para pedir el suplemento ${ }^{206}$. La acción puede dirigirse contra el heredero o herederos instituidos por el causante incluido los que a su vez sean legitimarios. El plazo para interponerla es el de 30 años a contar desde la muerte del causante ${ }^{207}$. La jurisprudencia se ha manifestado en el mismo sentido que la doctrina, así la STS de $17 / 01 / 2014^{208}$.

perjuicio los límites establecidos, la facultad de ejercitar las acciones de defensa cuantitativa de su legítima, con la reclamación del complemento (artículo 815 del Código Civil)".

205 OchoA Marco, R. y Sebastián Chema, M.S.: La herencia. Análisis Práctico de los problemas sustantivos y procesales del Derecho de sucesiones, Edisofer S.L, Madrid, 2017, pág. 182.

206 Torres García, T. F. y Dominguez Luelmo, A.: "La legítima en el Código civil...", (I) op. cit., pág. 52. "La acción debe de ir dirigida bien contra todos los herederos o bien contra toda la comunidad hereditaria, en función de si se ha realizado o no la pertinente partición de la herencia. El ejercicio de la acción de complemento, no comporta ni la anulación del testamento ni la de la institución de herederos.

${ }^{207}$ PANIZA FULlaNA, La acción ..., op, cit. pág. 865.

${ }^{208}$ STS de 10/06/2014 (Tol. 4.374.204). El Alto Tribunal en el punto tercero del F.J. $3^{\circ}$ hace una importante aportación al plazo para interponer la acción de complemento de la legítima, lo motiva de la siguiente manera: "En relación al primer motivo, debe señalarse que no procede la aplicación analógica dado que, técnicamente, no se está ante el supuesto reconducible al ámbito de la revocación y reducción de donaciones (644 a 646 del Código Civil), ni tampoco ante un supuesto de rescisión, ya por la vía específica de la lesión de la partición, o bien por el cauce general de la rescindibilidad de los contratos (artículos 1076 y 1299 del Código Civil, respectivamente), sino ante el ejercicio de una acción de suplemento de la legítima cuyo plazo de prescripción es de treinta años, desde el día del fallecimiento del causante". 
El Derecho civil gallego contempla la acción de complemento de la legítima en el artículo 247 LDFG y describe dicha acción disponiendo que si los bienes atribuidos por el disponente al legitimario son insuficientes para cubrir su legítima, este sólo tendrá derecho a su complemento siendo satisfecho conforme a las mismas reglas del pago del crédito legitimario. Al igual que en el Derecho común el sujeto activo es el legitimario perjudicado y el pasivo la comunidad hereditaria ${ }^{209}$.

\subsubsection{El derecho de representación}

De conformidad con el artículo 924 Cc el derecho de representación es el derecho a ocupar la posición de un pariente que de haber podido heredar hubiera ocupado en la herencia. Es de hacer notar que este precepto se encuentra emplazado dentro del Cápitulo que el Código civil dedica a la sucesión intestada, por lo que el ámbito de aplicación del derecho de representación es la sucesión intestada ${ }^{210}$. En efecto el objeto del derecho de representación es defender los intereses patrimoniales de los descendientes de un heredero premuerto. De ahí que solamente se prevea el derecho de representación a favor de los descendientes y nunca de los

\footnotetext{
${ }^{210}$ LaSARTe Álvarez, Derecho de sucesiones..., op. cit., págs. 23 y 24. No toda la doctrina es conforme con la definición que otorga al derecho de representación el artículo 924 Cc. Asi Lledó Yagüe, Monje Balmaseda, Herrán OrTiz, AAVV: Cuaderno (I) ..., op. cit., pág.45, mantienen que el representado nada ha podido adquirir para ser representado dada su incapacidad para aceptar la herencia. De otra da a entender el precepto que el representante sucede al representado y a quien sucede es al causante. Con respecto a los requisitos de capacidad se posiciona al artículo $928 \mathrm{Cc}$ que concede el derecho por renuncia a la herencia. Tampoco está conforme con la definición que le da al derecho de representación el artículo 924 Cc O'CALLAGHAN MuÑOz," Compendio...", op. cit., de hecho lo llama " el mal llamado derecho de representación". Entiende que la regla general de la sucesión intestada es que el pariente más próximo excluye al más remoto y el derecho de representación es una excepción a esta regla. La realidad es que nadie hereda por haber premuerto lo que ocurre es que el llamamiento se dirige a sus descendientes. El primer error es que no heredan los parientes, sino los descendientes del premuerto. El segundo error es que no se sucede al premuerto sino al causante. El tercer error es que el descendiente del premuerto no lo representa, no actua en nombre de otro, sino que se coloca en su puesto.
} 
ascendientes. En cuanto a la sustitución de grados por representación solo tiene cabida por lina recta descendente del premuerto. La línea colateral mantiene la limitación hasta el tercer grado $(\operatorname{art} .925 \mathrm{Cc})^{211}$.

Si bien el derecho de representación, como se ha dicho, únicamente se da en la sucesión intestada, en la sucesión forzosa también tiene cabida en sede de la desheredación, la indignidad y la premoriencia: significando ello, que la sanción que recogen las dos primeras figuras no deben afectar a la estirpe. Lo que en realidad ocurre es que por virtud de los artículos 857, 761 y 814 Cc atribuye el propio Código la condición de legitimario a los hijos o descendientes del desheredado, indigno o premuerto ${ }^{212}$. En la sucesión testada cuando se da la premoriencia, indignidad o la repudiación ocupa el lugar del afectado el llamado a la sucesión por el disponente, por aplicación de sustitución vulgar, pero no por derecho de representación. De no haberla previsto el testador (la sustitución) se dará el derecho de acrecer si procede y de no proceder se abriría la sucesión legal ${ }^{213}$.

La argumentación expuesta anteriormente podría acarrear circustancias bastante injustas para los descendientes del premuerto que el

\footnotetext{
212 O'CAllaghan MuÑoz," Compendio...", op. cit

213 Señala O'CALlaGHAN MuÑOZ," Compendio...", op. cit., que el testador puede haber dispuesto un derecho de representación, sin que ello sea una sustitución vulgar si bien es dudosa su distinción. Coinciden en principio con la opinión de que el derecho de representación no se da en la sucesión testada RAMS AlBESA, J., MORENO FlóREZ, R.M., RUBIO SAN ROMÁN, J.I.: "La representación establecida por la ley en la sucesión testamentaria", en Apuntes de Derecho de Sucesiones, Dykinson, Madrid, 2012, pág. 55. Tambien la STS de 06/12/1952 (RJ 1952 2430) Considerando $4^{\circ}$ “'(..) tal como lo define el artículo 927 del Código Civil, el pensamiento del legislador es claramente restrictivo hasta el punto de sustituir los nietos a su padre premuerto e instituido nominativamente en la porción libre de la herencia del abuelo de aquéllos, porque el hecho de haber sido regulado el derecho de representación en el capítulo que gobierna la sucesión intestada, pudiendo haberlo incluido en el grupo de disposiciones comunes a la herencia por testamento o sin él, revela el designio de que aquél derecho no tenga cabida en la porción libre de la herencia testada (...)".
} 
testador hubiera, por olvido, haber omitido en su testamento, se estaría frente a una preterición con todas sus consecuencias. Un supuesto testador $\mathrm{A}$, al que le ha premuerto su hijo $\mathrm{B}$, el cual tenía tres hijos: a,b,c de no mencionar expresamente el disponente a sus nietos a,b,c se hubiera producido un caso de preterición con la posibilidad de anulación de alguna institución. Precisamente para evitar dichas consecuencias se introdujo 1981 un tercer párrafo en el artículo $814 \mathrm{Cc}^{214}$. Con la reforma, aunque el disponente no incluyera a sus tres nietos del supuesto, no pasaría nada, sismplemente los tres hijos del premuerto heredarían lo que hubiera heredado su padre. He omitido la palabra "representar a su padre" porque hay autores que no admiten que con la inclusión del tercer párrafo al artículo $814 \mathrm{Cc}$ se haya incluido por ello el derecho de representación a la sucesión testada. Lo que se ha hecho con la reforma del articulo 814.3 Cc es declarar legitimarios directamente, a los descendientes del legitimario premuerto $^{215}$.

La representación opera en aquellos supuestos en que el llamado no puede heredar bien por haber premuerto al causante, bien por tener incapacidad hereditaria, es decir, ser indigno para suceder al causante. En cambio el derecho de representación nunca se produce cuando el llamado

${ }^{214}$ Artículo 814.3 Cc "Los descendientes de otro descendiente que no hubiere sido preterido, representan a éste en la herencia del ascendiente y no se consideran preteridos".

215 Mantiene O'CAllaghan MuÑoz," Compendio...”, op. cit., que no establece el artículo 814.3 Cc un derecho de representación en la sucesión testada. VALLET DE GoYTiSOLO, "Comentarios...", op.cit, pág. 199, con respecto a la disposición del artículo 814. 3 encuentra la duda de si el descendiente del premuerto sólo representa a este en la legítima o si la norma en realidad implica una sustitución vulgar tácita para el caso de premoriencia. Lo que en el segundo supuesto implicaría que el precepto de referencia no establece un derecho de representación en la sucesión forzosa. En cambio RAMS Albesa, Moreno FlóReZ, Rubio SAN ROMÁn, La representación..., op. cit., pág. 56 dan por sentado que con la reforma de 1981 del artículo 814 Cc se incluye el derecho de representación en el citado precepto. 
ha repudiado la herencia ${ }^{216}$. Ello se debe a los distintos preceptos que excluyen la representación sucesoria en la repudiación, así el artículo 923 Cc la excluye de manera expresa. El artículo 924 manifiesta el derecho que tiene el pseudorrepresentante a suceder en todos los derechos que tendría si viviera o hubiera podido heredar el representado. El artículo 981 dispone que la parte del que repudia acreceráa en sus coherederos ${ }^{217}$.

\subsection{LOS LEGITIMARIOS EN EL CÓDIGO CIVIL}

El artículo 807 Cc ha sido un precepto que desde su incorporación en 1889 , ha determinado quienes son "los herederos forzosos" $" 18$. Incluso tras su última reforma en 1981, sigue determinando con el mismo calificativo de "herederos forzosos" a los titulares del derecho a legítima ${ }^{219}$. Con esta

216 ARJONA GUAJARDO-FAJARDO, J.L.: "Derecho de representación sucesoria. Estudio sobre la operatividad del derecho de representación en el Código civil español, en caso de repudiación del sujeto llamado a una herencia", Anuario de Derecho Civil, núm. LXV-I, 2012, pág. 46.

217 ARJONA GuAJARDO-FAJARDO, "Derecho...", loc. cit., pág. 46. Comparte la misma postura O'CAllaghan MuÑoz," Compendio...", op. cit., manteniendo que no cabe derecho de representación por haber repudiado una herencia. Tambien RAMS ALBESA, MORENO FLÓREZ, RUBIO SAN ROMÁN, La representación..., op. cit., pág. 57 mantienen la exclusión de la representación en la repudiación. Tambien la jurisprudencia mantiene

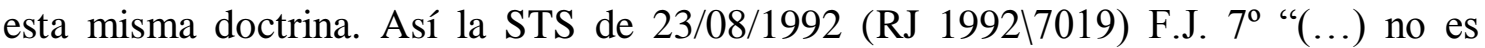
posible entender la atracción del mecanismo de la representación sucesoria, por el conocido principio de nuestro derecho de «viventis non datur representatio», que veda su juego ante la renuncia del ascendiente, en virtud de lo dispuesto en los arts. 924 y ss. $\mathrm{CC}$; en consonancia con lo afirmado, procede, pues, estimar en lo atinente los motivos del recurso (...)". Tambien se suma a la postura de que no hay más representación sucesoria que la de una persona viva, salvo en los casos de desheredación e indignidad. La SAP de Granada (S.3 ${ }^{a}$ ) de 04/03/2011 (AC 2011\1769) F. J. 2º lo que viene a reiterar es que no hay derecho de representación en la repudiación. "no hay más representación sucesoria de una persona viva que cuando es desheredada o indigna para suceder (art. 929 CC )".

${ }^{218}$ Artículo $807 \mathrm{Cc}$ : "Son herederos forzosos: $1^{\circ}$ Los hijos y descendientes respecto de sus padres y ascendientes. $2^{\circ}$ A falta de los anteriores, los padres y ascendientes respecto de sus hijos y descendientes. $3^{\circ} \mathrm{El}$ viudo o viuda en la forma y medida que establece este Código".

${ }^{219}$ IRURZUN GOICOA, D.: “¿Qué es la legítima para el Código Civil español? (Búsqueda de su concepto, naturaleza y caracteres", Revista Crítica de Derecho Inmobiliario, núm. 759, enero 2017, pág. 2521. Sólo dos preceptos en todo el Código civil (art. 824 y 841 
modificación se elimina todo rastro de distinción discriminatoria entre hijos nacidos dentro y fuera del matrimonio. Todos los hijos son herederos forzosos de sus progenitores, como lo son estos de aquellos en defecto de descendientes. La proximidad de parentesco con el causante es lo que condiciona el derecho legitimario de sus descendientes ${ }^{220}$. Como regla general, la muerte de un legitimario producida con anterioridad a la del progenitor (la premoriencia) da el derecho de legítima a sus descendientes.

Como se ha podido advertir, el artículo 807, del Código civil, enumera a los legitimarios de una manera poco extensa que, tal vez, podrían plantearse muchos interrogantes ante tal sencillez en la definición. Adviértase, por ejemplo, que el nacimiento del legitimario se produce en el mismo instante que fallece el causante, pues hasta entonces, lo único que mantiene es un derecho expectante de legítima. En el caso de descendientes desde que nacen, en el caso de ascendientes desde que nace el causante y en el caso del cónyuge supérstite, desde el momento de la celebración del matrimonio. El denominador común de los tres casos es que no nace el derecho a legítima mientras no haya un fallecimiento, el fallecimiento del causante. En todo caso, el legitimario expectante, tendrá que mantener el vínculo que le unía al difunto, caso de ser este jurídico, tendrá que sobrevivirle y disponer la preferencia que la Ley le exija ${ }^{221}$.

Cc) se refieren, directamente, a los titulares del derecho de legítima como "legitimarios". En su lugar se utiliza el término "herederos", que es muy distinto al de legitimarios primero porque se puede ser legitimario y no heredero o viceversa y segundo por entenderse por heredero al sucesor universal. Además, es bien sabido que a diferencia del heredero, el legitimario no responde de las deudas del causante. Aunque se extraigan las legítimas después de haber pagado dichas deudas, pero el acreedor no puede entrar en el patrimonio del legitimario, como lo puede hacer en el del heredero si no acepta este, la herencia, a beneficio de inventario.

${ }^{220}$ DíEZ- PiCAZO, L. y GUILLÓN, A.: Sistema de derecho civil..., op. cit., pág. 154.

${ }^{221}$ IRURZUN GOICOA, “¿Qué es la legítima para el Código Civil español?...”, op. cit., pags. 2530 y 2531. 
En virtud del parentesco que une al finado y a los legitimarios hay que distinguir entre los legitimarios que excluyen a los demás, como sucede en el artículo $807 \mathrm{Cc}$ con los ascendientes, que solo podrán ejercer su derecho a legítima en defecto de descendientes. Por ello los descendientes excluyen a los ascendientes de la sucesión. En cambio, el cónyuge supérstite concurre a la sucesión como usufructuario, tanto con descendientes como con ascendientes, en todo caso varía la cuantía de su legítima, pero ni unos ni otros le excluyen a él, y concurre con ambos a la sucesión.

\subsubsection{La legítima de los hijos y descendientes}

La legítima que corresponde a los hijos y descendientes, en virtud del artículo $808 \mathrm{Cc}$ es de las dos terceras partes del caudal relicto del causante. Dicho lo anterior, señala el precepto, que podrá el testador disponer de una de las dos terceras partes citadas, es decir, de un tercio de los dos destinados a legítimas, para mejorar a todos o a alguno de sus hijos o descendientes $^{222}$. Hay que tener presente que el disponente puede mejorar al nieto viviendo su padre e hijo de aquel ${ }^{223}$. No es necesario que se utilice

${ }^{222}$ Es evidente que la mejora requiere la voluntad inequivoca del causante de querer
mejorar cuando se desiguala a los hijos con una donación. Véase la STS de $29 / 05 / 2006$,
(RJ 200613343) cuando alude en su F.J. $3^{\circ}$ al artículo 825 Cc el cual distingue la mejora
de la donación." La recurrente cita como infringido el artículo 825 del Código Civil, lo
que esta Sala admite, pues en la escritura de donación no hay rastro alguno de que Doña
Amelia quisiera desigualar a sus hijas, favoreciendo a la donataria con una mejora. Por
ello, considerar que la donante mejoró a su hija por el hecho exclusivo de la donación
no es admisible de acuerdo con el citado precepto, que exige no sólo voluntad de donar
en el donante sino algo más, y es la voluntad inequívoca de mejorar, aunque no se
emplee la palabra mejora. En este caso falta por completo cualquier manifestación de
esa última voluntad".
223 Véase STS de 28/08/2005 (RJ $2005 \backslash 7154)$ cuando en su F. J. 4 o manifiesta que:
"Aunque la mejora sea parte de la legítima (sentencias de 26 de diciembre de 1989 [ RJ
1989 , 8872] y 22 de noviembre de 1991 [RJ 1991,8477 ] ) y el artículo 808 del Código
Civil (LEG 1889 , 27) no reconozca conjuntamente a los hijos y descendientes derecho a
reclamar esta última, es interpretado el artículo 823 Cc en el sentido de admitir la
posibilidad de que el abuelo mejore al nieto pese a vivir el hijo y, por lo tanto, pese a no
ser el mejorado legitimario de primer grado y, por ende, con derecho a reclamar
legítima". La posibilidad de que el causante mejore a nietos viviendo los hijos, además
de no contradecir ninguno de los artículos del Código Civil que regulan la mejora se 
todo el tercio en mejorar, siempre que se reintegre el resto en las propias legítimas $^{224}$. La mejora, que si bien puede ser expresa o tácita ${ }^{225}$, es legítima frente a extraños pero es de libre disposición frente a hijos y descendientes del disponente ${ }^{226}$. En consecuencia, la Ley permite al

basa en el precedente histórico de la Ley 18 de Toro, a cuyo tenor el padre o la madre, o cualquier de ellos pueden si quieren hacer el tercio de mejoría que podían hacer a sus hijos o nietos conforme a la Ley del fuero á cualquier de sus nietos, o descendientes legítimos, puesto que sus hijos, padre de los dichos nietos, o descendientes sean vivos, sin que en ello les sea puesto impedimento alguno. Dicha Ley fue recogida en la Novísima Recopilación (10.6.2) con el epígrafe la mejora del tercio se pueda hacer al nieto, aunque sus padres vivan. También se señala por la doctrina en apoyo de tal posibilidad el conocido rechazo de la tesis contraria al redactarse el artículo 654 del Proyecto de Código Civil de 1.851".

${ }^{224}$ Véase NúÑEZ MuÑIZ, C.: "De nuevo las legítimas en el código civil español y novedades del código civil brasileño", Revista Crítica de Derecho Inmobiliario, núm. 762, julio 2017, pág. 2026. El tercio de mejora además está gravado con el usufructo viudal, que supone el usufructo de dicho tercio de mejora.

${ }^{225}$ Señala la STS de 18/06/1982 (Tol. 1.739.425) en el F.J.3 ${ }^{\circ}$, que tendrá que ser el contenido del clausulado testamentario, más que la utilización de la palabra mejora, el que ponga de manifiesto la voluntad de mejorar del disponente. También la STS de 22/11/1991 (Tol. 1.728.561) F.J.7 $7^{\circ}$ se pronuncia al respecto de la mejora tácita "en el caso de que en la declaración del testador se evidencia una voluntad patente de mejorar cuando el testador se manifiesta de una forma tan contundente y reiterada que sea incompatible con la negación de los efectos de la mejora". En el mismo sentido la SAP de Badajoz (S. $3^{\text {a }}$ ) de 04 /02 /2016, (JUR 2016139324) F.J. $3^{\circ}$ resalta la voluntad expresa en el testamento del disponente de mejorar a su hija: "Pues bien, en este caso, resulta indiscutible la voluntad expresa de don Claudio de querer mejorar a su hija. No estamos ante una voluntad presunta o supuesta, pues contamos con un testamento donde el padre expresaba su intención de mejorar a su hija. El padre simplemente materializó en vida el deseo manifestado en el testamento".

${ }^{226}$ OCHOA MARCO, R. y SEBASTIÁN CHENA, M.S.: La herencia: análisis práctico de los problemas sustantivos y procesales del Derecho de sucesiones, $7^{\mathrm{a}}$ ed. Edisofer S.L., Madrid, 2017, pág. 57. También la SAP de Castellón, (S. $1^{\circ}$ ) de 31/05/2013 (JUR 2013\267723) F.J. $4^{\text {o }}$, hace alusión a la mejora tácita: “(...) lo que hay que hacer es dar solución al debate que las partes plantean acerca de la validez o no de las mejoras "tácitas", puesto que es obvio que la madre de los litigantes al hacer dichas donaciones no expuso de forma literal que las mismas suponían mejoras, sino que se limitó a manifestar que esta donación no es inoficiosa, no perjudica a las legítimas, no será colacionable y que se reserva bienes suficientes para su subsistencia (...). En el caso de que en la declaración del testador se evidencia una voluntad patente de mejorar, cuando el testador se manifiesta de una forma tan contundente y reiterada que sea incompatible con la negación de los efectos de la mejora, en tanto que otro también autorizado sector de la doctrina, con apoyo en lo establecido en el art. 825_del Código Civil y STS de 21 de enero de 1925 , se inclina por el criterio de que el Código Civil no reconoce tal modalidad de mejorar(...)". 
testador, bien en vida suya o después de su muerte, repartir entre sus hijos o descendientes un tercio de su masa hereditaria como mejora ${ }^{227}$. Siempre, claro está, que haya una pluralidad de legitimarios. En caso contrario, de ser sólo uno el titular del derecho, no tendría cabida el hablar de mejora, ya que se sobrentiende que, a este, le corresponderían los dos tercios destinados a legítima. Para el cálculo de la mejora se hace necesario remitirse a las reglas básicas del cálculo de la legítima del artículo $818 \mathrm{Cc}$ en los términos que ya se han visto anteriormente.

\subsubsection{Los ascendientes como legitimarios}

Conforme al artículo 807.2 Cc en defecto de descendientes, son legitimarios los ascendentes. Es decir, existe una incompatibilidad entre unos y otros puesto que los primeros excluyen a los segundos. La incompatibilidad existente entre ascendientes y descendientes, por lo que a legítima se refiere provoca que en el supuesto de indignidad, desheredación o que hayan premuerto al causante se trasmitirá su legítima, por derecho de representación a sus descendientes. No adquiriendo por ello el derecho a legítima los ascendientes (art. $925 \mathrm{Cc}$ ). En el supuesto de ser varios los descendientes, si alguno de ellos repudiara su legítima, esta parte incrementará la parte del resto de legitimarios en virtud del artículo 985. 2 Cc, es decir, ya no por derecho de acrecer, sino por derecho propio ${ }^{228}$. En el supuesto de repudiar todos los legitimarios descendientes la herencia,

\footnotetext{
${ }^{227}$ La STS de 29/07/2013 (RJ 2013\6395) F.J. $3^{\text {o }}$ se refiere precisamente a la libertad de distribución entre sus descendientes que tiene el causante sobre el tercio de mejora: "El tercio de mejora de la herencia puede distribuirlo el causante en la proporción que estime pertinente, si no hay disposición, ha de hacerse en partes iguales entre los herederos. Las donaciones no pueden considerarse mejora salvo expresa voluntad del testador, cosa que aquí no concurre".

${ }^{228}$ Señala LASARTE ÁlVAREZ, Derecho de sucesiones..., op. cit., pág. 188, “en el caso de repudiación de todos los hijos y descendientes, no son legitimarios los padres y ascendientes, sino que toda la herencia queda de libre disposición".
} 
recaería la legítima en los ascendientes. Esta manera de proceder parece explicar la incompatibilidad de concurrencia entre ambos colectivos.

La cuantía de la legítima de los ascendientes está en función de si concurren, o no, a la sucesión con el cónyuge viudo o, por el contrario, no existe este último ${ }^{229}$. De regular este aspecto se encarga el artículo $809 \mathrm{Cc}$. En el caso de concurrencia a la herencia con cónyuge viudo: un tercio para cubrir la legítima de los ascendientes. En el supueto de concurrencia a la herencia sin la existencia de viudo/a: la mitad del caudal relicto.

En el artículo 810 Cc se contempla otra variación en la cuantía a percibir, en el sentido de que se trate de los padres del causante o bien del resto de ascendientes. En el supuesto de tratarse de los dos padres del causante la parte de legítima correspondiente se reparte por mitades iguales entre ambos padres y en el supuesto de que uno de los progenitores hubiera fallecido, su parte acrecerá en el otro. En el caso de haber muerto, ambos padres, y existir ascendientes del mismo grado tanto de la línea materna como de la paterna. En tal supuesto la legítima se dividirá por mitades entre ambas líneas. Caso de variar el grado entre las distintas líneas corresponde por completo a los grados más próximos de ambas líneas (art. 810. 2 Cc). Dentro de la línea ascendente tiene cabida el artículo 921 Cc en virtud del cual se aplica el principio de proximidad de grado excluyendo los padres a los abuelos del causante. Teniendo en cuenta que en la línea

\footnotetext{
${ }^{229}$ Véase la SAP de Málaga, (S. $4^{\text {a }}$ ) de $12 / 11 / 1999$ (AC 1999\2595) F.J. $4^{\text {o }}$, acerca de la disposición del artículo $809 \mathrm{Cc}$. "El art. 809 del Código Civil establece que constituye la legítima reservada a los padres o ascendientes, a falta de hijos y descendientes, la mitad del haber hereditario de los hijos y descendientes, salvo el caso en que concurrieren con el cónyuge viudo del descendiente causante, en cuyo supuesto será de una tercera parte de la herencia".
} 
ascendente, como hemos dicho antes, no tiene cabida el derecho de representación ${ }^{230}$.

\subsubsection{La legítima del cónyuge viudo}

Salvo que el testador instituya al cónyuge viudo como heredero es legitimario, pero no es heredero. Por lo tanto, en principio, no queda obligada su persona por las deudas de la herencia, pero debe contribuir en los gastos que conlleve la partición. Todos los coherederos pueden exigir de cualquier modo la partición de la herencia (art. 1052 Cc). No obstante, como legitimario, el viudo/a tiene legitimación activa para promover la partición hereditaria, si bien no puede verificarse la partición hasta satisfacer sus derechos ${ }^{231}$. La institución del usufructo universal del cónyuge viudo no deja de ser un derecho consolidable y a la vez entrañable, al menos visto desde la perspectiva de la mutua entrega de los cónyuges, que no dejan de querer prolongar la que se han dispensado durante su vida conyugal. Lleva a tal afirmación la típica frase tan escuchada por los notarios a la hora de disponer para después de la muerte: "Lo del uno para el otro y después para nuestros hijos ",232.

Conforme al llamamiento que hace el artículo 807.3 Cc el viudo en principio sólo sería legitimario pero, como antes ya se ha apuntado, salvo disposición testamentaria en la que también se le nombrara heredero ${ }^{233}$. La

\footnotetext{
${ }^{230}$ Torres García y DomíngueZ Luelmo, La legítima en el Código civil (I)..., op. cit., pág. 41.

${ }^{231}$ OCHOA MARCO Y SEBASTIÁN CHEMA, La herencia ..., op. cit., pág. 68.

${ }^{232}$ Romero Coloma, A. M. "El usufructo universal del cónyuge viudo en el derecho sucesorio español: problemática sobre su admisibilidad", Revista de derecho de familia: Doctrina, Jurisprudencia, Legislación, núm. 58, 2014, págs. 2 y 3.

${ }^{233}$ OCHOA MARCO Y SEBASTIÁN CHEMA, La herencia..., op. cit., pág. 55. El autor manifiesta que el Código civil habla de "herederos forzosos", pero coincide con la doctrina más autorizada en la materia, que prefiere hablar de legitimarios. El argumento que aporta es que, "el legitimario a lo que realmente tiene derecho es a una parte alícuota de la herencia líquida (deducidas deudas y cargas), no responde por su sólo
} 
nueva redacción dada al artículo $834^{234}$ del Código civil, por la Ley 15/2005, de 8 de julio y que ha sido mantenida por la Ley 03/2015, de 2 de julio ha efectuado distintas modificaciones en el precepto, con relación a su redacción anterior ${ }^{235}$. Se han eliminado los motivos que restringían los derechos del viudo en determinados casos, es decir, el precepto no busca culpables o inocentes de la separación, para denegar u otorgar al cónyuge supérstite, su derecho a legítima. También se puede advertir en la evolución del precepto la equiparación que hace entre la separación legal y la separación de hecho ${ }^{236}$. La porción de usufructo que cita, el precepto

llamamiento legitimario de la herencia. Luego no es heredero. Sólo lo será cuando haya sido instituido como tal, supuesto en el que responderá de las deudas hereditarias (salvo beneficio de inventario)". Sólo me resta añadir a la opinión del autor que, bajo mi opinión, tampoco es forzoso, porque tiene a su disposición la institución de la repudiación, que le faculta para no aceptar su derecho a legítima. Coincide VÁZQUEZ IRUZubieTA, C.: Artículo 806, Cc en Código civil comentado, vLex, Barcelona, 2016, pág. 1, en que "El cónyuge viudo, pues, no es un heredero, pero sí un legitimario, porque por ley se le reconoce el derecho a usufructuar del tercio de mejora".

${ }^{234}$ Artículo 834 Cc: (redacción dada por la Ley de 03/2015, de 2 de julio.) "El cónyuge que al morir su consorte no se hallase separado de éste legalmente o de hecho, si concurre a la herencia con hijos o descendientes, tendrá derecho al usufructo del tercio destinado a mejora".

235 Señala DIEZ- PICAZO y GULLón, Sistema..., op. cit., pág.161, que el Código civil presta mucha atención al resultado de un procedimiento judicial y de ahí que regule los efectos de la reconciliación de los cónyuges para la pertinente aplicación del artículo $835 \mathrm{Cc}$ referente a la reconciliación entre los cónyuges. Precepto el citado ultimamente que O'CAllaghan MuÑOZ, Compendio..., op. cit. considera vacio de contenido: "El artículo 835, primer párrafo, añade la extraña previsión de que cuando estuvieren los cónyuges separados en virtud de demanda, se esperará al resultado del pleito. Norma que debe estimarse vacía de contenido, pues siendo la acción de separación de una acción personalísima, la muerte de un cónyuge no permite la continuación del proceso".

236 A este respecto sienta doctrina el Tribunal Supremo y la refrenda en STS de 16/04/2016 (RJ 20161844) F. J. $2^{\circ}$, cita la referida doctrina con respecto al artículo 834, del Código civil que sienta la sentencia de 28 /04/2014 (núm. 624/2014 SIC). «[...] En efecto, contrariamente a la fundamentación técnica seguida, por la Audiencia, y conforme a lo desarrollado por la doctrina científica al respecto, se debe puntualizar que la regla del artículo 9.8, in fine, del Código Civil, que determina que "los derechos que por ministerio de la ley se atribuyan al cónyuge supérstite se regirán por la misma ley que regule los efectos del matrimonio, a salvo siempre las legítimas de los descendientes" opera como una excepción a la regla general de la lex successionis previamente contemplada en el número primero del propio artículo nueve y reiterada en 
referido, es variable dependiendo con quién concurra a la sucesión, por lo que caben tres supuestos ${ }^{237}$ :

1. Cuando el viudo concurre a la sucesión con hijos o descendientes que pueden ser comunes o sólo del causante, así como los biológicos o por adopción. Entonces conforme al artículo $834 \mathrm{Cc}$ le corresponde el usufructo del tercio destinado a mejora, lo que supone que la nuda propiedad de dicho usufructo es la única mejora que puede el testador distribuir entre los descendientes legitimarios.

2. Cuando el viudo concurre a la sucesión con ascendientes del causante, en virtud del artículo 837 Cc tendrá derecho a la mitad de la herencia, también, en usufructo. Cuando el viudo concurre a la sucesión con personas que no sean ni ascendentes ni descendientes su derecho en usufructo alcanza los dos tercios de la herencia (Art. $838 \mathrm{Cc})$.

Los artículos $839,{ }^{238}$ y $840,{ }^{239}$ Cc presentan la figura conocida como la conmutación del usufructo viudal. Si bien es cierto que ambos preceptos atienden a la conmutación del usufructo viudal, cada uno tiene un objetivo distinto. Mientras que el primero de los señalados da facultad a los

el párrafo primero de su número o apartado octavo (la Ley nacional del causante como criterio de determinación de la ordenación sucesoria)".

${ }^{237}$ DíEZ PICAZO. Y GULLón, Sistema de derecho civil..., op. cit., págs. 160-161. “Con la palabra ascendentes se alude a los de cualquier naturaleza o adoptivos, pero quedan excluidos los ascendentes por naturaleza del adoptado salvo que concurran los supuestos legales (art. 178.1. $\left.{ }^{\circ}\right)^{\prime}$ ".

238 Artículo 839 Cc: "Los herederos podrán satisfacer al cónyuge su parte de usufructo, asignándole una renta vitalicia, los productos de determinados bienes, o un capital en efectivo, procediendo de mutuo acuerdo $\mathrm{y}$, en su defecto, por virtud de mandato judicial". "Mientras esto no se realice, estarán afectos todos los bienes de la herencia al pago de la parte de usufructo que corresponda al cónyuge".

${ }^{239}$ Artículo 840 Cc: "Cuando el cónyuge viudo concurra con hijos sólo del causante, podrá exigir que su derecho de usufructo le sea satisfecho, a elección de los hijos, asignándole un capital en dinero o un lote de bienes hereditarios". 
herederos del causante para conmutar el usufructo del viudo por una renta vitalicia, por el producto de determinados bienes, o un capital en efectivo. Procediendo los herederos de mutuo acuerdo y en su defecto por mandato judicial. En el supuesto del artículo 840 Cc también se recoge la facultad de conmutación, si bien ahora a instancia del cónyuge viudo. Pero sólo se le faculta cuando concurra con hijos que lo sean exclusivamente del cónyuge difunto $^{240}$. Pero una vez que el viudo ha hecho su solicitud, corresponde a los hijos del causante la elección entre satisfacer un capital en dinero o un lote de bienes hereditarios.

El artículo 839 Cc otorga la facultad de conmutación a los herederos, que pueden o no pueden conmutar el usufructo a su elección. El citado precepto exige el mutuo acuerdo por parte de los herederos ${ }^{241}$. Se entiende que se trata de un acuerdo entre sí mismos. De no alcanzarse el acuerdo citado, entre ellos, tendrá que ser por mandato judicial. Otra interpretación que se le podría dar al texto del precepto sería: mutuo acuerdo entre los herederos del causante y su cónyuge ${ }^{242}$, aunque previamente el acuerdo

${ }^{240}$ LaSARTe Álvarez, Derecho de sucesiones..., op. cit., pág. 195. "El artículo 839 y 840 del Código civil, responden a un fundamento y a una filosofía diferentes".

${ }^{241}$ Se pronuncia al respecto de la intervención del cónyuge viudo en la conmutación del usufructo y del "mutuo acuerdo" la DGRN de 04/04/2017 (RJ 2017\1406) "la Intervención del cónyuge viudo en la conmutación: No es cuestión pacífica en la doctrina oscilando las opiniones entre (i) quienes entienden que la facultad de conmutar corresponde a herederos y legatarios sobre los que recaiga la cuota viudal, de común acuerdo, de modo que el cónyuge sólo interviene en la valoración, (ii) y quienes consideran que la expresión «mutuo acuerdo» no puede referirse a los herederos entre sí, respecto de los cuales la expresión adecuada sería la de «común acuerdo», por lo que «mutuo acuerdo» presupone dos partes con intereses contrapuestos, es decir, que el cónyuge viudo debe intervenir también para decidir sobre la modalidad de conmutación".

${ }^{242}$ Véase la SAP de Murcia (S. 2 ${ }^{\mathrm{a}}$ ) de 4/02/2005 (JUR 2006/68577) F. J. $4^{\mathrm{o}}$ se pronuncia acerca del acuerdo entre el viudo/a y los herederos del causante: "El segundo motivo del recurso entiende que la sentencia de instancia vulnera lo dispuesto en el art. $839 \mathrm{Cc}$ al entender que el mutuo acuerdo alcanza también al que constituye, la voluntad del cónyuge, exégesis que se reputa desacertada por cuanto de la dicción del precepto no se desprende que el mutuo acuerdo esté sujeto a dos distintos acuerdos de voluntades: la de los herederos y la de éstos con la viuda, al ser manifiesto del propio tenor gramatical del 
también tendrá que ser alcanzado entre los herederos ${ }^{243}$. Parece ser esta, la interpretación más razonable al entender que de tratarse de un solo heredero $^{244}$, el mutuo acuerdo, sólo podría tener sentido entre este, y el

precepto, que son sólo los herederos quienes llevan a cabo toda una actuación tendente a entregar al cónyuge viudo un valor de la herencia conforme a 3 modalidades, y sólo cuando entre esos herederos falte el acuerdo, la decisión será judicial, exégesis confirmada por la dicción del precepto («podrán satisfacer...») en clara referencia a los herederos, siendo el cónyuge el complemento indirecto, por lo que atribuir el mutuo acuerdo a una segunda voluntad es faltar a la identidad de dicho precepto y a su significado teleológico". También la SAP de Cantabria (S. 3') de 25/08/2003 (AC 2003\1949) F.J. 4", mantiene que "Si la conmutación que regula el art. 839 CC ( LEG $1889,27)$ es la concreción en otros bienes del usufructo en que consiste la legítima del cónyuge viudo, resulta obvio que tal concreción no es posible respecto del usufructo que no constituye la legítima del cónyuge viudo. En consecuencia, si por la extensión del usufructo se ha rebasado los márgenes propios de la legítima viudal que señalan, según los casos, los arts. 834, 837 y 838 Cc no es posible el ejercicio de esa facultad de conmutación. En este supuesto, a la viuda le corresponde además del usufructo del tercio destinado a mejora como derecho legitimario, el de los restantes tercios por habérselos legado el testador. Consecuentemente con ello, en cuanto la conmutación se ha realizado también respecto de estos dos últimos tercios, ha infringido, desde esta óptica, el citado art. 839 CC".

${ }^{243}$ La de la STS de 13/072009 (RJ 2009\4465) F.J. $9^{\circ}$, en que se pronuncia con respecto a los derechos del viudo: "El artículo 839 CC establece que, actuando de común acuerdo, los herederos pueden hacer efectivo al cónyuge viudo su parte "asignándole una renta vitalicia, los productos de determinados bienes, o un capital en efectivo" y que, a falta de acuerdo, se decidirá judicialmente. La sentencia recurrida, en su fundamento tercero señala que el consenso sobre la forma de pago debe alcanzarse entre los herederos y el cónyuge, por lo que éste debe participar en la decisión, que no consta haya existido en el presente procedimiento. Por ello la sentencia recurrida considera que debe aceptarse la solución de capitalización "cuando ni tan siquiera se ofrece por la recurrente alternativa de las legales sobre ello limitándose a mostrar su disconformidad". Se señala que este derecho corresponde ejercerlo a los herederos, pero con la conformidad del cónyuge viudo, y que cuando falta el acuerdo corresponde a la autoridad judicial la decisión sobre la forma de pagar dicho usufructo (SSTS de 15 septiembre 1982 y 4 octubre 2001). Por ello, no puede afirmarse que se ha vulnerado el Art. 839 CC “.

${ }^{244}$ La SAP de Guipúzcoa ( S. 2a) de 15/02/2002 (JUR 2002\219208) F.J. 4 , atiende a los derechos del viudo/a, cuando concurre a la sucesión con un solo heredero: "A partir del contexto factual reseñado en el razonamiento jurídico segundo debe concluirse que la opción contenida en la letra A del cuaderno particional elaborado por el contador partidor dirimente es la asumible porque supone la forma específica de conmutación específica del usufructo vidual elegida por el único heredero. Además de esta manera se evita continuar con la situación de indivisión del patrimonio hereditario -finalidad esencial del presente proceso judicial-, garantiza atribuir el uso de la vivienda a la persona que, siendo heredero universal del causante, se encuentra en una situación vital en la que el disponer de una vivienda propia le permitiría contar con un ámbito físico en 
viudo $^{245}$. Ahora bien, procediendo de mutuo acuerdo, mantiene el precepto último citado, que en caso de no llegar a acuerdo en este aspecto tendrá que ser impuesta dicha conmutación, por mandato judicial y mientras tanto, no se materialice la conmutación estarán afectados al pago todos los bienes de la herencia.

El artículo 839 Cc al determinar la facultad de conmutación, por parte de los herederos, trata de evitar la división del dominio pleno. Es decir, la división entre el usufructo y la nuda propiedad de un mismo bien ${ }^{246}$. Manifestando, que la elección de la forma de satisfacer el usufructo viudal (conmutación) corresponde a los herederos. Por lo tanto, no corresponde al cónyuge viudo la elección de la forma en que se verá satisfecho su derecho y sólo tendrá derecho a interponer recurso en el supuesto de que del resultado de la conmutación fuera perjudicado su derecho viudal ${ }^{247}$. La

el que encauzar las relaciones paterno-filiales y conlleva dotar de sentido a la facultad de conmutación sin quiebra de la cuota legal usufructuaria en la medida que la totalidad de los bienes hereditarios están afectos al pago de los derechos hereditarios".

${ }^{245}$ LaSARTe Álvarez, Derecho de sucesiones..., op. cit., pág. 196. Mantiene el autor en apoyo de la STS de 28 de junio de 1962, "que el capital en efectivo puede consistir tanto en una cantidad dineraria como en la atribución en propiedad de bienes determinados, pero siempre a elección de los herederos".

${ }^{246}$ Señala RuIZ -RICO RuIZ - MORÓN, J.: "Lesión de la legítima" en $A A V V$., Curso de Derecho Civil IV, Derecho de Familia y Sucesiones, $4^{\mathrm{a}}$ ed, Tiran Lo Blanch, Valencia, 2009, pág. 587, la idea de evitar los inconvenientes de la desmembración del dominio es por lo que se concede la facultad de conmutar a los herederos y legatarios afectados por el usufructo viudal. Son precisamente aquellos los que de acuerdo con el artículo 839 Cc pueden acordar la conmutación del usufructo viudal, sin que el supérstite pueda oponerse a que se lleve a efecto. Si bien es necesaria la conformidad del viudo en la valoración del usufructo a efectos de conmutación y al pretender, por parte de los herederos, conmutar el usufructo viudal por distinta a las señaladas por el precitado artículo 839 Cc.

${ }^{247}$ De la STS de 25/10/2000 (RJ 2000\8549) F.J. $2^{\text {o }}$, se despejan prácticamente todas las dudas que podría plantear el artículo 839 del Código civil. En base a la doctrina científica sostiene el Alto Tribunal que la facultad de elegir una de las tres formas que dispone el artículo 839, del Código civil para poder el cónyuge viudo hacer efectivo su derecho- una renta vitalicia, los productos de determinados bienes, o un capital en efectivo- corresponde únicamente su elección a los herederos. Matiza el tribunal, que no importa que los herederos sean forzosos o voluntarios, con o sin testamentos e incluso si 
decisión judicial no surge únicamente ante la falta de acuerdo entre los coherederos, sino también entre estos y el supérstite ${ }^{248}$.

La conmutación a favor del cónyuge viudo preceptuada por el artículo 840 Cc sólo tiene lugar cuando el cónyuge supérstite concurre con hijos exclusivamente del causante ${ }^{249}$. En tal supuesto la facultad de exigir la conmutación del usufructo corresponde al supérstite. En cambio la elección de la forma de pago, a las que se refiere el precepto, corresponde a

son legatarios, lo que de veras importa es que les afecte el usufructo del viudo/a. Tampoco importa que sean descendentes, ascendentes, colaterales o incluso extraños al causante ni que la cuota en usufructo del viudo recaiga sobre el tercio de mejora o el de libre disposición. Lo importante es que la mención de herederos que hace el precepto se refiere a los afectados por el usufructo viudal y es a quienes compete la elección entre las tres opciones que expone el precepto que venimos analizando. En tiende el Tribunal, que tratándose de una carga sobre sus respectivas porciones (el usufructo) son a ellos como perjudicados y no al beneficiado al que le corresponde la facultad de elegir el modo de pago. Tambien la STS de 08/06/2011 (Tol. 2.155.265) F. J. $2^{\circ}$ se refiere a la determinación contenida en el artículo 839 Cc "el artículo 839 del Código Civil , que determina las formas en que los herederos podrán satisfacer al cónyuge su parte en el usufructo, sin que lógicamente se puedan atribuir para ello bienes en propiedad sin el consentimiento expreso de todos los herederos...".

${ }^{248}$ Véase la SAP de Alicante $\left(\right.$ S. $6^{\text {a }}$ ) de 04/06/2006 (Tol. 1.274.472) F.J. $1^{\text {o }}$ que hace referencias al artículo $839 \mathrm{Cc}$ “(...) de esta forma se instauran reglas específicas de composición de conflictos entre los herederos y el cónyuge viudo. La exégesis de este precepto permite concluir que:

a. La elección de la forma de satisfacer la legítima viudal corresponde a los herederos. b. No compete al cónyuge viudo exigir una de las formas subsidiarias de pago. c. El recurso a la autoridad judicial instando la revisión de la forma específica de pago elegida por el heredero solamente resulta admisible cuando el modo de satisfacción postulado por el heredero mediante el ejercicio de la facultad de conmutación hiciera ilusorio el derecho del cónyuge supérstite". "Por ello, la decisión judicial surge también no solo por la falta de acuerdo entre herederos sino también de estos con el cónyuge supérstite, por lo que éste no debe conformarse sin más con la solución acordada por los herederos si le es perjudicial para sus intereses. Por otra parte, conforme a la STS 25-102000 que sirve de sustento jurídico a la sentencia impugnada, la facultad de elegir una de las formas establecidas en el art. 839 del Código Civil, no puede ser exigida por el o la viuda, sino que son los herederos los que pueden plantear alguna de las opciones, cuestión que sí que ha ocurrido en el presente supuesto".

${ }^{249}$ VÁzQuez Iruzubieta, Código civil..., op. cit., pág. 1 mantiene que el artículo 840 Cc tiene aplicación para el supuesto que prevé el art. $837.2^{\circ} \mathrm{CC}$; es decir, cuando el cónyuge supérstite concurre con hijos extramatrimoniales de su consorte concebidos con otra persona distinta de la que era su cónyuge en vida. 
los hijos que concurran a la sucesión con el cónyuge usufructuario ${ }^{250}$. Al parecer trata el legislador, por medio de este precepto, de evitar los inconvenientes que puede acarrear el usufructo del viudo a unos hijos que, en el mejor de los casos, tengan unas relaciones no muy cordiales con el viudo. En este supuesto el papel del viudo una vez haya exigido que le sea satisfecho su derecho de usufructo se limita a aceptar la elección de los hijos del causante, no tiene opción entre el capital y el lote de bienes hereditarios ${ }^{251}$.

\subsection{LAS RESERVAS}

\subsubsection{La reserva lineal}

Muy a tener en cuenta, son las reservas que establecen los artículos 811 y 812 del Código civil. El artículo 811 Cc se refiere a una reserva también denominada troncal, por inspirarse en el principio de troncalidad y asimismo extraordinaria o especial, por estar en contraposición con la ordinaria o viudal del artículo $968 \mathrm{Cc}^{252}$. Esta reserva se compone de tres

${ }^{250}$ RUIZ -RICO RUIZ - MORÓN, Lesión..., op. cit., pág. 588 mantiene que la finalidad que se persigue con la conmutación del viudo en este caso es la de evitar relaciones entre personas que puedan estar enfrentadas. Tambien coincide VÁZQUEZ IRUZUBIETA, Código civil..., op. cit., pág. 1, en que con el artículo 840 Cc "Se prevé una situación distinta en cuanto que aquí la opción la ejercita el cónyuge supérstite y no los otros legitimarios. No obstante, se trata de una diferencia meramente teórica, ya que nada impide que el ofrecimiento del acuerdo nazca de la otra parte".

${ }^{251}$ La SAP de las Palmas (S. 5 $5^{\text {a) }}$ de 28/07/2011 (JUR 2011\6661) F.J. $3^{\text {o }}$ atiende a la concurrencia del viudo/a sólo con hijos del causante y no comunes: "Ostentando testamentariamente la actora, como cónyuge viuda del causante, el derecho de usufructo viudal (art. $834 \mathrm{Cc}$ ) sobre la tercera parte de los mencionados inmuebles al concurrir en la herencia con hijos sólo del causante (con hijos no comunes del matrimonio) el art. $840 \mathrm{Cc}$ autoriza a la mencionada actora, cónyuge viuda, a exigir que su derecho de usufructo le sea satisfecho, a elección de los hijos, mediante la asignación de un capital en dinero o un lote de bienes hereditarios. Como quiera que postulada la capitalización del usufructo sin que por los herederos demandados, hijos sólo del causante, se haya procedido a la elección de entrega de bienes [lo que visto el caudal relicto que ha sido probado sería materialmente imposible] resulta procedente acceder a dicha capitalización".

252 O’CAllagan Muñoz, X.: "La reserva lineal" en Compendio de Derecho Civil. (Derecho de sucesioens), Tomo 5, Edersa, Madrid, 2004, pág. 1. 
sucesivas trasmisiones de bienes, donde la primera en el tiempo tiene que ser a título gratuito, es decir, por donación o herencia, que alguien recibe de otro descendiente o de un hermano. En la segunda transmisión el heredero o donatario del bien y causante de la reserva ha de morir intestado y sin descendencia, transmitiendo el bien por sucesión legítima, además el bien lo tiene que heredar un ascendiente, el reservista proveniente de la línea de la que no proviene el bien. Podía ser el caso de cuando el heredero es la madre o el padre que no sean coincidentes con la línea de la que proviene el bien heredado. La tercera transmisión se produciría como efecto de la reserva, en favor de los parientes denominados reservatarios, que son quienes están dentro del tercer grado de la línea de donde proceden los bienes. El reservista tendría que reservar el bien a los parientes del causante de la reserva y por lo tanto, no podría disponer de él en favor de sus parientes de su misma línea ${ }^{253}$. El Tribunal Supremo entiende la reserva lineal del artículo 811 Cc como "la concatenación de tres sucesiones distintas" 254 .

${ }^{253}$ Véase en O'CALlaGHAN MuÑoz, X.: "La reserva lineal...”, op. cit., pág. 1, un ejemplo acerca de la reserva lineal: "un niño ha recibido gratuitamente, por herencia de su padre (primera transmisión) una finca; el niño muere intestado y hereda la finca su madre (segunda transmisión), que puede casarse de nuevo y tener otros hijos; cuando la madre muere, aquella finca no la hereda su segundo esposo o sus hijos del segundo matrimonio, sino que, por la reserva del artículo 811, la adquirirá uno o varios parientes del niño, causante de la reserva, dentro del tercer grado y de la línea, que será la paterna, de donde los bienes proceden, por ejemplo, un tío paterno, hermano del padre".

${ }^{254}$ Véase mayor información en la STS de 31/10/1964 (RJ 1964\4860) Considerando 5º, acerca de las tres sucesiones a tener en cuenta en la reserva lineal: "ha de tenerse en cuenta: A) Que, la reserva lineal, presupone la concatenación de tres sucesiones distintas: Primera. La transmisión, por título lucrativo, de determinados bienes, efectuada de ascendiente a descendiente o de un hermano a otro: en esta fase sólo se da el elemento material de la posible reserva futura y el carácter de la transmisión que, puede dar en su día, a los bienes, la calidad de reservables, pero no hay en cuanto a los elementos personales, derecho alguno a la reserva ni obligación ninguna de reservar. Segunda. La transmisión, por ministerio de la ley, de los bienes adquiridos, en las condiciones y por el título expresado que, en concepto de herencia, pasan desde el descendiente o hermano del primitivo «de cujus», a un ascendiente de aquéllos. En esta segunda fase, la Ley establece un derecho expectante de reserva, sobre tales bienes, a 
El artículo $811 \mathrm{Cc}$ que recoge la reserva lineal requiere una interpretación restrictiva, por lo que respecta a líneas y grados de parentesco. Los bienes reservables que se encuentran en el patrimonio del reservista son, a todos los efectos de su propiedad. El reservatario puede exigir que, en protección a su derecho, cumpla las garantías que para la reserva ordinaria establecen los artículos 977 y 978, ambos del Código civil, especialmente hacer constar en el Registro de la Propiedad el carácter de bienes objeto de la reserva de los inmuebles inscritos ${ }^{255}$. Sobre los bienes muebles no puede el reservatario impedir al reservista su venta, en

favor de los parientes que estén dentro del tercer grado y pertenezcan a la línea de donde los bienes proceden, los que podrán solicitar y obtener las oportunas medidas, en defensa de su derecho. Tercera. La transmisión, al fallecimiento del reservista, de los bienes que tengan la condición de reservables, a los parientes que la Ley señala con lo que se consolida el derecho de los reservatarios, en concepto de herederos, que podrán entrar en posesión de tales bienes, con arreglo a las normas que regulan la sucesión. B) Que es consecuencia de lo expuesto, que si bien el derecho a la reserva, se produce, para el reservatario por la concurrencia de dos causas: una «próxima» que es la muerte del reservista y otra «remota», que se operó por el fallecimiento del descendiente que transmitió los bienes al ascendiente reservista, la obligación de éste, nace en el momento de adquirir los bienes reservables, si existen los parientes con derecho a la reserva, al tiempo de abrirse la sucesión del descendiente o si surgen después, lo que sólo puede acontecer, con el nacimiento del hijo póstumo de parientes de primero o segundo grado, premuertos al causante del reservista, por lo que, en razón a que toda obligación, debe tener una fuente que la produzca (en este caso la Ley) y un hecho que la origine (transmisión del descendiente al ascendiente de los bienes que puedan ostentar la calidad de reservables), por el principio de razón suficiente, que hace que la causa deba preceder al efecto, la obligación de reservar, nace en el momento de heredar el reservista y tal momento hay que fijarlo, por imperio de lo dispuesto en los arts. $657 \mathrm{y}$ $661 \mathrm{del} \mathrm{CC}$, en el de la muerte del descendiente transmisor, cuya ley nacional, rectora de la sucesión, conforme al párrafo $2^{\circ}$ del art. 10, es la que ha de gobernar la reserva, en cuanto a su procedencia, extensión, condiciones y efectos, por lo que, al haberlo entendido así el Tribunal sentenciador, no ha infringido el art. 811 del CC, en relación con el precepto legal precitado, ni la doctrina jurisprudencial que se aduce como vulnerada, por el recurrente, todo lo que determina que, ese primer motivo del recurso interpuesto, no pueda prosperar".

${ }^{255}$ Mayor información en O' CALlAGHAN MuÑOz, "La reserva lineal...”, op. cit., pág. 1, donde el autor manifiesta que: "El reservatario o los reservatarios son titulares de los bienes reservables, pero sujetos a la condición suspensiva de sobrevivir al reservista, dándose todos los elementos de la reserva. 
cambio sí que puede pedir un inventario en vida del reservista, a fin de que se reserve el importe satisfecho por la venta del bien reservable ${ }^{256}$.

El artículo $811 \mathrm{Cc}$ persigue que los bienes poseídos por una familia desde siempre, no pasen fruto del azar - muertes inesperadas y prematurasa formar parte del haber de otra familia. La reserva lineal debe su implantación a ALONSO MARTíNEZ ${ }^{257}$, que incorporó esta institución al Código civil español argumentando que de no existir, dicha reserva, podría suponer que distintos bienes pertenecientes a una línea familiar determinada, por fruto de muertes inesperadas, contrariaran la lógica elemental de la sucesión. Es decir, el azar cambiara la línea regular de los

\footnotetext{
${ }^{256}$ Véase más información sobre la reserva lineal en la SAP de Guipúzcoa (S. $\left.3^{\text {a }}\right)$ de 07/04/2006 (JUR 2015\57262) FJ. $2^{\circ}$, en que se hace una importante descripción de la reserva líneal, así como las exigencias que se les permite a los reservatarios: "Durante la vida de la reservista (reserva pendiente) el bien reservable se encuentra en el patrimonio de aquélla y son propiedad exclusiva de la misma. Los reservatarios sólo están autorizados para exigir que se tomen medidas conservatorias de garantía:

a-Tratándose de bienes inmuebles los reservatarios sólo pueden pedir que la reservista inscriba en el R. de la Propiedad el carácter reservable de los bienes. Pero al no existir en este caso bienes inmuebles no procede seguir con la argumentación.

b-Tratándose de bienes muebles los reservatarios no pueden impedir al reservista su enajenación. únicamente pueden pedir en vida del reservista que se forme un inventario y que se reserve el precio de venta obtenido. La única obligación de $\mathrm{D}^{\mathrm{a}} \mathrm{xxx}$ sería reservar el valor obtenido por la venta de dichas acciones ".
}

${ }^{257}$ Albadalejo García, M.: Comentarios al Código civil y compilaciones forales, Tomo XI, $2^{\text {a }}$ ed, Edersa, 1982, págs. 59-60. Expone este autor, el supuesto que motivó a Alonso Martínez con relación al artículo 811 del Código civil. "El hijo de un magnate sucede a su padre en la mitad íntegramente de sus pingües mayorazgos tocando a sus hermanos un lote modestísimo en la división de la herencia paterna; aquel hijo se casa y fallece al poco tiempo, dejando un tierno vástago; la viuda todavía joven, contrae segundas bodas y tiene la desdicha de perder al hijo de su primer matrimonio, con exclusión de la madre y de los hermanos de su primer marido. No hay para que decir que, si hay descendientes del segundo matrimonio, a ellos se transmite en su día la herencia. Por donde resulta el irritante espectáculo de que los vástagos directos del magnate viven en la estrechez y tal vez en la miseria, mientras gozan de su rico patrimonio personas extrañas a su familia $y$ que, por orden natural, le son profundamente antipáticos". 
bienes. Para que tenga lugar y prospere la reserva lineal han de proceder dos transmisiones de bienes a título gratuito ${ }^{258}$.

La aplicación de la reserva lineal del artículo $811 \mathrm{Cc}$ supone una alteración del derecho sucesorio ordinario en cuanto a los llamamientos a suceder $^{259}$, por ello deben de ocurrir dos transmisores de bienes. La primera a título gratuito, el ascendiente ha de trasmitir al descendiente o bien entre hermanos. La segunda sucesión ha de ser legal y por ella se transmiten los bienes adquiridos por el descendiente a otro ascendiente. El descendiente o el hermano del primer causante pueden impedir el mecanismo de la reserva. Evitando que se adquieran los bienes por

\footnotetext{
${ }^{258}$ Señala Lledó Yagüe, Monje Balmaseda, Herrán Ortiz, A, AAVV: Cuaderno Teórico Bolonia I..., op cit., pág. 153, que la jurisprudencia del Tribunal Supremo citada como refrendo a la interpretación del artículo $811 \mathrm{Cc}$, cuya finalidad según los autores es: "impedir por una parte, la desviación por obra del azar (por las muertes prematuras del padre, la madre o varios hermanos) de su línea de los bienes heredados por ministerio de la Ley por un ascendiente de un descendiente que a su vez, lo hubiese adquirido a título lucrativo, de otro ascendiente o un hermano".

${ }^{259}$ La STS de 13/03/2008 (Tol. 1.297.095) se pronuncia en un caso de controversia con respecto a la interpretación del artículo 811 del Cc. Parte el litigio de la demanda interpuesta por Dña. Gabriela hija extramatrimonial de Dña. Sonia y que con posterioridad al citado nacimiento, se casa con D. Serafín, de cuyo matrimonio nacen dos hijos-D. Esteban y Dña. Filomena. Fallece Dña. Sonia mejorando a su hijo D. Esteban, después fallece este sin haber testado y sin descendencia y por consiguiente hereda por ministerio de la Ley (sucesión intestada) D. Serafín (padre) la parte que este que en su día heredó de su madre. Fallece después D. Serafín habiendo nombrado heredera universal a su única hija Dña. Filomena. Ante tales hechos Dña. Gabriela interpone demanda contra Dña. Filomena, reclamando una parte de los bienes que originariamente fueran de su madre. La sentencia de Instancia rechaza la demanda. Interpuesto recurso ante la Audiencia, esta lo admite y estima de tal manera que concede a la recurrente Dña Gabriela un tercio de los bienes en litigio.
}

Contra esta resolución interpuso recurso de casación Dña. Filomena, con el argumento interpretativo del artículo 811. El Alto Tribunal interpreta dicho precepto acorde con la realidad social actual, que es contraria a limitar al causante sus facultades de disposición sucesoria en concordancia con el artículo 3 del Cc y con la doctrina del TS. Que entiende la reserva lineal del artículo 811 del Código civil, como "una consideración restrictiva" por lo que basta que los bienes no pasen una línea distinta a la procedente para que la citada institución de reserva lineal haya cumplido su objetivo. En el presente caso, los bienes, no han cambiado de línea y pasan a los parientes del descendiente del que heredó y Dña. Filomena está dentro del tercer grado de consanguinidad, por lo tanto el TS estima el recurso de casación y anula el de apelación. 
ministerio de la Ley, es decir, otorgando en testamento los mismos bienes a la misma persona que de no hacerlo, los heredaría por ministerio de la Ley. Por ello puede decirse del artículo $811 \mathrm{Cc}$ que es previsor del azar o de la infortuna, de lo que pudo hacer y no hizo tanto el descendiente como el hermano en su caso ${ }^{260}$.

Con la finalidad de distinguir entre la reserva lineal o troncal y las demás reservas es muy importante diferenciar entre el reservista y el reservatario en cuanto a derechos y obligaciones se refiere. En la reserva lineal o troncal, el reservista, es el ascendiente que hereda bienes de un descendiente suyo (no hay obligación de reservar si el que hereda había sido el transmisor). El reservatario, en cambio, es el pariente que reúne la condición de estar dentro del tercer grado de consanguinidad, a contabilizar desde el pariente fallecido. Es necesario que el pariente pertenezca a la línea de donde proceden los bienes ${ }^{261}$.

\subsubsection{El derecho de reversión o retorno sucesorio}

El otro precepto aludido al tratar las reservas es el artículo 812 del Código civil ${ }^{262}$. Este contempla la denominada reversión de las donaciones

\footnotetext{
${ }^{260}$ Albadalejo García, Comentarios al Código..., op. cit., pág. 60.

${ }^{261}$ Donato VARA, A.: La Reserva Vidual, Ed. Reus, Madrid, 2010, pág. 510.

${ }^{262}$ No es pacífica ni menos unánime la interpretación del art. 812 Cc La SAP de Valencia, Secc. 6a, núm. 100/2016 de 19 /02/2016, (JUR 2016\145993) hace una recopilación de distintas SSAAPP con cuyo objeto es la interpretación del precepto citado. Lo hace en su FJ $3^{\circ}$, que de ello se puede desacatar: "Tanto la doctrina como la jurisprudencia es unánime al considerar que los bienes donados quedan fuera de la masa hereditaria y en consecuencia no se computan para el cálculo de las legítimas y, los legitimarios, carecen de cualquier derecho o cotitularidad sobre dichos bienes. El tenor literal del art. 812 Cc no deja dudas acerca de la exclusión de cualquier persona, sin distinción, en la sucesión de los bienes donados. Además, la finalidad de esta norma tiene un cierto carácter troncal pues, en definitiva, lo que consigue es la devolución automática de los bienes donados a su línea familiar de procedencia". Sin confundir, por ello otros bienes, que si bien han sido donados por el ascendente, no quedan incluidos en la sucesión: .'Distinta suerte ha de tener en cambio la pretensión referente a la improcedencia de incluir en el inventario el mobiliario y enseres que constituyen el ajuar de la vivienda habitual común de los esposos y ya que conforme a lo dispuesto en
} 
y se basa en la voluntad presunta del donante de los bienes, es decir, el ascendiente que ha donado bienes, (reversionario) a un descendiente y este, le premuere. Tiene pura lógica la permanencia de los bienes dentro de la línea de procedencia. Por lo tanto, tras el fallecimiento del descendiente beneficiario de los bienes donados, la ley llama a suceder, en dichos bienes, al reversionario de ellos, es decir, al que en su día se los donó al descendiente (donatario). Lo expuesto es lo que doctrinalmente se conoce como el derecho de reversión o retorno sucesorio $^{263}$. Este derecho, en términos cotidianos, significa la devolución de aquellos bienes a su procedencia de origen. La ley llama a suceder, dichos bienes, al titular anterior, que es un sucesor especial, que excluye a otras personas de la sucesión de los bienes por él donados (Art. $812 \mathrm{Cc})^{264}$.

No es requisito, para tal proceder, que las partes implicadas en la reserva ostenten la facultad de legitimarios, pero en caso de serlo, no computaran dichos bienes en su porción de legítima que por derecho les

el primer párrafo del artículo 1321 del Código Civil se entregarán al cónyuge sobreviviente sin computárselo en su haber".

${ }^{263}$ NúÑEZ NúÑEZ, La sucesión Intestada ..., op. cit., pág. 121 - 122.

${ }^{264}$ Se refiere la RDGRN de 13/06/2016 (RJ 2016\4994) F.J. $2^{\circ}$ y $3^{\circ}$ a dos cónyuges, en régimen de gananciales, otorgan una escritura de donación de la nuda propiedad de un bien inmueble a favor de su hija. Posteriormente fallece la esposa donante y luego la hija donataria sin descendientes. El esposo otorga escritura de reversión del bien donado, conforme al artículo $812 \mathrm{Cc}$. El registrador se opone a la inscripción del bien alegando que: "no se ha manifestado que no haya deudas en la herencia de la donataria" La DGRN "revoca la calificación. Señala en primer lugar que la reversión opera automáticamente con el fallecimiento de la donataria, por lo que los bienes sujetos a reversión no integran la masa de la herencia de la donataria y no responden de las posibles deudas". Además, añade: "que la reversión no es una especie de sucesión legal, sino un supuesto de resolución de la donación, aunque no tiene eficacia retroactiva. Atendiendo al espíritu y fundamento de la norma que regula dicho derecho, declara también que $1^{\circ}$ - En caso de donación de bienes gananciales, basta que uno de los cónyuges sobreviva, para que se entienda cumplido el requisito de la supervivencia de la parte donante. $2^{\circ}$ - La reversión se produce a favor del donante superviviente, pero con carácter ganancial y se integra en la masa ganancial de la que salió, por lo que ha de procederse después a la liquidación ganancial de dicho bien revertido". 
corresponda $^{265}$. Llega hasta tal extremo la reserva que incluso puede saltar grados de consanguinidad, en el supuesto de que los haya saltado con anterioridad el reversionario. Así se entiende que el abuelo dona un bien al nieto (salta un grado) y muere el nieto, el bien donado no va a su padre, sino al abuelo que es el origen de la donación. A diferencia del resto de la masa hereditaria que sí que iría a parar a sus padres ${ }^{266}$. El derecho de reversión que regula el artículo 812 Cc es raramente aplicado y raramente aceptado. Ello en base a que las circunstancias que tienen que ocurrir para que tenga aplicación este precepto, no suele ocurrir con frecuencia.

Al tener el derecho de reversión un origen legal ${ }^{267}$, no es preciso que esté expuesto en ninguna cláusula testamentaria para su aplicación ya que tiene cabida tanto en la sucesión testada como en la intestada. El

${ }^{265}$ Es destacable la independencia del derecho de reversión con la cuota legitimaria en la SAP de Álava (S. 1ª) de 23/08/1992 (AC 1992\1318) FJ. 30, "el derecho de reversión es independiente de la cuota legitimaria que puede corresponder al ascendiente, debida por el descendiente causante. Tampoco entra para el cómputo de las legítimas ni de la parte de libre disposición, pues los bienes donados se consideran excluidos del activo líquido de la herencia del descendiente. La exclusión del cónyuge viudo de la expresión «...exclusión de otras personas...» utilizada ex art. $812 \mathrm{CC}$, supondría, conforme a la indicada doctrina, el apartarse del inequívoco significado del precepto".

${ }^{266}$ Son varias las SSTS que, se pronuncian respecto al derecho de reversión, así la STS de 27/10/1950, (RJ 1950\1534) en que el Alto Tribunal califica como requisito imprescindible para tener aplicación el precepto $812 \mathrm{CC}$ "que se haya producido una donación del ascendiente al descendiente causante de la herencia. La STS expuesta, en relación al caso que está tratando: “(..) la adjudicación de la mitad de la finca que en el cuaderno particional se hizo al demandado por virtud de la reversión establecida en el artículo 812, del Código Civil, es intranscendente la calificación jurídica de la finca como parafernal o ganancial, ya que en cualquiera de estos supuestos la adjudicación no podría mantenerse sobre la base de la reversión hecha por no concurrir al requisito primordial de una donación del ascendiente-demandado a su hija, causante de la herencia discutida en este pleito (...)".

${ }^{267}$ Véase la reversión en PÉREZ GURREA, R.: "La donación con cláusula de reversión. Su régimen jurídico, naturaleza y efectos" Revista Crítica de Derecho Inmobiliario, núm. 736, marzo 2013, pág. 1182, la denomina el autor reversión legal. "En nuestro Código Civil además de la reversión voluntaria ex artículo 641 del Código Civil, existe otra reversión que puede denominarse legal, a favor de los ascendientes respecto a las cosas donadas por ellos a sus hijos o descendientes muertos sin posterioridad y que se encuentra regulada en el artículo 812 del Código Civil". 
fallecimiento del donatario produce dos sucesiones paralelas e independientes entre sí. Por un lado, la sucesión del haber hereditario y por otro la sucesión especial legal de los bienes donados y reservables. Por lo tanto, los bienes reservables quedan fuera de la masa hereditaria, nunca han pertenecido a ella, y se adjudican independientemente de los demás que la forman ${ }^{268}$.

Es curioso que no siendo la reversión un derecho de naturaleza legitimaría tenga su ubicación en el Código civil, entre el articulado que regula las legítimas ${ }^{269}$. Entre ambas figuras, reversión y legítima, sólo un denominador común las une, que es la limitación de la capacidad de testar. En este sentido se pronuncia la jurisprudencia menor manteniendo, de manera unánime, que los bienes afectados por el derecho de reversión forman un subconjunto que ha de separarse del caudal relicto ${ }^{270}$. Tiene que hacerse con el objeto de no ser computados en el pertinente cálculo de las legítimas. Prueba fehaciente de ello es que el legitimario puede ser, a su vez, reservatario o reservista ${ }^{271}$. Tampoco el derecho de reversión exige,

268 OChOA MARCO, R. y SEBASTIÁN CHEMA, M.S.: La herencia ..., op. cit., pág. 82. El autor confirma que, "los bienes donados quedan fuera de la masa hereditaria y se adjudican aparte, fuera de la herencia, sin llegar en ningún caso a formar parte de la misma (...)".

${ }^{269}$ LASARTE Álvarez, Derecho de sucesiones..., op. cit., pág. 190.

${ }^{270}$ La STS 25-9-2012 (RJ 2013 2269) cuyo supuesto de hecho trata de la donación por parte de los padres de una farmacia a su hijo. Este premuere a sus padres sin tener descendencia. La SAP de Madrid (S. 11) de 27/04/2007 (JUR 2007\210923) F.J. $2^{\circ}$ mantiene con respecto al derecho de reversión que: "Tanto la doctrina como la jurisprudencia es unánime al considerar que los bienes donados quedan fuera de la masa hereditaria y en consecuencia no se computan para el cálculo de las legítimas y, los legitimarios, carecen de cualquier derecho o cotitularidad sobre dichos bienes". Tambien la SAP de Valencia (S.6) de 19/02/2016 (JUR 2016\145993) F. J. $2^{\circ}$ mantiene que: "el derecho de reversión es incluso independiente de la cuota legitimaria que puede corresponder al ascendiente, debida por el descendiente causante".

${ }^{271}$ CORRAL GARCíA, E.: "El derecho de reversión legal del artículo 812 del Código civil: cuestiones suscitadas en la jurisprudencia más reciente", Revista Crítica de Derecho Inmobiliario, núm. 667, septiembre-octubre, 2001, pág. 3. Cita el autor como apoyo a sus explicaciones distinta jurisprudencia menor en la que se destaca el litigio que se 
para su aplicación, que el ascendiente sea legitimario. Pero si que tiene a su favor la reserva de los bienes que le hubiera donado al descendiente causante y es más, los bienes donados con derecho a reserva quedan excluidos, también, del cálculo de la legítima del cónyuge viudo ${ }^{272}$.

\subsubsection{La reserva viudal}

La reserva viudal proviene, como figura jurídica, del Derecho romano, se encuentra establecida dentro del Código civil en la Sección $2^{\mathrm{a}}$ "De los bienes sujetos a reserva", artículos 968, y siguientes. La finalidad de la referida institución tiene su razón de ser en el segundo matrimonio de una persona viuda puesto que se trata de proteger los interese de los hijos habidos en el primero ${ }^{273}$. Ello en base a que, el citado segundo matrimonio, puede alterar el destino de los bienes del primero, es decir, los bienes del

arrastra desde un mortal accidente de tráfico en que fallecen los dos cónyuges y la hija de ambos. Al no poder probar cuál de ellos murió primero, se consideró la presunción legal de que murieron los tres de manera simultánea (conmoriencia). A la esposa y madre de los otros dos fallecidos, respectivamente, resulta que la madre (viuda) de ésta, le había donado dos fincas, que vuelven a su patrimonio tras el fatal desenlace en que fallece intestada su hija, nieta y yerno, convirtiéndose en la única heredera. El fallecido cónyuge esposo y padre, mantiene la sentencia: "de tal modo que el marido de la causante no sólo no tiene derecho alguno a adquirirlas, sino que a la hora de calcular el valor de su usufructo vidual tampoco se tienen en cuenta las mismas.". La verdadera aportación de esta sentencia está en la confirmación que hace la Audiencia de Cáceres que no se contabilizan los bienes objeto de reversión para el cálculo del usufructo viudal.

${ }^{272}$ Torres García, T. F. y Domínguez Luelmo, A.: "La legítima en el Código civil (II)...", op. cit., pág. 111. Apoya sus manifestaciones en la STS 12/11/1990 (RJ 1990/8698). Esta sentencia aporta dos buenas definiciones a la reversión del artículo 812 del Código civil. La primera: que el derecho de reversión o retorno opera de manera automática cuando se cumple lo dispuesto en el artículo citado: "Por tanto, el derecho de reversión propiamente no es tal en este caso, sino que se trata más bien de acción de revocación de donación por supuesto incumplimiento de cargas; mientras que la reversión, como confirma el artículo 812 del Código Civil, opera automáticamente dado el hecho de que dependa.," La segunda atiende al grado de parentesco entre el donante y el recurrente: "No puede hablarse de que el recurrente tenga el carácter de dueño del inmueble debatido, en cuanto, como ya se razonó, no le alcanzan los efectos de la supuesta reversión que mantiene el recurrente, pues su parentesco con el donante se incardina fuera del alcance del segundo grado o generación".

273 LoRENZO-REGO, I.: El concepto de familia en Derecho español: un estudio interdisciplinar, Boch, 2014, pág.126. 
cónyuge premuerto. El legislador por medio de esta institución crea o trata de suponer la voluntad del causante y supone que este, no hubiera querido como destino para su patrimonio los hijos de la que un día fue su esposa/o y un tercero/a que poco tienen que ver con la línea de procedencia de dicho patrimonio. El legislador califica, el citado patrimonio, como reservable para los hijos del primer matrimonio, uno de cuyos progenitores es después, uno de los cónyuges del segundo ${ }^{274}$.

Puede que frente a la típica pregunta sobre la disposición de los bienes reservables por parte del cónyuge supérstite del primer matrimonio, tenga la respuesta el artículo $975^{275}$, del Código civil, sin dejarse de lado el artículo $977^{276}$, del mismo cuerpo legal, a que se haga inventario de todos los bienes sujetos a reserva de su anterior matrimonio. Y lo más importante es que se ha de anotar en el Registro de la Propiedad la calidad reservable de dichos bienes, que no presentaría más problemas, de adquirirse en conocimiento de carga por parte del adquiriente . La enajenación subsistirá sólo en defecto de descendientes del primer matrimonio. En el caso de muerte del titular de los bienes reservables (supérstite del primer matrimonio) de existir descendencia de este en su segundo matrimonio (reservatarios) tendrían cabida los artículos 34 y 37, de la Ley Hipotecaria

\footnotetext{
${ }^{274}$ DONATO VARA, A.: "La reserva viudal y la posible reserva de una bodega legada: análisis crítico de su concepto, naturaleza y utilidad", Revista de Derecho UNED, núm. 7, 2010, pág. 232. Tambien se refiere a lo expuesto la STS de 05/06/2008 (RJ 2008\3205) F. J. $8^{\circ}$ "lo que opera a partir de la presunción de que el transmitente no habría querido que tales bienes pasaran en ningún caso a la nueva línea creada por un posterior matrimonio".

275 Artículo 975. "La enajenación que de los bienes inmuebles sujetos a reserva hubiere hecho el viudo o la viuda después de contraer segundo matrimonio subsistirá únicamente si a su muerte no quedan hijos ni descendientes del primero, sin perjuicio de lo dispuesto en la Ley Hipotecaria."

${ }^{276}$ Artículo 977, "El viudo o la viuda, al repetir matrimonio, hará inventariar todos los bienes sujetos a reserva, anotar en el Registro de la Propiedad la calidad de reservables de los inmuebles con arreglo a lo dispuesto en la Ley Hipotecaria y tasar los muebles."
} 
y el adquiriente de buena fe, no sería apartado de su adquisición, de cumplir el resto de requisitos que la Ley exige ${ }^{277}$.

Los presupuestos que han de darse para que esta presunción legal de reserva al cónyuge supérstite tenga cabida han de ser: en primer lugar, la disolución de su matrimonio por muerte y que contraiga nuevas nupcias o tenga descendencia, extramatrimonial, en su periodo de viudedad. O bien obtenga dicha descendencia legal por adopción apartada del causante y cónyuge de su primer matrimonio ${ }^{278}$. En segundo lugar han de existir descendientes de su primer matrimonio con derechos sobre los bienes objeto de reserva. En tercer lugar han de existir bienes reservables, es decir, que de variar su destino quebrarían la línea de la que proceden. Son los bienes adquiridos por el viudo del causante por testamento, sucesión legal, donación o por cualquier otro título lucrativo ${ }^{279}$. La línea que, de

\footnotetext{
${ }^{277}$ FuENTES MARTíneZ, J.J.: "Un caso de reserva viudal. Su influencia en una concreta transmisión dominical", La Notaría, núm. 6, junio, 1997, pág. 114. "La reserva de bienes reservables no inscrita en el Registro de la Propiedad, según la doctrina, producirá menos efectos obligacionales. La enajenación transformaría dicha reserva en una reserva de valor, algo que ya viene a ocurrir en caso de enajenación de los bienes muebles reservables (art. 976 CC)"'. Mantiene MARTínEZ VÁZQUEZ DE CASTRO, L.: Hipoteca por bienes reservables en el Código civil, Anuario de Derecho Civil L 1, 2006, pág. 98 (cita 6), que lo que busca la Ley es que quien adquiera bienes del reservista sepa de la cualidad de dichos bienes a los efectos de los artículos 34 y 37 de la Ley Hipotecaria.

${ }^{278}$ Señala DIEZ- PICAZO y Gullón, Sistema ..., op. cit., pág. 190, que "la filiación ha de estar determinada legalmente, no basta sólo el hecho del nacimiento, aunque sus efectos (los de la determinación) serán retroactivos hasta entonces (art. $112 \mathrm{Cc}$ )".

279 DieZ-PICAZO y Gullón, Sistema..., op. cit., pág. 191. No incluyen los bienes reservables a la mitad de gananciales del cónyuge supérstite. Tampoco está sujeto a reserva el usufructo que corresponde a la legítima viudal, por ser esta un usufructo sobre bienes hereditarios supeditados a que a la muerte del viudo se consolide la nuda propiedad. Por lo que se refiere al caso de conmutación del usufructo (Arts 839 y 840) manifiestan estos autores la negativa a la obligación de reservar debido que no recibe dichos bienes por cualquiera de los títulos que contempla el artículo $968 \mathrm{Cc}$.
}

Coincide Moreno QueSADA, L.: Las reservas hereditarias en curso de Derecho civil IV Derecho de Familia y sucesiones (coor. F.J. Sánchez Calero), 5a ed, Tirant Lo Blanch, Valencia, 2009, pág.624, en que no son reservables los bienes gananciales 
manera supuesta, el legislador pensaba que de vivir el causante no hubiera querido que se apartasen sus bienes. Si bien es cierto que esta institución de protección a los hijos del primer matrimonio, de supuesta utilidad en su época de creación, (época romana) ha ido decreciendo en la medida que se han ido viendo con menos recelo las segundas nupcias del viudo/a ${ }^{280}$.

La protección que ejerce la reserva viudal y su relación con el tema que aquí se toca (la legítima) solamente tiene sentido el traerlo a colación para el cómputo de la legítima, es decir, se está ante bienes reservables que no formarían parte en el caudal relicto a nivel de computación de las distintas legítimas. Por lo demás se advierte más, con esta reserva, una limitación a la libertad de tener descendencia futura por parte del supérstite, que a la protección de la habida con anterioridad a la viudez. Tal afirmación la prueba el hecho de que empieza a tener que pensar el viudo/a en reservar sus bienes desde el momento en que se avecinan nuevas nupcias para él. De no penalizarse el que el viudo/a deje de serlo y que el espíritu de la institución de la reserva viudal fuera la protección de los hijos de su primer matrimonio, no pasaría por el hecho de casarse, a dar origen a la reserva de ciertos bienes a favor de unos hijos que ya han

correspondientes al supérstite ni las cosas dadas o dejadas por los hijos a sus padres conociendo las segundas nupcias de estos.

${ }^{280}$ DONATO VARA, “La reserva viudal...”, op. cit., pág. 232 a 233. Esta autora hace una alusión a la reserva lineal o troncal, manifestando que el legislador de 1968 aprovecho la ocasión para incorporarla al Código civil. "El caso regulado por la reserva lineal sería el siguiente: un ascendiente, el padre por ejemplo, hereda de su descendiente, su hijo, bienes que éste adquirió por título lucrativo (una herencia, una donación...) de otro ascendiente (su abuelo materno, por ejemplo) o de un hermano, debiendo reservar los que adquiera por ministerio de la ley (ejemplo, la cuota legitimaria) a favor de los parientes dentro del tercer grado y que pertenezcan a la línea de procedencia del bien, la rama materna. Se trataría de otro ejemplo más de reversión de un bien a su familia de procedencia". 
recibido, como mínimo, la legítima de su padre o madre y causante a la $\mathrm{vez}^{281}$.

En la actualidad cabría preguntarse por la posible aplicación analógica de la reserva viudal a las parejas de hecho. Concretamente me refiero al supuesto en que una pareja de hecho tiene un hijo y tras fallecer uno de los miembros de la pareja forma una nueva relación bien como pareja de hecho o bien como matrimonio ${ }^{282}$. En este punto es donde cabe la pregunta si únicamente se protegen con la reserva viudal los derechos de los hijos matrimoniales, o por el contrario también se protegen los intereses de los nacidos en una unión de facto o pareja de hecho, es decir, ¿En estos casos también se aplicaría la reserva vidual? La negativa a la pregunta planteada podría verse como una vulneración al artículo 14 de la Constitución por tratar de manera diferente en función de la filiación ${ }^{283}$

\footnotetext{
${ }^{281}$ DONATO VARA, "La reserva viudal...", op. cit., pág. 243. Mantiene la autora, la trayectoria que ha supuesto para esta reserva viudal, en otros países que también la tenían reflejada en sus respectivos Códigos civiles, así Francia e Italia, se prescindió de ella (hubo derogación de esta reserva) tras advertir que la citada contrariaba los derechos hereditarios del cónyuge viudo, así como su libertad matrimonial. También se refiere la autora a la estancación a las transmisiones, que ello podía acarrear los consecuentes perjuicios a nivel de impuestos que, dichas transacciones, podían suponer de no realizarse en los bienes reservados.
}

${ }^{282}$ Resalta GÁlvEZ CRIADO, A.: "El principio general del libre desarrollo de la personalidad y los pactos entre convivientes tras la STC 93/2013, de 23 de abril", Revista Crítica de Derecho Inmobiliario, núm. 750, juio 2015, pág. 1828, la comparación que hace Cataluña equiparando la posición de cónyuge viudo y conviviente supérstite "(esto es, en la sucesión intestada, en los derechos legitimarios, en la reserva viudal, en las atribuciones post mortem y en las disposiciones de la sucesión testada que afectan al cónyuge viudo)". En similar situación de equiparación se encuentran en la actualidad Navarra, Baleares, País Vasco, Galicia. Sin poder decir lo mismo de Aragón que lejos de acercar los derechos del viudo al sobreviviente de la pareja de hecho, únicamente le reconoce muy concretos derechos en el artículo 311 del CDFA.

${ }^{283}$ DONATO VARA, A.: "Revisión crítica de la reserva vidual en el Derecho Civil Foral: análisis particular de la reserva binupcial en el Derecho y jurisprudencia catalana hasta su definitiva derogación legislativa", Revista Crítica de Derecho Inmobiliario, núm. 729, enero 2012, pág 454. A este supuesto de reserva viudal a parejas de hecho se han pronunciado la jurisprudencia menor en distintas resoluciones. Así la SAP de Barcelona 
Es destacable la evolución sufrida por la institución de la reserva viudal en países de nuestro entorno cultural que contaban con una arraigada tradición como Francia o Italia en donde actualmente ha sido suprimida de sus respectivos ordenamientos ${ }^{284}$. También en nuestro Derecho el legislador catalán ha seguido la misma trayectoria de suprimir esta institución hereditaria a partir del 01 de enero de 2009, por la Ley 10/2008, de 10 de julio, fecha en que entra en vigor el actual Libro Cuarto del Código Civil de Cataluña relativo a las Sucesiones, en el que se suprimen las reservas del Derecho catalán, puesto que así lo dispone la Disposición Transitoria Séptima y el artículo 411-8, cuyo título de este precepto es: "Inexistencia de reservas y reversiones legales" deja fuera de toda duda la supresión de las reserva viudal ${ }^{285}$. En Aragón el artículo 149.3 de la Ley de

de 22/03/2010 (Tol. 1.889.576) F.J. $2^{\circ}$ antepone la falta de vigencia en Cataluña de la reserva viudal: "Pero no podemos pasar por alto que el Libro IV del CC Cataluña, aprobado por Llei 10/08, en su artículo 411-8 dice que "Los bienes adquiridos por título sucesorio o por donación de acuerdo con el presente código no están sujetos a ninguna reserva hereditaria ni reversión legal." En el F. J. $3^{\text {o }}$ considera la unión matrimonial y la convivencia more uxorio como instituciones diferenciadas y distintas. Concluyendo la Sala: "no podemos sino concluir afirmando que la interpretación ajustada a Derecho de la norma que nos ocupa no comprende el caso de la unión more uxorio ". En cambio la SAP de Castellón de 02/03/2010 (Tol. 1.877.571) F. J. $2^{\circ}$ ante el supuesto en que el disponente lega, con cláusula testamentaria, a su posible resolución en caso de un segundo matrimonio por parte de su esposa. La controversia se suscita al pretender extenter la cláusula testamentaria a la unión de hecho o pareja more uxorio: "De ahí que no pueda compartirse el argumento expuesto por la Juez de primer grado para estimar que el art. 793 del $\mathrm{Cc}$ no puede comprender las uniones de hecho por tener que interpretarse restrictivamente al limitar un derecho subjetivo individual. La misma resolución en el F. J. $4^{\text {o }}$ "Sobre la base de dichos criterios junto con las consideraciones precedentemente realizadas para integrar en el ámbito del art. 793 del Cc la convivencia more uxorio, estimamos que al referirse el testador a "ulteriores nupcias" comprendía dicho tipo de convivencia, en un sentido similar al plasmado en la sentencia del Tribunal Supremo de fecha 11 de junio de 1.964 previamente citada”.

${ }^{284}$ DONATO VARA, A.: "Revisión...”, op. cit., pág. 460.

${ }^{285}$ Señala DONATO VARA, A.: "Revisión...", op. cit., pág. 449, que el legislador catalán había mantenido en el Código civil de Cataluña de 1991(Art. 387 a 390) la reserva viudal hasta su derogación en 2009. Corrobora la citada supresión la jurisprudencia en STSJ de Cataluña de 21/05/2010 (RJ 2010\5129) F.J. $3^{\circ}$ "Cuanto hasta aquí se lleva dicho de la reserva binupcial -que tras la CDCC pervivió en el CS (art. 387 )- no puede hacer contemplación de la nueva situación legal producida por la aprobación del Llibre 
sucesiones por causa de muerte establece que no tendrá lugar la reserva de bienes salvo disposición impuesta por el testador en su testamento o en escritura pública. Igual tendencia ha seguido el legislador de Galicia al disponer en el artículo182 de la Ley de Derecho civil de Galicia a que en las sucesiones, allí regidas, no tendrá lugar la obligación de reservar ni la reversión legal ${ }^{286}$.

En ocasiones puede darse el caso de juntarse en mismo reservista varios derechos a reserva sobre unos mismos bienes. En tal caso se tendría que determinar que clase de reserva tiene preferencia para aplicarse sobre los bienes reservables. La coincidencia de reservas en un mismo individuo como pueda ser el derecho a la reserva lineal (art. $811 \mathrm{Cc}$ ) y la viudal o ordinaria (art. 968 y 969 Cc), sobre los mismos bienes. El Alto Tribunal, además de basarse en SSTS de 1911 y 1922, también se remonta a la tradición reservista del Derecho español, en el sentido de que la reserva lineal se reconoce por primera vez, en el ordenamiento español, por medio del Código civil. En cambio la reserva viudal u ordinaria "es tradicional de nuestro Derecho histórico". Por lo tanto ha de entenderse que llegada la colisión de ambas reservas sobre un mismo reservista respecto de unos mismos bienes ha de prevalecer la reserva tradicional, ordinaria o viudal. Es decir, la reserva viudal es recogida por los artículos 968 y ss del Código

Quart del Codi civil de Catalunya, del que ha desaparecido por motivos de política legislativa, que, por evidentes razones de seguridad jurídica (art. 9.3 CE ), no pueden ser aplicadas retroactivamente a situaciones surgidas jurídicas con notable anterioridad a su entrada en vigor (art. 2.3 C.C.), ni siquiera bajo el argumento del elemento hermenéutico sociológico (art. 3.1 C.C.)".

${ }^{286}$ Munar Bernat, P.A., Verdera IZQuierdo, B., Hualde Manso, T., AAVV "Reservas hereditarias" en Tratado de Derecho de Sucesiones (Código Civil y normativa civil autonómica: Aragón, Baleares, Cataluña, Galicia, Navarra, País Vasco), tomo II, Civitas, Pamplona, 2011, pág. 2429. 
civil que prevalece sobre la reserva lineal del artículo 811 del mismo Código $^{287}$.

\subsection{LA PÉRDIDA DE LA LEGÍTIMA: DESHEREDACIÓN E INDIGNIDAD}

Hasta este momento se han visto los derechos de los legitimarios y como poder ejercerlos. Hay supuestos en los que un legitimario puede perder tales derechos, es decir, se le priva de sus derechos a legítima, de cumplirse ciertos requisitos que la Ley prevé. Tales requisitos quedan recogidos en los artículos $756 \mathrm{Cc}$ para las causas de indignidad y en los artículos 853, 854 y 855 Cc para las justas causas de desheredación. Cabe distinguir entre ambas figuras, la de indignidad de la de desheredación, ya que la primera puede darse tanto en la sucesión testada como en la intestada y la segunda sólo cabe en la sucesión testada puesto que precisa de la expresión del testador en su testamento ${ }^{288}$. Así resulta del artículo 849 Cc por el cual la desheredación solamente puede hacerse en testamento, expresado en él, la causa legal en que se funde. Se entiende que la desheredación puede practicarse por medio de las distintas clases de testamento, es decir, común o especial ${ }^{289}$. En cuanto a la forma del

287 Véase como la STS de 05/06/2008 (Tol. 1.333.399) F.J. $3^{\text {o }}$ dedica una amplia argumentación al respecto de la colisión de reservas: “(...) en el caso de colisión de ambas reservas en la persona de un mismo reservista y respecto de unos mismos bienes, con distintos reservatarios, ha de prevalecer la reserva tradicional, ordinaria o viudal de los artículos 968 y ss. del Código Civil sobre la reserva lineal del artículo 811 como ya reconocieron las antiguas sentencias de esta Sala de 4 de enero de 1911 y 21 de enero de 1922, según las cuales, si quedan hijos o descendientes del primer matrimonio del ascendiente reservista se desvanece o queda inoperante la otra reserva que pudieran pretender los parientes del tercer grado".

${ }^{288}$ Martínez Atienza, G.: Derecho Civil, Penal Sustantivo y Procesal. Jurisprudencia del Tribunal Supremo, vLex, Madrid, 2015, pág. 36.

${ }^{289}$ La SAP de Vizcaya (S. 4 ${ }^{\text {a }}$ ) de 04/12/2002 (JUR 2003\92270) profundiza en su F.J. $3^{\circ}$, en la disposición del artículo $849 \mathrm{Cc} "(\ldots)$ debe analizarse como presupuesto previo, de conformidad con las alegaciones de la parte apelada, si la causa de desheredación se ha expresado con arreglo a lo preceptuado por la ley, ya que según lo dispuesto en el artículo 849 CC sólo puede hacerse en testamento expresando en él la causa legal en que se funde. Según viene manteniendo la doctrina, el cumplimiento de la 
testamento puede hacerse en la ordinaria o bien en la extraordinaria ${ }^{290}$. Por lo tanto, no puede tener cabida la desheredación en la sucesión legal.

En la desheredación se priva a los hijos y descendientes de sus derechos a legítima, si concurre una justa causa de desheredación de las reflejadas en los preceptos $853 \mathrm{Cc}$ y alguna causa de indignidad para suceder de los números 2, 3, 5 y 6 del $756 \mathrm{Cc}$. El primer precepto, de los citados, ha originado polémica jurisprudencial, al disponer entre otras, como causa de desheredación "el maltrato de obra" dando ello pié a dudar de si otros tipos de maltrato son causas, o no de desheredación. Se refiere a ello el Tribunal Supremo en STS de 03/06/2014 y esta, a su vez es tomada como referencia jurisprudencial por la STS de 30/01/2015. Aclara esta última, que en la actualidad, el maltrato psicológico visto como acción que lesiona la salud mental debe ser visto dentro del marco que encierra el maltrato de obra ${ }^{291}$.

expresión de la causa de desheredación queda cumplido: si se expresa la causa legal de desheredación, aunque no se precisen los hechos constitutivos, que sólo deben ser probados por los herederos en caso de ser controvertidos; si se hace referencia a los hechos constitutivos, aunque no se indique la causa legal específica en que se apoya la desheredación; si se señala genéricamente una causa que pueda comprenderse en alguna o varias de las legalmente tipificadas (STS de 6 de diciembre de 1963); si, aun sin precisar el hecho ni referirse a una causa legal genérica ni específicamente determinada, las palabras con las que el testador se exprese sean suficientemente explícitas para hacer entender que se refirió a hechos ocurridos calificados por la ley como causa de desheredación.".

${ }^{290}$ O'Callaghan Muñoz, X.: Compendio de Derecho Civil, tomo 5, Edersa, Madrid 2004, pág. 2.

${ }^{291}$ STS de 30/12/2015 (Tol. 4.748.346). Esta sentencia simplemente reitera la doctrina de su precedente de 2014: "En relación a la cuestión que plantea el presente recurso de casación, esto es, la interpretación del concepto de maltrato de obra que contempla el artículo 853.2 del Código Civil, debe señalarse que la reciente jurisprudencia de esta Sala se ha ocupado de esta figura en su sentencia de 3 de junio de 2014 (núm. 258/2014). Esto es lo que ocurre con los malos tratos o injurias graves de palabra como causas justificadas de desheredación, (artículo 853.2 del Código Civil), que, de acuerdo con su naturaleza, deben ser objeto de una interpretación flexible conforme a la realidad social, al signo cultural y a los valores del momento en que se producen.(...)". "En segundo lugar, y en orden a la interpretación normativa del maltrato de obra como causa justificada de desheredación, en la línea de lo anteriormente expuesto, hay que señalar 
El artículo $854 \mathrm{Cc}$ se ocupa de las causas que se requieren para poder privar de la legítima que la ley otorga a los padres y ascendientes, añadidas a las causas de indignidad del artículo 756 Cc. De las causas para poder desheredar al cónyuge supérstite, se ocupa el siguiente, es decir, el artículo 855 Cc. Como en los dos anteriores tambien incluye las causas de indignidad, más las que añade el propio precepto, como la de "haber incumplido grave y reiteradamente los deberes conyugales", entre otras causas allí expuestas ${ }^{292}$.

Como una legítima se puede perder, entre otros, por indignidad o por desheredación ${ }^{293}$. Esto significa que en el supuesto de un causante haber fallecido sin otorgar testamento cabría tal posibilidad de que un legitimario, perdiera su parte, por incurrir en alguna de las causas de indignidad del

que, en la actualidad, el maltrato psicológico, como acción que determina un menoscabo o lesión de la salud mental de la víctima, debe considerarse comprendido en la expresión o dinamismo conceptual que encierra el maltrato de obra, (...)".

${ }^{292}$ Véase la SAP de Madrid (S. 19) de 14/12/2015 (AC 2015\1715). En especial el F.J. $3^{\text {o }}$ sobre la desheredación por incumplir los deberes conyugales: "Es causa de desheredación del cónyuge el incumplimiento de los deberes conyugales, el incumplimiento es alternativo, o grave o menos grave pero entonces reiterado. No consta el divorcio, separación legal o de hecho como causa de desheredación pues en tales casos se extingue el derecho a legítima viudal y no se tiene legitimación para la acción, pero no solo es un incumplimiento reiterado o grave sino una total ruptura matrimonial que supone la situación más extrema, permanente y reiterada en la que no solo se incumplen, sino que cesan las presunciones y obligaciones maritales". También la SAP de la Coruña (S. 1 ${ }^{\text {a }}$ ) de 30/08/2003 (AC 2003\1952) detalla en su F.J. $4^{\circ}$, los deberes conyugales:" (...) en el artículo $855.1^{\mathrm{a}}$, que plantea la alternativa, si ha habido un incumplimiento grave o menos grave, pero en este último caso, reiterado de los deberes conyugales, es decir, los comprendidos en los arts. 67 y68, respetarse y ayudarse mutuamente, actuar en interés de la familia, vivir juntos, guardarse fidelidad y socorrerse mutuamente".

${ }^{293}$ La STS de 07/03 1980 (RJ 1980\1558) en su F.J. $2^{\text {o }}$ se refiere a la distinción entre desheredación e indignidad: " (...) toda vez que desheredación e indignidad son dos conceptos distintos, dado que si la primera puede efectivamente basarse en alguna de las causas de indignidad susceptibles de producir este efecto, como indica el invocado art. 852 , la segunda constituye por sí un motivo de incapacidad relativa para suceder, haya o no desheredación, de no mediar la remisión expresa o tácita a que alude el art. 757 del repetido Cuerpo legal sustantivo, por lo que al no constar la inexistencia del testamento rector de la sucesión de tan aludido causante claro es que ninguna infracción contiene la sentencia impugnada al respecto de los preceptos legales invocados por la recurrente". 
artículo 756 Cc. Hay que matizar al respecto que la perdida de los derechos de los legitimarios por causas de indignidad o por desheredación no impide que se trasmitan a sus descendientes conforme al artículo 761 y $857 \mathrm{Cc}^{294}$. En ambos casos el mecanismo legal para la adquisición de la legítima por el hijo o descendientes del indigno o del desheredado es el del derecho de representación del artículo 929 Cc. $^{295}$

En los supuestos de indignidad, la acción para suceder podrá ejercitarse por cualquiera de los herederos que tengan interés en acrecentar su parte y tal acción tendrá una caducidad de cinco años. Este plazo empieza a contar desde que el indigno toma posesión de la herencia o legado (art. $762 \mathrm{Cc}$ ). Lo que aporta al caso que aquí interesa es la diferente sustitución que se hace en ambas figuras jurídicas. En el caso de la indignidad cabe distinguir dos supuestos: si el declarado indigno no es legitimario su parte acrece en los demás herederos, pero en el supuesto de serlo, su legítima se traspasa a sus hijos o descendientes. En cambio en la desheredación, su legítima no se acrecienta en los demás ni se pierde (sólo se pierde para el desheredado) pasa a sus descendientes. La desheredación y la indignidad son dos vías distintas, que ambas, llevan al mismo destino. Una vía se activa automáticamente por la ley y la otra sólo a instancia de parte por el testador. Como se ha dicho la desheredación no es otra cosa que una indignidad plasmada en el testamento y la indignidad es una desheredación legal ${ }^{296}$.

\footnotetext{
${ }^{294}$ MARtín JimÉnEZ C.M.: Teoría y Práctica del Ejercicio de las Acciones Civiles. Comentarios y Formularios. Lex Nova, Valladolid, 2010, págs.1236 a 1240.

295 DieZ PICAZO y Gullón, Sistema ..., op. cit., págs. 35 y 189.

${ }^{296}$ ESPADA MALLORQUín S.: "El impedimento del ejercicio del derecho a una relación directa y regular entre abuelos y nietos como causal de desheredación e indignidad" Revista de Derecho, Vol. 28, N. 2, 2015, págs. 71-89.
} 
Siguiendo con la acción para ejercitar la indignidad se ha de tener presente que la indignidad nace por disposición de la ley, es decir, ex lege. Se produce cuando se está incurso en alguna de las circunstancias que contempla el artículo $756 \mathrm{Cc}$, por lo que no es necesario sentencia judicial para que prospere ${ }^{297}$. Por lo general se parte de una premisa importante, en que solamente cabría como una de las alternativas posibles la vía contenciosa, llegado el caso, de que el indigno no reconozca su conducta merecedora de sanción. Sin embargo no se puede pasar por alto que existen otras vías, como la mediación, antes de llegar a la vía judicial en los casos de indignidad. Si el que tiene derecho a reclamar la declaración de incapacidad no lo hace, el indigno cogerá su correspondiente parte de la herencia o legado y pasado el plazo su derecho será inatacable. No se trata de necesitar la vía judicial firme para la calificación de la indignidad, sino que únicamente se necesita una sentencia judicial inapelable, para cuando el indigno se niegue a entregar la herencia o legado ${ }^{298}$.

El motivo por el cual la indignidad puede suprimir los derechos legitimarios es porque el principio de intangibilidad de la legítima no es absoluto. Por ello el Alto Tribunal entiende que se ha de ceder cuando una persona se encuentra inmersa en alguna de las causas por las que se le puede

${ }^{297}$ BALAREZO REYES, E.J.: "Los efectos de la ley del adulto mayor sobre el derecho de sucesiones, un replanteamiento respecto a la figura de la indignidad", REDS (Revista de Derecho, Empresa y Sociedad), núm. 11, julio 2017, pág. 82, señala que la indignidad además de constituir una sanción civil sólo puede ser declarada por sentencia judicial solicitada por quienes tengan legitimación para ello.

${ }^{298}$ BEATO DEL PALACIO, E.: "la indignidad para suceder: causas de desheredación", en Raíces de lo Ilícito y Razones de Licitud,(cords. I. Hoyo Sierra y A. Sánchez de la Torre), Dykinson, Madrid, 2006. pág. 98. La autora se pronuncia en el sentido de que "aquí será precisa la existencia de sentencia, pero no para que haya indignidad, sino para declarar que realmente la hay en este caso". Comparando la resolución judicial de indignidad con el caso del titular de la propiedad que la reclama o con el acreedor que ejercita su derecho y reclama la deuda. En ambos casos la disponibilidad la tienen las partes, tanto de reclamar como de acceder tanto a la reivindicación como al pago de la deuda o no hacerlo". 
calificar judicialmente de indigno para suceder al causante de que se trate ${ }^{299}$. En cambio el criterio que ha de utilizarse, por parte de los tribunales, debe de ser restrictivo y ante la duda debe decantarse la resolución a favor del supuesto indigno $^{300}$.

\subsection{LA DESHEREDACIÓN}

Como ya se ha apuntado anteriormente las causas de desheredación están enumeradas en los artículos 852 a 855 Cc. El artículo $852^{301}$ Cc da la impresión de estar destinado a citar las justas causas de desheredación, pero simplemente se remite a otros preceptos y ni siquiera las apunta. Por ello, no hay más remedio, que buscarlas en los preceptos de remisión. Estimo conveniente antes de proseguir hacer unas breves matizaciones con respecto al artículo $813 \mathrm{Cc}^{302}$. Este artículo establece la intangibilidad

${ }^{299}$ STS de 28/02/1947 (Tol.4.452.460). En el encabezamiento de esta STS se pone de manifiesto que en los considerandos de la misma "se establece que las causas de indignidad son determinantes de la incapacidad para suceder, por estar reguladas en el Código Civil bajo la rúbrica "de la capacidad para suceder con testamento o sin él y con clara independencia de las de desheredación, no precisan de la expresión testamentaria para surtir efecto como no sean remitidas por el testador", en cualquiera de las formas estatuidas en el artículo 757 del precitado Cuerpo legal, y, en consecuencia, privan a quien en ellas incurran del derecho a suceder al agraviado, aunque sea heredero forzoso, porque la incapacidad, si es relativa con relación al "de cuius ", es absoluta por lo que afecta a su patrimonio, no sólo porque así cabe inferirlo de su naturaleza y fundamento, dada la trascendencia social de los hechos que la originan, sino también del contenido del artículo 761 del Código (...)".

${ }^{300}$ STS de 23/04/2018 (RJ 2018\1753) F. J. $4^{\circ}$ resalta el Alto Tribunal además del criterio restrictivo en cuanto a la interpretación de las causas de indignidad el no confundir el aspecto sentimental, ético o moral de las circustancias o actuaciones reprochables, con la apreciación y valoración jurídica.

301 Artículo 852: Cc "Son justas causas para la desheredación, en los términos que específicamente determinan los artículos ochocientos cincuenta y tres, ochocientos cincuenta y cuatro y ochocientos cincuenta y cinco, las de incapacidad por indignidad para suceder, señaladas en el artículo setecientos cincuenta y seis con los números $1^{\circ}$, $2^{\mathrm{o}}, 3^{\mathrm{o}}, 5^{\mathrm{o}}$ y $6^{\mathrm{o}}$."

${ }^{302}$ Artículo 813: "El testador no podrá privar a los herederos de su legítima sino en los casos expresamente determinados por la ley".

Tampoco podrá imponer sobre ella gravamen, ni condición, ni sustitución de ninguna especie, salvo lo dispuesto en cuanto al usufructo de viudo y lo establecido en el artículo 808 respecto de los hijos o descendientes judicialmente incapacitados. 
cualitativa de la legítima al establecer que "no se podrá privar a los herederos de su legítima sino en los casos expresamente determinados por la ley. Ello da pie a que se sobrentienda que se refiere a toda la legítima y no a parte de ella, es decir, todo o nada. Otra puntualización, con respecto al precepto señalado es que a partir del mismo se puede afirmar que la causa de desheredación tiene que estar expresamente determinada la Ley. Por lo tanto, en principio, no puede tener cabida ni la analogía ni la interpretación extensiva, ni la argumentación de minoris ad maiorem. Como ya se ha señalado anteriormente el testador debe señalar la causa legal de desheredación en su testamento, ello permite resaltar el derecho que asiste al presunto desheredado para negar tales hechos. Entonces entra en juego el artículo 850 Cc estableciendo que ante la negación de la causa de desheredación por parte del legitimario perjudicado corresponde la carga de la prueba a los herederos del testador que ha incluido la causa de desheredación en su testamento ${ }^{303}$.

\footnotetext{
${ }^{303}$ La SAP de Málaga (S. $5^{\text {a }}$ ) de 14/10/2014 (AC 2014 2380) se refiere en su F.J. $1^{\text {o }}$, a la necesidad de aportar la prueba de la causa que funda la desheredación por parte del heredero: “ (...) se alega el principio penal, in dubio pro reo, ya que se les acusa de injurias y mal trato psicológico, lo cual precisa de prueba determinante, contundente y abundante, sin que el demandado haya acreditado nada de ello a través de la prueba documental y solo a través de una testigo, $\mathrm{D}^{\mathrm{a}}$ Adela, la cual por demás no oyó decir a los recurrentes las expresiones que se les imputan, ni manifestó que la madre le hubiese dicho que sus hijos se las profirieran".También la SAP de Valencia, (S. 11) de 31/05/2012 (AC 2012\1069) F. J. $1^{\text {o }}$ corrobora lo expuesto en la anterior, con respecto a la carga de la prueba de la justa causa de desheredación por parte del heredero: "El examen del primer motivo debe partir de dos premisas: una fáctica que la testadora indicó textualmente que "... desheredaba expresamente a sus hijas Marí Luz y Josefa por haberle maltratado de obra e injuriado gravemente de palabra...", (cláusula tercera del testamento abierto otorgado el 21 de septiembre de 2007, folios 14 a 17), desheredación que se sustentó en el artículo 853.2 del Cc; y otra jurídica, en tanto que el artículo 850 del CC hace recaer la prueba de la causa de desheredación a los herederos del testador ya que tanto en la demanda como en el recurso se ha negado la misma".
} 


\subsubsection{La desheredación parcial y condicional}

La desheredación parcial consiste en privar al legitimario de una parte de su legítima, es decir, que no se le priva de toda ella ${ }^{304}$. El Código civil nada dice al respecto de la prohibición de desheredar parcialmente ${ }^{305}$. Por lo que no tiene cabida una parcialidad de la desheredación por cuanto que es difícil de entender una división del agravio. Ello es debido a la falta de pronunciación al respecto en el Código civil que no recogió la prohibición de desheredación parcial dispuesta en la Partida 6, Tit. 7, Ley $3^{\text {a }}$ que a su vez las Partidas recogieron del Derecho romano. Dos criterios totalmente contrapuestos, se mantienen por la doctrina, respecto de la desheredación parcial. El negativo u opuesto a ella viene por la doctrina clásica española, argumentando al respecto que la indivisión de la falta conlleva a la indivisión del castigo o el perdón ${ }^{306}$. También se argumenta al respecto el elemento histórico de interpretación de la Ley, por lo que procede tener en cuenta lo dispuesto en la Ley de Bases de 11 de mayo de 1888, cuya Base $11^{\mathrm{a}}$ dispone que "se mantendrá en su esencia la legislación vigenterefiriéndose al Código civil con respecto a la vigencia de la legislación

${ }^{304}$ DiEZ PICAZO y Gullón, Sistema ..., op. cit., pág. 187 mantienen que la desheredación debe de ser total, sin tener admisión en nuestro Derecho la desheredación parcial.

Si bien RePresa Polo, M. P.: La desheredación en el Código civil, Reus, Madrid, 2016, pág. 220 admite que nuestro Código civil no recoge la desheredación parcial pone de manifiesto que tampoco la prohíbe como sucedía en nuestro Derecho histórico.

305 VALLET DE GOYTISOLO, “comentarios...”, op. cit., pág. 529.

Más información en MONDRAGÓn MARTín, H.: "Ampliación de las causas de desheredación de hijos y descendientes”, vLex, núm. 167, abril, 2018, pág. 5.

306 Profundiza más en el tema de la graduación de la desheredación VALLET DE Goytisolo, "Comentarios...", op. cit., pág. 53, manifestando que la omisión de prohibir la desheredación parcial proviene ya del Proyecto de Código civil de 1851, criterio que compartía García Goyena. Este autor se pronuncia favorable a proveer de alimentos al desheredado. En cambio LASARTE ÁlvarEZ, Derecho..., op. cit., pág. 211, se muestra totalmente contrario a la desheredación parcial manifestando que "son numerosísimas las razones que avalan tal postura". Posición contraria la de REPRESA Polo, M. P.: La desheredación ..., op. cit., pág. 221, manifestando que "no existe norma en nuestro Código civil que permita negar la eficacia de la desheredación parcial". 
anterior. Esta, tal como se ha dicho, era contraria a la desheredación $\operatorname{parcial}^{307}$.

Ha quedado acreditado que el Derecho actual, a diferencia del histórico, no prohíbe la desheredación parcial. Por lo tanto, con el simple razonamiento de "lo que no está prohibido está permitido" se podría argumentar que la desheredación parcial no está prohibida por el Código civil. Por lo que tendría cabida que al legitimario desheredado sólo se le privara en parte su legítima y en cambio recibiera bienes a cuenta de la misma, antes o después de la desheredación. Por ejemplo una donación que supone un pago anticipado de la legítima al abrirse la sucesión del donante. Se le contaría al desheredado como un legitimario más, a efectos del cómputo de la legítima recibida en vida del disponente. Se le contaría como anticipo de la legítima a efectos de colacionar. Similar a la donación sería el efecto de una atribución patrimonial testamentaria del causante. Salvo que este acredite que dicha atribución sea con cargo del tercio de libre disposición se sacará de la cuota legitimaria. Sólo se le privará, al desheredado, de lo que sobrepase del valor de lo recibido inter vivos o mortis causa, es decir, quedará, en ambos supuestos, desheredado parcialmente ${ }^{308}$.

La desheredación condicional, se refiere a la previsión, por parte del testador, de que un legitimario pueda incurrir en un futuro en justa causa de

${ }^{307}$ Más información en O'CALlaghan MuÑoz, X.: Compendio de Derecho..., op. cit., pág. 3. Mantiene este autor la investigación al respecto hecha por BATLLE, Invalidez de la desheredación parcial en nuestro Derecho, Murcia, 1952, acerca del análisis que éste hizo sobre el tema que aquí se trata. “'Total, o cabe la desheredación parcial? Ha sido muy discutido en la doctrina, ante el silencio del Código civil, que no recogió la prohibición de desheredación parcial que se encontraba en las Partidas (Partida 6, tít. 7, Ley 3. ") proveniente del Derecho romano".

${ }^{308}$ RePresa POLO, M. P.: La desheredación..., op. cit., págs. 222 y 223. Debido a lo expuesto mantiene la autora "que podemos hablar de desheredación parcial", en base a los artículos 821, 822 y 1037 del Código civil. 
desheredación y lo plasma en su testamento para el caso de que así ocurra $^{309}$. Si bien se tendrá que esperar a que ocurra la justa causa para con posterioridad poder desheredar y no al revés ${ }^{310}$. Tampoco la desheredación condicional proveniente de las Partidas la recoge nuestro Código civil, si bien el artículo 849 Cc exige que la desheredación exprese la causa legal en que se funda, lo que requiere que la causa se haya producido ya para poder fundamentarla, lo cual significa que se requiere un hecho real ocurrido y no una mera presunción ${ }^{311}$. Tambien el artículo 850 Cc exige la certeza de la causa de desheredación $^{312}$. En principio al ser la legítima una institución intangible para el propio disponente debe reunir unos requisitos de seguridad y certeza que no pueden hacerse bajo condición. He puesto en principio porque si que hay supuestos en que no se impide la condición simpre que a la apertura de la sucesión este complida o incumplida tal

\footnotetext{
${ }^{309}$ Se refiere a ello la SAP de Barcelona (S. $4^{\text {a }}$ ) de 25/04/2017 (Tol. 6.414892) F.J. $2^{\text {o }}$, al artículo 451-17, del Código civil de Cataluña que recoge, este precepto, los requisitos de la desheredación, refleja que la desheredación no puede ser ni parcial ni condicional: "2. La desheredación no puede ser ni parcial ni condicional". En cambio no se puede encontrar en el Derecho común un precepto del que quepa deducir esa doble prohibición. La SAP de Barcelona (S. 17) de 17/11/2017 (Tol. 6.485.599) También en su F.J. $3^{\circ}$ se refiere a que la desheredación no puede ser ni parcial ni condicional. Desde el momento que el ordenamiento catalán dispone a favor de la prohibición de la desheredación parcial, no deja de dar cabida a que la falta de precepto que la prohíba en el Derecho común se pudiera interpretar como que está permitida.
}

${ }^{310}$ MANZANO FernÁNDEZ, M. M.: “La exclusión...”, op. cit., págs. 1864 y 1866.

311 VALlET DE GOYTISOLO, Comentarios...”, op. cit., pág. 532

312 Señala VAllet de Goytisolo, Comentarios...”, op. cit., pág. 533, el artículo 850 Cc que la certeza de la causa de desheredación la reclama el artículo $850 \mathrm{CC}$. En cambio MANZANo Fernández, M. M.: "La exclusión...", op. cit., pág. 1866. Pone de manifiesto que por el artículo $850 \mathrm{Cc}$ "En realidad no se está condicionando la concurrencia o no de la causa, sino su prueba, lo que el Código no exige para desheredar, sino solamente en el supuesto que sea contradicha". Comparte esta misma postura LORA-TAMAYO RODRÍGUEZ, I. Y PÉREZ RAMOS, C.: Cuestiones Prácticas sobre Herencias para Especialistas en Sucesiones, Francis Lefebvre-El Derecho S.A., Madrid, 2016, pág. 258, al manifestar que el artículo 849 requiere que la causa se haya producido con anterioridad a la apertura de la sucesión. Tambien comparte esta postura MONDRAGÓN MARTín, "Ampliación...", op. cit., pág. 5 al manifestar que "Por el contrario, no tendría sentido que fuera llamado en un futuro incierto en el supuesto de haber cumplido la condición impuesta por el causante en su testamento". 
condición. Se puede admitir la desheredación bajo condición cuando el disponente necesite probar un hecho o que necesite saber el resultado de una resolución judicial ${ }^{313}$.

La Jurisprudencia manifesta que la desheredación condicional iría, de estar permitida, contra la propia naturaleza de la desheredación ya que cualquier situación acaecida con posterioridad al otorgamiento del testamento puede hacerse constar mediante el otorgamiento de un nuevo testamento dada la naturaleza revocable del mismo ${ }^{314}$.

\subsubsection{La desheredación injusta}

La desheredación será injusta cuando no se cumplan los requisitos legales para hacerla justa ${ }^{315}$. Para que una causa de desheredación plasmada en un testamento sea calificada como injusta es necesario que así haya sido manifestado por una sentencia. En este caso la desheredación no producirá sus efectos. Será injusta la desheredación por no haberse plasmado en testamento, por no haberse desheredado por causa legal, por falta de alegación de justa causa o por no quedar esta probada conforme al artículo $851 \mathrm{Cc}^{316}$. Es suficiente que se pruebe sólo una aunque fuesen varias las causas de desheredación dispuestas por el disponente en su testamento ${ }^{317}$.

\footnotetext{
313 O'Callaghan MuÑoz, Compendio de Derecho..., op. cit.

${ }^{314}$ SAP de Valencia (S. $8^{\text {a }}$ ) de 29/02/2016 (Tol. 5.768.669) F. J. $2^{\text {o }}$ “como privación de un derecho prácticamente blindado en nuestro ordenamiento jurídico, tan solo puede ser objeto de exclusión, como hemos dicho, por causas muy concretas y definidas; además, cualquier posibilidad o situación que pueda suceder posteriormente puede y debe hacerse constar mediante el otorgamiento de nuevo testamento". En el mismo sintido con anterioridad la SAP de Vizcaya (S. 3 $)$ de 19/12/2013 (Tol. 4.315.545) F. J. 2 "Habrá de ser exigible igualmente conforme a la doctrina que estamos exponiendo, que dicha causa de desheredación exista ya al tiempo de otorgar el testamento en el que se especifique".
}

${ }^{315}$ DiEZ- PICAZO y GULlón, Sistema ..., op. cit. pág. 189.

316 Artículo 851 Cc: "La desheredación hecha sin expresión de causa, o por causa cuya certeza, si fuere contradicha, no se probare, o que no sea una de las señaladas en los cuatro siguientes artículos, anulará la institución de heredero en cuanto perjudique al 
También se da injusta causa de desheredación cuando se produce la reconciliación posterior entre desheredado y desheredante ${ }^{318}$. Si bien el precepto señalado no lo contempla, el incumplimiento de la disposición del artículo 849 Cc (falta de expresión en el testamento de la justa causa de desheredación) conllevaría a una desheredación injusta. En cambio no se puede hablar de desheredación injusta, sino de preterición intencional, en aquellos supuestos en los que el disponente omite a algún legitimario en el testamento con el objetivo de que no se beneficie de su herencia ${ }^{319}$. Sin embargo los efectos son similares en ambas figuras, ya que en ambos casos el legislador pretende salvaguardar los derechos del legitimario y la voluntad del testador, que no es otra que privar al legitimario de cualquier atribución patrimonial ${ }^{320}$. Los derechos del legitimario, en ambos casos no son otros que, el de percibir su legítima estricta ${ }^{321}$.

desheredado; pero valdrán los legados, mejoras y demás disposiciones testamentarias en lo que no perjudiquen a dicha legítima".

${ }^{317}$ BARCELÓ DOMENECH, J.: "La desheredación...", op. cit., pág. 5

${ }^{318}$ REPRESA POLO, La desheredación..., op. cit., pág. 224.

${ }^{319}$ Berrocal LanZAROT, "El maltrato psicológico...”, op. cit., pág. 935.

${ }^{320}$ Lledó Yagüe, F., Monje Balmaseda, O., Herrán Ortiz, A. I., AAVV: Cuaderno Teórico Bolonia I en La sucesión mortis causa, Dykinson, Madrid, 2012, pág. 48.

${ }^{321}$ VIVAS TESÓN, I.: "Intangibilidad cuantitativa de la legítima y preterición testamentaria: revisión crítica de las cuestiones controvertidas en materia de preterición, sus clases y efectos", Revista Crítica de Derecho Inmobiliario, núm. 742, marzo 2014, pág. 690. Tambien la jurisprudencia del Tribunal Supremo mantiene esta postura en STS de 09/07/2002 (Tol. 4.975.828) F.J. 5 "el preterido, como el desheredado injustamente, tiene derecho a la legítima, pero sólo a la legítima estricta o corta, es decir, un tercio, ya que la voluntad del causante, soberano de su sucesión, fue el privarle del todo y si por ley se le atribuye, no se puede extender a una parte (legítima larga) que corresponde a su libre disposición (entre hijos) y que voluntariamente nunca le quiso atribuir". Con anterioridad han seguido el mismo criterio las sentencias del Tribunal Supremo, de 13 de julio de 1985 ; 5 de octubre de 1991, 6 de abril de 1998 y 9 de julio de 2002, y las sentencias de la Audiencia Provincial de Asturias, de 26 de octubre y 7 de diciembre de 2005 (S. 5. ${ }^{\text {a) }} 6$ de noviembre de 1997 y 19 de diciembre de 2005 (S. $\left.6^{a}\right)$. 
Mientras que la desheredación no sea impugnada por algún legitimario desheredado, las disposiciones del testamento producirán todos sus efectos $^{322}$. Por lo que la desheredación es justa mientras el desheredado no se oponga a la causa judicialmente. No basta que lo haga extrajudicialmente. Es destacable en este punto, que la acción de impugnación de la desheredación, pese al carácter personalísimo de la misma, en virtud del artículo 1111 Cc (acción subrogatoria) también la tiene el acreedor del desheredado, cuando este último consiente la desheredación en perjuicio del acreedor ${ }^{323}$.

\subsubsection{Causas de desheredación de los hijos y descendientes}

Es el artículo $853 \mathrm{Cc}^{324}$ el primero en que se manifiestan dos causas concretas de desheredación, de las que se pasa seguidamente a analizar: (las que remiten al artículo 756 Cc se verán con las de indignidad)

1. Haber negado alimentos, sin motivo legítimo, al padre o ascendiente que le deshereda. No puede, conforme a la jurisprudencia del Tribunal

\footnotetext{
${ }^{322}$ SAP de Santa Cruz de Tenerife (S. 4 ) de 14/12/2015 (AC 20161383) F.J. $2^{\text {o }}$, "Sobre esta base hay que concluir que la actora carece de legitimación para impugnar la desheredación de su hermano, también legitimario, don Demetrio, pues ello implica el ejercicio de un derecho personal de éste para el que no se encuentra facultada como tampoco ostenta su representación; es el legitimario desheredado el que debe negar la causa de la desheredación e interponer la acción correspondiente, para lo que no se encuentra legitimado el otro heredero forzoso también desheredado, pues no es titular del objeto litigioso".

${ }^{323}$ Berrocal LANZAROt, "El maltrato psicológico...”, op. cit., págs. 935 y 936, señala la autora la definición de la desheredación injusta como el procedimiento judicial instado por una persona que ha sido desheredada y que tiene la finalidad de contradecir la causa de la desheredación expresada por el causante en el testamento y solicitar que el juez declare la desheredación es injusta por no haberse probado la existencia de la causa mencionada.

${ }^{324}$ Artículo 853 Cc: "Serán también justas causas para desheredar a los hijos y descendientes, además de las señaladas en el artículo 756 con los números 2, 3, 5 y 6, las siguiente: $1 .^{\mathrm{a}}$ Haber negado, sin motivo legítimo, los alimentos al padre o ascendiente que le deshereda. $2 .{ }^{a}$ Haberle maltratado de obra o injuriado gravemente de palabra".
} 
Supremo, incumplir la obligación de pasar alimentos, de manera literal ni menos general $^{325}$. Encuadrando dentro de esta figura jurídica, toda clase de cuidados y atenciones, sin limitación alguna ${ }^{326}$. Son los alimentos específicos que se recogen en los artículos 142 y el $143 \mathrm{Cc}$ a los que se refiere la justa causa de desheredación señalada en el artículo

325 Véase Berrocal LANZAROT, "El maltrato psicológico...", op. cit., pág. 940 la negativa a prestar alimentos estando obligado a ello y sin motivo justificado es lo que hace que subsista la causa de desheredación. Es un motivo justificado "cuando el descendiente carezca de capacidad económica para prestarlos, o el ascendiente no tuviera necesidad de reclamarlos". La STS de 23/04/2018 (RJ 2018\1753) F.J. 5, enjuicia un caso de indignidad en el cual se demanda la incapacidad para suceder, a un menor, de uno de sus progenitores. Se alega la falta parcial de pasar alimentos al menor del presunto indigno entre otros mitivos. Lo que valora el Alto Tribunal en su resolución es el abandono en sentido amplio que recoge entre otros el incumplimiento de pasar alimentos: "Coincide en ello autorizada doctrina que sienta que la expresión de abandono ha de entenderse en sentido amplio, como falta de cumplimiento de deberes de asistencia y protección, tanto físicos, como morales y económicos". SAP de Madrid (S. 12. ${ }^{\text {a) }}$ de 08/05/2013 (JUR 2013, 262389) en que el disponente no puede acreditar una situación de necesidad y por lo tanto petición de alimento a su hijos. la AP de Salamanca (S.1') de 19/12/ 2013 (AC 2013, 2219) F. J. $3^{\text {o }}$ "Ciertamente, como la doctrina y la jurisprudencia ha precisado, no es necesario que la negativa haya producido por efecto el hecho de quedar el ascendiente sin alimentos porque otra persona se los hubiera prestado, como, asimismo, no es necesario que éstos hayan sido reclamados judicialmente, pero, sin duda, tal negativa ha de venir probada fehacientemente y sin asomo de duda alguna, y siempre desde la premisa inexcusable de que si el descendiente a quien se piden alimentos se halla en la imposibilidad material de proporcionarlos, o si el ascendiente que los reclama no los necesita, (vínculo evidente con las causas extintivas de la obligación alimenticia expresadas en el art. 152 del CC".

${ }^{326}$ Avalan lo expuesto la SAP de Asturias (S.6 ${ }^{\text {a }}$ ) de 12/03/2007 (JUR 2008, 43795) F.J. $2^{\text {o }}$ "En cuanto a la negativa a prestar alimentos, debe ser ilegítima, como así lo exige el art. 853.1 $1^{\circ}$ del Código Civil, por lo que si el testador se encuentra en situación de necesidad y el descendiente tiene medios económicos suficientes para prestárselos, incurre en esta causa de desheredación si no lo hace, a menos que justifique una razón legítima para ello. No es necesario que los alimentos hayan sido reclamados judicialmente, aunque es precisa una exteriorización, cualquiera que sea, para deducir, caso de negarlos, el motivo de dicha negativa (St. 20-6-59), que habrá de ser alguna de las causas contenidas en el art. $152 \mathrm{CC}$. En todo caso, la negativa habrá de probarse conforme al art. $850 \mathrm{CC}$ " con el mismo criterio se pronuncian las SSAP de las sentencias de la A P de Barcelona (S 1. ${ }^{a}$ ) de 04/04/ 2000 (JUR 2000, 190162), en la que el causante disponía de una subsistencia asegurada sin que la situación económica de los hijos fuera mejor que la suya; A P de Jaén (S. 1 ${ }^{\text {a }}$ ) de 27/06/2003 (JUR 2003, 252778) en que se pone de manifiesto la falta de necesidad del disponente para subsistir AP de Valencia, (S. 6. ${ }^{\mathrm{a}}$ ) de 13/10/ 2003 (AC 2003, 1796), no se da constancia de negarse a proporcionar alimentos al ascendente. 
853.1 Cc. Se refiere el precepto, al incumplimiento sin motivo legítimo de la obligación legal de proporcionarse alimentos entre parientes. El segundo de los preceptos últimos señalados, hace reciproca tal obligación. Es precisamente su incumplimiento, por parte del hijo o descendiente, al que la propia Ley sanciona facultando, a su padre o ascendente, para poder desheredarle si lo estima conveniente. El artículo $143 \mathrm{Cc}$ remite a su precedente en cuanto a la aplicación de la obligación recíproca, es decir, a lo dispuesto en el $142 \mathrm{Cc}^{327}$. De este artículo $142 \mathrm{Cc}$ se puede deducir ${ }^{328}$, que no es necesario la existencia de resolución judicial, sino que basta, conforme a jurisprudencia, que se pueda demostrar la certeza de la petición de alimentos por parte del que deshereda y la negativa a la prestación, sin motivo justificado de entre los que se recogen en el artículo $152 \mathrm{Cc})^{329}$, por parte del desheredado para que la causa de desheredación prospere ${ }^{330}$.

${ }^{327}$ Véase más información en la STS de 02/03/2016 (Tol.5.656.949) F. J. 3º sobre cuándo existe obligación de afrontar los gastos de los nietos por los abuelos: "En conclusión, los abuelos tienen obligación de afrontar los gastos que generen sus nietos, ante la insolvencia de los padres, de acuerdo con lo establecido en el art. 142 del C. Civil y con respeto estricto del principio de proporcionalidad ( arts. 145 y 146 C. Civil ), (sentencias de 21 y 27 de octubre de 2015, recursos 1369 y 2664 de 2014)".

${ }^{328}$ BERROCAL LANZAROT, “Cuestiones controvertidas...”, op. cit., pág. 2225. La autora confirma el principio que protege el artículo $142 \mathrm{Cc}$. "El principio que aparece protegido en esta disposición es el de interés del menor que requiere alimentos que debe prestarse por el titular de la patria potestad, y entre los alimentos se encuentra la habitación (art. 142 del Código Civil)".

${ }^{329}$ Artículo 152 Cc Cesará también la obligación de dar alimentos: $1^{\circ}$ Por muerte del alimentista. $2^{\circ}$ Cuando la fortuna del obligado a darlos se hubiere reducido hasta el punto de no poder satisfacerlos sin desatender sus propias necesidades y las de su familia. $3^{\circ}$ Cuando el alimentista pueda ejercer un oficio, profesión o industria, o haya adquirido un destino o mejorado de fortuna, de suerte que no le sea necesaria la pensión alimenticia para su subsistencia. $4^{\circ}$ Cuando el alimentista, sea o no heredero forzoso, hubiese cometido alguna falta de las que dan lugar a la desheredación. $5^{\circ}$ Cuando el alimentista sea descendiente del obligado a dar alimentos, y la necesidad de aquél provenga de mala conducta o de falta de aplicación al trabajo, mientras subsista esta causa.

330 Torres García, y Domínguez Luelmo, "La legítima en el Código civil..”, (I) op. cit., pág. 78. Con respecto al artículo $152 \mathrm{Cc}$ como bien dice estos autores, no tiene 
2. La segunda causa de desheredación del artículo $853 \mathrm{Cc}$ consiste en "haberle maltratado de obra o injuriado gravamente de palabra". Cabe hacer aquí una importante distinción entre la obligación civil y la obligación moral, al sólo efecto de que la primera puede apartar al legitimario de su derecho a legítima y la segunda, es decir, la obligación moral no puede privar al legitimario del derecho que la Ley le otorga ${ }^{331}$. Por lo menos, así lo entiende la jurisprudencia ${ }^{332}$. Hasta aquí se ha

aplicación con respecto a las causas que extinguen la obligación de pasar alimentos, la primera que expone el precepto señalado- " 1 . $^{\circ}$ Por muerte del alimentista.". Cita como refrendo a lo expuesto la STS de 02/06/1959 (RJ 2922) en que se interpreta por parte del Alto Tribunal, dos causas de desheredación dispuestas en el clausulado de un testamento por su titular. La primera "Por haber negado sin motivo legítimo los alimentos a la testadora los indicados nietos". La segunda "Por haberla injuriado gravemente y maltratado de palabra y por escrito..." La interpretación que hace la Sala sobre la primera, es decir, inaplicación del artículo 853.1 (alimentos) lo desestima al no haberse apreciado "de que la testadora interesó de sus nietos la prestación de alimentos". En consecuencia, mal podía, por sus nietos, negarse la prestación de dichos alimentos si no se los había pedido. También se cita, por parte de los autores la STS 04/11/1997 RJ 7930, en que se denuncian por la recurrente las dos cláusulas de desheredación dispuestas en el artículo $853 \mathrm{Cc}$ (alimentos y maltrato e injuria) "pues no convivieron con el padre, no mantuvieron relación con él, le privaron al testador de su presencia en vida para confortarle de sus dolencias mortales y ni siquiera acudieron al entierro “. Interpreta la Sala los hechos imputados, no dándoles cabida dentro del artículo $853 \mathrm{Cc}$ (negar alimentos y maltrato e injuria) indicando el carácter sancionador y restrictivo de la jurisprudencia que interpreta del citado precepto, pues: "los desheredados ni negaron alimentos ni maltrataron de obra o palabra al padre, y no demostrada la causa de la desheredación (artículo 850) por la parte a quien le incumbe, la desestimación es la única decisión posible".

${ }^{331}$ MondRAGÓN MARTín, "Ampliación...”, op. cit., pág. 2. El autor distingue entre la obligación civil y la obligación moral al sólo efecto de la restricción del derecho a legitima que produce en el legitimario la vulneración de la obligación civil.

${ }^{332}$ Tal como afirma la jurisprudencia del Tribunal Supremo, en sentencias anteriores a 2014 se puede entender por obligación la falta de relación afectiva así como el abandono sentimental, la falta de interés de los descendientes por los problemas que afectan a sus ascendentes, son apreciados y valorados negativamente en el campo de la moralidad pero no puede hacerse lo mismo en el campo jurídico. Así lo pone de manifesto la STS de 28/06/1993 (Tol. 5.126.920). Trata la cuestión planteada en el texto sobre la incursión en el clausulado del testamento de una cláusula de desheredación señalada en el artículo 853.2 $2^{\circ}$ del Código Civil. (Maltratos de obra o injurias graves de palabra) El Alto Tribunal entiende: "la falta de relación afectiva y comunicación entre la hija y el padre, el abandono sentimental sufrido por este durante su última enfermedad, la ausencia de interés, demostrado por la hija, en relación con los problemas del padre, 
visto, como parte de la jurisprudencia es tajante con la interpretación restrictiva sobre las causas de desheredación del artículo 853 del Código civil. Por lo tanto, se aparta en principio, de las causas de desheredación, todo maltrato que se aparte del maltrato de obra o de la injuria de palabra dispuesto en el precepto señalado. La jurisprudencia entiende que debe existir intencionalidad y ánimo de injuriar (animus iniurandi) para que la injuria de palabra provoque desheredación ${ }^{333}$.

Cabe plantearse ahora, acerca del maltrato psicológico no contemplado como maltrato de obra. Ha sido la propia jurisprudencia, la que ha cambiado la interpretación restrictiva que se venía manteniendo, por otra más ampliada ${ }^{334}$. Lo ha hecho en el sentido, de que el testador tenga facultad para poder desheredar a descendientes que no mantengan la obligación moral de asistencia que la circunstancia requiere ${ }^{335}$. El Tribunal

etc, etc, son circunstancias y hechos que de ser ciertos, corresponden al campo de la moral, que escapan a la apreciación y a la valorización jurídica, y que en definitiva solo están sometidos al tribunal de la conciencia." Por consiguiente, entiende el Tribunal Supremo que las causas de desheredación no pueden basarse en criterios morales, todas las causas que se aparten de lo estrictamente señalado en la ley civil no implican una causa de desheredación.

${ }^{333}$ BARCELÓ DOMENECH, "La desheredación...”, op. cit., pág. 15. Se apoya este autor en jurisprudencia del Tribunal Supremo para resaltar que la falta del animus iniurandi, en la injuria grave de palabra, "hace inviable la acción de desheredación de que se trate". Por lo tanto su existencia es requisito necesario para que pueda progresar la desheredación por esta tasada causa.

334 MONDRAGÓN MARTín, “Ampliación...”, op. cit., pág. 12 se refiere a que tal ampliación sólo ha sido por parte de la jurisprudencia y no por parte del legislador, todo hace suponer, que no ha querido ampliar las causas de desheredación, ya que si que ha ampliado las de indignidad, equiparando el maltrato de psicológico al maltrato de obra.

335 Señala Mondragón MARTín, “Ampliación...”, op. cit., pág. 14 que la STS de 03/06/2014 (Tol. 4.395. 123) si bien admite el maltrato psicológico como causa de desheredación lo hace cuando ha existido previamente "violencia, marginación, falta de respeto, situación conflictiva y abandono en la última enfermedad del causante y padre de los desheredados. Todo ello si que desemboca en un acusado maltrato psicológico, pero no lo hace sólo la falta de relación familiar". En consecuencia no se puede admitir como supuesto de hecho que la falta de relación familiar conlleve al maltrato psicológico. En este mismo sentido, la STS de 30/01/ 2015 (RJ 2015/639) admite el maltrato psicológico, pero no lo hace como supuesto de hecho propiamente dicho, sino 
Supremo, ha dejado sentada doctrina jurisprudencial al disponer: que no se pueden ni añadir ni quitar causas a las tasadas legalmente por las que se puede privar de su legítima a un legitimario, pero lo que si que se pueden hacer son más extensivas las que contemplan los artículos 852 a 855 Cc. Entre estas está, la de dar cabida al maltrato psicológico dentro del maltrato de obra ${ }^{336}$.

No hay duda al respecto, que el cambio de criterio jurisprudencial sobre la inclusión del maltrato psicológico, dentro del maltrato de obra ha

que tal maltrato lo ha causado "un alto nivel de conflictividad derivado de un trato desconsiderado por parte del hijo hasta el extremo de este, despojar a su madre de todos sus bienes por medio de dudosas y obligadas donaciones, que efectivamente afectaron psicológicamente a la anciana madre y abuela de los desheredados. Por lo tanto se puede concluir que Tribunal Supremo únicamente sienta doctrina acerca del maltrato psicológico como causa de sufrimiento al ofendido.

${ }^{336}$ CARrau CARbonell, J. M.: "La desheredación por maltrato psicológico y su dificultad de aplicación práctica" en Actualidad jurídica iberoamericana, núm. 3, 2015, pág. 557.

Es la STS de 03/06/2014 (Tol. 4.395.123) la que sienta doctrina al respecto de la interpretación restrictiva del articulo 853 Cc por lo que a las causas de desheredación se refiere. Pasando, una nueva doctrina, al interpretar dichas causas de manera ampliada. Es la presente STS, en su F.J. $1^{\circ}$, la que interpreta la segunda causa del artículo $853 \mathrm{Cc}$ como cuestión de fondo, relacionado con el maltrato psicológico como posible causa de desheredación. El testador deshereda a sus dos hijos por las dos causas del artículo $853 \mathrm{Cc}$. A su hija por la primera (por negar alimentos a su padre) y la segunda (por haberle injuriado de palabra) y a su hijo también por lo dispuesto en el artículo $853 \mathrm{Cc}$ injurias verbales y maltrato de obra al testador-. Pese a no haberles pedido alimentos el causante a sus hijos, ambas Instancias coincidieron en desestimar, tanto la demanda como la apelación, que estos interpusieron contra las justas causas de desheredación plasmadas por su padre en el testamento. Por lo que al trato se refiere consideraron probado "un autentico abandono familiar" por los hijos para con su padre. En consecuencia, el Alto Tribunal sostiene como doctrina jurisprudencial aplicable el maltrato sicológico como justa causa de desheredación. En el punto 3 del Segundo Fundamento de Derecho dispone, el Tribunal Supremo, que si bien las justas causas de desheredación son únicamente las señaladas por la Ley (artículo $848 \mathrm{Cc}$ ) ello, supone una enumeración taxativa que no admite ni la analogía ni la interpretación extensiva, pero ello no supone que: "la concreta causa, previamente admitida por la ley, deba ser expresada con un criterio rígido o sumamente restrictivo". Por lo que el Tribunal de casación confirma las resoluciones tanto de Primera como de Segunda Instancia. En la STS de 30/01/2015 (RJ 2015\639) en el punto $2^{\circ}$ del Fallo se reitera en la doctrina jurisprudencial de la STS de 03/06/ de 2014, respecto de la interpretación del artículo 853.2 del Código Civil, con relación al maltrato psicológico. 
tenido como base de justificación el artículo $3 \mathrm{Cc}^{337}$. Este precepto faculta para valorar la realidad social actual, que difiere bastante de la época de promulgación del Código civil. Incluso muchos años después de que los tribunales siguieran aquel criterio. Esta nueva manera, extensiva, de entender las causas de desheredación, no deja de ser una mayor libertad de disponer post mortem. Se pretende, por parte de los tribunales, que el legitimario, no sólo cumpliendo con lo dispuesto en los preceptos civiles adquiere su legítima, sino que también ha de cumplir con sus obligaciones morales que le impone el actual sentir social y avala la actual doctrina del Tribunal Supremo.

Se entiende que no basta una interpretación extensiva por parte de la jurisprudencia para proteger al padre o ascendiente de la falta de relación familiar e incentivar ésta, con sus hijos. Se necesita una paridad entre las causas de desheredación y la familia actual plasmada por parte del legislador en el Código civil ${ }^{338}$. Estos cambios tan bruscos de opinión jurisprudencial, sólo consiguen, en mi opinión, acercarnos a los ordenamientos como el anglosajón o el ruso, en que la carencia de normativa otorga un mayor protagonismo a los tribunales. Ello podía explicar el mayor número de litigios en materia sucesoria en países

\footnotetext{
${ }^{337}$ Artículo 3. 1: "Las normas se interpretarán según el sentido propio de sus palabras, en relación con el contexto, los antecedentes históricos y legislativos, y la realidad social del tiempo en que han de ser aplicadas, atendiendo fundamentalmente al espíritu y finalidad de aquellas". 2: "La equidad habrá de ponderarse en la aplicación de las normas, si bien las resoluciones de los Tribunales sólo podrán descansar de manera exclusiva en ella cuando la ley expresamente lo permita".

${ }^{338}$ CARRAu CARBonell, J. M.: "La desheredación por maltrato psicológico...", op. cit., pág. 564. Entiende, este autor, que se hace necesaria una profunda reforma de la institución de la desheredación incluyendo la ausencia de relación familiar. También estima que la carga de la prueba de las causas de desheredación debería "invertirse", es decir, probar el legitimario desheredado su inocencia y no tener que ser el heredero el que pruebe la culpabilidad de aquél, como ocurre en la actualidad.
} 
carentes de normativa, con respecto a los países en que sus ordenamientos no dejan tanta libertad interpretativa a los tribunales ${ }^{339}$.

\subsubsection{Causas de desheredación de los padres y ascendientes}

A las justas causas de la desheredación de los ascendientes atiende el artículo $854^{340}$, del Código civil que al igual que su precedente incluye los números 1, 2, 3, 5 y 6, del artículo $756 \mathrm{Cc}$ (causas de indignidad), y dispone de tres causas específicas ${ }^{341}$ :

1. La primera de ellas, (la pérdida de la patria potestad) hace remisión al artículo $170 \mathrm{Cc}^{342}$. Esta primera causa se entiende que se refiere únicamente a los titulares de la patria potestad conforme dispone el artículo $108 \mathrm{Cc}$ tanto por naturaleza como por adopción. Es evidente que esta causa no afectaría a los abuelos ni a los bisabuelos, etc., al no detentar estos de la patria potestad sobre sus nietos o descendientes. La remisión al artículo $170 \mathrm{Cc}$ se entiende porque es en este precepto donde se recogen las causas por las que

\footnotetext{
${ }^{339}$ Ver en SIMEÓN PÉREZ M.: "La legítima en el Código Civil ruso. Un análisis histórico y comparado", InDret, 2016, pág. 5. Las afirmaciones de este autor, con respecto a una mayor litigiosidad, en Rusia que en occidente debido a las lagunas legales existentes en este país. Cabe resaltar de las manifestaciones hechas por el autor con relación a la legítima, la Sentencia del Tribunal Constitucional 209-O de 9 de diciembre de 1999, "declarando qué concepto de legítima resulta compatible con los derechos constitucionales a la herencia, a la justicia social y a la tutela judicial efectiva".

340 Artículo 834 Cc: "Serán justas causas para desheredar a los padres y ascendientes, además de las señaladas en el artículo 756 con los números 1, 2, 3, 5 y 6, las siguientes: $1 .^{a}$ Haber perdido la patria potestad por las causas expresadas en el artículo 170. 2. ${ }^{\text {a }}$ Haber negado los alimentos a sus hijos o descendientes sin motivo legítimo. 3. ${ }^{a}$ Haber atentado uno de los padres contra la vida del otro, si no hubiere habido entre ellos reconciliación".

${ }^{341}$ DieZ -PiCAZO y Gullón, Sistema de Derecho civil..., op. cit. pág. 187.

${ }^{342}$ Artículo $170 \mathrm{Cc}$ : "El padre o la madre podrán ser privados total o parcialmente de su potestad por sentencia fundada en el incumplimiento de los deberes inherentes a la misma o dictada en causa criminal o matrimonial". Los Tribunales podrán, en beneficio e interés del hijo, acordar la recuperación de la patria potestad cuando hubiere cesado la causa que motivó la privación.
} 
se puede privar, total o parcial, a los padres, de la patria $\operatorname{potestad}^{343}$. (se verá con más detalle, en la misma causa de desheredación, cuando afecta al cónyuge viudo).

2. La segunda de las causas por la que un descendiente puede desheredar a su ascendiente es la negación de alimentos sin motivo legítimo. Aquí vuelve a repetirse el mismo caso de la negación de alimentos por parte del hijo al padre como causa de desheredación. El deber paterno-filial de la prestación de alimentos está recogido en el artículo 154. 1 Cc como una de las obligaciones comprendidas en el ejercicio de la patria potestad. Para ser utilizado como causa de desheredación, para que opere esta, se requiere la previa petición de alimentos por parte del hijo o descendiente. Esta petición de alimentos no necesariamente ha de ser por vía judicial. La negación a otorgarlos, por parte del ascendente, ha de ser de manera que se pueda probar fehacientemente. Se puede producir aquí una situación bastante problemática al plantearse si persiste la causa cuando el descendiente obtiene los alimentos por resolución judicial después de la negativa del ascendente a otorgarlos ${ }^{344}$.

\footnotetext{
${ }^{343}$ TORRES GARCÍA, y DOMÍNGUEZ LuELMO, "La legítima en el Código civil (I)...”, op. cit., pág. 79.

${ }^{344}$ Señalan DIEZ- PICAZO y Gullón, Sistema de Derecho civil..., op. cit. pág. 188 que la ofensa castigada con la desheredación es simplemente la negativa injustificada a prestarlos. Mantiene O'CALlaGHAN MuÑOZ, X.: Compendio..., op. cit.. "Es aplicable lo dicho sobre la negativa a alimentos en relación a la desheredación de los hijos o descendientes (art. 853, 1. ${ }^{\circ}$ )". VÁzQuEZ IRUZUBIETA, Código civil..., op. cit., pág 1. Entiende que la diferencia del artículo 854 con el 853.1 Cc es la existencia de la excusa que plantea el primero con respecto al segundo cuando recoge el precepto " sin motivo legítimo" "que no puede ser otro que cualquiera de los contemplados en el artículo 152 Cc". Insiste DE LA IGLESIA MonJE, M.I.: "Algunas cuestiones sobre los diferentes intentos de elusión del progenitor obligado al pago de alimentos y el interés superior del menor", Revista Crítica de Derecho Inmobiliario, núm. 763, septiembre 2017, pág. 2598 , en que aun estando los padres privados de la patria potestad están obligados igualmente a la prestación de alimentos, como norma de origen moral (art. $110 \mathrm{Cc}$ ).
} 
Cabe aquí hacer una importante distinción por lo que se refiere a la justa causa de desheredación por no pasar alimentos, tanto de hijos a padres como a la inversa. La distinción estriba en que el padre tiene obligación de pasarle alimentos al hijo menor de edad sin que en todo caso exista causa de necesidad material contemplada. Tal obligación se dispone en el artículo 154 Cc. Por lo expuesto en el párrafo anterior, el hijo menor, no tendrá necesitad de pedirle alimentos a su padre para que se pueda alegar en juicio dicha falta de petición. Con frecuencia la negación de alimentos del ascendiente al testador tiene lugar años antes del otorgamiento del testamento, cuando además el testador era menor de edad. La jurisprudencia entiende que en ese caso los efectos de la desheredación se retrotraen a esa época ${ }^{345}$.

La STS de 23/04/2018 (RJ 2018\1753) donde el supuesto de hecho trata la demanda de incapacidad para suceder un padre a su hijo fallecido. Únicamente había pasado alimentos a su hijo por valor de 5000 euros e impuestos por sentencia judicial desde el año 2007 al 2013. La juzgadora desetimó la demanda por entender que "el demandado cumplió parcialmente la obligación de pagar alimentos acordados en convenio regulador en el año 2007". Interpuesto recurso de apelación la Sala lo admite y revoca la decisión judicial. De su motivación cabe destacar la valoración que hace la Sala a la omisión del padre de la obligación de prestar alimentos a su hijo: "En todo caso, aunque prescindiéramos del reproche que suscita el desapego paterno, reiteramos que bastará constatar que en efecto había incumplido su obligación de dar alimentos para considerarle incapaz para suceder a su hijo". Asimismo también es destacable la valoración que hace la Sala sobre la voluntariedad a pasar alimentos: "Debe entenderse que el incumplimiento de la obligación, de dar alimentos fue absolutamente voluntario y constituye causa de incapacidad por indignidad para suceder a su hijo". El Alto Tribunal desestima el recurso de casación y en el F. J. $5^{\circ}$ entiende que "Fruto de la gravedad de esa conducta paterna es que la reprochabilidad de la misma tenga suficiente entidad, como razona la sentencia recurrida, para acarrear, como sanción civil, su incapacidad por indignidad para suceder al menor.Tal reproche se implementa con el incumplimiento sustancial por parte del padre de las obligaciones alimenticias convenidas para el menor".

${ }^{345}$ La SAP de Ciudad Real (S. $1^{\text {a }}$ ) de 03/09/2011 (Tol.2.255.671) contesta a la pregunta planteada de si la negación a pasar alimentos tuvo lugar en una época anterior a la que se otorgó el testamento que contiene la justa causa de desheredación. Freud, L.: "La desheredación o indignidad del padre que abandona al hijo. La reforma del artículo 756 del Código Civil por la Ley de Jurisdicción Voluntaria. Padre e hija", Iuris Prudente, mayo, 2016, pág. Se apoya en esta SAP de Ciudad Real para hacerse semejante 
3. La tercera de las justas causas contempladas por el artículo $854 \mathrm{Cc}$ por las que un descendiente puede desheredar a un padre o ascendiente es el haber atentado, uno de los padres, contra la vida del otro sin posterior reconciliación. La cuestión a resaltar es que la conducta reprochada ha de darse entre los padres del testador, lo que parece que excluya el precepto a cualquier otro ascendente (abuelos por ejemplo). Se trata de una causa que no afecta

planteamiento. La Sala enjuicia y resuelve el caso en que un padre abandona a los hijos de un primer matrimonio para formar otro, sin tener contacto, ni pasarles pensión alguna. Con posterioridad fallece, en un accidente de tráfico uno de aquellos hijos intestado y mayor de edad. Por lo tanto, el abandono, según la Sala, se retrotrae a la minoría de edad de éste y en consecuencia la indignidad permanece y la única manera de repararla es conforme al artículo 757 del Código civil. A este respecto dice la Sala: “(...)sólo el causante puede rehabilitar al indigno y para ello es preciso que conociendo la causa lo declare heredero o legatario o lo perdone mediante declaración expresa en un documento público,(...)"Por lo expuesto se puede llegar a la conclusión de que el hijo puede privar de su legítima al padre si la negación de alimentos se ha producido durante la minoría de edad del testador. Una negación que por si misma excluye el requisito de la petición, ya que como titular de la patria potestad del hijo viene obligado el padre /madre a otorgarle alimentos a éste sin previa petición. También la AP de Cantabria en SAP de Santander (S. 2 ${ }^{\mathrm{a}}$ ) de 28/11/2011 (Tol. 2.733.453) entiende de la misma manera que la anterior de la SAP de Ciudad Real, en un caso que se plantea sobre la indignidad de un padre para suceder a su hija fallecida sin otorgar testamento. La Sala de Cantabria dice que, conforme a los informes admitidos, el padre ha incumplido respecto de su hija fallecida con los más mínimos deberes de asistencia efectiva y material durante el periodo de la minoría de edad de su fallecida hija y por ello estima la indignidad del recurrente. No conforme este, interpone recurso de casación, al que el Alto Tribunal le deniega su admisión por medio del Auto del Tribunal Supremo de 14/01/2014, (Id Cendoj: 28079110012014200125). De la valoración de los hechos que hace el Tribunal Supremo se puede extraer que alega el recurrente su disconformidad con la valoración de la prueba (faltaban unos meses para la mayoría de edad, les pasaba lo que podía a sus hijos, etc.) y no sobre la resolución dictada por la AP “(...)se han incumplido por el demandado, respecto de su hija fallecida, los más elementales deberes de asistencia afectiva y material, de manera constante y muchos años antes de que, en el año 1986, el demandado abandonara definitivamente su domicilio familiar Santander, constituyendo una nueva familia en Asturias, rompiendo todo contacto con los hijos nacidos de la primera relación, los cuales han subsistido gracias a las ayudas de terceros y al auxilio materno " añadiendo que "se ha de tener por demostrado un abandono total y absoluto de los hijos, sin atenuantes o paliativos, determinante de una situación de extremo desamparo de los descendientes". Pone de manifiesto el Alto tribunal que: "el recurrente configura su recurso mostrando su disconformidad con la valoración de la prueba efectuada por Audiencia y no sobre la real oposición de la sentencia recurrida a una jurisprudencia que si se respeta la base fáctica de la resolución recurrida no resulta vulnerada". 
directamente al testador. También es destacable el término "atentado", lo que implica que la conducta de uno de los padres sobre el otro ha de darse en grado de atentado contra la vida de éste. Sin que sea requisito indispensable la pertinente condena penal. En este aspecto la citada causa difiere con lo expuesto en la primera causa de indignidad dispuesta en el artículo $756 \mathrm{Cc}$ que requiere sentencia firme para tener cabida. Además, esta causa citada de indignidad, también tienen cabida no sólo para los descendientes y ascendientes del causante sino para cualquier persona. Otra nota a destacar, de esta tercera justa causa de desheredación, es que para que opere no haya habido reconciliación entre el progenitor agresor y el progenitor agredido $^{346}$. Cuestión esta, la de la reconciliación citada, que no aparece en la causa de indignidad del artículo 756.1.

\subsubsection{Causas de desheredación del cónyuge viudo}

\footnotetext{
${ }^{346}$ Torres GARCÍA, y Domínguez LuELMO, "La legítima en el Código civil (I)...”,op. cit., pág. 80. El precepto habla de la "reconciliación" dispuesta en el artículo 856, del Código civil, que priva al ofendido de poder desheredar al ofensor. El autor, entiende que al exigir, el precepto, reconciliación también exige bilateralidad y conforme al artículo $84 \mathrm{Cc}$ tendrá que ser de manera expresa, no basta que el agraviado perdone al ofensor. Apoya y refrenda sus exposiciones en la STS 265/1972 de 24/10/1972 que en su Tercer Considerando de los Fundamentos de Derecho manifiesta que la Sentencia objeto del recurso de casación parece que pretende otorgarle al simple perdón la fuerza conciliatoria de que dota el artículo 856 Cc a la reconciliación. Ello supone distinguir la diferencia que existe entre el perdón y la reconciliación que reclama la causa tercera de desheredación del artículo 854 del Código civil. Dice así el Alto Tribunal en el Considerando citado: “( ...)sin embargo, lo cierto es que, además de emplear esta palabra, los hechos que dicha sentencia estima probados revelan que, efectivamente, hubo esa reconciliación entre padre e hijo, pues aquéllos no hablan solamente de que se hubiese pedido y concedido el perdón, sino que aun añaden que tras aquella petición y concesión, hubo un abrazo, que dejó restablecidas las buenas relaciones entre ambos, lo cual ya implica la acción de reconciliarse, que, conforme al Diccionario de la Lengua Española, equivale a "volver a las amistades, o traer y acordar los ánimos desunidos», mientras que el perdón es sólo la "remisión de la pena merecida, de la ofensa recibida o de alguna deuda u obligación pendiente".
} 
El artículo $855 \mathrm{Cc}$ establece las causas por las que un testador puede privar a su cónyuge de su legítima ${ }^{347}$. Se determinan cuatro causas concretas, además de las dispuestas con los números $2,3,5$ y 6 , del artículo 756 Cc como causas de indignidad ${ }^{348}$ :

1. La primera justa causa se refiere al incumplimiento de los deberes conyugales. A los cuales hace referencia el Capítulo V (De los derechos y deberes de los cónyuges) del Título III del Código civil. Que no son otros, que los citados en el artículo 66 y siguientes. Cabe destacar el artículo $68 \mathrm{Cc}$ que obliga a los cónyuges a guardarse mutua fidelidad $^{349}$, por lo que dicho incumplimiento puede ser una causa de desheredación del cónyuge infiel ${ }^{350}$. Hay que tener presente, este

\footnotetext{
${ }^{347}$ Artículo 855 Cc: "Serán justas causas para desheredar al cónyuge, además de las señaladas en el artículo 756 con los números $2 .^{\circ}, 3 .^{\circ}, 5 .^{\circ}$ y $6 .^{\circ}$, las siguientes: $1 .^{\mathrm{a}}$ Haber incumplido grave o reiteradamente los deberes conyugales. $2 .^{a}$ Las que dan lugar a la pérdida de la patria potestad, conforme el artículo 170. 3. ${ }^{\mathrm{a}}$ Haber negado alimentos a los hijos o al otro cónyuge. $4 .^{\mathrm{a}}$ Haber atentado contra la vida del cónyuge testador, si no hubiere mediado reconciliación".
}

${ }^{348}$ DiEZ- PiCAZO y Gullón, Sistema de Derecho civil..., op. cit. pág. 188.

${ }^{349}$ NiETo PozAnCo, M. Y RoviRA Del Rio.: "Consecuencias legales de la infidelidad en el derecho español: una aproximación jurisprudencial", Revista Via Iuris, núm. 16, 2014, pág. 195.

${ }^{350}$ Así lo entiende la jurisprudencia del Tribunal Supremo en STS de 23/07/1990 (Tol. 1.730.741) en que pone de manifiesto el efecto vejatorio que supone para la esposa la infidelidad ejercida por el marido y el incumplimiento legal de este, a lo dispuesto en los artículos 67 y 68 del Código civil que obligan a los esposos a respetarse y a guardarse fidelidad entre sí. "Su incumplimiento es causa de separación traducida en incumplimiento grave o reiterado de los deberes conyugales (art. 855, 1 . $^{\circ}$ )" es causa de desheredación del cónyuge la infidelidad conyugal, traducida en incumplimiento grave o reiterado de los deberes conyugales (art. 855, $1 .^{\circ}$ ). En definitiva, no cabe duda que la atribución a uno de los cónyuges de una conducta de infidelidad hacia su consorte infringe esos preceptos que señalan consecuencias y la imposición de los deberes derivados del matrimonio." Por lo expuesto se puede afirmar y reiterar que la infidelidad conyugal puede ser causa de desheredación. Jurisprudencia mucho más reciente, refrenda lo hasta aquí expuesto. Concretamente la STS de 29/07/2011 (Tol. 2.238.301) reitera lo que refleja la motivación de SAP de Madrid (S. 14 ${ }^{\text {a }}$ ) de 14/07/2009 (Tol. 1.640.320) F. J. $8^{\circ}$ expone que "(la infidelidad es un hecho que merece desvaloración para la sociedad, pues es infracción de un deber conyugal y causa justa de desheredación - artículos 68 y 855.1 ${ }^{\mathrm{a}}$ del Código Civil - y la Constitución vigente continúa considerando al matrimonio base de la familia basada en él y confiere su 
respecto, debido a que en España, tanto el adulterio como el amancebamiento los despenalizó la Ley de 28 de mayo de 1978, pero no ocurrió lo mismo con la Ley civil por el hecho de ser causas de separación y de desheredación ${ }^{351}$.

Por lo que respecta a la relación que existe entre la separación y divorcio, con la causa $1^{\mathrm{a}}$ de desheredación, que recoge el artículo 855 Cc se advierte la voluntad del testador de desheredar al cónyuge supérstite. Aparece, dicha voluntad adjunta, en muchas ocasiones, en los casos de separación y divorcio, cuando no tendría que ser de esta manera. Ya que la vida por separado, como consecuencia de una sentencia de separación o divorcio o bien por separación de hecho priva, conforme al artículo $834^{352} \mathrm{Cc}$, del derecho a la legítima viudal. Este precepto ha sido modificado por la Ley15/2005, de 8 de julio y ratificado por la Ley 15/2015, de 2 de julio de Jurisdicción Voluntaria. Ha supuesto que ya no importa quien sea el culpable de la separación, para que pierda la legítima viudal el cónyuge supérstite ${ }^{353}$.

Vistos los hechos, sólo cabe estimar, que el testador que previendo que se avecina su separación o divorcio decide desheredar a su cónyuge, por temor quizá, a una muerte repentina que le pille en los

protección jurídica a esta institución básica (artículos 32.1 y 39.1 ). El Alto tribunal en su pertinente Fallo dispone: "1. Declaramos no haber lugar al recurso de casación interpuesto por la representación procesal de (...) S.A. contra la sentencia de 19 de noviembre de 2009 dictada por la Sección 14. ${ }^{a}$ de la Audiencia Provincial de Madrid en

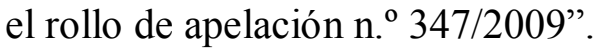

${ }^{351}$ Romero Coloma, A.M.: "La infidelidad conyugal como causa de separación: análisis y valoración", Revista Crítica de Derecho Inmobiliario, núm. 670, marzo-abril, 2002, pág. 2.

${ }^{352}$ Artículo $834 \mathrm{Cc}$ "El cónyuge que al morir su consorte no se hallase separado de éste legalmente o de hecho, si concurre a la herencia con hijos o descendientes, tendrá derecho al usufructo del tercio destinado a mejora".

${ }^{353}$ Torres GArcíA, y Domínguez Luelmo, “Tratado de...” (I), op. cit., pág. 80. 
trámites pertinentes de una separación o divorcio. Destacar, aquí la previsión que hace el artículo $102^{354} \mathrm{Cc}$ que, entre otros, dispone que admitida la demanda de nulidad, de separación o divorcio, se produce por ministerio de la Ley el cese de la presunción de la convivencia conyugal. Por consiguiente alcanzada la admisión formal de la demanda no cabe, ni tiene sentido tal recelo del disponente, puesto que ya se cumple el requisito de la "separación de hecho" que impide que el cónyuge tenga derecho al usufructo viudal (Art. $834 \mathrm{Cc})^{355}$.

\footnotetext{
${ }^{354}$ Artículo 102 Cc: "Admitida la demanda de nulidad, separación o divorcio, se producen, por ministerio de la Ley, los efectos siguientes: $1 .^{\circ}$ Los cónyuges podrán vivir separados y cesa la presunción de convivencia conyugal. 2. ${ }^{\circ}$ Quedan revocados los consentimientos y poderes que cualquiera de los cónyuges hubiera otorgado al otro".
}

Asimismo, salvo pacto en contrario, cesa la posibilidad de vincular los bienes privativos del otro cónyuge en el ejercicio de la potestad doméstica.

A estos efectos, cualquiera de las partes podrá instar la oportuna anotación en el Registro Civil y, en su caso, en los de la Propiedad y Mercantil".

${ }^{355}$ DE BARRÓN ARNICHES, P.: "Libertad de testar y desheredación en los Derechos civiles españoles", Indret, núm. 4, 2016, pág.17. La SAP de Madrid (S. 19a) de 14/12/2015 (Tol. 5.612.663), que cita la autora, en un caso de justa causa de desheredación en que se demanda la nulidad del testamento con reclamación de los derechos usufructuarios del cónyuge viudo. La Primera Instancia desestima la demanda alegando que no existe causa legal ni expresa de desheredación y el recurso de apelación se plantea por la antes demandante y ahora recurrente en base a que no se ha probado que no existe convivencia ni causa de desheredación. Es decir, se alega por el recurrente como causa del motivo no contener el testamento justa causa expresa de desheredación ni acreditarse ni probarse esta, ni tampoco probarse que no hubiera convivencia. La Sala de Audiencia se pronuncia en el sentido de que no tiene cabida frente a tal petición de nulidad de testamento en base a las alegaciones y que en tal caso la petición correcta sería, conforme al artículo 851 del Código civil, la nulidad de la institución de herederos. Sobre la alegación de la recurrente de no haber causa de desheredación expresa en el testamento, la institución de herederos sería anulable en aquello que perjudique al legitimario desheredado, pero no nula de pleno derecho dando plena validez al resto de lo dispuesto en el testamento. La justa causa de la desheredación del cónyuge demandante y recurrente la produce el incumplimiento reiterado de los deberes conyugales al no haber habido convivencia desde hacía unos años hasta la muerte del causante. De constar la separación legal o divorcio (resolución) o de hecho, en tal caso se hubiera extinguido el derecho a legítima viudal y la legitimación para atacar mediante la acción. Lo que aquí cesa es la presunción de convivencia conyugal reiterada (la hace grave) que comporta la acreditación de la justa causa de desheredación.] Por todo ello, la Audiencia desestima el recurso de apelación. 
2. La segunda justa causa de desheredación del cónyuge viudo dispuesta en el artículo $855 \mathrm{Cc}$ se refiere a la perdida de la patria potestad conforme al comentado artículo $170^{356}$ Cc. Esta segunda causa de desheredación del cónyuge viudo, que dispone el precepto de referencia, es idéntica a la dispuesta para las causas de desheredación de los padres y ascendientes del artículo 854.1Cc. Es evidente que para poder perder la patria potestad uno de los progenitores, antes ha de haber sido titular de ella, al tiempo que para aplicarse esta causa ambos cónyuges han tenido que haber sido los titulares de la patria potestad. Lo han de ser, para cuando llegado el caso, de que uno de ellos la pierda ha de ser el otro quien esté facultado para poder aplicar los citados artículos 855. 2 ó el 854. 1, ambos del Código civil. En ambos supuestos se requiere que la privación de uno de los progenitores de la patria potestad haya devenido conforme al ya señalado artículo $170 \mathrm{Cc}$ por sentencia fundada en el incumplimiento los deberes que comporta la titularidad de la patria potestad ${ }^{357}$. De concurrir las causas dispuestas en los preceptos señalados existirá privación de la patria potestad y en consecuencia el cónyuge viudo podrá ser desheredado ${ }^{358}$.

3. La tercera causa de desheredación del cónyuge se refiere a la negación de alimentos a los hijos o al otro cónyuge del testador. Se ha

\footnotetext{
${ }^{356}$ Artículo $170 \mathrm{Cc}$ : "El padre o la madre podrán ser privados total o parcialmente de su potestad por sentencia fundada en el incumplimiento de los deberes inherentes a la misma o dictada en causa criminal o matrimonial. Los Tribunales podrán, en beneficio e interés del hijo, acordar la recuperación de la patria potestad cuando hubiere cesado la causa que motivó la privación".

357 TORRES GARCía y DOMínguez LuELmo, "La legítima en el Código civil (I)...”, op. cit., pág. 80.

${ }^{358}$ REPRESA POLO, La desheredación..., op. cit. pág. 174. La autora manifiesta que ante la falta de resolución judicial, por cualquier razón, el cónyuge puede desheredar alegando la causa de pérdida de patria potestad. Ya que "donde la Ley no diferencia no debe hacerlo el intérprete".
} 
visto hasta aquí, que el hecho de negar alimentos a hijos y descendientes, así como a los padres o ascendientes es justa causa de desheredación (artículos 853 y $854 \mathrm{Cc}$ ) se reproduce nuevamente en el artículo 855 Cc. También se ha visto como varian, según los casos, las exigencias para reclamarlos y de otorgarlos, ya que en el caso de tratarse de un menor no se requiere previa petición para que opere la obligación de satisfacer los alimentos. Caso que se vuelve a repetir con lo dispuesto en el artículo 855.3 Cc. No obstante en esta tercera justa causa de desheredación del artículo $855 \mathrm{Cc}$ se omite por parte del legislador y con respecto a la otorgación de alimentos el requisito de que se niegue" sin motivo legítimo", (arts. 853 y $854 \mathrm{CC}$ ) por lo que debe presuponerse en coherencia con estos dos preceptos citados que no ha de existir motivos legítimos para oponerse a la prestación de alimentos $^{359}$. La petición de alimentos entre los cónyuges diferiría de los casos previstos en los artículo 853 y $854 \mathrm{Cc}$ en que, debe de haber habido petición o reclamación de alimentos, por parte del desheredante y negación por parte del desheredado a otorgarlos, simplemente bastaría poderlo acreditar por cualquier medio reconocido por el Derecho.

4. La cuarta justa causa de desheredación dispuesta en el artículo 855 Cc trata del atentado por parte de un cónyuge contra la vida del cónyuge testador. Es de pura lógica que el testador será la supuesta víctima y el desheredado será el presunto agresor. Lo que sí resulta necesario es que el atentado contra la vida del causante se quede ahí, en atentado, sin conseguir su fin $^{360}$. No se requiere condena penal por la tentativa, radicando ahí precisamente, la diferencia entre esta justa

\footnotetext{
${ }^{359}$ DíEZ- PiCAZO. y Gullón, Sistema de derecho civil..., op. cit., pág. 188.

${ }^{360}$ RePRESA POLO, La desheredación...,op. cit. pág. 176.
} 
causa de desheredación y la primera causa de indignidad del artículo 756 Cc. No contempla, esta cuarta causa de desheredación, la agresión contra ninguna otra persona que no sea el cónyuge, como ocurre con la $1^{\text {a }}$ causa de indignidad citada. Se reconoce justa causa de desheredación si no ha habido reconciliación, por lo que se repite todo lo dispuesto en el artículo 554. 3 Cc para la desheredación de los padres y ascendentes. Por ello vale todo, lo allí expuesto, en cuanto al grado de tentativa y los detalles del verdadero significado de la reconciliación del artículo 856 Cc que difiere bastante del simple perdón del ofendido ${ }^{361}$.

\subsubsection{La reconciliación}

De la lectura del artículo $856 \mathrm{CC}$ se pueden sacar dos conclusiones distintas. Cuando el precepto dice: "la reconciliación posterior priva al ofendido del derecho a desheredar". De lo cual se infiere que "posterior" se refiere a la reconciliación con posterioridad a las circunstancias que provocaron los hechos, pero con anterioridad a la expresión en el testamento. La segunda se refiere a la consecuencia de la reconciliación posterior a la desheredación, ya que efectuada aquella deja a esta sin efecto $^{362}$. La reconciliación del articulo 856 Cc no es sinónimo de perdón y por lo tanto requiere de una actividad bilateral ${ }^{363}$. De ahí que además de existir causa de desheredación, que sea esta, conocida de manera bilateral, es decir, por ofensor y ofendido. En el caso del ofensor no presenta dudas

\footnotetext{
361 TORRES GARCÍA, y DOMÍNGUEZ LuELMO, "La legítima en el Código civil...”, (I) op. cit., pág. 82.

${ }^{362}$ La SAP de Guipúzcoa (S. $3^{\text {a }}$ ) de 10/05/2005 ( JUR 2005\194235) F.J. $1^{\text {o }}$ atiende a la existencia de la reconciliación para que no prospere la desheredación. "En cualquier caso y tras la muerte de la segunda esposa, Dña. xxx, se sostiene que existió una reconciliación entre $\mathrm{D}$. xxx y D. xxx. Al existir una reconciliación la misma dejó sin efecto la cláusula de desheredación en aplicación del artículo 856 del Cc".

${ }^{363}$ DiEZ PICAZO y Gullón, Sistema de Derecho civil..., op. cit. pág. 189.
} 
su identificación. En cambio el ofendido requiere más precisión, en aquellos casos, en que la ofensa no se haya efectuado al desheredante directamente. Téngase en cuenta que la ofensa ha podido hacerse por lo dispuesto en los artículos 756 y $855 \mathrm{CC}$, al cónyuge, ascendientes o descendientes del testador. Se entiende, en estos casos, que el facultado para desheredar, también lo es el para reconciliarse ${ }^{364}$.

Como ya se ha señalado la misión de la reconciliación no es la remisión de la ofensa a través del perdón del ofendido, a diferencia de cómo se dispone en el artículo $757 \mathrm{Cc}$ para las causas de indignidad que exige la rehabilitación del indigno ${ }^{365}$. La propia naturaleza de la reconciliación exige la bilateralidad del acto conciliatorio en la desheredación ${ }^{366}$. Estando ello, lejos de la exigencia del precepto antes citado para la indignidad, en que se precisa un acto unilateral en que la remisión conste en testamento, o de conocerse con anterioridad, también se dé constancia en documento público. En cambio la reconciliación en la desheredación no está sometida a ningún requisito de forma, puesto que entiende la doctrina, que es suficiente con que sea clara, especial y concreta pudíendo ser expresa o tácita $^{367}$, con o $\sin$ solemnidades $^{368}$. La

\footnotetext{
${ }^{364}$ Vallet de Goytisolo, J.B.: Comentarios..., op. cit., pág. 856.

${ }^{365}$ VÁZQUEZ IruZuBIETA, C.: “Artículo 856”, en Código civil comentado, Vlex, Madrid, 2016.
}

${ }^{366}$ SAP de Castellón (S. 3 $3^{\text {a }}$ ) de 12/02/2014 (JUR 2014\119873) F. J. 2º "'De esta forma cualquier hecho que pudiera fundamentar la causa de desheredación tendría que haberse producido a partir de ese día 26 de mayo de 2009, porque de acuerdo con lo establecido en el artículo 856 del Código Civil "La reconciliación posterior del ofensor y del ofendido priva a éste del derecho de desheredar, y deja sin efecto la desheredación ya hecha", y en esa fecha resulta evidente de las dos actas notariales que se otorgaron ese día que la madre y la hija habían normalizado sus relaciones hasta el punto de indicar la madre que sería su hija que vive cerca de su domicilio la que se hará cargo de su madre, prueba evidente de que al menos hubo una reconciliación en ese momento".

${ }^{367}$ Define Moreno QuESADA, las reservas..., op. cit., pág. 614, la reconciliación como "el acto expreso o tácito, por virtud del cual el testador y el legitimario que ha incurrido en la causa de que se trate acuerdan dejar sin la sanción prevista de privación de la legitima la causa declarada con ese efecto". En el mismo sentido la STS de 04/11/1904 
jurisprudencia, si bien es cierto que se pronuncia en el sentido de considerar incluido en la reconciliación el perdón a que se refiere el artículo $756 \mathrm{CCc}$ para la indignidad, dentro del artículo $856 \mathrm{Cc}$ para la desheredación. Pero no es menos cierto que tiene que ser un perdón especial y concreto relativo al hecho en que conste la causa de desheredación $^{369}$.

(Tol. 5.854.897) F. J. $3^{\circ}$ considerando que a las manifestaciones de perdón hechas por el testador en la misma cláusula de desheredación, no se les puede atribuir el alcance jurídico que pretende el recurrente en el tercer motivo del recurso, pues solo revelan el ejercicio del derecho que la ley concede al padre, sin enojo, sin resentimiento, ni espíritu alguno de animadversión ni odio, pero no la reconciliación a que se refiere el artículo ochocientos cincuenta y seis del Código". Tambien se refiere a esta misma cuestión la posterior STS de 24/10/1972 (Tol. 4.262.002) manifestando que aunque al final de este fundamento la sentencia recurrida parece que quiere otorgarle al simple "perdón" "la fuerza cancelatoria de que le dota el artículo 856 del mencionado Código “ - cuando, en realidad, lo que ese precepto exige es la "reconciliación»-, sin embargo, lo cierto es que, además de emplear esta palabra, los hechos que dicha sentencia estima probados revelan que, efectivamente, hubo esa reconciliación entre padre e hijo, pues aquéllos no hablan solamente de que se hubiese pedido y concedido el perdón, sino que aun añaden que tras aquella petición y concesión, hubo un abrazo, que dejó restablecidas las buenas relaciones entre ambos, lo cual ya implica la acción de reconciliarse".

La SAP de Palencia (S. 1 ${ }^{\text {a }}$ ) de 05/11/2007 (AC 2008\444) en el F.J. $3^{\circ}$ dispone la Sala: "Aunque es cierto que en el Código Civil no existe ningún artículo específico para las causas de desheredación, como sin embargo si existe para las causas de indignidad, que regule la situación en que estas dejan de surtir efecto si el testador las conocía al tiempo de hacer testamento, tal disposición es aplicable analógicamente; y además tal solución encontraría amparo en la llamada doctrina de los actos propios, tanto porque el otorgamiento de testamento instituyendo heredero, a sabiendas de una pretendida causa de desheredación, supone un perdón tácito, como porque la manifestación de voluntad en que el testamento consiste determina una situación jurídica originada, salvo prueba en contrario, en plenitud de entendimiento y voluntad, que impide que se hagan valer pretendidas causas de desheredación después del otorgamiento de un primer testamento".

${ }^{368}$ TORRES GARCÍA y DOMÍNGUEZ LUELMO.: "La legítima en el Código civil (I)...", op. cit., pág. 85. Los autores invocan la STS de 4 de noviembre de 1904, en que se destaca la falta de valor jurídico a la manifestación del perdón del testador. En el mismo sentido la STS de 24 de octubre de 1972 RJ 4253, en la distinción que allí se hace entre la bilateralidad que preside la reconciliación y el simple perdón.

${ }^{369}$ SAP de Madrid (S. 20ª de 3/12/2001 (JUR 2002\120360) F.J. $2^{\text {o }}$ y $3^{\text {o }}$ la Sala trata de determinar su hubo reconciliación que deje sin efecto la desheredación: "El artículo $856 \mathrm{del}$ C.C. dispone (...) Se refiere a la reconciliación posterior a la producción del hecho que constituya la causa de desheredación, que impide una 


\subsection{LA INDIGNIDAD PARA SUCEDER}

\subsubsection{Las causas de indignidad}

Las causas de indignidad, tienen como objetivo el poder privar al heredero indigno de su parte de la herencia. Es indigno frente al causante de una herencia quien ha realizado ciertos y determinados actos que merecen la censura de la Ley ${ }^{370}$. Dispone el artículo 848 Cc que sólo tendrá lugar la desheredación, cuando tenga lugar, alguna de las causas que, de manera expresa, recoge la Ley. Entre otras, también hay que incluir a las causas de indignidad encuadradas dentro del artículo $756 \mathrm{Cc}$ modificado por la Ley15/2015, 2 julio de Jurisdicción Voluntaria. Son causas expresas por las que puede perder su derecho a herencia todo heredero ${ }^{371}$, tanto a los sucesores voluntarios como a los abintestatos y a los legitimarios. Aún a pesar de que en el artículo 756 Cc se utiliza la expresión testador de forma repetida $^{372}$. Las causas de indignidad se fundan principalmente en principios de moralidad, que como antes ya se ha dicho, pueden operar tanto en la sucesión testada como en la intestada, es decir, no requieren

posterior de desheredación, o a la reconciliación posterior a la desheredación otorgada en testamento (...)". "Aunque se considera incluido el perdón a que se refiere el artículo 757 del Cc para la indignidad dentro del artículo 856 Cc para la desheredación es necesario que tal perdón sea especial y concreto respecto del hecho en que consista la causa de desheredación, y que conste, o bien expresamente en documento público, o tácitamente mediante el otorgamiento de testamento (...)". "Así pues, todos los actos coetáneos y posteriores a la causa de desheredación van en la misma dirección, y excluyen de forma clara y manifiesta el perdón, ni siquiera mediante el otorgamiento del testamento de 3 de septiembre de 1.987, en el que instituye heredera universal a su hija, dejando al hijo la legítima estricta, que no hace sino expresar su voluntad de reducir en lo posible los derechos legitimarios de su hijo, frente al anterior testamento en el que les instituía por partes iguales. En consecuencia, no cabe inferir perdón tácito, cuando manifiestamente se refleja que fue otra la voluntad del testador, amparada por causa legítima (...)".

${ }^{370}$ DíEZ -PICAZO. y GULLÓN, Sistema de derecho civil..., op. cit., pág. 33.

${ }^{371}$ VÁZQUEZ IruZUBIETA, Artículo 806..., op. cit., pág. 1.

372 DíEZ- PiCAZO. y Gullón, Sistema de derecho civil..., op. cit., pág. 33. 
manifestación expresa en el testamento y en consecuencia su efectividad no está condicionada por aquél ${ }^{373}$.

Otras diferencias relevantes de la indignidad, con respecto a la desheredación, se pueden enumerar de la siguiente manera:

1. El momento en que tienden a producirse unas y otras causas. Mientras que todas las causas de desheredación han de producirse necesariamente con anterioridad a la apertura de la sucesión, no sucede igual con las de indignidad, concretamente la cuarta causa de indignidad puede tener lugar con posterioridad a la muerte del causante.

2. Otra de las importantes diferencias, entre una y otra figura es la forma de su extinción. Mientras que las causas de desheredación requieren para su ineficacia la reconciliación del artículo 856, del Código civil, que exige el concurso de ambas partes las causas de indignidad simplemente dejan de producir efecto sólo por el perdón, por parte del perjudicado, manifestado de manera expresa o tácita ${ }^{374}$. Aunque la indignidad es una sanción legal, se deja a voluntad del causante el que produzca o no efectos ${ }^{375}$.

Antes de tratar sobre las concretas causas de indignidad, dispuestas en el artículo $756 \mathrm{Cc}$ hay que reflejar que no se contienen en este precepto, todas las causas, por la que se hace indigno a quien las ejerce. Así podemos

\footnotetext{
${ }^{373}$ VÁZQUez IruZubieTA, Artículo 806 Cc..., op. cit., páp. 1.

${ }^{374}$ La SAP de Barcelona (S.17) de 25/05/2016 (AC 2016\1671) F.J. 5o señala los presupuestos necesarios para que se produzca el fin de la indignidad: "Así las cosas, es claro que se dan los presupuestos necesarios y suficientes para la declaración de indignidad, y que a pesar de las manifestaciones en orden a posibles relaciones entre el demandado y su madre en los últimos meses de la vida de ésta no se constituye la reconciliación que con el carácter de indudable exige el CCC”.
}

375 DíEZ- PICAZO. y Gullón, Sistema de derecho civil..., op. cit., pág. 35 
encontrar otras causas de indignidad en el artículo $111^{376}$ del Código civil que dispone, entre otros, la cancelación, por ministerio de la Ley, de los derechos sobre la herencia del hijo o sus descendientes, para el progenitor condenado penalmente por actos reprochables relacionados con dicho hijo. Resaltar que dispone el hijo, conforme al mismo precepto, de facultad para levantar la sanción civil impuesta. El otro precepto al que se hacía referencia anteriormente es el artículo $713^{377}$ Cc por cuya virtud también pierde los derechos hereditarios, tanto en sucesión testada como intestada, todo aquel que cumpla los requisitos que exige el precepto, tales como la ocultación o sustracción del testamento cerrado que a él, le traiga causa en su beneficio o perjuicio ${ }^{378}$.

El requisito de resolución judicial de la indignidad es requerida para que se cumplan los efectos de la institución ${ }^{379}$. Por lo tanto la indignidad requiere de resolución judicial para que cause sus efectos. Teniendo

${ }^{376}$ Artículo $111 \mathrm{Cc}$ : "Quedará excluido de la patria potestad y demás funciones tuitivas y no ostentará derechos por ministerio de la Ley respecto del hijo o de sus descendientes, o en sus herencias, el progenitor: $1 .^{\circ}$ Cuando haya sido condenado a causa de las relaciones a que obedezca la generación, según sentencia penal firme. $2{ }^{\circ}$ Cuando la filiación haya sido judicialmente determinada contra su oposición". En ambos supuestos el hijo no ostentará el apellido del progenitor en cuestión más que si lo solicita él mismo o su representante legal. Dejarán de producir efecto estas restricciones por determinación del representante legal del hijo aprobada judicialmente, o por voluntad del propio hijo una vez alcanzada la plena capacidad. Quedarán siempre a salvo las obligaciones de velar por los hijos y prestarles alimentos".

${ }^{377}$ Artículo 713 Cc: "El que con dolo deje de presentar el testamento cerrado que obre en su poder dentro del plazo fijado en el artículo anterior, además de la responsabilidad que en él se determina, perderá todo derecho a la herencia, si lo tuviere como heredero abintestato o como heredero o legatario por testamento. En esta misma pena incurrirán el que sustrajere dolosamente el testamento cerrado del domicilio del testador o de la persona que lo tenga en guarda o depósito y el que lo oculte, rompa o inutilice de otro modo, sin perjuicio de la responsabilidad criminal que proceda".

${ }^{378}$ BeAto Del PALACio, "la indignidad para suceder...”, op. cit., págs. 11 a 12.

379 SeÑala BALARezo Reyes, E. J., "Los efectos...", op. cit., pág. 82, que "La indignidad constituye, además una sanción civil, que solo puede ser declarada mediante sentencia judicial dictada en un juicio civil y a solicitud de quienes tienen legitimidad procesal para demandar; trayendo como consecuencia que el declarado indigno sea excluido de la sucesión". 
presente que de no ser, el indigno demandado en forma y en el plazo de cinco años, conforme al artículo 762 Cc será inatacable su derecho. Por ello es la resolución judicial la que aflora y hace efectivas las consecuencias de esta institución si el afectado se niega a aceptarlas ${ }^{380}$. La jurisprudencia entiende, la indignidad, como una subespecie de la incapacidad para suceder, puesto que, el propio artículo 756 Cc habla de "incapacidad para suceder" y le otorga un carácter relativo ${ }^{381}$, en el sentido que el título de indigno se refiere a una concreta sucesión, de modo que una persona puede ser indigna para suceder a determinada persona y no serlo para suceder a otra $^{382}$.

De presunción legal es calificada la indignidad, calificativo que sólo tiene aplicación en base al artículo que sigue al que expone las causas de indignidad, es decir, el $757 \mathrm{Cc}$ en cuya virtud dejan de surtir efecto, dichas causas, en el supuesto de ser éstas conocidas por el causante al tiempo de ${ }^{380}$ Albaladejo García, M.: Comentarios al Codigo Civil. Tomo X, Vol $1^{\text {o: }}$ Artículos 744 a 773 del Código Civi, Artículo 756, Edersa, Madrid, 2004, pág. 4.

${ }^{381}$ La STS de 07 /03 1980 (RJ 1980\1558) en el segundo considerando se pronuncia acerca de la incapacidad relativa para suceder que produce la indignidad: "toda vez que desheredación e indignidad son dos conceptos distintos, dado que si la primera puede efectivamente basarse en alguna de las causas de indignidad susceptibles de producir este efecto, como indica el invocado art. 852, la segunda constituye por sí un motivo de incapacidad relativa para suceder, haya o no desheredación, de no mediar la remisión expresa o tácita a que alude el art. 757 del repetido Cuerpo legal sustantivo".

${ }^{382}$ La SAP de la Rioja (S. 1 ${ }^{\text {a }}$ ) de 12/03/2013 (JUR 2013\171765) en el F.J. $3^{\text {o }}$ considera que "La indignidad es una incapacidad sucesoria de carácter relativo, referida en concreto a un determinado causante, y no constituye una cualidad personal y general del llamado (por otra parte, con toda razón) «indigno». Esto es, quien sea indigno respecto de una determinada persona, no la heredará, pero puede heredar a cualesquiera otras personas".

El propio Preámbulo de la Ley 15/2015, de 2 de julio de Jurisdicción Voluntaria expone los motivos por los que se da una nueva regulación al artículo 756 del Código civil y concretamente a las causas de indignidad para heredar 1, 2, 3. Entre otras, es la nueva realidad social, lo que mueve a la citada Ley a introducir estas modificaciones con respecto a las tres causas citadas de indignidad: "También se introduce, por considerarse necesario su adaptación a la nueva realidad social y desarrollo legislativo en el ámbito penal, una nueva regulación de las causas de indignidad para heredar, así como para ser testigo en el otorgamiento de los testamentos". 
hacer testamento. Por lo tanto se presupone que de el conocerlas hubiera tomado las oportunas y propias medidas contra el ofensor, bien testando o bien evitando la sucesión intestada. De modo que si habiendo podido tomar medidas no lo ha hecho es porque no quiso que produjeran sus efectos ${ }^{383}$. Dicho de otra manera, la indignidad opera por ministerio de la ley contra todo heredero, bien sea legitimario o extraño ${ }^{384}$, que de haber tenido noticias de ello el difunto hubiera este, obrado en consecuencia y hubiera podido desheredarle. No hacerlo presupone que no se quiere que se aplique la causa de indignidad tal como se dice en el artículo $757 \mathrm{Cc}$.

Si bien antes ya se ha apuntado, la indignidad, aparta de la sucesión del causante ofendido, a todo ofensor que pretenda adquirir, por cualquier título, bienes de aquel, sin importar la condición del heredero. Dicho de otra manera, la indignidad afecta a todos por igual sin importar el concepto por el que se tiene derecho a la sucesión. Afecta a todas las sucesiones, tanto a la voluntaria o testamentaria como a la legal o abintestato. Frente a la certeza de que el legitimario ofensor pierde su derecho a legítima cabe la

\footnotetext{
${ }^{383}$ RocA- SAStre MuncuniLl, L.: Derecho de sucesiones (I), op. cit., pág. 338. Este autor incluye el artículo 257 y 990, ambos del Código civil, como sanción ante el incumplimiento de las disposiciones hechas por el testador en su testamento. El legislador lo entiende como un reproche hacia el testador, pero dejando a salvo la legítima. Ello hace suponer, a quien suscribe, la gravedad que supone la indignidad. El Derecho considera la indignidad, mucho más grave, que un simple reproche ejercido por la Ley, en nombre del testador, que lo presume el legislador y que estima que de vivir aquel, lo hubiera reprochado de esa manera. De ahí, que el indigno no salve su legítima, caso de ser legitimario e indigno para suceder al causante que él, ha indignado.

${ }^{384}$ Señala BerrocAl LANZAROT, "El maltrato...", op. cit., pág.932, que "la indignidad afecta a cualquier sucesor mortis causa, lo que incluye a extraños". La indignidad tiene su campo de operación en aquellos supuestos en que el testador supuestamente no ha tenido conocimiento de las causas tipificadas y por lo tanto no ha pidido desheredar si se trata de un legitimario o bien tratándose de un heredero no legitimario no ha podido apartarlo de su herencia. Véase como ejemplo a lo expuesto la STS de 23/04/2018 (RJ $2018 \backslash 1753$ ) cuyo supuesto de hecho trata de un menor, que padecía una parálisis cerebral, carecía de una referencia paterna, la gravedad de la conducta paterna acarrea, como sanción civil, su incapacidad por indignidad para suceder al menor. Las circustancias del causante le impedían cualquier otro tipo de acuación.
} 
pregunta: ¿Qué ocurre con dicha parte de legítima? Pregunta, esta, a la que contesta el artículo $761^{385} \mathrm{Cc}$ que no nombra de manera directa a los legitimarios indignos, pero si a los hijos o descendientes, a los que se transmite el derecho a legítima del excluido por derecho de representación. Cabe la posibilidad de que el indigno sea un ascendiente o el cónyuge del causante y en este supuesto, el artículo no especifica el destino ni la trayectoria de dicha legítima parte ${ }^{386}$. No obstante como el derecho de representación sólo opera en la línea recta y descendente y nunca en la ascendiente, ni los ascendientes ni el cónyuge viudo del indigno podrán adquirir su legítima ${ }^{387}$.

Tratándose de la sucesión intestada, la cuota del indigno corresponderá a los otros parientes del causante por aplicación de los principios de la sucesión por grados y ordenes, successio graduum et ordinum. De manera que, la herencia deviene a los que estando dentro de la misma clase son los primeros llamados, después del que ostenta la imposibilidad de suceder (Succesio graduem). En el supuesto de que dentro de la clase del indigno no quedaran personas con capacidad para suceder (falten todos los de dicha clase) con arreglo a la sucesión por grados, la herencia devendría en los componentes de la siguiente clase ${ }^{388}$ (Succesio ordinum). Todo de conformidad con los artículos 922 y 923 Cc. Si por voluntad del testador, el indigno está instituido como heredero o legatario, dependiendo de los casos, su parte se transmitirá a otros por sustitución

\footnotetext{
${ }^{385}$ Artículo 761Cc: "Si el excluido de la herencia por incapacidad fuera hijo o descendiente del testador y tuviere hijos o descendientes, adquirirán éstos su derecho a la legítima".

${ }^{386}$ Albaladejo García, “Comentarios al Código..., ”, (Tomo X), op. cit., págs. 7 y 8.

${ }^{387}$ DíEZ-PICAZO. y Gullón, Sistema de derecho civil..., op. cit., pág. 42.

${ }^{388}$ MACKELDEY, F.: Elementos de Derecho Romano, $2^{\mathrm{a}}$ ed, Imprenta de la Sociedad Tipográfica y Literaria, Madrid, 1845, pág. 376.
} 
vulgar, por derecho de acrecer al que corresponda o bien, al titular del derecho sí se abre la sucesión legal ${ }^{389}$.

\subsubsection{Las reformas de las causas de indignidad}

Sobre todas las reformas que ha tenido el artículo $756 \mathrm{Cc}$ cabe destacar la de 2003 que añadió una séptima causa de indignidad a las seis existentes anteriormente. Posteriormente como consecuencia de la reforma del Código civil por la Ley 15/2015, de 2 de julio de Jurisdicción Voluntaria, se vuelve a modificar el precepto, si bien sufre modificación únicamente en los apartados 1, 2, 3.

La primera causa de indignidad encuadrada dentro del artículo $756 \mathrm{Cc}$ se refiere al atentado contra la vida de alguien del ámbito familiar del causante o haberle causado lesiones o ejercido la violencia ${ }^{390}$. Es decir, al propio causante, cónyuge, ascendientes o descendientes o bien personas unidas a aquél por analogía o relación de afinidad con el causante. Lo que resalta en este apartado es la existencia de condena por sentencia firme en

${ }^{389}$ RoCA- SAStre MunCUnill, Derecho de sucesiones...,(tomo I), op. cit., pág. 342. Mantiene que la indignidad no afecta a la perfección del testamento y dicho testamento ha podido revocar otro testamento anterior [últimas voluntades conforme al artículo 739 Cc] Sólo podría darse la sucesión intestada en el caso de no tener cabida la sustitución vulgar o el derecho de acrecer. Por lo que respecta a la revocación de un testamento para darle vigencia al anterior, sólo puede tener cabida este supuesto, en el caso de que se trate de la $5^{\mathrm{a}}$ causa de indignidad del artículo $756 \mathrm{Cc}$, que con arreglo al $673 \mathrm{Cc}$ será nulo el testamento. Será nulo el testamento otorgado con violencia, dolo o fraude. Frente a esta nulidad del testamento, de haberlo, recobrará fuerza el testamento anterior y si no existe testamento anterior válido, será conforme al artículo 912 Cc. Cuando se abra la sucesión intestada. El planteamiento que hace el autor tiene su parte lógica, ya que la $5^{\text {a }}$ causa de indignidad, de hacer indigno para suceder a una persona, precisamente es por obligar, contra su voluntad, al testador a modificar o a hacer un testamento. De ahí que se suponga que el testamento anterior al que se ha forzado al testador a realizarlo sea la verdadera voluntad del causante. Aquí el Derecho vuelve a hacer una presunción legal.

390 Artículo $756 \mathrm{Cc}$ : “Son incapaces para suceder por causa de indignidad: 1. ${ }^{\circ}$ El que fuera condenado por sentencia firme por haber atentado contra la vida, o a pena grave por haber causado lesiones o por haber ejercido habitualmente violencia física o psíquica en el ámbito familiar al causante, su cónyuge, persona a la que esté unida por análoga relación de afectividad o alguno de sus descendientes o ascendientes". 
grado de tentativa como mínimo para que pueda admitirse la indignidad. Se remite este precepto a suponer la indignidad si el causante conviviera con alguien con derecho post mortem sobre sus bienes o parte de ellos y se atentara, por parte del presunto indigno, con violencia-física o psíquica en su ámbito familiar ${ }^{391}$.

La segunda causa dispuesta en el artículo $756 \mathrm{Cc}$ también requiere sentencia firme que condene al indigno por delitos contra la integridad moral y la libertad e indemnidad sexual en la persona del causante, su cónyuge o pareja sentimental y alguno de sus descendientes o ascendentes.

Lo que se puede resaltar de esta causa es el requerimiento de sentencia condenatoria, es decir, la imputabilidad del sujeto en los delitos citados ${ }^{392}$. Si bien la jurisprudencia (como antes ya se expuesto para las causas de desheredación) entiende que los efectos de la incapacidad para suceder por indignidad se producen por el hecho de ser indigno sin necesidad de que lo tenga que declarar previamente una resolución judicial. Es en el supuesto

${ }^{391}$ La SAP de Lugo (S. $1^{\text {a }}$ ) de 07/07/2016, (JUR 2016\192970) entiende cumplida la primera causa de indignidad del artículo $756 \mathrm{Cc}$ por el recurrido tras ser probado y penalmente condenado por sentencia firme por habitual maltrato, en el ámbito familiar del causante. Los hechos se remontan a 1999. La Sala estima que los hechos han quedado suficientemente probados para poder encajar el caso en la primera de las causas de indignidad que preceptúa el artículo 756 del Código civil. El viudo y recurrente en apelación basa su recurso, entre otros, en que se interprete el precepto señalado, de una manera restrictiva para valorar y establecer la consecuencia jurídica. La Sala de apelación entiende que es suficiente con leer los hechos probados en Primera Instancia, para determinar el atentado contra la vida del causante ejercido por el recurrente. Matiza el Tribunal "incluso en la fecha de los hechos, permite su inclusión en los términos de atentar contra la vida". Se refiere a fecha anterior 1999, en que no operaban las pertinentes reformas que ha soportado el precepto, es decir, desde la promulgación del Código civil en 1889, hasta la reforma de 2015, por Ley de Jurisdicción Voluntaria, la condena penal por haber atentado contra la vida del causante, cónyuge, descendentes o ascendentes traía causa de indignidad dispuesta en el segundo apartado del artículo 756, Cc. Si bien, como dice el Tribunal, en la actualidad los mismos hechos los recoge el primero de los apartados del referido precepto que “incluye la violencia- física o psíquica en el ámbito familiar". La última valoración que hace la Audiencia Provincial trata sobre el conocimiento del citado atentado dado a tiempo de otorgar el testamento la causante.

${ }^{392}$ LORA-TAMAYO, Y PÉREZ RAMOS, C.: Cuestiones prácticas, pág. 117. 
de ser discutida la incursión del sujeto en causa de indignidad cuando se requiere la sentencia. Basta pues, la negación de los hechos que se le atribuyen como indigno para requerir resolución judicial que declare la indignidad e imponga sus consecuentes efectos declarativos. Efectos que aclaran las dudas preexistentes al respecto de la cuestión planteada. Muy lejos de tener efectos constitutivos, la resolución judicial, carece de ellos lo que significa que no es requisito esencial de la indignidad ${ }^{393}$.

Cabría en este punto plantearse un supuesto en que el atacante contra la vida del causante o sus familiares a que se refiere la segunda causa fuera un legitimario discapacitado judicialmente, por ejemplo, un hijo del causante discapacitado que le causa la muerte. Supuesto de hecho nada infrecuente en la realidad, en el que cabría preguntarse lo qué ocurriría. Se tiene que recalcar que al ser discapacitado no tendría condena penal en grado de tentativa contra la vida de su padre y como legitimario tendría derecho a su parte legítima de la herencia del causante, al que él, ha matado. Entendiendo como requisito constitutivo de la causa de indignidad, la sentencia penal condenatoria, no cumpliría lo dispuesto en el precepto y en consecuencia no progresaría la declaración de indigno para suceder. Cuestión distinta es la responsabilidad civil contraída por el discapacitado y quien ostente su patria potestad. En la jurisprudencia se ha sentado

\footnotetext{
${ }^{393}$ La SAP de Orense (S. $1^{\text {a }}$ ) de 29/07/2016 (JUR 20161208447) interpreta la $2^{\text {a }}$ causa de indignidad del artículo $756 \mathrm{Cc}$ con relación a un indigno parricida condenado por sentencia penal firme, en que éste esgrime el motivo del recurso de apelación alegando la falta de sentencia firme que lo declare indigno para suceder de su difunta esposa. En el Fundamento de Derecho Primero le contesta la Sala al apelante: “(...) se concuerda con la sentencia apelada, en que los efectos de la indignidad para suceder se producen por el hecho mismo de haber incurrido en ella, sin que sea preciso que medie sentencia que así lo declare previamente, como pretende la parte actora apelante. "Acto seguido la AP explica el cuándo y el porqué de la resolución judicial civil: “(...) Solo si su concurrencia fuese cuestionada o discutida (no es el caso) sería preciso acudir a la vía judicial para que así se declarase previamente, en cuyo caso, la sentencia que recayese no haría sino declarar la existencia de una causa de indignidad preexistente, imponiendo sus consecuencias, pero con efectos meramente declarativos y no constitutivos".
} 
doctrina, a este respecto, estimándose que la indemnización por causa de muerte no es un derecho sucesorio. Por lo que no se añade a la masa hereditaria, por el básico razonamiento de no formar parte del patrimonio del causante a tiempo de fallecimiento ${ }^{394}$.

La tercera causa de las recogidas en el artículo $756 \mathrm{Cc}$ se refiere al condenado por denuncia falsa por haber acusado al causante de delito sancionado con pena grave. Esta tercera causa ha sufrido una variación con respecto a su predecesor a fecha de promulgación del Código civil en $1889^{395}$. Varía en que el vigente precepto se refiere a la acusación señalada por la Ley que ha de referirse a delito sancionado con pena grave y la anterior disposición se refería a la pena como "aflictiva". También difiere lo modificado, del vigente precepto, en que aquel requería que la acusación fuera declarada como calumniosa, mientras que ahora se requiere condena por denuncia falsa. Tres presupuestos esenciales, se requieren, para cumplir con esta tercera causa de indignidad:

1. La materialización de la acusación por parte del indigno al ofendido.

2. Que la citada acusación se declare como falsa

\footnotetext{
${ }^{394}$ LORA-TAMAYO Y PÉREZ RAMOS, Cuestiones prácticas..., op. cit., págs. 117 a 118. Refrendan estos autores la tesis conforme a que "el derecho a la indemnización por causa de muerte no es un derecho sucesorio, sino ejercitable ex iure propio al no poder sucederse en algo que no había ingresado en el patrimonio del de cuius. Por lo tanto, la le legitimación para pedir la indemnización no la tienen los herederos sino aquel a quien el daño ha afectado de manera negativa el fallecimiento del finado. Se excluye éste último de los legitimados para reclamar por el hecho de que solamente los vivos adquieren derechos".

395 La variación fue debida a la modificación realizada, en el precepto $756 \mathrm{Cc}$ de referencia, por la Ley 15/2015, de 2 de julio de Jurisdicción Voluntaria.
} 
3. Que el indigno acuse al ofendido de algún delito tipificado por la Ley penal, con una pena grave, en el supuesto de ser condenado por denuncia falsa ${ }^{396}$.

Esta causa requiere dos resoluciones judiciales a personas distintas, ya que se ha de declarar la inocencia y la consecuente absolución del testador por una parte y la declaración judicial de denuncia falsa al que acusa. Por lo tanto, ambas resoluciones requieren, esta tercera causa, para poder prosperar. Ello viene a decir, que no basta una simple acusación sin fundamento, sino que se necesita una acusación formal contra el testador o causante, mediante querella o denuncia ${ }^{397}$. Sobre el acusador referido a la $3^{\text {a }}$ causa de indignidad $(756.3 \mathrm{Cc})$ se puede calificar de acusador a toda persona que contribuye a un procedimiento injustamente contra otra ${ }^{398}$. En este sentido se pronuncia, también, la reciente jurisprudencia menor, incluso cuando el testador ha afirmado la acusación falsa de que ha sido víctima en su testamento, con el propósito de que el legitimario no adquiera su derecho a legítima ${ }^{399}$.

\footnotetext{
${ }^{396}$ BEATO Del PALACIO, “la indignidad para suceder...”, op. cit.,págs. 11 a 12. pág. 86. Que hubiese habido acusación. $2^{\circ}$. Que hubiese sido declarada calumniosa. $3^{\circ}$. Que se tratase de delito al que la ley señalase pena no inferior a la de prisión mayor.

${ }^{397}$ BEATO DEL PALACIO, “La indignidad para suceder...”, op. cit., págs. 11 a 14. pág. 18. $\mathrm{El}$ autor estima que la denuncia o querella calumniosa contra el testador o causante, para que pueda prosperar como causa de indignidad, a de provenir del que no tenga obligación de interponerla, en el caso contrario viene obligado a denunciar, y por incumplimiento de ese deber, es inadmisible que pueda ser tachado de indignidad, en virtud de los artículos 259 y siguientes de la L.E.Cr".

${ }^{398}$ Albaladejo García, “Comentarios al Código...”(Tomo X), op. cit., pág. 23. El profesor Albadalejo califica al que acusa injustamente a otro, de acusador. Llama la atención de no ser acusador el que acusa justa o injustamente, sino que parece ser que tenga que tratarse de una acusación injusta para recibir este calificativo. Parece tener lógica sólo con pensar que el acusado, si es de manera injusta, deja de serlo para convertirse en absuelto.

${ }^{399}$ La SAP de Almería (S. 1 ${ }^{\text {a }}$ ) de 11/10/2016 (JUR 2017\87413) enjuicia un recurso en que el padre deshereda a su hija en una cláusula de su testamento instituyendo heredero universal a su otro hijo. A la muerte del causante la hija desheredada interpone demanda
} 
Las causas $5^{\mathrm{a}}$ y $6^{\mathrm{a}}$, de indignidad, dispuestas en el artículo $756 \mathrm{Cc}$ se refieren a las manipulaciones de la voluntad del testador. Tanto en el sentido de obligar al testador a otorgar testamento o a modificarlo bajo amenaza, fraude o violencia, a que se refiere la causa $5^{\text {a }}$. Si en los supuestos anteriores es calificado de indigno el inductor, el mismo calificativo recibe el que impide, por los mismos medios, hacer o modificar el testamento al testador, tal como expone la sexta causa de indignidad. Ambos apartados, del citado precepto, que recoge las causas de indignidad, no hacen sino castigar el impedimento a la libre voluntad de testar, sin requerir para ello la existencia de una condena penal ${ }^{400}$. Es evidente que el beneficiado con las acciones descritas en ambas causas $5^{\mathrm{a}}$ y $6^{\mathrm{a}}$ es el indigno ${ }^{401}$. Incluso el

que resuelve la Primera Instancia declarando a la demandante desheredada injustamente por el testador y por lo tanto se declara, entre otros, nula la cláusula testamentaria por cuya virtud ha sido desheredada la demandante. No conforme su hermano y demandado en Instancia, ejerce su derecho apelando esta sentencia. La AP citada desestima el Recurso argumentando, entre otros, que la causa de desheredación aludida se fundamentaba en el artículo 853. 2. en relación con el 756. 3, ambos del Cc y que el causante desheredaba a su hija por graves ofensas e injurias recibidas y plasmando en su testamento, el causante, que su hija lo había acusado de calumnias y falsos delitos a los efectos de los últimos preceptos que se invocan. La Sala entiende que tal prueba conforme al artículo 217, LEC, le corresponde: "a la parte que la sostiene que es el demandado." No pudiéndose probar las acusaciones de conducta injuriosa de la recurrida, por parte del heredero y recurrente frente al testador y causante, a pesar de haber habido sentencia del Juzgado de lo Penal por el que fue condenado el causante y no la desheredada. Por todo ello, la AP desestima el recurso.

${ }^{400}$ Sobre la coacción a que se refieren las causas $5^{\mathrm{a}}$ y $6^{\mathrm{a}}$ de indignidad dispuestas en el artículo $756 \mathrm{Cc}$ para testar, modificar o impedir la materialización del testamento, se podría plantear si el precepto $756 \mathrm{Cc}$ en sus causas de indignidad citadas se requiere una condena penal por coacción como ocurría por ejemplo en el caso de del atentado contra la vida del causante o sus familiares, para poder declarar indigno al titular de la coacción. La jurisprudencia es clara al respecto en la STSJ de Cataluña (S. $\left.1^{\text {a }}\right)$ de 08/04/2010 (Tol. 1.877.781) dispone que: No es cierto que la norma exija una condena penal. Basta con que se estime probado, no vamos a incidir más al respecto, que se ha inducido a realizar un otorgamiento ilegal e ilegal es emplear amenazas o inspirar al testador un temor insuperable, hallándose en una situación de especial desvalimiento para obligarse a realizar determinadas disposiciones, aunque no constituyan delito.

${ }^{401}$ VAQUER ALOY, A.: "Libertad de disponer y testador vulnerable". Duke Journal of Comparative \& International Law, 2008, pág. 1775. 
Código civil catalán califica de indigno al que, conociendo los hechos, saque beneficio de ellos ${ }^{402}$.

Estas manipulaciones, a la libre voluntad del testador, presentan el inconveniente de poder probarlas, ya que no suelen abundar los testigos cuando el supuesto indigno presiona al testador para que haga o no haga algo, en contra de su voluntad. En este sentido la jurisprudencia establece distintas pautas dignas de mención, como por ejemplo la edad y la condición física del testador. Dependiendo de las mismas (edad o estado físico) puede estimarse que un mismo acto intimidatorio sea calificado como grave o no grave. Puede resolverse la gravedad en función de si ha sido ejercido contra una persona joven y fuerte, con capacidad para valerse por sí misma, pedir información y asesoramiento de terceros. En cambio, adquiere mayor gravedad el mismo acto ejercido contra una persona vieja y desvalida que le es mucho más difícil acceder a la información o al

\footnotetext{
${ }^{402}$ DE BARRÓN ARNICHES, P.:"Libertad de testar y desheredación en los Derechos civiles españoles", Indret, 2016, pág. 28. La STSJ de Cataluña 15/2010 de 08/04/2010, núm. de Recurso143/2009. Trata sobre la intimidación a una testadora por parte de su hija. Dicha testadora en un periodo de 11 años había otorgado distintos testamentos a favor de sus dos hijos A y B de semejantes cuantías para ambos. Otorgaba en su testamento inicial, una casa para cada hijo de las dos que disponía la testadora. La premuere su hijo A, de ésta teniendo descendencia A1 y A2. La madre de A y B, desplaza su residencia junto a su hija B y poco después modifica el testamento inicial por otro en el que otorgaba la casa que en principio era para su hijo A, y por sustitución a los hijos de éste, a la hija de $\mathrm{B}$, es decir, a nieta de la testadora e hija de su hija. Un año después la testadora vuelve a modificar su testamento a semejanza de la inicial, es decir un inmueble para cada hijo y el del hijo fallecido para sus descendientes y nietos de ésta. Tras las insistentes intimidaciones, su avanzada edad de 97 años y la presión de la hija beneficiada ejercida sobre ella hacen que vuelva a modificar el testamento otro año después. Muerta la testadora los hijos de A, interponen demanda por manipulación de la voluntad testamentaria de su abuela por parte de su tía B. Efectivamente se pudo probar en Primera Instancia la manipulación de la verdadera voluntad de la causante, ya que su voluntad era legar la casa en un principio otorgada a A, a los hijos de éste y hoy demandantes. La interpretación de la Sala es: "Todos los indicios existentes fluyen en una misma dirección y existe el enlace preciso y directo según las reglas del criterio humano para deducir la poderosa presión que hubo de ejercer la hija cuidadora para influir en el ánimo de la madre, siendo fácil colegir que las coacciones fuesen del tipo moral o psicológico aprovechándose de la debilidad física de la causante que se hallaba postrada en un hospital".
} 
asesoramiento pertinente. Otro planteamiento es el juicio de capacidad del testador aseverado por el Notario, a la hora de hacer el testamento. Se estima verdadero a falta de pronunciamiento en vía judicial, que demuestre su incapacidad, haciendo invalida la presunción iuris tantum, de la apreciación de suficiente capacidad para otorgar testamento ${ }^{403}$.

Para que las causas de indignidad, que se vienen analizando, $\left(5^{\mathrm{a}}\right.$ y $\left.6^{\mathrm{a}}\right)$ progresen han de cumplirse unos mínimos presupuestos. Entre los que se encuentra la conducta ilegal manipuladora del indigno en su provecho, que la relación causa - efecto de la conducta del indigno constituya vicio en la voluntad y conducta del testador ${ }^{404}$. No se puede pasar por alto el artículo $761 \mathrm{Cc}$ cuando el indigno, por las referidas causas resulta ser un legitimario al que la ley priva de su legítima por indignidad. Aquí cabría preguntarse también por el destino de dicha parte. A diferencia de la repudiación que implica a toda la estirpe del que la ejerce, a salvo de la sustitución que pueda hacer el testador o la transmisión, a favor de sus descendientes, que pueda hacer el repudiante. En el caso de la indignidad, por el hecho de tener esta, carácter personalísimo y tratarse de un legitimario, sus descendientes ostentarían su derecho a la legítima, no por derecho de representación, sino por derecho propio, conforme al precepto último

${ }^{403}$ STS de 07/07/2016, (Tol. 5.775.242) "En este sentido, y pese a las dudas razonables que presenta este caso respecto a la posible captación de la voluntad de la prestadora, consideró que la carencia de capacidad mental ha de resultar acreditada, de una manera indudable, al tiempo del otorgamiento del testamento prevaleciendo, en caso contrario, la presunción iuris tantum de capacidad en virtud del principio favor testamentiy de la intervención notarial y el juicio de capacidad efectuado".

${ }^{404}$ La STS de 19/05/2015 (RJ 2015 2451 ) en cuyo F. J. $2^{\circ}$ se refiere a ejercer influencia sobre la declaración de voluntad del causante: "Con carácter general puede indicarse que el artículo $752 \mathrm{Cc}$ bien en el marco de las prohibiciones de disponer testamentarias, o bien como causa de indignidad, responde a las denominadas incapacidades relativas para suceder que en sede testamentaria pueden afectar a unas determinadas personas que, por su peculiar o especial relación con el testador, han podido influir en su concreta declaración de voluntad contenida en el testamento que es objeto de impugnación. Su finalidad, por tanto, no es otra que preservar la voluntad realmente querida por el testador (voluntas testandi) de posibles e ilícitas captaciones de la misma". 
citado $^{405}$. Aunque algunos autores mantienen que la transmisión es por derecho de representación del artículo $929 \mathrm{Cc}^{406}$.

La séptima causa de indignidad dispuesta en el artículo $756 \mathrm{Cc}$ trata de las personas con derechos sobre la herencia de un discapacitado. El protegido $\mathrm{u}$ ofendido por esta séptima causa es la persona con discapacidad $^{407}$. Lo es de aquellas otras personas con derechos sobre su herencia que no le hubieran prestado las atenciones debidas y recogidas en

${ }^{405}$ DE BARRÓN ARNICHES, "Libertad de testar...”, op. cit. págs. 29 y 30. La autora cita distintos presupuestos que requiere la $5^{\text {a }}$ causa de indignidad del artículo $756 \mathrm{Cc}$. La tendencia de la conducta del indigno sea hacia conseguir la manipulación de la voluntad del testador de tal manera que se vicie dicha voluntad. La conducta del indigno, si bien no requiere sentencia penal, si que requiere ser antijurídica. Que el otorgamiento, modificación, abstención del testamento por el causante manipulado sea consecuencia directa de la manipulación ejercida por el indigno. También matiza, la autora citada, que el legislador pretende con esta causa $\left(5^{\mathrm{a}}\right)$ de indignidad proteger la voluntad del testador a la hora de hacer su testamento y castiga dicho quebrantamiento de perturbar la paz del testador incluso con la privación de la legítima en los supuestos de que el indigno se trate de un sujeto con derecho a ella, si bien la indignidad tiene carácter personalísimo, es decir, solo afecta al indigno y en el caso expuesto de un legitimario, no afectaría a sus descendientes que podrían ocupar su posición por derecho propio.

406 DíEZ- PiCAZO. y Gullón, Sistema de derecho civil..., op. cit., pág. 44. Señalan el artículo $929 \mathrm{Cc}$ el cual dispone que no se puede representar a una persona viva fuera de los casos de incapacidad o desheredación. Coincide con ello, VÁZQUEZ IRUZUBIETA, Código..., op. cit. pág. 1, tras manetener que el incapaz para suceder pierde su derecho, paro tratándose de un legitimario sus descendientes adquirirían su derecho a legítima. Entiende el autor que la infamia no es hereditaria. Practicamente confirma el derecho a legítima de los descendientes del indigno por representación GARCÍA GARCíA, J. M.: "Asuntos pendientes en el derecho de transmisión: el cónyuge viudo del transmitente y otros supuestos" Revista Crítica de Derecho Inmobiliario, núm. 753, enero 2016, pág. 122 y Lacruz Berdejo, J. L, Derecho de Sucesiones, I, Parte General, Barcelona, Bosch, 1971, pág. 75 si bien mantiene este último que el artículo 761. 2 Cc [en su redacción original] que el indigno no pueda tener la administración o el usufructo de dichos bienes. En la redacción de dada a este precepto en 1981 se suprimió el punto 2 del articulo 761 Cc. VAQUER AlOY, A.: "La protección del testador vulnerable" Anuario de Derecho Civil, núm. LXXI-I, enero 2018, pág. 346 mantiene, sin hacer alusión concreta al derecho de representación, que la sanción por indignidad "no afecta a los descendientes del indigno, que incluso ocuparán la posición de este en los derechos sucesorios legales como la legítima (art. 761 CC, 451-3.2 CCCat, 336.1 CFA)”.

407 GONZÁLEZ PORRAS, J. M.: Algunas cuestiones sobresalientes en La reforma del código civil sobre la protección de las personas discapacitadas o incapacitadas, ( coord. R. Casado Raigón e I. Gallego Domínguez), Vol. 2, Universidad de Córdoba, Cordoba, 2005, pág. 699. 
los artículos 142 y $146 \mathrm{Cc}^{408}$. Si se retrocede, al ya citado anteriormente, artículo 852 Cc en el que se regulan las causas de desheredación efectúa una remisión a las causas de indignidad $1^{\mathrm{a}}$ a $6^{\mathrm{a}}$ del artículo $756 \mathrm{Cc}{ }^{409}$. Se advierte, sin dificultad, que falta esta $7^{\text {a }}$ causa de indignidad. Siendo el ofendido una persona con discapacidad, también la indignidad debería poder operar como causa de desheredación en los casos en que en la sentencia de incapacitación se le reconociera capacidad para testar. Ello ocurre al ser una causa muy similar al supuesto contemplado por el artículo 854. 2 Cc como causa de desheredación, el negar alimentos a sus hijos y descendientes, sus padres o ascendentes ${ }^{410}$.

${ }^{408}$ Lledó Yague, F., Monje Balmaseda, O., Herrán Ortiz, A. I., AAVV, Examen particular de las causas de indignidad en Cuaderno Teórico Bolonia I. La sucesión mortis causa, Dykinson, Madrid, 2012, pág. 56.

${ }^{409}$ Berrocal Lanzarot, A. I.: "El maltrato...", op. cit., pág. 939. El artículo 853 del Código Civil contiene, en primer lugar, una remisión genérica a las causas de desheredación generales contempladas en el artículo 852 del citado cuerpo legal y que son enunciadas como causas de indignidad para suceder, en concreto las señaladas en los números 2, 3, 5 y 6 del artículo 756. Se omite la referencia a las contenidas en el número 1 que se refiere a los padres; elnúmero 4, a una causa que tiene lugar después del fallecimiento del testador; y, la número 7 que, es consecuencia de un olvido del legislador que, con la reforma por Ley 41/2003, de 18 de noviembre, no procedió a modificar también los preceptos dedicados a enumerar las causas de desheredación pues la persona con discapacidad no incurre, por esta razón en incapacidad para testar-, por lo que puede considerarse incluida en el ámbito de aplicación de la causa número 1 del artículo 853”.

410 TORRES GARCíA, y DOMínguEz LuELmo, "La legítima en el Código civil...” (I) , op. cit., págs. 74 y 75. Las razones que se han alegado por parte de la doctrina, según estos autores, para no incluir la $7^{a}$ causa de indignidad en el artículo 854. $2 \mathrm{Cc}$ es por una parte lo relativo al principio de legalidad de no poderse adicionar otras causas de las previstas en el texto legal. Por otra parte, se tendría a la imposibilidad material del causante como persona discapacitada, poder otorgar testamento y éste es requisito esencial para hacer valer las causas de desheredación. Si bien estos autores se inclinan por la utilización de la $7^{a}$ causa de indignidad también como justa causa de desheredación y ello en virtud del artículo 2 LPPD que le otorga capacidad para testar, si la tiene, a un discapacitado. Muy distinto el caso del discapacitado que preceptúa el artículo 808. 3 Cc.

La SAP de Albacete (S. 1 $1^{\text {a }}$ ) de 01/02/2017 (JUR 2017\67928) F. J. $3^{\text {o }}$ interpreta y refrenda lo expuesto sobre la $7^{\mathrm{a}}$ causa de indignidad "La Ley 41/2003, de 18 de noviembre, de protección patrimonial de personas con discapacidad, que introdujo el nuevo apartado $7^{\circ}$ al art. 756, permite avanzar en una interpretación extensiva como la 
Esta $7^{\mathrm{a}}$ causa del artículo $756 \mathrm{Cc}$, ha sido redactada de acuerdo con la ley 41 /2003, de 18 de noviembre de protección patrimonial de las personas con discapacidad que, como se ha dicho, afecta a los familiares que no le prestasen las atenciones necesarias al causante persona con discapacidad ${ }^{411}$.

Según la mencionada Ley tendrán la consideración de personas con discapacidad los afectados por una minusvalía igual o superior al 33\% y los afectados por una minusvalía física o sensorial igual o superior al $65 \%$. El dilema se desprende, al no coincidir esta persona discapacitada con la persona incapacitada judicialmente del artículo $200 \mathrm{Cc}$. Si bien, en algunas ocasiones no se descarta que puedan coincidir ambas figuras en una misma persona. Dicho de otra manera, no toda persona incapacitada judicialmente tendrá, la consideración de persona con discapacidad que requiere la causa

postulada por el recurrente pues insiste calificando tal causa de " indignidad generadora de incapacidad para suceder abintestato el no haber prestado al causante las atenciones debidas durante su vida, entendiendo por tales los alimentos regulados en el Código Civil , ello aunque el causahabiente no fuera una de las personas obligadas a prestarlos". En F. J. $4^{\circ}$ la Sala pone de manifiesto que de existir causa de indignidad no cabría su apreciación, si su contenido hubiera coincidido con la disposición del artículo art. 843.2 como la contempla el precepto para la desheredación, "porque el art. 757 se cuida de señalar que las causas de indignidad dejan de surtir efecto si el testador las conocía al tiempo de hacer testamento, o si habiéndolas sabido después, las remitiere en documento público ". Ello es debido a que los testadores sólo desheredan a su hija y no a las hijas de esta y nietas de los causantes en sus respectivos testamentos habiendo todos (hija y nietas) cortado la relación en la misma fecha. Por consiguiente la Sala entiende que "Lo cierto es que, tal como reza el art. 757 del Código Civil, los testadores conocían a la fecha de otorgar sus testamentos que sus nietas habían cesado toda relación con ellos, y a pesar de todo no las desheredaron".

La SAP de Albacete (S. $1^{\text {a }}$ ) de 14/06/2006 (Tol. 992.740) F. J. $4^{\text {o }}$ pone de manifiesto la voluntad pretendida por el legislador con el apartado $7^{\circ}$ del artículo $756 \mathrm{Cc}$ : "es que los incapaces reciban de sus familiares la parte de la asistencia que los poderes públicos no deben suministrarles, esa "prevención general" solo va a producirse para el futuro, para después de su entrada en vigor, no siendo conforme a derecho que se produzcan consecuencias jurídicas negativas de comportamientos no tipificados legalmente".

411 Botello HermosA, P. I.: "Sustitución del término incapacitado por el de persona con discapacidad necesitada de una especial protección. ¿Acierto o desacierto del legislador de la Ley Orgánica 1/2015?", Revista Crítica de Derecho Inmobiliario, núm. 754, marzo 2016, pág. 814. 
de indignidad que se viene analizando aquí ${ }^{412}$. No obstante la causa de indignidad opera aún cuando se trate de discapacitados físicos con capacidad sensorial. Realmente el problema aparece solucionado en la Exposición de Motivos de la Ley 41/2003, donde se dice que la $7^{\text {a }}$ causa de indignidad se configura como incapacidad para suceder abintestato.

\title{
2.10. LA PRETERICIÓN
}

La preterición es la omisión en el testamento de uno, varios, o todos los legitimarios ${ }^{413}$. El Tribunal Supremo entiende que la preterición no es

\begin{abstract}
${ }^{412}$ Véase en HERNÁNDEZ IBÁÑEZ, C.: "La causa séptima de indignidad sucesoria: una medida de protección jurídica para personas discapacitadas", RDUNED. Revista de Derecho UNED, núm. 1, 2006, págs. 182 a 184, la Exposición de Motivos de la Ley 41/2003, para fundamentar la aplicación de la $7^{\mathrm{a}}$ causa de indignidad advirtiendo que allí se expone sobre ésta: "Se configura como causa de indignidad generadora de incapacidad para suceder abintestato el no haber prestado al causante las atenciones debidas durante su vida, entendiendo por tales los alimentos regulados por el Título VII del libro I del Código Civil, y ello aunque los causahabientes no fueran una de las personas obligadas a prestarlos". Por lo que se refiere a la capacidad para testar de unos y otros discapacitados resulta que conforme a lo dispuesto en el artículo 2.2 de la Ley $41 / 2003$, solo se les restringe la capacidad para testar a aquellas personas cuya discapacidad provenga de una minusvalía psíquica que en el momento de otorgar testamento no estén en su sano juicio. Sí que pueden testar aquellas personas con discapacidad, cuya minusvalía psíquica, no les impida su sano juicio en el momento de otorgar el testamento. También gozan de capacidad para testar las personas que como consecuencia de una minusvalía física o sensorial superior al $65 \%$ que no afecte al estado psíquico del que se dispone a testar. Por lo expuesto se puede concluir que la regla general es la facultad para testar de las personas con discapacidad, si bien la exposición de motivos de la referida Ley pone de manifiesto que la $7^{\mathrm{a}}$ causa de indignidad se configura generadora de incapacidad para suceder abintestato.
\end{abstract}

413 Señala De la CÁMARA Álvarez, M.: Compendio de derecho sucesorio, Wolters Kluwer, Madrid, 1990, pág. 183, que la omisión de un heredero forzoso en el testamento se considera preterición. Véase VALlet DE GOYTISOLO, "Comentarios...", op. cit. pág.183, en que manifiesta cuándo no hay preterición. "cuando el testador instituye herederos a sus hijos vivos al tiempo de hacer el testamento y a los que nacieran después”. PARA DíEZ PICAZO. y Gullón, Sistema de derecho civil..., op. cit., págs.184, si bien pone de manifiesto que nuestro Código civil regula la preterición pero no la define, pero "de la normativa de tal regulación y de la de las legítimas se puede extraer que es la omisión de un heredero forzoso sabiendo que existe".

La STS de 01/07/1969 (RJ 1969\3824) señala en su primer considerando:"nacida la hija del testador antes del fallecimiento de éste, aunque su condición legal como natural le haya sido reconocida por Sentencia firme posterior a su testamento y fallecimiento, la doctrina sostiene que tal omisión del heredero forzoso implica la preterición que 
otra cosa "que el olvido del legitimario en el sentido de falta de atribución de bien alguno en concepto de legítima" ${ }^{414}$.En el Capítulo primero de este trabajo, ya se habla que en la Ley de las XII Tablas la preterición ya se considera como la omisión de un legitimario aunque fuera para desheredarlo. En principio ello faculta al preterido para atacar el testamento con la consecuente anulación y la apertura de la sucesión legal. El espíritu de la preterición es que no se anule a ningún legitimario en el testamento ${ }^{415}$.

La preterición difiere de la desheredación, en que no hay privación explicita de la condición de legitimario como sucede con la desheredación sino mera elipsis del preterido ${ }^{416}$. Conviene al inicio de esta exposición distinguir entre la preterición, anteriormente referida del artículo $814 \mathrm{Cc}$ que se refiere a un caso típico, restringido de preterición a los distintos legitimarios en el testamento, de la preterición particional encuadrada en el artículo 1080 del mismo cuerpo plegal ${ }^{417}$. Este precepto se refiere

sanciona el art. 814 del CC, sea que el heredero forzoso viva al otorgarse el testamento, bien que nazca después de éste y antes de la muerte del testador («cuasi póstumo») o que nazca después del mismo (póstumo), y establece los términos claros a los que debe aplicarse la anulación de la institución de herederos, sin perjuicio de la validez de las mandas y mejoras en cuanto no sean inoficiosos, y así lo declara la Sentencia de esta Sala de 17 junio de 1908 ".

${ }^{414}$ STS de 08 /10/2010 (RJ 2010 /7449).

${ }^{415}$ Se refiere al concepto de preterición la SAP de Granada (S. 4 ${ }^{\mathrm{a}}$ ) de 27/04/1999 (AC 19991817) "La preterición entraña un faltar al deber, por parte del causante de dejar, por cualquier título, a los herederos forzosos su cuota legitimaria. Ante tal deber incumplido de modo absoluto, con privación de la legítima (artículos 813 y 814 del Código Civil y demás preceptos concordantes), surge, tras la reforma de 13 de mayo de 1981 ( RCL 1981\1151 y APNDL 2354), a tenor del artículo 814 antes citado, la obligada reducción de la institución de herederos, para dejar a salvo la legítima del preterido (Sentencias del TS de 13 julio 1985 [ RJ 1985\4052] y de 10 febrero 1986 [ RJ 19861513])”.

${ }^{416}$ VIVAS TESÓN, I.: “Intangibilidad cuantitativa de la legítima y preterición testamentaria: revisión crítica de las cuestiones en materia de preterición, sus clases y efectos" Revista Crítica de Derecho Inmobiliario, núm. 742, marzo 2014, pág. 681.

417 Señala MoReno QuesadA, B., Desheredación y Preterición en Curso de Derecho civil IV. Derecho de familia y sucesiones, $5^{\mathrm{a}}$ ed, Tirant lo Blanch, Valencia, 2009. pág. 616 y 617, tres clases de preterición: la instituida, la dispositiva y la enunciativa. Siendo 
únicamente a los herederos pretridos en la partición y no a los que sean preteridos en el testamento ${ }^{418}$.

Cuando el legitimario no haya sido mencionado en el testamento, pero se cumpla con la disposición del artículo 815 Cc que permite satisfacerle la legítima por cualquier título (herencia, legado o donación) ${ }^{419}$. Tambien tiene aquí aplicación la disposición del artículo 819 Cc para reiterar que la donación hecha en vida del testador a uno de sus legitimarios es un anticipo de la legítima de este ${ }^{420}$. Ello viene a demostrar que no ha sido preterido el legitimario, no mencionado en el testamento, que ha recibido del disponente una donación a cuenta de su legítima ${ }^{421}$. En el supuesto de no haber omisión y simplemente se trate de menor atribución de la que por ley le corresponde en concepto de legítima, no se puede atacar un testamento

la primera la aplicada por el Derecho romano en el supuesto de que un legitimario no sea ni citado ni desheredado en el testamento. La segunda la recoge el vigente artículo 141 del Código civil de Cataluña. Se trata de no dejarle nada a algún legitimario por cualquier título que no se ha excluido expresamente. La tercera, es decir, la enunciativa la recoge el Derecho Foral de Aragón en los artículos 120 y 122, que trata cuando se omite mencionar a alguno de los legitimarios.

418 VAllet DE Goytisolo, “Comentarios...", op. cit., pág. 206. El autor aclara la diferencia entre la preterición de los artículos 814 y 1080, ambos del Código civil manifestando la distinta voluntad del legislador en cada uno de ellos. En el primero debe aplicarse a los legitimarios como precepto especial de preterición testamentaria, mientras que el segundo debe aplicarse de manera general a la preterición particional, que lo mismo alcanza a la sucesión testada que a la intestada".

${ }^{419}$ OCHOA MARCO, R. y SEBASTIÁN CHENA, M.S.: La herencia: análisis práctico de los problemas y procesales del Derecho de sucesiones, $7^{\mathrm{a}}$ ed, Edisofer S.L., Madrid, 2017, pág. 79.

${ }^{420}$ DíEZ PiCAZO. Y Gullón, Sistema de derecho civil..., op. cit., págs.184. Se preguntan los autores si la donación encaja en ese "cualquier título del artículo 815 Cc. Simplemente contesta manifestando que el citado precepto no dice que "el título por el que el legitimario adquiera su legítima haya que ser testamentario".

${ }^{421}$ Corrobora lo expuesto en el texto VIVAS TESÓN, I.: "Intangibilidad...," op. cit., pág. 680, al mantener que existe preterición "cuando el heredero forzoso no haya recibido nada del causante por actos inter vivos ni mortiscausa, y además cuando ni tan siquiera es nombrado en su testamento". Además subraya que cuando el legitimario recibe "una asignación ( inter vivos o mortis causa) que satisface su derecho a la porción que legalmente le corresponde, no se trata de preterición sino de insuficiencia de legítima, procediendo el ejercicio de la acción de complemento de la misma ex artículo 815 Cc". 
por preterición. En tal caso, en virtud del artículo $815 \mathrm{Cc}$ el perjudicado siempre puede pedir el complemento de legítima ${ }^{422}$. Las disposiciones testamentarias conservan su validez ante la preterición después de la reforma del Código civil de 1981.

\subsubsection{La preterición intencional}

La preterición intencional se basa en la intención deliberada y consciente del testador de omitir a un legitimario en el testamento existiendo otros no preteridos y de dejar sin su legítima a alguno de los que

${ }^{422}$ LaSARTe Álvarez, Derecho de sucesiones..., op. cit., págs. 202 y 203. Los dos presupuestos que este autor atribuye a la preterición, son: "Que se reconozca al causante la posibilidad de establecer el destino de sus bienes a través del testamento. Que existan sucesores por ministerio de la Ley, llamados doctrinalmente legitimarios y por el Código, precisamente, herederos forzosa".

La STS de 23/04/1932 (Tol. 5.028.091) cuyo supuesto de hecho trata de una hija natural nombrada en el testamento de su madre en que esta le otorga unos bienes determinados en concepto de legado. El Alto Tribunal mantiene en el F. J. $1^{\circ}$ que no existe preterición cuando el testador, lejos de omitir, mencione en su última voluntad la persona del heredero forzoso, aunque no le instituya, pero dejándole manda especial e inferior a lo que por legítima le corresponda, caso previsto taxativamente en los artículos 815 y 817 del citado Código". Tambien con el mismo criterio la STS de 17/07/1996 (Tol. 216.987). En que en el Tribunal Supremo confirma la resolución de la Audiencia Provincial de Oviedo (S. 1) de 29/02/1996, que reproduce aquel en el $4^{\circ}$ A. H. "Para que se produzca la preterición de un heredero con los efectos que pretende la parte, ha de ser esta absoluta y completa, de modo que omita mencionar al heredero forzosa o pase a hacerlo, no le sea adjudicado nada. En aras del respeto al principio de conservación del testamento, la doctrina (Puig Brutau, siguiendo a Vallet, Manresa, Valverde, etc) opinan que pese a ser omitido el heredero en la disposición testamentaria, si ha recibido por título intervivos (donación) en vida del causante, no habría preterición, sino acción de complemento de legítima". La SAP de Pontevedra (S. 3 $3^{\text {a }}$ ) de 13/12/2007 (JUR 2008171998) cuyo supuesto de hecho trata de un disponente que en su testamento no omite a ninguna de sus dos hijas. A una de ellas la instituye heredera pero a la otra simplemente le otorga un legado de bienes determinados. Dispone la Sala en el F. J. $1^{\circ}$ de la resolución que no procede la preterición "por la sencilla razón de que preterición es la omisión de un legitimario en el testamento y en el impugnado figuran las dos únicas legitimarias, ninguna ha sido omitida. El testador no omitió a ninguna de sus hijas ni de forma intencional ni tampoco no intencional, sino que reconoce a las dos y a cada una le deja bienes". En el F. J. $2^{\circ}$ La demanda sólo plantea ese perjuicio formalmente, sin contenido material. La misma Jurisprudencia ya referida admite en aquéllos casos la acción de complemento de la legítima prevista por el art. 815 CC". 
tienen derecho a ella, la regula el primer párrafo del artículo $814 \mathrm{Cc}^{423}$. Por lo tanto, la preterición intencional puede afectar a todos los herederos forzosos contemplados en el artículo $807 \mathrm{Cc}$ : descendientes, ascendientes y cónyuge viudo, si bien este último recibe su parte ipso iure (por ministerio de la ley). La jurisprudencia equipara los efectos de la preterición intencional con los que produce la desheredación injusta ${ }^{424}$. Se trata de la desheredación que recoge el artículo 851 Cc. Ello se deduce en base a la presunción que hace el legislador de que si el testador ha omitido a uno de los legitimarios es porque no quería que recibiera nada suyo y en consecuencia menos querría que fuera mejorado ${ }^{425}$. Como de la mejora

${ }^{423}$ VIVAS TESÓN, I.: “Intangibilidad...”, op. cit., pág. 685.

Artículo $814 \mathrm{Cc}$ : "La preterición de un heredero forzoso no perjudica la legítima. Se reducirá la institución de heredero antes que los legados, mejoras y demás disposiciones testamentarias".

${ }^{424}$ DíEZ PiCAZO. y Gullón, Sistema de derecho civil..., op. cit., pág.185 asemejan los efectos de la preterición no intencional con la desheredación injusta. Así también respalda lo expuesto la STS de 09/07/2002 (Tol. 202.882) F.J.4 ${ }^{\circ}$ que equipara los efectos de ambas figuras. "El efecto de la preterición intencional se equipara al de la desheredación injusta (artículo 851): el preterido, como el desheredado injustamente, tiene derecho a la legítima, pero sólo a la legítima estricta o corta, es decir, un tercio, ya que la voluntad del causante, soberano de su sucesión, fue el privarle del todo y si por ley se le atribuye, no se puede extender a una parte (legítima larga) que corresponde a su libre disposición (entre hijos) y que voluntariamente nunca le quiso atribuir".

${ }^{425}$ Véase VALLET DE GOYTISOLO, comentarios...", op. cit., pág. 200, en que este autor se planea que al tratarse de hijos y descendientes preteridos de manera intencional que concurran a la sucesión con otros hijos y descendientes no preteridos si la legítima a que se refiere el artículo 814, Apartado 1,2,5 se trata de la legítima corta o la larga. Seguidamente afirma que la solución aceptada para la desheredación injusta es la correcta para la preterición intencional, es decir, únicamente poder acceder a la legítima corta o estricta. Tambien coincide con el mismo criterio VIVAS TESÓN, I.: "Intangibilidad...", op. cit., pág. 686, manteniendo que "sólo tiene derecho a reclamar lo que por legítima estricta le corresponde". Por lo que respecta al criterio evolutivo jurisprudencial, la STS de 23/01/1959 (Tol. 4.348.959) F.J.4º cuyo supuesto de hecho trata un marcado caso de desheredación injusta, el Tribunal supremo expone que que "en cuanto a la extensión de la legitima ha de desvanecerse una duda consistente en si para determinar, en el caso concreto de que se trata, el perjuicio del desheredado, ha de entenderse la legítima corta o la larga (...)los derechos del heredero necesario, frente al testador, reducidos a la legitima estricta...". STS de 9 /07/2.002 (RJ 2002, 8237); STS de $7 / 10 / 2.004$ (RJ 2004, 6230) La cuestión que se ha planteado es si esta legítima es la larga (dos tercios: primer párrafo de dicho artículo 808) o la estricta (un tercio). Más, 
dispone el testador para repartirla entre los legitimarios se supone que, de poder el testador, jamás se la hubiera otorgado al legitimario preterido. La jurisprudencia sólo le ha otorgado al legitimario preterido de manera intencional únicamente la legítima corta. Salvo que se trate del único heredero forzoso, que entonces, sí que le corresponde, como es lógico, la legítima larga de los dos tercios ${ }^{426}$.

Los efectos previstos para la preterición intencional en el artículo 814 Cc no pretenden la anulación de la institución de heredero frente a la clase de preterición señalada ${ }^{427}$, sino sólo a proporcionarle, al legitimario preterido, su correspondiente parte ${ }^{428}$. Por consiguiente, cubierta la legítima

como bien expone la Juez "a quo" el efecto de la preterición intencional se equipara al de la desheredación injusta (artículo 851) ya que el preterido, como el desheredado injustamente, tiene derecho a la legítima, pero sólo a la legítima estricta o corta. La STS de 08/10/2010 (Tol.1.981.606) F. J. $2^{\circ}$ en que se enjuicia un supuesto en que la demandante hija adoptiva de los disponentes (los padres) había sido preterida de manera intencional por ambos testadores ordenando reducir las disposiciones patrimoniales hasta poner a salvo los dos tercios de legitima correspondientes a la demandante, sin anular completamente ninguno de los dos testamentos". Tambien la jurisprudencia menor coincide en la SAP de Cádiz (S. 5) de 28/01/2009 (JUR 2009\156817 ) F.J. $1^{\circ}$ se remite a afirmar con palabras, del Alto Tribunal, lo que se ha expuesto en el texto: " es decir, un tercio, ya que la voluntad del causante, soberano de su sucesión, fue el privarle del todo y si por ley se le atribuye, no se puede extender a una parte (legítima larga) que corresponde a su libre disposición (entre hijos) y que voluntariamente nunca le quiso atribuir, (...)".

${ }^{426}$ DíEZ PICAZO y GuILLÓN, Sistema de derecho civil..., op. cit., pág.184.

${ }^{427}$ SAP de Barcelona (S. 19ª de 12/10/2017 (JUR 2017\293914) F.J.3º "'La preterición del legitimario no da lugar a la nulidad del testamento, pero el preterido tiene derecho a exigir aquello que por legítima le corresponde", tratándose de una acción sujeta a plazo prescriptivo y no de caducidad, puesto que el artículo 378 del mismo texto legal establecía que la acción para exigir el pago de la legítima y su suplemento prescribe, en todo caso, al cabo de quince años, a partir de la muerte del causante".

${ }^{428}$ Véase la consecuencia de la preterición en La SAP de Murcia (S. $4^{\text {a }}$ ) de 31/10/2008 (AC 2009/829) F. J. 20. "(...) esta Sección de la Audiencia Provincial ha declarado en sentencia de 25 de febrero de 2008 ( JUR 2008, 304486) que la consecuencia de la preterición no puede ir más allá de lo establecido en el artículo 814-2 $2^{\circ}$ del Código Civil ( LEG 1889, 27) , que sólo dispone la anulación de la institución de herederos, pero deja a salvo las mandas y mejoras ordenadas por cualquier título, en cuanto unas y otras no sean inoficiosas. Es decir, el derecho de D. xxx , de haberlo ejercitado dentro de plazo, podía ir dirigido a que se le reconociera su legítima, pero no a obtener la nulidad del testamento del Sr.xxx , porque el artículo 814 del Código Civil establece que sólo se 
del preterido, la voluntad del testador y causante debe ser mantenida. Como dice el aludido precepto $814 \mathrm{Cc}$ en su último párrafo: "salvadas las legítimas prevalecerá la voluntad del testador “429. Destacar la crítica a la solución legal que establece el citado precepto de no sancionar la voluntad ilegal del testador con la anulación de la institución de heredero ${ }^{430}$. El precepto simplemente se limita a salvar las legítimas preteridas y a seguir con todas las demás disposiciones testamentarias tal como lo ha ordenado que se haga el testador ${ }^{431}$. El Tribunal Supremo ha defendido ese criterio con referencia a la preterición intencional. Entiende que se trata de subsanar el perjuicio causado por el testador al legitimario, pero su tendencia, mientras sea posible es que se tendrá que conservar la validez y

anularán las disposiciones testamentarias de contenido patrimonial si resultaren preteridos todos los hijos o descendientes, y el último párrafo de dicho artículo dice que, a salvo las legítimas, tendrá preferencia en todo caso lo ordenado por el testador(...)".

${ }^{429}$ Lasarte Álvarez, Derecho de sucesiones..., op. cit., pág. 203.

${ }^{430}$ Así la STS de 23/06/2015 (RJ 2015/2547) en el F.J. $3^{\circ}$ refrenda lo expuesto en el texto: " en primer lugar, tal y como esta Sala ha señalado en su sentencia de 10 de diciembre de 2014 (núm. 695/2014 (RJ 2014, 6842) ), a propósito de la ineficacia testamentaria por la preterición de un heredero forzoso (814 del Código Civil), debe tenerse en cuenta que, pese al tenor literal del precepto, la acción que se ejercita no se incardina, en sentido técnico, en el marco de una acción de nulidad que provoque la invalidez estructural de lo ordenado por el testador sino que responde, más bien, a la dinámica de las acciones o medidas de resolución propias de la defensa de la intangibilidad cuantitativa de la legítima. De ahí que la causa de la impugnación no sea otra que la propia preterición del heredero forzoso, esto es, heredero legitimario, y que la ineficacia resultante se dirija funcionalmente a purgar los efectos que resulten lesivos de cara al derecho que le asiste al heredero preterido como legitimario del causante. En todo caso, el ejercicio de la acción de preterición de heredero forzoso no condiciona o impide el curso de las otras acciones que también le asisten al heredero en la defensa de sus derechos hereditarios".

${ }^{431}$ SERRANO FERNÁNDEZ, M.: "La sucesión forzosa" en Derecho de sucesiones. (coords J. P. Pérez Velázquez y E. Pizarro Moreno),2ª ed, Tirant lo Blanch,Valencia, 2017, pág. 150.

La STS de 09/07/2002, (Tol. 4.975.828) declara que se ha dado la preterición, regulada por el artículo 814, del Código Civil que fue reformado por la Ley 11/1981, de 13 de Mayo , cuya disposición transitoria $8^{\mathrm{a}}$ dispone que la nueva legislación se aplica a las sucesiones que se abran después de entrar en vigor. Se da exactamente el concepto de preterición intencional: omisión de los legitimarios en el testamento, sabiendo que existen y que no han recibido nada en concepto de legítima. 
eficacia de todo lo ordenado por el testador, como la institución de herederos, legados, etc ${ }^{432}$.

Ante el supuesto de preterición intencional de todos los hijos y descendientes, estos pueden reclamar su legítima completa, es decir, los dos tercios conforme al artículo $808 \mathrm{Cc}$, que dispone para el testador solamente de un tercio para libre distribución. En consecuencia un extraño sólo puede recibir un tercio de la herencia siendo los dos restantes legítimas. Por lo que frente a la preterición de todos los legitimarios se reducirá la institución de herederos y en su caso los legados hasta cubrir tanto la legitima estricta como la mejora de los preteridos ${ }^{433}$. Incluso en el supuesto de que el cónyuge supérstite fuera instituido y el único legitimario el preterido correspondería a este la parte de legítima y de mejora ${ }^{434}$. Por lo

${ }^{432}$ La STS de 07/11/2006 (Tol. 1.022.988) en su F. J. $7^{\circ}$ hace especial referencia al planteamiento arriba mantenido cuando citando un gran número de SSTS anteriores mantiene que: "En los supuestos de omisión en el activo partible de alguno de los objetos de la herencia y en el de preterición de algún heredero en la partición, el CC tiende a conservar la validez y eficacia de la partición, sin perjuicio de subsanar el defecto de que adolece y el perjuicio irrogado a alguno de los herederos (beneficio de la partición ofavor partitionis)". No hay duda al respecto que el Alto Tribunal se refiere a la preterición intencional.

En el mismo sentido se pronuncia la STS de 07/10/2004 (Tol. 514.224) en la que se formula recurso de casación precisamente contra la sentencia de la AP en que se pronuncia a favor de una preterición intencional. El Alto Tribunal, se pronuncia a este respecto en su Fundamento de Derecho Tercero argumentando que: "La preterición protege al legitimario en la intangibilidad cuantitativa de su legítima. Como declaración de principio el artículo 814 comienza diciendo que la preterición de un heredero forzoso (legitimario) no perjudica lo legítimo. Y termina previendo que: a salvo de las legítimas, tendrá preferencia en todo caso los ordenado por el testador." Se refiere la Sala de casación al concepto de la preterición intencional como "la omisión de los legitimarios en el testamento, sabiendo que existen y que no han recibido nada en concepto de legítima. El efecto lo declara, como principio, el inicio del artículo 814: la preterición de un heredero forzoso (legitimario) no perjudica a la legítima".

${ }^{433}$ ViVAs Tesón, I.: “Intangibilidad...”, op. cit., pág. 687.

${ }^{434}$ VIVAS TESÓN, I.: "Intangibilidad...”, op. cit., pág. 687. Respalda esta postura la SAP de Las Palmas (S.5 ) de 28/04/2009 (JUR 2014\147032) en que enjuicia un caso en que es preterida la única hija del causante e instituida la viuda como única heredera. La Sala en el F.J. $1^{\circ}$ dispone: "En definitiva, y como bien se indica en la resolución de primera instancia, la demandante, ahora apelada, como hija y única descendiente del causante, tiene derecho a los dos terceras partes del haber hereditario y la demandada, ahora 
tanto en los casos de preterición intencional la acción rescisoria tendrá como finalidad el conseguir un resultado económico para el legitimario omitido sin anular la institución de herederos o los legados ${ }^{435}$. La cuestión jurídica que se podría plantear es la calificación de la preterición, es decir, si se puede calificar de la misma manera a tiempo de otorgar el testamento que a la muerte del disponente.

\subsubsection{La preterición no intencional o errónea}

La reforma del Código civil por la Ley de 13 de mayo de 1981 distinguió dentro de la preterición la tradicional o intencional y la no intencional o errónea ${ }^{436}$. El vigente artículo 814 Cc distingue la preterición atendiendo además de por el sujeto preterido, por la intencionalidad de la

apelante, como viuda del causante, al usufructo del tercio destinado a mejora, y, como únicaheredera voluntaria instituida por el testador, tiene derecho a la parte de libre disposición restante. Todo lo cual, determina que se mantengan íntegramente los dos primeros apartados del fallo de la sentencia recurrida". Una sentencia que sin duda aporta interesantes aclaraciones como: Finalmente, la reforma de 13 de Mayo de 1.981 aparta al art. 814 de la solución tradicional al decir que "la preterición de un heredero forzoso no perjudicará la legítima. Se reducirá la institución de heredero antes que los legados, mejoras y demás disposiciones testamentarias...". Tambien la SAP de Alicante de (S.6 ${ }^{a}$ ) de 22/09/2010 (AC 2010\1868) F. J. $1^{\circ}$ en un caso de preterición intencional sobre la única hija del causante en que la Primera Instancia rechaza la demanda que reclamaba la anulación del testamento, pero es adimitdo el caso en Segunda Instancia cuyo F. J. $1^{\circ}$ dice: "al ser la actora la única heredera forzosa del difunto Señor Segundo , por lo que no debe realizarse reducción de legitima alguna al corresponderle las dos terceras partes del haber hereditario según lo previsto en el artículo 808 en relación con el artículo 823 del C.C . en consecuencia y a pesar de la preterición intencional de la actora en el testamento de su padre, y no siendo procedente reducir la institución de heredero al no existir otros herederos forzosos, debe estimarse el recurso interpuesto en cuanto a la nulidad parcial del testamento, declarando a la actora Doña Antonieta heredera de las dos terceras partes del haber hereditario de su padre Don Segundo correspondiendo a la demanda el usufructo del tercio destinado a mejora ( art.834 del C.C.)".

435 Moretón SANZ, M. F.: "Cuestiones litigiosas sobre la preterición intencional y errónea: efectos y consecuencias de la tutela de la legítima cuantitativa sobre la sucesión testamentaria", Revista Crítica de Derecho Inmobiliario, núm. 772, noviembrediciembre 2010, PÁG. 2896.

${ }^{436}$ DíEZ- PiCAZO y Gullón, Sistema de derecho civil..., op. cit., pág.185. 
misma, es decir, según sea esta intencional o no intencional ${ }^{437}$. La inclusión de la preterición no intencional en la actual redacción del artículo 814 Cc encuentra su fundamento en la equiparación de las filiaciones ${ }^{438}$, como prevención ante el supuesto aumento de la preterición en la línea descendente, puesto que se limita únicamente, la preterición no intencional a hijos y descendientes del causante ${ }^{439}$. En el ya señalado, último párrafo del citado precepto $814 \mathrm{Cc}$ se infiere la importancia que concede el legislador a salvar las legítimas, de ahí que se advierta el carácter no imperativo y si dispositivo de las normas que regulan la preterición no intencional, de modo que puede el testador disponer un régimen diferente para el caso en que su testamento incurra en preterición no intencional ${ }^{440}$.

La preterición no intencional hace suponer al legislador que el causante ignoraba que tenía hijos o descendientes y por ello no los ha incluido en su testamento ${ }^{441}$. Es importante la determinación de la no intencionalidad de la preterición que deberá fundarse dentro y fuera del testamento, si bien puede encontrarse entre su clausulado datos que demusestren el desconocimiento, por el disponente, de la existencia del hijo o descendiente preterido ${ }^{442}$. Por ejemplo el disponente acogiéndose al apartado quinto del artículo $814 \mathrm{Cc}$ pueda haber regulado en su testamento los efectos de uno u otro tipo de preterición. Por otra parte atendiendo al artículo $675 \mathrm{Cc}$ la voluntad del testador puede advertirse tanto del texto

\footnotetext{
${ }^{437}$ Véase VALlet DE GOYTISOLO, “Comentarios...”, op. cit., pág. 199.

${ }^{438}$ VIVAS TESÓN, I.: “Intangibilidad...”, op. cit., pág. 682.

${ }^{439}$ LaSARTe Álvarez, Derecho..., op. cit., págs. 203 y 204. Sigue el mismo criterio OCHOA MARCO Y SEBASTIÁN ChEMA, La herencia..., op. cit., pág. 80, siguen estos autores al reiterar que la preterición no intencional sólo es aplicable a hijos y descendientes.

${ }^{440}$ DíEZ- PICAZO y GULLÓN, Sistema de derecho civil..., loc.. cit., pág.185.

${ }^{441}$ Moreno Quesada, Desheredación..., op. cit., pag. 617.

${ }^{442}$ Moreno Quesada, Desheredación..., op. cit., pag. 618.
} 
como del contexto del testamento. Por lo tanto el supuesto de preterición no intencional se puede reducir a la omisión por parte del tesdador de un legitimario en línea descendente, cuando no resulte ni del texto ni del contexto del testamento, su voluntad de excluirle de la sucesión ${ }^{443}$. La distinción de la intencionalidad o no, de la preterición sólo encuentra sentido cuando afecta a hijos o descendientes. En cambio de afectar al resto de legitiamrios (ascendentes o cónyuge) el resultado, en ambos tipos de omisión, sería el mismo ${ }^{444}$.

La otra cuestión importante para la verificación de la no intencionalidad de la preterión es al momento que hay que atender para su apreciación, que sin duda es al tiempo del otorgamiento del testamento ${ }^{445}$.

443 Señala VALLet DE GOYTISOLO, “Comentarios...", op. cit. pág. 169, para la calificación de preterición no intencinal no basta lo dispuesto en el texto del testamento, para advertir la intencionalidad de omitir al hijo o descendiente, sino también ha de ser negativa la intencionalidad del testador en el contexto del testamento. Coincide con esta misma postura LINARES NOCO, R.: "La preterición intencional y no intencional después de la reforma de 13 de mayo de 1981", Revista Crítica de Derecho Inmobiliario, núm. 588 , septiembre-octubre 1981, pág. 1536, con la manifestación de que "la preterición no intencional (atendiendo a lo dispuesto en el art. 675, 1, CC) debe constatarse dentro y fuera del testamento. Tambien en la línea expuesta está de acuerdo MORENO QUESADA, Desheredación..., op. cit., pag. 618, dando importancia, para la calificación de la preterición no intencional, a la fundamentación dentro y fuera del testamento. Tambien manifiestan la misma opinión García Rubio, M. P., Nieto Alonso, A., y Herrero, OvIEDO, Las legítimas ..., op. cit. pág. 269. La STS de 22/06/2006 (RJ 200613082) F. J. $2^{\circ}$, cuyo ponente es X. O'callaghan Muñoz corrobora lo expuesto en el texto disponiendo que: "En consecuencia, se estima que en el presente caso el testador omitió al único legitimario, su hijo, en el testamento, ignorando su existencia y, cuando la supo no lo modificó y quedó viciado de preterición errónea con el importante efecto (que reconoce la sentencia de primera instancia) de anulación de las disposiciones testamentarias de contenido patrimonial, según dispone el artículo 814, párrafo segundo, número primero".

\footnotetext{
${ }^{444}$ Linares Noci, R.: "La preterición...”, op. cit., pág. 1537.

${ }^{445}$ LINARES NOCI, R.: “La preterición...”, op. cit., pág. 1538.
}

El tribunal Supremo en la anteriormente referida STS de 22/06/2006 (RJ 2006।3082) en cuyo fallo revoca la resolución de la A. P. de Cadiz por conculcar expresamente el artículo 814 Cc precisamente por ver la Sala una preterición intencional por conocer el disponente la existencia del hijo preterido con posterioridad al otorgamiento del testamento y no modificar este, hasta su muerte. El Alto Tribunal en su F.J. $3^{\circ}$ estima: como se ha apuntado: la preterición viene referida al tiempo de otorgar testamento y si 
Por consiguiente el momento temporal relevante para apreciar la omisión de un legitimario y la calificación que esta omisión ha de recibir, no es a tiempo de la muerte del disponente, sino a tiempo de la otorgación del testamento ${ }^{446}$. Dicho lo anterior la identificación del tipo de preterición no encuentra dificultad cuando la alteración de las circustancias no presentan una alteración resaltada desde el otorgamiento del testamento hasta la apertura de la sucesión, pero en el caso contrario, es decir, si las circustancias resaltan en dicho intervalo de tiempo. Ante tal incertidumbre cabe plantearse el interrogante del momento a que se debe atender para la calificación de la preterición. La respuesta es idéntica al supuesto de no haberse modificado las circustancias desde el otorgamiento a la muerte del causante, es decir, no se puede variar la calificación hecha al momento de otorgación del testamento ${ }^{447}$. De manera que para la calificación de la

en éste se produce preterición, aunque sea porque el hijo legitimario nace después, la preterición es errónea y despliega sus efectos como tal".

446 VIVAs Tesón, I.: “Intangibilidad...”, op. cit., pág. 693.

En contraposición está la STS de 12/05/2005 (RJ 2005/3994) que en su F.J. $3^{\circ}$, el Alto tribunal, advierte el tipo de preterición al tiempo de la muerte del disponente y no a la fecha de otorgación del testamento. "La preterición es la omisión de un legitimario en el testamento, sin que el mismo haya recibido atribución alguna en concepto de legítima; lo cual no puede advertirse hasta que haya muerto el causante, con testamento y haya sido examinado este; no se puede hablar de preterición respecto a un acto producido antes de la apertura de la sucesión”. En cambio la STS de 22/06/2006 (RJ 200613082) F. J. $2^{\circ}$, "la preterición se produce si en el testamento se omite al legitimario, sin importar que en la apertura de la sucesión, producida por la muerte del causante, este haya sabido o no de la existencia de aquel. No se tiene en cuenta la preterición al tiempo de la muerte, según conozca o no de la existencia del legitimario, sino al tiempo del testamento", y la STS de 31/05/2010 (RJ 2010/2653) que sigue el mismo criterio que la anterior: La preterición intencional y errónea (...) "En todo caso exige la omisión de todos o alguno legitimarios en el contenido patrimonial del testamento, sin haberles atribuido en el mismo o anteriormente ningún bien y que le sobrevivan. La intencional se produce cuando el testador sabía que existía el legitimario preterido, al tiempo de otorgar testamento y la no intencional o errónea, cuando el testador omitió la mención de legitimario hijo o descendiente ignorando su existencia, siempre al tiempo de otorgar testamento".

${ }^{447}$ Véase LiNARES Noci, R.: "La preterición...”, op. cit., págs. 1538 y 1539, en que el autor argumenta esta postura "la voluntad o intención del causante en él [testamento] 
preterición no se tendrán presentes otras circustancias que las que concurran a fecha de otorgamiento del testamento ${ }^{448}$.

Los efectos de una y otra preterición son bien distintos, mientras que la intencional, como se ha visto, la acción tiene como finalidad restablecer la legitima del preterido respetando las disposiciones testamentarias de las que detrae su parte. En la no intencional o errónea procede anular la institución de heredero y en su caso las disposiciones patrimoniales del testamento $^{449}$. La diferencia de intensidad de las consecuencias entre ambos tipos de preterición (de menor intensidad en la intencionada que en la errónea) se pueden distinguir, de la lectura detenida, del artículo 814 Cc teniendo presente que la voluntaría se refiere a cualquier legitimario y la errónea se circunscribe a los hijos y descendienetes. Cuando el error del disponente afecta a todos los hijos o descendientes o bien al único hijo o descendiente, el artículo 814. 2. párrafo $1^{\circ} \mathrm{Cc}$ dispone la anulación de las disposiciones testamentarias de contenido patrimonial, con la consecuente apertura de la sucesión intestada. Ello conforme al artículo 912.1 Cc en que así lo dispone este precepto cuando el testamento pierda su validez ${ }^{450}$.

contenida queda cristalizada, sin posibilidades de alteración, salvo que otra declaración de voluntad, manifestada con arreglo a las formalidades previstas por la ley para testar (así se desprende de relacionar entre sí los arts. 676, 677, 678, 737, 1, y 738, todos los del Código Civil), modifique la inicialmente contenida en el testamento".

${ }^{448}$ García Rubio, M. P., Nieto Alonso, A., y Herrero, Oviedo, Las legítimas..., op. cit. pág. 270.

${ }^{449}$ VIVAs Tesón, I.: “Intangibilidad...”, op. cit., pág. 682.

La STS de 31/05//2010 (1.878.581) F.J. $1^{\circ}$, distingue la clase de preterición, entre otros, para fundamentar el fallo. Dispone el Alto Tribunal que: "los efectos que producen ambas pretericiones son bien distintos: "mientras en la intencional se rescinde la institución de heredero en la medida que sea precisa para satisfacer la legítima y si no basta, se rescinden los legados a prorrata, en la errónea de alguno de los hijos o descendientes, se anula la institución de heredero y si no basta, los legados".

${ }^{450}$ VIVAS TESÓN, I.: "Intangibilidad...”, op. cit., pág. 690. Se pronuncia en el mismo sentido LASARTE Álvarez, Derecho..., op. cit., pág. 204, de una manera incluso más drástica manteniendo que "el testamento es papel mojado en relación con los bienes, careciendo de virtualidad la institución de heredero". MORENO QUESADA, 
Teniendo validez únicamente las disposiciones carentes de dicho contenido patrimonial $^{451}$.

Los efectos de la preterición no intencional dependen de si resultan preteridos todos los legitimarios o únicamente alguno de ellos. En el primer caso se anulan todas las disposiciones testamentarias de contenido patrimonial, es decir, se anulan todas las disposiciones que contengan algún valor para heredarlo, incluidos los legados. Los legitimarios preteridos, sin intención de perjudicarlos, heredan su legítima abintestato. En cambio, si sólo ha preterido a alguno y no a todos, de modo que alguno de ellos sea designado testamenatriamente como heredero o legatario varían bastante las consecuencias. En tal caso se anula la institución de herederos, pero no las mandas, ni las mejoras que no sean inoficiosas ${ }^{452}$. La excepción la impone el legislador para el caso del cónyuge viudo, puesto que en el supuesto de que se haya instituido heredero y su derecho perjudique a la legítima, si que se anulará la institución de heredero (no cualquier disposición) hecha a favor del cónyuge viudo ${ }^{453}$. La jurisprudencia ha

Desheredación..., op. cit., pág. 619. Tras confirmar las manifestaciones de los dos anteriores autores, añade algunos ejemplos de las disposiciones de contenido no patrimonial que no perdirian su eficacia ante la preterición no intencional de todos los hijos o descendientes: "reconocimiento de hijos, nombramiento de contador- partidor, tutor, etc y otras cuestiones referentes a la situación creada por el fallecimiento del disponente". En resumen lo que acertadamente ha dicho el profesor Lasarte, " el testamento sin la institución de heredo es " papel mojado". VALLET DE GOYTISOLO, "comentarios...", op. cit. pág. 204, valida la línea seguida por los anteriores autores sobre las consecuencias de la preterición no intencional de todos los hijos y descendientes de la invalidez de la institución de herederos y se mantendrían las disposiciones de carácter no patrimonial como puedan ser el reconocimiento de hijos naturales, nombres de tutor, protutor, así como las previsiones del destino del cadáver, (cremación, donación de órganos, lugar de enterramiento, etc".

451 Señala LASARTE ÁlvareZ, Derecho..., op. cit., pág. 204, como ejemplos de contenido no patrimonial: "declaraciones por parte del testator de pertenecer a uno u otra religión normas sobre exequias fúnebres, agradecimientos, etc".

452 VIVAS TESÓN, I.: “Intangibilidad...”, op. cit., pág. 690

${ }^{453}$ SERRANO FERNÁNDEZ, La sucesión forzosa ..., op. cit., pág. 151. La opinión del autor a este respecto es muy acertada, pues argumenta las distintas consecuencias de la 
modificado su doctrina en octubre de 2014 , con respecto a la interpretación del artículo $814 \mathrm{Cc}^{454}$. Lo ha hecho en el sentido de que ahora el principio del favor testamenti se interpreta, a pesar del tenor literal del artículo 814 Cc en el sentido de no proceder a la anulación del testamento y en

anulación de la institución de herederos. De ser un legitimario hijo del causante anulando, la institución de herederos, este hereda abintestato. En cambio, de ser un colateral, el instituido heredero, no es llamado a la sucesión abintestato habiendo legitimarios y el colateral no recibirá nada, a pesar, de ser la voluntad del testador que fuera su heredero. Tambien VIVAS TESÓN, I.: "Intangibilidad...", op. cit., pág. 690. Señala las mismas pautas a seguir, manifestando que en este caso "se sigue el mismo orden que en la preterición intencional".

Véase VAllet DE GoyTisolo, "Comentarios...", op. cit., pág. 2013, que profundiza más en esta situación manifestando que "de concurrir, con la institución del viudo, legados y mejoras, aquéllos y estos gravitaran sobre la institución de herederos, incluidas la contra tábulas del preterido y la del cónyuge viudo. De producirse inoficiosidad, de acuerdo con las reglas de la reducción, de las que es de aplicación la norma del ap. 2, del punto 1del mismo artículo 814: "Se reducirá la institución de heredero antes que los legados, mejoras y demás disposiciones testamentarias".

${ }^{454}$ La STS de 15/09/2015 (Tol. 5.583.589) plantea como cuestión de fondo una nulidad testamentaría y su consecuente apertura de la sucesión legitimaria. Justo en el primer motivo, el recurrente en casación, sostiene: "el testador ha sufrido un error grave al disponer la exclusión testamentaria de todos sus descendientes, siendo de aplicación lo dispuesto para estos casos respecto de la preterición no intencional, esto es, la delación intestada de la herencia." La conclusión a que llega el Alto tribunal en el F. J. $2^{\circ}$ es la no anulación del testamento, es decir, su conservación. Es el "(favor testamenti)", el principio que la Sala, le alega al recurrente es precisamente con relación al régimen de ineficacia testamentaria previsto en el artículo 814 del Código Civil, por la preterición no intencional del heredero legitimario. En este mismo aspecto, la STS de 10/12/2014, (Tol. 4.748.252) aporta la reciente doctrina jurisprudencial dispuesta, en la STS de 28 /10/2014 (Tol. 4.561.606), al caso que allí si plantea. En el punto cuarto del Fundamento de Derecho Segundo, la primera de las SSTS aquí expuestas, explica los cambios de la citada y reciente doctrina con respecto a la anterior, que tratan del "régimen de la ineficacia testamentaria del artículo 814, del Código civil". La Cuestión interpretativa del citado precepto con relación a la "anulación radical o anulabilidad o rescisión". Dice el Alto Tribunal que debe de ser resuelta a favor de la anulabilidad o rescisión "por razón de su carácter funcional, parcial, relativo y sanable". Ello en base a que la interpretación del 814, Cc con relación a la preterición no intencional de hijos y descendientes en aquellos supuestos en que todos ellos no resulten preteridos, "lejos de descansar en la mera literalidad del apartado segundo, $(814 \mathrm{Cc})$ esto es, la anulación de la institución de herederos. Se apoya este en la voluntad testamentaria (voluntas testatoris como ley suprema de la sucesión), remitiéndose la STS que se analiza, al último párrafo del ariculo 814 , Cc en que salvadas las legítimas se otorga preferencia a la voluntad del testador. Por lo tanto, simplemente confirma la doctrina que señala esta STS lo que se ha venido diciendo desde el principio sobre el precepto $814 \mathrm{Cc}$ en que sólo le importa poner a salvo las legítimas y una vez cumplido su objetivo da prioridad a las disposiciones testamentarias. 
consecuencia la apertura de la sucesión intestada si es todavía es posible salvar las legítimas.

No es difícil encontrar autores que le otorgan un tratamiento a la preterición no intencional de "excepción" de la preterición, es decir, la regla general sería la preterición intencional y la excepción, la no intencional. La explicación que se le da a tal exposición radica, en la expresión de "sin embargo" en que se antepone a la preterición no intencional en el segundo apartado del artículo $814 \mathrm{Cc}^{455}$. El carácter de, acción reparadora, que tiene este precepto, es decir, que se trata de una acción rescisoria del artículo $1076 \mathrm{Cc}^{456}$, a pesar del tenor literal resolutorio que resulta de su lectura. Cabría preguntarse en este punto, por la acción de impugnación testamentaria por preterición no intencional de un legitimario y el plazo para interponerla. En base a ello la STS de 10/12/2014, ya citada, entiende que el plazo de la acción es de 4 años y que tratándose de preteridos legitimarios menores de edad se contabilizaran, dichos 4 años, a partir de su mayoría, es decir, de que cumplan la mayoría de edad para empezar el cómputo del plazo. Sin olvidar el principio general de que la prescripción no corre contra aquellos que son incapaces de ejercitar acciones $^{457}$.

\footnotetext{
${ }^{455}$ LORA-TAMAYO Y PÉREZ RAMOS, Cuestiones prácticas sobre herencias..., op. cit. pág. 251. Comparte esta postura LINARES NOCI, R.: "La preterición...", op. cit., pág. 1524 y señala que el término "sin embargo" que recoge el apartado $2^{\circ}$ del art. $814 \mathrm{Cc}$ : "introducía la idea de que lo que se iba a decir, que era: "no obstante lo dicho anteriormente". De tal manera que si lo que se iba a decir, "no obstante lo dispuesto antes", se refería a los efectos previstos para un determinado tipo de preterición (la no intencional de hijos o descendientes) resultaba coherente entender que lo dispuesto con anterioridad también aludía a los efectos que desencadenaría una preterición distinta de la anteriormente citada".

${ }^{456}$ Artículo $1076 \mathrm{Cc}$ : "La acción rescisoria por causa de lesión durará cuatro años, contados desde que se hizo la partición".

${ }^{457}$ La ya citada STS de 10/12/2014 (Tol. 4.748.252), comienza el procedimiento a raíz de una demanda interpuesta por la representante legal y madre de un menor preterido de
} 
Puede que el $2^{\circ}$ apartado del artículo $814 \mathrm{Cc}$ sea, de este precepto, el que más dudas puede plantear al tratar de aplicar en la práctica la preterición no intencional, por la mención que efectúa a la institución de heredero. Consecuentemente abriendo la sucesión intestada, pero respetando las mandas y las mejoras que el testador haya ordenado por cualquier título, siempre que la inoficiosidad no las invada. Un supuesto de hecho que puede producirse con bastante facilidad es el caso de un legado de usufructo universal del cónyuge viudo, con el agravante de una cautela socini a su favor, dispuesta por el testador. Para asegurar dicho usufructo viudal, en el que de no respetar tal decisión, a alguno de los llamados se le privaría de la parte de mejora que incluye la legítima. Aplicando el $2^{\circ}$ apartado del precepto, antes aludido, resulta que dicho usufructo grava la totalidad de la herencia y cabría la duda de si al abrirse la sucesión intestada, dicha cautela socini, quedaría vigente o por el contrario se extinguiría con la anulación de la institución de herederos. Es decir, lo dispuesto por el testador en su testamento ¿Tendría vigencia en la sucesión intestada?

Una de las posibilidades al respecto, sería la aplicación del último párrafo del artículo $814 \mathrm{Cc}$ en que salvadas las legítimas prevalece la voluntad del testador y la voluntad de este es que su viudo disponga del usufructo de toda la herencia. Llegado el caso que en la sucesión intestada se oponga alguno de los legitimarios llamados, a que el cónyuge de su causante, usufructúe lo que el testador ha dispuesto para él. En tal caso recibirá su parte legítima sin la carga del usufructo viudal, pero será la

manera no intencional. En el Fundamento de Derecho Segundo entiende el Alto Tribunal en alusiones a la razón de fondo: "sigue la autoridad doctrinal de Vallet de Goytisolo radica precisamente en el cómputo del plazo, pues conforme al tronco común de la rescisión ( artículo 1299 del Código Civil ) dicho plazo no comienza a transcurrir para las personas sujetas a tutela hasta que cesa la incapacidad; extremo que trasladado a la esfera de los menores de edad, caso que nos ocupa, nos lleva a su mayoría de edad como fecha de inicio del cómputo del plazo". 
parte de la legítima estricta, es decir, un tercio de la herencia. Los otros legitimarios que acaten la voluntad del testador, recibirán los dos tercios de la nuda propiedad ${ }^{458}$. Otra situación que se da, con bastante frecuencia, es el nacimiento de un hijo del testador con posterioridad a la fecha de otorgamiento del testamento. Tal circunstancia hace evidente la preterición no intencional y con ello sus consecuencias ${ }^{459}$.

\footnotetext{
${ }^{458}$ LORA-TAMAYO Y PÉREZ RAMOS, Cuestiones prácticas..., op. cit., pág. 254. Los trámites con respecto a la anulación de la institución de herederos y la apertura de la sucesión legítima pueden tomar dos caminos dependiendo de si están conformes todos los herederos llamados a la sucesión. En el supuesto de haber discrepancias, el camino a seguir es la declaración judicial de la nulidad de la institución de herederos y acto seguido, por medio de requerimiento notarial llamar a los que su derecho los asista a tal requerimiento de conformidad con el artículo $912 \mathrm{Cc}$. Por más evidente que sea la preterición, el Notario no tiene capacidad para declararla, pero "Si hubiese mutuo acuerdo entre todos los herederos nombrados manifestando notarialmente que hubo preterición no intencional, de que la institución de herederos es nula y de que se proceda sin más a la declaración de herederos abintestato, creemos que puede prescindirse de la declaración judicial de nulidad de la institución de herederos".

${ }^{459}$ Señala la STS de 23/01/2001 (Tol. 4.964.722) F.J. $3^{\text {o }}$ según doctrina pacífica, cuando haya nacido algún hijo después de haber otorgado el testamento, con ello, ya queda demostrada la preterición no intencionada y su la concepción del preterido es posterior al otorgamiento del testamento, la no intencionalidad de la preterición todavía se demuestra con más fuerza.
}

En sentido, de preterición no intencional, se pronuncia la SAP de Álava (S. $1^{\text {a }}$ ) de 27/06/2016 (Tol. 5.826.138) ante el recurso de apelación contra la sentencia dictada en Primera Instancia como consecuencia de una demanda interpuesta por la madre en representación de su hija, nacida con posterioridad al otorgamiento del testamento del padre de la menor. Dicho de otra manera, el padre sin tener descendencia otorgó testamento a favor de colaterales suyos y con posterioridad nació la hija que trae causa a este enjuiciamiento. Fallecido el causante sin otorgar posterior testamento se procedió a realizar la partición de la herencia en la procedente notaría y se le otorgaba a la menor la legítima estricta (1/3). Al llegar dicha partición para ser inscriba en el correspondiente Registro de la Propiedad, su titular, argumentaba: "que en este caso existe una preterición no intencional de la menor por parte de su padre que otorgó testamento antes de su nacimiento, por lo que hubiera podido exigir la anulación de dichas disposiciones testamentarias." Se interpone, entonces, demanda solicitando del Juzgado: "se declare la nulidad de la escritura de aceptación y partición de la herencia del fallecido otorgada el 8 de febrero de 2.013 en la Notaria de $\mathrm{D}^{\mathrm{a}} \mathrm{xxx}$. Que se realice nueva escritura de aceptación y partición de la herencia de D. xxx declarando única heredera de todos sus bienes a [la hija del causante]. Y que se condene a xxx y xxx, sobrinos del causante, a restituir la suma de 31.500 euros cada uno de ellos más los intereses..." El Juzgado de Primera Instancia dicta sentencia desestimando la demanda, en cuya motivación manifiesta que se ha cumplido la voluntad del causante dispuesta en la cláusula cuarta 
2.10.3. La preterición mixta de hijos o descendientes: simultánea y sucesiva

Se conoce como preterición mixta de hijos o descendientes cuando una pluralidad de legitimarios que hayan sobrevivido al testador, quedan preteridos unos de manera intencional y otros de manera no intencional. El problema se plantea en que si los que reclaman son preteridos de forma intencional no se anula la institución de heredero. Mientras que si son los preteridos erróneamente cabe la anulación de la institución de heredero, con la consecuente apertura de la sucesión intestada y el beneficio para los preteridos intencionalmente que pueden, incluso llegar a repartirse la herencia a partes iguales ${ }^{460}$. Es decir, al anular la institución de heredero no sólo se beneficia el preterido de manera errónea sino que también lo hace el preterido con intención, ya que únicamente, conforme al artículo 814. 1 Cc le hubiera correspondido, en principio, su legítima corta, puesto que si el

del testamento en la que se dispone que: "se reconozca la legítima estricta a las personas que legalmente les corresponda, que en este testamento no hayan sido mencionadas ni individualmente ni genéricamente como herederas, legatarias, o sustitutas" La actora a la vista de los hechos recurre en apelación invocando infracción del artículo 814, del Código civil. La AP. Interpreta el citado precepto al respecto de la preterición no intencional de los hijos y descendientes que está muy lejos de la mera literalidad de lo dispuesto en el apartado segundo del precepto, es decir, la anulación de la institución de herederos. La interpretación es que: "se apoya en la voluntad testamentaria como la Ley suprema de la sucesión" En consecuencia la AP. desestima el recurso con argumentaciones que aquí ya han sido expuestas y manteniendo que: "dar preferencia a la validez testamentaria aun en el supuesto de que carezca de institución de heredero o que dicha institución resulte ineficaz".

460 Bolas Alonso, J.: La preterición tras la reforma de 13 de mayo de 1981. Conferencia pronunciada en la Academia Matricense del Notariado el día 25 de marzo de 1982, en Anales de la Academia Matritense del Notariado, Tomo XXV, Edersa, Madrid, 2004, pág. 231. "El problema se presenta al tratar de cohonestar los distintos intereses en juego, pues el preterido no intencionalmente tendrá derecho a la nulidad de la institución de heredero y la consiguiente apertura del abintestato, lo que en ocasiones podrá implicar el reparto del caudal hereditario a partes iguales,con claro beneficio del preterido intencionalmente". Mantiene el autor que para evitar tal desequilibrio cabría: "un acuerdo entre el pretendo sin intención y el legitimario instituido". Con el mismo criterio FERnÁndeZ Domingo, J.I.: Derecho de sucesiones, Reus, Madrid, 2010, pág. 138. 
causante lo ha apartado de su sucesión, su intención tampoco era la de mejorarlo $^{461}$.

Un problema, el citado en el párrafo anterior, que lo introduce la disposición del párrafo $1^{\circ}$ y párrafo $2^{\circ}$ del punto 2 del articulo $814 \mathrm{Cc}$ y que lo denomina algún autor como preterición mixta simultánea ${ }^{462}$. Únicamente se le encuentra salida llegando a un acuerdo entre los afectados ${ }^{463}$. Un acuerdo que encuentra licitud teniendo en cuenta que el legitimario omitido puede renunciar a utilizar la acción, incluso puede transigir y aceptar los bienes que le entreguen los demás herederos en pago de su legítima ${ }^{464}$.

${ }^{461}$ LiNARES NOCI, R.: "La preterición...", op. cit., pág. 1553. Mantiene este autor que si el causante no dispuso de la mejora la legítima objeto de la reducción será la larga, pero si el causante dipuso correctamente de la mejora, la legítima que le corresponda al preterido con intención será la corta.

${ }^{462}$ Bolas Alonso, La preterición..., op. cit., pág 231.

463 LiNARES NoCI, R.: "La preterición...”, op. cit., pág. 1554. Según este autor, el preterido sin intención cuenta, si así lo desea, con resortes jurídicos suficientes para impedir, si ese fuera el caso, que el preterido con intención pueda beneficiarse, en detrimento del primero, de la anulación de la institución de heredero con la que se encuentra sancionada su preterición". Tambien comparte esta postura BOLAS ALONSO, La preterición..., op. cit., pág. 54. El autor a fin de hacer más comprensible el acuerdo citado expone un supuesto de hecho: "Pensemos que el testador tenía tres hijos: A, que es nombrado heredero universal; $\mathrm{B}$, que es preterido intencionalmente, y $\mathrm{C}$, que es objeto de preterición errónea. El caudal hereditario asciende a 9. Si C exige la nulidad de la institución de heredero, al amparo del número 2 del precepto que comentamos, todos tendrán derecho a su cuota de abintestato, $=3$. Si B reclama su legítima, al amparo del párrafo $1 .^{\circ}$ del artículo 814 , tendrá derecho a la legítima estricta, $=1$. En tales circunstancias, y dado que, como veremos, la legitimación de la acción de preterición es personal del perjudicado, y que cabe la sanación por consentimiento expreso de éste, parece inevitable admitir que C convenga con el instituido, A, la satisfacción de sus intereses en la herencia por un camino distinto de la nulidad de la institución de heredero y que suponga un beneficio para ambos frente a $\mathrm{B}$, cuyo único derecho se reduce a su tercera parte en la legítima estricta, $=1$. Por este camino A y $\mathrm{C}$ se repartirán 8,4 cada uno, en lugar de los 3 que les corresponderían por abintestato. No se diga que es este un arreglo fraudulento, pues hemos repetido hasta la saciedad que el principio fundamental en sede de preterición es el de la voluntas testatoris y no cabe duda de que la solución apuntada es menos mala que la contraria, que llevaría a repartir la herencia a partes iguales en contra de la voluntad del testadorque omitió voluntariamente a uno de sus hijos".

464 Véase VAllet DE GoYTiSOlO, "Comentarios...", op. cit., pág. 185. "Sí los preteridos, teniendo capacidad suficiente al respecto, renunciaran a ejercitar su acción 
Deshechando el omitido la posibilidad de acuerdo y debido a que el precitado artículo 814 Cc no establece presunción alguna a favor de uno u otro tipo de preterición es el que ejercite la acción el que debe probar la calificación de la omisión del testador en consonancia con los efectos que reclame $^{465}$. Como es lógico admitida la omisión, la disyuntiva será preterición intencional o preterición no intencional, de probar el actor uno u otro tipo de preterición será este el que se entienda por producido. De no

de impugnación o transigieren con los instituidos herederos". Tambien comparte este mismo criterio VIVAS TESÓN, "Intangibilidad...", op. cit., pág. 691. Si bien Bolas AlONSO, La preterición ..., op. cit., pág. 34, comparte la postura sobre la posibilidad de la sanación de la preterición con el consentimiento expreso del preterido que recibirá los bienes hereditarios que le correspondan sin necesidad de ejercitar la acción, sin embargo argumenta que "no tendrá aplicación en los supuestos de preterición no intencional total, pues difícilmente cabrá hablar de sanación por acuerdo entre los afectados cuando el preterido o preteridos tienen derecho a la totalidad de la herencia".

${ }^{465}$ VIVAS TESÓN, “Intangibilidad...”, op. cit., pág. 690. No todos los autores comparten esta postura LACRUZ Berdejo, J. L. (1988), Elementos de Derecho Civil, V, Derecho de Sucesiones, Bosch, Barcelona, 1988, págs. 550 y 551, "pese a no existir dicha presunción a favor de una u otra clase de preterición, la omisión intencionada del legitimario constituye la regla general, mientras que la errónea es la excepción". TORRes GARCÍA, y Domínguez Luelmo, La legítima en el Código civil (I)..., op. cit, pág. 65, mantiene que si bien es cierto que el artículo 814 no establece presunción favorable de ninguna clase de preterición la regla general es la preterición intencional, mientras que la excepción es la errónea o no intencional. En cambio otros autores como GARROTE FERNÁNDEZ - DIEZ, I.: El tespamento viciado por preterición en el Código civil y en los Derechos civiles forales, Comares, Granada 2004, págs. 2013 y ss, mantiene que tanto en un tipo u otro de preterición se tendría que anular la institución de heredero. La jurisprudencia también se prununcia admitiendo la presunción citada en similar sentido, la SAP de Mdrid (S. 21) de 27/03/2007 (Tol. 1.907.529) F.J. 6 ${ }^{\circ}$ "debemos concluir que es la demandante, hijo o descendiente del causante, como legitimario preterido al que incumbe la carga de la prueba de que su preterición fue no intencional y, si no logra acreditarlo, debe partirse de una preterición intencional". Tambien la SAP de Jaen (S. $2^{\mathrm{a}}$ ) de 08/02/2013 (JUR 2013\188552) F. J. $2^{\text {o }}$ en que se ejertitaba en la demanda acción de nulidad de la institución de heredero por haber sido desheredada la actora, madre y hermanas sin causa: "Es cierto, como se alega en el escrito de recurso que el hecho de haber solicitado sólo la nulidad de la institución de heredero por causa de preterición no intencionada, no obstaba a la apreciación de la preterición intencionada estimada en atención a que al tiempo de otorgar testamento el causante sí tenía conocimiento de los legitimarios que omitía, pues no se puede entender con ello se altere la causa petendi y en consecuencia está habilitado este Tribunal por el principio general "iura novit curia", no incurriendo en incongruencia alguna al concederse menos de lo solicitado en base a una mismo fundamento y así debió entenderse en la resolución recurrida". 
poder probar el tipo que el demandante pretende y quedando admitida la omisión sólo queda admitir la contraria a la que se pretendía probar ${ }^{466}$.

Por otro lado también podría plantearse el supuesto en que un testador hubiera preterido de manera intencional a un legitimario y no intencional a los hijos de este y nietos de aquel recibiendo este tipo de preterición el calificativo de preteriricón mixta sucesica ${ }^{467}$. Un supuesto de hecho, nada extraño, podría ser el testador que tiene dos hijos solteros y omite a uno de ellos en su testamento ignorando que el preterido tenia descendencia. Entonces la doctrina se inclina por la aplicación de lo dispuesto para la preterición errónea del artículo $814 \mathrm{Cc}^{468}$.

\subsection{LA ACEPTACIÓN DE LA HERENCIA}

La adquisición de la herencia depende de la conjugación de dos requisitos: la delación o llamamiento y la aceptación o adición. Por el llamamiento sólo adquiere el llamado el derecho a adquirir la herencia, si decide aceptarla. Este derecho es el conocido ius delationis o ius adeundi. Si el llamado usa su derecho, de manera expresa o tácita, para aceptar la

\footnotetext{
${ }^{466}$ LinARES NOCI, R.: "La preterición...”, op. cit., pág. 1542. Tambien TORRES GARCÍA, y Domínguez Luelmo, La legítima en el Código civil (I)..., op. cit, pág. 65, mantienen que si el ejercicio de la acción trae como resultado la anulación de la institución de herederos, ello también arrastrará a los demás en el perjuicio o beneficio que ello suponga para cada uno.

${ }^{467}$ Véase Bolas Alonso, La preterición..., op. cit., pág. 33, que define la preterición mixta sucesiva como aquella que se produce "cuando en relación con la misma estirpe el testador incurre en preterición intencional de su descendiente y en preterición errónea de los descendientes de éste".

${ }^{468}$ FERnÁNDEZ DOMINGO, J.I.: Derecho de sucesiones ..., op cit., pág. 138. Tambien en la misma línea entiende BOLAS AlONSO, La preterición..., op. cit., pág 231, "el descendiente fue preterido. Además, no hay base para presumir que el testador ha querido limitar los derechos de la estirpe del preterido también a la legítima estricta, pues para ello debía y podía haber acudido a la desheredación injusta. Si no lo hizo así deberán jugar las reglas generales en sede de preterición y entender que hay preterición errónea de los nietos cuya existencia desconocía el testador". Además matiza que la solución no varía tanto si se trata de preterición "no intencional total o parcial".
} 
herencia se convierte en heredero ${ }^{469}$. Tambien el llamado puede usar su derecho para repudiar la herencia, es decir, rechazarla de manera legal ${ }^{470}$. La aceptación de la herencia puede ser pura y simple (se subdivide en expresa o tácita) o a beneficio de inventario ${ }^{471}$.

\subsubsection{La aceptación pura y simple}

La aceptación pura y simple también podría responder al calificativo de la aceptación no acogida a beneficio de inventario. Es este tipo de aceptación aquella que recoge el artículo $1003 \mathrm{Cc}$ en que se produce la confusión de patrimonios entre el del causante y el heredero que acepta, de

469 Véase Rivas MartíneZ, J.J.: Derecho de sucesiones. Común y foral, tomo III, Dykinson, Madrid, 2009, pág. 2484, "que los actos de mera conservación o administración de los bienes de la herencia no implican aceptación; o sea, no convierten al llamado en heredero".

${ }^{470}$ Señala MORETón SANZ, M. F.: "Vocación hereditaria, personalidad y criaturas abortivas: la reforma del artículo 30 del código civil e incidencia de la eliminación del requisito de la viabilidad en el régimen de la capacidad de suceder por testamento o abintestato", Revista crítica de Derecho Inmobiliario, núm. 728, noviembre 2011, pág. 3489, la delación u ofrecimiento. "Esta etapa es el momento donde el heredero habrá de aceptar o renunciar cerrándose el proceso con la adquisición de las titularidades susceptibles de transmisión por parte de quien o quienes ocupen el lugar del de cuius". Coinciden con esta posición OCHOA MARCO, R. Y SEBASTIÁN CHEMA, M.S.: La herencia..., op. cit., pág.142, al entender la delación "como el ofrecimiento efectivo y actual de la herencia que atribuye a una o varias personas la posibilidad inmediata de aceptar o repudiar la herencia”. En este sentido la STS de 02/07/2014 (RJ 2014\4251) F. J. $2^{\circ}$ identifica la delación como: como el derecho que tiene cada uno de los coherederos -caso de que sean varios- sobre la herencia mientras ésta permanece indivisa". La STS de 20/01/2014 (RJ 2014\2229) F. J. $3^{\circ}$ califica el ius delationis como como razón informadora del derecho hereditario". La STS de 20/07/2012 (RJ 201219001 ) F.J. 2 “ “ el ius delationis como derecho actual de aceptar la herencia, esto es, la existencia de una sucesión abierta, la designación del beneficiario a través del negocio testamentario, su determinación y supervivencia respecto del causante y su pertinente aptitud y capacidad para heredar". La STS de 10/06/2013 (RJ 2015\6242) F. J. $2^{\circ}$ califica la delación como: "esto es el ius delationis, que informa y posibilita el derecho a adquirir la herencia, y a la aceptación de la herencia, como presupuesto lógico o conceptual de la propia adquisición hereditaria".

${ }^{471}$ Rivas MartínEZ, Derecho...,( tomoIII), op. cit., pág. 2504. 
esta manera, una herencia ${ }^{472}$. Ante tal supuesto el patrimonio del heredero responde junto con el del causante de las deudas contraídas por este, así como de los legados que haya otorgado ${ }^{473}$. Cabe citar aquí, pese a la confusión entre ambos patrimonios, la Resolución de la Dirección General de Registros y Notariado, de 01 de septiembre de 1976, manifestando que: "la confusión de patrimonios que produce la aceptación pura y simple, opera sólo en daño del heredero y no en perjuicio de terceros, como son los acreedores hereditarios y legatarios". Se entiende tal manifestación en el sentido en que tendrán preferencia los acreedores del patrimonio hereditario y los legatarios frente a los acreedores del heredero ${ }^{474}$. Por lo tanto, no se puede entender, dicha confusión, cuando se produce este supuesto y en consecuencia se podía hablar de una separación patrimonial en este sentido ${ }^{475}$.

${ }^{472}$ CASADO CASADO, B.: "La aceptación tácita por los padres de la herencia de los hijos menores de edad. (a propósito de la sts 801/2002, de 26 de julio)", Anuario de Derecho Civil, núm. LVI-3, julio 2003, pág. 1440.

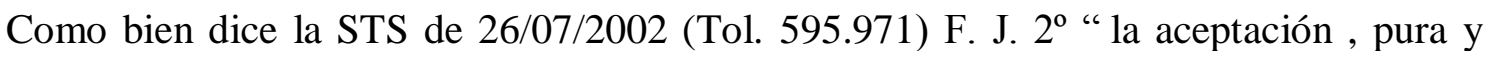
simple y desde que se produce esta, es a partir de la cual, cuando los herederos quedan obligados a responder de todas las cargas de la herencia, no sólo con los bienes de esta, sino con el propio patrimonio de los herederos, y esta aceptación no se ha producido". Tambien la STS de 07/11/06 (Tol. 2.060.194) F.J. $2^{\circ}$ y la STS de 26/07/2002 (Tol. 595.971) F. J. $2^{\text {o }}$ "En el primer motivo del recurso al amparo del $\mathrm{n}^{\circ} 4$ del art. 1692 de la L.E.C ., alega infracción por no aplicación del art. 1003 del Código civil, en atención a que nuestro ordenamiento jurídico, no se sucede al causante por el mero hecho del fallecimiento, sino como dice el precepto indicado, por la aceptación pura y simple desde que se produce esta, es a partir de la cual, cuando los herederos quedan obligados a responder de todas las cargas de la herencia, no sólo con los bienes de esta, sino con el propio patrimonio de los herederos, y esta aceptación no se ha producido".

${ }^{473}$ Señala VIVAS TESÓN, I.: “Aceptación...”, op. cit., pág. 3146 que la aceptación pura y simple " conlleva la responsabilidad ilimitada del heredero o ultra vires hereditatis ex art. 1003 del Código Civil)"

474 DieZ - PICAZO, Y PONCE DE LEÓN, L.: “ La aceptación de la herencia por los acreedores del heredero", Anuario de Derecho Civi, núm. 1, 1959, páginas 127 y ss.

${ }^{475}$ SÁnchez CAlero, Moreno Quesada, GonzÁlez Porras, AA VV, Curso de Derecho..., op. cit., pág. 378 manifiesta que admitida e indiscutida la confusión de patrimonios entre causante y el heredero que ha aceptado pura y simple la herencia, permanecen como separados frente a quienes tienen créditos contra el patrimonio 
Por lo que respecta a la confusión de patrimonios, citada en el párrafo anterior, cabe destacar las medidas tomadas el respecto por el Derecho anglosajón que recoge el principio de separación de patrimonios de manera automática $^{476}$. Este sistema rechaza la confusión entre el patrimonio del causante y el del heredero. Más bien procede, no a separar ambos patrimonios, sino a no dejar que se junten. Consigue tal propósito, con la previa obligación de liquidar la herencia. En el Derecho español tenemos como regla general la confusión de patrimonios y de hecho es lo que ocurre en la mayoría de las sucesiones que se producen en la actualidad. La excepción sería la aceptación a beneficio de inventario o el derecho a deliberar. Una importante diferencia con el sistema anglosajón es precisamente la regla general de este, de anteponer la liquidación de la herencia a todos pasos hereditarios ${ }^{477}$.

Por lo expuesto se puede sintetizar que la aceptación de la herencia por parte del heredero es la declaración de voluntad del llamado a la sucesión que admite la herencia deferida a su favor ${ }^{478}$. Por lo que respecta a las formas de aceptar la herencia, son las dos maneras ya señaladas de conformidad con el artículo 999 del Código civil ${ }^{479}$ :

hereditario, como pueden ser acreedores y legatarios. Éstos pueden exigir sus derechos con preferencia a los acreedores del heredero.

${ }^{476}$ Rivas MARTíneZ, Derecho...( tomoIII),,op. cit., pág. 2482.

${ }^{477}$ Mingorance Gosálvez, C.: "Los principios de confusión y de separación de patrimonios en el derecho hereditario español", Revista Crítica de Derecho Inmobiliario, núm. 752, noviembre 2015, pág. 2238.

478 OCHOA MARCO, R. y SEBASTIÁN CHEMA, M.S.: La herencia ..., op. cit., pág.142.

479 Rivas MartíneZ, J.J.: Derecho...( tomoIII), pág. 2489. . La STS de 29/07/2012 (RJ 2012\9001) F.J. $2^{\circ}$ refrenda las formas de aceptación expuestas en el texto: debe tenerse en cuenta el artículo $999 \mathrm{Cc}$ referido a las formas que puede presentar la aceptación pura y simple de la herencia, ya sea expresa o tácita. 
1. La aceptación expresa, que recoge el artículo citado del Código civil, es la que se hace en documento público o privado ${ }^{480}$. Ello quiere decir que la forma escrita es necesaria en cualquiera de las dos modalidades señaladas (Art. 999 II Cc) ${ }^{481}$.

2. La aceptación tácita puede producirse conforme a los artículos 999, 1000 y $1002 \mathrm{Cc}$ por distintos supuestos. El primero lo recoge de los artículos citados en su apartado tercero dispone la aceptación tácita para actos que necesariamente supongan la voluntad de aceptar o que no se pudieran ejecutar sin la cualidad de heredero ${ }^{482}$. Existen actos de los que

${ }^{480}$ LaSARTE Álvarez, Derecho..., op. cit., pág. 278.

${ }^{481}$ Señala VIVAS TESÓN, I.: “Aceptación y repudiación de la herencia tras la ley de jurisdicción voluntaria", Revista Crítica de Derecho Inmobiliario, núm. 758, noviembre, 2016, pág. 3161, la posibilidad de formalizar la aceptación en documento no público: "Dudas genera también la fecha de inicio del cómputo del plazo cuando la aceptación genérica de la herencia se realice de forma expresa pero no en documento público, o bien tácitamente, lo que es perfectamente posible ex artículo 999 del Código Civil, quedando aquellas irresueltas. Tambien coincide con esta afirmación Lasarte Álvarez, Derecho..., op. cit., pág. 278, tras manifestar la imposibilidad de que manifestaciones verbales del llamado a la herencia sean hábiles para la adquisición de la misma". Sin embargo matiza el autor, que ello "no presupone de manera necesaria que el documento en que se materialice la aceptación sea redactado con tal objeto, sino que ha de admitirse cualquier manifestación escrita que comporte la inequívoca voluntad de aceptación". Corrobora estas afirmaciones Rivas Martínez, Derecho...,( tomoIII), op. cit., pág.2489, encluso matiza que "Una declaración verbal ante testigos o recogida por éstos por escrito no tendría valor”.

482 Rivas MartínEZ, Derecho...,( tomoIII), op. cit., pág. 2490.

La STS de 27/04/1955 (Tol. 4.381.862) en relación al artículo 999.3 Cc: " El párrafo tercero del artículo 999 del Código Civil dice, que existe aceptación tácita de la herencia cuando se realiza por actos que suponen necesariamente la voluntad de aceptar; esa aceptación tiene que referirse a actos que por su eficacia natural e intrínseca ofrezcan la misma garantía de madura reflexión que supone el documento escrito, en el que se toma la cualidad de herederos, y por eso la jurisprudencia ha dicho que no puede entenderse aceptada la herencia por el hecho de haber cobrado el hijo las insignificantes rentas vencidas antes del fallecimiento del padre, que era usufructuario de una parte de dicha finca y los hijos nudos propietarios".

Véase la STS de 27/06/2000 (Tol. 4.973.800) F.J. $2^{\circ}$, en que se refiere al artículo 999.3 Cc de manera histórica: Este precepto procede sustancialmente del Derecho Romano (Instituta, libro $2^{\circ}$, tít. XIX, párrafo 7, "de heredum qualitate et differentia", con arreglo al que "obrar como heredero es obrar como dueño, porque los antiguos decían herederos significando dueños"), y de las Partidas (la ley 11, título VI, Partida Sexta, sobre "en que manera deue el heredero tomar la heredad", se refiere a que "se puede fazer por 
se deduce una voluntad de aceptar. El segundo supuesto, que recoge el artículo $1000 \mathrm{Cc}$, establece tres casos de aceptación tácita de la herencia. El primero se refiere al titular del ius delationis, que de transmitir este derecho equivale a una aceptación tácita de la herencia $^{483}$. Por lo tanto, transmitir o ceder el llamamiento equivale a

fecho: maguer non lo diga paladinamente", y se hace hincapié en la necesidad de la intención de ser heredero), y ha sido objeto de una profusa jurisprudencia".

La SAP de Santander (S. 4) de 11/05/2007 ( Tol. 2.706.762) F. J. $1^{\circ}$ aclara a qué actos se refiere el artículo 999.3 Cc para que la aceptación se considere tácita. Lo hace en un supuesto de hecho en que el actor en Primera Instancia ejercita acción de reparación de daños en una vivienda propiedad de una tia suya fallecida, siendo dicho actor nombrado heredero por la prepietaria de de la vivienda. El hecho de interponer una demanda contra la comunidad de propietarios, estima la Sala, que excede de una mera administración y por consiguiente es una aceptación tacita de la herencia. El demandante en $1^{\text {a }}$ Instancia dice en los hechos de su demanda: "Mi mandante es propietario de la vivienda sita en..." la Sala estima que: "dicha propiedad no podría atribuírsela de no suponer una aceptación tácita de la herencia. A ello debe añadirse que la propia apelante ha considerado legitimado al actor respecto a la vivienda mencionada". La SAP de Madrid (S. 18) de 24/03/2010 (Tol. 1,872.822) más que aportar actos por los que se puede entender una aceptación tácita aporta actos que no son considerados como tal. El supuesto de hecho trata de unos hijos que con anterioridad al fallecimiento de sus padres ya habitaban la casa propiedad de estos y corrian con los gastos de suministros y comunidad de propietarios. Fallecidos los padres y propietarios de la vivienda la propia junta de la urbanización interpone demanda contra los hijos que no es admitida por el juzgado. La Junta de la urbanización apela la resolución de Inatancia alegando claros indicios de aceptación tácita de la herencia de sus padres por parte de sus hijos. En el F.J. $1^{\circ}$ la Sala entiende que "no supone necesariamente, por el mero hecho de vivir en la misma, que hayan aceptado la herencia de sus padres, como tampoco se deriva esa aceptación tácita, del hecho de abonar los gastos de suministros y de comunidad de propietarios, puesto que son actos de mera conservación o administración provisional que no implican aceptación de la herencia si con ellos no se ha tomado el título o cualidad de heredero, conforme establece el tercer párrafo del artículo 999". Los apelantes manifestaron como actos de aceptación tácita el hecho que los demandados estarán pagando las pertinentes cuotas de la hipoteca que gravaba la vivienda, que incluso lo hacían con anterioridad al fallecimiento de sus padres. En el F.J. $2^{\circ}$ la Sala estima que "el pago de deudas si no se realiza con bienes del caudal hereditario, no implica ni supone aceptación tácita de la herencia, puesto que tienen derecho al pago de las deudas de otro independientemente de su condición de herederos".

${ }^{483}$ Señalan DíEZ- PiCAZO. y Gullón, Sistema de derecho civil..., op. cit., pág. 236, que "los adquirientes adquieren lo que al transmitente le correspondería, no su cualidad que es intrasmisible". Así lo refrenda la STS de 20/07/2012 (Tol. 2.654.655) F.J. 2 ${ }^{\circ}$ "entendida en términos de aceptación de la herencia, no comporta, en ningún caso, la transmisión directa del ius delationis al beneficiario de la misma; por tanto, el 
aceptar la herencia de manera tácita, puesto que no se entiende la transmisión de no pretender su aceptación ${ }^{484}$. El segundo apartado del artículo $1000 \mathrm{Cc}$ el llamado ha intervenido como adquiriente de la herencia y realiza un nuevo acto de trasmisión, aunque lo haga a título gratuito $^{485}$. El tercer apartado del citado artículo $1000 \mathrm{Cc}$ trata de cuando el heredero renuncia a la herencia en favor del resto de herederos y lo hace a título lucrativo, es decir, renuncia a la herencia a cambio de un precio en favor de todos los demás herederos. El precio en este caso es la contraprestación de un derecho propio que enajena ${ }^{486}$. En cambio de ser la renuncia a título gratuito a favor de quienes favorecerá el derecho de acrecer de la renuncia se considera que la herncia no ha sido aceptada, ya que nada ha cambiado en el destino de los bienes ${ }^{487}$.

adquirente lo será siempre del heredero y no del causante cuya herencia es aceptada con esta fórmula".

Véase a este aspecto en la Resolución de 9 de junio de 2015, de la DGRN (RJ 201513619) Adición de herencia. Derecho de transmisión en Comentarios a las Resoluciones de la Dirección General de Registros y Notariado, núm. 127, julio, 2015, "La doctrina legal sentada por el Tribunal Supremo en dos sentencias sucesivas pone fin a la polémica doctrinal que constituía "un clásico" en el Derecho español. Partiendo de la unidad del fenómeno sucesorio, entiende el TS que el transmisario sucede directamente al primer causante sin que los bienes hagan tránsito por la herencia del transmitente, quien lo único que transmite es el ius delationis".

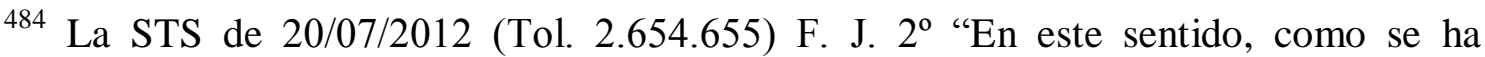
recalcado, si la renuncia traslativa comporta una implícita aceptación ex lege de la herencia lo es, en la medida, en que también presupone el ejercicio de aceptación del pertinente ius delationis, como presupuesto de legitimación para adquirir el derecho hereditario". En el F. J. $2^{\circ}$, apartado $3^{\circ}$ se refiere a lo expuesto en el texto señalando que "Delimitado, de este modo, el contexto interpretativo, no hay inconveniente alguno en señalar, conforme a la doctrina reciente, que la fórmula de la renuncia traslativa, a tenor del artículo 1000.1 del Código Civil, comporta una implícita aceptación ex lege de la herencia y, por tanto, del ius delationis, que causaliza al inmediato negocio de atribución intervivos realizado, particularmente el de una cesión gratuita del derecho hereditario".

${ }^{485}$ Rivas MARTíneZ, Derecho... (tomoIII), op. cit., pág. 2492.

${ }^{486}$ Rivas Martínez, Derecho... (tomoIII), loc. cit., pág. 2492.

${ }^{487}$ Rivas MartíneZ, Derecho...( tomoIII), op. cit., pág. 2492. Tambien en esta línea DíEZ- PicAZO. y Gullón, Sistema de derecho civil..., op. cit., pág. 236. 
El tercer supuesto recogido por el artículo 1002 Cc esta referido a los herederros que sustraigan u oculten efectos de la herencia. Ello les hace perder la facultad de renunciar a la misma, quedando como herederos puros y simples ${ }^{488}$. Es decir, sin poderse acoger al beneficio de inventario $^{489}$.

No se puede pasar por alto el punto $4^{\circ}$ del artículo $999 \mathrm{Cc}^{490}$ que dispone que los actos de mera conservación o de administración provisional de la herencia ${ }^{491}$, no impliquen la aceptación de la misma, si

${ }^{488}$ Matiza Rivas MartíneZ, Derecho... (tomoIII),op. cit., pág. 2493, sin perjuicio de las penas en que hayan podido incurrir.

${ }^{489}$ Ejemplos referenciados por el Tribunal Supremo de aceptación Tácita, entre otros, podían ser: STS de 15/06/1982 (Tol. 1.739.290) F.J. $5^{\circ}$ Cobro de créditos hereditarios; STS 20/11/91 (Tol. 1.728.486) F.J. $2^{\circ}$ que cita los efectos del artículo 999 del Código Civil. Se deduce claramente de la actividad que desplegaron, instando ante los servicios oficiales correspondientes la calificación de ganancial en vez de parafernal de la finca onjeto de la controversia; STS 24/11/1992 (Tol. 5.122.947) F.J. $7^{\circ}$ "La expresada calificación de aceptación tácita ha de atribuirse, sin duda alguna, a la conducta de D. Juan, al impugnar la validez del testamento de su hermana"; STS de 12/07/1996 ( Tol. 1.658.936) F.J. $1^{\circ}$ cuyo supuesto de hecho trada de que un coheredero e hijo del causante cierra la empresa de su padre, que en vida de este hacía funciones de gerente en dicha empresa. Ello se considera aceptación tácita de la herencia: "En definitiva, aparte de otras manifestaciones de la conducta de Don Carlos María con clara incidencia en la conclusión expuesta al principio, el pago de deudas contra el caudal hereditario y la cesación y cierre de la empresa de Don Juan Pedro , actos de indudable significación patrimonial y cáracter definitivo, encajan indiscutiblemente entre los que esta Sala, en sentencias, entre otras, de 13 de Marzo de 1.952, 23 de Mayo de 1.955, 16 de Junio de 1.961, 14 de Marzo de 1.978 y 15 de Junio de 1.982, considera como propios de aceptación tácita de la herencia”. Así la STS de 15/05/1955 (Tol. 4.381.440) F. J. pagos con bienes hereditarios de deudas de la misma herencia.

${ }^{490}$ Artículo 999. 4 Cc: "Los actos de mera conservación o administración provisional no implican la aceptación de la herencia, si con ellos no se ha tomado el título o la cualidad de heredero".

${ }^{491}$ VIVAS TESÓN, I.: “Aceptación...”, op. cit., pág. 3172, "los efectos de esta aceptación a beneficio de inventario es que hasta que resulten pagados todos los acreedores conocidos y los legatarios, se entenderá que se halla la herencia en administración (ex art. 1026 del Código Civil) y, pagados los acreedores y legatarios, quedará el heredero en el pleno goce de la herencia (ex art. 1032 del Código Civil), pues las limitaciones impeditivas del pleno goce son precisamente la de permanecer la herencia en administración. Ocurre que esa administración carece de trascendencia real por lo que no tiene acceso al Registro de la propiedad". 
con dichos actos no se ha tomado el título o la cualidad de heredero. Entiendo que aquí lo que cabe aclarar es a qué llama el precepto título o cualidad de heredero. Por lo tanto, un padre fallecido al que un tercero le debe dinero, si se presenta el hijo del fallecido y le reclama la deuda identificándose como el heredero de su padre está de manera tacita aceptando la herencia de aquél. En cambio si se presenta como hijo del acreedor y reclama la deuda simplemente, está haciendo meros trámites de administración y no se puede decir que haya aceptado de manera tácita ${ }^{492}$. Es de suma importancia tener esto en cuenta, de cara a posibles reclamaciones por parte de acreedores de la herencia, pues, en tanto no acepte no responde de las deudas de la herencia, puesto que simplemente es un llamado a suceder y no un heredero ${ }^{493}$.

\footnotetext{
${ }^{492}$ Es relevante, al respecto de la aceptación tácita, la STS de 13/02/2003 (RJ 2003\1017) F. J. $2^{\circ}$ cuando en su en contestación a la recurrente, que alega haberse infringido el artículo $999 \mathrm{Cc}$ entre otros. Se sostiene por parte de los demandantes en Instancia que, no hay constancia de que se hubiera aceptado la herencia. El Alto Tribunal responde acerca del artículo 999 Cc: “también contempla la aceptación tácita que tiene lugar cuando se interpone demanda, tanto en nombre propio como en nombre de la herencia yacente respecto de los bienes relictos." Entiendo que el hecho de interponer demanda con respecto a los bienes relictos hace suponer un interés legítimo al demandante tanto si actúa en nombre propio, como si lo hace en nombre de la herencia. Caso contrario no se molestaría en entrometerse en algo que no le afecta.
}

${ }^{493}$ LÓPEZ BELTRÁN DE HEREDIA, C. "Aceptación y repudiación de la herencia. El derecho a deliberar", en Cuadernos Prácticos Bolonia (coord. F. Lledó Yagüe), Dykinson, Madrid, 2010, págs. 66 y 67. Por lo que respecta al arrepentimiento de haber repudiado una herencia hay que tener presente que no tiene vuelta atrás, así como tampoco la tiene la aceptación, es decir, tanto en la aceptación como en la repudiación no se puede aceptar y luego repudiar o viceversa. Lo único que se puede hacer, llegado el caso de que concurra causa legal para ello, es pedir la declaración de nulidad de la aceptación o de la revocación. La autora pone como ejemplo los vicios de consentimiento de la autonomía de la voluntad, en aquellos supuestos en que el aceptante o repudiante, respectivamente, hubieran emitido su declaración de voluntad bajo alguno de los vicios de consentimiento que recoge y regula el artículo 1265 y ss., Cc. Por ejemplo, lo dispuesto en el artículo del propio precepto $1265 \mathrm{Cc}$ cuya disposición: "Será nulo el consentimiento prestado por error, violencia, intimidación o dolo". 
2.11.2. La aceptación a beneficio de inventario y el derecho a deliberar

La aceptación de una herencia a beneficio de inventario, no deja de ser una opción, ante la duda si dicha herencia se acepta o se repudia. Todo ello deriva del temor de que el pasivo supere al activo, pero no se tienen suficientes datos para saberlo. De conocer de manera cierta y segura que el debe supera al haber, la figura que tiene cabida por los motivos que seguidamente se verán es sin ninguna duda la repudiación. En definitiva, el objetivo del beneficio de inventario, es limitar la responsabilidad del heredero en la herencia del causante ${ }^{494}$. El beneficio de inventario puede definirse como una facultad que la Ley atribuye al heredero para limitar su responsabilidad respecto a los bienes de la herencia (responsabilidad intra vivos $)^{495}$. Lo que hace que esta se configure de manera especial: permanece como un patrimonio en liquidación de sus cargas y deudas separado del propio heredero, al que pasará lo que reste de la liquidación ${ }^{496}$.

Si bien el legislador, por medio del beneficio de inventario, limita la responsabilidad del heredero frente al acreedor del causante. También el propio legislador le impone al heredero el cumplimiento de ciertas reglas, dispuestas en el artículo 1024 Cc cuyo incumplimiento supondría la

\footnotetext{
494 Señala EsPEJO LERDo DE TEJADA, M.: La cesión de la herencia en el código civil: ¿cambio personal del heredero?, Anuario de Derecho Civil, núm. LXI-4, Octubre 2008, pág. 1881, el beneficio de inventario "como mecanismo para suavizar los efectos de la aceptación de la herencia en cuanto a la responsabilidad del heredero por las deudas hereditarias".

${ }^{495}$ ArAgOnÉs SEIJO, S.: "El beneficio de inventario, de Miguel Ángel Pérez Álvarez", Revista Crítica de Derecho Inmobiliario, núm. 762, Julio 2017, pág. 1882. Define el beneficio de inventario como "una solicitud del llamado a una herencia por la que manifiesta al Notario su voluntad de acogerse al beneficio de inventario en base al inventario que se elaborará posteriormente".
}

${ }^{496}$ DíEZ- PiCAZO. y Gullón, Sistema de derecho civil..., op. cit., pág. 240. 
aplicación de la sanción civil de perdida, para el heredero, del beneficio de inventario concedido ex lege ${ }^{497}$.

Los artículos que regulan la aceptación a beneficio de inventario son el artículo 1010 y ss del Código civil. El artículo 1011 Cc dispone que la potestad de hacer uso del derecho a aceptar a beneficio de inventario se tenga que hacer de forma notarial ${ }^{498}$. No ha sido siempre así, ya que con anterioridad a la modificación del precepto por la Ley 15/2015, de 2 de julio, de Jurisdicción Voluntaria además de poder hacerse ante Notario se podía hacer por escrito por vía judicial con las formalidades requeridas por el artículo 1012 y ss $\mathrm{Cc}^{499}$. Por lo tanto la citada Ley de Jurisdicción Voluntaria ha dejado al Notario como única figura ante quien procede hacer tal declaración y ha cambiado el término aceptación a beneficio de inventario por el de hacer uso del inventario. Ello supone hacer uso de él, con posterioridad a la aceptación ${ }^{500}$. Además los nuevos artículos 67 y 68

497 STS de 28/01/2011 (RJ 2011\301) F. J. $2^{\text {o }}$ "De aquí que se pierda el beneficio de inventario si realiza algún acto doloso o culposo de enajenación de bienes hereditarios, conforme al artículo $1024.2^{\circ}$ del Código civil, debidamente interpretado; es decir, se trata de enajenación irregular, anómala; se trata de una enajenación que es válida pero que entraña una irregularidad que se sanciona con la pérdida del beneficio de inventario. Una antigua sentencia de 4 de abril de 1903, refiriéndose el número $1^{\circ}$ del mismo artículo lo aplica cuando el heredero ha actuado "maliciosamente con el propósito de lucrarse o de perjudicar a los interesados en la sucesión o con cualquier otro intento más o menos".

498 VIVAS TESÓN, “Aceptación...”, op. cit., pág. 3155 señala a partir de la entrada en vigor de la LJV, [Ley de Jurisdicción Voluntaria] la nueva redacción permite concluir que es posible declarar hacer uso del beneficio de inventario con posterioridad a la aceptación hereditaria.

${ }^{499}$ VIVAS TESÓN, “Aceptación...”, op. cit., pág. 3156. La autora considera acertado que la única vía válida para tal proceder sea la notarial.

${ }^{500}$ LORA-TAMAYO, RODRÍGUEZ, I. Y PÉREZ RAMOS, C.: Cuestiones prácticas... ”, op. cit., pág. 433. Define este autor, conforme a la doctrina, la aceptación de la herencia a beneficio de inventario como: "la facultad que el ordenamiento atribuye al heredero para que pueda aceptar la herencia manteniéndola separada de sus propios bienes hasta que se haya pagado a todos los acreedores conocidos y a todos los legatarios y para que, apareciendo otros acreedores después de la confusión, sólo responda, personalmente en la medida en que se haya enriquecido a consecuencia de la sucesión". 
de la Ley Orgánica del Notariado han dotado por primera vez de una normativa que regula la forma en que los notarios han de realizar el inventario. La formación de inventario es ahora un expediente notarial de justificación voluntaria que se tramita bajo forma de acta.

Es lógico que antes de aceptar una herencia haya que saber lo que hay en la propia herencia. Para ello hay que inventariarla teniendo en cuenta las excepciones del artículo1321 Cc que puede de manera directa afectar a los legitimarios, tanto en beneficio como en perjuicio, dependiendo de la clase de legitimario que sea. El precepto dispone que tratándose de un causante que deje viudo, "las ropas, el mobiliario y enseres"pasan al supérstite superviviente y además no se le computa en la herencia. De ahí que si el legitimario es el viudo le beneficia, pero perjudica al resto de legitimarios $^{501}$.

Precisamente esta manera de adquirir la herencia, por medio de la aceptación, le otorga el carácter romano, es decir, es el modelo romano el que usa el derecho español al adquirir, los bienes de la herencia, por medio de la aceptación. A diferencia de la tesis germanista que sin que medie la aceptación de la herencia esta pasa, ipso iure (automáticamente por ministerio de la Ley) del causante al heredero. Simplemente, en aquel Derecho, la aceptación tiene lugar con posterioridad a título de consentimiento de los bienes adquiridos. Dicho de otra manera vendría a ser como renunciar al derecho de repudiación ${ }^{502}$. No se puede seguir

\footnotetext{
${ }^{501}$ DíEZ- PiCAZO. y Gullón, Sistema de derecho civil..., op. cit., pág. 271.

${ }^{502}$ LÓPEZ LÓPEZ, M. Y HORNERO MÉNDEZ C.: "La sucesión mortis causa: conceptos generales", en Derecho de sucesiones (coords. J. P. Pérez Velázquez y E. Pizarro Moreno) $2^{a}$ ed, Tirant lo Blanch, Valencia, 2017, págs. 48 y 49. Resalta el autor, que la mayoría de la doctrina se adhiere al sistema romanista de que la herencia se adquiere por la aceptación. Bajo la modesta opinión de quien suscribe el argumento que esgrimen los romanistas de que la aceptación es un rechazo de repudiar la herencia, sólo hace que resaltar el perfilado que tiene el Derecho español con respecto al germano, por ejemplo.
} 
hablando de la figura de la aceptación a beneficio de inventario, sin identificar su procedencia. Como es de suponer, tal figura jurídica procede de Justiniano, concretamente de la Constitución del año 513 d C. con el propósito de no confundir los patrimonios de cara al acreedor. Ello ya nos anticipa que el beneficio de inventario está sometido a una serie de pautas formales nada sencillas ${ }^{503}$.

Las distintas pautas, antes descritas, para aceptar la herencia a beneficio de inventario comienzan con el artículo 1002 Cc. Precepto, el citado, que hay que tener muy en cuenta, puesto que tanto la sustracción como la ocultación de efectos de la herencia es contraria a la facultad de poder aceptar la misma a beneficio de inventario ${ }^{504}$. Incluso, estimo, que del precepto cabe resaltar que se refiere a "efectos", por lo que no determina los bienes y se puede entender con ello cualquier cosa que esté incluida en la masa hereditaria. Por lo que respecta a los plazos de solicitud, el artículo $1016 \mathrm{Cc}$ dispone que, salvo excepciones, pueda instarse, el beneficio de inventario o el derecho a deliberar, mientras no prescriba la acción para reclamar la herencia. Dicho esto parece que el precepto, en principio, no concuerda con sus inmediatamente anteriores del mismo cuerpo legal. Así de los artículos 1014 y 1015 Cc simplemente se desprende un plazo de 30 días para utilizar el derecho a deliberar o el

Pienso que la herencia o se rechaza o se repudia y que todo lo que se añada es rizar el rizo, por muy germano que sea el rizador.

${ }^{503}$ LaSARTE Álvarez, Derecho de sucesiones..., op. cit., págs. 202 y 203.

504 STS de 20/10/1011, (RJ 2012\426) F. J. 4o "Según establece el artículo 1002 del Código Civil , cuyo texto ha sido transcrito, la realización de la conducta típica del llamado a la herencia a título de heredero hace que "ex lege" adquiera tal condición sin posibilidad de acogerse al beneficio de inventario. Es la conducta de sustracción u ocultación de bienes hereditarios, después de la apertura de la sucesión y mientras subsiste el derecho de aceptar o repudiar, la que da lugar a la aplicación de dicha norma por razón de la realización de actos de indebida apropiación. Se trata, en definitiva, de una atribución legal de la herencia por causa de un comportamiento ilícito, privando así al heredero de la posibilidad de acogerse al beneficio de inventario, lo que constituye una verdadera pena o sanción de carácter civil". 
beneficio de inventario $^{505}$. El heredero podrá aceptar la herencia a beneficio de inventario o con derecho a deliberar, mientras tenga plazo de acción para poder reclamar la herencia ${ }^{506}$.

Por lo que se refiere a la realización del propio inventario hay que remitirse al artículo $1013 \mathrm{Cc}$ del Código civil que no ha sufrido modificación alguna desde la promulgación del Código que lo contiene. Este precepto exige que la declaración de hacer uso de inventario vaya seguida de inventario fiel y exacto de todos los bienes de la herencia en los plazos y formalidades señaladas en los artículos siguientes. Los plazos para la realización del inventario los recoge el artículo 1017, del Código civil. Como regla general el inventario comenzará dentro de los treinta días siguientes a la citación de los acreedores y legatarios promovida por el heredero y deberá de finalizar dentro de los sesenta días siguientes al día de

\footnotetext{
${ }^{505}$ VIVAS TESÓN, I.: “Aceptación...”, op. cit., pág. 3173. Se apoya la autora para hacer tales afirmaciones en las palabras del Tribunal Supremo, concretamente en lo dispuesto en la STS 15/11/1985,RJ 1985\5611 F.J. $3^{\circ}$, en que se denuncia la incorrecta aplicación del artículo $10114 \mathrm{Cc}$ "la simple aceptación o repudiación de herencia, habida cuenta del contenido de los artículos 1005 y 1016 in fine, no está sujeta a ningún otro plazo que no sea el de prescripción del derecho a reclamar la herencia o derecho de petición, por lo que extraer del artículo 1014 la conclusión de que el plazo específicamente señalado para utilizar el derecho de deliberar o el de beneficio de inventario es extensivo al de simple aceptación o repudiación de la herencia incurre en error de interpretación y, por ende, hay que constatar la indebida aplicación del mismo al supuesto aquí contemplado". También la STS de 06/06/1016 (RJ 201612337) F.J. $1^{\circ}$ se pronuncia de la misma manera, pero en diferente sentido, distinguiendo el artículo $1020 \mathrm{Cc}$ destinado a regular el beneficio de inventario, de los que preceptúan la aceptación o repudiación de la herencia como el 1016 Cc. "Dicho precepto no resulta de aplicación al caso de autos ya que el mismo aparece recogido en la sección dedicada al beneficio de inventario y el derecho de deliberar. Por lo tanto, se regula una situación previa a la decisión sobre la aceptación o repudiación de la herencia. En efecto, el citado precepto describe una situación propia de la fase de elaboración de inventario generada antes de producirse la aceptación de la herencia, y encaminada a propiciar el ejercicio de los derechos de aceptación o repudiación de la herencia en las mejores condiciones posibles (beneficio de inventario y derecho de deliberación)".

${ }^{506}$ LORA-TAMAYO, RODRÍGUEZ Y PÉREZ RAMOS, Cuestiones prácticas..., op. cit., pág. 435.
} 
su comienzo. El Notario, siempre que no exceda de un año, podrá prorrogar este plazo en determinadas circunstancias (art. 1017 II Cc) ${ }^{507}$.

\subsubsection{Los efectos del beneficio de inventario}

El primer efecto que se deriva de la aceptación a beneficio de inventario es la limitación de la responsabilidad del heredero. Este sólo queda limitado hasta donde alcancen los bienes hereditarios. Deudas y cargas hereditarias se hacen efectivas únicamente sobre los bienes de la herencia. Si bien el heredero que ha hecho uso del beneficio de inventario también sucede en las deudas del causante. Lo que ocurre es que la Ley le reconoce una facultad especial que limita su responsabilidad excluyendo su propio patrimonio de la agresión que pudieran ejercer los acreedores hereditarios del causante. La consecuencia inmediata conlleva la separación entre el patrimonio del causante y el del heredero. Tal separación patrimonial la recoge el artículo $1023 \mathrm{Cc}$ con el objeto de evitar daño contra los bienes que pertenezcan de manera particular al heredero. Sin pasar por alto el artículo 1026 Cc que dispone el régimen de administración para la herencia hasta que resulten pagados todos los acreedores conocidos y legatarios. Consecuencia de la administración es la custodia, seguridad y conservación de los bienes hereditarios entre otras obligaciones ${ }^{508}$.

Debido a que el objetivo de la separación de patrimonios es que se paguen sus propias deudas y cargas el patrimonio del causante ha de interpretarse que este es un patrimonio en liquidación. En el que tiene cabida la enajenación de bienes para saldar deudas y cargas, en el caso de faltar caudal líquido en la propia herencia, ello hay que hacerlo conforme

\footnotetext{
${ }^{507}$ LaSARTe ÁlvareZ, Derecho de sucesiones..., op. cit., págs. 281 y 282. Como ya se ha indicado y confirma el profesor Lasarte, el beneficio de inventario provoca la separación entre los patrimonios del causante y los del heredero.

${ }^{508}$ DíEZ- PICAZO. y Gullón, Sistema de derecho civil..., op. cit., págs. 243 y 244.
} 
dispone el artículo $1030 \mathrm{Cc}$ con remisión al artículo 1024. 2 Cc en que el heredero perdería el beneficio de inventario en el caso de incumplimiento de la disposición allí preceptuada. Las reglas para el pago de las deudas y cargas de la herencia son las dispuestas en los artículos 1027 a $1033 \mathrm{Cc}^{509}$.

\subsubsection{El derecho a deliberar}

Por lo que respecta al derecho a deliberar del artículo 1010. 2 Cc no deja de sorprender este precepto, no por la manera que comienza, sino por la que acaba. Comienza facultando a todo heredero para aceptar la herencia a beneficio de inventario y acaba desvirtuando el principio que dice: "el testador es la Ley en su sucesión". Dispone el precepto que puede aceptar el heredero a beneficio de inventario, aunque el testador lo prohíba en su testamento. Simplemente cabe matizar que, de no contar el legislador con esta prohibición dispuesta en el precepto, le sería muy fácil al disponente coaccionar la libre decisión del heredero desinformado sobre el patrimonio del causante. De la misma manera, el segundo apartado del precepto citado, le da derecho al heredero para que pueda hacer inventario, estudiarlo y en consecuencia deliberar la pertinente aceptación o repudiación de la herencia. En concordancia con lo expuesto es la propia Ley la que le concede al heredero la facultad de inventariar y examinar, en los plazos previstos por la misma Ley, cómo se encuentra la herencia con respecto a su activo y a su pasivo, para poder aceptar o repudiar la misma ${ }^{510}$.

Al igual que la aceptación de la herencia a beneficio de inventario, el derecho a deliberar, como ya se ha apuntado, faculta al heredero para hacer inventario cuya temporalidad es la que recoge, el también citado, artículo 1014, de Código civil, así como, son aplicables, los plazos para realizar el

\footnotetext{
${ }^{509}$ DíEZ -PiCAZO. y GULLón, Sistema de derecho civil..., op. cit., págs. 245 y 246

${ }^{510}$ JuÁREZ GONZÁlEZ, J. M.: GPS..., op. cit., pág. 379.
} 
inventario del artículo 1017. Dichos plazos de solicitud tanto de deliberación como de beneficio de inventario resaltan por su brevedad ${ }^{511}$. Son sumamente breves o del mismo texto legal, sin dejar de tener en cuenta, que las sanciones por no cumplir lo dispuesto en del artículo 1018 Cc tienen aplicación al principio del derecho a deliberar.

El inventario solicitado para deliberar y recogido por el artículo $1019^{512}$ Cc produce el efecto de tener la obligación de manifestar ante el Notario, y no al juzgado, como ocurría con anterioridad a la reforma del precepto por la Ley 15/2015, de 2 de julio de Jurisdicción Voluntaria. Lo ha de hacer dentro de los 30 días contados desde el siguiente al que se hubiese concluido, tanto si acepta como si repudia la herencia y añade el precepto citado que, de pasar dichos 30 días sin pronunciamiento a favor o en contra de la aceptación, se dará por entendido que acepta la herencia. También el artículo $1018 \mathrm{Cc}$ da la herencia por aceptada si como consecuencia de negligencia o culpa del heredero, el inventario no se comenzara a realizar o bien no se acabara dentro de los plazos y con la solemnidades previstas y predispuestas por la Ley. Por lo tanto, si el heredero deja pasar el plazo de 30 días sin pronunciarse o si por su culpa el inventario no comienza a realizarse o se queda inacabado, en ambos casos

\footnotetext{
${ }^{511}$ ViVAS TESÓN, I.: “Aceptación...”, op. cit., pág. 3157. "Los plazos para solicitar el derecho de deliberar o el beneficio de inventario (a no confundir con los de aceptación o repudiación de la herencia) son muy breves (en la redacción vigente hasta el 22 de julio de 2015), diez días desde el día en que supiere ser heredero si residía en la misma población en que hubiere fallecido el causante y treinta si residía fuera; tras la LJV, treinta días desde aquel en que supiere ser tal heredero, sin distinción del lugar de su residencia)".

512 Artículo 1019 Cc: "El heredero que se hubiese reservado el derecho de deliberar, deberá manifestar al Notario, dentro de treinta días contados desde el siguiente a aquel en que se hubiese concluido el inventario, si repudia o acepta la herencia y si hace uso o no del beneficio de inventario. Pasados los treinta días sin hacer dicha manifestación, se entenderá que la acepta pura y simplemente".
} 
se le entiende que ha aceptado, si bien de manera tácita, pero por aceptada queda la herencia $^{513}$.

Se podría pensar que el derecho a deliberar y el beneficio de inventario son dos figuras bastante semejantes, ambas a fin de cuentas tratan de advertir al heredero del peligro que puede encontrarse en una determinada herencia y en consecuencia no aceptarla. Pero nada más lejos de la realidad, puesto que ambas figuras son instituciones completamente distintas. El derecho a deliberar da facultad previa, de que dispone el heredero, para aceptar o no aceptar la herencia. Mientras que la aceptación a beneficio de inventario es simplemente una las clases o maneras de aceptar la herencia. El derecho a deliberar, tiene la ventaja frente al uso del beneficio de inventario, que una vez conocida la composición del activo y del pasivo ya puede renunciarse o aceptarse. Por el contrario el que acepta la herencia y el beneficio de inventario luego tiene que liquidar la herencia cumpliendo trámites y procedimientos. Téngase presente que se puede aceptar, por ejemplo, de manera pura y simple en lugar de hacerlo a beneficio de inventario. Lo que sí que ambas figuras tienen la misma finalidad, dicha anteriormente, de advertir al heredero de supuestas deudas en la herencia. El motivo de mantener en el vigente Código civil el derecho a deliberar es puramente histórico ${ }^{514}$.

\subsection{LA REPUDIACIÓN}

2.12.1. La repudiación de la legítima

Repudiación, en palabras de García Goyena, significa: “desaire o afrenta" al testador por parte del heredero testamentario que repudia toda o

\footnotetext{
${ }^{513}$ SÁnchez CALERo, , Moreno QuesadA, GonZÁlez Porras, AA VV, Curso de Derecho..., op. cit. pág. 389.

${ }^{514}$ Lledó Yagüe, F., Monje Balmaseda, O., Herrán OrtiZ, A.. I., AAVV.: Cuaderno Teórico Bolonia I... op. cit., pág. 85.
} 
parte de la herencia. De ahí que en el Proyecto de 1851, el repudiante, perdiera todos sus derechos ante otros llamamientos del mismo causante, como pudieran ser los legados o las mejoras, artículos 839 y 665 del Proyecto de Código civil de $1851^{515}$. Por repudiación se entiende que un llamado a la sucesión que pudo haberla aceptado y, sin embargo, no lo hizo $^{516}$. Antes de proseguir con esta figura jurídica deseo manifestar que me referiré a ella, bien como renuncia o bien como repudiación. Sin desconocer por ello que el sentido técnico de la repudiación de herencia no es exactamente una renuncia a la misma, por el simple motivo que la primera es una figura con rasgos jurídicos propios que no la puede suplantar la segunda ${ }^{517}$.

Sí el llamado a la sucesión renuncia a la misma, con ello renuncia a convertirse en heredero del causante, cuya manifestación no admite otra forma que no sea la expresa, conforme al artículo $1008 \mathrm{Cc}$ que exige formalizar la renuncia ante Notario en escritura pública ${ }^{518}$. Otro precepto, a

${ }^{515}$ Galván Gallegos, A.: "La indivisibilidad de la aceptación y repudiación de la herencia", Anuario de Derecho Civil, núm. L-4, 0ctubre, 1997, pág.1821, cita (7) (García Goyena, Concordancias, motivos y comentaros del Código Civil Español, II, Madrid, 1852, p. 212). También pone de manifiesto la autora la posibilidad actual, en caso de varios llamamientos, de repudiar unos y aceptar otros.

516 ARJONA GUAJARDO, J.L.: "Derecho de representación sucesoria y repudiación. Estudio sobre la operatividad del derecho de representación en el Código civil español, en caso de repudiación del sujeto llamado a una herencia", Anuario de Derecho Civil, núm LXV-I, enero 2012, pág. 114. Tambien OCHOA MARCO Y SEBASTIÁN CHEMA, La herencia..., op. cit., pág. 143, mantiene como definición de la repudiación el rechazo formal de la herencia deferida a favor de quien repudia.

${ }^{517}$ FeÁs Costilla, J.: "la renuncia de herencia: problemas y riesgos", Anales de la Academia Sevillana del Notariado, Tomo XXV, Conferencias del curso académico 2013-2014, Sevilla 2014, pág. 151.

${ }^{518}$ DíEZ PiCAZO. y Gullón, Sistema de derecho civil..., loc.. cit., pág. 236, mantienen que la forma notarial tiene carácter constitutivo en la repudiación. Tambien hace la misma aseveración Vivas Tesón, "Aceptación...", op. cit., pág. 3153. FERNANDEZ EGEA M.A.: "La aceptación y la repudiación de herencias por las fundaciones" Revista Vasca de Economía Social, núm 13, 2016, pág. 72, con relación al artículo 1008 Cc y especialmente en su nueva redacción por la LJV que dispone que la repudiación de la herencia deberá hacerse siempre en documento público ante Notario. Entiende la autora: 
destacar de la repudiación es el artículo 923 Cc que impide que los descendientes del repudiante lo representen en la herencia que ha repudiado. Dentro de las consecuencias que puede acarrear la repudiación de una herencia, siendo o no siendo legitimario, se encuentra lo dispuesto en el artículo 890.2, 833 y 928 Cc. Todos ellos permiten, entre otros, mantener otras relaciones jurídicas o derechos con el causante de la herencia que ha repudiado ${ }^{519}$. El primero de los preceptos señalados permite al repudiante, que a la vez es legatario, renunciar a la herencia y aceptar el legado o, al contrario, es decir, renunciar al legado y aceptar la herencia. El segundo, (833 Cc.) en principio, permite habiendo renunciado a la herencia aceptar la mejora. El tercero de los preceptos expuestos permite el derecho de representar a una persona incluso en el supuesto de haber renunciado a su herencia.

Otra de las facultades que envuelve la repudiación a la herencia es su transmisión. Esta en virtud del artículo 1006 Cc en el supuesto de que un heredero haya muerto antes de haber aceptado o repudiado una herencia, los herederos de éste, heredan su derecho a aceptarla o a repudiarla, de la misma manera que aquel lo tenía. La jurisprudencia del Tribunal Supremo siempre ha destacado tanto de la aceptación como de la repudiación de la

\footnotetext{
"que en el seno de un procedimiento de división judicial de la herencia, se documente judicialmente la renuncia de uno de los herederos parte en el procedimiento".

El artículo $1008 \mathrm{Cc}$, antes de la entrada en vigor de la Ley de Jurisdicción Voluntaria, tenía el siguiente redacción: " La repudiación de la herencia deberá hacerse en instrumento público o auténtico, o por escrito presentado ante el Juez competente para conocer de la testamentaría o del abintestato". La nueva redacción del artículo 1008 Cc a partir de la vigencia de la LJV es el siguiente: La repudiación de la herencia deberá hacerse ante Notario en instrumento público". Es interesante traer a colación con

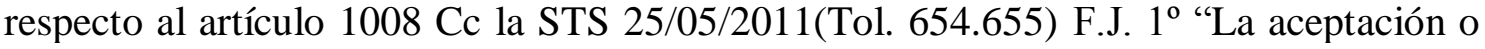
la repudiación de la herencia puede hacerse en alguna de las formas establecidas en losartículos 999 y 1008 del CC respectivamente".

${ }^{519}$ LÓPEZ DE LA CruZ, L. Y PiZARro Moreno, E.: "Los efectos de la sucesión” en Derecho de sucesiones (coords J. P. Pérez Velázquez y E. Pizarro Moreno) $2^{\mathrm{a}} \mathrm{ed}$, Tirant lo Blanch ,Valencia, 2017, pág. 198.
} 
herencia su irrevocabilidad, salvo cuando aparezca algún vicio que ponga en duda el consentimiento del que repudia ${ }^{520}$.

En el supuesto de que la repudiación del heredero venga motivada por causar un perjuicio a sus acreedores, estos tienen facultad para pedirle al juez que los autorice a aceptarla en su nombre. Para así cubrir hasta donde llegue su crédito y no más. Es decir, aceptar la herencia, los acreedores, en nombre del heredero, para poder cobrar lo que se les debe ${ }^{521}$. Del sobrante, en caso de haberlo, conforme al artículo 1001 Cc no irá a parar a manos del repudiante, sino que se adjudicará conforme a las reglas que establece el propio Código civil $^{522}$. Podía darse el caso de, en una misma persona,

${ }^{520}$ La STS de 28/03/2003 (Tol. 2.579.535) F.J. $4^{\text {o }}$ "la aceptación y la repudiación de la herencia, una vez hechas, son irrevocables, y no podrán ser impugnadas sino cuando adoleciesen de alguno de los vicios que anulan el consentimiento, o apareciese un testamento desconocido". La DGRN de 17-10-2017 (BOE 11-11-2017) sigue el mismo criterio señalado en la anterior STS. "la aceptación y repudiación de la herencia, «una vez hechas» son irrevocables y no podrán ser impugnadas sino cuando adoleciesen de algunos de los vicios que anulan el consentimiento, o apareciese un testamento desconocido". Además matiza que "debe también precisarse que esa rectificación no de oficio o voluntaria deben consentirla no ya solo los otorgantes, a los que se refiere el artículo 153 del Reglamento Notarial, sino todos los afectados por la misma".

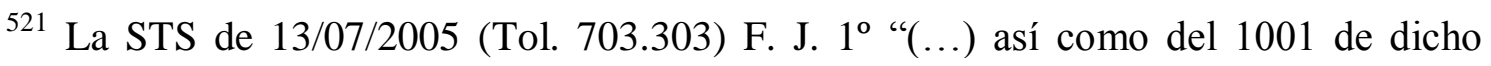
Código que permite a los acreedores perjudicados, cuando el heredero repudia la herencia, a solicitar del Juez que les autorice aceptarla en nombre del renunciante, sin referencia literal al legatario. La aportación de dicho artículo resulta innecesaria desde el momento que la sentencia de apelación no lo tuvo en cuenta y por ello no puede considerarse infringido". Tambien en este sentido la STS de 03/05/2003 (Tol. 49.928.581) F.J. $2^{\text {o; }}$ STS 30/05/2003 (RJ3917). Bajo las mismas pautas se pronuncia la STS de 30/05/2003, (Tol. 274.500) F. J. $2^{\circ}$ si bien recalca la voluntariedad y la libertad tanto de la aceptación como de la repudiación de la herencia. En consecuencia, los acreedores no pueden obligar al heredero a que acepte la herencia, para poder cobrar sus créditos. Si bien de manera tácita pone de manifiesto la acción rescisoria como propicia para los acreedores poder hacer efectivo su derecho: "como sería el caso de que tuviese éxito la acción rescisoria, sin embargo, para el supuesto de que la repudiación de la herencia provoque un perjuicio a los acreedores del heredero, se les concede a aquellos la posibilidad de que previa autorización judicial puedan aceptar la herencia en nombre de aquél, pero solo aprovechará a los acreedores en cuanto baste para cubrir el importe de sus créditos, (...) tal como previene el artículo citado por la parte como infringido en los dos primeros motivos del recurso, el artículo $1001 \mathrm{Cc} "$.

522 Lledó Yagüe, F., Monje Balmaseda, O., Herrán Ortiz, A. I., AAVV: "La repudiación...", op. cit., pág. 113. "destinándose el resto de los bienes a las personas 
producirse dos llamamientos de una misma herencia, uno por testamento y otro abintestato. De renunciar el primero lo haría también al segundo, pero siendo al contrario, es decir, renunciando al llamamiento de la sucesión legal podría aceptar la sucesión testamentaria siempre que la repudiación se produzca sin tener noticia del título testamentario. Todo ello conforme a lo dispuesto en el artículo 1009 Cc. Sobre la cuota hereditaria repudiada, caben diversos planteamientos, ya que puede ser incluida en otros llamamientos o delaciones, en favor de otras personas e incluso puede ser incluida dentro de otros llamamientos pasados ${ }^{523}$.

Dentro de la sucesión legitimaria con hijos y descendientes tienen cabida distintos supuestos. Puede acontecer que renuncien todos los hijos a la herencia de uno de sus padres habiendo nietos. Además el testador puede que no haya dispuesto nada para el caso de renuncia y que no exista, en el testamento, sustitución vulgar. Frente a tal supuesto, la repudiación, dejará la sucesión sin heredero testamentario y conforme al artículo $912 \mathrm{Cc}$ tendría que abrirse la sucesión intestada. Nadie puede representar al repudiante por disposición del artículo 929 Cc y conforme al $923 \mathrm{Cc}$, de darse el caso planteado, heredarían los del siguiente grado, es decir, los nietos del causante e hijos de los repudiantes por derecho propio. Las consecuencias que ello podría acarrear es que dentro de la siguiente estirpe (los nietos) heredarían por cabezas con la consecuente problemática que eso conlleva. Conllevaría la división de la herencia entre el número de

que corresponda según las reglas establecidas en el Código (sustitutos, coherederos con derecho de acrecer, herederos abintestato, etc.)".

${ }^{523}$ LORA-TAMAYO Y PÉREZ RAMOS, Cuestiones prácticas sobre herencias..., op. cit., págs. 115 y 423. De figura jurídica compleja y problemática, califica este autor, a la repudiación de la herencia. Hace tales afirmaciones al respecto de que no era una figura, la citada institución, de uso muy frecuente, es decir, no era muy habitual el que alguien repudiara o renunciara a una herencia. No se puede decir lo mismo hoy en día, ya que la repudiación de herencias, no es una cosa excepcional, "materia de moda", como bien la califica el autor. 
nietos, mientras que al heredar por representación, lo que se divide es la parte que le hubiera correspondido al padre. Problemática, la expuesta, al haber varios hijos con diferente número de descendientes cada uno de estos provocaría un perjuicio para aquellos nietos sin heremanos o un reducido número de estos ${ }^{524}$.

Al tratar lo dispuesto en el artículo 833 Cc se ha dicho, "en principio", porque pueden surgir distintas maneras de interpretar el precepto. Teniendo presente el artículo $115 \mathrm{Cc}$ en que la legítima se le puede atribuir al legitimario por cualquier título, quiere ello decir, que se le puede atribuir la legítima corta por herencia y la mejora en concepto de legado. Conforme al artículo $990 \mathrm{Cc}$ la herencia no puede ser aceptada o repudiada de manera parcial desde el momento que el mejorado haya sido instituido heredero. En consecuencia, la disposición del artículo $833 \mathrm{Cc}$, antes referido, sólo tiene aplicación cuando el legitimario instituido heredero reciba la mejora a título de legado. Es entonces cuando el legitimario no acepta ni repudia la

${ }^{524}$ LORA-TAMAYO Y PÉREZ RAMOS, Cuestiones prácticas sobre herencias..., op. cit., pág. 424. Plantean el dilema, estos autores, al referirse el precepto $923 \mathrm{Cc}$ cuando preceptúa "grado siguiente" si se refiere a grado de parentesco o a grado equivalente a orden de suceder, que en el primer caso serían llamados los nietos y en el segundo serían los llamados los padres y en defecto de estos el cónyuge supérstite. Tiene lógica porque de llamar, el precepto, a los del siguiente grado de parentesco se va en línea recta descendiente y de llamar a los del siguiente grado en orden de sucesión se busca el orden que se buscaría de no existir descendientes, que la línea cambiaría a sentido ascendente. Así también la RDGRN de 21/01/2013 (RJ 201318264) que dice: "Que, al haber renunciado la totalidad de los hijos a la herencia, habrá de heredar el siguiente grado -los nietos- que lo harán por su derecho propio y no por derecho de representación.". El problema que se presenta es que existan dos (o más) hijos en la sucesión del padre y repudien ambos su herencia legítima, conforme a la resolución de la citada RDGRN el llamamiento o delación pasa al siguiente grado de parentesco, es decir, a los nietos que al no heredar por derecho de representación, lo han de hacer por cabezas dentro de la estirpe siendo igual parte para cada nieto, que si uno de los hijos del causante tenía un hijo y el otro 12, suman un total de trece nietos para el causante y es por el número que se dividiría la herencia. Se ve con ello un importante desequilibrio y repercusión para el hijo que podría suponer el haber repudiado su padre la herencia de su abuelo. 
herencia en parte, a plazo ni condicionalmente, es decir, en contra de lo que dispone el artículo citado $990 \mathrm{Cc}^{525}$.

\subsubsection{La repudiación y el impuesto de sucesiones}

El motivo de incluir en este subepígrafe el impuesto de sucesiones con respecto a la repudiación, no es otro, que el incremento que esta figura, prácticamente en desuso, ha tenido en los últimos años ${ }^{526}$. Quien repudia una herencia no puede en ningún momento ser considerado como heredero y ello quiere decir que tampoco puede ser sujeto pasivo del impuesto de sucesiones, pero quien acepta una herencia y con posterioridad la repudia genera una doble transmisión que derivará en una doble tributación de la misma parte repudiada ${ }^{527}$. Dentro de la propia repudiación, a efectos fiscales, se pueden advertir dos tipos de repudiación. La simple, en la que el repudiante simplemente no acepta la herencia sin más dilaciones, por lo que este, ni adquiere ni dispone de su derecho a herencia. En consecuencia, el repudiante no genera consecuencia fiscal alguna y es completamente excluido del Impuesto de Sucesiones y Donaciones. La otra renuncia es la "traslativa" en la que el heredero o legitimario no acepta la herencia, pero

\footnotetext{
${ }^{525}$ TORRES GARCÍA y DOMingueZ Luelmo: "La legítima en el Código civil...” (II), op. cit., pág. 96.

${ }^{526}$ FeÁs CostiLla, "la renuncia de herencia...", op. cit, pág. 150. Con datos del Centro de Información Estadística del Notariado CIEN, señala, el autor, el importante incremento de demanda que ha tenido en España últimamente la institución de la repudiación. "De 2007 a 2012, han aumentado de once mil a veinticuatro mil las repudiaciones ante notario. En 2013 se han incrementado otro 21\% más. Pero las repudiaciones han sido muchas más, puesto que normalmente no se computan las que puedan incluirse en una escritura de partición de herencia en que unos repudien y otros acepten". Incluso matiza que la repudiación era tan rara el 1980, que parecía no existir.

${ }^{527}$ LASARTE Álvarez, Derecho de sucesiones..., op. cit., págs. 288. El profesor Lasarte reproduce la Consulta Vinculante 1258/08, de 17 de junio, de la Subdirección General de Impuestos de la que se puede resaltar: Desde el punto de vista fiscal, la repudiación y la renuncia a la herencia se regulan en el artículo 28 de la ley 29/1987, de 18 de diciembre (BOE de 19 de diciembre), del Impuesto sobre Sucesiones y Donaciones, y en el artículo 58 del Reglamento del Impuesto sobre Sucesiones y Donaciones, aprobado por el Real Decreto 1629/1991, de 8 de noviembre (BOE de 16 de noviembre).
} 
transmite su derecho a favor de un tercero. Lo hace bien de manera onerosa o gratuita. Dicho de otra manera, el repudiante dispone a favor de otra persona, que queda favorecida con su acto.

La renuncia que más consecuencias puede causar es la traslativa, es decir, la que traslada el derecho a otro de una herencia o de un legado. Esta repudiación no exime del pago al repudiante. Dependiendo si el traslado del derecho se ha hecho a título gratuito u oneroso, queda considerado, a nivel de impuesto, como TPO (Transmisiones Patrimoniales Onerosas) del ITP (Impuesto de Transmisiones Patrimoniales) o bien al impuesto de Sucesiones y Donaciones ${ }^{528}$. Una costumbre bastante arraigada en estos tiempos es la renuncia al usufructo ya aceptado. Suele darse el caso cuando renuncia, a título gratuito, el cónyuge viudo a su parte del usufructo, ya aceptado en la delación, del tercio de mejora. Se considera o se entiende como una donación que le hace el viudo/a al nudo propietario de dicho tercio de mejora ${ }^{529}$. Todo, según dispone el artículo 51.6, de RISD (Reglamento del Impuesto de Sucesiones y Donaciones). Es frecuente en la práctica cotidiana encontrar cónyuges viudos que renuncian a sus derechos en la sociedad de gananciales que tenían constituida con el causante y ello supone aumentar el caudal hereditario. Dicha renuncia por lo que a tributación se refiere, queda regulada en el artículo $58.4,{ }^{530}$ del RISD y

${ }^{528}$ STS 29/05/2018 (Tol. 6.640.058) F.J. $3^{\text {o }}$ "Es cierto que el artículo 24 de la Ley 29/1987 establece que el impuesto se devenga el día del fallecimiento del causante, pero esto lo único que supone es retrotraer los efectos tributarios del Impuesto a ese momento, y así hay que entenderlo en concordancia con el artículo 989 del Código Civil, que establece "Los efectos de la aceptación y de la repudiación de la herencia se retrotraen siempre al momento de la muerte de la persona a quien se hereda", lo que significa que es el hecho de la aceptación el determinante de la adquisición".

${ }^{529}$ JuÁreZ GONZÁLEZ, J. M.: GPS Sucesiones..., op. cit., págs. 391 a 393.

530 Artículo 58.4 del RISD (repudiación y renuncia): "4. Para que la renuncia del cónyuge sobreviviente a los efectos y consecuencias de la sociedad de gananciales produzca el efecto de que los bienes renunciados pasen a formar parte, a los efectos de la liquidación del Impuesto, del caudal relicto del fallecido será necesario que la renuncia, además de reunir los requisitos del apartado 1, se haya realizado por escritura 
supone una donación, con todas sus consecuencias, a favor de los beneficiados por ella ${ }^{531}$.

En cuanto a la fiscalidad del acrecimiento que puede suponer la repudiación de una legítima o herencia se debe de entender que el acrecimiento hace suponer, que el legitimario o heredero hereda directamente del causante. Su tributación, por lo tanto, se atiende a las reglas y condiciones generales del Impuesto de Sucesiones y Donaciones. Dicho lo anterior, cuando el derecho al acrecimiento lo ha provocado la repudiación de un legitimario o heredero podría tener cabida, en principio, el artículo 58.1, ${ }^{532}$ RISD, por lo que al parentesco del causante, con el renunciante y beneficiado de la renuncia supone la diferencia. Dicho de otra manera, es la diferencia de parentesco con el causante, entre uno y otro ya que, si el primero es un hijo y el segundo un sobrino del causante, no se tributa lo mismo en ambos casos y en consecuencia tendría aplicación el precepto último señalado. La excepción, tendría lugar, en el supuesto de haber previsto el testador la supuesta repudiación y la hubiera prevenido con una sustitución vulgar. Entonces sí que tributaría por el precepto que regula el impuesto de las sustituciones y no por el de la repudiación y en consecuencia tendría cabida, lo dispuesto el artículo 53. $1,{ }^{533}$ RISD $^{534}$.

pública con anterioridad al fallecimiento del causante. No concurriendo estas condiciones se girará liquidación por el concepto de donación del renunciante a favor de los que resulten beneficiados por la renuncia”.

${ }^{531}$ JUÁREZ GONZÁLEZ, GPS..., op. cit., pág. 394.

532 Art. 58.1 del RISD (repudiación y renuncia): "1. En la repudiación o renuncia pura, simple y gratuita de la herencia o legado, los beneficiarios de la misma tributarán por la adquisición de la parte repudiada o renunciada aplicando siempre el coeficiente que corresponda a la cuantía de su patrimonio preexistente. En cuanto al parentesco con el causante, se tendrá en cuenta el del renunciante o el del que repudia cuando tenga señalado un coeficiente superior al que correspondería al beneficiario".

533 Art. 53.1 RISD (Sustituciones): “1 En la sustitución vulgar se entenderá que el sustituto hereda al causante y, en consecuencia, se le exigirá el Impuesto cuando el heredero instituido falleciera antes o no pudiera o quisiera aceptar la herencia, teniendo en cuenta su patrimonio preexistente y atendiendo a su parentesco con el causante". 

18 DE NOVIEMBRE

Por medio de la Ley 41/2003, de Protección Patrimonial de las Personas con Discapacidad, el legislador español cumple dos funciones destacables y entrelazadas entre sí. Por un lado se resuelve un problema de suma actualidad y verdadero alcance jurídico, como es el de las personas incapacitadas judicialmente. Para conseguirlo se vulnera, por primera vez en el Derecho común, la legítima estricta de los descendientes y con ello se pone fin a la intangibilidad de la legítima corta o estricta ${ }^{535}$. Como consecuencia de ello un testador puede, en virtud del último párrafo del artículo $808 \mathrm{Cc}$ establecer una sustitución fideicomisaria, en beneficio de sus hijos o descendientes incapacitados judicialmente. Lo puede hacer con toda la legítima, es decir, incluida la legítima corta o estricta que era inalcanzable para el testador, hasta la vigencia de la Ley 41/2003. Conforme al artículo 782, (también modificado por la Ley) en su redacción original de 1889 disponía que "las disposiciones fideicomisarias nunca podrán gravar la legítima"536.

\footnotetext{
${ }^{534}$ JUÁREZ GONZÁLEZ, GPS..., op. cit., pág. 396. Mantiene el autor como conclusión a lo expuesto:
}

1. "Cuando el derecho de acrecer està previsto en el testamento por el testador $\mathrm{o}$ causante no procederà la aplicación del articulo 58.1del RISD." Ello encuentra fundamento en la similitud entre el derecho de acrecer expresso por parte del causante con la sustitución vulgar, ya que en ambas figuras se entiende que se hereda directamente del causante".

2. "En el supuesto de que el derecho de acrecer tanga tenga caràcter tácito, procedirà la aplicación del articulo 58.1 del RISD”. El que tenga caràcter tácito supone que no tiene caràcter expresso, es decir, se acrece por otras razones y se tendrá en cuenta el parentesco con el causante respecto del repudiante y el beneficiado con la repudiación".

${ }^{535}$ Botello Hermosa, P.:“Un problema actual de enorme trascendencia jurídica en España: las personas curateladas como posibles beneficiarias de la sustitución fideicomisaria especial", Revista Crítica de Derecho Inmobiliario, núm. 762, julio 2017, pág. 1677.

${ }^{536}$ LA SAP de la Coruña (S. 5 ${ }^{\text {a }}$ ) de 13/10/2017 (AC 2017\1530) F.J. $4^{\text {o }}$ hace referencia a lo establecido en el artículo $808 \mathrm{Cc}$ respecto de los hijos o descendientes judicialmente 
Mediante la voluntad del testador, se puede gravar toda la legítima estricta en beneficio del judicialmente discapacitado, conforme al artículo 199 Cc perjudicando con ello, a los legitimarios capacitados. Cabe destacar, por tanto, que se requiere disposición testamentaria y con ello, su correspondiente sucesión, para constituir la mencionada sustitución fideicomisaria ${ }^{537}$. El legislador común de 2003, al fijar la sustitución fideicomisaria a favor de las personas incapacitadas judicialmente engloba dentro de ello tanto a los tutelados como a los curatelados. Bajo mi opinión debía de haber seguido el modelo italiano y haber excluido a los incapacitados judicialmente cuartelados ${ }^{538}$.

incapacitados:"La legítima es aquella porción de bienes de la herencia que el testador no puede disponer libremente sino que ha de reservar forzosamente por ley para determinados parientes, legitimarios, como en el caso de los hijos (arts. 763 y 806ss. Código Civil ). Es intangible. Ha de respetarla tanto cuantitativa como cualitativamente. En este sentido dice el artículo 813 que el testador no podrá privar a los herederos de su legítima (salvo casos justificados por la ley), ni imponer sobre ella gravamen, ni condición, ni sustitución de ninguna especie, salvo lo dispuesto en cuanto al usufructo de viudo (no se refiere al universal voluntario sino al legal del art. 834ss) y lo establecido en el artículo 808 respecto de los hijos o descendientes judicialmente incapacitados. Es materia de orden público jurídico. El artículo 782 especifica que las sustituciones fideicomisarias nunca podrán gravar la legítima (salvo en el caso de hijos o descendientes judicialmente incapacitados en los términos del artículo 808), y si recaen sobre el tercio de mejora sólo a favor de los descendientes".

${ }^{537}$ LA SAP de la Coruña (S. $5^{\text {a }}$ ) de 13/10/2017 (AC 2017\1530) F.J. $4^{\text {o }}$ hace referencia a lo establecido en el artículo $808 \mathrm{Cc}$ respecto de los hijos o descendientes judicialmente incapacitados:"La legítima es aquella porción de bienes de la herencia que el testador no puede disponer libremente sino que ha de reservar forzosamente por ley para determinados parientes, legitimarios, como en el caso de los hijos (arts. 763 y 806ss. Código Civil). Es intangible. Ha de respetarla tanto cuantitativa como cualitativamente. En este sentido dice el artículo 813 que el testador no podrá privar a los herederos de su legítima (salvo casos justificados por la ley), ni imponer sobre ella gravamen, ni condición, ni sustitución de ninguna especie, salvo lo dispuesto en cuanto al usufructo de viudo (no se refiere al universal voluntario sino al legal del art. 834ss) y lo establecido en el artículo 808 respecto de los hijos o descendientes judicialmente incapacitados. Es materia de orden público jurídico. El artículo 782 especifica que las sustituciones fideicomisarias nunca podrán gravar la legítima (salvo en el caso de hijos o descendientes judicialmente incapacitados en los términos del artículo 808), y si recaen sobre el tercio de mejora sólo a favor de los descendientes".

${ }^{538}$ Botello Hermosa, P.:“Un problema...”, op. cit., pág. 1677. Mantiene el autor, que hoy en día en nuestro Derecho común, cualquier persona, incapacitada judicialmente 
En los casos que el incapacitado deja de serlo, por simple lógica, dejaría de cumplirse el requisito para poder constituir el fideicomiso y entonces cabe su resolución. En consecuencia a ello, la masa hereditaria gravada con la sustitución fideicomisaria volvería a su estado inicial o esencial ${ }^{539}$. Es decir, como de no haber tenido lugar la carga impuesta sobre la legítima estricta de los hijos o descendientes y así, recuperar su legítima los que a ella tengan derecho ${ }^{540}$. Podría también darse el caso de un mismo testador o donante tener varios herederos incapacitados y todos ellos por resolución judicial. ¿Podría el testador o donante instituir como fiduciario sólo a uno en detrimento del resto? La respuesta es que sí que lo podría hacer, es decir, de tener varios incapacitados judicialmente no estaría obligado a favorecer a todos. Entiendo que se alude a una obligación legal, si bien también aquí tiene cabida la obligación moral, para con todos sus hijos que tiene el testador o donante ${ }^{541}$.

No se puede pasar por alto el artículo 784 del Código civil que mantiene el derecho a la legítima del fideicomisario desde la muerte del

puede beneficiarse de una sustitución fideicomisaria sobre el tercio de legítima estricta de la herencia, eso sí, se requiere la voluntad del testador, plasmada en su testamento, para ello.

${ }^{539}$ DE VERDA Y BEAMONTE, J. R.: "Constitución y ususfructo en cuaderno particional sin asignación coétanea de nuda propiedad”, Aranzadi, núm. 12, 2004, pág. 184, señala el gravamen que representa para el heredero la sustitución fideicomisaria. Además representa un obstáculo para la libre circulación de los bienes, razón por la cual requiere para su constitución que se establezca en el propio testamento, de manera que no pueda llevar a confusión alguna. El autor se apoya en jurisprudencia del Tribunal Supremo, la cual afirma que: "la institución de la sustitución fideicomisaria no puede presumirse".

${ }^{540}$ DíAZ AlABART, S.:"La sustitución fideicomisaria sobre el tercio de legítima estricta a favor de hijo o descendiente incapacitado judicialmente", Revista de Derecho privado, mayo-junio 2004, págs. 259 a 270. "No dispone, el artículo 808 Cc la clase de sustitución fideicomisaria que permite hacer con carga a la legítima estricta, por lo que opina la autora que debe de tratarse de una sustitución fideicomisaria "normal".

${ }^{541}$ DONATO VARA, A.: “Apuntes sobre la protección de los niños con discapacidad en el sistema de sustituciones hereditarias: la reforma del artículo 782, del Código Civil español", Comunicación presentada al Precongreso: Rumbo al Congreso Mundial en Lima-Perú, 2006, pág. 8. 
causante, incluso, en el supuesto que falleciera con anterioridad al heredero fiduciario. Su derecho pasará a sus descendientes con derecho a heredarle. Por lo tanto, sobre los bienes fideicomitidos se adquiere el derecho, por parte del fideicomisario, a obtenerlos cuando fallezca el fiduciario, no a la muerte de este, puesto que ya tenían ese derecho desde que se produjo la muerte del fideicomitente. Es decir, los fideicomisarios heredaron del fideicomitente el derecho a heredar su legítima a la muerte del fiduciario ${ }^{542}$.

\subsection{LAS CAUTELAS DE OPCIÓN COMPENSATORORIA: CAUTELA SOCINI}

Al tratar la sucesión testada es casi tan normal que aparezca la figura del Notario como la de la cautela socini o cláusula sociniana ${ }^{543}$. Este término responde al nombre de su propulsor, el jurista italiano de mediados del siglo XVI Mariano Socino. La cautela socini, una vez abierta la sucesión, incentiva a los legitimarios para soportar los gravámenes que el testador les impone sobre sus legítimas, a cambio de recibir con posterioridad más de lo que por legítima estricta les hubiera correspondido. Parece encontrar encuadre dentro del artículo $820.3^{544}$ Cc con respecto a la atribución al cónyuge supérstite del usufructo universal ${ }^{545}$. Es decir, del

\footnotetext{
${ }^{542}$ Botello HermosA, P.I.: "El incomprensible uso como sinónimos de dos figuras jurídicas diferentes: el fideicomiso y la sustitución fideicomisaria." Revista Crítica de Derecho Inmobiliario, núm. 756, 2016, págs. 121-122.

${ }^{543}$ Véase la RDGRN de 4/09/2012 (RJ 2012\10396): "Partición hereditaria con menores interesados: conflicto de intereses. Cautela socini" en Comentarios a las Resoluciones de la Dirección General de Registros y Notariado, núm. 151, agosto 2017, pág. 243. "La mayor parte de los testamentos incluyen esta cautela por la que el testador impone un usufructo universal en favor del viudo y una adquisición en nuda propiedad para los hijos de toda la herencia. Al suponer ello un gravamen sobre la legítima estricta, el testador amenaza al hijo que la impugne con la pérdida de lo que le asigna en los tercios de libre disposición y de mejora, por lo que, en la práctica, son totalmente marginales los casos de hijos mayores de edad que impugnan ese usufructo universal de su madre".

${ }^{544}$ RuIz-Rico RuIz-Morón, J.: Lesión de la legítima en Curso de Derecho Civil IV, Derecho de familia y sucesiones, $5^{\mathrm{a}} \mathrm{ed}$, (coor. F. J. Sánchez Calero) Tirant lo Blanch, Valencia, 2009, pág. 610.
} 
usufructo de toda la herencia ${ }^{546}$. La disposición testamentaria, que mantiene tal atribución dentro de una disposición testamentaria se suele reforzar o amparar con una cautela socini frente a los legitimarios del disponente. ${ }^{547}$.

El ordenamiento español no contempla de manera expresa la cautela socini, de ahí su falta de regulación. De no aceptar, ninguno de los legitimarios, con respecto al usufructo universal del cónyuge viudo, mientras quede uno que acepte la cautela socini, el exceso de los demás

\begin{abstract}
${ }^{545}$ RAGEL SÁNCHEZ, L.F.: Desde la cautela gualdense o socini al artículo $820.3^{\circ}$ del codigo civil, Dykinson, Madrid, 2004, pág.119. El juego que hace el testador entre la cautela socini y el artículo 820. 3 Cc tiene lugar cuando aquel le atribuye más al legitimario que por legítima estricta le corresponde, pero estableciendo un gravamen sobre esta. El legitimario tiene la opción de elegir entre quedarse, únicamente, con la legítima corta libre de cargas, o bien acceder a la voluntad del testador y aceptar la legítima aumentada, pero gravada. Refuerza esta postura la STS de 10/07/2003 (Tol. 295.861) F. J. $2^{\text {o }}$ "nos hallamos ante un testamento notarial y de cierta complejidad y en el que el testador otorga a su cónyuge el usufructo universal sobre todos los bienes de la herencia, pero establece asimismo que en caso de que no fuese aceptada dicha fórmula por cualquiera de sus hijos y herederos, se trueca en la plena propiedad del tercio de libre disposición. Ello implica la denominada cautela sociniana o gualdense, consistente en la opción concedida por el testador al legitimario para elegir entre dos alternativas, o tolerar el usufructo universal del cónyuge viudo, o atribuirle el pleno dominio de todo el tercio de la herencia denominado de libre disposición, a más de los derechos que la ley concede al cónyuge supérslite como legitimario. La sentencia de esta Sala de 3 de diciembre de 2001 ha señalado la validez de tal cláusula y asimismo que el legitimario afectado tiene derecho a realizar la opción del art. 820,3". La STS de 30/01/1995 (Tol. 1.667.023) F. J. hace una interesante exposición de la opinión de la doctrina acerca de la validez de esta cláusula de opción compensatoria al enjuiciar un supuesto de hecho en que el esposo le lega a la viuda el tercio de libre disposición además del usufructo universal del articulo $820 \mathrm{Cc}$ y establece una cautela socini que "El heredero que no respete esta voluntad tomará solo su legítima estricta; y si ninguno lo hiciere, tomará la viuda el pleno dominio del tercio libre, además de su cuota legal usufructuaria. En cambio rechaza el gravamen y los herederos recibirán por terceras e iguales partes sus correspondientes cuotas en los tercios de mejora y legítima, pero sigue vigente el resto de la cláusula testamentaria, y tomará la viuda el tercio de libre disposición en pleno dominio, además de su cuota legal usufructuaria".
\end{abstract}

${ }^{546}$ Señala OCHOA MARCO y SEBASTIÁN CHEMA, La herencia ..., op. cit., pág. 71, que "es más habitual la cautela socini en testamentos otorgados por testador casado y con descendencia”.

${ }^{547}$ JuÁreZ GonZÁleZ, GPS..., op. cit., pág. 410. Conforme al autor, “de ser el legitimario un menor o un discapacitado, en ningún caso su representante legal, sea progenitor o tutor, puede consentir la aceptación de una cautela socini sin previa autorización o aprobación judicial". 
acrecería en su favor, pero al ser todos parece dudoso el destino de la nuda propiedad del tercio destinado a mejorar a los legitimarios. Todo lo que no sea distribuir dicho tercio entre ellos sería contrariar lo dispuesto en los artículos 808,813 y 824, todos del Código civil ${ }^{548}$. Hay autores que no ven, perjuicio alguno para los legitimarios, en este tipo de cautela. Incluso mantienen que no viola el principio de intangibilidad de la legítima ${ }^{549}$.

La doctrina jurisprudencial no ha sido siempre conforme con la validez de la cautela socini ${ }^{550}$. Considerándola una condición ilícita y contraria a la ley que de conformidad con el artículo $792 \mathrm{Cc}$ debe de tenerse por no puesta en el testamento. En España entre un 90\% y un 95\% de los testamentos otorgados por personas casadas con descendientes otorgan un usufructo universal a favor del cónyuge supérstite. Con la consecuente nuda propiedad del total del patrimonio para sus hijos ${ }^{551}$.

${ }^{548}$ CUCURULl POBLET, T.: “Ámbito jurídico del protocolo familiar. El protocolo familiar mortis causa", Dykinson, 2015, pág. 194.

${ }^{549}$ O'Callaghan Muñoz, X.: Compendio de Derecho Civil, tomo 5, Edersa, Madrid, 2004, pág. 12. “(...) Con ello no se viola el principio de intangibilidad de la legítima con el que únicamente se pretende asegurar al legitimario un minimum de participación en la herencia sin impedir la posibilidad de utilizar una opción que pueda reportarles mayores beneficios que los que su derecho estricto les otorga (...)". Tambien VALLET DE GOYTISOLO, "Comentarios...", op. cit., pág. 305 acepta la cautela socini, si bien matiza que "la opción sólo puede ser ejercida individualmente por cada legitimario afectado”. Tambien DiEZ-PICAZO y GuILlón, Sistema..., op. cit., pág. 182 es conforme con la cautela socini hasta manifestar, que no es el testador el que otorga el gravamen, sino la Ley, por medio del artículo 820.3 Cc.

${ }^{550}$ Incluso la jurisprudencia del Tribunal Supremo ha tenido épocas en que no admitía este tipo de cautelas de opción compensatoria. Así la propia jurisprudencia del Tribunal Supremo reconoce su inadmisión en tiempos pasados. La STS de 03/09/2014 (Tol. 4.521.095) F.J. $2^{\circ}$. Esta polémica tampoco ha sido cerrada o resuelta, con carácter general, por la doctrina jurisprudencial de esta Sala, enfocada, primordialmente, desde la perspectiva casuística de las características del supuesto en cuestión, y centrada particularmente en torno al alcance del condicionante de la prohibición del recurso a la intervención judicial; con pronunciamientos que han ido desde la admisión y validez de esta cautela hasta su inaplicación; SSTS 6 de mayo de 1953,12 de diciembre de 1958 , 8 de noviembre de 1967 y 8 de junio de 1999 , entre otras".

${ }^{551}$ NÚÑEZ MUÑIZ, M. C.: "El usufructo universal y el legado de usufructo universal: análisis particular del ejercicio y titularidad de la acción de desahucio", Revista Crítica 
Otra de las posturas doctrinales favorables a la licitud de la cautela entiende que en el artículo 820.3 Cc existe una cautela socini tácita, es decir, entender el mecanismo del precepto similar al de una cautela socini expresa. Si bien se ha de señalar aquí, que el artículo citado la opción está predispuesta por la ley y por lo tanto, no tiene necesidad el testador de inferirla en el testamento ${ }^{552}$. Lo hacen porque el precepto citado concede al legitimario dos opciones- la de cumplir la disposición testamentaria o la de entregar al legatario la parte de libre disposición de la herencia ${ }^{553}$. La diferencia entre el precepto señalado y la cautela socini puede advertirse por los requisitos doctrinales que esta exige para su eficacia: la atribución testamentaria ha de serlo en concepto de legítima, el testador ha de atribuirle, al legitimario, mayor quantum del que por legítima estricta le corresponde, El gravamen ha de ser impuesto sobre la legítima, ha de imponérsele al legitimario la opción, y por último, el legitimario ha de aceptar la carga, para la eficacia de la cautela de opción compensatoria ${ }^{554}$.

de Derecho Inmobiliario, núm. 747, enero, 2015, pág. 437. Señala, la autora, la postura de Iglesias López de Vivigo como opuesta a la validez de la cautela socini y a A. M. Romero Coloma, J. Sapena Tomás y M.C. Núñez Muñiz, como favorables a la validez de la cautela, en base al elevado número de solicitudes que esta recibe. Matiza al respecto que también la jurisprudencia admite la validez de la cautela socini.

${ }^{552}$ Ragel SÁncheZ, L.F.: Desde la Cautela Gualdense..., op. cit., pág. 313. Tambien con esta opinión DiEZ-PICAZO y GuILlón, Sistema ..., op. cit. pág. 183.

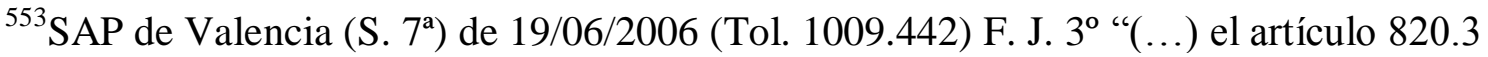
$\mathrm{Cc}$ reconoce a los herederos para sustituir el usufructo universal y vitalicio por la entrega de bienes de la parte disponible por el testador. La doctrina aborda el gravamen de las legítimas por constitución de un usufructo vitalicio, tanto desde la perspectiva de su fundamento normativo como de su ejercicio, destacando lo siguiente: a) Debe calcularse el valor del usufructo según su valor venal, y solo en caso de que exceda de la cuota disponible podrán los herederos rechazarlo y cumplir dejando al usufructuario la propiedad plena de la porción disponible que el testador les hubiese atribuido; b) Que es preciso la unanimidad de los legitimarios para aceptar el gravamen del usufructo sobre la legítima; de no haberla habrá de cederse al usufructuario la propiedad de la porción disponible.

${ }^{554}$ NÚÑEZ MUÑIZ, M. C.: “El usufructo universal...”. op. cit., pág. 440. 
En cambio, el artículo 820. $3 \mathrm{Cc}$ no requiere de los requisitos anteriormente expuestos, es más, la opción la puede ejercitar el legitimario sin que el testador la haya establecido expresamente en el testamento, puesto que ya la prevé el propio precepto y entonces la deja a voluntad del legitimario $^{555}$. De ahí que la jurisprudencia entienda el caso de testamentos abiertos donde el Notario aconseja sobre la legalidad de las disposiciones, que el hecho de que no se haya dispuesto el gravamen sobre la legítima así como la opción, en el testamento, únicamente significa que el testador no ha querido imponer un carga sobre la legítima ${ }^{556}$. Gravamen, como pueda ser un usufructo universal, que no deja de ser una contradicción con el articulo 813 Cc. Lo que opera en el artículo 820.3 es la voluntad del legitimario, es decir, deja a su voluntad de acatar la disposición testamentaria con más participación o bien se ciñe únicamente a recibir su legítima legal, incumpliendo con ello la voluntad del testador.

No todas las disposiciones testamentarias que prohíben la intervención judicial, aunque se suelen calificar de la misma manera, son cautela socini. Esta no prohíbe, sino que faculta el testador al legitimario para que escoja. En cambio hay infinitud de testamentos en los que se prohíbe la intervención judicial por parte del testador en su testamentaria, que nada

\footnotetext{
555 Señalan DiEZ-PicAZO y GuILlón, Sistema..., op. cit., pág. 183, que es la Ley por medio del artículo 820.3 la que otorga la opción al legitimario.

${ }^{556}$ La STS de 03/12/2001 (Tol. 4.924.412), que enjuicia un supuesto de usufructo universal otorgado por el marido a la esposa en cuya consecuencia les adjudica a sus dos hijos la nuda propiedad de toda la herencia. Fallecido el disponente, la hija demanda a su madre y a su hermano estimando que no tenía aplicación el artículo $820.3 \mathrm{Cc}$ puesto que el testador no había dispuesto en su testamento la facultad de optar bien a su legítima estricta y libre de cargas o bien a la nuda propiedad de su legítima más, la parte correspondiente del tercio de libre disposición. El Tribunal Supremo aclaró al respecto que el legitimario puede usar la opción, aunque no la haya dispuesto el testador en su testamento, porque la prevé expresamente el artículo 820.3 Cc. Hace la Sala en el F.J. apartado $6^{\circ}$ una aclaración de suma importancia, ya que mantiene la validez de la cláusula testamentaria que establece el usufructo universal. Además, argumenta que al legitimario le asiste el derecho a la opción que le otorga el precitado precepto sin necesidad de que se la haya concedido el testador de manera expresa.
} 
tiene que ver esto, con una cautela socini. En este sentido se pronuncia el artículo 675. $2,{ }^{557} \mathrm{Cc}$. De la misma manera lo hace la jurisprudencia, al respecto de que el testador hubiera prohibido impugnar su testamento ${ }^{558}$. Es evidente que puede el testador disponer de los bienes que, según sus circunstancias, la Ley le permita, incluso en defecto de legitimarios, de todos sus bienes y condicionarlos de la mejor manera que estime. Así como los destinatarios de dichas condiciones son libres de aceptarlas o repudiarlas. Lo que no puede el testador arrebatarle al legitimario uno de los derechos que la Constitución le ha otorgado como es el de la tutela judicial efectiva (art. $24 \mathrm{CE})^{559}$.

Con respecto a la cláusula testamentaria que, en muchos testamentos, prohíbe la intervención judicial. Si bien unas veces concuerda y otras no,

${ }^{557}$ Artículo $675.2 \mathrm{Cc}$ : "El testador no puede prohibir que se impugne el testamento en los casos en que haya nulidad declarada por la ley".

${ }^{558}$ Véase la STS de 21/11/2011 (Tol. 2.299) F. J. $2^{\text {o }}$, punto $3^{\circ}$ en que el Alto Tribunal manifiesta que, si el disponente trata de prohibir la intervención judicial, nunca podrá conseguir que el legitimario acuda a los tribunales a defender su derecho sobre la legítima estricta. Es más, se reitera en el siguiente F. J. y reitera la doctrina jurisprudencial manifiestando que el testador no puede limitar la legítima estricta y en consecuencia no puede imponer una cautela socini sobre dicha parte de legítima. En el mismo F. J. aporta la Sala lo dispuesto por la STS de 19/11/1901 "la cláusula testamentaria prohibitiva de la intervención judicial bajo la pérdida de los derechos hereditarios adquiridos en virtud del testamento por el heredero... que promoviere juicio de testamentaría o suscite reclamación judicial de cualquier clase no es aplicable al caso de que, terminadas las operaciones testamentarias, uno de aquellos demandase un derecho no procedente de la voluntad del testador sino de la ley...". Cuya doctrina es reiterada por distintas STS posteriores 8/11/1967; 08/06/1999, etc. Para acabar manifestando El Tribunal Supremo que no puede impedirse la vía judicial si estima, el legitimario, lesionado su derecho.

${ }^{559}$ RAgel SÁnChEZ, L.F.: Desde la Cautela Gualdense..., op. cit., pág. 155. Alude el autor a las STS 12/12/1959; 03/03/1980; 08/06/1999, para manifestar que la jurisprudencia mayor considera contraria a Derecho la disposición testamentaria que prohíba la intervención judicial. Explica en este mismo sentido la TSJ de Galicia de 09/11/2002, en que se impone en un testamento la condición absoluta de no contraer matrimonio. En Consecuencia el TSJ dice al respecto: "esta condición ha de «reputarse contraria a la moral en cuanto priva al individuo de la libre decisión respecto a su estado, así como del ejercicio de un derecho fundamental recogido en el artículo 32 de la Constitución, conforme señala la más autorizada doctrina". 
con las pautas de la cautela socini. Pone de manifiesto el Tribunal Supremo y sienta doctrina al respecto, en que se requiere valorar la impugnación que pretende llevar a cabo el heredero, legitimario o legatario determinante de la demanda por él interpuesta, para valorar si efectivamente se trata de una cautela socini ${ }^{560}$. En base a ello cabe afirmar que solamente aquellas impugnaciones testamentarias que se interpongan contra la voluntad dispositiva (en las materias que pueda disponer) y distributiva ejercida por el testador, en su testamento, chocarían frontalmente con la voluntad de este. Consecuentemente se habla de otorgarle al demandante la opción dispuesta por el testador para tal acción ${ }^{561}$.

Muy distinto sería que las impugnaciones judiciales fueran encaminadas a denunciar la estructura del testamento, como pudiera ser entre otros, la no inclusión de bienes del causante o la liquidación de gananciales, previa a la adjudicación de bienes. Es decir, anticiparse con la adjudicación de bienes pertenecientes a la sociedad ganancial y no al causante de manera exclusiva. Tales impugnaciones, no tiene disponibilidad sobre ellas, el testador, para poder prohibirlas. El legitimario que advierta actos de semejante estilo le asiste el derecho a poder

${ }^{560}$ STS de 21/04/2015 (Tol 4.988 .929 ) F. J. $3^{\text {o }}$ "En efecto, desde el desarrollo lógicojurídico de la figura, se observa que la prohibición impuesta por el testador de recurrir a la intervención judicial, en las operaciones de ejecución testamentaria llevadas a cabo por el comisario contador-partidor, no afecta directamente al plano material de ejercicio del derecho subjetivo del legitimado, que conserva, de modo intacto, las acciones legales en defensa de su legítima, pues su incidencia se proyecta exclusivamente en el marco de la disposición testamentaria como elemento condicionante que articula el juego de la correspondiente opción que da sentido a la cautel socini. No hay, por tanto, contradicción o confusión de planos en orden a la eficacia estrictamente testamentaria de la cautela dispuesta".

${ }^{561}$ Romero COlOMA, A. M.: "La prohibición de intervención judicial en los testamentos”, El Notario del Siglo XXI, núm. 58, noviembre-diciembre, 2014. 
impugnarlos judicialmente ${ }^{562}$. La cláusula que prohíbe al legitimario impugnar en contra de todo o parte del testamento, mantiene el Tribunal Supremo, que no es ilegítima sino por el contrario la considera legítima, pero a la vez también la considera ineficaz cuando trata de restringir derechos de los legitimarios ${ }^{563}$.

\begin{abstract}
${ }^{562}$ Romero COLOMA, "La prohibición de intervención judicial...", op. cit. Basa su exposición, esta autora, en la doctrina sentada en la STS de 10/06/2014 (Tol. 4.374.204) que determina el verdadero alcance de la cautela socini. La doctrina jurisprudencial referida es: "lo relevante a los efectos de la aplicación testamentaria de la cautela socini es tener en cuenta que el incumplimiento de la prohibición que incorpora no se produce, o se contrasta, con el mero recurso a la intervención judicial, sino que es preciso valorar el fundamento del contenido impugnatorio que determina el recurso a dicha intervención, pues no todo fundamento o contenido impugnatorio de la ejecución testamentaria llevada a cabo queda comprendido en la prohibición impuesta en la cautela socini. En efecto, desde la validez conceptual de la figura, se debe indicar que solo aquéllos contenidos impugnatorios que se dirigen a combatir el ámbito dispositivo y distributivo ordenado por el testador son los que incurren frontalmente en la prohibición y desencadenan la atribución de la legítima estricta, como sanción testamentaria”.
\end{abstract}

En comentarios a esta misma STS, ALEMÁN URIS J.: "Cautela Socini: análisis a propósito de la STS de 17/01/2014", ROED (Revista Online de Estudiantes de Derecho), núm. 4, 2014, pág. 19, (cita 71). El autor se refiere a la doctrina del Tribunal Supremo coincidente con la postura de Roca Sastre y Puig Brutau al respecto de la cautela socini en que si bien presenta una postura aparentemente de sanción, no es otra cosa, que una opción que el testador le ofrece, o le brinda al legitimario para que él, elija.

563 La STS de 10/06/2014 (Tol.4.374.204) no estima el recurso de casación cuya principal causa deriva de la disposición de un testador que en su testamento prohíbe la intervención judicial y cualquier otra que no sea la del contador partidor por él determinado en el citado testamento. El incumplimiento de dicha voluntad del testador por parte de alguno de los legitimarlos suponía para éste la inmediata institución en la legítima estricta que la ley señala, es decir, en un tercio (1/3) únicamente y acreciendo, su parte de mejora, en el resto de legitimarios consentidores de la voluntad del testador. En el Primero de los Fundamentos de Derecho de esta STS se alude a la "cautela socini”, como cuestión de fondo, con relación a la intangibilidad de la legítima y en especial a la validez de aquella, cuando un legitimario reclama su derecho a legítima. En la cláusula que se prohíbe la intervención judicial, el testador, la prohíbe incluso cuando en la "testamentaria haya menores de edad, ausentes o incapacitados". De polémica, trata el Alto Tribunal la admisión o inadmisión de la cautela socini "Esta polémica tampoco ha sido cerrada o resuelta, con carácter general, por la doctrina jurisprudencial de esta Sala, enfocada, primordialmente, desde la perspectiva casuística de las características del supuesto en cuestión, y centrada particularmente en torno al alcance del condicionante de la prohibición del recurso a la intervención judicial; con pronunciamientos que han ido desde la admisión y validez de esta cautela hasta su 
Sigue el Tribunal Supremo, aplicando el mismo criterio doctrinal, citado anteriormente en las expuestas SSTS de validar la cautela socini ${ }^{564}$. Así, la STS de 21/04/2015 señala en su F.J 4º que la acción se ha dirigido a combatir las disposiciones dispositivas y distributivas. Lo cual había prohibido su combate la testadora en su testamento. Tal acción por parte de la heredera comporta, según el Tribunal, la correspondiente "sanción" que no es otra, que la elegida por la heredera, en que su parte de mejora, acrecerá en el resto de herederos ${ }^{565}$.

inaplicación; SSTS 6 de mayo de 1953, 12 de diciembre de 1958, 8 de noviembre de 1967 y 8 de junio de 1999 , entre otras." Acto seguido el Tribunal Supremo admite la validez de la cautela socini dentro de la estructura dispositiva del testamento y motiva dicha validez atendiendo la función de la legítima como límite a la libertad absoluta de disposición y distribución del testador. Por ello dice el Tribunal: "la respuesta debe ser favorable a la admisión testamentaria de la cautela socini”.

${ }^{564}$ La STS de 19/07/2018 (Tol. 6.676.446) cuyo supesto de hecho trata de un testador carente de legitimarios que distribuye sus bienes en distintos legados y nombramiento de herederos universales. Impone una cautela socini que el otorgante en su testamento, por la cual impone la prohibición de la intervención judicial en su herencia. De reclamar alguno de sus herederos, quedará privado de cualquier derecho que el testador le haya legado, acrecentando su parte al caudal hereditario citado como remanente. El Alto Tribunal dispone en su F. J. $3^{\circ}$, la validez de la denominada cautela socini, y cita como doctrina seguida en particular las SSTS 835/2013, de 17 de enero de 2014 y 254/2014, de 3 de septiembre, 717/2014, de 21 de abril de 2015. "En efecto, desde la validez conceptual de la figura, se debe indicar que solo aquéllos contenidos impugnatorios que se dirigen a combatir el ámbito dispositivo y distributivo ordenado por el testador son los que incurren frontalmente en la prohibición y desencadenan la atribución de la legítima estricta, como sanción testamentaria. Por contra, aquellas impugnaciones que no traigan causa de este fundamento y se dirijan a denunciar irregularidades, propiamente dichas, del proceso de ejecución testamentaria, tales como la omisión de bienes hereditarios, la adjudicación de bienes, sin la previa liquidación de la sociedad legal de gananciales como, en su caso, la inclusión de bienes ajenos a la herencia diferida, entre otras, escapan de la sanción prevista en la medida en que el testador, por ser contrarias a la norma, no puede imbricarlas, ya de forma genérica o particular, en la prohibición testamentaria que acompaña a la cautela y, por tanto, en la correspondiente sanción" .

${ }^{565}$ En el F. J. $3^{\circ}$ de la anteriormente citada STS de 21/04/2015 (Tol. 4.988.929) dentro de la Doctrina jurisdiccional aplicable, el Alto Tribunal en esta Sentencia hace una nutrida motivación al por qué de la salvaguarda de la legítima cuando en un testamento se le prohíbe, por parte del testador, acudir al legitimario a los tribunales. Dicho de otra manera, el Tribunal motiva la no confrontación de la cautela socini con la intangibilidad de la legítima de esta manera: "En efecto, desde el desarrollo lógico-jurídico de la figura, se observa que la prohibición impuesta por el testador de recurrir a la 
Entiendo que simplemente depende desde la postura que se quiera mirar la prohibición de acudir a los tribunales en busca de derechos legitimarios. Ello se puede observar al equiparar las posibilidades $\mathrm{y}$ facultades de que dispone el testador en vida de hacer las propuestas a sus legitimarios que estime. No se puede pasar por alto que tiene facultad para repartir el tercio de mejora entre sus legitimarios. Simplemente entiendo, que traslada dicha facultad al clausulado de su testamento y la opción de hacer o de no hacer, que le pudiera ofrecer en vida al legitimario se la ofrece post mortem. Desde la parte legal, como opinión personal, veo que la legítima estricta queda salvada y por lo que respecta a la mejora nunca la ha tenido asegurada. El legitimario, siempre la ha tenido supeditada a la voluntad del testador tanto en vida por la simpatía que se pudieran intercambiar testador y legitimario. Tras la muerte de aquel, la mejora también sigue supeditada a su voluntad a través de la cláusula testamentaria de prohibición y consecuente sanción al incumplimiento. Como bien dice la DGRN de 22 de junio de 2015 cabe examinar las circunstancias concurrentes en cada caso y alejarse de las soluciones generales y apriorísticas atendiendo a elementos de carácter objetivo para determinar si hay o no conflicto de intereses ${ }^{566}$.

intervención judicial, en las operaciones de ejecución testamentaria llevadas a cabo por el comisario contador-partidor, no afecta directamente al plano material de ejercicio del derecho subjetivo del legitimado, que conserva, de modo intacto, las acciones legales en defensa de su legítima, pues su incidencia se proyecta exclusivamente en el marco de la disposición testamentaria como elemento condicionante que articula el juego de la correspondiente opción que da sentido a la cautela socini. No hay, por tanto, contradicción o confusión de planos en orden a la eficacia estrictamente testamentaria de la cautela dispuesta".

${ }^{566}$ En la RDGRN de 22/06/2015 (RJ 2015\3733) cuyo supesto de hecho trata de una escritura de herencia en la que el cónyuge viudo interviene en su propio nombre y como representante legal de sus hijos menores cuya patria potestad le corresponde. No se plantea problemas en la adjudicación de bienes, que se hace pro indiviso, pero sí se cuestiona la existencia de conflicto de intereses cuando el cónyuge opta por adjudicarse el tercio de libre disposición en propiedad más la cuota viudal usufructuaria, en vez de elegir el usufructo universal y vitalicio sobre la herencia. La Doctrina de la DGRN: "En 
el supuesto de este expediente no hay conflicto de intereses porque la opción de la viuda de adjudicarse el tercio de libre disposición en propiedad más el usufructo legitimario no crea una situación que obligue a los menores a tomar una decisión. La elección tomada por la viuda lo ha sido en los términos ordenados en el testamento y no afecta a la intangibilidad de la legítima de los menores, que no ven gravada su legítima estricta por el usufructo de su madre". En cambio si que hay conflicto de intereses cuando: el cónyuge viudo opta por el usufructo de viudedad universal, pues la cautela socini pone en juego la posibilidad de que los herederos -menores o incapaces para decidir por sí solos- deban elegir entre que su parte de herencia esté gravada con el usufructo o que se concrete en el tercio de libre disposición, lo que producía una colisión de intereses entre ellos y quien les representa (R. 5 de febrero de 2015)". 


\subsection{INTRODUCCIÓN AL DERECHO FORAL ESPAÑOL}

El Derecho propio o foral español, si bien es un producto histórico, debe su existencia a que España, en la Edad Media, ha estado formada por diversos Reinos, cada uno con su propio Derecho diferenciado del resto. A comienzos de la baja Edad Media los Estados cristianos de la Reconquista española e incluso aquellos unidos por un mismo Gobierno tenían cada uno su particular Derecho. Un derecho compuesto por leyes, costumbres, sentencias, preceptos, etc. Se trataba de Derechos consuetudinarios muy antiguos fruto de una tradición jurídica que, debido a la intención de los reyes visigodos, de incluir a todos los españoles bajo una misma legislación, es decir, que no se distinguiera la Ley en función de la raza o del territorio en el que se aplicara. Pero la invasión española por parte de los árabes y el consecuente declive del poder visigodo, hizo resurgir los viejos Derechos propios de cada territorio.

No es fácil encontrar los orígenes del Derecho Foral, ni siquiera lo es encontrar el origen del término "foral". La expresión de "Derecho foral" fue utilizada por primera vez en 1759, por el Claustro de la Universidad de Valencia, para reivindicarle a Felipe $\mathrm{V}$ las instituciones perdidas por el reino de Valencia en virtud de los Decretos de Nueva Planta. De ahí se puede deducir que "Derecho foral" puede significar, el Derecho contenido en los Fueros e instituciones propias del régimen foral ${ }^{567}$.

Durante el gran vacío de poder público habido en España desde la caída de la Monarquía visigoda, hasta finales del siglo XII habian tenido lugar importantes cambios en la patria potestad visigoda. Por esta época aparecían, de manera brusca, una nueva forma en los fueros extensos, con

567 FernándeZ Costales, J.: "Las Comunidades Autónomas y el Derecho Civil: Derecho Foral y Derecho Consuetudinario Leonés." Tierras de León: Revista de la Diputación Provincial, Vol. 25, núm. 60, 1985, pág. 5. 
una marcada diferencia con la legislación visigoda. Sin duda el dato más relevante es el cambio estructural patrimonial de la familia durante la Reconquista. Se pasaba de un patrimonio exclusivo del padre a la consagración de una comunidad familiar en la que el padre ya no era el único dueño y señor del patrimonio familiar. Esto quizás podía explicar porqué cada territorio en el futuro estimara mejor atenerse a su viejo Derecho que al promulgado en la unificación ${ }^{568}$.

Sobre la recepción del Derecho romano en todos los territorios españoles medievales. Ello se puede constatar conforme a lo ocurrido en otros países del ámbito europeo. La falta de demostración de que en Aragón no se produjera un rechazo a la implantación del Derecho romano en su territorio hace precarias las afirmaciones con certeza. También mantiene la desigualdad de la romanización del Derecho, si bien en el mismo territorio, dentro de las distintas instituciones y precisamente el Derecho sucesorio o el Derecho de familia entre otras, las encuadra el profesor LALINDE dentro de las más resistentes a la romanización. Se basa para hacer tales afirmaciones en que no aparece en las Observancias ninguna cuota de legítima romana, ni la patria potestad, ni signo alguno que convenza de la romanización del Derecho aragonés ${ }^{569}$.

Se podría hablar de alejamiento del Derecho castellano, en los ordenamientos de Derecho sucesorio de Aragón, Navarra, Vizcaya y Álava. Hay diferencias sustanciales entre los principios rectores de estos Derechos forales y los del Derecho común. En el Derecho aragonés y en el del País Vasco, las legítimas se mantienen dentro del núcleo de la familia y recae en

\footnotetext{
${ }^{568}$ OTERo VARELA, A.: "La patria potestad en el Derecho histórico español”, Anuario de historia del derecho español, núm. 26, 1956, pág. 221.

${ }^{569}$ LALinde ABADIA, J.: "Precisiones conceptuales sobre la legítima aragonesa", Anuario de Derecho civil (Ref. ANU-H-1985-10033300388), 1985, pág. 343.
} 
aquellos descendientes elegidos por el testador. Reduciéndose el derecho del resto de legitimarios, a que se les nombre en el testamento o en el pacto sucesorio, siquiera para excluirlos de la sucesión. De ahí que en Vizcaya y en Aragón se le otorgue escaso valor a la legítima individual que queda manifestado en el apartamiento de los legitimarios no elegidos. En Vizcaya, cuyo objeto es impedir el desmembramiento de la propiedad familiar. En Aragón se admite el reparto desigual de la legítima e incluso la posibilidad de hacerlo entre vivos. En ambos Derechos está previsto un derecho de alimentos a favor de aquellos descendientes que cumplan las condiciones legales para poder pedirlos ${ }^{570}$.

El Derecho de Aragón, País Vasco y Navarra se encuadran dentro del llamado "grupo germánico" por predominar en ellos la tradición histórico jurídica. Ello, en base al sistema de copropiedad familiar que consta de un único sucesor designado entre los hijos del disponente. Tal tradición existe en estos Derechos desde tiempos muy antiguos perviviendo a través de la costumbre. Como valor añadido a dicha tradición, también coexiste el pacto sucesorio como medio de deferir la herencia en vida del disponente, que cabe dentro de la tradición germánica que trata de ordenar su sucesión, el disponente, en vida ${ }^{571}$.

Por virtud del artículo 149.1 .8 de la CE de 1978 se reconoce capacidad legislativa en materia civil a los parlamentos de las CC AA. En consecuencia, se les permite conservación, modificación y desarrollo de su propio Derecho civil, en el supuesto que fuese preexistente al momento de la promulgación de la CE de 1978. Por lo tanto, he aquí, el hecho de porqué

\footnotetext{
${ }^{570}$ DE BARRÓN ARNICHES, P.: "La renuncia anticipada a la legítima en el derecho foral" en El pacto de renuncia a la legítima futura, CEDECS, Barcelona 2001, págs. 91 a 95.

${ }^{571}$ De BARRÓN ARNICHES, P.: "La legítima y el pacto de Non Succedendo en el Derecho Foral de Navarra", Revista jurídica de Navarra, núm. 22, 1996, pág. 227.
} 
son Comunidades de Derecho Foral Aragón, País Vasco, Navarra, Galicia, Cataluña y Baleares, es decir, contaban, con Derecho especial Foral anterior a la CE de 1978. Este Derecho Foral se encontraba integrado en las Compilaciones. Comunidades Autónomas, como pueda ser la valenciana, no disponian de Derecho foral propio.

\subsection{LA LEGÍTIMA EN ARAGÓN}

No se puede hablar, en la actualidad, de legítimas en Aragón tal como lo contemplaba la Compilación de $1967^{572}$. Conforme al artículo 486 del Código de Derecho Foral de Aragón (CDFA en adelante) los únicos legitimarios son los descendientes de cualquier grado del causante no hay por exclusión, ni legítima de ascendentes ni legítima del cónyuge supérstite. Por lo tanto, los únicos legitimarios los descendientes de cualquier grado del causante. De ahí que únicamente se contemple en el CDFA la legítima en singular. Con ello ya se produce una importante diferencia con el Derecho común, puesto que en defecto de descendientes no tendrá ya aplicación supletaria el Código civil ${ }^{573}$.

Conforme al artículo 486 CDFA la legítima en Aragón se compone de la mitad del caudal relicto, es decir, entre el activo y el pasivo de la herencia, que se calculará de acuerdo con lo estipulado en el artículo 484 CDFA. Se amplía de manera considerable la libertad de disponer del testador con relación al Código civil, ya que la legítima pasa de ser de dos tercios a la mitad. Por lo tanto, se reduce la parte de legítima y se aumenta,

\footnotetext{
${ }^{572}$ Compilación de 1967 Derogada por el Decreto Legislativo 1/2011, de 22 de Marzo del Gobierno Aragón, por el que se aprueba con el título de "Código de Derecho Foral de Aragón”, el texto Refundido de leyes civiles aragonesas.

${ }^{573}$ SERrAno GARCÍA, J.A.: "La legítima en Aragón”, Revista de derecho civil aragonés, núm. 16, 2010 pág. 79. Manifiesta el autor que "no puede defenderse la aplicación supletoria del sistema legitimario del Código civil a falta de descendientes".
} 
con ello la libertad de disposición del disponente ${ }^{574}$. No se pueden pasar por alto, en Aragón, los bienes troncales del artículo 528 CDFA que son los que el causante ha recibido de ascendentes o colaterales a título gratuito. Un precepto, el citado, que hay que entenderlo de una manera más profunda que en su pura literalidad ${ }^{575}$.

\subsubsection{La legítima colectiva}

La legítima en Aragón es colectiva. Tal como se señala en el el artículo 486 CDFA y su funcionamiento es de similares características al de la mejora en el Derecho común. Debe de recaer, de manera obligatoria, en uno o más de los descendientes del causante ${ }^{576}$. La legítima es colectiva cuando atiende al grupo o conjunto de legitimarios y no al individuo en particular. Por lo tanto, la legítima se respeta siempre que el grupo de los descendientes, titulares del derecho, haya recibido su parte legal,

\footnotetext{
${ }^{574}$ SERRANO GARCíA, "La legítima en...", op. cit., pág. 81. Piensa el autor que, quien sacará beneficio de ello será, con frecuencia, el cónyuge supérstite, como bien dice la Exposición de motivos del Decreto Legislativo 1/2011, de 22 de marzo, del Gobierno de Aragón, por el que se aprueba, con el título de «Código del Derecho Foral de Aragón», el Texto Refundido de las Leyes civiles aragonesas. Efectivamente coincido con el autor en que, primero viene reflejado en la Exposición de Motivos citada la reducción de la porción de legítima de dos tercios a la mitad del caudal. Lo segundo, en que tal decisión. "Se atiende así a las voces, procedentes sobre todo de los ambientes urbanos, que demandan mayores posibilidades para favorecer al cónyuge con los bienes que se adquirieron durante el matrimonio (...) no se restringe la mayor libertad a este fin específico, sino que queda abierta a las variadas circunstancias y motivaciones de cada causante". coincido plenamente, con el legislador aragonés, pues cada causante tiene su propia motivación y entre ellas podría encontrarse aquel causante que le deja su parte libre, a un extraño y contribuir con ello a aumentar sustancialmente por medio del impuesto de sucesiones, las arcas de la CC AA.

${ }^{575}$ La mejora efectuada en un bien troncal mantiene la STSJ de Aragón de 20/02/2017 (RJ 2017\1740) F. J. $4^{\text {o }}$ que: "El artículo 528.1 CDFA no resulta infringido en la sentencia recurrida pues se declara que la paridera era un bien troncal simple dada su adquisición por el causante a título gratuito, pero también declara que lo que se pretende adquirir como bien troncal es algo bien distinto. Como decíamos en la sentencia de 3 de marzo de 2015, la literalidad del precepto lleva a la conclusión contraria a la pretendida por la parte: "Son bienes troncales simples los que el causante haya recibido a título gratuito de ascendientes...".

${ }^{576}$ RAGEL SÁnChEZ, L.F.: Desde la cautela ..., op. cit., pág. 142.
} 
independientemente de lo que haya recibido cada individuo. En consecuencia ninguno de los legitimarios, salvo que sea el único, tiene un derecho individual sobre parte alguna. Tal carácter colectivo supone una total libertad de distribución por parte del testador, entre los miembros del grupo de descendientes con derecho a legítima (art. 171-2; 486. 2 CDFA) $)^{577}$.

La legítima colectiva es la que impera en la actualidad, en el Derecho Foral de Aragón y en el País Vasco. Con este sistema de legítimas, la Ley sólo le impone obligación al testador para con sus parientes más próximos. Pero, al mismo tiempo, tiene libertad y facultad para, dentro de ellos elegir a aquel o aquellos que van a recibir la legítima material. El testador puede disponer de entre ellos, a quién le otorga la porción que se supone la legítima, sin importar el grado de parentesco. Por lo que pueden elegir a un descendiente de grado más lejano. En Aragón, conforme al artículo 486 CDFA la legítima supone la mitad de la herencia y debe recaer en descendientes, de cualquier grado, ya que son los únicos legitimarios del causante $^{578}$.

No se puede dejar de citar el artículo 488 CDFA que reputa legitimarios de grado preferente a los hijos del finado. En el supuesto de que estos premueran al causante, sean desheredados con justa causa o calificados de indignos para suceder, adquieren la condición de preferencia

\footnotetext{
${ }^{577}$ SERRANO GARCíA, "La legítima en ...”, op. cit., pág. 81. Manifiesta el autor, la preferencia de calificar a la legítima aragonesa como de "legítima de libertad de disposición", en lugar de denominarla "legítima colectiva". Tratando de buscar un objetivo, se encuentra en que nadie puede reclamar a otro legitimario un derecho que no tiene, es decir, la legítima estricta y debido a ello, "no existe en Aragón la acción de suplemento de legítima, ni por Ley la colación de los bienes donados a los descendientes".

${ }^{578}$ Badoy LóPez, C., Delgado Echevarría, J. y Serrano García, J.A.: Comentarios al Código del Derecho Foral de Aragón. Doctrina y Jurisprudencia, Dykinson, Madrid, 2015, pág. 66.
} 
sus descendientes por sustitución. El mismo precepto señala que no tendrán la calificación de legitimarios preferentes los descendientes de aquellos que hubieran repudiado la herencia. La legítima aragonesa no está configurada como pars hereditatis, ya que los titulares del derecho pueden recibir su legítima colectiva bien en concepto de herederos como legatarios o bien como donatarios. En el supuesto de existir donaciones hechas en vida del causante a los legitimarios, lo expuesto trataría solamente de la falta para cubrir la legítima colectiva efectuada la pertinente colación ${ }^{579}$.

El artículo 513. $2^{580}$ CDFA prevé para el legitimario de grado preferente el derecho de representación por parte de sus estirpes si la tienen, cuando aquel haya sido excluido de manera absoluta de la herencia ${ }^{581}$. La legítima colectiva en Aragón está a mucha distancia de la legítima individual del Derecho común. No sólo porque se considera legítima a la mitad del caudal relicto, sino porque el testador tiene facultad de distribuirla entre todos los legitimarios o bien entregársela solamente a uno de ellos ${ }^{582}$. Con la excepción ya citada, de que sólo haya un legitimario y entonces sí que constituye un derecho único sobre el descendiente

\footnotetext{
${ }^{579}$ BERNAD MAINAR, R.: "La porción legítima...”, op. cit., pág. 1789.

${ }^{580}$ Artículo 5132 CDFA (Exclusión absoluta): "2 Los excluidos absolutamente quedan privados del derecho a suceder abintestato y del de ejercitar la acción de lesión que pudiera corresponderles, en los que serán sustituidos por sus estirpes de descendientes si los tuvieran".

581 De BARRón ARniches, P.: "Libertad de testar y desheredación en los Derechos civiles españoles”, Revista para el Análisis del Derecho, núm. 4, 2016, págs. 19 y 24.

${ }^{582}$ La SAP de Huesca (S. $1^{\text {a }}$ ) de 20/11/2015 (Tol. 5. 612.122) F. J. $3^{\text {o }}$ explica la distribución de la legítima colectiva en Aragón, que bien puede distribuirla el disponente de manera igualitaria entre sus descendientes o bien hacerlo de manera desigual y favorecer a alguno de sus descendientes. "Esta legítima colectiva puede distribuirse, igual o desigualmente, entre todos o varios de tales descendientes, o bien atribuirse a uno solo." por lo que ninguna lesión de la legítima supone que el causante sólo quisiera favorecer a su hijo, el hermano de la hoy apelante, como el que está pretendiendo hacer valer por un veinticinco por ciento de la herencia frente a su hermano, quien no es un tercero sino un legitimario de grado preferente".
} 
también único ${ }^{583}$. La legítima aragonesa, en cuanto a la potestad distributiva que la Ley concede al testador, es semejante a la que se le concede a este, en el Derecho común para distribuir la mejora entre los hijos y descendientes.

Hasta que no se distribuya la legítima, ningún legitimario sabe, ni puede estimar, el montante de su parte a excepción, como se ha dicho, de que sea él, el único legitimario. Por lo tanto, al tratarse de una legítima colectiva, no cabe reclamación alguna, como pudiera ocurrir en el Derecho común, en caso de violarse la legítima estricta. Ello ocurre simplemente porque no existe porción mínima que reclamar. Confirma lo dicho la inexistencia, en aquel Derecho de la acción de suplemento de la legítima. Tampoco, conforme al artículo $362^{584}$ CDFA existe la obligación legal de colacionar, cuando se ha donado bienes, entre vivos, a descendientes del causaste. Por lo que se refiere a la desigualdad en la distribución de la legítima entre hermanos. El artículo 486. $2^{585}$ CDFA autoriza a que se produzca tal desigualdad. Incluso llegado el caso puede, el testador, excluir

${ }^{583}$ GÓMEZ- CORNEJO TEJEDOR, L.: "El cambio de sesgo en la jurisprudencia en torno a las causas de desheredación en el Derecho común español ", Revista Crítica de Derecho Inmobiliario, núm. 755, mayo 2016, pág. 1621.

${ }^{584}$ Artículo 362 CDFA (Voluntariedad): “1. La colación de liberalidades no procede por ministerio de la ley, mas puede ordenarse en el título de la propia liberalidad o en pacto sucesorio o testamento. 2. La obligación de colacionar impuesta podrá ser dispensada posteriormente por el disponente en testamento o en escritura pública”.

585 Artículo 486 CDFA (Legítima colectiva): “1. La mitad del caudal fijado conforme al artículo 489 debe recaer en descendientes, de cualquier grado, del causante, que son los únicos legitimarios. "2. Esta legítima colectiva puede distribuirse, igual o desigualmente, entre todos o varios de tales descendientes, o bien atribuirse a uno solo. Si no se ha distribuido o atribuido de otra manera, la legítima colectiva se entiende distribuida entre los legitimarios de grado preferente conforme a las reglas de la sucesión legal". 
de su herencia a un hijo sin tener que alegar causa para hacerlo como ocurre, entre otros, en el Derecho común ${ }^{586}$.

\subsubsection{Los legitimarios en el CDFA}

El Derecho aragonés distingue, entre los legitimarios, a los de grado preferente. Si le han premuerto hijos al causante, los hijos de aquellos, tendrán el grado de preferencia, al igual que los hijos de los desheredados por causa legal o indignidad, es decir, los hijos de los hijos del causante desheredados o tachados de indignos. No son legitimarios de grado preferente, los nietos del causante mientras viva su padre. Tampoco ostentan tal condición, los hijos o descendientes de los hijos del que hubiera renunciado a su legítima, en la herencia de su padre ${ }^{587}$. El Derecho aragonés tiene en cuenta especialmente a los legitimarios de grado preferente, para otorgarles legitimación para ejercitar acciones a que se refieren los artículos $492.4 ; 508.2 ; 514 ; 515$, todos del CDFA, es decir, se les otorga acción por lesión cuantitativa de la legítima, preterición no intencional, desheredación o exclusión por error, así como para pedir alimentos. En cambio, los legitimarios que no ostenten el grado preferente, no tienen legitimidad para ejercitar la acción de lesión cuantitativa de la legítima, salvo lo dispuesto en el artículo 494. $2 \mathrm{CDFA}^{588}$.

\footnotetext{
${ }^{586}$ PARRA LUCÁN y BARRIO GALLARDO, "La Legítima en el Derecho aragonés...”, op. cit., pág. 362. Ponen de manifiesto los autores que, "se sigue el artículo 119 de la Compilación, que se disponía en él la distribución igualitaria o bien desigual entre los descendientes o bien atribuirla a sólo uno de ellos". Lo entienden los autores, bajo el punto de vista en que la legítima colectiva permite poner todo el patrimonio del causante en una sola persona, con la única condición de que dicha persona sea un descendiente del causante.

${ }^{587}$ JuÁreZ GonZÁleZ, J. M.: GPS Sucesiones, ed. 2a , Tirant lo Blanch, Valencia, 2017, págs. 439.

${ }^{588}$ PARRA LUCÁN, M. Y BARRio GALlARDO, "La Legítima en el Derecho aragonés...", op. cit., pág. 364.
} 
Sigue con respecto al legitimario no preferente, la misma idea que inspiró al legislador precedente al vigente CDFA, es decir, la idea que tenía en mente el legislador 1977, y transmitió al de 1999. La inspiración legislativa, no es otra, que al legitimario no preferente lo asista sólo el derecho que para él, disponga el testador por donación o por testamento. Quiere esto decir simplemente que la Ley no le otorga nada que no le haya otorgado el testador. Por lo tanto, no cabe preterición ni desheredación injusta cuando el legitimario es de grado no preferente. Ello viene a cuenta de que este, no tiene un derecho expectante de legítima del que pueda ser privado y al que nada tiene, nada se le puede quitar. El único interés que puede tener es el referido a las distintas aperturas de una misma sucesión en que él, cada vez queda más cerca de convertirse en legitimario preferente. Puede, ello, darse en el nieto del causante que hoy es legitimario no preferente, pero en el caso de morir su padre se convertiría en legitimario de derecho preferente ${ }^{589}$.

\subsubsection{Intangibilidad de la legítima}

Al igual que ocurre en el Derecho común se entiende la legítima en Aragón como la parte de los bienes relictos que el legitimario tiene que recibir por cualquier título ${ }^{590}$. En el Derecho aragonés la intangibilidad cualitativa de la legítima se regula en el artículo 494 CDFA, que tiene su equivalencia en el artículo $815 \mathrm{Cc}$ salvando las distancias que provoca el que la legítima aragonesa sea colectiva. La intangibilidad de la legítima

\footnotetext{
${ }^{589}$ Moreu BALlONGA, J. L.: "El apéndice foral aragonés de 1925 y encrucijadas del Derecho civil y de la cuestión territorial en España", Ius fugit: Revista interdisciplinar de estudios histórico-jurídicos, núm. 15, 2007-2008, pág. 194.

590 Vease la RDGRN de 25/02/2008 ( RJ 2008, 2791) y RDGRN de 17/10/ 2008 (RJ 2009\637) en que se pone de manifiesto que la legítima se configura generalmente como una pars bonorum, y se entiende como una parte de los bienes relictos que por cualquier título debe recibir el legitimario, sin perjuicio de que en determinados supuestos reciba su valor económico, o pars valoris bonorum. Viene a ser lo mismo que regula el Código civil para dichos "determinados supuestos".
} 
afecta al disponente en el sentido que no puede gravar al legitimario ni dejarle menos de lo que por ley le corresponde. La intangibilidad otorga opción al legitimario para interponer las acciones y poder corregir las disposiciones que perjudiquen su derecho ${ }^{591}$. Existen dos clases de intangibilidad de la legítima, la que se refiere a vulnerar su cantidad y la que se refiere a mermar su calidad, es decir, la cuantitativa y la cualitativa. Si bien en el primero de los casos la Ley impide que se otorgue menos cantidad de la que por derecho les corresponde a los legitimarios. En el segundo caso lo que se impide es que se le reste calidad, es decir, que lo que se les otorgue a los legitimarios una legítima gravada y por lo tanto de una calidad inferior a la que les corresponde a los titulares de ese derecho. Todo según dispone el artículo 498 CDFA "prohibición de gravámenes sobre la legítima", cuyo contenido es similar al del artículo 813 Cc.

\subsubsection{Intangibilidad cuantitativa de la legítima}

La intangibilidad cuantitativa se regula en el Capítulo II Tit. VI (De la legítima) del Libro Tercero (Derecho de sucesiones por causa de muerte CDFA). Si se ha producido lesión cuantitativa es por haber habido exceso de atribución a los no legitimarios y por tanto no llegar a cubrir la legítima colectiva, es decir, se ha producido un exceso en las liberalidades y es ahí donde hay que atacar y hay que pedir, una reducción de las liberalidades hechas a favor de los no descendientes, es decir, si las liberalidades superan el 50\%, ello conforme al artículo 496.1 y ss CDFA. Dicho de otra manera, como se sabe, la legítima en Aragón la forma la mitad de la herencia del difunto, que conforme al artículo 487 CDFA se compone del relictum más el donatum. Si sumadas las liberalidades hechas en vida del causante a favor de los legitimarios más, lo que les haya otorgado post mortem, equivale a menos de la mitad de la herencia de aquel, hay lesión

${ }^{591}$ SAP de Zaragoza (S. 5 ${ }^{\text {a }}$ de 12/07/2016 (Tol. 5.825.734) F. J. $3^{\text {o. }}$ 
cuantitativa de la legítima ${ }^{592}$. Hay que resaltar aquí que, en la legítima colectiva, lo que prima, para saber si hay o no hay lesión cuantitativa de la legítima es la suma de las legítimas sin importar la distribución entre los legitimarios. De haber tal lesión se aplicará la acción de reducción del artículo 494 y ss CDFA $^{593}$.

\begin{abstract}
${ }^{592}$ SAP de Zaragoza (S. $5^{\text {a }}$ ) de 27/06/2014 (Tol. 4.438.671). La jurisprudencia aragonesa atiende las controversias con respecto a la intangibilidad de la legítima aragonesa, manifestando lo que entiende por tal el artículo 806 Cc- como porción de bienes de que el testador no puede disponer por haberla reservado la Ley, a los herederos forzososEsta SAP en su FJ $2^{\text {a }}$ hace una brillante aportación de lo que la Sala entiende por intangibilidad cuantitativa de la legítima y su acción: "El sistema se califica como de reglamentación negativa, dado que la Ley deja al causante disponer de sus bienes en la confianza de que va a cumplir voluntariamente, y por cualquier título, el deber de atribución y confiere al legitimario ( artículo 763.2 del Código Civil, para el caso de que se superen en su perjuicio los límites establecidos, la facultad de ejercitar las acciones de defensa cuantitativa de su legítima, con la reclamación del complemento ( artículo 815 del Código Civil ), la reducción de legados excesivos ( artículos 817 y 820 del Código Civil y Sentencia de 24 de julio de 1986 ). o, en su caso, de las donaciones inoficiosas (artículos 634, 651, 819 y 820 del Código Civil), aunque estén ocultas bajo negocios aparentemente onerosos (Sentencia de 14 de noviembre de 1986). Como consecuencia, la legítima se calcula adicionando al valor del relictum el del donatum (artículo 818 del Código Civil y Sentencias de 17 de marzo de 1989, 27 de febrero de 1997, 15 de febrero de 1999 y 28 de febrero de 2002), y se imputan a ella las donaciones hechas a los hijos, que no tengan el concepto de mejora (artículo 819 del Código Civil y Sentencia de 21 de abril de 1997). Del mismo modo, el legitimario que hubiera recibido íntegramente la legitima por herencia, legado o donación carece del derecho a reclamarla como heredero forzoso, independientemente del título de su atribución por el causante, pues no ha sido favorecido por una delación legal inmediata y directa". Cabe destacar, y recomiendo su lectura detallada, acerca de las alusiones que hace esta SAP de Zaragoza al Derecho común como motivación a su resolución.
\end{abstract}

${ }^{593}$ Rivas MartíneZ, J.J.: Derecho de sucesiones..., op. cit,.., pág. 1773. Señala que acción de reducción se contemplaba en el artículo 179 de la derogada Ley de Sucesiones de Aragón.

También la SAP de Zaragoza (S. 5 ) de 27/06/2014 (Tol. 4.438.671), antes citada, se refiere a la acción por intangibilidad cuantitativa de la legítima en su FJ 2a: "Si la partición lesionara los derechos de los legitimarios, puede ser impugnada, pues lo contrario conculcaría el ordenamiento sucesorio. El artículo 494 CDFA señala sobre este particular: " Lesión de la legítima. 1. No alcanzando los beneficios percibidos por el conjunto de los descendientes la cuantía de la legítima colectiva, podrán reducirse las liberalidades hechas en favor de no descendientes en la forma regulada a continuación", añadiendo el artículo 497 siguiente que lo que falte para alcanzar la cuantía de la legítima "Faculta individualmente a los legitimarios afectados para pedir que la parte proporcional que en las diferencia le corresponda les sea entregada en bienes relictos por lo extraños que los han recibido...", Estas son en su conjunto las razones por las que 
En ordenamientos de legítima individual, como en el Derecho común, el legislador soluciona el problema de lesión cuantitativa de la legítima, atribuyendo al legitimario perjudicado acción para reclamar el defecto al no legitimario que haya sido beneficiado (art. $817 \mathrm{Cc}$ ). En cambio en el ordenamiento de Aragón se necesita establecer un mecanismo que legitime a uno o más legitimarios para poder reclamar de los beneficiados lo que le falte de legítima colectiva al grupo o conjunto de legitimarios ${ }^{594}$. Hay que tener muy en cuenta que, en Aragón, la no ejercitación del derecho de reclamación, así como en la renuncia a la legítima no se acrece su parte en los demás. Tienen preferencia de acción los que haya dispuesto para ello el testador y en defecto de ellos los legitimarios preferentes. La acción de complemento de la legítima colectiva es de carácter individual, cada titular que ejerciera la acción citada tiene derecho a un importe en proporción a la cuota que obtendría en la sucesión abintestato. Comprobado que se han producido liberalidades que perjudican la legítima colectiva, lo segundo es saber cómo se procede a efectuar el orden de reducción conforme al artículo 495 CDFA. Este precepto antepone la voluntad del testador para la reducción de liberalidades y sólo tendrá cabida para el caso de no existir pronunciamiento del causante al respecto ${ }^{595}$ :

Se reducirán las liberalidades consecuentes de las disposiciones efectuadas por el testador en su testamento, sin importar por el título que se hayan atribuido, es decir, no importa que se hayan atribuido por herencia o

los actores [en la señalada SAP de Zaragoza] solicitan la reducción de las disposiciones económicas realizadas por el testador a favor de su esposa, al afirmar que perjudican los derechos que por disposición legal han de corresponderles".

${ }^{594}$ Delgado Echeverría, J. Y BAyod López, M.C.: Comentarios al Código del Derecho Foral de Aragón. Doctrina y Jurisprudencia, Dykinson, Madrid, 2015, pág. 678.

${ }^{595}$ Rivas MartíneZ, J.J.: Derecho de sucesiones común y foral, Tomo II, Dykinson, 2009, pág. 1773. 
por legado, entre otros. Procederá hacer las pertinentes reducciones en las liberalidades que el causante haya hecho en vida, o sea entre vivos. Dicho de otra manera, las donaciones que el causante haya hecho a legitimarios viviendo él. Debiendo empezar a reducirse por las últimas realizadas y prorrateando las de la misma fecha ${ }^{596}$.

Como se ha podido advertir en el párrafo anterior, nada queda del carácter colectivo de la legítima tras haber sido esta lesionada cuantitativamente y en consecuencia la acción de suplemento funciona de manera similar a como se hace en los sistemas de legítima individual. De no ejercer su derecho a reclamar, alguno de los legitimarios, la lesión sufrida, no acrece en los demás legitimarios de grado preferente. Ni pueden sustituirle su descendencia, es decir, no existe comunicación de derechos entre los legitimarios, ni tampoco sustitución posible (art. 488.1 CDFA). Por lo que se refiere a la reducción de las liberalidades lesivas para la legítima se reducirán conforme al orden establecido por el testador. Para el supuesto de falta de previsión testamentaria se reducirán primero las liberalidades mortis causa a prorrata, independientemente de su título de atribución. En el supuesto de no cubrirse la legítima, se reducirán las liberalidades entre vivos comenzando por las de fecha más reciente y si hay de igual fecha se reducirán prorrateadas ${ }^{597}$.

\footnotetext{
${ }^{596}$ La SAP de Zaragoza (S. $2^{\text {a }}$ ) de 12/07/2016 (Tol. 5.825.734) con referencias a la STS de 16/01/2013 (Tol. 3.407.348) para poner de manifiesto que, "incluso la donación disimulada aún remuneratoria de un bien inmueble es nula si el negocio simulado lo es, entre otros motivos por cuanto el criterio favorable a la validez de la donación disimulada propicia por si mismo fraude a los acreedores y legitimarios del donante, en cuanto les impone la carga de litigar para que se descubra la simulación, a fin de que se revele el negocio disimulado, y una vez conseguido, combatirlo si perjudica a sus derechos (acción rescisoria) o para que sean respetados (acción de reducción de donaciones por inoficiosidad)".

${ }^{597}$ Delgado EChEVARría, BAdOY LÓPEZ, Y SERRANO GARCÍA, Comentarios al Código..., op. cit., pág. 678, analizando la sentencia del TSJ de Aragón, de 22/09/2011, ponen de manifiesto que "La aplicación de las reglas de la sucesión legal no puede
} 


\subsubsection{Intangibilidad cualitativa de la legítima}

La intangibilidad cualitativa de la legítima desde la Compilación de 1967, hasta el Derecho actual ha sufrido dos modificaciones ${ }^{598}$. Así el artículo $125^{599}$ de la Compilación de 1967 recogía aquellos gravámenes con que la Ley permitía que se cargara la legítima aragonesa. Todos los gravámenes impuestos sobre ella que no fueran los que recogía el precepto se tenían por no puestos. La reforma practicada y plasmada en el artículo 497. 1 CDFA establece que la legítima debe atribuirse a los legitimarios sin cargas y además con bienes relictos (pars bonorum). Dicho lo anterior se pueden sacar dos importantes conclusiones que caracterizan de lleno la intangibilidad cualitativa de la legítima aragonesa: la prohibición de cargar la legítima con gravámenes no tipificados por la Ley y el mandato imperativo de que la legítima ha de pagarse con bienes relictos. Conforme al precepto 497. 2 CDFA $^{600}$ no parecen las cosas ser tan simples ya que el artículo citado se refiere cuando dice de "pagar la legítima con bienes

conducir a que el importe total de las cuotas que se pueden reclamar por lesión cuantitativa resulte inferior al montante total de la cuota legitimaria".

${ }^{598}$ La intangibilidad cualitativa de la legítima se regula en el CDFA en el capítulo III, del Título VI, del Libro Tercero (arts. 497 a 502 )

${ }^{599}$ Artículo 125 de la Compilación de 1967 (Intangibilidad de la legítima. Los gravámenes sobre la legítima se tendrán por no puestos, salvo): Primero. Aquellos dispuestos en beneficio de otros descendientes legítimos. Segundo. Los establecidos para el caso de fallecer todos los legitimarios sin descendencia, y sólo relativamente a los bienes de que cada uno no hubiere dispuesto. Tercero. Las prohibiciones de enajenar u otras limitaciones establecidas con justa causa. Cuarto. Los demás gravámenes y prohibiciones previstos por la Compilación".

600 Artículo 497 CDFA. (Cumplimiento en bienes relictos): 1. La legítima debe atribuirse en bienes relictos. 2. El incumplimiento del deber de atribuir en bienes relictos lo que falte para alcanzar la cuantía de la legítima colectiva, computadas las donaciones imputables, faculta individualmente a los legitimarios afectados para pedir que la parte proporcional que en la diferencia les corresponda les sea entregada en bienes relictos por los extraños que los han recibido, renunciando en favor de éstos a los correspondientes bienes no relictos. 3. La reducción de liberalidades de bienes relictos hechas en favor de no descendientes no podrá afectar al cónyuge viudo y para su práctica será de aplicación el artículo 496". 
relictos", concretamente, a las liberalidades por causa de muerte, es decir, las dispuestas en testamento o pacto sucesorio ${ }^{601}$.

La intangibilidad cualitativa afecta a la forma del pago de la legítima. Conforme exponen el artículo 497.1 y ss CDFA la legítima es una parte del caudal relicto y conforme al precepto citado, ha de atribuirse en bienes que formen parte de la herencia. En consecuencia, la legítima es una pars bonorum que por cualquier título debe recibir el legitimario sin perjuicio de que, en determinados supuesto, los legitimarios reciban su valor en metálico, o parte de éste, de dicha manera.

Por lo tanto, la intangibilidad cualitativa de la legítima, se refiere a la forma en que se ha materializado la legítima a los legitimarios. Frente al incumplimiento de lo expuesto, y haberse dejado menos de lo que por legítima corresponde. Cabe pensar que se han atribuido bienes relictos a los no legitimarios y ello, faculta de manera individual a los legitimarios, conforme al artículo 497. $2^{602}$ CDFA para pedir esa reducción, es decir,

${ }^{601}$ SERRANO GARCÍA, "La legítima en Aragón...”, op. cit., pág. 101, El supuesto que describe este autor: "si las liberalidades entre vivos recibidas por los descendientes por si solas o sumadas a las liberalidades por causa de muerte en bienes relictos cubren el importe de la legítima colectiva, no habrá incumplimiento de este deber". Mantiene a este respecto que, el fin del precepto es evitar que el extraño haga suyos los bienes de la herencia, pagando a los legitimarios con dinero. Destacar la observancia que hace el autor sobre el artículo 479 CDFA: "cuando pone dificultades a los derechos de los legitimarios frente al legatario de cosa cierta y especifica existente en el caudal relicto". Este precepto, bajo mi punto de vista, no hace sino, presumir la voluntad del testador, en el sentido que, al legar una cosa cierta y específica parece dar a entender como si detrás hubiera algo de sentimiento añadido, en que sería muy difícil poderlo valorar en metálico.

${ }^{602}$ La SAP de Zaragoza, (S. 5 ${ }^{\text {a }}$ ) de 18/05/2016 (Tol. 6.028.028) F. J. $3^{\text {o }}$ se refiere al artículo 497 CDFA, en este sentido: "Cumplimiento en bienes relictos. La legítima debe atribuirse en bienes relictos. 2. El incumplimiento del deber de atribuir en bienes relictos lo que falte para alcanzar la cuantía de la legítima colectiva, computadas las donaciones imputables, faculta individualmente a los legitimarios afectados para pedir que la parte proporcional que en la diferencia les corresponda les sea entregada en bienes relictos por los extraños que los han recibido, renunciando en favor de éstos a los correspondientes bienes no relictos. 3. La reducción de liberalidades de bienes relictos hechas en favor de no descendientes no podrá afectar al cónyuge viudo y para su 
pueden pedir que los extraños que han recibido bienes, que los aparten conforme al artículo 496 CDFA. Siempre que dicha reducción de las liberalidades no afecte al cónyuge viudo según el artículo 497. $3^{603}$ CDFA.

A pesar de que siempre puede evitar la reducción pagando en metálico. Siendo el quantum total colectivo no es colectiva la acción de reclamación ya que le corresponde de manera individual a cada legitimario de lo que se les haya atribuido con bienes no relictos. Para conseguir la efectividad del derecho, por los legitimarios perjudicados por haberles atribuido un crédito contra el caudal y no bienes relictos. Se ha de averiguar si se han atribuido bienes relictos a otros descendientes (de cualquier grado) que cubran la totalidad de legítima colectiva. La acción es individual y corresponde a cada uno de los legitimarios perjudicados, contra los no legitimarios que si hayan recibido bienes del caudal relicto, cuyo objeto es la permuta de unos por otros ${ }^{604}$. Diferente es el caso, que recoge el artículo 494 CDFA para la lesión cuantitativa, pues en el presente caso, en la reducción de la intangibilidad cualitativa donde la legitimación para obtener la reducción corresponde a los legitimarios de grado

práctica será de aplicación el artículo 496". El 498, del mismo cuerpo legal lo entiende la Sala de la citada Audiencia Provincial de Zaragoza de este modo: El artículo 498 del Código Aragonés expone: "Prohibición de gravámenes sobre la legítima. El causante solo puede imponer gravámenes sobre los bienes relictos que atribuya a sus descendientes cuando el valor de los atribuidos libres de gravamen sumado al de las donaciones imputables a la legítima cubra el importe de la legítima colectiva. 2. Se entiende a estos efectos por gravamen toda carga, condición, término, modo, usufructo, obligación, prohibición o limitación impuestos en el título sucesorio que disminuya el valor de los bienes relictos o la plenitud de la titularidad o del conjunto de facultades que correspondían al causante. No se consideran gravámenes los legados en titularidad plena de bienes ciertos con que el causante hubiera gravado a un descendiente". Incluso dispone la AP citada, que en el supuesto de que el legitimario titular del derecho a acción fuera menor de 14 años al iniciarse el cómputo, es decir, a la muerte del causante, el plazo para este menor finalizaría al cumplir los 19 años.

${ }^{603}$ AlzAte MonRoy, P.: "El Derecho expectante de viudedad", Blog de Patricia Alzate Monroy, enero 2010.

${ }^{604}$ Delgado Echeverría, J. y BAdoy LóPez, Comentarios al Código..., op. cit., pág. 682. 
preferente. La acción no se atribuye necesariamente a los legitimarios de grado preferente, sino a cualquier legitimario que cumpla las condiciones que reclama esta acción de permuta ${ }^{605}$.

\subsubsection{Las cautelas de opción compensatoria}

Más que regular podrían encontrar acomodo estas cautelas de opción compensatoria (sociniana o socini), en el artículo 500 CDFA que tiene su antecedente en el artículo 185, de la Ley de sucesiones de Aragón. Este precepto tiene sus equivalentes en el artículo 459-1. 2 y 3 del Código civil de Cataluña y también con el artículo 40 de la Compilación de Baleares. Se trata, la citada cautela, al igual que ocurre con el Derecho común ${ }^{606}$, de una

${ }^{605}$ Para determinar los bienes concretos objeto de la permuta son de aplicación las reglas de los números 2 y 3 del art. 496, CDFA, según pone de manifiesto DELGADO EcheVarría, BAdoy LóPez, y SERrano García, Comentarios al Código...,op. cit., pág. 682. También este autor niega el ejercicio de la acción de permuta "cuando el beneficiado con bienes relictos en detrimento de los legitimarios es el cónyuge del causante, viudo al causarse la sucesión, por lo que si la legítima está cubierta en términos cuantitativos no cabe ejercitar acción alguna frente él por lesión cualitativa, y si con esta lesión concurriese la cuantitativa, ya hemos visto que el precedente art. 496.1, permite al viudo satisfacer en metálico la parte de la legítima material que falte.

${ }^{606}$ La STS de 21/04/2015 (Tol. 4988.929) resuelve un caso en que la testadora en la cláusula $10^{\mathrm{a}}$ de su testamento prohíbe "toda intervención judicial en su herencia y expresamente dispone que aquel que impugnase lo establecido en este testamento, por cualquier motivo, quedará privado de cualquier derecho sobre la herencia de la testadora. El Alto Tribunal en el F.J. $3^{\circ}$, punto $2^{\circ}$ trae a colación la doctrina jurisprudencial al respecto de las cautelas de opción compensatoria y en particular de la cautela socini: "En el contexto doctrinal debe señalarse que aunque la figura de la cautela socini goza de un cumplido reconocimiento en la práctica testamentaria que desarrolla el contenido dispositivo del testador, de suerte que su previsión no resulta extraña o inusual a la misma, conforme también a la estela más reciente de las denominadas cautelas de opción compensatoria; no obstante, tampoco puede desconocerse la polémica que en el ámbito de la doctrina científica ha acompañado (prácticamente desde la época de su valedor, el jurista Mario Socino, autor a mediados del XVI de un dictamen a su favor) la aplicación de esta cautela ante su posible ilicitud por comprometer o gravar, indebidamente, la legítima de los herederos". En aplicación de la doctrina jurisprudencial al caso enjuiciado, la STS, anteriormente citada, concretamente en el Pto. $3^{\circ}$ del mismo F. J. dispone Conforme al contexto doctrinal descrito, que no cabe duda que el contenido impugnatorio del testamento y partición que subyace en la acción ejercitada por la heredera demandante, ya sea calificada de acción de suplemento, del artículo 815 del Código Civil, ya sea de acción de rescisión 
opción a escoger que se le ofrece al legitimario entre atribuirle su legítima libre de cargas u otra de más valor, pero con gravamen. La validez de estas cautelas de opción compensatoria está sujeta a dos requisitos esenciales esta última:

1. En la opción libre por la atribución de cargas: que no se lesione la legítima colectiva. (Art, 500.1.a CDFA)

2. En la opción por la atribución gravada. El conjunto de liberalidades a optar por los legitimarios ha de cubrir la mitad de la parte de libre disposición, es decir, a los legitimarios el gravamen se les compensará, al menos, con la mitad de la parte de libre disposición.

El apartado $2^{\circ}$ del precepto anteriormente referido es tajante, ya que, de incumplirse los requisitos antes señalados, el gravamen carecerá de eficacia por la aplicación del artículo 499 CDFA, por lo tanto, la carga se tendrá por no puesta. Se encuentra aquí una falta de proporción entre la el gravamen y la adjudicación pudiendo ser mínima o máxima la carga, sin variar el montante de la atribución ${ }^{607}$.

Como se puede apreciar, hay un permiso dispuesto por el artículo 500 CDFA por el que se le otorga facultad al testador para que exponga su propuesta de opción a los legitimarios, independientemente, de lo acertado

de la partición, del artículo 1074 del Código Civil, se dirige a combatir el ámbito dispositivo y distributivo ordenado por la testadora, de forma que incurre frontalmente en el marco de la prohibición dispuesta y comporta la sanción correspondiente, esto es, el acrecimiento de los derechos hereditarios a favor de los demás herederos y la atribución de la legítima estricta al beneficiario impugnante. En este caso, de la legítima prevista en la Compilación de Navarra. Se puede sonsacar de esta resolución que, frente a la interposición de demanda por parte del heredero, contradiciendo la voluntad de la testadora se le asigna solamente la legítima estricta y por lo tanto perdería el tercio de mejora de atenerse a Derecho común. Ello se traduce de la cláusula $10^{\mathrm{a}}$ del testamento "quedará privado de cualquier derecho", significa derechos disponibles por el testador, como la mejora que acrecerá en el resto de legitimarios.

${ }^{607}$ Delgado Echevarría, Badoy López, y Serrano García, Comentarios al Código..., op. cit., pág. 685. 
de los requisitos exigidos. Cosa muy distinta es que el testador asegure la eficacia total o parcial de su testamento con base a condiciones de tipo resolutorio y de carácter sancionador. Tratando así de impedir la impugnación de las disposiciones testamentarias y la división judicial de la herencia, entre otros supuestos, de cláusulas testamentarias que proscriben la intervención judicial. Nada tienen esto que ver con las cautelas de opción compensatoria antes descritas ${ }^{608}$. En este sentido la postura jurisprudencial a la hora de apreciar la ilicitud de la condición parece no ser del todo pacífica $^{609}$. Si bien hay un criterio jurisprudencial generalizado frente a la condición que supone coacción o interviene en los derechos que afecten a la personalidad. Así como las condiciones que impongan, bien por acción o

\footnotetext{
${ }^{608}$ La S.T.S.J., de Cataluña de 18/12/2014 (Roj: STSJ CAT 12148/2014) refleja un supuesto en que la testadora otorga en su testamento un legado gravado a su hijo, concretamente le adjudica parte un inmueble en que él es el inquilino, con la condición que a de desalojarlo como tal, en el plazo de noventa días, a contar desde la muerte de la causante. En el caso de incumplir tal condición el hijo e inquilino perderá el beneficio del legado. Se pronuncia el TSJ de Cataluña, en su F. J. $3^{\circ}$ Pto. 1. con el siguiente criterio: "De manera que, siendo evidente que la testadora se limitó a disponer de la propiedad de sus bienes de la manera que creyó más oportuna para evitar disputas sucesorias, permitiendo al actor continuar con sus derechos arrendaticios respecto a los inmuebles legados a cambio de perder la posibilidad de acceder a la propiedad de la mitad de uno de los dos edificios legados, que en este caso acrecería el legado de los nietos de la causante, no es posible apreciar ilicitud ni coacción ilegítima de ninguna clase desde el momento en que, dejando a salvo la legítima cuando proceda, los legados pueden ser gravados por el testador de diferentes formas". [Adviértase del texto: "dejando a salvo la legítima"]

${ }^{609}$ La STS de 10/06/2014 (Tol 4.374.205) discrepa con la anteriormente señalada STSJ de Cataluña de 18/12/2014 (Roj: STSJ CAT., 12148/2014) en que esta apoya su motivación, cuando aquella dice en su F.J., $8^{\circ}$, "si el testador imposa la condició de no impugnar el testament o de no recórrer als tribunals de justícia amb relació a la seva successió, aquesta condició es té per no formulada i no afecta en cap cas l'eficàcia del testament ni de la institució sotmesa a la condició ", sin perjuicio, naturalmente, de lo dispuesto en el art. 10 LA 2003". Cuya traducción al castellano sería: [si el testador impone la condición de no impugnar el testamento o de no recurrir a los tribunales de justicia en relación a su sucesión, dicha condición se tiene por no puesta, sin afectar por ello a la eficacia del testamento ni a la institución sometida a la condición].
} 
por omisión, actos improbados por la Ley o por la moral. Como por ejemplo la prohibición de contraer matrimonio ${ }^{610}$.

\subsubsection{La prohibición de gravar la legítima}

Se refiere el artículo 498 CDFA a que sólo se les pueden imponer cargas a los bienes relictos atribuidos a los descendientes cuando se haya cubierto la legítima colectiva con bienes no gravados. Tanto los procedentes de las donaciones imputables a la legítima como de los atribuidos post mortem a los legitimarios ${ }^{611}$. Por gravamen, dice el precepto, se concibe toda carga, condición, término, modo, usufructo, obligación, prohibición o limitación que disminuya el valor de los bienes relictos o la plenitud de la titularidad o del conjunto de facultades que correspondían al causante. Esta relación no puede tomarse de manera exhaustiva, ya que lo que pretende el precepto es salvaguardar el valor neto de la legítima colectiva, por lo que tiene cabida cualquier otra restricción que le mengue. Hay que tener muy presente que los gravámenes que benefician a otros descendientes los excluye la prohibición de cargas del

\footnotetext{
${ }^{610}$ Así la STSJ, de Cataluña de 04/03/3013 (Tol. 3.752.625) que recoge en su motivación la anteriormente señalada STSJ de Cataluña de 18/12/2014 (Roj: STSJ CAT 12148/2014) en su F.J. $3^{\text {o }}$ señala como condiciones ilícitas “Aquellas que establecen una coacción injustificada o interfieran en los denominados derechos de la personalidad, como son, entre otras, la imposibilidad absoluta de... contraer matrimonio (p. ej. prohibida en el 793 CC)o las captatorias (que anulan la institución de heredero, vid. arts. 160 CS y 794 CC )"o también las que" imponen actos u omisiones que son reprobados por la Ley o la moral atendidas las pautas ético-sociales dominantes en el momento de la apertura de la sucesión".

${ }^{611}$ STSJ de Aragón de 30/01/2008 (Roj: STSJ AR 2/2008). En su F.J. $2^{\circ}$ mantiene esta sentencia: "El Sr. xxx entiende que el legado dispuesto por su madre, consistente en el usufructo vitalicio de la vivienda sita en la CALLE000 , $\mathrm{n}^{\circ}$ NUM001, NUM002, NUM003, de Zaragoza, vulnera la prohibición contenida en el artículo 183 de la Ley 1/1999, de 24 de febrero, de Sucesiones por causa de muerte, según el cual "el causante solo puede imponer gravámenes sobre los bienes relictos que atribuya a sus descendientes cuando el valor de los atribuidos libres de gravamen sumado al de las donaciones imputables a la legítima cubra el importe de la legítima colectiva", en razón a lo cual pide en su demanda que se declare nulo dicho legado y que como consecuencia de ello se requiera al Sr. xxx, a que le entregue la posesión de la mentada vivienda".
} 
artículo 501.1 CDFA, ya que al tratarse de una legítima colectiva lo que se le mengua al descendiente gravado se le imputa al descendiente beneficiado y no hay alteración alguna de la legítima global. Por lo tanto, el gravamen sólo afecta a la legítima cuando el beneficiario no es descendiente del causante ${ }^{612}$.

De conformidad con el artículo 499 CDFA el legitimario con un gravamen de los que recoge el artículo 498 CDFA tiene derecho a que se tenga por no puesto en la parte que vulnere la prohibición. De no ser posible, se tendrá por no puesto en su totalidad. Conforme al artículo 500. 2 CDFA la infracción de la norma que prohíbe la imposición de gravámenes (Art. 499 CDFA), sobre la legítima conlleva la supresión del gravamen en su totalidad, a voluntad del legitimario gravado, como un acto propio, puesto que según el tenor literal del precepto tiene derecho a que se tenga por no puesto. Cabría hacer aquí el planteamiento de cuándo se da por renunciado el derecho a la acción de la intangibilidad cualitativa de la legítima de forma tácita. La jurisprudencia entiende que para que los actos propios puedan ser tenidos "como efectivamente concurrentes han de revestir la condición de concluyentes e "indubitados", es decir, han de tener un significado inequívoco y jurídico. Por lo tanto, la aceptación de la herencia no implica hechos o actos concluyentes e inequívocos de los que se pueda deducir renuncia tácita de la acción de protección de la intangibilidad cualitativa de la legítima ${ }^{613}$.

${ }^{612}$ Delgado Echevarría, BAdoy LóPez, y SERRAno GARCÍA, Comentarios al Código..., op. cit., pág. 683.

${ }^{613}$ STSJ de Aragón de 30/01/2008 (Roj: STSJ AR 2/2008) En su F.J. $3^{\circ}$ mantiene esta sentencia al respecto de la renuncia tácita al derecho que le asiste de que el gravamen en su legítima se tenga por no puesto en el testamento: "En suma, D. xxx, no dio voluntaria ejecución al legado dispuesto por su madre y de lo expresado en la escritura de aceptación de herencia de fecha xxx, en relación con su actuación posterior, no se desprenden hechos o actos concluyentes e inequívocos que permitan deducir una renuncia tácita de la acción de protección de la intangibilidad cualitativa de la legitima, 


\subsubsection{Usufructo viudal en Aragón}

No se incidirá profundamente, en esta figura, debido a que en Aragón el cónyuge supérstite y los ascendientes, no son legitimarios. Pero en cambio, el usufructo viudal cuyo matrimonio se rija por el Derecho de Aragón es el gravamen más relevante que recae sobre la legítima colectiva, que como nudos propietarios deberán soportar los descendientes legitimarios en aquellos bienes en que se pague su legítima. Con excepción de la parte de legítima que se hubiese satisfecho por donación entre vivos ya que no está sujeta al gravamen del usufructo viudal, si la donación es de fecha anterior al matrimonio. Tampoco tiene sujeción si el cónyuge hizo renuncia al derecho expectante de viudedad. Una carga, la citada, que no la contempla el artículo 498.1 CDFA ya que no la impone el testador a sus descendientes sino que la impone la Ley y por lo tanto, es ajena a la voluntad del disponente ${ }^{614}$. Cabe decir que en Aragón, Navarra o Galicia la regulación de los derechos de usufructo universal del cónyuge supérstite tiene caracteres propios y especiales que los distancia del Derecho común $^{615}$.

El 23 de abril de 2003, entró en vigor la Ley 2/2003, de 12 de febrero de Régimen Económico Matrimonial y Viudedad que afectó al derecho de

por lo que no cabe hablar de infracción, por inaplicación, ni del artículo 7 del Código Civil, en cuyo párrafo primero encuentra apoyo legal la doctrina de los actos propios, ni del artículo 113 de la Ley 1/1999".

${ }^{614}$ No se pueden tomar en consideración las cargas del usufructo viudal, pues según manifiestan DElgado ECHEVARRÍA, BADOY LóPEZ Y SERRANO GARCíA, Comentarios al Código..., op. cit., pág. 687, ya afectaban al causante con anterioridad a su fallecimiento: "de otra parte, la prohibición alcanza únicamente a las cargas impuestas en el título sucesorio, cuyo autor es el disponente por causa de muerte, que produzcan disminución de la titularidad o del conjunto de facultades que correspondían al causante, por lo que no deben tomarse en consideración las cargas y limitaciones que ya afectaban al causante".

${ }^{615}$ NÚÑEZ MUÑIZ, M.C.: "El usufructo universal y el legado de usufructo universal: análisis particular del ejercicio y titularidad de la acción de desahucio", Revista Crítica de Derecho Inmobiliario, núm. 747, enero de 2015, pág. 435. 
usufructo del cónyuge viudo cuya aplicación "era inmediata cualquiera que fuere la fecha de inicio del usufructo viudal”. Así lo recoge la Disposición transitoria Primera de dicha Ley. Tras la derogación de aquella Ley, ahora las normas reguladoras del usufructo del supérstite las recogen los artículos 271 y ss del CDFA cuya vigencia es de 23 de abril de $2011^{616}$. Conforme al artículo 192 CDFA el matrimonio atribuye a cada cónyuge el usufructo viudal de todos los bienes del primero de ellos que fallezca como efecto de la celebración matrimonial de los preceptos señalados ${ }^{617}$. Es de resaltar la diferencia con el régimen del usufructo viudal en el Derecho común. Donde su extensión puede variar, según con los parientes del difunto con quienes concurra, desde un tercio hasta dos tercios como máximo (arts. 834 a $838 \mathrm{Cc}$ ). Este derecho usufructuario no se ve afectado por el hecho de que el causante fallezca testado o intestado ni tampoco le afecta que tenga o no tenga descendencia. Solamente por los supuestos tasados en el artículo 301 CDFA se extingue el Derecho expectante de viudedad ${ }^{618}$.

\subsubsection{La desheredación con causa legal}

Sobre esta concreta institución de la desheredación se hacía referencia en el propio Preámbulo de la derogada Ley de sucesiones en su Apartado VIII, punto 9 manifestando que "debido a que en el Derecho aragonés siempre se ha podido excluir de la herencia a alguno de los hijos del testador, sin más que dejarles la manda simbólica de los cinco sueldos

\footnotetext{
${ }^{616}$ Precepto, el citado, que se encuentra dentro del Capítulo Primero, del Título V (De la viudedad) del Libro Segundo (Derecho de la familia) del CDFA.

${ }^{617}$ La SAP de Zaragoza (S. 5 ${ }^{\text {a }}$ ) de 27/06/2014 (AC 2014\1144) F. J. $4^{\text {o }}$ pone de manifiesto que no existe duda de que lo que se instituye en el testamento es un legado de cantidad mensual vitalicia, por los conceptos y cuantía que antes se han señalado. Por tanto, no se puede confundir con un usufructo de naturaleza vidual, ni resulta por ello de aplicación el artículo 192 del Código Aragonés". Por otra parte, en el F. J. $6^{\circ}$ despeja toda duda entre el artículo 192 del Código aragonés y la cautela Socini.

${ }^{618}$ FAUS I PUJOL, M.: "Testamento con legado especial a un hijo y nombrando herederos a los otros. Derecho aragonés", en Formularios de Derecho de sucesiones (2010), vLex, actualizado a octubre de 2017.
} 
jaqueses. Debido a ello se advierte con facilidad que la desheredación en Aragón sólo tiene sentido práctico cuando el disponente pretende apartar de su herencia a todos o al único descendiente" ${ }^{\text {619 }}$. Es precisamente cuando tiene cabida, para poder conseguir la citada finalidad, alguna de las causas tasadas de desheredación, que se tendrá que probar. Solamente de esta manera puede, el testador utilizar la excepcional privación de la legítima colectiva de sus descendientes ${ }^{620}$. De las palabras del citado Preámbulo se puede deducir la poca incidencia que conlleva la desheredación a la legítima en Aragón. El testador puede no asignar bienes a alguno de sus descendientes sin tener que recurrir a justa causa de desheredación que ampare su voluntad ${ }^{621}$.

${ }^{619}$ La SAP de Zaragoza (S. 4 ${ }^{\text {a }}$ ) de 09/11/2010 (Tol. 2.029.598) F. J. $2^{\text {o }}$ refrenda lo expuesto en el texto acerca de la falta de sentido que tiene la desheredación en Aragón si el testador no pretende desheredar a todos o al único legitimario: "Porque en Aragón la desheredación individual ofrece unas peculiaridades derivadas de la circunstancia de la falta de una legítima propia reservada a cada legitimario. De manera que la misma sólo tiene un verdadero sentido cuando se desheredan a todos los legitimarios, dado que la legítima es colectiva. Por eso el art. 198.3 LS previene para la desheredación absoluta, a la que, como ya hemos dicho, queda parificada la desheredación colectiva, que todos los legitimarios conservarán el derecho a suceder abintestato (cuando no hay institución de heredero) y a reclamar la legítima colectiva frente a terceros, y ello cuando exista lesión de la misma".

${ }^{620}$ La SAP de Zaragoza (S. 2 ${ }^{\text {a }}$ ) de 12/07/2016 (Tol. 5.825.734) F. J. $3^{\text {o }}$ pone de manifiesto acerca de la desheredación en Aragón “(...) de hecho en el derecho aragonés tiene poco campo de aplicación en la medida en que la regulación de la legítima aragonesa se configuró en su día como colectiva y en beneficio de hijos y descendientes sin necesidad de atribución de concreta cuota individual, siendo suficiente la expresión de la mención a uno de los legitimarios en la disposición testamentaria para cumplir con el requisito necesario para su exclusión. Sólo en el caso de que el causante quiera dejar sin efecto la legítima atribuida por la norma, cabe que opte por la alegación en aquélla disposición de su existencia, lo cual exige su realidad y su constancia en el pacto sucesorio, testamento o ejecución de fiducia. Así se configura en la regulación del artículo 509 del CDFA (sólo produce los efectos dispuestos en el artículo 511 la que se funda en una causa legal, cierta y expresada en el pacto o testamento, o en el acto de ejecución de la fiducia. 2. La prueba de ser cierta la causa corresponde a los herederos del causante, si el desheredado la niega). En el presente caso no hay testamento, fiducia sucesoria ni pacto por lo que mal puede existir una causa de desheredación".

${ }^{621}$ Coincide con la falta de interés de la desheredación en Aragón debido a su legitima colectiva Rivas MarTíneZ, Derecho..., op. cit., pág. 1928, puesto que el disponente 
La figura de la desheredación priva al legitimario, no sólo de sus derechos, sino también de la condición como tal, es decir, el desheredado deja de ser legitimario. Sólo se puede privar a un legitimario de tal condición cuando incurre en una justa causa de desheredación. De modo que, de no concurrir la causa, nadie podría privarle de su derecho. La desheredación no tiene aplicación de forma autónoma, sino que requiere que el testador lo plasme expresamente en el clausulado de su testamento o pacto sucesorio. La desheredación en Aragón, como ya se ha dicho, sólo tiene sentido cuando el testador pretende desheredar a todos sus descendientes, o bien, si solo tiene un hijo y pretende desheredarle. Téngase presente que si este único hijo del testador tiene un hijo, el padre del primero, puede dejarle la legítima a su nieto incluso viviendo su padre, por lo que no necesita desheredarlo ${ }^{622}$. Solamente son causas legales de desheredación las que se exponen en el artículo 510 CDFA. Es una declaración del testador de porqué deshereda a un legitimario. Las causas de desheredación incluyen a las causas de indignidad del artículo 328 CDFA.

Entre las causas de desheredación que recoge el precitado artículo 510 CDFA no figura la ausencia de relación familiar como causa tasada de desheredación. Como es el caso de Cataluña que incorpora esta causa de desheredación a su ordenamiento en 2008. La recoge el artículo 451-17.2 e del Cc Cat. Dando con ello una interpretación más amplia al maltrato de obra. En este aspecto, Aragón, ha preferido mantenerse en el sistema

puede privar a cualquiera de sus descendientes de su legítima. Sólo tiene sentido cuando se pretenda excluir de la herencia a todos los legitimarios. Parar que produzca, la desheredación, los efectos del artículo 196, de la Ley de sucesiones, ha de fundarse en una causa legal, cierta y expresada en testamento o pacto sucesorio.

${ }^{622}$ GómeZ- CoRnejo TeJEDOR, "El cambio de sesgo en la jurisprudencia...", op. cit., pág. 1621. 
tradicional del maltrato de obra, es decir, como lo hace el Código civil o el Derecho Foral de Galicia entre otros ${ }^{623}$.

Para que la desheredación produzca efecto, o lo que es lo mismo, para que la desheredación prive al legitimario de tal condición deben de cumplirse una serie de requisitos, que no son otros, que los tipificados en las causas de desheredación o de indignidad. La desheredación debe fundarse en una de las causas legales recogidas en el artículo $510^{624}$ CDFA. Las causas de desheredación dispuestas en el Derecho aragonés, de modo similar al Derecho común, también son causas tasadas que no se pueden ampliar por analogía con otras semejantes.

También son coincidentes ambos derechos, el común y el foral aragonés, con la carga de la prueba. En ambos Derechos la carga de la prueba corresponde al heredero del causante, en aquellos supuestos en que el desheredado no la admite como cierta (art. 509.2 CDFA). Las causas de desheredación deben de expresarse, conforme al artículo 509. 1 CDFA $^{625}$, en el testamento o pacto sucesorio o en el acto de ejecución de la fiducia. Al nombrar este acto está el precepto reconociendo de manera implícita la facultad de desheredación al fiduciario ${ }^{626}$.

\footnotetext{
${ }^{623}$ BerRoCAL LANZAROT, “E1 maltrato...”, op.cit., pág. 941, cita (78).

${ }^{624}$ Artículo 510 CDFA (Causas legales de desheredación): "Son causas legales de desheredación: a) Las de indignidad para suceder. b) Haber negado sin motivo legítimo los alimentos al padre o ascendiente que le deshereda. c) Haberle maltratado de obra o injuriado gravemente, así como a su cónyuge, si éste es ascendiente del desheredado. d) Haber sido judicialmente privado de la autoridad familiar sobre descendientes del causante por sentencia fundada en el incumplimiento del deber de crianza y educación".

${ }^{625}$ Artículo 509. (Desheredación con causa legal): 1. Solo produce los efectos dispuestos en el artículo 511 la desheredación que se funda en una causa legal, cierta y expresada en el pacto o testamento, o en el acto de ejecución de la fiducia. 2. La prueba de ser cierta la causa corresponde a los herederos del causante, si el desheredado la niega.

${ }^{626}$ PARRA LUCÁN Y BARRIO GALLARDO, La Legítima en el Derecho aragonés..., op. cit. pág. 401.
} 
Los efectos que produce la desheredación es la de privar al legitimario de tal condición y con ello las atribuciones sucesorias que le hayan sido atribuidas por cualquier título. Asimismo, la desheredación extingue la legítima colectiva salvo que hubiera otros descendientes que conserven la condición de legitimarios (art. 511.2 CDFA). la legítima colectiva salvo que hubiera otros descendientes que conserven la condición de legitimarios. Excepto las que de conformidad con el artículo 511 CDFA se le hayan atribuido con posterioridad a la desheredación. La desheredación fallida, es decir, la que no cumple alguna de las causas dispuestas en el anteriormente citado artículo 509 CDFA dispone el artículo 513. 1 del mismo Código que tendrá la consideración de exclusión absoluta por el testador $^{627}$. Con la consecuencia devenida, para el excluido, de no poder suceder abintestato y no poder ejercer la acción por lesión que le pudiera corresponder. Si bien la Ley concede, el citado derecho de ejercer la acción por lesión, a los sustitutos de los desheredados. Cualquier legitimario puede ser desheredado con independencia del grado que tenga. Lo que ocurre es que el derecho de la acción de la legítima sólo la tienen los legitimarios de grado preferente conforme a lo dispuesto en el artículo 492. $2 \mathrm{CDFA}^{628}$.

\footnotetext{
${ }^{627}$ SAP de Zaragoza (S. 4a ) de 25/02/2011 (Tol. 2.161.731) F.J. $3^{\text {o }}$. Los dos hijos del testador quedan excluidos de manera absoluta en la sucesión de su padre, debido a que la desheredación dispuesta por el testador fue declarada nula e ineficaz: "En el caso de autos, los iníciales legitimarios de grado preferente del citado causante, D. Florián, que eran sus dos únicos hijos, D. Luis Alberto y $\mathrm{D}^{\mathrm{a}}$. Berta, resultaron incursos en causa de sustitución legal prevista en el artículo 24.2 , en relación con el artículo 198.1, inciso final, de la citada Ley aragonesa de sucesiones por causa de muerte, al quedar afectos por una situación de exclusión absoluta en la sucesión de su referido padre, situación a la que se equipara la desheredación de ambos pretendida por el causante en el testamento otorgado por él sin cumplir los requisitos expresados en el artículo 194 de dicha Ley, desheredación que fue declarada nula e ineficaz por sentencia firme (...)".
}

La SAP de Zaragoza (S. 2 $2^{\text {a }}$ ) de 12/07/2016 (Tol. 5.825.734) en su F.J. $3^{\circ}$ sienta importante doctrina al respecto del perjuicio de los legitimarios cuando el disponente pretende favorecer a alguien con una donación.

${ }^{628}$ La STSJ de Aragón de 22/09/2011 (RJ: 2012/3073) se refiere a ello en su F. J. $3^{\text {o. }}$ "Entiende conforme a lo dispuesto en el artículo 198.1, inciso segundo, que la posición 
Conforme a lo dispuesto en el artículo 198.1 CDFA inciso segundo, la posición de los desheredados sin causa justificada, "que no cumpla los requisitos expresados en el artículo $194 \mathrm{CDFA}$ " es la misma que la de los excluidos absolutamente por el disponente. Es decir, quedan privados del derecho a suceder abintestato y del de ejercitar la acción de lesión que pudiera corresponderles. En tal caso serán sustituidos por sus estirpes de descendientes si los tuvieran (Art. 198. 2 CDFA).

\subsubsection{La exclusión}

En términos generales la exclusión viene a ser equivalente a la no inclusión. Trasladado el tema a la sucesión, basta con decir, que todas aquellas personas a quien no ha incluido el causante en su testamento han sido excluidas de él. Pero como es bien sabido en la sucesión determinadas personas que entran en la ella, no lo hacen por voluntad del causante, sino por ministerio de la Ley. En consecuencia, no basta con no incluirlas para que queden excluidas. La naturaleza colectiva de la legítima aragonesa es la que permite al testador, sin concurrir causa de desheredación y sin alegar causa alguna, poder excluir de la sucesión a los legitimarios de grado preferente $^{629}$.

La desheredación no deja de ser, en Aragón, una exclusión amparada en una causa legal y la simple exclusión que se ampara en la voluntad del

de los desheredados sin causa justificada ("que no cumpla los requisitos expresados en el artículo 194 ") es la misma que la de los excluidos absolutamente por el disponente, es decir, que quedan privados del derecho a suceder abintestato y del de ejercitar la acción de lesión que pudiera corresponderles, en los que serán sustituidos por sus estirpes de descendientes si los tuvieran (artículo 198. 2). Por lo tanto, la ley priva a los excluidos absolutamente del derecho a ejercer la acción de lesión, pero concede tal derecho a sus sustitutos, si existen".

${ }^{629}$ Rivas Martínez, J.J.: Derecho de sucesiones..., op. cit., pág. 1931. Se apoya el autor, en Cereceda Marquínez para definir la exclusión voluntaria como "una declaración de voluntad en el acto dispositivo y distinta de la simple omisión de asignación de bienes del caudal relicto". 
testador plasmada en su testamento. En virtud del artículo $512^{630}$ CDFA el testador puede excluir a los legitimarios de grado preferente sin tener que alegar ninguna causa. Si bien por el emplazamiento del precepto en el Título de la legítima podría hacer suponer que sólo afecta a legitimarios. Cuando en realidad también tiene campo de aplicación en la sucesión intestada o legal. Lo tiene cuando el causante pretende excluir a determinado pariente de su sucesión, aunque no sea un legitimario suyo ${ }^{631}$. En este sentido, la exclusión, operaria de tal manera que se impediría que una persona con derechos sucesorios a su favor, en la sucesión legal, no se aplicara la norma legal que le otorga tales derechos.

El único requisito formal para la exclusión es que la disposición hecha para tal fin conste bien en testamento, en pacto sucesorio o bien en el acto de ejecución de fiducia, conforme a las facultades que le otorga el artículo 457. 1 CDFA al fiduciario ${ }^{632}$. A partir de los artículos 512 y 513 CDFA se deducen dos clases de exclusión, pues el primer precepto se titula, "Exclusión voluntaria de descendientes" y el segundo, "Exclusión absoluta" ${ }^{633}$. En el primer caso el de la exclusión no absoluta, voluntaria o

${ }^{630}$ Artículo 512. Exclusión voluntaria de descendientes.

1. El disponente puede excluir a los legitimarios de grado preferente, aunque no concurran los requisitos del artículo 509 y aun sin alegación de causa alguna.

2. Los legitimarios excluidos no tienen otros derechos que el que pueda corresponderles a reclamar la legítima colectiva frente a terceros, cuando exista lesión de la misma, y los que les correspondan en la sucesión legal, salvo lo dispuesto en los dos artículos siguientes.

${ }^{631}$ Delgado Echeverría y BAyod LóPeZ, Comentarios ..., op. cit., pág. 698.

${ }^{632}$ Artículo 457 CDFA. Modo de actuar: "1. Salvo disposición en contra del comitente, cuando en el momento de ejecutar la fiducia existan descendientes suyos, el fiduciario habrá de ordenar la sucesión exclusivamente a favor de alguno o algunos de ellos, con la misma libertad con que podría hacerlo el causante."

${ }^{633}$ Rivas MARTínEZ, Derecho de sucesiones común..., op. cit., pág. 1931. Mantiene este autor que "la naturaleza colectiva de la legítima permite al disponente excluir a los legitimarios de grado preferente, aunque no concurran los requisitos de la desheredación y sin necesidad de alegar causa alguna". 
relativa el legitimario de grado preferente excluido no pierde la condición de legitimario y en consecuencia a ello puede reclamar la legítima frente a terceros. Además, conserva el derecho de alimentos que le otorga el artículo 515 CDFA salvo declaración de indignidad. Otra de las características de la exclusión simple o relativa es que no se le excluye de la sucesión legal, puesto que sólo es excluido de la sucesión voluntaria que hace el causante ${ }^{634}$.

Por último, el excluido simple, además de conservar los derechos que le correspondan en la sucesión legal y la acción por lesión de la legítima colectiva. Los artículos 338 y 339 CDFA otorgan, también, derecho de sustitución por parte de sus descendientes en los casos de desheredación por causa legal, premorir al causante o indignidad. Por lo que respeta a la exclusión a que se refiere el precepto antes referenciado 812 CDFA no se le encuentra demasiada aplicación. En el sentido de que si el testador no desea otorgarle nada al legitimario en su testamento no necesita excluirlo. Le basta con no otorgarle nada, al fin y al cabo, también lo ha de nombrar para excluirlo.

En cuanto a la exclusión absoluta que regula el artículo $513^{635}$ CDFA se da cuando el testador dispone en su testamento o pacto sucesorio, conforme al punto uno del precepto citado, que quiere privar al excluido de

\footnotetext{
${ }^{634}$ PARRA LUCÁN Y BARRIO GALLARDO, La Legítima en el Derecho aragonés..., op. cit. pág. 408.

${ }^{635}$ Artículo 513 CDFA (Exclusión absoluta): 1. "La exclusión es absoluta cuando el disponente ha expresado su voluntad de privar al excluido de todo derecho en la sucesión. La misma consideración tiene la desheredación pretendida que no cumpla los requisitos expresados en el artículo 509. 2. Los excluidos absolutamente quedan privados del derecho a suceder abintestato y del de ejercitar la acción de lesión que pudiera corresponderles, en los que serán sustituidos por sus estirpes de descendientes si los tuvieran. 3. No obstante, si la exclusión absoluta afecta a todos o al único legitimario, conservarán el derecho a suceder abintestato y a reclamar la legítima colectiva frente a terceros, cuando exista lesión de la misma".
} 
todo derecho a la sucesión ${ }^{636}$. En Aragón, como se ha dicho, existen dos modalidades de exclusión la simple y la absoluta. Es evidente que, si el testador no detalla el tipo de exclusión que desea aplicar, por defecto, se entenderá la menos perjudicial para el excluido que es la simple. Por lo tanto, debe de quedar totalmente claro en el testamento o pacto sucesorio que la voluntad del disponente es apartar totalmente de la sucesión al excluido. La exclusión absoluta incluso aparta al excluido, conforme al precitado artículo 513. 2 CDFA de la sucesión legal. Así como del derecho de acción por lesión cuantitativa de la legítima, es decir, por vulnerar la legítima colectiva en lo que a cantidad se refiere. Si bien el derecho de acción es un derecho individual ${ }^{637}$.

La segunda mitad del citado artículo 513. 2 CDFA da a entender que el disponente, cuando priva a los legitimarios por medio de la exclusión, estos serán sustituidos por sus estirpes (descendientes) si los tuviera. Ello en el caso de que el testador no disponga en contrario. Es decir, excluya también a los descendientes del excluido de los derechos de su sucesión. Si bien el legitimario de grado preferente excluido de forma absoluta, conforme se ha dicho, no pierde el derecho de alimentos. Por lo tanto no pierde de manera

${ }^{636}$ Se refiere a la exclusión absoluta la STSJ de Aragón de 22/09/2011 (Tol. 2.266.338) F.J. $3^{\circ}$ aclarando que: "pese a la exclusión absoluta, el propio excluido conserva el derecho a reclamar por lesión cuantitativa, de igual modo que lo conserva al amparo del artículo 198.3 cuando es el único legitimario. Es evidente que al excluido absolutamente no le corresponde derecho alguno salvo en caso de exclusión de todos los legitimarios pues, conforme al artículo 198.3, cuando la exclusión absoluta afecta a todos o al único legitimario los excluidos conservarán el derecho a suceder abintestato y a reclamar la legítima colectiva frente a terceros cuando exista lesión de la misma, y no se puede acoger la interpretación del recurrente precisamente porque no fueron absolutamente excluidos todos los legitimarios (artículos 24.2 y 25.1)". [Los preceptos citados por el TSJ de Aragón, son referidos a la Ley 1/199, de 24 de febrero, de sucesiones derogada por el Decreto Legislativo 1/1011, de 22 de marzo, que aprueba el CDFA].

${ }^{637}$ PARRA LUCÁN Y BARRIO GALLARDO, La Legítima en el Derecho aragonés..., op. cit. pág. 405. 
total la condición de legitimario, como anteriormente se podría presuponer $^{638}$.

\subsubsection{Error en el motivo o en la causa}

La expresión motivo se refiere al hecho que provoca la exclusión y la causa a la desheredación, al menos, eso se deduce del artículo $514^{639}$ CDFA cuyo título es precisamente "Error en el motivo o en la causa". Lo verdaderamente sorprendente de la exclusión no es el hecho en sí mismo. El testador puede hacer lo que le plazca con sus bienes y en tal caso no atribuir bienes a un legitimario y parece ser que no hay ningún reproche jurídico al respecto. En cambio, si el disponente para llegar al mismo objetivo, es decir, para conseguir que el legitimario no se lleve nada de su herencia efectúa una exclusión o alega una causa de desheredación que resulta al final ser errónea, produce dos clases de consecuencias: si el motivo o la causa es determinante para la exclusión o la desheredación, ello hace anulable tanto la exclusión como la desheredación. Ello por virtud del artículo 424. 2 CDFA. Si el motivo o el error no han sido determinantes se tienen por no puestos ${ }^{640}$, pero si han sido determinantes serán anulables el motivo de exclusión o la causa de desheredación. Se producen para los

\footnotetext{
${ }^{638}$ SERRANO GARCÍA, "La legítima en Aragón...", op. cit., pág. 124. Este autor mantiene que: "la Ley de Sucesiones ha llamado a la estirpe del excluido absolutamente cuando no debía hacerlo (artículo 513, CDFA) y ha dejado de llamarla cuando sí que debía hacerlo (artículo 513.3 (CDFA)". Entiendo que se refiere a que en el apartado $3^{\circ}$ del precepto trata de cuando son todos los legitimarios excluidos de la sucesión o bien cuando solo existe un legitimario y es excluido por el testador, en ambos supuestos el legislador no llama a la estirpe. En cambio, cuando la exclusión absoluta se refiere a uno o varios legitimarios, pero quedan de no excluidos, llama a la estirpe. Coincido plenamente con el autor en su exposición contradictoria.

${ }^{639}$ Artículo 514 CDFA (Error en el motivo o la causa): "Si el motivo de la exclusión, aun absoluta, o la causa de la desheredación, expresados en el título sucesorio, son erróneos, pero no han sido determinantes, se tienen por no puestos. Si han sido determinantes, se producen para los legitimarios de grado preferente las consecuencias de la preterición no intencional".

${ }^{640}$ Delgado Echevarría, BAdoy LóPEZ, Y SERrano GARcíA, Comentarios al Código..., op. cit., pág. 700.
} 
legitimarios de grado preferente las consecuencias de la preterición no intencional. En cambio no lo será la voluntad del disponente, que sería requisito indispensable para que el excluido (simple o absoluto) o desheredado erróneamente tenga derecho a su parte en la legítima colectiva $^{641}$.

No es otro lo expuesto en el párrafo anterior que, lo dispuesto en el artículo 514 CDFA, por lo que habrá que ver lo que ocurre con los legitimarios de grado preferente. Hay que recordar, aquí y ahora, que la preterición no intencional no hace sino recoger errores cometidos por el disponente. Errores como puedan ser el de ignorar la existencia o condición de un legitimario. Por lo tanto, el derecho del legitimario de gado preferente o excluido de manera absoluta cuyo motivo de exclusión o causa de desheredación sean determinantes para la exclusión o la desheredación y tengan su fundamento basado en un error por parte del disponente sus consecuencias serán las de la preterición no intencional ${ }^{642}$.

${ }^{641}$ SERRANO GARCÍA, "La legítima en Aragón...”, op. cit., pág. 125. Todo ello conforme al artículo 514 CDFA. "Cuando el error o la causa, no han sido determinantes se tienen por no puestos. Como la exclusión no requiere motivación alguna, no produce consecuencias su eliminación. En cambio, la desheredación con causa legal, necesita causa tipificada cierta y probada, de manera que, si la causa legal se tiene por no puesta, bien si es falsa o no se puede probar su certeza, la pretendida desheredación deja de cumplir los requisitos del artículo 509, CDFA y adquiere la consideración de una exclusión absoluta, conforme al artículo 513. 1, CDFA". Efectivamente es magistral el razonamiento que hace el autor, y tal como dispone el precepto 513. 1 CDFA que tendrá la consideración de exclusión absoluta" la desheredación pretendida que no cumpla los requisitos expresados en el artículo 509 CDFA". Al ser equivalente a la exclusión absoluta es cuando no tiene derecho individual sobre la legítima colectiva, por mucho que se anule la errónea causa.

${ }^{642}$ Véase la prescripción de las acciones en la SAP de Zaragoza (S. $4^{\mathrm{a}}$ ) de 27/05/2014, (Tol. 4.420.879) F. J. $2^{\text {o }}$ "la prescripción de las acciones derivadas de la legítima (por lesión cuantitativa o cualitativa, preterición no intencional, desheredación o exclusión por error determinante, o por derecho a alimentos) y se ha hecho un precepto general, el artículo 178 LS (493 CDFA) cuyo apartado 1 dice que "las acciones reguladas en este Título prescriben en el plazo de cinco años contados desde el fallecimiento del causante o desde la delación de la herencia si ésta se produce con posterioridad". Dicho plazo, inferior a los que rigen en otros derechos sucesorios, es el mismo del artículo 33 del Apéndice de 1925, recuperándose y estableciéndose un plazo de prescripción único para 
Consecuentemente reajustando la disposición hecha por el testador o su fiduciario. Es precisamente esa presunción que hace el legislador de la modificación que hubiera hecho el testador en su disposición testamentaria o pacto sucesorio, la que permite que al preterido no intencional le aporte la Ley un complemento a la voluntad del causante, conforme a lo dispuesto en el artículo 508. $1{ }^{643}$ CDFA (se verá al tratar la preterición).

\subsubsection{La preterición en Aragón}

Se define la preterición aragonesa como "la ausencia de atribución y de mención de un legitimario de grado preferente". Por lo tanto se entiende por preterición, en Aragón, la no inclusión de un legitimario de primer grado o grado preferente en el testamento, pacto sucesorio o acto de ejecución de la fiducia (art. 503. 1 CDFA $)^{644}$. Siempre que no haya sido favorecido en vida del causante ni en la sucesión legal ${ }^{645}$. Cabe resaltar que

todas las acciones derivadas de infracciones a la legítima. El momento del cómputo del plazo se computa desde el fallecimiento del causante".

643 Artículo 508 CDFA (Consecuencias de la preterición no intencional): “1. E1 legitimario preterido no intencionalmente tiene derecho, salvo previsión distinta del disponente, a una porción del caudal relicto igual a la que después de la reducción corresponda al menos favorecido por aquél. Esta porción se formará reduciendo proporcionalmente las participaciones de los restantes legitimarios, aunque éstos tendrán derecho a pagar al preterido su parte en metálico. A la reducción se le aplicará lo dispuesto en el artículo 496".

${ }^{644}$ La SAP de Zaragoza (S. 4 ${ }^{\text {a }}$ ) de 25/02/2009 (Tol. 1.495.016) F. J. $5^{\text {o }}$ mantiene que la preterición es un mecanismo de tutela formal de la legítima, que con ella se sanciona el olvido del causante, o se repara el desconocimiento que el testador podía tener de un legitimario.

${ }^{645}$ La SAP de Huesca (S. $1^{\text {a }}$ ) de 20/11/2015 (Tol. 5.612.122) F.J. $3^{\text {o }}$ explica que la legítima aragonesa, al tratarse de una legitima colectiva puede recibirse por cualquiera de sus legitimarios, por lo tanto, si ha sido citado el legitimario en el testamento, con independencia de su atribución particular, si el colectivo de los mismos ha recibido la pertinente cuantía en concepto de legítima, no se ha lesionado la legítima. "(...) pareciendo claro que la recurrente está pretendiendo convertir la legítima colectiva aragonesa en una legítima suya individual, ignorando así que dicha legítima, como colectiva que es, puede ser recibida por cualquiera de los legitimarios por lo que, siendo que la recurrente, que no era descendiente única, ni siquiera hija única, fue citada en el testamento y siendo que el colectivo de los legitimarios ya ha recibido más de la mitad de la herencia mediante la institución hecha en favor de su hermano, también hijo del 
la falta de mención de legitimarios de grado ulterior al preferente no provoca preterición, así como los desheredados con justa causa. Otro aspecto importante es cuando un legitimario de grado preferente ha sido favorecido en vida del causante con liberalidades (por ejemplo, donaciones imputables a la legítima) incluso el nieto no se puede sentir preterido si las donaciones se las hizo el causante a su padre. La mención que se le exige al testador es a los solos efectos de dar cuenta de que tiene conocimiento de lo que hace ${ }^{646}$.

Es curioso el motivo que se señalaba la exposición de motivos de la derogada Ley de Sucesiones de Aragón. En su apartado 36 señalaba como motivo de la implantación de la preterición no intencional el evitar que, sin quererlo el causante, un legitimario de grado preferente quedase excluido de la herencia. Bien por desconocer su existencia, su condición de legitimario preferente, o bien por haber nacido con posterioridad. Con ello pueda pensar, el testador, que había fallecido o desconocer, incluso, que era su descendiente. En tales supuestos otorgaba un derecho la señalada Exposición de Motivos de la Ley de Sucesiones aragonesa. Tal derecho es el que tiene, el legitimario preterido, a una porción en el caudal relicto, igual a la que adquiere el menos favorecido por el causante en su testamento ${ }^{647}$. En el supuesto de ser el preterido el único o bien hayan sido

causante, no hay preterición ni lesión alguna a la legítima tal y como con todo detalle y corrección lo ha explicado la sentencia apelada(...)".

${ }^{646}$ SERrAnO GARCía, “La legítima en Aragón...”, op. cit., pág. 110.

${ }^{647}$ Decreto Legislativo 1/2011, de 22 de marzo, del Gobierno de Aragón, por el que se aprueba, con el título de «Código del Derecho Foral de Aragón», el Texto Refundido de las Leyes civiles aragonesas. «BOA» núm. 67, de 29/03/2011. Exposición de Motivos apartado 36: "Se ha evitado el concepto de «legítima formal», una novedad de la Compilación, que no parece haya podido cumplir la función sistematizadora y de auxilio a la interpretación que cabía esperar de ella. No hay, por tanto, un deber de nombrar o mencionar a ningún legitimario en el acto de disposición mortis causa. La preterición se ha regulado de acuerdo con la que se entiende debe ser su función propia en nuestro Derecho, que es evitar que un legitimario de grado preferente quede excluido de la herencia sin haberlo querido así el causante, como consecuencia de que éste, al 
preteridos todos los legitimarios de grado preferente se abriría la sucesión legal de toda la herencia.

De lo expuesto sobre la preterición no intencional cabe destacar la esencia y la cuantía. En la primera se trata de contrarrestar el olvido o la ignorancia del testador con respecto a un legitimario de grado preferente. Con ello deja fuera de toda duda la exclusión de acción en contra de la preterición intencional. Está claro que lo que no se protege es la exclusión voluntaria, por parte del testador, de su herencia y por lo tanto no caben consecuencias jurídicas en este sentido ${ }^{648}$. La segunda, es decir, la cuantía de la preterición, no se va a buscar el término medio de los favorecidos, sino que asemeja al preterido con el menos favorecido. Una presunción por parte del legislador que, bajo mi punto de vista, en algunos casos será acertada, pero en muchos otros no. La preterición la recoge y regula el CDFA en sus artículos 503 a 508.

Con carácter general se entenderán preteridos los legitimarios de grado preferente que no hayan sido mencionados en el testamento y no hayan sido favorecidos en vida del causante ni en su sucesión legal. Tal como dispone el artículo 503.1 CDFA. No se considerará preterición la no inclusión en el testamento de aquellos en que en el momento de la delación sean legitimarios de grado preferente por sustitución de quien no había sido preterido (art. 503. 2 CDFA).

disponer, desconocía la existencia del legitimario o su condición de tal, en particular por haber nacido después, creer el causante que había fallecido o desconocer que era descendiente suyo. En estos casos, el legitimario preterido tiene derecho a una porción en el caudal relicto igual a la del menos favorecido por el causante, salvo que el preterido haya sido el único o todos los legitimarios de grado preferente, caso en que se produce la delación abintestato de todo el caudal relicto, a no ser que haya sido designado heredero o legatario algún otro descendiente".

${ }^{648}$ DE BARRÓN ARNICHES, “Libertad de testar y desheredación...," op. cit., pág. 24. 
Para descartar cualquier indicio de preterición bastará mencionar al legitimario en cualquier parte o cláusula del testamento, aunque no se disponga a favor ni en contra de este (art. 504 CDFA). Destacar del último punto de este precepto que excluye de la simple mención a los nacidos después de otorgarse el testamento cuando no vayan las expresiones especialmente referidas a ellos. Tampoco se admite la referencia a un descendiente como fallecido cuando en realidad vive. Por consiguiente no es necesario recurrir a una declaración solemne por la que se priva al legitimario de sus derechos. Basta con cualquier alusión de la que pueda inferirse que el testador tuvo en mente a todos sus descendientes al distribuir las legítimas. En el supuesto de nombrar un legitimario y no hacerle atribución alguna a su favor, evidentemente, será porque no se le ha querido dejar nada ${ }^{649}$. Conforme al artículo 505 CDFA la preterición es intencional cuando el testador ha omitido mencionar al legitimario convencido y conforme de lo que hacía, puesto que como "al ordenar la sucesión conocía la existencia del legitimario y su condición de tal”. Este precepto dispone que, salvo prueba en contrario, la preterición se presumirá intencional.

Puede que el artículo $507^{650}$ CDFA sea uno de los más complejos de entender de cuantos regulan la preterición aragonesa. Teniendo en cuenta que en el derecho aragonés no existe ningún derecho de legítima individual, por lo que hay que reclamar la legítima colectiva. Es decir, la de todos los legitimarios y ha de ser reclamada frente a extraños. No se puede reclamar contra descendientes del testador. En consecuencia, cuando el

\footnotetext{
649 PARRA LUCÁN y BARRIO GALLARDO, La Legítima en el Derecho aragonés..., op. cit., pág. 393.

${ }^{650}$ Artículo 507 CDFA (Consecuencias de la preterición intencional): "El legitimario preterido intencionalmente no tiene otro derecho que el que pueda corresponderle a reclamar la legítima colectiva frente a terceros, cuando exista lesión de la misma".
} 
testador haya atribuido la mitad de su herencia, conforme al artículo 489 CDFA, a alguno o algunos de sus descendientes el preterido no tiene derecho a reclamar ${ }^{651}$. En el supuesto del preterido haber sido favorecido en la sucesión legal, conforme al artículo 503.1 CDFA, no se le considera preterido $^{652}$.

El artículo $508{ }^{653}$ CDFA regula las consecuencias de la preterición no intencional. En primer lugar, salvo disposición en contrario por parte del testador, cuando se dan las causas antes ya expuestas, se le da al preterido el derecho a la reducción proporcional de las "participaciones" del resto de legitimarios hasta que cubra la suya. Como también se ha dicho, será igual a la del menos favorecido. Respecto a dicha participación del preterido,

${ }^{651}$ Mayor información en SAP de Huesca (S. $1^{\circ}$ ) de 20/11/2015 (AC 2015/1703) F. J. $3^{\text {o }}$ “(...) más de dos años antes de que tuviera lugar el fallecimiento del causante cuya sucesión ahora nos ocupa, pareciendo claro que la recurrente está pretendiendo convertir la legítima colectiva aragonesa en una legítima suya individual, ignorando así que dicha legítima, como colectiva que es, puede ser recibida por cualquiera de los legitimarios por lo que, siendo que la recurrente, que no era descendiente única, ni siquiera hija única, fue citada en el testamento y siendo que el colectivo de los legitimarios ya ha recibido más de la mitad de la herencia mediante la institución hecha en favor de su hermano, también hijo del causante, no hay preterición ni lesión alguna a la legítima tal y como con todo detalle y corrección lo ha explicado la sentencia apelada que, como ha quedado dicho(...)".

${ }^{652}$ PARRA LUCÁN y BARRIO GALLARDo, La Legítima en el Derecho aragonés..., op. cit., pág. 396. "Mantienen estos autores que la omisión consciente y querida produce los mismos efectos que la exclusión expresa. Esta consecuencia ha llevado a muchos autores a subrayar el efecto inocuo que tiene esta clase de preterición tras la reforma operada por la Ley de 1999 y conservada en el texto refundido del CDFA".

653 Artículo 508 CDFA (Consecuencias de la preterición no intencional): “1. El legitimario preterido no intencionalmente tiene derecho, salvo previsión distinta del disponente, a una porción del caudal relicto igual a la que después de la reducción corresponda al menos favorecido por aquél. Esta porción se formará reduciendo proporcionalmente las participaciones de los restantes legitimarios, aunque éstos tendrán derecho a pagar al preterido su parte en metálico. A la reducción se le aplicará lo dispuesto en el artículo 496. 2. Cuando todos o el único legitimario de grado preferente hayan sido preteridos no intencionalmente y no haya sido designado heredero o legatario ningún otro descendiente, se produce la delación legal de todo el caudal relicto. 3. El preterido no intencionalmente tendrá, además, el derecho que pueda corresponderle a reclamar la legítima colectiva frente a terceros, cuando exista lesión de la misma". 
tiene derecho, el resto de legitimarios a pagársela en metálico. Podría plantearse el dilema de si la equiparación a la participación del menos favorecido ¿Ha de ser antes o después de practicada la reducción? Efectivamente ha de ser después de practicada la reducción, ya que en el caso contrario no sería equiparable al menos favorecido, sino que sería superior. Por lo tanto, el preterido no intencional obtendrá su parte de restársela de manera proporcional al resto de legitimarios ${ }^{654}$.

\subsubsection{Acción de complemento de la legítima}

Puede que lo primero que hay que tener en cuenta a la hora de interponer la acción de complemento es el plazo previsto para ello. Sin tener en cuenta esta previsión, el resto no sirve para nada. Así, la SAP de Zaragoza de 27/05/2014, en su FJ. Segundo cita el artículo 178 de la derogada Ley de Sucesiones, en el que se manifiesta que las sucesiones por causa de muerte se regirán por la ley vigente en el momento de la apertura de la sucesión. Coincidente con el momento del fallecimiento del causante. También el citado precepto establece el plazo de cinco años como límite para la acción de la intangibilidad de la legítima. Tanto cualitativa como

\footnotetext{
${ }^{654}$ PARRA LuCÁN, y, BARRio GALlARdo, La Legítima en el Derecho aragonés..., op. cit., pág. 398. "El cálculo, según los autores, se efectúa dividiendo el caudal relicto entre el resultado de haber añadido, a dicho caudal, la cuota inicial del menos favorecido y calcular así el cociente de reducción. Las cuotas individuales de cada legitimario se han de multiplicar por ese factor y la suma de los productos arroja como resultado la cuota del preterido que recibirá su porción como sucesor por disposición legal, en virtud del artículo317CDFA". Un supuesto práctico para el cálculo de la porción de legitima del preterido no intencional en Aragón podría ser: El padre reparte su patrimonio de 270 entre cuatro hijos, dando a (A), 30; a (B), 33; a (C), 60 y a (D), 147. Queda un quinto hijo preterido (E). Se ha de dividir todo el caudal (270) entre dicho caudal más la cuota del menos favorecido, es decir $(270 / 270+30=0,9) 270$ dividido entre 300 que, arroja un cociente de 0,9 . Ahora es cuando se procede a operar:
}
A: 0,9 × $30=27$; se le han detraído 3
B: 0,9 x $33=29,7$; se le han detraído 3,3
C: 0,9 × $60=44$; se le han detraído 16
D: 0,9 x $147=132,3$; se le han detraído 14,7 
cuantitativa. Plazo que se contabiliza desde el fallecimiento del causante o desde la delación de la herencia ${ }^{655}$.

Hay que tener presente que en caso de haber intangibilidad tanto cuantitativa como cualitativa de la legítima (suelen ir cogidas de la mano) habrá que atacar primero la cuantitativa. Una vez haya conformidad con la cantidad será cuando habrá que ver los bienes relictos que han recibido los legitimarios, conforme a los derechos que les asisten. Como consecuencia de la legítima colectiva en Aragón tendrá lugar el incumplimiento del pago de la legítima en bienes relictos cuando: al conjunto de las donaciones se le sumen los bienes relictos otorgados post mortem y no se alcance el importe de la legítima colectiva. Ello viene a significar que cubierta la parte de bienes relictos de la legítima colectiva, por parte del testador, tanto en vida como después de la muerte ha cumplido con la Ley y puede proceder a repartir con bienes relictos a herederos o legatarios extraños, si ese es su deseo $^{656}$.

\subsection{LA LEGÍTIMA EN EL PAÍS VASCO}

${ }^{655}$ SAP de Zaragoza (S. 4 ${ }^{\text {a }}$ ) de 27/05/2014 (JUR 2014\180455). Esta sentencia en su FJ. $1^{\circ}$ se refiere a los plazos de que el legitimario dispone para reclamar su derecho de legítima colectiva: "La sentencia objeto de recurso estimó la acción, sobre la base del artículo 178 de la Ley 1/1999, de 24 de febrero, de sucesiones por causa de muerte, de acuerdo con su DT, que dispone que las sucesiones por causa de muerte se regirán por la ley vigente en el momento de la apertura de sucesión, que es momento del fallecimiento de la causante. Dicho precepto establece el plazo de prescripción de cinco años para las acciones reguladas en dicho Título, entre ellas, las relativas a la intangibilidad cuantitativa y cualitativa de la legítima, plazo que se cuenta desde el fallecimiento de la causante o desde la delación de herencia. Por lo tanto, habiendo fallecido la causante el 25 de noviembre de 2002, las acciones han prescrito desde el 25 de noviembre de 2007, sin que se haya producido la interrupción de la prescripción de la acción." En contestación de la Sala, señala la Sentencia de 14 de marzo de 2014 que: "El art 178 regula la prescripción de acciones basadas en el art 171 y ss. Su ejercicio corresponde al legitimario en el plazo de cinco años contados desde el fallecimiento del causante o desde la delación de la herencia si esta se produce con posterioridad".

${ }^{656}$ SERrANO GARCÍA, "La legítima en Aragón...”, op. cit., pág. 102. El autor cita a Cereceda Marquínez, RDCA, 1999-1º, P. 116; Brún Araqües, 2006, P. 414, como favorables a acumular ambas acciones. 
La legítima en el Derecho foral de Vizcaya no tiene sus orígenes en el Derecho romano, entre otras cosas, porque no llegaron a romanizar Vizcaya. La legítima de los cuatro quintos con posibilidad de mejorar con el tercio de esos cuatro quintos era visigoda, al menos en su esencia ${ }^{657}$. Con relación a lo expuesto y citando el Fuero Viejo de Vizcaya de 1452 y el de 1526, Capítulos 76 y 62, respectivamente, para alegar que en dichos Capítulos se permitía elegir heredero entre los tronqueros ${ }^{658}$. Teniendo cabida lógica la curiosidad por el origen de la citada costumbre, siendo una posible respuesta no confirmada, o más bien, una hipótesis como contestación, la que afirma que: desde la baja Edad Media existió una fuerte comunicación jurídica entre los países europeos que se consideraban cristianos y ello pudo dar lugar a la formación del Derecho consuetudinario medieval cristiano ${ }^{659}$.

Puede que buscando una primera legítima vasca se pueda encontrar con bastante similitud en el Fuero Viejo de Vizcaya de 1452. Donde las costumbres que se exponen en sus Capítulos CXII y CXXVI dan a entender que los bienes raíces procedentes de la familia, es decir, los bienes a su vez

657 Vallet De Goytisolo, J.B.: “ La legítima en el Derecho Foral de Vizcaya" Estudios de Deusto: revista de la Universidad de Deusto, núm.1,Vol. 41,1993, pág. 204, afirma el autor acerca de los visigodos llegados a España "el desvanecimiento de la tradición germánica desde el primer siglo de invasión" No se puede pasar por alto, el texto del siglo XVI, original de J. Gutiérrez, que aporta Vallet de Goytisolo: "la costumbre inmemorial, usada y guardada generalmente en todo el país de Infanzonado de aquella tierra, es que los padres siempre donan a sus hijos varones mayores la casa y casería principal, y todos los demás bienes raíces que tienen, y apartan a los otros sus hijos, y hijas con un árbol y raíz, distribuyendo entre ellos la dote de la nuera futura o presente".

${ }^{658}$ PÉREZ ESCOLAR, M.: "El cónyuge heredero legal”, en El cónyuge supérstite en la sucesión intestada, Dykinson, 2003, pág. 163. Los tronqueros, conforme al Fuero de Bizkaia son los que deben de heredar los bienes raíces, estos derechos, son los que debe respetar el testador. El principio de troncalidad queda manifestado tanto en la sucesión testada como en la intestada, así como también en actos inter vivos o mortis causa, a título oneroso o lucrativo.

${ }^{659}$ VALLET De Goytisolo, “La legítima en el Derecho Foral...”, op. cit. pág. 206. 
heredados se debían de dejar a los parientes tronqueros ${ }^{660}$. En el que los hijos ocupan el lugar preferente, si bien con la facultad del padre de elegir de entre ellos al sucesor. Los bienes muebles y raíces no troncales eran para poder disponer libremente el testador ${ }^{661}$. Por lo tanto parece encontrarse aquí con una parte destinada a reserva de determinados parientes y otra parte para poder disponer libremente ${ }^{662}$. También se sitúa el origen de la legítima, al coincidir otros autores, en que se encuentra en el Fuero Viejo, por establecer, esta Ley, un sistema de reserva total de los bienes raíces con una libertad absoluta para el testador en lo que a los bienes muebles se refiere. ${ }^{663}$.

\subsubsection{El Fuero nuevo. Aparición de la legítima}

Es el Fuero nuevo, el que da paso por primera vez a la legítima, sin eliminar de los bienes comprados el carácter troncal. Así se expone en la

${ }^{660}$ AVD - ZEA - Academia Vasca de Derecho - Zuzenbidearen Euskal Akademia Parientes tronqueros:

"En la línea descendente, los hijos y demás descendientes, incluso los adoptivos. En esta línea, el parentesco troncal se prolonga sin limitación de grado".

"En la línea ascendente, los ascendientes de la línea de donde proceda la raíz. En esta línea, el parentesco troncal termina en el ascendiente que primero poseyó la raíz".

"El padre o madre supervivientes respecto de los bienes comprados o ganados constante el matrimonio de aquéllos y heredados del cónyuge premuerto por sus hijos comunes".

- En la colateral, los parientes que lo sean por la línea paterna o materna de donde proceda la raíz troncal. En esta línea, el parentesco troncal llega hasta el cuarto grado civil, inclusive, de consanguinidad.

${ }^{661}$ PÉREZ EsCOLAR, M.: "El cónyuge heredero legal...”, op. cit., pág. 164. El carácter familiar del patrimonio accionaba una gran limitación de disposición al titular de los bienes raíces que a u vez tenían la condición de troncales.

${ }^{662}$ VALLET DE Goytisolo, "La legítima en el Derecho Foral ...”, op. cit., pág. 212. Hace referencia este autor, al Fuero Viejo de Vizcaya de 1452, afirmando que las costumbres que se exponían en sus Capítulos CXII Y CXXVI, lo que los bienes raíces procedentes de la familia se debían dejar a los parientes tronqueros, en el que los hijos ocupaban el lugar preferente con la facultad del padre, de elegir de entre ellos al sucesor y los muebles y raíces no tróncales, eran de libre disposición.

${ }^{663}$ Celaya Ibarra, A.: "Curso de Derecho Civil del País Vasco", Universidad de Deusto, Bilbao, 1998, págs. 88 a 89. 
compilación de 1959 que todavía conserva "la amplia legitima de 4/5 de todos los bienes". Explicada la típica libertad de Vizcaya a la hora de testar, en el sentido de elegir heredero entre los hijos o entre los tronqueros, pero no en el sentido liberal de la cuantía legitimaria. Por lo tanto, el Fuero nuevo incide sobre la libertad de disposición post mortem, que lo hace como consecuencia de la tradición legal castellana prohibiendo al testador disponer de bienes raíces habiendo parientes tronqueros dentro del cuarto grado $^{664}$. Por lo que respecta a legislación regulada por la Ley 3/1992, de 01 de julio del Derecho Civil Foral del País Vasco dedica el Libro I a Bizkaia.

Las novedades son que se reduce la legítima de los ascendentes, a la mitad de los bienes hereditarios. Son herederos forzosos conforme a la citada Ley foral en su artículo 53: (sin perjuicio de lo dispuesto para la troncalidad) los hijos, incluso los adoptivos, y demás descendientes y los padres y demás ascendientes. En consecuencia, hay que sacar dos conclusiones importantes de este precepto: la primera en lo referente a la troncalidad y la segunda que solo en defecto de descendientes son herederos forzosos los ascendientes ${ }^{665}$.

\subsubsection{El derecho sucesorio vigente en el País Vasco}

Desde el 03 de octubre de 2015, se ha aplicado en todo el País vasco la Ley 5/2015, de 25 de junio, de Derecho Civil Vasco (LDFV, en adelante). Como ya se ha dicho, se mantienen algunas especialidades en determinados territorios, como es el caso del denominado usufructo poderoso en Ayala. El artículo 91 LDFV establece este usufructo para los que allí tengan su

\footnotetext{
${ }^{664}$ MONASTERIO ASPIRI, I.: La metodología: prácticas y principios del análisis de documentos. derecho civil foral (SS. XVII-XIX), en El Derecho civil vasco del siglo xxi, de la ley de 2015 a sus desarrollos futuros", Eusko Legebil tzarra / Parlamento Vasco, Bilbao, 2016, pág. 67.

${ }^{665}$ Celaya Ibarra, Curso de Derecho Civil..., op. cit., pág. 90.
} 
vecindad. Este usufructo poderoso se caracteriza porque permite al usufructuario, por lo general es el cónyuge viudo, que pueda disponer de los bienes, en todo o en parte, en favor de los hijos o descendientes del constituyente o de otras personas ${ }^{666}$.

El principal punto de conexión entre la Ley y su aplicación se encuentra en la vecindad civil vasca, que supone tenerla en cualquiera de los tres territorios históricos que componen la Comunidad Autónoma del País Vasco. Esta Ley puede afectar a otro tipo de causantes conforme al Reglamento 650/2012 es a los extranjeros cuya última residencia habitual ha sido el País Vasco. Si bien es cierto, que pueden, estos últimos, optar por la Ley de sucesiones de su país de origen.

\subsubsection{La cuota de legítima y los legitimarios}

Atendiendo al artículo 47 LDFV son de manera exclusiva legitimarios los hijos o descendientes y el cónyuge viudo o pareja de hecho superviviente. Estos últimos con una cuota de usufructo concurriendo a la sucesión con cualquier clase de herederos. Por lo que a los descendientes se refiere, se trata de una legítima colectiva, cuya cuantía es de una tercera parte de la herencia (art. 49 LDFV). En el artículo 48 LDFV se regula la distribución de dicha tercera parte de legítima. El disponente puede distribuirla entre los legitimarios a su voluntad. La legítima se ha de entregar a sus titulares libre de todo gravamen, a excepción del usufructo viudal (art. 56 LDFV). El disponente puede entregar la legítima a sus legitimarios por cualquier título, es decir, herencia, legado, donación o pacto sucesorio. Por lo que respecta a la repudiación, los legitimarios pueden renunciar a la legítima, incluso en vida del causante, por pacto

\footnotetext{
${ }^{666}$ FAUS I PUJOL, M.: "Testamento legando...", op. cit., El autor expone un modelo de testamento que en la cláusula segunda del mismo se advierte como un testador lego a su esposa además del usufructo universal el poderoso: "Segunda: Lega a su esposa el usufructo universal y poderoso de sus bienes, sin obligación de inventario".
} 
sucesorio (art. $56 \mathrm{LDFV})^{667}$. El apartante puede a través del apartamiento rescindir la legítima a cualquiera de sus legitimarios, sin tener necesidad de alegar causa para ello ${ }^{668}$.

\subsubsection{El cónyuge viudo o el superviviente de la pareja de hecho}

De la Ley 5/2015, de 25 de junio, de Derecho Civil Vasco cabe destacar su artículo 52 que otorga al viudo o la pareja de hecho superviviente, el derecho a usufructo. En el supuesto de concurrir a la sucesión con descendientes le concede el usufructo de la mitad de todos los bienes del causante. En el caso de no concurrir con estos a la sucesión tendrá derecho a usufructuar dos tercios de la herencia. También es destacable la existencia de un derecho de habitación en la vivienda conyugal o de la pareja de hecho. Este derecho se mantiene mientras dure el estado de viudedad, no haga vida marital ni tenga hijos extramatrimoniales, o no constituya una nueva pareja de hecho. Todo ello, conforme al artículo $54^{669}$ LDFV.

Es por el artículo $55 \mathrm{LDFV}$ por el cual pierde sus derechos legitimarios, salvo disposición expresa por el causante, el viudo o pareja de hecho legalmente separado, o bien de mutuo acuerdo. También pierde los derechos legitimarios, si el causante no ha dispuesto en contrario, el viudo

\footnotetext{
${ }^{667}$ Entiende ARTAMENDi GutiéRREZ, A.: "Visión integral de la fiscalidad del pacto sucesorio" Actualidad Jurídica (Uría \& Menéndez), núm. 42, enero de 2016, pág. 63, que el pacto sucesorio, prohibido en el Derecho común, que ha supervivido en los Derechos especiales forales, en la mayoría de regiones donde el Código civil no completa su eficacia, sino que es más bien una norma residual. Por lo que encuentra acomodo, la citada institución, en los Derechos de Galicia, Navarra, Aragón, Cataluña, Mallorca, Ibiza (no en Menorca) y en especial resulta relevante en el País vasco.

${ }^{668}$ JuÁREZ GONZÁLEZ, GPS de Sucesiones..., op. cit. págs. 443.

${ }^{669}$ Mollá NeBOt, S.: "Supuestos de eventual autorización del usufructuario, en derecho común, foral y civil especial en los casos de sucesión legal y voluntaria. Usufructo de pecunia". En Aplicación a los fondos de inversión desde la ley de jurisdicción voluntaria, Dykinson, 2015, pág. 98.
} 
o pareja de hecho que haga vida marital o mantenga una relación afectivosexual con otra persona. Si bien este precepto parece que mantenga una contradicción con el artículo 114. 2 LDFV del mismo texto legal, cuando dispone, este último, que en todo caso conservará el viudo o pareja superviviente, los derechos legitimarios de usufructo.

Los derechos del supérstite o pareja de hecho inscrita, con la Ley $5 / 2015$, de 25 de junio, el legislador vasco le concede el derecho a heredar en propiedad a falta de descendientes del finado. Cuando concurre a la sucesión intestada ${ }^{670}$, con descendientes del causante, tienen aquellos el derecho al usufructo de la mitad del haber hereditario. En el supuesto de concurrir con parientes no descendientes o con extraños se aumenta el usufructo del cónyuge superviviente hasta los dos tercios. Así lo dispone el artículo 52 LDCV.

\subsubsection{El Título II de la Ley 5 /2015 de 25 de junio de 2015}

El Título II de la precitada Ley Foral Vasca de 2015 está dedicado a las sucesiones y destaca las siguientes novedades con respecto a la legislación pasada y aquí comentada:

-El artículo 21.2 $2^{671}$ LDFV dispone que el heredero responde de las obligaciones del causante, de los legados y de las cargas hereditarias. A diferencia del artículo 1003 del Código civil solamente hasta que se agote el valor de los bienes heredados. Este precepto es digno de tener en cuenta, ya que puede evitar muchas repudiaciones por el temor del

\footnotetext{
${ }^{670}$ La Ley 5/2015, de 25 de junio, en el título de su artículo 110, se refiere a la sucesión intestada y no solamente a la sucesión legal como cabría esperar. Por lo tanto, con ello se entiende conformidad a que sean utilizados ambos términos como sinónimos. En cambio, en todo el texto legal, no se utiliza el término "sucesión legítima".

${ }^{671}$ Artículo 21. 2 LDFV: "Gastos de la sucesión y beneficio de separación. 2. El heredero responde de las obligaciones del causante, de los legados y de las cargas hereditarias hasta el valor de los bienes heredados en el momento de la delación".
} 
heredero a la confusión de patrimonios y como no, al protocolo que comporta aceptar a beneficio de inventario.

-También es destacable el artículo 24 y ss LDFV dedicados al testamento mancomunado, que le puede afectar a un legitimario a la hora de impugnar un testamento. Se considera mancomunado el testamento de dos personas, sin importar la existencia de relación de convivencia o parentesco, que dispongan post mortem en un solo instrumento. Pueden disponer de esta conjunta manera los que ostenten la vecindad civil del País Vasco, dentro y fuera de dicha CCAA. Incluso pueden hacerlo en el supuesto que alguna de las partes no tenga vecindad civil vasca, siempre que su ley personal no se lo prohíba. Sería el caso de una persona que su ley personal fuera el Código civil. Esta forma de testar no goza de mucha difusión en España a excepción de algún Derecho foral y ciertas legislaciones europeas como puedan ser el Derecho austriaco y alemán. Es una figura excluida por la mayoría de países que han seguido los pasos del Code francés, el cual la prohibió de forma tajante. El Código civil la suprime en los artículos 669 y $773^{672}$.

-Los ascendientes no son legitimarios en la LDFV ello por lo dispuesto a contrario sensu en el artículo 47, de la precitada Ley que reconoce únicamente como legitimarios a los hijos y descendientes y al cónyuge viudo o superviviente de la pareja de hecho. A diferencia de lo dispuesto en artículo 807.2, del Código civil que si que reconoce a los ascendientes como legitimarios. El propio precepto citado 47 LDFV dispone que la troncalidad prevalezca sobre la legítima en los territorios del infanzonado o tierra llana de Bizkaia y en los municipios alaveses de Aramaio y Llodio. Ahora bien cuando el

${ }^{672}$ Señala Rivas MARTíneZ, J.J.: Derecho de sucesiones ..., op. cit., pág. 316. 
tronquero sea legitimario los bienes troncales se le imputarán a la legítima. También resaltar la libertad de disponer post mortem del valle de Ayala y la normativa específica de los artículos 96 y ss. LDFV sobre la sucesión del caserío en Guipúzcoa ${ }^{673}$.

- En el País Vasco la sucesión se difiere por testamento y por pacto testamentario y en defecto de ambos por disposición de la Ley (art. 18 LDFV). Por medio del pacto sucesorio recogido en los artículos 100 y ss. LDFV el ciudadano vasco puede disponer de sus bienes para después de su muerte y también cabe su uso para la renuncia a los derechos sucesorios de una herencia o de parte de ella en vida del causante. Evidentemente, estos pactos necesitan de instrumento público para su validez ${ }^{674}$. Como su nombre indica, los pactos requieren la concurrencia de dos o más personas, que serán las que acuerden y ordenen la sucesión de uno de ellos. Esta figura está prohibida en el Derecho común por el artículo 1271 Cc que sólo autoriza los contratos sobre la herencia futura para unos supuestos muy limitados.

-El artículo 48 LDFV cuyo título es "La legítima" es precisamente este y los que lo siguen los que regulan la legítima. Se establece únicamente para los hijos o descendientes de cualquier grado. Abarca un tercio del caudal relicto, con la particularidad que dicho caudal

\footnotetext{
${ }^{673}$ Conforme al artículo 12, LDFV, "El caserío es una explotación agrícola o ganadera familiar constituida por una casa de labor, con diversos elementos muebles, semovientes, derechos de explotación, maquinaria, instalaciones y una o varias hereda des, tierras o montes. Estas tierras o heredades pueden o no estar contiguos a la casa de labor y reciben la denominación de pertenecidos del caserío".

${ }^{674}$ FAUS I PUJOL, M.: "Testamento legando usufructo...", op. cit. Invoca el artículo 18 de la Ley 5/2015, de 25 de junio, de Derecho Civil Vasco para matizar que la sucesión en el País Vasco se defiere por testamento o pacto sucesorio y en su defecto por disposición legal. Un disponente puede disponer de sus bienes post mortem, en parte por testamento y en parte por pacto sucesorio, no revocando éste a aquel, pero si lo dispuesto en el pacto sucesorio al testamento, en caso de contradicción de disposiciones.
} 
puede otorgarse, por parte del disponente, a uno o a varios de los legitimarios, simplemente apartando al resto de legitimarios de la sucesión. También el Derecho Foral aragonés, contempla (como se indica en este mismo Capítulo) la legítima colectiva ${ }^{675}$.

\subsubsection{La troncalidad en la Ley $5 / 2015$}

La troncalidad deriva de cuando en la Vizcaya medieval los bienes se dividían en muebles y raíces. Siendo estos últimos los conocidos hoy como inmuebles ${ }^{676}$. Por lo tanto, los llamados bienes raíces o inmuebles debían ser reservados, en aquella época, a la familia a la que pertenecen desde varias generaciones. La sucesión troncal trata de impedir la salida de estos bienes de la familia de procedencia. Entre estos se excluían los comprados por el disponente, ya que para considerar un bien raíz o inmueble era requisito una adquisición anterior dentro de la propia familia. De faltar este requisto, el bien en cuestión, era tratado como mueble, que ello implicaba su libre disposición tanto en vida como mortis causa ${ }^{677}$. En el Código civil la troncalidad se recoge en la reserva troncal del artículo $811 \mathrm{Cc}$.

675 RDGRN de 12/06/2017 (RJ 2017\3257), Herencia de causante vasco con superveniencia de hijos al testamento. derecho interregional e intertemporal) entiende con respecto al artículo 48 LDFV, en su apartado segundo, en relación a la exclusión del resto de hijos, al absorber la legítima colectiva sólo uno de ellos, habiendo sido preteridos el resto de hijos: "siendo además de aplicación el artículo 48, de la Ley $5 / 2015$, en su número 2, con la literal y rigurosa aplicación de las normas, nada pueden reclamar los otros hijos habidos por el causante, aun cuando eran absolutamente desconocidos por el testador al tiempo del otorgamiento de su testamento". Adviértase que impera la aplicación rigurosa del precepto en que el disponente puede disponer libremente a quien le entregue la legítima de entre sus legitimarios.

${ }^{676}$ Véase GUERro PÉrEZ, V.: “Acción de nulidad de las donaciones de inmuebles. aspectos sustantivos y procesales, en Los 25 temas más frecuentes en la vida práctica del derecho de familia, (coord. F. Lledó YAGUE, Y A. SÁNCHEZ SÁNCHEZ), Dykinson, Madrid, 2011, pág. 760, en que cita el artículo 17.1 LDFV, cuya disposición declaraba que disponía que la troncalidad es una cualidad de los bienes raíces, por la cual se protege "el carácter familiar del patrimonio".

${ }^{677}$ Mantiene Rivas MartíneZ, J.J.: Derecho de sucesiones..., op. cit., pág. 1831 que en la actualidad la troncalidad en Bizkaya recoge a todos los bienes raíces o inmuebles, sin 
En Tierra Llana de Vizcaya, así como en los municipios de Aramaio y Llodio prevalece la troncalidad ${ }^{678}$, sobre la legítima. Ello se puede sonsacar del artículo 61 de la propia Ley 5 /2015 de 25 de junio de 2015. Dicha Ley dedica su Sección Cuarta del Capítulo II del Título II, al valle de Ayala en Álava, cuyo artículo $89^{679}$ del citado cuerpo legal, lleva por título "Libertad de testar" en el valle de Ayala. Digno de mención en esta Ley es lo establecido en su Sección cuarta. Son unas normas sucesorias únicamente para el Fuero del valle de Ayala otorgándole en su artículo 89 una libertad de testar absoluta ${ }^{680}$. De la vigente Ley de 2015, se deduce en base a sus artículos 61.1; 63.3; y 68 LDFV que se requieren tres condiciones indispensables para que pueda operar la troncalidad ${ }^{681}$ : que existan bienes

que importe el modo de su adquisición. Se extiende a todos los parientes hasta el cuarto grado (ascendiente, descendiente y colateral), siempre que su procedencia venga del tronco familiar. Su ámbito de aplicación es para toda clase de actos dispositivos. El autor se refiere con "la actualidad" a la LDCFPV de 1992.

${ }^{678}$ Señala NúÑEZ NúÑEZ, M.: "Reglas del código civil y legislaciones forales sobre la sucesión intestada de los parientes colaterales", en La sucesión intestada de los parientes colaterales, Dykinson, Madrid, 2008, pág. 237. como la más destacada peculiaridad del Derecho civil de Bizkaya, el profundo arraigo a la troncalidad manifestada en la sucesión intestada. El significado de troncalidad, según la autora, "es el privilegio sucesorio por virtud del cual los derechos hereditarios de una persona, de naturaleza familiar conocida, vuelven al tronco del que proceden cuando esa persona muere sin dejar descendientes".

${ }^{679}$ Artículo 89. Libertad de testar en el valle de Ayala:

1. Los que ostenten la vecindad civil local ayalesa pueden disponer libremente de sus bienes como quisieren y por bien tuvieren por testamento, donación o pacto sucesorio, a título universal o singular, apartando a sus legitimarios con poco o mucho. 2. Se entiende por legitimarios los que lo fueren con arreglo al artículo 47 de esta ley.

${ }^{680}$ GÓMEZ - CORNEJO TEJEDOR, "El cambio de sesgo en la jurisprudencia...", op. cit., pág. 1622.

${ }^{681}$ La STSJ del País Vasco de 02/06/2004 (Tol. 498.987) F. J. $2^{\circ}$ reafirma lo expuesto al mantener que "Cuando el artículo 112 de la Ley Civil Foral del País Vasco estable la norma general que reconoce a los parientes tronqueros un derecho preferente para adquirir los bienes troncales, determina el ámbito de aplicación de este derecho refiriéndose a los bienes "que se intentare enajenar a extraños y a título oneroso", con lo que la expresión literal del precepto está indicando que el derecho preferente existe cualquiera que sea la figura contractual bajo la cual se lleve a cabo la enajenación, si ésta se verifica a título oneroso". 
troncales concordantes con la definición del artículo 61.1, LDFV, ${ }^{62}$ que hayan sido transmitidos por primera vez en base a lo dispuesto por el artículo $63.3^{683}$ LDFV y que el propietario tenga vecindad civil vizcaína aforada o no. Ejerce el derecho un pariente tronquero de cualquier vecindad civil o nacionalidad ${ }^{684}$. No obstante, la segunda condición parece que arroja alguna que otra duda interpretativa ${ }^{685}$.

\subsubsection{La intangibilidad de la legítima en el País Vasco}

Por lo que respecta a la intangibilidad cuantitativa de la legítima en la Ley 5 /2015 de 25 de junio de 2015, ha seguido los mismos pasos que la desheredación, es decir, no se ha regulado. En consecuencia a ello, no existe remedio específico vasco para instar la reducción de las liberalidades entre vivos como mortis causa a favor de terceros que mermen o anulen cuantitativamente la legítima global. Para instar la pertinente reducción hay

${ }^{682}$ Dispone el artículo 61.1 LDFV (Aplicación territorial de la troncalidad): "Sólo son bienes raíces, a efectos de troncalidad, los que estén situados en el infanzonado o tierra llana de Bizkaia o en los términos municipales alaveses de Aramaio y Llodio".

${ }^{683}$ Artículo $633 \mathrm{LDFV}$ "Los bienes adquiridos de quien no fuese pariente tronquero, aunque hayan pertenecido anteriormente a alguno de ellos, no se hacen troncales mientras no se hayan transmitido a un descendiente".

${ }^{684}$ Artículo 68, dice bajo el título (Nacimiento y extinción de la troncalidad): “1. La troncalidad nace desde el momento en que un bien raíz es adquirido por una persona de vecindad civil local vizcaína o de los términos municipales de Aramaio y Llodio y se extiende desde ese momento a todos sus descendientes, salvo lo establecido en el artículo 63.3 de esta Ley. 2. Una vez constituida la troncalidad, los parientes tronqueros, tengan o no vecindad civil vasca, mantienen su derecho de preferencia en cualquier acto de disposición que haga el titular tanto inter vivos como mortis causa. 3. La troncalidad se extingue en una familia si al fallecimiento del titular no existen parientes tronqueros. Se extingue también si en el momento en que el titular pierde la vecindad civil local vizcaína, no existen parientes tronqueros en la línea recta ni en el segundo y tercer grado de la colateral".

${ }^{685}$ Acogerse a la tesis que invoca el artículo citado 61. 1 LDFV, supondría según IRIARTE ÁNGEL, J. L.: “Ámbito material y personal y normas conflictuales", en El Derecho Civil Vasco del Siglo XXI: de la Ley de 2015, a sus desarrollos futuros, Eusko Legebiltzarra / Parlamento Vasco, 2016, pág.158, "prescindir de los antecedentes históricos. En concreto el artículo 68.1 en sus imprecisos términos puede favorecer una interpretación restrictiva en el sentido de que la troncalidad únicamente opera cuando el propietario tronquero tiene vecindad civil local vizcaína aforada". 
que acudir al Derecho común, donde los artículos 817, 820, 654, 655 y 656, todos del Código civil se encargan de regular la citada acción. El problema entre ambos Derechos común y foral se plantea en la legitimación, entre otros, para interponer la pertinente acción de reducción. Si todos los descendientes son legitimarios, todos estarán legitimados para interponerla. Si bien parece ser que los artículos 50 y 51.3 LDCV dan a entender que los legitimarios preferentes ostentarían el derecho ${ }^{686}$.

La intangibilidad cualitativa de la legítima sí que se recoge en el artículo $56 \mathrm{LDCV}$ que establece que no podrá imponerse a los hijos y descendientes, sustitución o gravamen que exceda de la parte de libre disposición. A no ser en favor de otros sucesores forzosos. Con esta concesión, al testador, no le resultaría difícil burlar el derecho de los legitimarios restringiendo o mermando el pleno disfrute de los bienes legitimarios. Si bien la primera condición tiene que ser que la carga beneficie a herederos forzosos. La segunda la recoge el artículo 56. 2 LDCV. Dispone este precepto que no afectará a la intangibilidad cualitativa de la legítima el legado de usufructo universal, otorgado por el testador, a favor del supérstite o pareja de hecho. Tampoco afectaran los demás derechos reconocidos al viudo ${ }^{687}$.

La intangibilidad cualitativa de la legítima del precitado artículo 56 LDCV es mucho más débil que la dispuesta por el Código civil. Allí se

${ }^{686}$ Sobre la legitimación se pregunta GALICIA AIZPURUA, G.: "La sucesión forzosa: planteamiento general", en El Derecho Civil Vasco del Siglo XXI: de la Ley de 2015, a sus desarrollos futuros, Eusko Legebiltzarra / Parlamento Vasco, 2016, pág. 415, “a quién se la reconocemos? ¿A cualquiera de los descendientes puesto que todos son legitimarios? ¿O solo a los que hemos calificado como preferentes?”.

${ }^{687}$ Entiende GALICIA AizPURUA, "La sucesión forzosa..." op. cit., págs. 415 y 416 que "En ausencia de previsión del disponente, la legítima usufructuaria del viudo o pareja recaerá en primer lugar sobre los bienes adjudicados para el pago del tercio legitimario de los descendientes, y solo en lo que falte gravitará sobre los bienes dejados a extraños con cargo a los dos tercios libres". 
permite el gravamen cuando este favorece a otros legitimarios o bien se ha dispuesto un usufructo universal a favor del supérstite. Ello conforme al artículo $60 \mathrm{LDCV}^{688}$. Si bien en el artículo $57 \mathrm{LDFV}$ sí que podría encontrar cabida una opción compensatoria de manera concordante con el artículo 820. 3 del Código civil. A diferencia que en el Derecho común la opción la tiene el legitimario y aquí la tiene el superviviente de la pareja. El viudo en este caso puede optar entre recibir el usufructo universal o el legado de la parte de libre disposición, pero no ambas cosas. De ahí que se pueda ver, en este precepto vasco, una cierta cautela de opción compensatoria como ocurre con el 820. 3 del Código civil ${ }^{689}$.

\subsubsection{La preterición y la desheredación}

La Ley 5 / 2015 de 25 de junio, anteriormente citada, dispone en su artículo 51. 2 LDCV que sólo la preterición de todos los legitimarios abre las puertas a la sucesión abintestato. En la actual y vigente regulación si la preterición no afecta a todos los legitimarios, la sucesión sigue su curso ${ }^{690}$. La imposición obliga al disponente, por virtud del artículo 48. 2 LDCV a que deje la legítima a sus legitimarios. Al mismo tiempo le otorga facultad

\footnotetext{
${ }^{688}$ RAGEL SÁNCHEZ, L.F.: Desde la cautela ..., op. cit., pág. 144.

${ }^{689}$ RAGEL SÁNCHEZ, Desde la cautela...”, op. cit., pág.144, cita (86).
}

${ }^{690}$ GRANADOS DE AsEnSIO, D.M.: "Preterición de los hijos sobrevenidos (RDGRN de 12/06/2017)", Notaría Abierta, julio, 2017, en una manifestada crítica personal a la Resolución de la Dirección General de Registros y del Notariado de 12 de julio de 2107, que resuelve acerca de un causante guipuzcoano con vecindad civil común a fecha de otorgación del testamento con arreglo al Cc de 1994. El testador a la fecha señalada era divorciado e instituyo heredero a su único hijo. Excluyendo a su ex esposa de la administración de los bienes que su hijo heredara. Posteriormente, tuvo otros dos hijos de otra relación. El causante falleció en 2016, bajo la vigencia de la nueva Ley de Derecho civil vasco, vigente desde el 3/10/2015, pero el fallecido sin modificar su primitivo testamento. La RDGRN "resuelve la cuestión señalando que, respetada la legítima colectiva, es de plena aplicación el artículo 48 de la LDCV que, en su apartado 4, dice que "la preterición, sea o no intencional, de un descendiente heredero forzoso equivale a su apartamiento", conforme a lo cual, solo será heredero el hijo nombrado en el testamento, ya que sus otros dos hijos, al haber sido preteridos, se consideran apartados conforme a la dicción del art. 48.4 de la LDCV". 
de disposición para, entre todos, elegir al que quiera o a los que quiera, que sobre ellos recaiga la legítima. Es más, mantiene el precepto último aludido, que el apartamiento de los no favorecidos en su herencia lo puede hacer el testador de manera expresa o tácita. Puesto que el precepto no exige la voluntad expresa de $\operatorname{apartar}^{691}$. Ello explica porque el legislador no ve preterición, si no es en el caso de dejar sin nombrar a todos los legitimarios. La verdad sea dicha, que el legislador entienda como preterición intencional el apartamiento de un legitimario, es decir, su omisión por ejemplo, en el testamento, pero no se entiende ni se comparte que la preterición no intencional también sea considerada como un apartamiento por parte del disponente ${ }^{692}$.

La Ley 5/2015, de 25 de junio se refiere a la desheredación de manera expresa en los artículos 50 y el 108.3 LDFV pero no regula esta institución. Lo que hace es remitirla al Derecho supletorio del Código civil, concretamente a los artículos 848 y ss., con las consecuencias de adaptación que ello supone. Puesto que el artículo LDFV establece el

\footnotetext{
${ }^{691}$ La vigente Ley 5/2015, de 25 de junio, no exige que conste la voluntad expresa de apartar, y equipara al apartamiento la preterición, intencional o no. Así lo pone de manifiesto la DGRN.: "Comentarios a la resoluciones de La Dirección General de Registros y del Notariado", núm. 150, julio 2017,en un supuesto en que la legitima colectiva se cubre en lo atribuido a uno sólo de los hijos, absorbiendo éste, la del resto. Hecho que lo respalda el artículo 48.2, LFV. " Así pues, siendo que en la presente sucesión queda un heredero que es hijo y que absorbe la legítima de todos los descendientes, preteridos o no, y siendo además de aplicación el artículo 48 de la Ley $5 / 2015$ en su número 2, con la literal y rigurosa aplicación de las normas, nada pueden reclamar los otros hijos habidos por el causante, aun cuando eran absolutamente desconocidos por el testador al tiempo del otorgamiento de su testamento".

${ }^{692}$ CAROL Roses, F.:'La preterición: entre la libertad para testar y los derechos fundamentales. Una revisitación del derecho foral y ordenamientos comparados", Revista Crítica de Derecho Inmobiliario, núm. 759, enero, 2017, pág. 431. "Mantiene este autor, que la solución adoptada por la LDCV, no tiene precedentes en los ordenamientos civiles españoles, el que no comporte consecuencias, cuando son preteridos de manera no intencional. Solo comporta consecuencias cuando se ha preterido a todos los legitimarios, entonces y sólo entonces son nulas todas las disposiciones de contenido patrimonial".
} 
carácter supletorio del Código civil en defecto de ley o costumbre foral aplicable. Lo que una mala solución dada entre la legítima individual que contempla el Derecho común y la colectiva que recoge el Derecho foral vasco. Se puede dar el supuesto de una desheredación injusta en uno de los legitimarios de los varios que forman el conjunto de ellos en una determinada sucesión. En este caso de darse el supuesto en un legitimario que ostenta vecindad civil donde tiene aplicación el Derecho común se le aplicaría la disposición del artículo $851 \mathrm{Cc}$, pero en el caso de vecindad civil vasca, donde la legítima es colectiva, no tiene sentido la anulación de la institución de heredero que proclama este precepto. Es lo mismo que ocurre en el Código de Derecho foral de Cataluña, con los artículos 451-17 a 451-21; en el Código de Derecho Foral de Aragón artículos 509 a 511, o con la Ley de Derecho Civil de Galicia con los artículos 262 a $266^{693}$.

Se ha pronunciado el Tribunal Supremo, en distintas sentencias admitiendo el maltrato de obra como causa de desheredación válida para poder el testador desheredar a un legitimario ${ }^{694}$. En este aspecto resulta que el testador vasco puede preterir o apartar a los legitimarios de su sucesión sin expresar causa alguna. Por el contrario de haber un solo legitimario o pretender excluirlos a todos ha de recurrir a las causas de desheredación

\footnotetext{
${ }^{693}$ GALICIA AizPURUA, "La sucesión forzosa...”, op. cit. pág. 414.

${ }^{694}$ La STS de 03/06/2014 (Roj: 2484/2014) en su F.J. $2^{\text {o }}$, punto sexto, entiende en el presente caso, y conforme a la prueba practicada, debe puntualizarse que, fuera de un pretendido "abandono emocional", como expresión de la libre ruptura de un vínculo afectivo o sentimental, los hijos, aquí recurrentes, incurrieron en un maltrato psíquico y reiterado contra su padre del todo incompatible con los deberes elementales de respeto y consideración que se derivan de la relación jurídica de filiación, con una conducta de menosprecio y de abandono familiar que quedó evidenciada en los últimos siete años de vida del causante en donde, ya enfermo, quedó bajo el amparo de su hermana, sin que sus hijos se interesaran por él o tuvieran contacto alguno; situación que cambió, tras su muerte, a los solos efectos de demandar sus derechos hereditarios". En el mismo sentido también la STS de 30/01/2015, Roj: STS 565/2015, en su F.J. $2^{\circ}$, pto. $2^{\circ}$ se remite a la citada STS de 03/06/2014, como doctrina jurisprudencial a seguir, en todo lo que afecta al abandono emocional que implica "la interpretación del concepto de maltrato de obra que contempla el artículo 853.2 del Código Civil”.
} 
que invoca el Código civil. Puede que en este sentido la libertad de disposición de que dispone el testador vasco se vea condicionada, más bien por el número de hijos que tenga que por su propia voluntad. Un mismo disponente con dos hijos puede apartar a ambos de la legítima colectiva, únicamente mediando una causa de desheredación de las tasadas en el Código civil. En cambio puede preterir intencionalmente a uno de ellos, o apartarlo de la sucesión de manera expresa, sin alegar causa alguna ${ }^{695}$.

\subsubsection{La libertad de testar en el Valle de Ayala}

Por lo que respecta al valle de Ayala, como anteriormente ya se apuntaba, todo aquel que tenga allí su vecindad civil puede disponer libremente de sus bienes para después de su muerte. Lo puede hacer tanto por testamento, donación o pacto sucesorio, incluyendo o apartando a sus legitimarios, que son dispuestos por el artículo 47, de la precitada Ley de 2015. Es decir, los hijos y descendientes de cualquier grado del causante y su cónyuge supérstite o pareja de hecho. Que la Ley le otorgue al testador libertad de disponer post mortem, no significa que no tenga legitimarios. En cambio sí que significa conforme al artículo 90.2 de la citada Ley 2015, que la omisión que aparta de la sucesión a uno o varios legitimarios producen el apartamiento tácito. Entendiendo por apartamiento la exclusión de cualquier derecho sobre la herencia que, parece ser, va en este sentido el artículo 51 de la vigente ley LDFV. Trata de evitar posibles reclamaciones sobre su legítima a los que han sido privados de ella por el propio disponente $^{696}$.

\footnotetext{
${ }^{695}$ GALICIA AizPURUA, "La sucesión forzosa...”, op. cit. pág. 414.

${ }^{696}$ FAUS I PUJOL, M.: "Escritura de herencia testada a favor de hijos y legítima a la pareja de hecho. País vasco", vLex, 2010, pág. 5. Hace el autor un buen señalamiento sobre el pilar fundamental del Fuero de Ayala que lo constituye la libertad sucesoria, y el texto de 1992, en especial el artículo 134 regla básica de este verdadero sistema de Derecho Civil, hasta el punto de que ha habido autores que han estimado que no sería precisa una
} 


\subsection{LAS LEGÍTIMAS EN EL DERECHO FORAL DE NAVARRA}

La tradición histórico-jurídica que caracteriza al Derecho de Navarra al igual que al País Vasco y Aragón encuadra estos dentro del llamado "grupo germánico" por predominar en ellos la citada tradición histórico jurídica. Ello, en base al sistema de copropiedad familiar que consta de un único sucesor designado, entre los hijos del disponente. Tal tradición existe en Navarra desde tiempos muy antiguos, perviviendo a través de la costumbre. Como valor añadido, a dicha tradición, también coexiste el pacto sucesorio como medio de deferir la herencia en vida del disponente que cabe dentro de la tradición germánica que trata de ordenar su sucesión, el testador en vida ${ }^{697}$.

La Compilación del Derecho Civil Foral de Navarra es aprobada por la Ley $1 / 1973$, de 1 de marzo en la que cabe de destacar que el también denominado Fuero Nuevo es la única compilación que no ha sido objeto de una importante reforma desde su publicación. Es en el Capítulo II, del Título X, del Libro II (CDFN, en adelante) donde se regulan las sucesiones y con ello las legítimas. La legítima en Navarra, es más bien una legítima simbólica. Conforme al artículo $267^{698} \mathrm{CDFN}$ consiste en atribuir formalmente, a cada heredero forzoso, cinco sueldos febles o carlines- en concepto de bienes muebles - y una robada de tierra en los montes

mayor regulación, recoge esencialmente la redacción de 1487, con unas pequeñas adaptaciones".

${ }^{697}$ DE BARRÓN ARNICHES, P.: "La legítima...", op. cit., pág. 227.

${ }^{698}$ CAPÍTULO II De la legítima. LEY 267, "La legítima navarra consiste en la atribución formal a cada uno de los herederos forzosos de cinco sueldos febles o carlines por bienes muebles y un robada de tierra en los montes comunes por inmuebles. Está legítima no tiene contenido patrimonial exigible ni atribuye la cualidad de heredero, y el instituido en ella no responderá en ningún caso de las deudas hereditarias, ni podrá ejercitar las acciones propias del heredero". 
comunes- en concepto de bienes inmuebles- ${ }^{699}$. Este simbolismo carece de todo contenido patrimonial, y le da un carácter a la legítima meramente formalista. En cambio, el artículo 268 CDFN exige que sean instituidos, mediante testamento o pacto sucesorio, en la legítima foral, los hijos tanto matrimoniales como no matrimoniales así como los adoptados. Ante el supuesto de premoriencia de cualquiera de ellos han de ser instituidos, sus descendientes más próximos en grado.

El artículo 269 CDFN dispone sobre la forma en que se manifiesta la legítima en Navarra señalando su carácter de legítima colectiva. Esta legítima foral navarra no atribuye la cualidad de heredero. En consecuencia, en ningún caso podrá ejercitar las acciones pertinentes. Frente a la consagrada absoluta "libertad de testar" de Navarra. Más bien creo que se puede aludir, como lo hacen algunos autores, a su debilidad para calificar y encuadrar el sistema legitimario foral navarro. Es decir, se reconoce que es difícil considerarlo como un verdadero sistema de legítimas $^{700}$. En cambio es de resaltar la práctica existente entre los cónyuges de la institución universal de herederos de manera recíproca. Se trata de instituirse, el uno al otro, heredero universal con el objetivo de que el supérstite haga una distribución de los bienes mutuos de manera coherente y justa entre sus hijos. Por lo demás, el hijo no favorecido por

\footnotetext{
${ }^{699}$ STS de 02/01/1946 (Tol. 609/1946). En palabras del Tribunal Supremo en refenencia a los "sueldos febles o carlines y a la robada de tierra en los montes comunes" entiende y dispone que ni la moneda existe, ni el testador puede disponer de la propiedad comunal. El Tribunal Supremo en sentencias de 4 de mayo de 1863 , 14 de abril de 1885 , de febrero de 1913 y otras mantiene que dicho tipo de legítima foral navarra es, según queda dicho, "formularia, puesto que no concede derecho ninguno (sino resta, el de impugnar en su caso el testamento) ni tiene tampoco ningún contenido económico; tanto que-como» dice Lacarra, ni la moneda existente (la equivalencia de los cinco sueldos sería lo céntimos de peseta) ni de la robada de tierra en los montes comunes pueden disponer los testadores".
}

${ }^{700}$ JuÁREZ GoNZÁLEZ, GPS Sucesiones..., op. cit., pág. 442. 
donación ni mencionado en el testamento es con la porción simbólica, antes citada, de sueldos y bienes públicos con lo que se queda ${ }^{701}$.

Si bien es cierto que la Ley $1 / 1973$, de 01 de marzo es modificada por la Ley Foral 5/1987, de 1 abril, también lo es que, con respecto a las legítimas, no se presentan novedades con respecto a ella, es más, se mantiene la disposición de la Ley 267 anteriormente citada. En cambio, presentan alguna modificación en la Ley 268 acerca de la institución en la legítima foral los hijos matrimoniales y los no matrimoniales, así como también los adoptivos y ante la premoriencia de alguno de ellos sus descendientes más cercanos. La Ley $270^{702} \mathrm{CDFN}$ dispone que en caso de que el hubiera dotado a los legitimarios habiéndoles atribuido cualquier liberalidad a título mortis causa, o haber desheredado, entre otros supuestos, a los legitimarios, no será necesario instituir aquel a estos, en la legítima foral. Con respecto a las justas causas de desheredación, el artículo 270 CDFV remite a los artículos 852 y 853, del Código civil ${ }^{703}$.

Son legitimarios en el Derecho foral navarro únicamente los hijos del causante y en su defecto los hijos y descendientes de estos. No son legitimarios los padres ni los demás ascendientes, sin perjuicio del derecho de reversión en caso de donaciones hechas por el ascendente al causante y del principio de troncalidad en la sucesión intestada. Existen algunos supuestos, en el Derecho navarro, en que el disponente no necesita instituir en legítima foral. Son cuando hubiera dotado en vida a los legitimarios,

\footnotetext{
${ }^{701}$ BERNAD MAINAR, R.: “La porción legítima...”, op. cit., pág. 1790.

${ }^{702}$ Ley 270 CDFN: "No será necesaria la institución en la legítima foral cuando el disponente hubiera dotado a los legitimados, le hubiese atribuido cualquier liberalidad a título mortis causa, o los hubiere desheredado por justa causa, o ellos hubieran renunciado a la herencia de aquél o hubiesen premuerto sin dejar descendencia con derecho a legítima. Serán justas causas de desheredación las comprendidas en los artículos 852 y 853 del Código Civil”.
}

${ }^{703}$ GómEZ-CORNEJO TEJEDOR, L.: “El cambio...”, op. cit., pág. 1622. 
cuando les hubiera atribuido liberalidades a título mortis causa, hubieran sido desheredados con justa causa legal, por repudiación o por premoriencia, sin tener cabida el derecho de representación ${ }^{704}$.

\subsubsection{LÍMITES DE DISPOSICIÓN. LOS HIJOS DEL ANTERIOR MATRIMONIO}

Es de suma importancia el límite que se le impone al disponente dentro de la propia libertad de disposición para con sus hijos de anteriores matrimonios. Estos descendientes por virtud de la Ley 272. 1CDFN se les conceden poderosos derechos en la herencia de su padre. El Derecho vigente de Navarra les concede el derecho a no recibir menos que el más favorecido de los hijos o cónyuge de ulterior matrimonio. Además el Derecho navarro les concede a estos, acción de inoficiosidad para defender su derecho, ello conforme a la Ley 272.2 CDFN. En cambio no se da esta circunstancia en aquellos descendientes que simplemente se les otorga la legítima simbólica y son hijos del ulterior matrimonio, es decir, nada pueden reclamar al respecto ${ }^{705}$.

El mismo precepto $272 \mathrm{CDFN}$ excluye, en su último apartado, los derechos que concedía a los hijos del anterior matrimonio en los apartados $1^{\mathrm{o}}$ y $2^{\mathrm{o}}$. Lo hace en el caso de haber sido desheredados estos, conforme a los artículos 852 y 853 del Código civil. Ello es debido a que el Derecho

\footnotetext{
${ }^{704}$ JUÁREZ GONZÁlEZ J.M.: GPS sucesiones, $2^{\mathrm{a}}$ Ed, Tirant lo Blanch, Valencia 2017, pág. 443.

${ }^{705}$ Más información en DE BARRÓN ARNICHES, "La legítima y el pacto...,", op cit., pág. 230. Esta autora cita (Cita 14) y se refiere al respecto de los derechos que la Ley les concede a los hijos del anterior matrimonio "este principio actúa o se manifiesta en un doble sentido: a) como elemento creador de muy diversas instituciones, posiblemente las más características y genuinamente forales, la libertad de testar, la libertad de ordenación de los capítulos matrimoniales, la sociedad familiar de conquistas, la viudedad o usufructo de fidelidad, la institución de fiducia sucesoria, la tendencia a evitar la sucesión legal por falta de ordenación mortis causa; b) como principio interpretativo de todos los pactos y disposiciones voluntarias y de las costumbres y leyes".
} 
foral remite al Código civil para desheredar a un descendiente. A mi juicio no tendría sentido lo contrario, es decir, que al desheredado con justa causa por el disponente, el ordenamiento, le concediera iguales o más derechos por otra vía. Destacar del tenor literal de la Ley 272 CDFN acerca de los requisitos normativos para su aplicación, que el precepto no contempla el supuesto de hijos de una anterior pareja more uxorio. Destacar también que toda la regulación al respecto se basa en que la persona haya contraído dos o más matrimonios, de manera sucesiva y reiterando nupcias. No obstante parece ser que la citada Ley 272 CDFN estaría, en este supuesto, produciendo una discriminación por razón de filiación o nacimiento, contraria a los artículos 14 y 39 de la Constitución Española ${ }^{706}$.

\subsubsection{El usufructo de fidelidad}

El usufructo de fidelidad no se puede considerar legítima ni a su beneficiario, que es el viudo, como legitimario. En cambio sí que lo encuadra el CDFN dentro de los límites a la libertad de disponer ${ }^{707}$. La Ley

${ }^{706}$ Para mayor información en la STSJ de Navarra de 09/09/2014 (RJ 2014/5741). La Sala anula el Recurso de apelación en que la recurrente, hija extramatrimonial del causante, apelaba por sus derechos que pensaba que en virtud de la Ley 272 del Fuero Nuevo le correspondían. En su F. J. $6^{\circ}$ dispone la sentencia: "la aplicabilidad al caso de la ley 272 del Fuero Nuevo y la incidencia de su validez o nulidad en el fallo a pronunciar, en función y congruencia con la pretensión deducida en la demanda, que define el objeto del proceso y los límites de su resolución, es incuestionable que la pretensión deducida por la actora (hija no matrimonial del testador) frente a la viuda del único matrimonio contraído por su padre y heredera universal suya, no halla acomodo en los términos de la citada norma legal (dirigida a igualar a los hijos de anteriores nupcias, para el caso de reiterarlas cualquiera de sus progenitores, en las atribuciones que éste realice a favor del su nuevo cónyuge o de los hijos habidos con él)". Hay un voto particular que me permito aquí resaltar su punto $1^{\circ}$ : "En la sentencia de la que discrepo ya se exponen detalladamente los antecedentes fácticos del litigio y la cuestión jurídica planteada, aspectos a los que me remito. Pues bien, entiendo que la Ley 272 del Fuero Nuevo (FN), aplicable al caso, plantea serias dudas sobre su constitucionalidad, dado que su tenor literal produce en el presente caso una discriminación por razón de filiación o nacimiento, discriminación contraria a los arts. 14, 39.2 y 39.3 de la Constitución Española".

${ }^{707}$ La STSJ de Navarra de 09 /09/2014, (RJ 2014/5741) concretamente en su F. J. $3^{\text {o }}$ se refiere a esta limitación dispositiva: “ (...) en el vigente Fuero Nuevo de Navarra, cuya 
253 CDFN establece que el cónyuge supérstite tiene el usufructo de fidelidad sobre todos los bienes y derechos que al momento de fallecimiento hubieran pertenecido al finado. Se pierde este derecho por renuncia, separación (salvo excepciones) por haber atentado contra la vida del otro cónyuge, por haber sido privado de la patria potestad de los hijos comunes, por nuevo matrimonio o por convivencia marital con otra persona entre otros supuestos reflejados en la Ley 254 y ss $\mathrm{CDFN}^{708}$. También la Ley 257 CDFN exige que el supérstite haga inventario de los bienes a usufructuar en escritura pública dentro de los cincuenta días siguientes al fallecimiento o declaración de fallecimiento del otro cónyuge y se finalice dentro de otros cincuenta días ${ }^{709}$.

ley 149 proclama que " los navarros pueden disponer libremente de sus bienes sin más restricciones que las establecidas en el Título $X$ " del mismo Libro II, donde se regulan, junto al usufructo de fidelidad, la institución en la legítima foral y las limitaciones dispositivas derivadas de la reiteración de nupcias por progenitores con descendencia de anterior matrimonio".

708 Más información en O' CALlAGHAN MuÑOZ, X.: "Legitima en los derechos forales" en Compendio de Derecho Civil. Tomo 5 (Derecho de sucesiones), Edersa, Madrid 2004.

${ }^{709}$ La STSJ de Navarra de 01/09/2016, (RJ 201615499). En su F.J. $3^{\circ}$ explica la razón del usufructo de fidelidad diciendo: "Así las cosas, no ofrece dudas el sentido del legislador y la ausencia de formalismos que se deduce del precepto, siempre que se haya respetado, como en el presente caso, el plazo y el otorgamiento de escritura pública. De tal suerte que si lo que se pretende por el legislador es la protección de los derechos del nudo propietario, aquí los actores, bastará con que en este inventario conste con toda claridad y sin asomo de duda el objeto o bien que se quiere inventariar y sobre el que se pretende extender el usufructo de fidelidad". En el mismo F.J. la STSJ de Navarra se refiere a la TSJ de Navarra de 18/10/2000 (RJ 2001/1849) para indicar motivos por los que se puede perder el citado usufructo de fidelidad: "también se pierde el usufructo de fidelidad por una ocultación maliciosa de bienes significativamente decisivos del caudal relicto del cónyuge premuerto, que en todo caso también se exige que sea dolosa. Por tanto, no hay sanción de pérdida del usufructo de fidelidad, cuando la inexactitud del inventario se deba a desconocimiento, olvido u error subsanable, "u otro caso de fuerza mayor" (ley 257), omisión que puede subsanarse bien por el propio usufructuario o a requerimiento de los herederos. Tal es el sentido que se deduce de la justificación histórica del precepto". 


\subsection{2- La preterición en Navarra}

Como se ha apuntado en Navarra existe preterición sin que exista legítima, por lo menos material. Conforme a la Ley 269 CDFN la legítima puede atribuirse para todos los legitimarios de manera colectiva. La mención en el testamento o pacto sucesorio basta para dar cumplimiento al precepto y no dar cabida a la preterición, cuyo efecto puede ser total o parcial. La preterición, de acuerdo con la Ley 271 CDFN conlleva la nulidad de la institución de heredero, sin afectar al resto de disposiciones $^{710}$. La consecuencia es que un testamento sin institución de herederos no puede prosperar, por lo tanto, tendrá que abrirse la sucesión legal $^{711}$. Debe tenerse en cuenta que, en virtud de la Ley $207 \mathrm{CDFN}$ en su último inciso ${ }^{712}$, se regula la nulidad parcial de las disposiciones

\footnotetext{
${ }^{710}$ La STSJ de Navarra de 01/12/2008 (RJ 2009/1454) en su F. J. $3^{\circ}$ aclara que el efecto de la preterición en Navarra es la nulidad de la institución de heredero dejando a salvo el resto de disposiciones testamentarias, matizando la innecesariedad de la institución de heredero para la efectividad del resto de disposiciones: "la preterición tiene por efecto la nulidad de la institución de heredero", dejando a salvo las demás disposiciones, "la ley 271 del Fuero Nuevo de Navarra se limita a resolver, en el mismo sentido que lo hicieron la Recopilación Privada (Ley 271 ) y el Proyecto de Fuero Recopilado (ley 235 ) la cuestión suscitada en el período compilador acerca de si la preterición determinaba la nulidad del testamento en su conjunto o sólo la de la institución de heredero, decantándose por ésta última, como más conforme al Derecho romano (Nov. 115, 315 y 4,9$)$ y a la innecesariedad de la institución de heredero para la validez del testamento".
}

${ }^{711}$ La referida STSJ de Navarra de 01/12/2008 (RJ 2009/1454) F. J. $3^{\text {o }}$ entiende que la declaración inicial de la ley 271, literal y aisladamente considerada, puede dar a entender que la preterición de cualquiera de los legitimarios determina siempre la declaración de nulidad de la institución de heredero, cuya consecuencia por aplicación de la Ley 300 CDFN, la apertura de la sucesión legal. La citada no es la opinión del TSJ: "No es aquélla, sin embargo, a juicio de la Sala, la consecuencia que se deriva de las leyes 271 y 300 de nuestra Compilación. La preterición se traduce legalmente en la nulidad de la institución de heredero; pero el alcance -total o parcial- de la nulidad vendrá determinada en cada caso por el de la preterición sufrida y la impugnación deducida por ella".

${ }^{712}$ Más información en NAGORE YÁRNOZ, J.J.: “Capítulo II. De la legítima Ley 271”, en AAVV., Comentarios al Código civil", Tomo XXXVII - Vol.2. Leyes 253 a 345 de la Compilación o Fuero Nuevo de Navarra, Edersa, Madrid 2005, pág. 3. Mantiene el autor que, "la solución puede ser distinta en disposiciones hechas en pacto sucesorio, dado su carácter contractual". 
testamentarias al decir que en los actos dispositivos de última voluntad, la nulidad o ineficacia de alguna de sus disposiciones no afectará a la validez o eficacia del resto. La acción por preterición únicamente la posee el legitimario preterido y sus herederos, ello de conformidad con la Ley 271CDFN. El Derecho de Navarra no distingue entre preterición intencional y no intencional o errónea ${ }^{713}$.

No existe preterición aunque no se haya instituido al legitimario en el testamento o pacto sucesorio en la legítima formal, siempre que el disponente lo haya dotado en viva, le hubiese atribuido alguna liberalidad mortis causa, o bien lo hubiese desheredado con justa causa. Tampoco se considera preterición cuando el propio legitimario hubiera repudiado la herencia, igualmente si hubiera premuerto al causante sin descendencia $(\text { Ley } 270 \mathrm{CDFN})^{714}$.

\subsubsection{La desheredación y la exclusion en Navarra}

El Derecho civil de Navarra como gran seguidor del Derecho romano primitivo no quiere que los legitimarios caigan en el olvido, el error o la ignorancia del testador. Por ello exige, este Derecho, al disponente que se les incluya en la legítima formal. Aunque sea sin asegurarles bienes al respecto si el disponente no desea hacerlo. Simplemente se exige bienes simbólicos (sueldos, tierras públicas, etc.). El Derecho trata de que el

\footnotetext{
${ }^{713}$ CAROL Roses, “La preterición...”, op. cit., pág. 430.

${ }^{714}$ La STSJ de Navarra de 25/11/2002 (RJ $2003 \backslash 2210$ ) F. J. $4^{\circ}$, declara en su primera conclusión acerca del alcance de la Ley 270 CDFN “(...) sobre el alcance de la Ley 270 del Fuero Nuevo, en cuanto se deba decidir acerca de lo que constituya «atribución de liberalidad mortis-causa» a un legitimario en el propio testamento (fuera de los casos de desheredación, premoriencia o no aceptación de la herencia), y en cuanto que no haya sido instituido en la legítima foral o dotado o designado legatario, todo ello a efectos de que no deba proceder la declaración de nulidad de la institución de heredero (o del testamento, en su caso, si no establece, en sustancia, más que ésta) por preterición, de acuerdo con la Ley 271, en relación con las 267 y 268 de la referida Compilación navarra".
} 
testador tenga presentes a sus legitimarios, tanto si es para dejarles como para negarles parte de su patrimonio. En consecuencia, como ya se ha dicho, el Derecho foral navarro contempla en la Ley 271 CDFN la pena por no incluir al legitimario en la legítima formal. Esta es la anulación de la institución de heredero, sin afectar ello a las demás disposiciones testamentarias. Es decir, comporta que se mantenga la voluntad del testador en el resto de disposiciones ${ }^{715}$.

Los legitimarios no preteridos e instituidos en la legítima formal, no serán llamados en la sucesión legal derivada de la anulación de la institución de heredero. Ello conlleva que la preterición de un legitimario en la legítima formal signifique su exclusión total en la sucesión legal si esta progresa. Ha de verse socialmente, en Navarra, como una desheredación al no haber atribuido ningún bien al legitimario del caudal relicto. En realidad ha sido el disponente el que lo ha apartado de la sucesión testada y de la legal, pero no lo ha desheredado simplemente lo ha excluido. Es decir, no ha dispuesto justa causa de desheredación para que este legitimario se tenga por desheredado ${ }^{716}$. En cambio el preterido

${ }^{715}$ La referida STSJ de Navarra de 01/12/2008 ((RJ 2009\1454) F. J. 3º. Manifiesta la Sala, la limitación de la acción está supeditada a los efectos de la propia preterición "De su exitoso ejercicio no puede -no debe- pues derivarse, la apertura de la sucesión legal, con el llamamiento a ella del resto de los legitimarios, aun aquietados a su eventual preterición, como tampoco podría derivarse el de quienes, en su caso, renunciaron a la herencia, fueron desheredados causalmente o exheredados mediante la institución en la legítima foral, o fueron dotados o favorecidos por una liberalidad mortis causa, por no tener la consideración de preteridos (ley 270 del Fuero Nuevo ) y no quedar afectadas por la nulidad de la institución las disposiciones voluntarias con que, en sus respectivos casos, hubieran sido desheredados, exheredados o favorecidos".

716 La STS de 08/09/1973 (Roj 1973/4111) se refiere al tema en su segundo Considerando desestimando el motivo "porque el derecho del hijo legítimo preterido para reclamar igual porción hereditaria que los demás legítimos, sólo puede interpretarse con relación a los que hayan sido verdaderamente instituidos herederos, en este caso la recurrente, y no con los que hayan sido apartados simplemente con la atribución de la legítima foral como la otra recurrente doña María Socorro M. de I. I., pues lo pretendido supondría un derecho de acrecer a favor de la instituida, que no encuentra fundamento alguno en la ley". En el siguiente Considerando manifiesta: "la 
inductor de la apertura de la sucesión legal será llamado allí como titular del ius delationis. Ha de verse la maniobra del testador en que su voluntad ha sido apartar al legitimario instituido en la legítima formal de toda participación material de la herencia ${ }^{717}$.

Parece ser que en Navarra la desheredación en cuanto a la interpretación del artículo 850 del Código civil, por parte de los tribunales, no acaba de ser concordante. No lo es, en el sentido en que se mantienen distintos criterios con respecto a la analogía de las tipificadas justas de desheredación. Concretamente me refiero a la causa del maltrato de obra, tipificado en el artículo 853 del Código civil en que debido al carácter sancionador que tiene la desheredación su interpretación es totalmente restrictiva y en consecuencia no se extiende su aplicación a casos tratados por la Ley. Se trata concretamente de extender la falta de relación familiar al maltrato de obra ${ }^{718}$. Si bien con la postura del Alto Tribunal en la STS 03/06/2014 (Roj: 2484) se rechaza una interpretación restrictiva del artículo 853.2 del Código civil sin pretender una interpretación extensiva de la

ley está lejos de prescribir que se declare al preterido heredero en la misma participación que le hubiera correspondido en concurrencia con todos sus hermanos en la sucesión legítima o intestada, y esta Ley 271 recogida en la Compilación de Derecho Civil de Navarra aprobada por la Ley de 1 marzo 1973 ( RCL 1973\408 y 456), que no tiene carácter retroactivo, omite toda referencia a la declaración de heredero del preterido conforme a la ley...".

${ }^{717}$ Roncesvalles BARBer CÁRCAMO, M.: "LEY 301" en AAVV., Comentarios al Código Civil, Tomo XXXVII , Vol.2 . Leyes 253 a 345 de la Compilación o Fuero Nuevo de Navarra, Edersa, Madrid 2005.

718 SAP de Navarra (S. $3^{\text {a }}$ ) de 28/07/2016 (Tol. 5.940.978) F. J. 5. "Es evidente por tanto que desde el año 1992 no ha existido relación alguna entre el progenitor y sus hijos si bien es necesario añadir que ello por si sólo no puede considerarse como causa de desheredación, debiendo ser interpretadas las mismas conforme a reiterada jurisprudencia del TS de forma restrictiva. Así se recoge por ejemplo en la STS 4 de noviembre de 1997. (...) no extiende su aplicación a casos no previstos en la ley, rechazando dicha sentencia la falta de relaciones afectivas como causa de desheredación en aquel caso los herederos forzosos privaron al testador de su presencia en vida para confortarle de sus dolencias mortales y ni siquiera acudieron al entierro; en el mismo sentido en la anterior S.T.S. de 28 de junio de 1993". 
causa de maltrato de obra, sino una interpretación de las normas adecuadas al tiempo y a la realidad social ${ }^{719}$.

\subsubsection{El mantenimiento de la casa en Navarra}

Tanto en Navarra como en otros Derechos Forales, el conservar el patrimonio de la familia unido es uno de los pilares fundamentales de su derecho sucesorio. Por ello se hace uso de la mal llamada libertad de testar. Todos esos Derechos Forales contemplan la libertad de pactos entre el titular del patrimonio y el que pretende tenerlo. Se trata de buscar un sucesor que administre la casa solariega y continúe con las costumbres familiares ${ }^{720}$. Otros autores en cambio consideran el precepto que recoge esta figura de la unidad y mantenimiento de la casa (Ley $75 \mathrm{CDFN}$ ) como uno de los que distinguen el Fuero Nuevo de Navarra como el Derecho más perfecto de los ordenamientos forales o el más avanzado en sus disposiciones $^{721}$.

Solamente para confirmar lo expuesto en el párrafo anterior cabe leer la Ley $75^{722}$ CDFN dentro de la Vigente Ley $1 / 1973$, de 01 de marzo, cuyo Título VII se proclama como: "De los principios fundamentales del régimen de bienes en la familia". La precitada Ley 75 preceptúa la observancia del principio fundamental de la casa y de sus explotaciones

\footnotetext{
${ }^{719}$ BERROCAL LANZAROT, "El maltrato psicológico...”, op. cit., pág. 942.

${ }^{720}$ CREMAdES GARCíA, P.: "Pactos sucesorios y derecho foral", en Sucesión mortis causa de la empresa familiar: la alternativa de los pactos sucesorios, Dykinson, Madrid, 2014, pág. 176.

${ }^{721}$ De BARRón ARNiches, P.: "La legítima y el pacto...”, op cit., pág. 229. Cita esta autora. algunas disposiciones, que conceden tal distinción al actual sistema sucesorio de Navarra: Leyes 57. 140, 155, 156,172, entre otras.

${ }^{722}$ Ley 75 CDCN "En la interpretación de todos los pactos y disposiciones voluntarias, costumbres y leyes se observará el principio fundamental de la unidad de la Casa y de sus explotaciones agrícolas, ganaderas y forestales, así como el de su continuidad y conservación en la familia".
} 
agrícolas, ganaderas y forestales, así como su continuidad, en todos los pactos, disposiciones, costumbres e incluso Leyes. La institución de la legítima navarra se concibe como un medio adecuado para la continuidad de la propiedad en el seno de la familia. Para ello necesita de la citada libertad de disposición para poder, el disponente, repartir su patrimonio de manera desigual entre su prole e incluso, si procede, apartar a alguno de ellos de su patrimonio ${ }^{723}$.

La Ley 149 CDFN lleva por título: "Libertad de disposición" que en su primer apartado dispone que la también citada libertad de disposición de los navarros sólo se verá restringida por lo dispuesto en el artículo 84 de la misma Ley - son básicamente los gastos de mantenimiento familiar-. Es por lo tanto, más que el principio de unidad familiar, el principio de unidad de la casa y sus explotaciones. Para que proporcione el sustento a la familia y es el propio Derecho navarro el que así lo recoge en su Ley 75 CDFN.

\subsubsection{El pacto o contrato sucesorio}

Las disposiciones especiales sobre los pactos sucesorios se recogen en la Ley 177 y ss, de la Ley 1/1973, de 01 de marzo. El artículo 178 de la misma Ley citada se pronuncia al respecto de la irrevocabilidad de los pactos sucesorios que han sido suscritos por dos o más personas. Manteniendo este, que la irrevocabilidad por una de las partes, es decir, una de las partes por sí sola, no puede revocar lo que en su día se pactó entre todas $^{724}$. En cambio con el consentimiento de todas las partes sí que cabe la

\footnotetext{
${ }^{723}$ De BARRÓN ARNICHES, P.: “La legítima y el pacto...”, op. cit., pág. 230.

${ }^{724}$ STSJ de Navarra de 04/04/2006 (Tol. 946.211) F. J. 3 . “ En efecto, estimamos que tan relevante modificación, o la resolución del pacto sucesorio litigioso, exigía una declaración de voluntad por parte de la instituida expresada en términos de suma claridad, de tal suerte que no dejase traslucir la menor duda sobre la verdadera, firme y tajante intención de la actora de revocar o modificar el pacto sucesorio en lo atinente a la herencia del adoptante: en suma, y dados los contornos de este puntual conflicto, podríamos proyectar aquí la jurisprudencia recaída sobre la renuncia de derechos - por
} 
alteración del contenido de lo pactado y plasmado en la escritura pública. Este medio (escritura pública) es requisito esencial para formalizar el pacto sucesorio $^{725}$. Asimismo, la Ley $179 \mathrm{CDFN}$ requiere del consentimiento de las partes para evitar la nulidad del pacto ${ }^{726}$.

El contenido del pacto sucesorio dispuesto en el CDFN o Fuero Nuevo también determina el contenido que puede tener. Al respecto se puede establecer, modificar, extinguir o renunciar derechos para después de la muerte en vida del disponente. De no ser así no tendría razón de ser como contrato. Puede que el contenido del pacto o contrato sucesorio que recoge la Ley 177 CDFN sea una de las características más llamativas de la regulación de esta clase de contratos post mortem. Pueden contener disposiciones a favor de alguno o de todos los contratantes o, bien a favor de un tercero, también puede hacerse a título universal o singular. Sin duda la amplia disponibilidad de utilizaciones a que se refiere la citada Ley 177

todas, nuestra sentencia de 20.9.97 y las que en ella se citan-, que habla de que sea "expresa, clara, terminante e inequívoca, con expresión indiscutible del criterio de voluntad determinante de la misma, y revelarse expresa o tácitamente, en este caso mediante actos concluyentes, claros e inequívocos".

${ }^{725}$ Cremades García, P.: Pactos sucesorios ..., op cit., pág. 182.

${ }^{726}$ La STSJ de Navarra de 29/01/2009 (Tol. 1.509.393) en su F. J. $3^{\text {o }}$ se refiere a la nulidad del pacto por falta de consentimientos de una de las partes: " en la vulneración de los artículos 1.137 y 1.138 del Código Civil ( LEG 1889, 27) y la ley 179 del Fuero Nuevo de Navarra ( RCL 1973, 456 y RCL 1974, 1077) pues, además de que, partiendo del carácter mancomunado de las cuentas en las que la actora y todos los codemandados figura como cotitulares, la disposición de fondos requiere de la firma conjunta de todos ellos, no sólo de los dos que así lo han venido efectuando (Don Abilio y Doña Carmen ), tras la fecha de 24 de octubre de 2.003 en que se suscribió el pacto sucesorio referido en el primer fundamento de derecho de la presente sentencia; actos que requerían el previo consentimiento de todos los instituidos, entre ellos la actora hoy recurrente, por lo que su carencia supone infracción de lo dispuesto en la ley 179 del Fuero Nuevo de Navarra ". 
CDFN le permite al pacto sucesorio navarro tener cumplida aceptación para la sucesión mortis causa de la empresa familiar ${ }^{727}$.

\subsubsection{Naturaleza jurídica de la legítima en Navarra}

Este tipo de legítima, como la de Navarra, es conocida como una fórmula indirecta de desheredación. Ello se dice porque al legitimario simplemente se le instituye en la legítima de manera formal y simbólica, lo que realmente equivale a una desheredación. En este sentido se ha pronunciado el Tribunal Supremo afirmando que, tanto en Aragón como en Navarra, su legítima foral equivale a una desheredación. También ha afirmado en numerosas ocasiones, el Alto Tribunal, que a los hijos instituidos en la legítima foral de Aragón y Navarra no se les puede considerar como herederos. Sólo se puede considerar heredero al hijo que su padre lo ha instituido como heredero en su testamento ${ }^{728}$. También en el mismo sentido se pronuncia la DGRN en relación a las legítimas en Navarra $^{729}$. En realidad, la legítima navarra, es una mera atribución formal sin contenido patrimonial exigible tal como establece la Ley 226 CDFN. En cambio, sí que se le reconoce, como se ha dicho, al cónyuge supérstite, un usufructo de fidelidad sobre todos los bienes del causante. Es destacable

${ }^{727}$ Más información en CRemades García, P.: Pactos sucesorios..., op cit., pág. 182. Pone el ejemplo la autora de "incluir en el pacto o negocio sucesorio una condición resolutoria consistente en la conservación de la empresa familiar".

${ }^{728}$ Véase la ya citada STS de 02/01/1946 (Tol. 4.455.830) en que el Tribunal Supremo, recogiendo esas características de la legítima foral (no ya la de Navarra, sino incluso la de Aragón, menos típica en este aspecto) y el concepto legal de heredero (sucesor en todos los derechos y obligaciones del testador) ha resuelto repetidamente que esos hijos instituidos en la legítima foral no tienen el carácter legal de herederos, ya que dicho carácter sólo puede ser ostentado por el hijo a quien el padre o padres hayan instituido como tal en su testamento. Sentencias de 30 de noviembre de 1901, 3,0 de junio de 1905, 28 de octubre de 1935, todas las cuales, así como las leyes 62, libro 56, títulos 17 y 37, libro 29, título segundo del Digesto y artículos 660 y 661 del Código Civil.

${ }^{729}$ Véase Rivas Martínez, J.J.: Derecho de sucesiones. Común y foral, Tomo II, Dykinson, Madrid, 2009, pág. 1828 en que cita la R.D.G.R.N de 17 de febrero de 1927, relativa a Navarra, en que declaró: "Según el testamento, fuera de la legítima foral, los hijos están desheredados, "excepto si algo les dejaren" sus padres". 
este usufructo, que regulan las Leyes 253 a $256 \mathrm{CDFN}$, por ser una marcada limitación de la libertad de disposición que se le atribuye al testador $^{730}$.

Hay una particular distinción del Derecho foral navarro con el Derecho común y con el resto de los Derechos forales, e incluso con muchos europeos como el alemán, italiano, etc. Tal distinción es su peculiar forma de aceptar o "renunciar" a la herencia. He dicho renunciar y no repudiar, porque en Navarra el heredero adquiere de manera provisional la herencia a la apertura de la sucesión. Si renuncia a ella es porque se ha desprendido de algo que, si bien de manera provisional, ya le pertenecía. En cambio, en el resto de ordenamientos españoles, como el común, el llamado nada adquiere hasta que no acepta la herencia, es en ese preciso momento en el que adquiere la cualidad de heredero y no antes. En cambio, en Navarra la aceptación y la renuncia produce los siguientes particulares efectos: la primera de confirma la adquisición provisional y la segunda la no confirmación. La renuncia tiene dos efectos fundamentales en Navarra:

1. La pérdida de la cualidad de heredero y la consecuente provisionalidad de la titularidad de los bienes hereditarios.

2. Adquisición automática por parte del heredero que sigue al renunciante, que debido al carácter retroactivo de la renuncia, se entiende que sucede desde el momento de la apertura de la sucesión y no desde el momento de la renuncia de su predecesor ${ }^{731}$.

\footnotetext{
${ }^{730}$ Polo ArÉVAlo, E.M.: “Concepto y naturaleza...”, op. cit., pág. 353.

${ }^{731}$ Véase más información en GARCÍA HERRERA, V.: "Herencia yacente y usucapión" en La usucapión a favor de la herencia yacente, Dykinson, Madrid 2008, págs. 16 y 17. Mantiene la autora que para "garantizar la voluntariedad de la adquisición del heredero, el Fuero Nuevo le concede la facultas renunciandi mientras no haya aceptado expresa o tácitamente la herencia", Sin que se señale plazo para la aceptación ni tampoco para la renuncia.
} 


\subsection{LA LEGÍTIMA EN EL DERECHO FORAL DE CATALUÑA}

Es el Derecho romano la base indiscutible del Derecho civil catalán, en el que se distinguen dos aspectos importantes de la legítima catalana, con respecto a la legítima del Derecho común. El primero es su caudal, un cuarto del haber hereditario a repartir entre los legitimarios (legítima individual). El segundo se trata de su carácter crediticio por el cual se puede pagar la legítima en metálico al legitimario. No otorga derecho a participar en los bienes relictos de la herencia ${ }^{732}$. Las dos características citadas, provienen de su tradición histórica. La primera, la cuantía de un cuarto, nace en la Edad Media como confrontación con la legítima visigoda de los célebres cuatro quintos. Primeramente, en 1283 se redujo a 8/15 y más tarde, en 1343, se convirtió en un cuarto como privilegio para los habitantes de Barcelona. Junto con el de poder satisfacer a los legitimarios su parte en metálico, en lugar de hacerlo en bienes relictos. El resto de Cataluña se regía por la legítima de Justiniano ${ }^{733}$.

Hasta 1585, no era necesario instituir heredero al legitimario, si que lo fue a partir de la citada fecha, cuando se generalizó tal práctica por todo el principado. Este sistema legitimario estuvo vigente hasta la Compilación de 1960 consolidándose la citada cuantía de un cuarto ${ }^{734}$. Así como su carácter crediticio, para poderse pagar en metálico, sin derecho a participar en los

\footnotetext{
${ }^{732}$ De Brocà, I DE Monteagut, G M.: "Historia del Derecho de Cataluña. Especialmente del Civil, Generalitat de Catalunya, Departament de Justicia, Textos Juridics Catalans, Barcelona, 1985, pág. 20.

${ }^{733}$ VAQUER ALOY, A.: “La Legítima...”, op. cit., pág. 472.

${ }^{734}$ El artículo 129 de la Compilación de 1960, disponía para el cálculo de la legítima: "La cuantía de la legítima es la cuarta parte de la cantidad base resultante de aplicar las reglas siguientes: Se partirá del valor que los bienes de la herencia tenían al tiempo de fallecer el causante, con deducción de las deudas del mismo, los gastos de su última enfermedad entierro y funeral. A este valor líquido se añadirá el de los bienes que hayan sido donados por el causante, sin más excepción que las donaciones, liberalidades y expensas a que se refiere el artículo mil cuarenta y uno del Código civil, las efectuadas de conformidad con el uso, el esponsalicio o escreix y la soldada".
} 
bienes de la herencia ${ }^{735}$. Hasta que pasó su regulación al Libro IV del Código Civil de Cataluña relativo a las sucesiones de 2008, estando entre medio regulada por el Código de sucesiones de 1991, en que por virtud de la reforma operada en 1990, se suprimía la mención de legítima. El paso de la legítima por esta serie de leyes ha influenciado en su decrecimiento, es decir, se ha rebajado su cuantía. Para ello se han ido utilizando distintas herramientas jurídicas, como pueda ser la de aumentar las causas de desheredación o limitar la legítima de los ascendientes, entre otras. Es el propio preámbulo de la Ley 10/2008, de 10 de julio, del libro cuarto del Código Civil de Cataluña relativo a las sucesiones en que allí se afirma que la legítima se mantiene vigente, pero también se afirma, que se debilita y se restringe su reclamación.

Un ciudadano con vecindad civil catalana tiene, hoy en día, tres maneras de disponer de sus bienes para después de la muerte:

1. Otorgar un testamento, que el testador mientras viva, podrá anularlo con sólo hacer otro que revoque el anterior. Ello porque el testamento no surge efecto hasta la muerte del disponente.

2. Puede pactar y designar uno o varios sucesores mediante un pacto sucesorio de los recogidos en el artículo 431 del Código civil de Cataluña (CCC en adelante), que debe ser aceptado por las partes. Los pactos sucesorios son de gran relevancia en Cataluña ${ }^{736}$.

\footnotetext{
735 El artículo 137, de la Compilación de 1960, se refiere al derecho de crédito sobre la legítima: "La legítima o su suplemento podrán pagarse en dinero o en bienes de la herencia, a elección del heredero que haya de satisfacer una u otro, siempre que a los legitimarios no les haya correspondido percibirlos por vía de institución, de legado, señalamiento o asignación de cosa específica o donación. Comenzado el pago en dinero o en bienes, el legitimario podrá exigir el resto en la misma forma inicial”.

${ }^{736}$ Los pactos sucesorios son aquellos, según JUÁREZ GONZÁLEZ, GPS Sucesiones..., op. cit., pág. 165, por los cuales "dos o más personas pueden convenir la sucesión por causa de muerte de cualquiera de ellas, mediante institución de uno o más herederos y atribuciones a título particular".
} 
3. Puede no hacer lo expuesto en el punto uno (testamento) ni lo del punto dos (pacto sucesorio), es decir, no hacer nada y dejar a la Ley que se encargue del destino de sus bienes por medio de la sucesión intestada ${ }^{737}$.

La normativa más importante en el vigente Código civil de Cataluña, por lo que a legítimas se refiere, se encuentra en el artículo 451-1 y ss. Precepto que ha sido modificado por la Ley 6/2015, de 13 de mayo, de armonización del Código civil de Cataluña. Esta Ley define a la legítima como el derecho, de determinadas personas, a obtener de la sucesión del causante, un valor patrimonial que este puede atribuirles a título de institución hereditaria, legado, atribución particular o donación, o de cualquier forma. Al configurarse como un simple derecho de crédito, no grava los bienes inmuebles en el Registro de la Propiedad.

No es legitimario el cónyuge viudo en Cataluña, ni tampoco lo es el superviviente de la pareja de hecho. Como tampoco lo son otros ascendientes que no sean los padres del causante, los abuelos por ejemplo $^{738}$. Ello no significa que no tenga derechos en la sucesión del causante, pero unos derechos más bien relacionados con el matrimonio. Entre otros, el artículo 231-30 CCC en su Sección 5a , le concede el derecho al ajuar de la vivienda, la propiedad de la ropa, y del mobiliario. Quedan excluidos conforme al segundo apartado del precepto aludido, las joyas, los muebles de procedencia familiar en los supuestos en que el testador haya dispuesto de ellos a favor de terceros ${ }^{739}$.

\footnotetext{
${ }^{737}$ Alascio CARRASCo L.: Los pactos sucesorios en el Derecho Civil Catalán, Atelier, Barcelona, 2016, pág. 32.

${ }^{738}$ VAQUER ALOY, “La Legítima en el Derecho civil...”, op. cit., pág. 477.

${ }^{739}$ JuÁrEZ GONZÁLEZ, GPS Sucesiones..., op. cit., pág. 449. 


\subsubsection{La legítima de los descendientes}

Conforme al artículo 451-3 CCC son legitimarios todos los hijos del causante por partes iguales. Sobre el derecho de representación dispone el artículo 451-3.2 CCC que representarán por estirpes sus descendientes a los hijos que hayan premuerto al causante, a los desheredados justamente, a los indignos y a los ausentes. Este derecho de representación conforme al siguiente punto del precepto, sólo tiene por objeto el derecho a legítima y no a atribuciones patrimoniales dispuestas por el disponente a favor del representado, salvo que el llamamiento atienda a la sustitución ${ }^{740}$. La legítima de los descendientes es compatible con la cuarta viudal y asciende a una cuarta parte del valor de los bienes de la herencia (Art. 451-5).

\subsubsection{La legítima de los ascendientes}

A falta de descendientes del causante y conforme al artículo 451-4 CCC son legitimarios los progenitores por mitades iguales ${ }^{741}$. El precepto dispone, sin embargo, que los padres del causante no tienen derecho a legítima en aquellos supuestos en que este tenga descendientes y aquellos hayan sido desheredados con justa causa o declarados indignos para suceder. Al igual que ocurría con los descendentes. También es compatible la legítima de los ascendentes con la cuarta viudal, que no está considerada,

\footnotetext{
${ }^{740}$ FAus PuJOL, M.: "Testamento con legado especial a un hijo y nombrando herederos a los otros. Derecho aragonés", en Formularios de Derecho de sucesiones, 2010 (actualizado a octubre de 2017), págs. 3 y 4.

741 Artículo 451-4 CCC (Legítima de los progenitores.): “1. Si el causante no tiene descendientes que le hayan sobrevivido, son legitimarios los progenitores por mitad. Estos no tienen derecho a legítima si el causante tiene descendientes pero han sido desheredados justamente o declarados indignos".

Si solo sobrevive un progenitor o la filiación solo está determinada respecto a un progenitor, le corresponde el derecho de legítima íntegramente. Si sobreviven los dos pero uno de ellos ha sido desheredado justamente o ha sido declarado indigno, la legítima corresponde solo al otro. En este caso, debe aplicarse lo establecido por el art. 451-6.
} 
esta figura, de naturaleza legitimaría ${ }^{742}$. Otros aspectos importantes de la legítima de los ascendientes es su consideración como derecho personalísimo y su intransmisibilidad ya que se extingue el derecho si el legitimario no lo reclama en vida. Esta forma de regulación, entienede la jurisprudencia, que es acorde con el debilitamiento de la legítima que se le viene dando también en Galicia, Aragón, Navarra, entre otros ${ }^{743}$.

\subsubsection{La cuantía y el cómputo de la legítima}

La cuantía de la legítima es una cuarta parte del valor de los bienes de la herencia, es decir, resulta de aplicar las reglas de que dispone el artículo 451-5 CCC. Estas reglas son:

\footnotetext{
${ }^{742}$ Es interesante resaltar la SAP de Barcelona (S. 19) de 6/11/2017 (JUR 2017 292770 ) F.J, $2^{\circ}$ al establecer la porción legitimaria a que pueda tener derecho cada legitimario, teniendo en cuenta que el importe de la legítima global es la cuarta parte del caudal relicto y, a su vez, para el cálculo de la legítima individual, hay que estar a lo dispuesto en los artículos 451-1, 451-3 y 451-6 CCCAT". del indicado texto legal, que señalan que todos los legitimarios detraen su legítima de una única cuarta y que, para determinar la legítima individual entre varios legitimarios, también debe ser contado el legitimario que a su vez sea heredero, por lo que en el caso presente, la cuota legitimaria global debe ser dividida entre los dos hermanos legitimarios". Asi mismo la SAP de Barcelona (S. 13) de 5/12/2012 (AC 2013 22387) F.J. $2^{\circ}$ profundiza en la cuarta viudal y la expone como "un derecho sucesorio que permite (facultad) al consorte superviviente reclamar, siempre que concurran los presupuestos legalmente previstos, a los herederos como máximo una cuarta parte de la herencia del cónyuge premuerto; esto es, se configura como una acción personal (derecho de crédito) frente a los herederos, pero ni confiere la viudo la condición de heredero o de legitimario ni su procedencia comporta la posibilidad de impugnar el testamento o la partición de la herencia".

${ }^{743}$ La SAP de Barcelona (S. $1^{\text {a }}$ ) de 25/11/2014 (JUR 2015\55961) F.J. $2^{\text {o }}$ se refiere a la diligencia exigida en el ejercicio de su a la reclamación de la correspondiente legítima ya que de ellos no reclamar su derecho, este se extingue ex lege. Mantiene la Sala que "Es un caso de intransmisibilidad de la acción de reclamación. De esta manera, como señala un sector de la doctrina, se pone a disposición de los ascendientes una forma sencilla de renunciar tácitamente a la legítima de los hijos sin efectuar un acto de renuncia expresa. Este es el criterio que sigue el Código de Sucesiones por causa de Muerte (Ley 40/1991) en los artículos 351 y 376 que se refieren a la renuncia pura o simple de legítima".
} 
A) El valor de los bienes a la muerte del causante, deducidos los gastos de última enfermedad y entierro, así como el valor del "any de plor $^{\text {,744. }}$.

B) Al valor de la operación anterior se le añade el valor de los bienes enajenados por otro título gratuito por el causante en los diez años precedentes a su muerte.

C) La letra d, del precepto de referencia ha sido modificada por la Ley 6/2015, de 13 de mayo, de armonización del Código civil de Cataluña, referente a la enajenación o pérdida de los bienes donados por parte del donatario. Se añade el valor que tenían dichos bienes al momento de enajenación o perdida, al valor obtenido en el primer apartado del artículo 451-5, CCC $^{745}$.

\footnotetext{
${ }^{744}$ JuÁREZ GONZÁLEZ, J. M.: GPS Sucesiones, ed. 2a , Tirant lo Blanch, Valencia, 2017, pág. 445.

"Any de plor" Tiene una traducción literal al castellano de año de llanto. Es el nombre que adquiere la figura jurídica que contempla la posibilidad que el cónyuge supérstite reciba una prestación anual en concepto de alimentos con cargo a la herencia del causante. También esta figura contempla el derecho a que el viudo/a disfrute tanto de la casa como del ajuar que fueron del finado.
}

La Ley 3/2017, de 15 de febrero, del libro sexto del Código civil de Cataluña, relativo a las obligaciones y los contratos, y de modificación de los libros primero, segundo, tercero, cuarto y quinto. Se modifica el artículo 231-31 del Código civil de Cataluña, que queda redactado del siguiente modo: Artículo 231-31. Año de viudedad: "1. Durante el año siguiente a la muerte o declaración de fallecimiento de uno de los cónyuges, el superviviente no separado legalmente o de hecho que no sea usufructuario universal del patrimonio del premuerto tiene derecho a continuar usando la vivienda conyugal y a ser alimentado a cargo de este patrimonio, de acuerdo con el nivel de vida que habían mantenido los cónyuges y con la importancia del patrimonio. Este derecho es independiente de los demás que le correspondan en virtud de la defunción del premuerto. 2. El cónyuge superviviente pierde los derechos a que se refiere el apartado 1 si, durante el año siguiente a la muerte o declaración de fallecimiento de su cónyuge, vuelve a casarse o pasa a vivir maritalmente con otra persona, así como si abandona o descuida gravemente a los hijos comunes en potestad parental. En ningún caso está obligado a devolver el importe de los alimentos percibidos".

${ }^{745}$ FAus Pujol, ““Testamento con legado...”, op. cit., pág. 9. 
D) Con respecto a la legítima individual, se determina por el artículo 451-6 CCC se contabiliza al legitimario heredero, al que ha renunciado a su legítima, al legitimario desheredado con justa causa y al indigno para suceder.

\subsubsection{La legítima como pars valoris}

La Ley 10/2008, de 10 de julio, del libro cuarto del Código civil de Cataluña relativo a las sucesiones, en virtud del artículo 451-1 CCC el heredero responde personalmente del pago de la legítima a los legitimarios. En consecuencia, estos están legitimados para reclamar su derecho mediante anotación preventiva de demanda de reclamación de legítima. Tratándose su legítima de una pars valoris el legitimario no interviene en la partición hereditaria y por lo tanto, no alcanza su derecho a promover juicio de división hereditaria. Conviene tener presente que la legítima en Cataluña es un derecho de crédito a favor del legitimario, es decir, el legitimario se convierte, a la muerte del causante, en un acreedor de la herencia. Tiene, como todos los acreedores, unos derechos que consisten en obtener el valor de su legítima, pero no a participar en los bienes que componen la herencia $^{746}$.

\subsubsection{La intangibilidad de la legítima}

Se refiere a ella el artículo 451-9 del CCC relativo a sucesiones. Si bien el Preámbulo de la Ley 10/2008, de 10 de julio, del libro cuarto del Código Civil de Cataluña, en su apartado VI ya se refiere a esta protección

\footnotetext{
${ }^{746}$ GARCíA- MON QUIRÓs, F.: "Efectos de las adquisiciones onerosas con pacto de supervivencia", en La compraventa con pacto de supervivencia Dykinson, Madrid, 2016, cita (447) "La legítima se articula como un valor patrimonial y como tal tiene derecho a participar en los bienes que integran la herencia", para hacer tales afirmaciones en la STS de 27/05/1967. Por otra parte, cita este autor define la legítima catalana como: "el valor mínimo que la ley atribuye en la sucesión del causante a determinados parientes suyos con el carácter de inembargable e irrenunciable en vida, con independencia de toda necesidad vital".
} 
de la legítima. Entre otros, mantiene que la semejanza con la cautela socini será regla por defecto en toda sucesión. Con en ello, se le concede al legitimario la opción de aceptar mayor porción de legítima de la que por ley le corresponde, pero gravada. Ante la falta de conformidad, puede renunciar a la institución de herederos, o al legado y reclamar la legítima estricta sin cargas de ninguna clase. Se respeta sólo la intangibilidad cuantitativa y no la cualitativa. En consecuencia, los legitimarios a quienes se les haya gravado su legítima sólo tienen la opción de aceptarla gravada, o bien renunciar a la misma. Esta decisión del legislador catalán, no deja de ser, bajo mi opinión personal, como bien dice el Preámbulo de la citada Ley una debilitación más de la legítima ${ }^{747}$.

\subsubsection{La inhabilidad en Cataluña}

El artículo 412-5. $2{ }^{748} \mathrm{CCC}$ más que establecer una inhabilidad sucesoria restringe las formas de disposición que se pueden establecer por parte del disponente a favor de los las personas físicas o jurídicas. Es de destacar la reforma a sus cuidadores- residencias o personas físicas- en que su relación provenga de un contrato ${ }^{749}$. Sólo deja de tener cabida la

\footnotetext{
${ }^{747}$ Dispone el Preámbulo de la Ley 10/2008, de 10 de julio, del libro cuarto del Código Civil de Cataluña, relativo a las sucesiones, en su apartado VI: "Se generaliza la fórmula de la cautela compensatoria de legítima, o cautela socini, como regla por defecto en toda sucesión. Esta decisión, también debilitadora de la legítima, implica que se respeta solo la intangibilidad cuantitativa, y no la cualitativa. Los legitimarios gravados deben optar por aceptar la legítima gravada o por renunciar a la institución de heredero o al legado y reclamar la que estrictamente les corresponda, sin poder pretender la supresión de cargas ni gravámenes si el valor de lo recibido es superior al de la legítima".
}

${ }^{748}$ Artículo 412-5. Inhabilidad sucesoria. "2. Las personas físicas o jurídicas y los cuidadores que dependen de las mismas que hayan prestado servicios asistenciales, residenciales o de naturaleza análoga al causante, en virtud de una relación contractual, solo pueden ser favorecidos en la sucesión de este si es ordenada en testamento notarial abierto o en pacto sucesorio".

${ }^{749}$ STS de 08/04/2016 (Tol. 5.687.871) se pronuncia acerca del artículo 412- CCC en su F.J. $3^{\circ}$ de la siguiente manera: "se ubica junto a las incapacidades sucesorias, bajo la rúbrica específica de «inhabilidad sucesoria», siendo ello una novedad por cuanto 
inhabilidad si se ofrece la suficiente garantía que aporta el notario mediante un testamento notarial abierto o pacto sucesorio. Supuestos, los citados, que ambos requieren la presencia del fedatario público. Adviértase que no se incluye este supuesto entre las personas inhábiles para suceder que recoge el punto primero del citado precepto, en los que incluye al notario e incluso a sus familiares hasta el cuarto grado ${ }^{750}$.

El legislador común se pronuncia al respecto de la inhabilidad de las disposiciones testamentarias que haga el testador, en el artículo 752 del Código civil. Distinguiendo con ello la inhabilidad de la ineficacia. Esta última la recoge el Derecho catalán en el artículo 412-6, y el Código civil en su artículo $755^{751}$.

tradicionalmente sus precedentes figuraban dentro de la regulación de la institución de heredero, integrando un listado de prohibiciones de disponer. Conocido es el debate doctrinal sobre el Código Civil en el que se entiende por algún sector como más exacto hablar de «prohibiciones» en vez de usar el término «incapacidades relativas". En el F. J. $2^{\circ}$, se resalta el parecido entre el precepto del Código catalán y artículo 752 , Cc. "Cualquiera de los supuestos relacionados en el artículo 412 ha de ser objeto de cumplida prueba, pues según la doctrina del Tribunal Supremo (STS de 20 mayo de 1992), respecto del artículo 752 Cc, precepto de contenido similar al examinado, su aplicación es eminentemente restrictiva y la interpretación de la norma ha de ser estricta”.

${ }^{750}$ Mantiene MARTín PÉREZ, J. A.: "La protección de las personas mayores y con discapacidad en el derecho de sucesiones de Cataluña", en La codificación del derecho civil de Cataluña. Estudios con ocasión del cincuentenario de la compilación, (coord. J.M. Fontanellas Morel), Marcial Pons, Madrid, 2011, pág. 366, citando el Preámbulo de la Ley 10/2008, "que no se ha optado por inhabilitar a estas personas, (Los cuidadores) «entendiendo que una regla tan drástica podría dar lugar a situaciones injustas, pero, a fin de reducir el riesgo de captación de la voluntad, ha parecido oportuno exigir, en estos casos, que la disposición se realice en testamento notarial abierto".

751 STS de 16/07/2003 (Roj: STS 5087/2003) el Tribunal Supremo se pronuncia acerca de la estafa sufrida por una anciana de 90 años y de su hijo disminuido psíquico, ingresados ambos en una residencia de ancianos cuya dirección del centro la ostentaba una de las condenadas en las instancias y recurrentes en casación. En el F.J. $2^{\circ}$, la sentencia recoge la doctrina al respecto de casos de similares: "La doctrina de esta Sala (...) considera como engaño "bastante" a los efectos de estimar concurrente el elemento esencial de la estafa, aquél que es suficiente y proporcional para la efectiva consumación del fin propuesto, debiendo tener la suficiente entidad para que en la convivencia social actúe como estímulo eficaz del traspaso patrimonial, valorándose 
Con esta medida el legislador catalán trata de evitar el riesgo de captación de la voluntad del disponente que bien por su avanzada edad o vulnerabilidad y con marcada dificultad para administrar sus bienes. Quizá lo que más destacable es que, en la mayoría de los casos, no se ha producido su incapacitación con la consecuencia que conlleva carecer de tutor que actúe en todo lo que afecte a su gestión. Todo ello afecta en general a su plena libertad de disposición, de ahí que pretenda el legislador salvaguardar dicha libertad que ostenta el testador El riesgo es patente y evidente dado que ya se ha pronunciado, el Alto Tribunal, al respecto de responsables de centros geriátricos en relación a disposiciones testamentarias y actos inter vivos y mortis causa otorgadas por sus clientes. Se trata de "la ratio preventiva relativa a la libertad de disponer del testador vulnerable ${ }^{\text {c6752. }}$.

dicha idoneidad tanto atendiendo a módulos objetivos como en función de las condiciones personales del sujeto engañado y de las demás circunstancias concurrentes en el caso concreto".

752 STS de 08/04/2016, (Tol. 5.687.871) en que se insta la nulidad de un testamento otorgado a favor de una congregación religiosa dedicada al cuidado de ancianos en la que residía como cliente el causante. La sentencia recoge el pronunciamiento de la jurisprudencia acerca de la interpretación del artículo 752Cc, así como la de su homólogo catalán: "La sentencia de 19 de mayo de 2015, Rc. 230/2014, aunque dictada en relación con el artículo $752 \mathrm{Cc}$, puede ser traída como pauta interpretativa del precepto del Código Civil Catalán que nos ocupa, por cuanto, como hemos expuesto, ambos responden a una misma ratio preventiva relativa a la libertad de disponer del testador vulnerable. La sentencia declara lo siguiente: "conforme a la necesaria interpretación sistemática del precepto, también debe puntualizarse que su incidencia en el plano de la ineficacia testamentaria tampoco escapa a su debida ponderación por el criterio de conservación de los actos y negocios jurídicos que esta Sala tiene reconocido, no sólo como mero canon interpretativo, sino también como principio general del derecho, con una clara proyección en el marco del Derecho de sucesiones en relación a la voluntad manifestada por el testador ( favor testamenti )".

"En atención a lo expuesto es acertada la interpretación que hace la sentencia recurrida entre asistencia espiritual (artículo 412-5.1c)) y prestación de servicios asistenciales, residenciales o de naturaleza análoga en virtud de una relación contractual (artículo 4125. apartado 2), para concluir, conforme a la valoración de la prueba practicada, que se está en presencia del segundo supuesto, ya que no se ha acreditado que las religiosas pertenecientes a la Congregación favorecida le prestasen asistencia espiritual”. 


\subsubsection{La preterición}

La preterición en Cataluña tiene lugar cuando bien no se nombra en el testamento a un legitimario, o se nombra y no se le hace atribución alguna imputable a su legítima (art. 451-16.2). No procede la preterición, cuando la atribución ha sido hecha fuera del testamento, como puede ser el caso de una donación entre vivos que se haya imputado a la legítima. Siendo el legitimario preterido, un descendiente del causante, nacido o devenido titular del derecho con posterioridad al otorgamiento del testamento, se trata de una preterición no intencional o errónea. Puesto que el disponente ignoraba su existencia, de ahí que haya cometido el error al testar. Las consecuencias de ese error pueden dar lugar a la ineficacia del testamento, conforme a los artículos 422-7 y 451-16. 2 del Código civil de Cataluña. Con la pertinente apertura de la sucesión intestada. Lo sorprendente aquí es que en virtud del artículo 431-9.3 CCC los pactos sucesorios no resultan afectados por la preterición ${ }^{753}$.

No se pueden pasar por alto los tres supuestos en que el precitado artículo 451-16. 2 CCC excluye la ineficacia del testamento frente a la preterición no intencional. Las tres excepciones dispuestas en el precepto atienden al principio que "la voluntad del testador es ley en la sucesión". El primero es cuando el testador ha instituido único heredero en su testamento a su cónyuge o pareja de hecho estable. Aquí el legislador catalán ha presumido la voluntad del testador en el sentido de que de haber conocido la existencia del preterido, el testador, hubiera hecho exactamente lo mismo que hizo al ignorarlo ${ }^{754}$. La segunda trata de la misma idea puesta en la

\footnotetext{
${ }^{753}$ VAQUER AlOY, A.: "La legítima en el Derecho civil de Cataluña", en Tratado de legítimas, Atelier, Barcelona, 2012, pág. 504.

${ }^{754}$ La STSJ de Cataluña de 28/07/2016 (Tol. 5.825.934) enjuicia un caso en que el testador ha instituido como única heredera a su esposa y ha preterido erróneamente a un hijo suyo de un anterior matrimonio. En el F. J. $2^{\circ}$, el Tribunal resalta: "La sentencia de la Audiencia Provincial, valorando los hechos antes citados, consideró que podía 
mente del testador: el deseo de designar un único heredero a un hijo o a otro descendiente. Por lo que hace presumir que de haber conocido la existencia de uno más, no hubiera modificado su primitiva voluntad. La tercera excepción trata de la relación de filiación por la cual se deviene legitimario el preterido con posterioridad al fallecimiento del causante. No puede apreciarse aquí error del testador debido a que en vida no conocía la identidad del preterido. Por lo tanto, siendo la presunción iuris tantum, y no, iuris et de iure y siendo la preterición errónea la excepcional se inclina el legislador hacia la no intencional que es la preterición general ${ }^{755}$.

La impugnación del testamento por el legitimario preterido erróneamente se limita a los descendientes que son legitimarios por derecho propio y también a los que lo son por derecho de representación. Ello en el caso de que el representado hubiera podido impugnar el testamento. Por lo tanto, no tienen la legitimación los representantes en cualquier caso ni los ascendientes. Tampoco cabe preterición en el supuesto de ser desheredado, el legitimario, aunque lo sea injustamente, sin perjuicio

calificarse jurídicamente a la Sra. xxx como pareja estable de xxx. Además, debe destacarse también que la voluntad de D. xxx al otorgar testamento fue dejar todos sus bienes a la Sra. xxx, voluntad que rige la sucesión testada (art. 421-1 CCC) y a la que debe estarse para la interpretación del testamento (art. 421-6 CCC) (...)". En consecuencia, concurre la excepción prevista en el apartado a) del art. 451-16-2 CCC que, ante la preterición errónea de un descendiente, admite la validez y eficacia del testamento cuando el causante ha instituido heredero único, en toda la herencia, al conviviente en pareja estable, y ello sin perjuicio de los derechos legitimarios que le corresponden al actor Sr. xxx en la herencia de su padre".

${ }^{755}$ STSJ de Cataluña de 25/02/2016 (Tol. 5.685.918) F. J. $4^{\text {o }}$ se remite a jurisprudencia pasada para motivar que en el FJ. $3^{\circ}$ de la STSJ de Cataluña de 21/12/1992 (Tol. 207. 942) "en que la existencia de preterición errónea no puede declararse en base a criterios eminentemente objetivos transcribiendo la opinión de Cáncer conforme a la cual la preterición errónea afecta a los póstumos, engendrados y nacidos después del testamento. Indica la sentencia que parece obvia la fundamentación eminentemente subjetiva y de presunción iuris tantum y no iuris de iure de la preterición errónea, y que la misma es de carácter excepcional. La regla general es la preterición intencional de modo que la no intencional, como excepción que es, debe ser interpretada restringidamente. Manteniéndose la intangibilidad del testamento se contribuye a la operatividad del principio general de la conservación del negocio jurídico - favor testamenti - sin detrimento legal al conservar el legitimario su derecho a la legítima”. 
de los efectos que produce el desheredamiento injusto. Sin entrar ahora a valorar los efectos que son básicamente los mismos de la preterición intencional. En virtud del artículo 451-16. 4 CCC la acción de impugnación del testamento por preterición errónea caduca a los cuatro años desde el fallecimiento del causante ${ }^{756}$.

\subsubsection{1.- La sucesión contra testamento (actio ad supplendam legitimam)}

Atribuida a Justiniano, la actio ad supplendam legitimam, era la querella por medio de la cual, el legitimario al que no se le había otorgado aquello que por ley le correspondía tenía acción. Con anterioridad era de aplicación la querella inoffíciosi testamenti. Lo era para el supuesto de que al legitimario le faltara parte de su legítima. Por medio de esta querella podía atacar el testamento y destruirlo y en consecuencia a ello tenía cabida la sucesión legal. Para evitar tal supuesto Justiniano promulgó, la actio ad supplendam legitimam, que lejos de destruir todo el testamento, sólo incidía en aquellos aspectos que influían en la satisfacción completa de la legítima al legitimario. Tal procedimiento se puede encontrar en el Derecho sucesorio catalán, concretamente en el artículo 451-10 CCC que regula el suplemento de la legítima ${ }^{757}$.

\subsubsection{Las causas de desheredación del Código civil de Cataluña}

La desheredación, en virtud del artículo 451-17. 1 del CCC es el medio por el cual el causante puede privar a los legitimarios de su legítima. Lo puede hacer si incurren en alguna de las causas de desheredación tipificadas por la Ley. Las causas de desheredación en Cataluña las recoge el precitado artículo, que a su vez se remite al artículo 412-3 CCC que

\footnotetext{
${ }^{756}$ VAQUER AlOY, “La legítima en el Derecho...”, op. cit., pág. 505.

${ }^{757}$ JuÁreZ GonZÁleZ, GPS Sucesiones..., op. cit., pág. 446. Mantiene que la actio ad supplendam legitimam, pervive en el derecho catalán, por medio del artículo 451-10 CCC precepto que regula la acción de suplemento de la legítima.
} 
enumera las causas de indignidad. Ello significa estar ante una sanción civil y privada, cuya potestad de aplicación, únicamente corresponde al disponente. No supone la extinción de derecho a legítima ya que conforme al artículo 451-3. 2 CCC los descendientes del desheredado pueden ejercer su derecho de representación y reclamar la legítima de aquel, puesto que no acrece su parte en el resto de legitimarios. Es más, para el cómputo de la legítima hace número la parte del desheredado ${ }^{758}$.

Dentro de las citadas causas del artículo 451-17. 2 CCC hay dos cuestiones que dejan en manos del juez la apreciación de la infracción cometida por el legitimario. Se trata de los apartados "c" y "e" siendo el primero el maltrato grave y el segundo la falta de relación familiar. Esta falta de relación familiar imputada al legitimario sólo trae causa si se produce exclusivamente con el causante. Por lo tanto no queda afectado aquel si se ha producido con los familiares de este. La consecuencia del comportamiento del legitimario y el reproche del causante hace que el legislador entienda que el primero no merezca la legítima del segundo, si este así lo pone de manifiesto en su testamento ${ }^{759}$.

\footnotetext{
758 Señala VAQUER AlOY, La Legítima en el Derecho civil..., op. cit., pág. 497, apoyándose en Ribot Igualada, Egea Fernández /Ferrer Riba. Comentaris al llibre quart, pág. 1394, "que la desheredación es una sanción no graduable en función de la gravedad de la conducta del legitimario, pues no cabe moderar los efectos de la desheredación reduciendo la cuantía de la legítima, sino que la concurrencia de la causa de desheredación y el cumplimiento de sus requisitos formales conlleva la privación total; téngase en cuenta, en este sentido, que la desheredación no puede ser parcial según el art. 451-18.2 CCC".

${ }^{759}$ De BARRÓN ARNICHES, P.: "Libertad de testar...", op. cit., pág. 42. Mantiene la autora que el legislador catalán mantiene la legítima y opta por buscar un punto de equilibrio entre los conceptos de libertad de testar, sucesión y protección a la familia. Comparto en parte la opinión de la autora el que se busca por parte del legislador la protección a la familia con esta causa (e) de desheredación, pero no comparto en que se presuma la libertad de testar por medio de esta justa causa, ni siquiera la libertad de testar dispuesta en el artículo 421-1 CCC.
} 
Lo novedoso, en esta materia, para el Derecho común es, como ya se ha hablado de ello en el Capítulo II, que se recurre por parte del Tribunal Supremo a la privación de la legítima debido a un comportamiento no tipificado dentro de las causas de desheredación de aquel Derecho ${ }^{760}$. Se trata del abandono o despreocupación del legitimario por el estado del disponente. Siendo el criterio judicial el elevar la falta de relación a "maltrato psicológico"761. Lo que no produciría novedad en el ordenamiento catalán es que se desheredase a un legitimario, por cumplir a partir del 01 de enero de 2009, con lo dispuesto en el apartado "e" del señalado artículo 451-17. 2 del Código de Cataluña. La jurisprudencia la entiende como justa desheredación para el legitimario cuando la ausencia

${ }^{760}$ La STS de 03/06/2014 (Tol. 4.395.123) F. J. $2^{\text {o }}$ "En primer lugar, y en orden a la caracterización general de la figura debe señalarse que aunque las causas de desheredación sean únicamente las que expresamente señala la ley ( artículo 848 del Código Civil ) y ello suponga su enumeración taxativa, sin posibilidad de analogía, ni de interpretación extensiva; no obstante, esto no significa que la interpretación o valoración de la concreta causa, previamente admitida por la ley, deba ser expresada con un criterio rígido o sumamente restrictivo. Esto es lo que ocurre con los malos tratos o injurias graves de palabra como causas justificadas de desheredación (artículo 853.2 del Código Civil),". De otro lado en el punto $6^{\circ}$, de mismo F.J. alude el Alto Tribunal al "abandono emocional" manifestando: "(...), fuera de un pretendido "abandono emocional", como expresión de la libre ruptura de un vínculo afectivo o sentimental, los hijos, aquí recurrentes, incurrieron en un maltrato psíquico y reiterado contra su padre del todo incompatible con los deberes elementales de respeto y consideración que se derivan de la relación jurídica de filiación, con una conducta de menosprecio y de abandono familiar que quedó evidenciada en los últimos siete años de vida del causante en donde, ya enfermo, quedó bajo el amparo de su hermana, sin que sus hijos se interesaran por él o tuvieran contacto alguno; situación que cambió, tras su muerte, a los solos efectos de demandar sus derechos hereditarios".

${ }^{761}$ ARROYO I AMAÑUELAS, E. Y FARNÓS AMORÓS, E.: Entre el testador y el legitimario desheredado ¿A quén prefiren los tribunales?, Indret, núm. 2, 2015, pág. 5. Expone la autora, como ejemplo de causas abiertas de desheredación, en que tiene cabida la" discrecionalidad judicial", el artículo 451-17, del Derecho civil catalán, tras la reforma de 2008. Introduce, el precepto citado, dos cláusulas generales o abiertas de privación de legítima: "el maltrato grave" y "la falta de trato familiar con el causante". 
prolongada y continuada de la relación familiar, por parte del legitimario, le sea exclusivamente imputable ${ }^{762}$.

Volviendo al Derecho común sobre el maltrato psicológico habría que resaltar dos importantes cuestiones: la primera es sobre su inclusión dentro de la causa del maltrato de obra del artículo 853. $2^{\circ}$, del Código civil. La segunda es cuando recoge el menosprecio y abandono familiar del disponente. Con ello el Tribunal Supremo realza la gravedad de los hechos y pone de manifiesto que se trata de algo superior a la simple falta de relación familiar. Si bien la jurisprudencia se refiere al maltrato psícológico como aquellos hechos que producen descalificación, humillación o discriminación de una persona a otra ignorando el agresor los sentimientos del agredido $^{763}$. La tendencia que se deriva de la jurisprudencia del Tribunal Supremo es la ampliación de las causas por las que se le puede privar al legitimario del derecho a legítima. De hecho, se ha podido comprobar en la ya citada STS de 03/06/2014, como se sanciona, con la

\footnotetext{
762 SAP de Gerona (S. 1 ${ }^{\text {a }}$ ) de 14/05/2015 (Tol. 5.187.109) FJ. $5^{\circ}$ expone que progresa la causa de desheredación, sólo cuando ésta sea exclusivamente imputada al legitimario: "Aceptando plenamente la argumentación jurídica que da el Juzgador respecto de esta causa de desheredación, especialmente en que la causa de desheredación sea imputable exclusivamente al legitimario, es claro que tal causa no está justificada, pues no puede imputarse a las nietas la falta de relación con su abuela, pues en el momento en que se otorgó el testamento tenían una seis años y diez meses y la otra cinco años, por lo que difícilmente puede imputárseles la falta de relación familiar a ellas, en su caso, tal falta de relación sería imputable al padre, que impide que su hijas se relacionen con la abuela, y dado que las causas de desheredación deben interpretarse restrictivamente, no puede fundamentarse una causa de desheredación de unos nietos en la conducta de sus padres".

${ }^{763}$ La STSJC de 02/02/2017, (Tol. 6.0033.342) F. J. $3^{\circ}$ define en la situaciones que se da el maltrato psicológico: "El maltrato emocional o psicológico se da en aquellas situaciones en las que una persona vinculada a otra, la hace sufrir con descalificaciones, humillaciones, discriminación, ignorando o menoscabando sus sentimientos siendo ejemplos de ese tipo de maltrato, el abandono emocional, la descalificación, la violencia verbal, las amenazas, el control excesivo, el chantaje afectivo o la presión moral, el desprestigio o las descalificaciones ante personas del entorno familiar, laboral, etc. del afectado, las burlas y cualquier tipo de castigo que no sea físico, siempre que estos actos tengan la suficiente intensidad para producir un menoscabo en la salud mental de la persona que los padece".
} 
privación de la legítima, un comportamiento no tipificado por la Ley como pueda ser el maltrato psicológico ${ }^{764}$.

Buscando la comparación con la justa causa (e) de desheredación del artículo 451-17. 2 del Código civil de Cataluña, el artículo 1621 A del Código civil de Luisiana recoge y reconoce el derecho a la legítima de los hijos. Pero parece que aquel texto legal también se ha unido a la moderna tendencia que de manera progresiva van buscando los distintos mecanismos para ir debilitando la legítima. Establece una causa de desheredación bastante parecida a la dispuesta en el texto legal de Cataluña ${ }^{765}$. De modo similar, el perjudicado, en el ordenamiento austriaco es el que tiene que demostrar la falsedad de la causa de desheredación ${ }^{766}$. Son sin duda herramientas legislativas cuyo objetivo es mermar la institución de la legítima. La jurisprudencia, tanto en el Derecho común como foral sigue la doctrina tajante al respecto de la carga de la prueba. En el caso catalán cuando el legitimario no acepta alguna de las justas causas del artículo 45117.2 del Código civil de Cataluña alegando su ineixtencia corresponde

\footnotetext{
${ }^{764}$ Estos hechos revelan una tendencia hacia el debilitamiento de la legítima y por lo tanto ampliación de la libertad de testar, pero antes se pregunta VAQUER ALOY, A.: "Acerca del fundamento de la legítima", Indret, núm. 4, 2017, pág. 4, "si los mismos colaboran a desvelar el fundamento de la legítima".

765 Código civil de Luisiana de 2017, Artículo 1621, Causas de desheredación de los padres, el apartado núm. 8 dispone: "El niño, después de alcanzar la mayoría de edad y saber cómo ponerse en contacto con el Padre, no ha podido comunicarse con el padre sin justa causa por un período de dos años, a menos que el niño estuviera en servicio activo en cualquiera de las fuerzas militares de los Estados Unidos en el momento".

${ }^{766}$ Así, DE BARRÓN ARNICHES, "Libertad de testar y desheredación...", op. cit., pág. 42, pone de manifiesto que la causa (e) de desheredación referente al comportamiento de legitimario con el padre o el abuelo lleva vigente en Luisiana desde 1985. En el caso concreto de la causa (8) del artículo 1621, del Código civil de Luisiana tendría que demostrar el hijo, no conforme con la desheredación, que no ha estado dos años alejado de sus sin interrupción o que no tenía posibilidad de contacto con sus padres o bien que no ha contactado con ellos por una justa causa. En virtud de los artículos 1624 y 1625 , podría también el hijo alegar que su padre lo había perdonado o que sencillamente había habido reconciliación entre ellos. Véase el Código civil de Luisiana, artículos $1621,1622,1624$ y 1625 .
} 
tener que probarla el heredero del desheredante ${ }^{767}$. Claro está, en el caso que el desheredado la impugne ${ }^{768}$.

Lo que prima para los Tribunales españoles en general es la demostración de la justa causa, no la certeza o incerteza de la misma ${ }^{769}$. La jurisprudencia española podía dar una impresión de benevolente con el legitimario al entender que la desheredación requiere un carácter de flexibilidad. Lo requiere en base a que los hechos en los que se produce se reducen a un ambiente íntimo y privado en que solamente el núcleo familiar y los autorizados a entrar en él conocen del fondo del asunto.

La filiación comporta, en particular en la línea recta descendente, una serie de medidas de fomentos de la convivencia alimentos, educación, etc. Ya en edad adulta les impone alimentos recíprocos, si llega su necesidad. Toda esta benevolencia mutua se acaba cuando el legitimario falta al

${ }^{767}$ La SAP de Gerona (S. 2 ${ }^{\text {a }}$ ) de 20/02/2017 (Tol. 6.186.103) en su F. J. 5. "En el caso examinado es evidente que el heredero demandado no ha demostrado la primera de las causas de desheredación expresadas en el testamento, de denegación de alimentos a la testadora, pues la prueba analizada ha demostrado que disponía de bienes, ingresos y pensión suficientes para subvenir sus necesidades y si bien los dos últimos años residía con su hijo (...)" En el mismo FJ cabe advertir varios incisos muy interesantes al tema que se está tocando: "En definitiva, el demandado designado heredero universal en el testamento en que a su vez desheredaba a los legitimarios demandantes, no ha cumplido con la carga de demostrar la existencia de las causas de desheredación alegadas en el mismo que el art. 451-20 le impone. Y la consecuencia de esa improbanza no es otra que la declaración de desheredamiento injusto, art. 451-21. b), y con ello la ineficacia de la cláusula testamentaria primera de desheredación, pero sin declarar la nulidad total del testamento, que continúa válido en cuanto a la declaración de heredero universal (...)" Es a lo que me refería, con la "doctrina tajante", pues el Tribunal no se para a que sea o no sea cierta la justa causa, sino a que el heredero no la ha podido probar. En consecuencia, de la "improbanza", deviene la ineficacia de la cláusula testamentaria, pero no se invalida todo el testamento y el heredero puede seguir atendiendo a sus obligaciones como tal".

${ }^{768}$ Véase la diferencia que existe en ambos Derechos a la hora de enjuiciar la misma causa de ausencia manifiesta y continuada de relación familiar los dos años de distanciamiento entre legitimario y causante en el Derecho catalán se valora el diferente lugar de residencia entre ambos y la mala relación con el hijo con el que vivía la testadora en la citada SAP de Gerona (S. 2 ${ }^{\text {a }}$ ) de 20/02/2017 (Tol. 6.186.103) F. J. $5^{\circ}$.

${ }^{769}$ VAQUER ALOY, “La Legítima en el Derecho civil...”, op. cit., pág. 499 y 500. 
mantenimiento de relación familiar de manera manifiesta y continuada. El legislador de Luisiana, en cambio, sólo es benevolente frente a esta causa de falta de relación familiar, si el legitimario se enlista o está en el ejército estadounidense. El catalán ni si quiera quiere saber el motivo, solo si la ausencia manifiesta es imputable al legitimario ${ }^{770}$.

Puede que una solución al caso que plantea la SAP de Barcelona citada anteriormente fuera, en principio, la que adopta el Código civil austriaco. Es decir, no a la total pérdida de la legítima, sino a una reducción de la misma por parte del testador frente a la inexistencia de relación familiar entre legitimario y causante. No se trata, en este Derecho europeo, de suprimir la legítima para el que incurre en justa causa de desheredación sino de reducirla a la mitad. No deja de ser una solución a tener en cuenta

${ }^{770}$ La SAP de Barcelona (S. 16) de 04/05/2006 (Tol. 1.009.895). En este litigio se ejercita por Dña xxx, legitimaría en la sucesión de su padre una acción de impugnación de desheredación contra aquel testador. La heredera demandada es la propia madre de la demandante desheredada y esposa del causante. Los motivos que se transcriben en el testamento como justificantes de la justa causa de desheredación son: "ya desde joven robó dinero a sus propios padres en repetidas ocasiones"; 2on/ "habiéndole llamado con adjetivos tales como cabrón, maricón, etc"; 3er/ "habiéndole echado a empujones de su casa"; 4rt/ "recientemente opta por ignorarle, y cuando se dirige a él, sólo lo hace para insultarle, habiéndole manifestado en repetidas ocasiones ¿que no le quiere' e incluso [que] no le considera como familia suya". La Sala de Audiencia no comparte la resolución de Instancia, en el sentido de que frases como: "no os quiero" o "no os considero familia mía". Sí que comparte con el Juez que sólo fueron insultos verbales, sin el menor indicio de maltrato de obra. La visita de los padres a un psicólogo como consecuencia de las constantes disputas de la única hija con el matrimonio compuesto por el causante y la hoy heredera hizo ver a la Sala, tras el testimonio de dicho facultativo que los insultos al causante eran ciertos, puesto que la paciente era la hoy heredera y la acompañaba su entonces marido y hoy causante y padre de la apelada. Pero lo que inclinó a la Sala a revocar la Sentencia de Primera Instancia y admitir la justa causa de desheredación fue que la hija desheredada, tras dar a luz una niña, no le permitiera ver su hija a su padre y abuelo de la recién nacida. El abuelo se desplazaba diariamente desde su domicilio al de su hija, para ver a su primer nieto y no lo pudo conseguir por oposición a ello de su propia hija, cinco meses después el padre deshereda a su hija. Hechos que afirma su certeza la desheredada. Pone de manifiesto la Sala, la estimación que los abuelos sienten por sus nietos y el impacto emocional que les provoca el primer nieto. Actualmente hay que resaltar el deber legal que se impone a los padres que los abuelos puedan relacionarse con sus nietos menores de edad (Art. 135.2 CF). Pienso personalmente que el Tribunal ha sabido distinguir entre unos insultos no aprobados y el verdadero impacto que le produjo a su padre negándole ver a su nieta. 
para supuestos como el de la SAP de Barcelona que se ha citado anteriormente, en que el Juez de Primera Instancia, no advierte justa causa, pero la Audiencia Provincial de Barcelona sí que estima que queda probada por parte del heredero la argumentación dispuesta por el testador en su testamento para desheredar a su única hija. Advierta el lector, que se ha dicho su "única hija" lo cual significa que le corresponden dos tercios de legítima y el testador no puede reducirla. De tener un hermano sí que el Derecho español le da potestad al testador, sin recurrir a la desheredación, para graduar la legítima por medio de la mejora que se asimilaría al Derecho austriaco $^{771}$.

En cambio, como ya se ha dicho sin matices, sí que ha sido admitida en 1989, la ausencia de relación familiar por el Derecho de Austria, en que el testador podía reducir la legítima a la mitad. Matizando que, en 2001 se introdujeron ciertos límites a dicha posibilidad, si era el propio causante el que había propiciado la ausencia de relación familiar. En tal caso la causa le es imputable al disponente, cuya consecuencia deriva en la imposibilidad de reducir la legítima a su titular ${ }^{772}$. También apuntar que el testador francés no tiene causas de desheredación a su disposición para privar, del derecho a legítima, a sus titulares. Ello tras las últimas reformas empobrecedoras de la legítima. También se distingue este rasgo en aquellos Códigos civiles de inspiración francesa en esta línea: Italia, Grecia,

\footnotetext{
${ }^{771}$ De BARRón ARNICHES, Libertad de testar y desheredación..., op. cit., pág. 43, esta autora mantiene que en 1989, el legislador austriaco introdujo la posibilidad de que el causante redujera la legítima a la mitad si nunca había habido trato familiar con los legitimarios, es decir, el trato que se dispensa entre padres e hijos normalmente. Con posterioridad en este ordenamiento ha habido dos reformas más tratando de disculpar al legitimario, cuando se dé el supuesto en que la falta de relación familiar no es imputable al legitimario. Se ve claramente la calidad de la legítima española con el sólo hecho de advertir su majestuosa regulación. Cuando uno lee lo expuesto por el Derecho austriaco, se da cuenta que en el Derecho español esa reducción a la mitad de la legítima por descontentos del testador con el legitimario, la puede obtener con el tercio de mejora.
}

${ }^{772}$ ARROYO I AMAÑUElAS Y FARNÓS AMORÓs, “Entre el testador...”, op. cit., pág. 17 
Argentina, etc ${ }^{773}$. A tener en cuenta que no mantiene, esta carrera debilitadora de la legítima, el Derecho alemán que, tras la modificación del Derecho de Sucesiones de 24 de septiembre de 2004, en que reformó las causas de desheredación no incorporó la falta de trato familiar como causa de privación de su derecho al legitimario ${ }^{774}$.

El Tribunal Constitucional alemán mantiene que no cabe introducir como causa de desheredación la falta de trato familiar con el disponente. Dispone el citado Tribunal que la privación de legítima requiere causas muy graves debido a que ella constituye un derecho que no depende ni de la necesidad del legitimario ni de la del testador ${ }^{775}$. Como opinión personal, coincido con estas palabras del Tribunal Constitucional alemán que corroboran lo antes expuesto de que la legítima no es una compensación por los servicios prestados por el legitimario al disponente.

\subsubsection{LA LIBERTAD DE TESTAR. ARTÍCULO 421-1 CCC}

Puede que la primera impresión que ofrece el título del artículo 421-1 $\mathrm{CCC}^{776}$ "Libertad de testar", de cierta manera parece que puede confundir al lector con la libertad de disposición post mortem. Realmente lo que trascribe su disposición es que puede el disponente optar para marcar el des el ejército estadounidense tino de sus bienes para después de su muerte, a través del testamento y su contenido. Dicho de otra manera, en Cataluña está claro que la sucesión voluntaria puede establecerse por pacto sucesorio

\footnotetext{
${ }^{773}$ En este punto de no permitirle al testador desheredar al legitimario en los Códigos de referencia francesa (Code francés) se refiere VAQUER AlOY, A.: "Acerca del fundamento de la legítima", Indret, núm. 4, 2017, pág.6, concretamente al Código italiano, desde 1865 , por lo menos está la coincidencia en lo que a desheredar a los legitimarios se refiere.

${ }^{775}$ VAQUER AlOY, A.: “Acerca del fundamento...” op. cit., pág.11.

${ }^{776}$ Artículo 421-1 CCC (Libertad de testar): "La sucesión testada se rige por la voluntad del causante manifestado en testamento otorgado de acuerdo con la ley".
} 
y por testamento. Por lo tanto, la bien llamada libertad de testar del artículo 421-1 del Código civil de Cataluña le otorga libertad al disponente para ordenar su sucesión por medio de testamento o por pacto sucesorio. La regulación del heredamiento o pacto de institución de heredero está regulada en los artículos 431- 18 a 431-28. Es muy aclaratorio, a este respecto, el artículo 411-377 CCC que establece la libertad de testar y la libertad de otorgar pactos sucesorios. Otros derechos, como el Fuero Nuevo de Navarra sí que titula su Ley 149 CDFN como "Libertad de disposición”. Manifestando con ello que los navarros pueden disponer libremente de sus bienes para después de su muerte sin más trabas que las dispuestas en el citado Fuero navarro ${ }^{778}$.

\subsection{LAS LEGÍTIMAS EN EL DERECHO FORAL DE GALICIA}

Se podría calificar, la Alta Edad Media, como periodo de pluralidad normativa en Galicia. Debido a que se pueden hallar testimonios germánicos, visigodos o franceses, así como también vestigios prerrománicos $^{779}$. Parece ser que el territorio gallego quedó pronto integrado en el Reino de León y con posterioridad en el de Castilla, Navarra o Aragón. La falta de protagonismo político de la comunidad

777 Artículo 411-3 CCC (Fundamentos de la vocación): “1. Los fundamentos de la vocación sucesoria son el heredamiento, el testamento y lo establecido por la ley. 2. La sucesión intestada solo puede tener lugar en defecto de heredero instituido, y es incompatible con el heredamiento y con la sucesión testada universal. 3. La sucesión testada universal solo puede tener lugar en defecto de heredamiento."

${ }^{778}$ VAQUER ALOY, A.: "Libertad de testar y condiciones testamentarias", Indret, núm. 3, julio 2105 .

${ }^{779}$ Más información en MARTíneZ MARTíneZ, F.: “Antología de textos forales del Antiguo Reino de Galicia (siglos XII-XIV)", Cuadernos de Historia del Derecho, núm. 10, 2003, pág. 259. "La previa romanización no fue tan abundante e intensa como en otras áreas peninsulares en donde se asimiló de manera plena el modo de vida latino2. La conquista romana fue tardía y la dominación no tan continuada y férrea. Pero sí se dio cierta influencia a través de la creación de algunos núcleos urbanos y la presencia de los ejércitos, con la consiguiente consecuencia de índole cultural que dicho proceso comportó (le lengua romance surgida en esta región...”. 
gallega propició que sus costumbres no se convirtieran en leyes forales como ocurrió en otros territorios como Aragón, Cataluña, Vizcaya, etc ${ }^{780}$.

Tras la decadencia del poder público visigodo hubo muchos abusos señoriales e incluso la formación de un Derecho señorial. Después de la reconquista se fueron extinguiendo tales abusos dando paso a un Derecho autónomo conforme a las situaciones creadas en la época. Este Derecho era de aplicación especial complementario del Liber Indiciorion, cuya aplicación era de Derecho común para toda la Península. El Derecho romano justinianeo se recibió como Derecho común y sustituyo al Derecho común visigodo de distinta manera en cada reino de España. Por lo tanto, el Derecho romano se introdujo en España, a través de las Partidas, convirtiéndose en Derecho común español o más bien Derecho de Castilla $^{781}$.

Los campesinos de Castilla se asentaron en el territorio conquistado a los musulmanes concediéndoles Fueros y Cartas Pueblas. En cambio, a los campesinos gallegos al no participar en la reconquista y su consecuente repoblación, no participaron de los regímenes municipales como lo hicieron otras regiones. Vivieron, hasta épocas más bien recientes sometidos a vínculos de carácter señorial. Sólo con la supresión de los citados señoríos- las desamortizaciones del siglo XIX y la emigración de la población gallega- pudieron acceder, los campesinos gallegos, a formar pequeñas propiedades de tierra en Galicia. Como consecuencia de la tardía producción de la estructura económica y social gallega, no se produjo una

\footnotetext{
${ }^{780}$ Herrero OviEDO, M.: "De un Derecho consuetudinario y especial a un Derecho civil de Galicia" Ius fugit: Revista interdisciplinar de estudios histórico.juridicos, núm. 16, 2009-2010, pág. 106.

${ }^{781}$ OtERo VARELA, A.: "Sobre la compilación del Derecho Foral Gallego", Anuario de historia del Derecho español, núm. 34, 1964, pág. 154.
} 
necesidad inminente de una regulación jurídica nueva y se aplicaba entonces la vigente Ley de las Partidas así como las Leyes de Toro ${ }^{782}$.

\subsubsection{El Derecho foral gallego en la codificación}

Se puede hablar de un Derecho especial gallego de carácter fundamentalmente consuetudinario. Se puede referenciar con disposiciones administrativas anteriores y posteriores a la codificación española de 1889, como el Real Decreto de 2 de febrero de 1880, entre otros, que agrega un representante para Galicia ${ }^{783}$. Este mismo Real Decreto no otorgó a Galicia naturaleza como región foral y por tanto obligó a aportar argumentos justificantes de un representante gallego en la Comisión codificadora ${ }^{784}$. Galicia no contaba con suficientes normas escritas para hablar de un Derecho Foral. Lo que sí que había, en aquel territorio, eran muchas costumbres históricas "usus terrae". Menos dos instituciones- el foro y la Compañía Familiar Gallega todo lo demás se regía, en materia civil, por la normativa común que imperaba en España. Tras la promulgación de la Ley de bases de 1888, en la que su artículo 5, manifestaba la confección de

\footnotetext{
${ }^{782}$ Rodríguez Montero, R. P.: "El Derecho Civil en Galicia, La Ley de Derecho Civil de Galicia y el Futuro Derecho Civil de Galicia: Apuntes, Ideas y Sugerencias" Anuario da Facultade de Dereito da Universidade da Coruña, 2001, pág. 59.

${ }^{783}$ RodríGUEZ MONTERO, El Derecho Civil en Galicia..., op. cit., págs. 738 y 739.Entre las mismas se han señalado las siguientes: el Decreto de 2 de febrero de 1880 -dictado siendo Ministro el gallego Álvarez Bugallal-, a través del cual se procedió a modificar la Comisión General de Codificación -creada por Real Decreto de 10 de mayo de 1875, agregando un representante por Galicia; la Ley de Bases del Código civil, de 11 de mayo de 1888 -promulgada siendo Ministro de Gracia y Justicia Alonso Martínez-, que en su Base 13a incluía a Galicia entre las legislaciones que habían de ser tomadas en consideración para incorporar al Código el mayor número posible de sus normas sobre servidumbres; el Real Decreto de 24 de abril de 1889, que incluía a las provincias de Galicia, junto a las de Cataluña, Aragón, Navarra, Vizcaya y Mallorca, al determinar cuáles habían de ser las Comisiones especiales encargadas de redactar los proyectos de ley en que se contuvieran las instituciones forales que convenía conservar; y, finalmente, la Orden de 10 de febrero de 1948, que, en aplicación de lo dispuesto en el Decreto de 23 de mayo de 1947, designó entre las nuevas Comisiones, la correspondiente a Galicia.
}

${ }^{784}$ Otero VArela, A.: Sobre la compilación del Derecho..., op. cit., pág. 156. 
unos apéndices con las instituciones de Derecho Foral, que se pretendía conservar $^{785}$.

Este proyecto de apéndice nunca logró la aprobación, teniendo que esperar hasta el Congreso Nacional de Derecho Civil de Zaragoza de 1946 cuya consecuencia inmediata fue la publicación del Decreto de 23 de mayo de 1947, en que se implantaban unas comisiones especiales para elaborar unas Compilaciones. La región de Galiacia, que nunca tuvo órganos legislativos en materia civil, se vió reconocida entre las seleccionadas para formar dicha Compilación que se convirtió en Ley de 2 de diciembre de 1963 sobre la Compilación del Derecho Civil especial de Galicia ${ }^{786}$. Compilación que no fue más que una recolección de normas jurídicas consuetudinarias y haciéndose conocidas por el hecho de compilarlas pero sin transcribirlas en Leyes formales. Se puede añadir, que la parte más importante del Derecho civil gallego quedó fuera de la Compilación. ${ }^{787}$

\subsubsection{Antecedentes recientes del Derecho foral gallego}

La existencia de una compilación en Galicia permite que a esa comunidad le sea de aplicación lo previsto en el artículo 149.1.8 de la CE de 1978, que reconoce capacidad legislativa en materia civil a los parlamentos de las CC AA. Se les permite conservación, modificación y desarrollo de su propio Derecho civil, en el supuesto que dicho Derecho civil fuese preexistente al momento de la promulgación de la CE de 1978. Por lo tanto, he aquí, el hecho de por qué Galicia es comunidad de Derecho

\footnotetext{
${ }^{785}$ Véase la Ley de Bases de 11 de mayo de 1888, por la que se autoriza al Gobierno para publicar un Código civil con arreglo a las condiciones y Bases establecidas en la misma (Gaceta de Madrid del 22). Artículo 6. "El Gobierno, oyendo a la Comisión de Códigos, presentará a las Cortes, en uno o en varios proyectos de ley, los apéndices del Código Civil, en los que se contengan las instituciones forales que conviene conservar en cada una de las provincias o territorios donde hoy existen".

${ }^{786}$ Herrero OviEDO, De un Derecho consuetudinario..., op. cit., pág. 106.

${ }^{787}$ RodríGUEZ MonTERO, El Derecho Civil en Galicia..., op. cit., pág. 1031.
} 
Foral y, como ya se ha apuntado, no lo es por ejemplo Valencia, es decir, Galicia contaba con Derecho especial Foral anterior a la CE del 78. De esta manera Galicia, Aragón, Navarra, Baleares, el País Vasco y Cataluña pasaron de tener un Derecho civil excepcional frente al Código civil español a tener un Derecho común Foral propio de cada territorio y de aplicación prioritaria al Código civil español ${ }^{788}$. La Compilación de 1963 se integró en el ordenamiento jurídico de la Comunidad gallega mediante la Ley 7/1987, de 10 de noviembre, del Parlamento de Galicia bajo el título "Compilación del Derecho Civil de Galicia".

Posteriormente la ley 4/1995 de 24 de mayo, de Derecho Civil de Galiacia deroga la Ley de 10 de noviembre de 1987, de la Compilación de Galicia. En este texto legal se regulaba las legítimas en los artículos 146 a 151. Sólo con empezar y leer el artículo 146. 2 de la citada Ley, ya se puede ver una semejanza, muy pronunciada, con el Código civil, de todo el sistema legitimario. Por lo tanto, conforme a esta legislación se tiene en Galicia el tercio para legítima corta, otro tercio para mejora y el tercio de libre disposición. Ni más ni menos que el reparto típico del Código Civil.

La Ley 4/1995 de 24 de mayo, a su vez es derogada por la Ley 2/2006, de 14 de junio ${ }^{789}$ (LDCG, en adelante). Dispone esta última de 29 artículos para regular las legítimas, es decir, del artículo 238 al 266 LDCG que los encuadra dentro del título X Capítulo V (De las legítimas). El artículo 238 reconoce como legítimario. El artículo 238 LDFG reconoce como legitimarios a los hijos y descendientes de los hijos premuertos, justamente desheredados o indignos. Asimismo el cónyuge viudo no separado

\footnotetext{
${ }^{788}$ Se pronuncia RODRÍGUEZ MONTERO, El Derecho...”, op. cit., pág. 745 con respecto al alcance de la naturaleza y el ámbito de aplicación de las normas contenidas en la LDCG. ${ }^{789}$ Más información en La Ley 2/2006, de 14 de junio, de derecho civil de Galicia. BOE-A-2006-14563.
} 
legalmente o de hecho el artículo 253 LDCG, con referencia al cónyuge viudo, si concurre con descendientes del causante le corresponde en concepto de legítima el usufructo vitalicio de un cuarto del haber hereditario. Artículo 254 LDCG si no concurre con descendientes del causante el viudo tendrá derecho al usufructo de la mitad del caudal hereditario. Los artículos últimamente citados y correspondientes a La Ley, 2/2006, de 14 de junio se estructuran en cuatro secciones referidas a las disposiciones generales, legítimas de los descendientes, la legítima del cónyuge viudo, de la preterición y la desheredación.

\subsubsection{La legítima en el Derecho foral gallego}

La discusión actual que se produce, en toda Europa, es si se mantienen las legítimas, o bien se suprimen. La postura de los que piensan que la mejor opción sería concederle la total libertad de disposición post mortem al testador. La otra postura, total mente opuesta a la primera, es constreñir esa libertad de disposición post mortem. La realidad parece decantarse, a la vista de las reformas sucesorias a nivel continental, a favor de la primera de las posturas expuestas. Si bien hay que resaltar que ningún sistema llega al extremo absoluto. Parece ser que la tendencia europea, en tema de legítimas, pretende hacer lo que ha hecho el sistema legitimario gallego, es decir, pasar de una rigidez palpable a una proyección clara hacía la libertad de disponer post mortem. Sin duda es la Ley 2/2006, de 14 de junio, la que introduce estas pioneras modificaciones, o "mejoras", como dicen algunos autores en las instituciones ya existentes. Cuyo objetivo es dar solución, entre otros, a las instituciones como la de la legítima ${ }^{790}$.

\footnotetext{
${ }^{790}$ Véase Rebolledo VARela, A.L.: "La iniciativa legislativa en el Derecho Civil de Galicia", Boletín de la Academia Vasca de Derecho = Zuzenbidearen Euskal Akademiaren aldizkaria, año 10, núm. 21, 2011, pág. 86.
} 
El mantenimiento de una parte de la herencia como reserva legal a favor de los hijos en los bienes transmitidos post mortem es todavía una realidad en los países del entorno cultural más cercano. Está basado en la solidaridad que sigue amparando y agrupando a la familia que, parece encontrar dicha solidaridad, en otros campos de actuación. Otro sector, frente a la argumentación del desamparo de los legitimarios por la supresión de la legítima argumenta que se puede conseguir la misma solidaridad que cubren las legítimas, con un derecho de alimentos post mortem $^{791}$.

\subsubsection{Naturaleza jurídica de la legítima en Galicia}

Conforme al artículo 249 LDCG la legítima actual gallega es pars valoris $^{792}$. Un simple derecho de crédito cara al heredero con la acción legal de reclamación de legítima, como acción personal y no real. Ello por virtud del precitado artículo 249 LDCG. Es decir, se configura como un derecho de crédito del legitimario ${ }^{793}$. Por lo tanto, en el caso de los descendientes se trata de un cuarto del haber hereditario, según dispone el artículo 243 LDCG. Con la excepción de que el testador hubiera designado, en su testamento, la forma de satisfacer la legítima a los legitimarios, los herederos del causante tienen la opción de pagarla en bienes relictos o en

\footnotetext{
${ }^{791}$ García Rubio, Nieto Alonso, A, Herrero Oviedo, "Las legítimas...", op. cit., pág. 204. Resaltan estas autoras un arraigo gallego del sentir popular la idea de que los hijos son por naturaleza herederos y que desheredar a un hijo es dejar reducida su herencia a lo que le corresponda por legítima. También resaltan palabras del autor Gallego del Campo, acerca de una costumbre del ámbito rural de Galicia, con plena vigencia hoy en día. Se trata de hacer la partición de los bienes de los padres a favor de sus hijos en vida de los primeros, con un acuerdo entre padres e hijos en que lo que se reparte es la conjunta herencia de padre y de la madre, es decir, se juntan los bienes de ambos progenitores y se reparten como si de uno sólo se tratara.

792 Artículo 229. 1 LDCG: “1. El legitimario no tiene acción real para reclamar su legítima y será considerado, a todos los efectos, como un acreedor".

${ }^{793}$ AragonÉs SeIJo, S.: "Curso de derecho civil de Galicia”, (Director: J. M. Busto Lago) Revista Crítica de Derecho Inmobiliario, núm. 761, mayo 2017, pág. 1655.
} 
metálico. Lo pueden hacer incluso en metálico extrahereditario. De no haber acuerdo entre los herederos, en la forma de satisfacer su derecho al legitimario, tendrá que satisfacerse su parte a estos, con bienes hereditarios.

Conforme al artículo 251. 3 LDCG en el supuesto de tener que hacer reducción de legados, donaciones u otras atribuciones, hechas por el causante, cuyo concepto es satisfacer las legítimas, los herederos pueden evitar, tal reducción, pagando en dinero la legítima correspondiente. También es destacable que toda transacción o repudiación sobre la legítima, con excepción de la apartación, es nula si se hace con anterioridad a la apertura de la sucesión ${ }^{794}$.

Se deduce del primer párrafo del artículo 244 LDCG que el legitimario en Galicia no es cotitular del caudal hereditario. Por lo tanto, significa que el legitimario no soporta las bajadas ni las subidas a que está expuesto el caudal hereditario. Lo está desde el fallecimiento del causante, hasta la satisfacción del derecho a legítima. Ello también implica que al no ser cotitular de la herencia no pueda instar la partición de la misma y ello concuerda con el artículo 782. 1 LEC 2000 que únicamente reconoce legitimación activa al heredero o legatario de parte alícuota para interponer juicio divisorio. La legítima gallega, como un simple derecho de crédito, sigue también la tendencia que sigue la legítima europea, de los países que han efectuado reformas sobre esta institución. Lo han hecho en base a una supuesta actual realidad social, más acorde que con aquellos sistemas que todavía conservan la institución de la legítima como pars hereditatis o pars bonorum $^{795}$.

\footnotetext{
794 JuÁrez GonZÁLEZ, GPS Sucesiones..., op. cit., pág. 442. Se refiere este autor a la apartación como el acuerdo en el que el legitimario renuncia a su derecho y condición a cambio de la entrega actual de bienes.

795 Véase García Rubio, Nieto Alonso, Herrero Oviedo, Las legítimas en la Ley 2/2006..., op. cit., pág. 208. Manifiestan las autoras que, la nueva configuración, es 
3.6.5. Los legitimarios en el sistema gallego

Conforme al artículo $238^{796}$ LDCG son legitimarios en Galicia los hijos y descendientes de hijos premuertos y el cónyuge viudo. Este precepto es fiel reflejo de los cambios producidos en el sistema legitimario gallego con respecto a la legislación anterior. Es decir, la de 1995, que como ya se ha dicho, hacia remisión al Derecho común del Código civil. De esta legislación de 1995, se suprimen como legitimarios a los ascendentes. Si es cierto que los ascendientes han sido suprimidos como legitimarios, también es cierto que dichos ascendientes son llamados en segundo lugar en la sucesión legal. El primer lugar lo ocupan los descendientes, el segundo los ascendientes y el tercero el viudo o pareja de hecho superviviente. Ello en virtud del artículo 267 LDCG que remite al Código civil y por lo tanto es aplicable el artículo 913 y ss ${ }^{797} \mathrm{Cc}$. Este precepto del Derecho común es claro y conciso, disponiendo que sólo a falta de parientes del causante hereda el viudo y después el Estado ${ }^{798}$.

decir, la legítima como pars valoris, evita cotitularidades indeseadas que infieren frecuentes conflictos. El pago en metálico de la legítima es más favorable para la libre circulación de los bienes inmuebles y ayuda a mantener activos los negocios que tenía el causante en vida. El Derecho napoleónico, incidía en las legítimas, buscando la misma causa, la circulación de los bienes, por lo tanto, no se puede, tal bendecía, atribuir a la necesidad actual, sino más bien a la necesidad de siempre de que los bienes circulen.

796 Artículo 238, LDCG son legitimarios: 1. ${ }^{\circ}$ Los hijos y descendientes de hijos premuertos, justamente desheredados o indignos. 2. ${ }^{\circ}$ El cónyuge viudo no separado legalmente o, de hecho".

797 Artículo 913 Cc: “A falta de herederos testamentarios, la ley defiere a los parientes del difunto, al viudo o viuda y al Estado".

${ }^{798}$ Más información en GARCía RUBIO, NIETO AlONSO, HERRERO OVIEDO, Las legítimas en la Ley 2/2006... ", op. cit., pág. 216. Se sorprenden las autoras acerca de la exclusión de los ascendentes como legitimarios, sin tener en cuenta el supuesto de tener necesitad y resérvales un derecho de alimentos, en una Comunidad Autónoma caracterizada por un fuerte envejecimiento de la población y la solidaridad entre familiares ha sido una constante sociológica. No sólo las autoras se sorprenden, sino también quien suscribe, de que por un deterioro de la mente o cualquier otra razón, los progenitores de una persona, aquellos que un día le dieron la vida pasaran necesidad mientras un extraño disfruta con sus bienes. 


\subsubsection{Los descendientes}

La legítima de los descendientes es una legítima colectiva y reducida, como se ha dicho, a la cuarta parte del caudal hereditario. Ello sin hacer mención alguna, en su Preámbulo la citada Ley 2/2006, de 14 de junio. Dicha cuarta parte tendrá que dividirse entre los hijos o sus estirpes, conforme al artículo $243 \mathrm{LDCG}^{799}$. Es el artículo 245 LDCG el referente para determinar si los legitimarios han satisfecho su derecho a legítima. Este precepto incluye las bases de imputación individual de la legítima recibida por los descendientes en concepto de legítima. Bien sea por sucesión mortis causa, bien por herencia, legado o pacto sucesorio, en concepto de mejora, o bien a través de donaciones hechas en vida del causante. Las atribuciones citadas hechas a favor del legitimario, a excepción de las liberalidades, serán imputadas en su legítima de manera individual. Con el fin de comprobar si su legítima ha sido satisfecha correctamente o bien tiene derecho al complemento de legítima que recoge el artículo $247^{800}$ LDCG. Por lo que se refiere a atribuciones hechas a extraños hay que tener presente si en todo caso perjudican a la legítima. Por si llega el caso de ser afirmativo, el perjuicio, proceder a su correspondiente reducción.

\subsubsection{El cónyuge viudo}

Como rasgo importante y novedoso cabe destacar que la Ley 2/2006, de 14 de junio regula la legítima del cónyuge viudo en el Capítulo $\mathrm{V}$ dedicado a las legítimas dentro del Título X. Cabe advertir que en Galicia

\footnotetext{
${ }^{799}$ Mantiene Lasarte Álvarez, C.: Derecho de sucesiones, tomo $7^{\circ}$, 10 ${ }^{\mathrm{a}}$ Ed., Marcial Pons, Barcelona 2015, pág. 169, que "frente a la tradición histórica, la legítima de los descendientes queda reducida ahora a la cuarta parte del valor del haber hereditario líquido".

${ }^{800}$ Artículo 247 LDCG "Si los bienes atribuidos por el causante a un legitimario no fueran suficientes para satisfacer su legítima, este sólo tendrá derecho a su complemento, el cual se satisfará de acuerdo con las reglas del artículo anterior".
} 
le corresponden los mismos derechos que al viudo, al superviviente de las parejas de hecho inscritas en el pertinente Registro. Conforme al artículo 238 LDCG es legitimario el cónyuge no separado legalmente o de hecho. Su legítima de conformidad con los artículos 253 y ss LDCG consiste en una cuarta parte del caudal hereditario en usufructo vitalicio, si concurre a la sucesión con descendientes. En el supuesto de concurrir a la sucesión con no descendientes le corresponde la mitad del caudal hereditario en concepto de uso y disfrute ${ }^{801}$. Solamente el artículo $255^{802}$ LDCG no se encuentra equivalente en el Código civil. Precepto el citado que proclama la opción de que dispone el causante de atribuirle determinados bienes al viudo por cualquier título, en usufructo o en propiedad. Destacar aquí, que no se ha contemplado la concurrencia del supérstite con los ascendientes debido a que estos, no gozan de cualidad de legitimarios ${ }^{803}$.

La potestad de cómo debe atribuírsele la legítima al viudo corresponde primeramente al causante, tanto el título por que se le atribuye, como los bienes que se incluyen en dicha atribución. Para los supuestos en que el causante no se pronuncie al respecto del precitado artículo 255 LDCG entran en juego los artículos 253 y 254 del mismo Código. Lo hacen para satisfacer su derecho de legítima al cónyuge supérstite o al sobreviviente de la pareja de hecho inscrita, en el llamamiento legal directo. También el mismo derecho le asiste en el supuesto de la sucesión intestada, en el caso

\footnotetext{
${ }^{801}$ JUÁREZ GONZÁLEZ, GPS Sucesiones..., op. cit., pág. 453.

802 Artículo 255 LDCG "El causante podrá satisfacer la legítima del cónyuge viudo atribuyéndole por cualquier título, en usufructo o propiedad, bienes determinados de cualquier naturaleza, un capital en dinero, una renta o una pensión".

${ }^{803}$ Se encuentra más información en: ARAGONÉS SEIJO, "Curso de derecho civil...", op. cit. págs. 1655 y 1656. "Los legitimarios son los hijos y los descendientes de hijos premuertos, justamente desheredados e indignos -a los que se le atribuye una cuarta parte del valor hereditario líquido- y el cónyuge viudo o pareja de hecho -que tendrá el usufructo de una cuarta parte si concurre con descendientes o de la mitad en caso de extraños-, careciendo de tal calidad los ascendientes del causante".
} 
de concurrir con herederos con preferencia, por ejemplo, con descendientes. Su derecho alcanzaría, en usufructo vitalicio, la cuarta parte del caudal hereditario. La legítima viudal gallega, como se ha anticipado, se ha reducido con respecto a su anterior legislación y en consecuencia se aparta de lo dispuesto para el mismo menester en el Derecho común ${ }^{804}$.

En los artículos 244 y 245 LDCG se dispone cómo determinar el haber hereditario del cónyuge viudo. Consiste en sumar el valor de todos los bienes y derechos al momento de la muerte del causante más el valor de todas las atribuciones hechas en vida del disponente. También se incluirán las dadas en apartación como pago de legítima (donatum). Estas últimas se atenderán al valor del momento de la transmisión del patrimonio. Tras haber desaparecido en Galicia la legítima de los ascendientes, en el supuesto de concurrir con ellos, no implica diferencia alguna de hacerlo con no legitimarios o con extraños. Para la fijación, de estos últimos, se tendrá que seguir lo dispuesto en el artículo 254 LDCG. Para el cálculo de la cuota, cuando el viudo concurra con extraños, se atenderá a lo dispuesto para calcular la concurrencia con descendientes, es decir, al artículo 254 LDCG que a su vez remite al 245 del mismo Código ${ }^{805}$.

\footnotetext{
${ }^{804}$ Señala GARCía Rubio, Nieto AlOnSO, Herrero Oviedo, Las legítimas en la Ley 2/2006..., op. cit., pág. 244. Basta recordar que el Código civil atribuye en su artículo 834, al viudo/a concurriendo con descendientes, el usufructo de un tercio del caudal hereditario, es decir, el usufructo del tercio que se destina a mejoras. Conforme a los artículos 837 y 838 del Código civil, si concurre a la sucesión con ascendientes o con no legitimarios tendrá derecho a la mitad o a los dos tercios en usufructo vitalicio de la herencia. El cambio en el sistema actual gallego, de conformidad con el artículo 254, LDCG, de no concurrir con descendientes- ascendientes, colaterales o extraños el derecho usufructuario del viudo siempre será sobre la mitad de la herencia.

${ }^{805}$ Véase García Rubio, NiETo AlOnSO, Herrero Oviedo, Las legítimas en la Ley $2 / 2006 \ldots$. op. cit., pág. 246. Alerta este autor, de la paradoja que se produce en lo referente al llamamiento de los ascendientes, que ya ha quedado claro que no son legitimarios, con oposición al artículo 807.2 del Código civil que reconoce a los ascendientes como herederos forzosos. Si dichos ascendientes son llamados en la sucesión legal, conforme al artículo 267, LDCG, cuando este precepto remite al Código
} 


\subsubsection{Los pactos sucesorios}

El artículo 181 LDCG de la Ley 2/2006, de 14 de junio de Derecho Civil de Galicia establece la posibilidad de hacer pactos sucesorios, como segunda forma de disponer la sucesión mortis causa. Evidentemente han de ser pactos sucesorios admitidos por la Ley. Es decir, son aquellos pactos por los que se les otorga bienes concretos a los descendientes que pueden conllevar, incluso, la entrega de bienes presentes. Estos pactos sucesorios tendrán que otorgarse en escritura pública (Art. 211 LDCG). En el pacto de apartación el legitimario apartado queda excluido de la sucesión, por si y su linaje, es decir, queda excluido de la herencia del causante. Una modalidad del pacto de mejora puede ser "el de labrar y poseer". que está enfocado de cara a un pactante que quiera conservar íntegro e indivisible un bien concreto $^{806}$. Entonces puede pactar con alguno de sus descendientes su adjudicación total. Los pactos de mejora del artículo 214 LDCG son aquellos que se convienen a favor de descendientes para la sucesión de determinados bienes ${ }^{807}$. Estos pactos se llevan a cabo entre parientes que

civil en las secciones 1. ${ }^{\mathrm{a}}, 2 .^{\mathrm{a}}$ y $3 .^{\mathrm{a}}$ del capítulo IV del título III. Que recoge los artículos 935 a 942, ambos del Código civil.

${ }^{806} \mathrm{Al}$ respecto de la sucesión paccionada en Galicia se refiere, ARAGONÉS SEIJO, S.: "Curso de derecho civil de Galicia", (Director: J. M. Busto Lago) Revista Crítica de Derecho Inmobiliario, núm. 761, mayo 2017, pág. 1655," en la que se distingue entre los pactos de mejora y los pactos de apartación. En los de mejora el ascendiente atribuye determinados bienes, de forma irrevocable, a favor de un hijo o descendiente y puede ser con o sin entrega coetánea de los bienes. Una modalidad de mejora es la de labrar y poseer, para mantener indiviso un lugar acasarado. En los pactos de apartación se excluye irrevocablemente a un legitimario y a su linaje de la condición de herederos forzosos a cambio de la adjudicación de bienes por el apartante".

${ }^{807}$ El pacto sucesorio es un negocio jurídico mortis causa, de naturaleza jurídica, cuyo contenido es la ordenación sucesoria del causante. Difiere con el testamento en la forma de revocación, ya que este puede revocarse de manera unilateral, mientras que el pacto sucesorio requiere el consentimiento de ambas partes. Conforme al artículo 209, LDCG son pactos sucesorios los pactos de mejora y los de apartación. Por medio de la apartación de la legítima se adjudica al legitimario, en vida del causante, la titularidad de determinados bienes y queda excluido como legitimario. La exclusión se refiere a la condición de legitimario, con independencia de que llegada la sucesión el valor de la legítima sea superior al valor recibido por apartación. 
puede suponer la entrega de bienes presentes cuya consecuencia puede derivar en adquirir la propiedad del bien por parte del mejorado ${ }^{808}$.

La sucesión vigente en Galicia por causa de muerte es diferente, al menos, de la recogida por el Derecho común. Cuya razón deriva de la prohibición de la sucesión contractual que se dispone en el artículo 1271. 2 Cc. Ya se ha dicho que la sucesión voluntaria en Galicia puede ordenarse toda o en parte, bien por testamento, bien por pacto sucesorio, además de la sucesión legal. Al igual que ocurre con el resto de Comunidades que se rigen por Derecho foral y sus ordenamientos contemplan la validez del pacto sucesorio, como segundo sistema de delación sucesoria. Contrariando con ello al principio romano: "nemo pro parte testatus pro parte intestatus decedere potest" (Nadie puede morir en parte testado y en parte intestado $)^{809}$. Surge el problema de la naturaleza del pacto sucesorio cuando no cabe duda que sea jurídica, pero tampoco cabe duda que su carácter sea contractual $^{810}$. No cabe duda que a efectos de tributos, las ventajas de tributar por impuesto de sucesiones es mucho mayor que hacerlo por actos

\footnotetext{
${ }^{808}$ CREMADES García, P.: "Pactos sucesorios y Derecho foral" en Sucesión mortis causa de la empresa familiar: la alternativa de los pactos sucesorios, Dykinson, 2014, págs. 215 a 22. "Sólo hay dos cuestiones en las que se permite a las partes disponer al respecto; en primer lugar, se pueden recoger expresamente en el pacto los supuestos en que quedará sin efecto, y en segundo lugar cabe la delimitación de las facultades dispositivas de los adjudicantes, por actos inter vivos, a título oneroso o gratuito (art. 216 LDCG)".

${ }^{809}$ RÓDENAS GÓMEZ, A.: "El principio nemo pro parte testatus pro parte intestatus decedere potest: estudio sobre el origen, evolución y trascendencia en el ordenamiento jurídico actual", Revista de Derecho UNED, núm. 17, 2015, pág.836. "El Principio que tratamos es la lógica y natural consecuencia de los demás principios reguladores de la sucesión romana. Así, en todo testamento ha de existir institución de heredero, si el que es heredero lo es siempre, y si al heredero acrece la porción vacante de la herencia. En definitiva, tres elementos: Existencia; Perdurabilidad y Universalidad atañen a la institución del heredero. Esa es la verdadera razón de ser del Principio Nemo Pro Parte, dar coherencia al conjunto del ordenamiento, como norma y valor".

${ }^{810}$ EstÉVEZ ABELEIRA, T.: "El pacto de mejora como negocio jurídico mortis causa", Revista Crítica de Derecho Inmobiliario, núm. 758, noviembre 2016, pág. 3116.
} 
inter vivos. De hecho, como actos mortis causa, ha calificado el TSJ de Galicia el pacto sucesorio ${ }^{811}$.

\subsubsection{Causas de desheredación}

Es el artículo 263 LDCG el que recoge las justas causas de desheredación en Galicia. Constituye una innovación que la desheredación y la preterición estén reguladas en una misma sección, concretamente en el Capítulo dedicado a las legítimas. Es la primera vez que estas instituciones se regulan de manera autónoma en Galicia, es decir, sin remisión al Código civil. Es sin duda alguna la desheredación en Galicia, una institución restrictiva de derechos que se regula en los artículos 262 a 265, de la Ley 2/2006, de 14 de junio. Al igual que el Código civil, la desheredación en Galicia ha de expresarse en el testamento, con la correspondiente justa causa de desheredación de las tasadas en el artículo 263 LDGC. El artículo 262. 2 LDGC excluye cualquier otra posibilidad de desheredar post mortem, es decir, para que la causa de desheredación se tenga por justa en

\footnotetext{
${ }^{811}$ Lo ha hecho a efectos de tributos, es decir, tributar por el impuesto de sucesiones. En cambio el Tribunal Económico Administrativo Regional, la Abogacía del Estado y la Dirección General de Tributos consideraban que los pactos de mejora y de apartación debían tributar por la Ley del IRPF ${ }^{811}$. Ha sido el Tribunal Supremo el que ha tenido que resolver tal controversia y lo ha hecho a favor de la incursión del pacto sucesorio en los tributos atinentes al a la sucesión por causa de muerte. En este sentido la STS de 09/02/2016 (Roj: STS 407/2016) F..J. 4 ${ }^{\circ}$ apartado $3^{\circ}$, dispone además de incluir en el Derecho patrio [Derecho español] el Derecho foral de cada Comunidad de España con derecho a ello y competencias en la materia, razona lo siguiente: "No se hace cuestión que entre los títulos sucesorios se encuentran las formas convencionales de pactar la sucesión, que prohibidos en el Código Civil, sin embargo se contemplan en algunas de las legislaciones especiales y forales, y que permiten que en vida del causante se produzca la transmisión de elementos patrimoniales, esto es, son atribuciones patrimoniales por causa de muerte o mortis causa aunque la transmisión se produzca en vida del causante; lo cual es tenido bien presente por el legislador estatal tributario, como se comprueba al regular el Impuesto sobre Sucesiones y Donaciones, Ley 29/1987, de 18 de diciembre".
} 
el Derecho foral gallego ${ }^{812}$. Por lo tanto no tendría validez, lo dispuesto en pacto sucesorio para desheredar a un legitimario por una justa causa ${ }^{813}$.

Son tres las causas de desheredación recogidas en el artículo 263 LDGC además de la remisión que hace a las de indignidad del artículo 756 del Código civil. A simple vista puede parecer que ha habido una reducción de causas con respecto a las dispuestas por el Código civil. Estimo que el legislador gallego sólo ha hecho que simplificar y agrupar las dispuestas en el Derecho común. Ello se sonsaca al advertir la mayor parte de los comportamientos recogidos por la indignidad y la desheredación, en que el legislador estatal los califica como propios de la desheredación. Como también lo hace el legislador gallego. La jurisprudencia menor interpreta de manera flexible, conforme a la realidad social, las causas desheredación, por lo que la prohibición de la analogía y la interpretación extensiva no es

\footnotetext{
${ }^{812}$ La ya citada STSJ de Galicia de 26/01/2017, (Tol. 5.998.345) F. J. $3^{\text {o }}$ hace una aportación muy esclarecedora a la diferencia que existe entre una desheredación sobrevenida o consecuente y una desheredación "como realidad jurídica contemplada en su verdadera dimensión formal y material", es decir, una verdadera causa de desheredación articulada en el testamento conforme y concordante con las causas de desheredación que el Código civil contempla en su artículo 849, con relación a los artículos 852, 853 y 854 Cc. Se sonsaca de las palabras del TSJ de Galicia que el término desheredación es jurídico cuando cumple los requisitos que estipule el pertinente ordenamiento de que se trate. De lo contrario sería incorrecto hablar de desheredación, al menos, desde el campo de la judicatura. Por ejemplo, sería incorrecto, jurídicamente hablando, decir: que un hermano ha "desheredado" a otro. Entre otros, porque no hay causas de desheredación previstas para los colaterales.

${ }^{813}$ Véase la SAP de Orense (S. $1^{\text {a }}$ ) de 02/03/2017 (Tol. 6.086.793) en que la Sala recoge la doctrina del Tribulan Supremo al respecto al testamento como único instrumento válido para incluir en él, la voluntad del testador de desheredar a un legitimario e incluir una justa causa de desheredación, de las tasadas por la Ley de Galicia. Dice la referida SAP en su F. J. $2^{\circ}$ "La solución de instancia no es compartida por este Tribunal de apelación que llega a conclusiones contrarias a las del órgano a quo recogiendo doctrina contenida en sentencia del TS 1 de julio 1969 y 22 de junio de 2006, entre otras. Y por ello podemos concluir diciendo: Que la desheredación y la preterición han de resultar exclusivamente del testamento por ser este la expresión más solemne de quien dispuso sus bienes para después de su muerte con los efectos que ello conlleva valorando la voluntad del testador al tiempo del otorgamiento de dicha disposición. Al ser preterido uno de los hijos del testador, debe anularse la institución como heredero universal de D. $\mathrm{xxx}$, con las consecuencias que se exponen en la parte dispositiva".
} 
equivalente de un criterio valorativo rígido o sumamente restrictivo ${ }^{814}$. La justa causa de desheredación, goza de presumida veracidad, hasta que es negada por parte del legitimario afectado por la causa predispuesta. El artículo 263. 2 establece que corresponde la carga de la prueba de la causa de desheredación al heredero del testador si la persona desheredada la negare. Hay que resaltar ante este hecho que la jurisprudencia analiza con rigor y detalle la citada prueba practicada en juicio ${ }^{815}$.

La primera causa de las tasadas en el artículo 263 LDGC es la de haberle negado alimentos al causante, que no es otro, que el deber de alimentos que regula el Código civil en sus artículos 142 y ss, para poder valorar dicho deber. Esta primera causa de desheredación recogida en el

\footnotetext{
${ }^{814}$ SAP de La Coruña (S. 6 ${ }^{\text {a }}$ ) de 15/04/2016 (Tol. 5.733.055). Invoca la Sala, la ya citada en este trabajo STS de 3/6/2014 (Roj: 2484/2014) como justificación a la analogía e interpretación extensiva de las causas de desheredación en Galicia. F.J. 1" , "Los apelantes invocan a su favor la jurisprudencia delimitada por la sentencia del Tribunal Supremo de 3/06/2014. A este respecto, se pronunció ya esta Sección de la Audiencia Provincial, en su sentencia de 24 de noviembre de 2014, a cuyo tenor: "Ha de asumirse como postura interpretativa adecuada la expresada por la reciente y difundida STS $\mathrm{n}^{\mathbf{o}}$ 258/2014 de 3/6/2014 pues, aunque no nos hallamos en el ámbito normativo del derecho común como luego se desarrollará, la identidad de la regulación legal del presupuesto de la desheredación en la norma gallega hace que tal pauta interpretativa, en ausencia de jurisprudencia propia y distinta del Tribunal Superior de Xustiza de Galicia sobre la cuestión, deba guiar la interpretación de la norma autonómica, en especial dada la primacía de la voluntad del causante y la restricción de la extensión de la legítima introducidas por la Ley de Derecho Civil de Galicia de 2006. Dicha resolución considera que la imposibilidad de analogía o de interpretación extensiva de las causas de desheredación no equivale a un criterio valorativo rígido o sumamente restrictivo, sino que ha de permitir una "interpretación flexible conforme a la realidad social, al signo cultural y a los valores del momento en que se producen".
}

${ }^{815}$ Véase la SAP de La Coruña (S. 6 ${ }^{\text {a }}$ ) de 31/03/2015 (Tol. 4.948.043) por lo referente a la carga de la prueba que recae en el heredero conforme a la legislación vigente de Galicia. F.J. 20 " "Por otro lado, como señala la sentencia de instancia, el artículo 850 del mismo texto legal dispone que la prueba de ser cierta la causa de la desheredación corresponderá a los herederos del testador si el desheredado la negare. "Por tanto, negada por el demandante la causa de desheredación corresponde a los demandados acreditar el comportamiento injurioso o vejatorio de aquél hacia sus padres y en el supuesto de autos no se ha acreditado tal circunstancia. La sentencia de instancia analiza con rigor y detalle la prueba practicada en el acto del juicio y llega a la conclusión de que no hay prueba del comportamiento achacado al demandante como fundamento de la desheredación, razonamientos que esta Sala comparte plenamente". 
artículo 263. 1 LDGD es la prevista en el artículo 853. 1 de Código civil. Ello en base a que en ambas legislaciones, común y foral, la causa y la desheredación han de ser justas y ello conlleva a que el legitimario niegue al testador los alimentos sin tener motivos legítimos para proceder de tal manera ${ }^{816}$. Se entiende trasladable al ámbito gallego, la doctrina del Tribunal Supremo, al efecto de "no a la vía judicial" para la reclamación de alimentos por parte del testador y la negativa a otorgarlos por parte del legitimario. Ello no obsta que se tenga que acreditar dicha negación por parte del legitimario ${ }^{817}$.

La segunda justa causa de desheredación trata del maltrato de obra o injuria grave. El Derecho común recoge esta causa en el artículo 853. 2 del Código civil, distinguiendo entre el maltratado de obra o injuriado gravemente de palabra. Queda aquí la duda, de ¿Si el maltrato es de otra forma al de palabra, concurre igualmente la justa causa de desheredación? El legislador gallego al omitir el término "palabra" del precepto admite todo tipo de maltrato como comportamiento apto para poder desheredar a un legitimario. El artículo 263.2 LDGD no exige resolución judicial condenatoria previa como acreditación del maltrato, lo que implica que será el juzgador el que tendrá que valorar, a través de la práctica de la prueba

${ }^{816}$ Dice la SAP de La Coruña (S. 6 $6^{\text {a }}$ ) de 16/07/2013 (Tol. 3.921.688) F. J. 1 ${ }^{\text {. }}$ " "Se mantiene en apelación solamente la concurrencia de la causa de desheredación de negación de alimentos prevista en el art. 263.1 LDCG., que no debe estimarse distinta de la regulada en el art. 853.1 CC., pues al deber ser "justas" (arts. 262 y 263 LDCG) la desheredación y su causa, tal condición no concurriría si el legitimario cuenta con los motivos legítimos para negar los alimentos que prevé el art. 853.1 Cc".

${ }^{817}$ Véase GARcía Rubio, NiETo AlOnSO, HeRrero OVIEDO, LAS legítimas en la Ley 2/2006..., op. cit., pág. 279, cuando cita a Espinosa de Soto, nota 348, debido a que el legislador gallego antepone, en el artículo 263.1, LDCG, "persona testadora". Efectivamente hubiera bastado con sólo poner "testador". Ocurre lo mismo en el caso de "persona desheredada" o "persona preterida". Supongo que ha de ser una persona tanto la testadora como la desheredada como la preterida y no otra clase de ser vivo. Pero, estimo que el legislador gallego, es una opinión personal, simplemente ha tratado de no incurrir en supuestos malentendidos relativos al género y tener que escribir Testador/a, Preterido/a o desheredado/a. 
decidir la existencia o no de maltrato. La jurisprudencia, como se ha visto a lo largo de este trabajo, encuadra el maltrato psicológico dentro del maltrato de obra que recoge Ley 2/2006, de 14 de junio, de Derecho civil de Galicia ${ }^{818}$. También se considera la falta de atención un maltrato a efectos del artículo 263. 2 LDGD a pesar del carácter restrictivo de las causas de desheredación.

Incluso la jurisprudencia menor de la Comunidad de Galicia remite al Tribunal Supremo como refrendo de la interpretación para calificar de maltrato de obra, sin que necesariamente haya mediado violencia física. También es reiterada la jurisprudencia del Tribunal Supremo, a la hora de interpretar el maltrato de obra, así como la voluntad reiterada del testador de desheredar al legitimario ${ }^{819}$. Cabría la posibilidad incluso de encontrarse en esta segunda causa de desheredación el maltrato y la injuria, ya que

\footnotetext{
${ }^{818}$ La ya referida SAP de La Coruña (S. 6 ${ }^{\text {a }}$ ) de 15/04/2016 (Tol. 5.733.055) F. J. $1^{\text {o }}$ se refiere a la inclusión del maltrato psicológico dentro del maltrato de obra: "la Ley de Derecho Civil de Galicia de 2006, para considerar que "el maltrato psicológico, como acción que determina un menoscabo o lesión de la salud mental de la víctima, debe considerarse comprendido en la expresión o dinamismo conceptual que encierra el maltrato de obra", para concluir, que fuera de un pretendido "abandono emocional, como expresión de la libre ruptura de un vínculo afectivo o sentimental, los hijos, aquí recurrentes, incurrieron en un maltrato psíquico y reiterado contra su padre. (...) Cabe pues considerar una de las especies del maltrato el constituido por actuaciones que supongan una grave falta de respeto o consideración, o el grave desentendimiento y abandono respecto del causante, que ha de traducirse en actos externos que puedan así considerados y que no deben confundirse con que en los ámbitos afectivos o subjetivos las relaciones entre el legitimario y el causante puedan ser frías, conflictivas o muy tenues; ni con aspectos valorativos sobre el grado de compromiso personal del legitimario hacia el causante (...)".

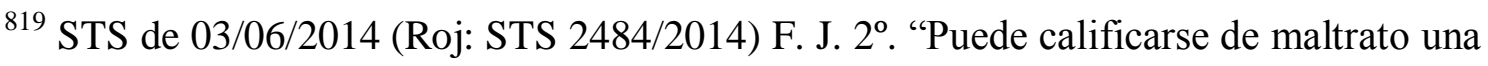
actuación concreta de uno de los herederos, aunque en su actuación no haya mediado violencia física. Concretamente, en un caso manifestó, que, " no es necesario que la expulsión del domicilio por el hijo o por su esposa pero aceptada por él, sea mediante el empleo de fuerza física para que en la conducta de éste deba reputarse existente el maltrato de obra que la norma del artículo 853.2 del Código recoge como causa de desheredación, máxime cuando el estado de cosas que sigue a la salida de la casa de la madre, continúa durante años en los que ésta, vive precariamente sin ser mínimamente atendida en modo alguno por el descendiente cuya desheredación, por maltrato según el testamento de la víctima ha de reputarse legalmente correcta ".
} 
suelen andar bastante cerca la una de la otra. El precepto parece ser bastante aclaratorio cuando dice maltrato o injuria. La cosa cambiaría si entre ambas se interpusiera la conjunción "y" que entonces sí que tendrían que darse las dos para que la desheredación fuera justa ${ }^{820}$. Si bien destacan algunos autores que tanto el maltrato como la injuria han de ser graves con un perjuicio considerable para el perjudicado. O bien la conducta en ese aspecto ha de ser reiterada o habitual. Ello es debido a la importancia de las consecuencias que conlleva tanto el maltrato como la injuria para el legitimario $^{821}$.

La tercera y última causa de desheredación del artículo 263.3 LDGC viene referida al incumplimiento grave o reiterado de los deberes conyugales. Como es evidente únicamente tiene aplicación al legitimario, cuando este es cónyuge o superviviente de la pareja de hecho. Como en la causa anterior ha de tratarse de un comportamiento grave o bien de manera reiterada. Cuestión la citada que tendrá que ser valorada por el juzgador de Instancia. Para conocer esta causa con profundidad se deben de tener en cuenta los derechos y deberes conyugales dispuestos en los artículos 66 a 69 ambos del Código civil ${ }^{822}$.

${ }^{820}$ Véase SAP, de La Coruña (S. $5^{\mathrm{a}}$ ) de 04/12/2014 (Tol. 4.746.336) en que dispone la Sala en el F. J. $2^{\circ}$ que no han de darse el maltrato y la injuria para que prospere la justa desheredación por maltrato: "En el caso que nos ocupa no es necesario que concurran de manera cumulativa las dos causas de desheredación previstas en el artículo 263.2 $2^{\mathrm{a}}$ de la Ley de Derecho Civil de Galicia: haberle maltratado de obra o injuriado gravemente. Es suficiente la concurrencia de una de las dos. En el presente caso, ha quedado suficientemente acreditado que concurre el maltrato de obra, precisamente, porque los actos de la actora en vida de su padre son claros: no atendió, cuidó ni se ocupó del mismo, tanto es así que ya en 2001 (nueve años antes de su fallecimiento) el Sr. xxx la desheredó por esa falta de atención".

${ }^{821}$ GARCÍA Rubio, Nieto Alonso, Herrero Oviedo, Las legítimas en la Ley 2/2006..., op. cit., pág. 279.

${ }^{822}$ GARCÍA Rubio, Nieto Alonso, Herrero Oviedo, Las legítimas en la Ley 2/2006..., op. cit., pág. 279. 
La cuarta causa de desheredación deriva a las causas de indignidad del artículo 756 del Código civil. Sin detallar el precepto qué causas son asumibles por la legislación civil gallega. Sólo con citar la primera de las que recoge el precepto señalado del Código civil- la desheredación de los padres que prostituyeren o corrompieren a los hijos- ya se advierte que no puede tener cabida en el Derecho foral gallego. Ya que la Ley 2/2006, de 14 de junio, de Derecho civil de Galicia, como se ha dicho, no reconoce a los padres como legitimarios. Tampoco la causa cuarta tiene operatividad como causa de desheredación ya que se incurre en indignidad por el hecho de no haber denunciado la muerte violenta del testador. Es evidente que el testador no ha podido disponer en el clausulado de su testamento tal circunstancia. Por consiguiente, no puede ser causa de desheredación.

\subsubsection{Preterición}

De manera semejante a como trata el Código civil tanto la preterición intencional como la no intencional se regula esta institución en los artículos 258 y ss de la Ley 2/2006, de 14 de junio, de Derecho civil de Galicia. Destacar con respecto al Derecho común que, al no haber ascendientes como legitimarios en Galicia, tampoco pueden ser preteridos estos. Por lo tanto, sólo tendrá cabida la preterición cuando la omisión afecte a descendientes o al viudo o pareja superviviente de hecho. Según dispone el

artículo 258 LDGD la preterición intencional para los descendientes o también la no intencional para el viudo, no ataña a las disposiciones testamentarias. Aquí difiere y bastante con la nulidad de la institución de herederos que pregonaba el Código civil ante tal supuesto. Hay que decir al respecto, que con la reforma de 13 de mayo de 1981 se ha suavizado esta citada rotunda nulidad. Por la remisión que hace, el artículo antes citado, 
258 LDGD "percibir la legítima conforme a la presente Ley" Todo indica que hace remisión al artículo 243 y ss. LDGD ${ }^{823}$.

Siguiendo con lo expuesto en el párrafo anterior, simplemente se le pagará su legítima al legitimario en metálico ejercitando la acción de reclamación o de reducción de legítima. Sin olvidar lo dispuesto en el artículo 251.3, LDGD en que los afectados por la reducción podrán evitarla pagando las legítimas en dinero. Tampoco se puede olvidar la SAP de La Coruña, referida en el epígrafe de la apartación, en que precisamente pone este apartado $3^{\circ}$ del precepto último citado, como previsión para evitar la reducción por parte del afectado $^{824}$. El legislador gallego, al igual que el legislador común, en el artículo 814. 2 del Código civil siguen el mismo camino, por lo que a la preterición no intencional de los descendientes se refiere. En el sentido de diferenciar si la omisión ha tenido lugar en un solo o en todos los legitimarios. La preterición no intencional la regula el artículo 259 LDGD. Precepto este, que en su primer apartado, otorga facultad al legitimario preterido para solicitar y obtener la declaración de nulidad de la institución de heredero dispuesta por el testador ${ }^{825}$.

$\mathrm{Si}$ bien no afectara dicha nulidad al resto de disposiciones testamentarias. Los pactos sucesorios mantendrán su validez mientras su

\footnotetext{
${ }^{823}$ García Rubio, Nieto Alonso, Herrero Oviedo, Las legítimas en la Ley 2/2006..., op. cit., pág. 272.

${ }^{824}$ La SAP de La Coruña (S. 6 ${ }^{\text {a) }}$ de 31/03/2016 (Tol. 5.733.157) define la preterición como: "la omisión de un legitimario en el testamento sin que el mismo haya recibido atribución alguna en concepto de legítima y puede ser bien intencional, cuando el testador ha omitido al heredero ni le ha hecho atribución alguna sabiendo que éste existe, o bien errónea cuando el testador omite al legitimario porque sencillamente ignora su existencia. Los efectos de la preterición intencional coinciden con los de la desheredación injusta y vienen establecidos en el artículo 814 del Código Civil se reducirá la institución de heredero antes que los legados, mejoras y demás disposiciones".

825 Más información en GARcía Rubio, Nieto Alonso, Herrero Oviedo, Las legítimas en la Ley 2/2006..., op. cit., pág. 272.
} 
reducción no sea necesaria para pagar las legítimas. Se nota en falta que el precepto pase por alto las donaciones que en el anterior artículo 251. 1, LDGD las sitúa en orden de reducción después de los legados. Es tajante el precepto $259.1^{826}$ LDGD cuando anula de plano toda la institución de heredero del testamento, lo cual significa que también se anula la disposición hecha en favor del viudo. Se encuentra aquí un agudizado distanciamiento con el artículo 814. 2 del código civil, al disponer que mientras no perjudique a las legítimas, no se anulará la institución de heredero a favor del cónyuge viudo ${ }^{827}$. Sin embargo, se percibe un cierto privilegio hacia el legitimario en el segundo inciso, del ya citado artículo 251. 1 LDGD cuando trata de hacer efectiva la legítima. En el supuesto de ser preteridos, de manera no intencional, todos los descendientes, tanto en el Código civil, como en el artículo 259.2 LDGD pueden pedirse la nulidad de todas las disposiciones de contenido patrimonial ${ }^{828}$.

Se ha hablado en los párrafos precedentes de nulidad de la institución de heredero, cuyo paso siguiente tendrá que ser la apertura de la sucesión legal. De cuyos bienes, el testador, ha dispuesto en dicha institución de heredero. Pueden darse dos situaciones con la apertura de la sucesión legal. La primera que sólo se anule la institución de herederos en aquello que

\footnotetext{
${ }^{826}$ Artículo 259, LDGD, 1. "La preterición no intencional de un legitimario descendiente faculta a la persona preterida para obtener la declaración de nulidad de la institución de heredero hecha en testamento. Las demás disposiciones testamentarias y los pactos sucesorios serán válidos en cuanto su reducción no sea necesaria para el pago de las legítimas".

827 Para García Rubio, Nieto Alonso, Herrero Oviedo, Las legítimas en la Ley $2 / 2006 \ldots$.. op. cit., pág. 273, "es un poco incongruente con un ordenamiento jurídico moderno que busca dar mayor protagonismo al cónyuge viudo".

${ }^{828}$ Para Busto Lago, J. M.: "Los pactos sucesorios en la Ley 2/2006, de 14 de junio, de Derecho Civil de Galicia" Revista Crítica de Derecho Inmobiliario, núm. 706, marzoabril, 2008, pág. 540, "La apartación hace plenamente efectiva la legítima, sin perjuicio de la posibilidad de su reducción en cuanto sea necesaria para el pago de las legítimas, como precisa el inciso segundo del artículo 259.1 de la LDGC/ 2006, al regular los efectos de la preterición no intencional".
} 
afecte para satisfacer la legítima del preterido y no anular el resto. La segunda posibilidad es que todos los descendientes sean llamados a la sucesión legal. En el supuesto de ser preteridos de manera no intencional todos los descendientes, tanto en el Código civil, como en el artículo 259.2, de Derecho civil gallego, puede pedirse la nulidad de todas las disposiciones de contenido patrimonial. La doctrina jurisprudencial del Tribunal Supremo recogida por sentencias de las Audiencias Provinciales despeja toda clase de dudas. Mantiene, entre otros, la fecha que afecta a la preterición no intencional, que es la fecha en que el testador hace su testamento y no incluye al legitimario por ignorar su existencia. No importa que con posterioridad conozca de él ${ }^{829}$.

También la jurisprudencia, en este caso referida a Galicia, confirma lo anteriormente expuesto, sobre los efectos que despliegan ambas clases de preterición, es decir, la preterición intencional y la preterición no intencional o errónea. Donde la primera, desplegaría la reducción de la institución de heredero y la segunda la anulación de la misma. Ello conllevaría la consecuente apertura de la sucesión legal. Un hecho que pasa bastante desapercibido, pero que es un requisito imprescindible, es

${ }^{829}$ Véase la doctrina seguida por la STS de 22/06/2006 (Tol. 961.826) F.J. $2^{\text {o }}$ que señala: "la presente resolución no hace sino seguir la doctrina jurisprudencial que plasman las sentencias de 30 de enero de 1995 y 23 de enero de 2001. La primera dice textualmente: "preterición no intencional de la heredera forzosa nacida con posterioridad a su otorgamiento". Y desarrolla la segunda: "en el caso de que los hijos hayan nacido después de otorgado el testamento la no intencionalidad de su preterición en el mismo queda demostrada ex re ipsa. Sobre este respecto dispone el Alto Tribunal en el siguiente F.J. $\left(3^{\circ}\right)$ entiende que " La preterición viene referida al tiempo de otorgar testamento, en el caso de producirse preterición, aunque sea porque el hijo legitimario nace después, las pretericiones son es intencional o errónea y despliega sus efectos." Los efectos que despliega son: "Tales efectos son la anulación de las disposiciones testamentarias de contenido patrimonial, ya que el legitimario preterido en el presente caso por preterición errónea, es hijo del causante y único legitimario, por lo que cae en la norma antes citada del artículo 814CC". 
comunicar los cambios habidos al Registro de Actos de Última Voluntad $^{830}$.

\subsection{LAS LEGÍTIMAS EN EL DERECHO FORAL DE BALEARES}

El Derecho civil de Baleares, de marcada procedencia romana, en su Compilación de 1961, reconocía para los legitimarios, la tercera parte del caudal hereditario. Reconociendo por tales solamente a los hijos legítimos. En el supuesto de ser cuatro o más, la cuota ascendía a la mitad de la herencia. En defecto de descendientes pasaban a ser legitimarios los ascendientes. El Decreto Legislativo 79/1990, de 6 de septiembre, por el que se aprueba el Texto Refundido de la Compilación del Derecho Civil de las Islas Baleares (CDIB en adelante) conlleva distinguir según las islas de que se trate. Este Decreto Legislativo introduce distintas modificaciones al sistema legitimario balear. Dentro de las novedades a destacar cabe citar la condición de legitimario, la cantidad y la naturaleza jurídica de dicha cantidad en ambas agrupaciones forales, es decir, Mallorca y Menorca e

\footnotetext{
${ }^{830}$ A ello se refiere la SAP de Orense (S. $1^{\text {a }}$ ) de 02/03/2017 (Tol. 6.086.793) F. J. $2^{\text {o }}$ pone de manifiesto acerca de las consecuencias tanto de la preterición intencional como de la errónea: "Ante ello podría aquí hablarse de una preterición sobrevenida que se funda en causas que el testador no pudo racionalmente conocer al tiempo de testar; el nacimiento posterior de un hijo. Entonces frente a la preterición primeramente indicada " la intencional" surge otra sobrevenida no intencional que llevaría no a la reducción de institución de heredero, antes que los legados mejoras, sobre las que en el caso no se contiene disposición alguna en el testamento, sino a la anulación de la institución de heredero, apertura de sucesión abintestato con su comunicación al Registro de Actos de Última Voluntad".
}

La SAP de Orense de 02/03/2017 (Tol. 6.086.793) sigue la doctrina del Tribunal Supremo dispuesta en la STS núm. 669/2016, de 22/06/2006, Tol. 961.826, referida anteriormente. En base a dicha doctrina concluye en su F.J. 20, diciendo: "Que la desheredación y la preterición han de resultar exclusivamente del testamento por ser este la expresión más solemne de quien dispuso sus bienes para después de su muerte con los efectos que ello conlleva valorando la voluntad del testador al tiempo del otorgamiento de dicha disposición. Al ser preterido uno de los hijos del testador, debe anularse la institución como heredero universal de D. xxx, con las consecuencias que se exponen en la parte dispositiva, con la anulación de las disposiciones testamentarias de contenido patrimonial, ya que el legitimario preterido en el presente caso por preterición errónea". 
Ibiza y Formentera ${ }^{831}$. La Ley $7 / 2017$, de 3 de agosto ha introducido modificaciones en algunos preceptos de la Compilación de 1990.

\subsubsection{Las legítimas en Mallorca y Menorca}

Conforme al texto legal citado se debe distinguir entre Mallorca y Menorca e Ibiza y Formentera. En Mallorca y Menorca de conformidad con los artículos 41 y ss CDCIB son legitimarlos los hijos y descendientes. Lo son tanto los matrimoniales, los naturales, los no matrimoniales y los adoptivos. En concreto el artículo 42 CDCIB dispone que constituye la legítima de los hijos por naturaleza y adoptivos y en representación de los premuertos, de sus descendientes, la tercera parte del haber hereditario si fueran cuatro o menos de este número. Si excedieran de los anteriores, por legítima, les correspondería la mitad del caudal relicto. Con facilidad se advierte que no hay tercio de mejora en este Derecho foral.

La legítima de los ascendientes la regula el artículo 43 CDCIB disponiendo, en defecto de descendientes, tres supuestas situaciones que se pueden dar:

1. En el caso de que el causante sea el hijo del matrimonio, sus progenitores serán los legitimarios.

2. En la sucesión del hijo no matrimonial, los padres que lo hayan reconocido, o que una resolución judicial los haya reconocido como tales.

3. En la sucesión del hijo adoptivo, los padres que lo han adoptado.

Este precepto 43 CDCIB en su cuarto inciso dispone que la cuota legitimaría de los ascendientes será la cuarta parte del caudal hereditario.

${ }^{831}$ BERNAD MAINAR, R.: “La porción legítima...”, op. cit., pág. 1786. 
De vivir los dos padres se dividirá por iguales mitades entre ambos. De haber fallecido alguno de ellos, el sobreviviente heredará todo el haber hereditario. Finaliza el precepto disponiendo que todo ello sea sin perjuicio de lo establecido en los artículos 811 y 812 del Código civil. Estos dos preceptos, como se recordará hacen referencia, respectivamente, a las reservas de concretos bienes y a la preferencia sucesoria del donante cuando el donatario se convierte en causante.

El cónyuge supérstite, por virtud del artículo 45 CDCIB es legitimario si al morir su pareja no está separado por resolución judicial firme o de hecho. Por lo que respecta a la cuantía de su legítima depende de la concurrencia a la sucesión ${ }^{832}$. Si concurre con descendientes, su derecho se verá satisfecho con el usufructo de la mitad del haber de la herencia. Si concurre con los padres del causante, su derecho de usufructo, ascenderá hasta dos tercios de la herencia. En el resto de supuestos el viudo se convierte en usufructuario de todo el caudal relicto. Al referirme a "viudo" en el Derecho balear, me refiero también a la pareja superviviente de la pareja o unión estable, que en virtud del artículo 13 de la Ley 18/2001, de 19 de diciembre se equipara a la pareja de hecho estable, con el cónyuge supérstite ${ }^{833}$.

${ }^{832}$ Así la SAP de las Islas Baleares (S.5) de 12 /12/2016 (AC 2017\164) F.J.3 cuyo supuesto de hecho trata de la alegación de la esposa del causante de que este no estaba separado de su esposa a tiempo de fallecimiento con el propósito de ejercitar su derecho el usufructo vudal. La Sala argumenta que "no hubo separación definitiva, y que a pesar de la interposición de la demanda de divorcio, había convivencia entre la actora y el padre de la demandada, aun con muchas desavenencias y altibajos en la misma. Con todo, y a pesar de no retirar la demanda de divorcio ni plasmarse una voluntad reconciliatoria entre ambos, o de la propia iniciativa, individual, los dos incurrieron en causas imputables o, en concreto, no se deduce, en su conjunto, causa imputable de separación de hecho exclusivamente a la actora que pueda excluirle del derecho a la legítima (...)".

${ }^{833}$ VILA RIBES, C.: "La legítima en el Derecho civil de las Islas Baleares", en Tratado de legítimas, (Coord.T. F. Torres García), Atelier, Barcelona, 2012, págs. 294 a 295 cita la STSJ de Baleares de 03/10/2011 (Tol. 2.250.780) F. J. $2^{\circ}$ el tema de la equiparación 


\subsubsection{Naturaleza jurídica de la legítima en Mallorca y Menorca}

Como anteriormente ya se apuntaba ha habido una variación, por lo que a naturaleza jurídica se refiere, con respecto a la legislación anterior. La Compilación de 1961 disponía por medio de su derogado artículo 46 que se atribuía una porción del haber hereditario al legitimario y matizaba que debía de ser pagada con bienes de la misma. Incluso añadía la ineficacia de toda disposición en contrario por parte del testador. En cambio, la Legislación vigente en Mallorca y Menorca, conforme a los artículos 47 y 48 CDCIB dispone que se pueda atribuir su derecho al legitimario por cualquier título. En principio puede el testador entregarle su parte al legitimario mediante herencia, legado o donación. Por lo tanto, su carácter es de pars bonorum. El artículo precitado 48 CDCIB le atribuye el derecho al legitimarlo a una porción de bienes hereditarios en pago de su legítima. Si bien cabe la posibilidad de que el testador, o "el heredero partidor", autorice su pago en metálico, incluido el supuesto de que no exista dinero en la herencia ${ }^{834}$. Por consiguiente, sigue siendo la legítima una pars bonorum, pero se le permite al testador que la convierta en pars valoris, si así lo estima y en su testamento lo dispone ${ }^{835}$.

\subsubsection{Atribución y forma de pago de la legítima en Mallorca y Menorca}

Partiendo de la premisa de que la imputación es una herramienta legal por la que el testador imputa al legitimario en alguno de los distintos modos, de que dispone, para atribuirle su legítima. Como ya se ha apuntado el artículo 48. 7 CDCIB permite que al imputado por el testador como legitimario, le pueda aquél atribuir su legítima por medio de la institución

de la pareja de hecho estable y registrada en el procedente Registro de Parejas de Hecho, de esta manera: "La convivencia constituye el presupuesto indispensable de los derechos que la L.18/01 otorga al sobreviviente en caso de fallecimiento del otro".

${ }^{834}$ BERNAD MAINAR, La porción legítima ..., op. cit., pág. 1788.

${ }^{835}$ VILA RiBES, “La legítima en el Derecho...”, op. cit., pág. 301. 
de heredero, de la asignación de bienes concretos, del legado o de la donación. Las distintas maneras de atribuir la legítima en Mallorca y Menorca: En primer lugar, la atribución de la legítima por institución de heredero. Con este tipo de atribución, el disponente efectúa dos atribuciones en un mismo individuo, es decir, le paga su derecho a legítima y lo hace heredero suyo. En este supuesto cumple un doble papel el instituido. Se convierte en heredero y en legitimario, papeles los citados, que se pueden ver confrontados en el supuesto de que la parte debida (portio debita) fuera insuficiente para cubrir su legítima.

Ha quedado ya aclarado con anterioridad que el heredero representa al causante y en consecuencia es él, en representación de aquel, quien le debe su parte al legitimario. De verse mermada su parte de legítima, el herederolegitimario sería absurdo atacarse a sí mismo con la querella inoffciosi testamenti. Justiniano puso en funcionamiento la actio ad supplendam legitimam que es el derecho del legitimario-heredero al complemento de legítima hasta completar la poción que por derecho le corresponde ${ }^{836}$.

La segunda forma de atribución de la legítima es por legado. Puede el testador atribuirle la legítima al legitimarlo por medio de un legado. Si bien el mismo precepto 48 CDCIB en su punto dos dispone que "Deberán ser respetados los legados de cosa especifica...", donde cabría hacerse la pregunta de si ¿La cosa especifica podría ser una suma de dinero incluso extrahereditario? Partiendo de la disposición del artículo 48.1 CDCIB el

\footnotetext{
${ }^{836}$ FerRer VANRELL, M.P.: "La legítima en el Derecho civil de la Islas Baleares", en Tratado de legítimas, (Coord. T. F. Torres García), Atelier, Barcelona, 2012, pág. 300. "De una misma sucesión no se pueden detraer dos legítimas", este principio lo trae la autora a colación para justificar el supuesto de que el testador le haya otorgado bienes suficientes al heredero-legitimario para pagar su cuota de legitima y este reclame además su legítima. También cabría el planteamiento de que el disponente le haya atribuido más bienes que por legítima le corresponde. En este supuesto cabe decir que ha sido la voluntad del testador la que ha imperado.
} 
testador puede autorizar el pago de la legítima (pars bonorum) en metálico al legitimario. Entiendo que si puede autorizar también puede hacer y por lo tanto sería completamente válida la disposición y el legado de cosa específica que recoge el artículo 48. 7 CDCIB antes citado. Pero podría darse el caso de un legado de dinero a un legitimario sin imputación, en dicho legado, del sujeto como legitimario. Es decir, no lo ha imputado legitimario, simplemente le ha otorgado una suma de dinero. Adviértase que sólo tiene facultad de imputación el testador y que de él, depende que la legítima se pueda pagar con dinero. En este supuesto siendo la legítima en Baleares pars bonorum produciría los mismos efectos que hubiera producido en vigencia del artículo $46.1^{837}$ de la Compilación de $1961^{838}$.

La tercera modalidad es la atribución por asignación o distribución de bienes. Dispone el artículo 48. 7 CDCIB que la asignación o distribución de bienes, entre otras, es un medio por el que el testador puede cumplir su obligación de satisfacer el derecho que tienen los legitimarios. Esta asignación o distribución de bienes no es otra cosa que la voluntad del testador de pretender atribuir una serie de bienes concretos a sus legitimarios. Estos bienes deberán ser respetados por estos, en virtud de lo dispuesto en el artículo 48.1 segundo inciso CDCIB.

La cuarta modalidad es la de atribución delegitimas por donación. Entre los modos que el artículo 48. 7 CDCIB faculta al disponente para

\footnotetext{
${ }^{837}$ Artículo 46.1, de la Compilación de Baleares de 1961: "La legítima debe ser pagada en bienes de la misma herencia siendo ineficaz toda disposición en contrario del testador".

${ }^{838}$ Véase la comparación que hace a este respecto FERRER VANRELL, La legítima en el Derecho civil..., op. cit. pág. 302. cuando afirma que el Código civil de Cataluña en su artículo 451-7,2 permite además del legado (simple de legítima) incluso cuando el dinero de es de fuera de la sucesión. La diferencia está en que, en Cataluña, a diferencia que naturaleza jurídica de la legítima en Baleares es pars bonoúm, allí es pars valoris bonorum.
} 
atribuir su legítima a los legitimarlos, figura la donación. Esta donación puede ser entre vivos o mortis causa, o también por donación universal ${ }^{839}$. La donación es conforme al artículo $618^{840}$ del Código civil que es un acto de liberalidad y un contrato. Aunque el citado precepto la califique de "acto". Cabe destacar de este respecto, la opinión de la doctrina científica que pone de manifiesto su crítica diciendo: en donde debería poner "contrato" pone "acto", en cambio otros autores como Castán Tobeñas atribuyen el error a Napoleón tras advertir este, que no podía tener cabida en el proyecto de Código francés, un contrato sin obligaciones reciprocas. De ahí que mandara sustituir, el citado emperador francés, contrato por acto $^{841}$.

La donación universal es de marcadas características en el Derecho sucesorio balear. En virtud del artículo 10 CDCIB la donación universal revoca los testamentos y codicilos anteriores otorgados por el donante y en lo que se refiere a los testamentos hechos con posterioridad al contrato de

${ }^{839}$ Véase FERRER VANRELL, “La legítima en el Derecho civil...”, op. cit. pág. 303.

${ }^{840}$ Artículo 618 Cc. "La donación es un acto de liberalidad por el cual una persona dispone gratuitamente de una cosa en favor de otra, que la acepta".

${ }^{841}$ Castán Tobeñas, J.: Derecho Civil Español, Común y Foral, Tomo 4, Reus. $14^{\text {a }}$ Ed., Madrid, 1.988, pág. 220.

${ }^{841}$ Artículo 8 CDCIB: "La donación universal es valedora de presente e irrevocable. No obstante, puede ser revocada, solamente por el donante, en el caso de incumplimiento de cargas o de ingratitud. Se consideran causas de ingratitud las del tercer párrafo del artículo 4.3 de esta Compilación. También puede dejarse sin efecto o modificarse por acuerdo del donante y del donatario, o de los herederos de éste, consignado en escritura pública. En su caso será de aplicación el artículo 1.342 del Código civil”".

${ }^{841}$ Señala BADENAS CARPIO, J.M.: Las donaciones colacionables en el Derecho civil balear, Tirant lo Blanch, Valencia, 2006, pág. 44 y 45, que la prohibición de quedar un contrato supeditado a una de las partes, proviene del artículo 1256 del Código civil, que prohíbe este precepto dejar al arbitrio de una de las partes la validez y el cumplimiento de los contratos. Este mismo autor manifiesta la opinión de la doctrina, al respecto de la donación universal mortis causa, en todo aquello que no previene el CDCIB y que regirá ante lagunas legales, las disposiciones relativas al resto de actos de la misma naturaleza jurídica (testamentos), cuyas reglas sólo dejaran de tener aplicación cuando tropiecen con las características propias de los pactos sucesorios, derivadas del matiz contractual de la donación. 
la donación ${ }^{842}$. Su eficacia sólo afectará a los bienes no incluidos en la donación. Acaba disponiendo el precepto que el llamado a la sucesión en concepto de los bienes donados tendrá el carácter de "instituido en cosa cierta y determinada y será considerado como legatario". La donación universal tal y como la describe el citado artículo 10 CDCIB no deja de reflejar la última voluntad del disponente, como lo pueda ser el testamento. Con una marcada diferencia, con este último, en que el testamento es revocable y la donación no lo es salvo, lo dispuesto en el segundo inciso del artículo 8 CDCIB ${ }^{843}$ CDCIB. Dicho carácter de irrevocabilidad trae causa en que los artículos 623 y 629 del Código civil exigen la aceptación por parte del donatario para que la donación adquiera la perfección. Es de pura lógica que con posterioridad a la aceptación de las dos partes, el contrato, no pueda quedar supeditado a la voluntad de una de ellas ${ }^{844}$.

Cabe hacer dos distinciones al respecto de las donaciones, como modo de atribución de su derecho a los legitimarios. La primera sería en concepto de un derecho que todavía no ha nacido y contempla el artículo 50.1 CDCIB. Sería el legitimario, en caso de llegar a serlo, el que tendría facultad de renunciar a dicho derecho de legítima y quedarse con la donación en su día a él, otorgada por el causante. También podría tener cabida la donación hecha en favor de un legitimario a cuenta de la legítima que al fallecimiento del donante recibirá el donatario. La segunda distinción son las donaciones no atribuidas por el donante como pago de legítimas. Tras la muerte de este y el donatario adquirir el derecho a legítima es la Ley la que le imputa los bienes donados como anticipo de la 
porción legal que por derecho le corresponde. Le corresponde tras convertirse en donatario y legitimario a la vez. Así lo preceptúa el artículo $48.7^{845}$ CDCIB.

No se puede pasar por alto que el donante, en el supuesto de poder dispensar la computación de la donación podría extralimitarse. Podría estar con ello perjudicando las legítimas. Lo que trata la Ley es precisamente que se sepa si ha perjudicado o no las legítimas. De ahí que en palabras del Tribunal Supremo el espíritu de la colación no sea el de proteger las legítimas, sino la determinación de lo que le corresponde al legitimario de la herencia ${ }^{846}$.

Para terminar con la donación universal decir que, con respecto a su ámbito de aplicación, puede aplicarse en Mallorca. Por estar el artículo 8 CDCIB dentro del Libro I dedicado a las Disposiciones Aplicables a

\footnotetext{
${ }^{845}$ Distingue FERRER VANRELL, “La legítima en el Derecho civil...", op. cit. pág. 305, dos tipos de donaciones a las llamadas ob causam, como modos de atribución de la legítima que se imputan expresamente por el donante o por la propia Ley. Distingue este tipo de donaciones de aquellas en que el donante las excluye, o no las imputa a las legítimas y las denomina donaciones no causales.

${ }^{846}$ Véase a este respecto la STS de 15/02/2001, (Tol. 4.964.708) que en su F. J. $2^{\text {o }}$ dispone acerca de la colación: "Estrictamente la colación es una operación particional, cuya finalidad no es la protección de las legítimas, sino de determinar lo que ha de recibir el heredero forzoso por su participación en la herencia, que puede ser mayor que la que le corresponde por su legítima, si el causante le ha dejado más. En suma, la colación se refiere a la cuenta de participación de heredero forzoso en la herencia. Por otra parte, en nuestro sistema legitimario el testador puede dejar la legítima "por cualquier título", sin excluir ninguno, por tanto, inter vivos o mortis causa. Así lo dispone el artículo 815 del Código civil. La sentencia de esta Sala de 20 de febrero de 1981 declaró que el heredero forzoso, a quien en vida haya hecho alguna donación su causante, no puede considerarse desheredado ni preterido, y sólo puede reclamar que se complete su legítima, al amparo del artículo 815”.
} 
Mallorca y por lo dispuesto en el artículo $65^{847}$ CDCIB. En cambio no tiene aplicación en Menorca, per sí que la tiene en Ibiza y Formentera ${ }^{848}$.

\subsubsection{La intangigilidad de la legítima}

Por el hecho de ser la legítima intangible, no es otra cosa la intangibilidad de la legítima, que el límite que la ley impone al testador sobre el libre destino de parte de sus bienes. El disponente puede, por cualquier título, atribuirles les derechos que sus legitimarios mantienen en esa sucesión. De faltar tal atribución es la ley sucesoria la encargada de suplirla cualitativa y cuantitativamente por medio de los mecanismos a disposición del legitimario que pone la propia ley sucesoria. Son varias las actuaciones del disponente, por medio de las cuales, puede lesionar la legítima de manera cualitativa o cuantitativa e incluso lo puede hacer de ambas maneras a la vez ${ }^{849}$.

\subsubsection{La desheredación y sus causas en Mallorca y Menorca}

Lo más destacable sobre la desheredación en Baleares viene dispuesto en la Ley $3 / 2009^{850}$ que modifica la indignidad para suceder y la desheredación. Tres cuestiones importantes a destacar del precepto 7 bis

\footnotetext{
${ }^{847}$ Artículo 65 CDCIB "Rige en la isla de Menorca lo dispuesto en el Libro I de esta Compilación, excepción hecha de los artículos 6 y 7, en lo referente a la donación universal de bienes presentes y futuros, del Capítulo II del Título II, de los artículos 50 y 51 y del Título III".

${ }^{848}$ Véase la SAP (S.5) de las Islas Baleares de 29/12/2003 (AC 20041350)F.J. $2^{\circ}$ en que la Sala se refiere al valor de la colación, el cual supone: "la agregación puramente contable de unas partidas de valor con el fin de calcular la cuota patrimonial de cada heredero forzoso, y en el caso de que resulten inoficiosas las donaciones, no se resuelven ni revocan en virtud de la colación, originando únicamente un crédito con la correlativa obligación del colacionante de abonar la diferencia o restituir el exceso, tratándose de una deuda dineraria o de valor, no específica de la cosa que fue donada".

${ }^{849}$ FerRer VANRELL, “La legítima en el Derecho civil...”, op. cit. pág. 315.

${ }^{850}$ Ley 3/2009, de 27 de abril, de modificación de la compilación de derecho civil de las Illes Balears, sobre causas de indignidad sucesoria y desheredamiento, BOE» núm. 121, de 19 de mayo de 2009.
} 
CDCIB. La primera es la determinación que hace de las causas de indignidad $^{851}$. La segunda cuestión a destacar es la remisión que hace a las causas de indignidad como justas causas de desheredación. El tercero y último punto destacable es el relativo a la supletoriedad del Código civil, que la limita a lo no dispuesto en el propio precepto de la Compilación balear. Importante modificación, ya que con anterioridad a la modificación que introdujo la Ley3/2009, la Compilación de 1990, no hacía, sino que remitirse al Código civil. Hay que tener muy presente que este precepto no ha sido derogado y ello significa que se tendrán que comparar dichas causas, en uno y otro ordenamiento, por si todas las de aquel no estuvieran reflejadas en este.

Como ya se ha mencionado ha habido una reciente modificación por parte del legislador balear. Concretamente el artículo 6 de Ley 7/2017, de 3 de agosto, por la que se modifica la Compilación de Derecho civil de las Islas Baleares. Se modifican distintos apartados del artículo 7 bis del Texto refundido de la Compilación de Derecho civil de les Illes Balears para Mallorca y Menorca. Sin duda lo que más interesa es la adición de un nuevo subapartado del primer punto del artículo 7 bis CDCIB. La introducción de una nueva causa de indignidad que a la vez por virtud del apartado $3^{\circ}$ del mismo precepto se convierte en causa de desheredación. Trata, esta causa, de dar protección a las personas con discapacidad en el grado que indica la Ley ${ }^{852}$. Es decir, por medio de esta nueva causa de indignidad, pretende el legislador balear, que no pueda heredar quien haya

851 No está de más, recordar que la indignidad va orientada a los herederos y la desheredación a los legitimarios, sin perjuicio de que se remitan unas a otras en determinados casos. Un fiel ejemplo es el apartado 3 del artículo 7 bis CDCIB que dispone: "3. Las causas de indignidad del punto 1 son también justas causas de desheredamiento".

${ }^{852}$ Artículo 7 bis, apartado 1. HCDCIB: "En la sucesión de las personas con discapacidad, los que no hayan prestado las atenciones debidas en concepto de alimentos". 
negado alimentos al causante incapacitado. Hecho que entiendo que al ser a la vez la negación de alimentos, causa de indignidad y de desheredación podría tener cabida tanto en la sucesión testada como en la intestada.

Por lo que respecta a la descendencia del desheredado, el artículo 42.2 CDCIB su cuota individual en el caso de que tenga descendencia la recibirá esta por derecho de representación. En el supuesto de no existir descendientes del desheredado, su cuota acrece en la parte de libre disposición y no a las legítimas del resto de titulares. Se sobrentiende que el desheredado es con justa causa ${ }^{853}$. La jurisprudencia equipara los mismos efectos a la preterición intencional que a la desheredación sin causa, puesto que en ambos casos el legitimario puede pedir lo que por legítima le corresponda $^{854}$. En la desheredación injusta lo puede hacer por virtud del último párrafo del artículo $46 \mathrm{CDCIB}^{855}$.

\subsubsection{La preterición en Baleares}

El artículo 46 CDCIB regula tanto la preterición formal como la material. Si el testador lesiona al titular del derecho a legítima, no nombrándolo como legitimario, se trataría de una preterición formal. En cambio si el disponente, en su omisión, afecta a la cantidad de la porción de

\footnotetext{
${ }^{853}$ FERRER VANRELL, M.P.: La legítima en el Derecho civil de las Islas Baleares, en Tratado de legítimas, Atelier, Barcelona, 2012, pág. 325. Mantiene la autora que a diferencia de la desheredación la indignidad puede operar en cualquier sucesión incluso sin conocimiento del causante. La indignidad tiene cabida con parientes y con extraños

${ }^{854}$ STSJ de Baleares de 05/06/2014, (Tol. 4.424.457) F. J. $4^{\circ}$ dispone: "Hemos dicho más arriba, en consonancia con las sentencias de instancia, que no hubo desheredación, y sólo "en el más que hipotético caso" de que la hubiera habido, dedujeron rectamente que, preterición o desheredación injusta, tendrían los mismos efectos del art. 46 de la Compilación, es decir, la exigencia de los derechos legitimarios que correspondieran a la viuda, como así ha hecho". Tambien interesa la SAP de Baleares (S. 4 $)$ de 15/10/2013 (Tol. 3.990.754) F. J. $3^{\text {o }}$ "el efecto de la desheredación sin causa y la preterición intencional es el mismo, conforme el Derecho civil de las Islas de Mallorca, es decir, el derecho a solicitar la legítima. Tambien la
}

${ }^{855}$ FerRer VANRELL, “La legítima en el Derecho civil...”, op. cit. pág. 323. 
legítima que, al titular del derecho, por ley le corresponde se trata de preterición material $^{856}$. Ello en base a que la Ley obliga al disponente a respetar tanto la calidad como la cantidad de la legítima. El precepto último citado, distingue también entre preterición intencional y no intencional. Sobre la preterición intencional, dice el primer inciso del referido precepto 46 CDCIB que no anulará el testamento, pero le otorga derecho al legitimario preterido para que exija lo que por legítima le corresponda. Ello significa que el legitimario preterido de manera intencional tiene acción para reclamar su legítima, pero no la tiene para pedir la anulación del testamento.

La preterición no intencional tiene lugar cuando el disponente no nombra al legitimario. Este, sí que tiene acción para pedir la nulidad del testamento. A este tipo de preterición se refiere el punto dos del precitado artículo 46 CDCIB que mantiene un error de impresión al citar a hijos y ascendientes en lugar de hijos y descendientes. El artículo 8. 5 CDCIB, dispone que no quedara sin efecto la donación universal por preterición y le otorga facultad al legitimario preterido, para que reclame su legítima. Se advierte que el precepto sólo se refiere a preterición, sin especificar su clase, pero se sobrentiende que, de ser intencional, carecería de todo sentido quitarle el efecto de que no dispone. Por lo tanto, se sobreentiende que se trata de la preterición no intencional que si que otorga facultad al legitimario para pedir la anulación del testamento que lo ha preterido. Tiene un plazo para ello de 4 años.

${ }^{856}$ Se pronuncia a este respecto de la preterición material la citada anteriormente STSJ de Baleares de 05/06/2014, (Tol. 4.42.457) que en su F.J. $4^{\circ}$ argumenta: "está la cláusula testamentaria sexta, en la que se dice "que se deja a salvo los derechos especialmente legitimarios, que pudieran corresponder a cualquier persona que hubiese sido omitida en este testamento, o que, mencionada, no se le atribuye ningún bien". Es paladino que la entonces esposa no fue omitida, mientras que sí fue mencionada sin atribución de ningún bien, de manera que la salvaguarda de sus derechos legitimarios sólo se podía referir a ella, única persona mencionada sin atribución de bienes que aparecía en el testamento". 
También el artículo 46. 3 CDCIB dispone en relación a un legitimario que premuere al testador: que no se consideraran preteridos los descendientes de un legitimario que ha premuerto al testador no preterido. Tiene su pura lógica, este precepto, ya que si el descendiente del disponente ha premuerto a este, sus descendientes por el derecho de representación adquieren la legítima de su ascendente. En este aspecto cabe recordar el artículo 814. 3, del Código civil cuando dispone lo mismo que el referido 46. 3 CDCIB. Teniendo presente que en la sucesión testada el derecho de representación se produce a favor de quien se produciría de no existir testamento. Refiriéndose al derecho de representación en que operaría el llamamiento a los nietos en la sucesión del abuelo, sólo en el caso de que el hijo de este le hubiera premuerto ${ }^{857}$.

\subsubsection{La protección de la legítima en Baleares}

El ordenamiento balear protege al legitimario para que reciba el contenido económico que requiere su título por medio de las acciones de que dispone de petición y división de herencia. Así como a promover el juicio de testamentaria del artículo 47.1 CDCIB. El legitimario puede ejercitar tanto la acción de petición de legítima, como el suplemento de esta, si su cuantía no es la correcta. Esta acción de suplemento de legítima tiene la excepción para el pacto de renuncia dispuesto en el artículo 50 $\mathrm{CDCIB}^{858}$. Si el disponente no ha dispensado de colacionar al legitimario y

${ }^{857}$ Lacruz Berdejo J. L., Sancho Rebullida, F., Luna Serrano, A., AA VV: Elementos de Derecho civil V, nueva edición, Dykinson, Madrid, 2001, págs. 419 y 420. ${ }^{858}$ Por medio del pacto de definición el ascendente adelanta una parte de herencia al legitimario a cambio de la renuncia de este a su derecho de legítima de haber fallecido aquel. El pacto de definición deberá formalizarse en escritura pública. El ordenamiento balear dedica al pacto de definición los artículos 50 y 51 CDCIB. El renunciante será el descendiente definido. No hay que olvidarse que el artículo 816 del Código civil prohíbe todo pacto sobre la legítima futura e incluso sanciona con la nulidad del pacto que lo disponga. Sería también el caso de Menorca en que le es aplicable el Derecho común y por lo tanto estaría allí prohibido el pacto de definición. Tiene tal excepción debido a que el artículo 51 dispone que la definición deja sin efecto cualquier 
su atribución no cubre su legítima, lo atribuido se considera un anticipo de la legítima. El resto hasta cubrir el total, tiene acción para su cobro por medio de petición de suplemento de legítima salvo que se trate de un descendiente definido ${ }^{859}$. Este pacto le impide llevarla a cabo por el artículo $51 \mathrm{CDCIB}^{860}$. En los supuestos de inoficiosidad legitimaria, no regulada por la Compilación balear tiene aplicación supletoria el Derecho común por medio de la acción de reducción conforme a los artículos 820 y 821 del Código civil ${ }^{861}$.

\subsubsection{La legítima en Ibiza y Formentera}

A las Islas de Ibiza y Formentera, el Decreto Legislativo 79/1990 de 6 de septiembre, por el que se aprueba el texto refundido de la Compilación del Derecho Civil de las Islas Baleares, les dedica los artículos 79 a 83 de dicho cuerpo legal. La legítima en las citadas Islas de Ibiza y Formentera,

disposición relativa a la legítima del descendiente renunciante. No sería lógico haber renunciado a la legítima a cambio de una parte de la herencia y después pedir suplemento de la legítima.

${ }^{859}$ Pons SAlVA, M.: "El pacto sucesorio mallorquín: La "diffinitio", Revista Jurídica de les Illes Balears, núm. 11, 2013, pág. 61. Puede que, según la autora, la definición en Mallorca aclara lo que en realidad es un pacto sucesorio. Se regula el pacto de definición en los artículos 50 y 51 CDCIB. "Consiste en una atribución patrimonial fundada en un título lucrativo, creado por un negocio dispositivo, realizado por el ascendiente, que tiene como destinatario un descendiente legitimario". Esta institución facilita que el legitimario que el disponente decida salga de la sucesión, previo pago de su legítima. La finalidad del pacto de definición es que se pueda transmitir un bien o toda la herencia de manera indivisa a favor de un solo heredero. Por lo tanto, el descendiente definido será, evidentemente, el apartado de la sucesión.

860 CREMAdES GARCÍA, Sucesión mortis causa..., op. cit., pág. 184. Esta autora encuadra el pacto de renuncia a la legítima para Mallorca y Menorca, denominado "pacto de definición" en los artículos 50 y 51 CDCIB. En cambio, el pacto de renuncia a la legítima para Ibiza y Formentera denominado "finiquito" lo sitúa entre los artículos 72 a 77 CDCIB.

${ }^{861}$ FerRer VANRELL, “La legítima en el Derecho civil...”, op. cit. pág. 324 
también conocidas como las Islas Pitiusas ${ }^{862}$, tiene lugar la reserva de bienes de la que el testador no puede disponer, por reservarla la Ley para sus legitimarios en caso de tenerlos. Por consiguiente en defecto de ellos, cabe decir, que el testador puede disponer libremente, de sus bienes, para después de su muerte, tal como ocurre en Mallorca y Menorca. Sin embargo no se puede decir lo mismo de su contenido, ya que como se ha visto, en estas últimas citadas Islas, la legítima es una pars bonorum. Por lo tanto, el legitimario es cotitular del caudal relicto. En cambio en las Islas Pitiusas la legítima es pars valoris bonorum, es decir, tal y como preceptúa el artículo 82.1 CDCIB el derecho del legitimario consiste en una parte de valor concretada en bienes de la herencia o en dinero líquido ${ }^{863}$.

\subsubsection{Los legitimarios en Ibiza y Formentera. Cuantía}

Conforme establece el artículo 79 CDCIB. Son legitimarios, en estas Islas, los hijos y descendientes (los segundos en defecto de los primeros) y los padres. En cambio, no dice nada del cónyuge viudo, por lo que se sobreentiende que no es legitimario. Por lo que respecta a los hijos y descendientes decir que son legitimarios: los naturales, los matrimoniales y

${ }^{862}$ Lo de "Pitiusas" proviene del griego en que pitys significa pino, y ello conlleva a que las citadas Islas de Ibiza y Formentera estaban en la antigüedad muy pobladas de pinos.

${ }^{863}$ Véanse las normas que principalmente otorgaron a la legítima de Ibiza y Formentera su naturaleza jurídica en la SAP de Les Illes Balears, (S. $3^{\mathrm{a}}$ ) de 21/02/2001(Tol. 69.105) F. J. $2^{\circ}$ "la Novela 18 de Justiniano que estableció una legítima variable según el número de hijos, y las Ordinations de Arnaldo de Erill, aprobadas en 1363 por Pedro el Ceremonioso que dieron base para entender que la legítima podía pagarse en dinero".

También es interesante, la aportación que hace esta sentencia en el encabezamiento del F. J. $2^{\circ}$ al respecto de la naturaleza jurídica de la legítima: "No existe duda de que la legítima en Ibiza y Formentera tiene la naturaleza de pars valoris bonorum. Así se deducía del art. 81 de la antigua Compilación en el que se establecía el principio de que el legitimario tenía derecho a que se le abonara su legítima en bienes de la herencia salvo disposición distinta del testador o pacto en contra entre heredero y legitimario; y así se deduce de la regulación que de la legítima se contiene en los arts. 81 y 82 de la actual compilación. La exposición de motivos de la ley de 28 de junio de 1990, coincidiendo con los comentaristas de la antigua Compilación la califica como pars valoris bonorum qua in specie heres solvere debit". 
no matrimoniales así como los adoptados. Los padres, dispone el precepto, que son legitimarios por naturaleza y adopción, no dice nada del resto de ascendentes. Por lo que se entiende que únicamente son legitimarios los padres del causante. Al igual que ocurre en Mallorca y Menorca, en Ibiza y Formentera, la legítima de los hijos y descendientes está en concordancia con el número de ellos. Para 4 o menos descendientes su legítima asciende a un tercio del caudal relicto. De ser más de cuatro su legítima será de la mitad del haber hereditario. Este cómputo de los hijos y descendientes, tiene sus peculiaridades al objeto de saber la cuantía global de la legítima que puede variar, como se ha visto, entre un tercio y la mitad del haber de la herencia. Para saber los qué hacen número hay que remitirse al artículo $80 \mathrm{CDCIB}^{864}$.

La legítima de los ascendentes queda limitada a los padres, al igual que el resto de Baleares. Conforme dispone el artículo 79. 3 CDCIB su legítima se remite a lo dispuesto en los artículos 809 y $810.1^{865}$ del Código civil, siempre que no contradiga la Compilación vigente en Baleares ${ }^{866}$. No

\footnotetext{
${ }^{864}$ MunAR Bernat, P. A.: "La legítima en el Derecho civil de la Islas Baleares", en Tratado de legítimas, (Coord.T. F. Torres García), Atelier, Barcelona, 2012, pág. 334.

865 Artículo 809 Cc: "Constituye la legítima de los padres o ascendientes la mitad del haber hereditario de los hijos y descendientes salvo el caso en que concurrieren con el cónyuge viudo del descendiente causante, en cuyo supuesto será de una tercera parte de la herencia".
}

Artículo $810.1 \mathrm{Cc}$; "La legítima reservada a los padres se dividirá entre los dos por partes iguales; si uno de ellos hubiere muerto, recaerá toda en el sobreviviente."

${ }^{866}$ La SAP de Baleares (S. 4 ${ }^{\text {a }}$ de 16/11/2017 (Tol. 6.493.190) F. J. 6º hace referencia precisamente a lo expuesto en el texto. La Sala de Instancia estima aplicar al caso enjuiciado los artículos 815 y 820 del Código civil al advertir una laguna legal en los artículos 47 y 48 CDCB estimando que estos preceptos únicamente regulan la colación y no el suplemento y complemento de la legítima. No obstante, la parte apelante entiende que regulan el orden de reducción los artículos 48 a $51 \mathrm{CDCB}$, lo único que estos preceptos fijan un orden distinto de reducción al previsto por el Código civil. La Sala de Audiencia entiende: "que no nos encontramos ante una laguna de la Compilación que deba ser suplida directamente mediante la aplicación del Código Civil, pues en todo caso habría que acudir antes a la interpretación e integración ex art 1 párrafo 2 de la Compilación bajo los principios generales que informan el derecho civil 
son pocos los problemas que se pueden presentar, al no contemplar al cónyuge viudo o sobreviviente de pareja de hecho como titular de la legítima en usufructo. Al ser diferente la cuota legitimaría de los descendientes, en Ibiza y Formentera, con respecto a la que otorga a estos, el Código civil. Entones resulta un poco inusual, con respecto a los otros ordenamientos, que descendientes y ascendientes tengan la misma cuota legitimaría, en el supuesto de aquellos ser más de cuatro a repartir la legítima global ${ }^{867}$.

\subsubsection{El cónyuge viudo}

En Ibiza y Formentera, como se ha dicho, no es legitimario el viudo ni tampoco el superviviente de la pareja de hecho. Tampoco en la legislación precedente a la actual, es decir, en la Compilación de 1961, se contemplaba al viudo como legitimario. Sin embargo, por virtud del artículo 84 CDCIB, que remite al Código civil, sí que se contempla al cónyuge viudo como titular del derecho al usufructo de la mitad del haber hereditario, si concurre con descendientes y dos tercios si lo hace con ascendientes en la sucesión intestada. Es más, es llamado a la sucesión legal con antelación a los colaterales ${ }^{868}$. No es pacifica la doctrina al respecto de la exclusión del

balear, así como las leyes costumbres jurisprudencia y doctrina que encarnan la tradición jurídica de las Islas". Pone, acto seguido, las diferencias entre el Derecho civil balear y el Derecho civil común como la mejora que no existe en Baleares, la repudiación de la legítima no acrece en los legitimarios, como en el Código civil, sino en los herederos. Tampoco el orden de reducción coincide con el derecho común.

${ }^{867}$ En tal caso, como se ha dicho, la legítima de los descendientes cuyo número es mayor de 4, su legítima ascendería a la mitad de la herencia. El artículo 809 del Código civil dispone la misma porción legitimaría (1/2) para los padres o ascendientes que no concurran con el viudo/a. La consecuencia, por lo tanto, de no ser el viudo/a o pareja de hecho legitimario conlleva a igualar la legítima de los descendientes con la de los ascendientes.

${ }^{868}$ Véase en este sentido la STSJ Illes Balears (S. 1 ${ }^{a}$ ) de 24/10/2012 ( Tol. 2.707.910) F. J. $1^{\circ}$. Ante tal situación, en virtud del artículo 84 I de la CDCB, en el que se lee "La sucesión intestada en Eivissa y Formentera se rige por las normas del Código Civil ", aplica el llamamiento a la sucesión en todos los bienes del difunto que el artículo 944 CC hace al cónyuge sobreviviente, en defecto de ascendientes y descendientes y antes 
cónyuge viudo en Ibiza y Formentera en la sucesión testada y que se le reconozca el derecho usufructuario en la intestada. No faltan autores que mantienen que el artículo 84 CDCIB simplemente actuó frente al vacío legal que suponía la derogación del artículo 953 del Código civil, por el artículo 4 de la Ley 11/1981, de 13 de mayo ${ }^{869}$.

\subsubsection{La desheredación en Ibiza y Formentera}

En las islas de Ibiza y Formentera tienen aplicación supletoria las normas recogidas en el Código civil, artículos 844 y ss. La tiene en todo aquello que no regula el Código de Derecho civil de Baleares en el Capítulo VI del Libro III, modificado por la Ley 3/2009, de 27 de abril, de modificación de la Compilación sobre causas de desheredación y de indignidad en el ámbito de la sucesión. Al igual que ha ocurrido en Mallorca y Menorca, la misma Ley 7/2017, de 3 de agosto, por la que se modifica la Compilación de Derecho civil de las Islas Baleares en su artículo 30 y 31 hace distintas modificaciones al artículo 69 bis del Texto refundido de la Compilación de Derecho civil de las Islas Baleares. Lo hace incorporando un nuevo párrafo que se designa con la letra " $h$ " impedir heredar a los que no hayan prestado al causante con discapacidad,

que los colaterales, dado que no nos encontramos ante la concreta causa de exclusión del artículo 945 CC , en su versión dada por la Ley 11/1981 de 13 de mayo aplicable al haber fallecido el causante el 15 de marzo de 2002, consistente en que el cónyuge "estuviera separado de hecho por mutuo acuerdo que conste fehacientemente" y que el CC "excluye la separación unilateral aun siendo consentida" por lo que estima la demanda y declara que "la actora tiene derecho preferente, como viuda, a suceder directamente en toda la herencia ...".

${ }^{869}$ JuÁreZ GONZÁlEZ, GPS Sucesiones..., op. cit., pág. 456. El derogado artículo 953, Cc disponía: "En el caso de existir hermanos o hijos de hermanos, la legítima que en todo caso corresponde al viudo en la sucesión intestada será la parte de herencia en usufructo asignada en el artículo ochocientos treinta y ocho" Dicho precepto $838 \mathrm{Cc}$, al que se remite el anterior dice: "No existiendo descendientes ni ascendientes el cónyuge sobreviviente tendrá derecho al usufructo de los dos tercios de la herencia".

${ }^{870}$ Artículo 69 bis, apartado h): "En la sucesión de las personas con discapacidad, los que no hayan prestado las atenciones debidas en concepto de alimentos". 
las atenciones debidas en concepto de alimentos. La equiparación que hace el precepto de las causas de indignidad- que actúan como causa que impide en nacimiento del derecho a legítima- con las de desheredación ${ }^{871}$. Ello conlleva a que se dé la desheredación tanto en la sucesión voluntaria como en la legal.

Con anterioridad a la citada inclusión del subapartado "h" del artículo 69 bis Ley 7/2017, de 3 de agosto, ya tenía aplicación el $7^{\circ}$ apartado del artículo 756 del Código civil. Ello, por remitirse de manera supletoria a él en su cuarto apartado el artículo 69 bis CDCIB. De Hecho así se ratifica en SS AP de Baleares anteriores a Ley 7/2017, de 3 de agosto $^{872}$.

\subsubsection{La desheredación}

La desheredación es una pena que se le impone por parte del testador al titular del derecho a legítima. La pena es precisamente la pérdida del citado derecho por haber incurrido en justa causa de desheredación. No produce únicamente efectos en el legitimario penado, sino que se refleja también en sus hijos de la siguiente manera: Al legitimario, la desheredación le produce su total exclusión de la sucesión tanto testada

\footnotetext{
${ }^{871}$ A la expresión de que la indignidad es una causa de extinción de la legítima, utilizando las palabras que utiliza el mismo artículo 83, CDCIB, se refiere MUNAR BERNAT, P.A.: "La legítima en el Derecho civil de las Islas Baleares", en Tratado de legítimas, (coord. T.F. Torres García), Atelier, Barcelona 2012, pág. 343. Citando a Roca i Trias, para manifestar que la indignidad impide el nacimiento de la legítima, es decir, en el indigno nunca llega a nacer el derecho a legítima.

${ }^{872}$ SAP de Baleares (S. 5 ${ }^{\mathrm{a}}$ ) de 09/07/2012 (Tol. 2.617.510) donde en el F.J.3 ${ }^{\circ}$ invoca el apartado $7^{\circ}$ del precitado artículo $756 \mathrm{Cc}$ acerca de las personas que no hubieran prestado las atenciones debidas al causante en vida conforme a los artículos 142 y 146, del mismo cuerpo legal. El mismo F.J. de la Sentencia mantiene que "la indignidad no representa una categoría especial o distinta de la incapacidad para suceder, sino que el legislador la configura como una subespecie de aquella". Por lo tanto, "se considera al indigno incapaz de entrar en la sucesión de que se trate". Adviértase la diferencia entre impedir la entrada en la sucesión por indigno a ser desheredado. En el primer caso se le impide la entrada por carecer del derecho y en el segundo para poder ser desheredado antes ha tenido que ser heredero y cumplir con una justa causa tasada.
} 
como intestada. En el supuesto de decaer la institución de heredero contenida en el testamento en el que es desheredado y abrirse la sucesión legal no entraría en ella por mandato de la cláusula testamentaria. Respecto a los hijos del desheredado: por virtud del artículo 83.1 $\mathrm{CDCH}$ tienen derecho a la legítima que hubiera correspondido a su padre en el supuesto de no haber sido desheredado ${ }^{873}$.

\footnotetext{
${ }^{873}$ MunAR BeRnAt, "La legítima en el Derecho...", op. cit., pág. 342. Se ampara la autora para hacer tal afirmación en Vallet de Goytisolo, J.: El apartamiento y la desheredación, Madrid 1968, pág. 60, nota 266. "quien ha sido excluido de la sucesión legalmente forzosa, tanto más ha de entenderse privado de la porción que la Ley atribuye con carácter meramente subsidiario".
} 
- 374 - 


\section{CAPÍTULO IV}

4. RESTRICCIÓN Y LIBERTAD DISPOSITIVA POST MORTEM EN ALGUNOS PAÍSES DE NUESTRO ENTORNO CULTURAL

\subsection{DERECHO FRANCÉS}

\subsubsection{La codificación francesa}

El Código Civil de los franceses, también conocido como Código de Napoleón, es aprobado por la Ley del 21 de marzo de 1804 que, si bien se han hecho en él muchas reformas, todavía sigue vigente en la actualidad. El citado Código Civil es fruto del encargo realizado a una comisión de juristas presidida por Cambacérès ${ }^{874}$ para la recopilación de la tradición jurídica civil francesa. Estos hechos acontecieron en Francia durante el mandato de Napoleón Bonaparte. El propósito de esta recopilación era acabar con la estructura jurídica del Antiguo Régimen. Con ello se pretendía suprimir las leyes destinadas a los distintos sectores, como la aristocracia, los campesinos, gremios, etc. y suprimir las normas locales que eran un obstáculo para la Administración Pública. En resumen, se pretendía con el "Code civil des Français" establecer y extender de manera generalizada una nueva normativa civil aplicable a toda la ciudadanía denominada oficialmente Código Civil Francés.

Si bien es en el Libro III (los diferentes modos de adquirir la propiedad) Título Primero (de las sucesiones). Es en el Capítulo I, concretamente en el artículo $724 \mathrm{CCF}$ con el que comienza a regularse el tema de los herederos legítimos ${ }^{875}$. El Capítulo III dedicado a los diversos

\footnotetext{
${ }^{874}$ JEAN-JACQUES-RÉGIS DE CAMBACÉRÈS, DUQUE DE PARMA (18 de octubre de 1753 - 8 de marzo de 1824) fue un abogado y político francés, recordado principalmente por ser uno de los autores principales del Código Civil francés, que todavía es la base de la legislación francesa. Fue segundo Cónsul de la República desde 1799 a 1804.

${ }^{875}$ Art. 724. "Los herederos legítimos se considerarán ipso jure, poseedores de los bienes, derechos y acciones del difunto, y adquieren la obligación de pagar todas las 
órdenes de suceder, concretamente el artículo 731CCF antepone a los hijos y descendientes del causante a sus ascendientes y colaterales a la hora de sucederle. Este orden descrito en el artículo 731 CCF no es del todo exacto. El articulado del propio Código civil francés establece los siguientes órdenes de suceder en el artículo $734 \mathrm{CCF}^{876}$ :

En ausencia de cónyuge con capacidad para suceder, se llamará a los parientes a suceder como sigue:

1. Los hijos y descendientes

2. El padre y la madre; los hermanos y hermanas y los descendientes de estos últimos.

3. Los ascendientes diferentes de padre y madre; los parientes colaterales diferentes de los hermanos y hermanas y los descendientes de estos últimos.

\subsubsection{La adquisición de la herencia ipso iure}

El ordenamiento francés junto con el alemán se caracteriza por acogerse al sistema de adquisición de la herencia ipso iure. Es el artículo 724 del Code civil francés el que de manera provisional consagra la personalidad del difunto en la del llamado. Se produce con ello una adquisición automática en el momento de la muerte del causante. Por consiguiente, el llamado a la sucesión, que todavía no ha aceptado, deviene titular de los derechos y bienes hereditarios y acciones del difunto sin necesidad de ningún requisito formal. Adquiere la titularidad de los bienes y derechos simplemente por ser la voluntad del de cuiu. Esta transmisión de manera automática de los bienes y derechos es de aplicación tanto a la

cargas de la herencia: los hijos naturales, el cónyuge supérstite y el Estado, deben solicitar la posesión judicialmente y conforme á las reglas que se determinarán”.

${ }^{876}$ Aguilera y VelasCo A.: Colección de Códigos Europeos, anotados y concordados. Código Civil Francés. Tomo I, 1876”, pág. 113. 
sucesión testamentaria como a la sucesión intestada. La adquisición de la herencia es meramente provisional ya que tiene el llamado la facultad de la renuncia. Si bien pierde retroactivamente su cualidad de heredero, tal como recoge el artículo $785 \mathrm{CCF}$. El que renuncia es como si nunca hubiera sido heredero. Es precisamente esta facultad de renuncia la que garantiza la voluntariedad de la aceptación ${ }^{877}$.

Esta aceptación de la herencia ipso iure es una importante diferencia que mantiene el sistema sucesorio francés y alemán con el español, portugués e italiano. En estos tiene lugar la herencia yacente, es decir, la adquisición de la herencia tiene lugar, únicamente, mediante la aceptación de la misma por el llamado. Es precisamente el espacio temporal entre la apertura de la sucesión y la aceptación el que produce la yacencia ${ }^{878}$.

\subsubsection{Las legítimas en el Derecho francés}

Las legítimas están reguladas en el Título II, Capítulo III (de la porción de bienes disponibles y de la reducción) la Sección Primera trata, concretamente, "la porción de bienes disponibles". La legítima francesa es variable en función de los hijos que deje el causante. El artículo $913^{879} \mathrm{CCF}$ contempla la legítima de los hijos: si sólo hay un hijo, la legítima será de la mitad del caudal hereditario. Si hay dos hijos, será de dos terceras partes, y si hay tres hijos o más, tres cuartas partes. En el artículo 914-1 se regula la legítima del cónyuge supérstite que será igual a la cuarta parte del caudal

\footnotetext{
${ }^{877}$ Más información en GARCÍA HeRRERA, V.: Herencia yacente..., op. cit., págs. 26 y 27. "El plazo durante el cual puede el heredero renunciar a la herencia es el señalado en el artículo 780, párrafo I0, del Code civil: La facultad de opción prescribe por diez años a contar desde la apertura de la sucesión".

${ }^{878}$ GARCÍA HERRERA, Herencia yacente..., op. cit., pág. 3.

${ }^{879}$ Artículo. 913 CCF: "Las donaciones o dádivas hechas por contrato entre vivos ó por testamento, no pueden exceder de la mitad de los bienes del donante si a su fallecimiento dejare un solo hijo legítimo; de la tercera parte, si deja dos hijos, y de la cuarta parte si estos fuesen tres o más ".
} 
relicto que sólo existe en defecto de descendientes y ascendientes. El Código civil francés acabó por fusionar la legítima romana con la reserva germánica, en una única institución. Debido a ello se habla indistintamente tanto de legítima como de reserva y de reservatorios o de legitimarios ${ }^{880}$.

Se entiende la legítima francesa, como una parte de sus propios bienes de los cuales no dispone el testador. Ello, si se decide a formalizar un instrumento de transmisión post mortem. Además, la legítima francesa entra en el ámbito del orden público sucesorio. Por lo tanto, la legítima, en el ordenamiento francés es de carácter imperativo y de manera evidente su incumplimiento alteraría dicho orden público ${ }^{881}$.

\subsubsection{La reforma de la legítima por la ley de 23, de julio de 2006}

En materia hereditaria es importante la reforma llevada a cabo por la citada Ley de 23, de julio de 2006. La reforma ha aumentado el poder de disposición del testador y ha disminuido la fuerza imperativa de la legítima y ha variado su naturaleza. Dichos cambios han alterado, en la reserva, sus principios estructurales. Ha desaparecido, con la reforma la legítima de los ascendientes. La parte disponible del legitimario es variable pero no la del testador, por lo que la legítima deja de ser de orden público. Ello en base a que el legitimario dispone de cierta libertad de negociación en su complemento de legítima. Le otorga facultad al legitimario, de poder renunciar al complemento en favor de una determinada persona (art. 929 CCF). Incluso sorprende lo dispuesto por el artículo 1076.1 CCF en que se

\footnotetext{
${ }^{880}$ Véase BERNAD MAINAR, R.: "La porción legítima..., op. cit., pág. 1774. “Así pues, se produce la absorción de la legítima romana por la reserva germánica, de tal manera que la llamada legítima adquiere los caracteres de la reserva germánica. En efecto, aun cuando la redacción final del Código, fruto de discusiones arduas".

${ }^{881}$ Furgado EsteVILl, J. M.: Regímenes económicos del matrimonio y de la pareja. Sucesión y prueba de la cualidad de herederos en el Derecho francés, Bosch, Primera edición, Barcelona, 2011, pág. 367.
} 
permite al legitimario transferir toda o parte de su legítima a sus descendientes. Si bien no se puede dejar de lado la reducción de las liberalidades, efectuadas por el causante, que no deja de contradecir el principio de intangibilidad de la legítima ${ }^{882}$.

\subsubsection{La reserva a los distintos reservatarios o legitimarios}

La legislación francesa define la porción de la herencia reservada a los legitimarios en sus artículos 913 a 919 CDCF pero lo hace de un modo inverso. Nombra la parte de la que puede disponer el testador. La Ley de 23, de julio de 2006 (entró en vigor el 1 de enero de 2007), si bien es cierto que ha mantenido la legítima en su posición, no es menos cierto que le ha otorgado menor rigor. En cuya consecuencia, como ya se ha apuntado, otorga mayor libertad para disponer post mortem al testador. Como también ya se ha apuntado se suprime, con esta Ley, la legítima de los ascendientes. De manera que los descendientes son legitimarios de los ascendientes, pero no lo son las ascendientes de los descendientes, es decir, no hay reciprocidad. Sólo son legitimarios los descendientes con un medio del caudal hereditario, si hay un solo hijo; dos tercios, si hay dos hijos y tres cuartos, si deja tres o más hijos. Ello en virtud del artículo 913 CDCF. El cónyuge supérstite concurriendo sin descendientes su derecho asciende a una cuarta parte del haber hereditario ${ }^{883}$.

La citada reforma de 2006 trajo también modificaciones para la reserva o legítima del cónyuge viudo, fruto de la supresión de los derechos

\footnotetext{
${ }^{882}$ Furgado Estevill, Regímenes..., op. cit., pág. 370 a 374.

${ }^{883}$ Véase BERNAD MAINAR, R.: “La porción legítima...”, op. cit., pág. 1778 en que matiza acerca del "artículo 17 de la Orden 2005-759 de 4 de julio de 2005 (entra en vigor el 1 de julio de 2006) modifica nuevamente el artículo 913 del Código Civil y suprime la frase que introdujo la reforma de 2001 ("sans qu'il y ait lieu de distinguer entre les enfants légitimes et les enfants naturels"), puesto que se da por sentado que ya no existe distinción alguna entre los hijos legítimos y los naturales, razón por la cual no es necesario reseñarlo".
} 
legitimarios de los ascendientes se acrecentaron los del supérstite ${ }^{884}$. El artículo $1094^{885}$ del Code francés dispone que el derecho del viudo, tanto si existen descendientes comunes como si no los hay, se equipare a la parte de libre disposición que con arreglo al número de hijos adquiriría un extraño. Sería la sustracción de la cuota antes descrita para los descendientes:

- Un descendiente $1 / 2$; queda para el viudo: $1 / 2$.

- Dos descendientes 2/3; queda para el viudo: $1 / 3$.

- Tres o más descendientes 3/4; queda para el viudo: $1 / 4$.

El viudo puede optar por todo el usufructo del haber hereditario o bien de un cuarto en nuda propiedad o de las tres cuartas partes en usufructo.

El legislador francés trata de equiparar las parejas de hecho con las parejas conyugales, por medio de un pacto dispuesto en la Ley de 15 de noviembre de 1999, del Pacto Civil de Solidaridad (PACS en adelante) ${ }^{886}$. En que hay una regulación de la convivencia de las parejas de hecho (del mismo o diferente sexo). Este pacto lo recoge y define el artículo 515.1 del Code francés. El PACS describe los efectos jurídicos de las parejas que se han sometido al pacto, que se diferencian sustancialmente de las parejas que viven en concubinato, es decir, en situación puramente de hecho. Al

\footnotetext{
${ }^{884}$ MARTínez MARTíneZ, M.: “Avance de posición...”, op. cit., pág. 212.

${ }^{885}$ Artículo 1094 del Código civil francés: "En el caso de que el cónyuge deje hijos o descendientes comunes o no, podrá disponer a favor del otro esposo, bien de la propiedad de la cual podría disponer a favor de un extraño, o bien de un cuarto de los bienes en propiedad y de los otros tres cuartos en usufructo, o bien de todos los bienes en usufructo. Salvo disposición en contrario del disponente, el cónyuge sobreviviente puede limitar su derecho sobre una parte de la herencia de los bienes dispuestos a su favor. Esta limitación no será considerada como una liberalidad hecha a los demás herederos".

${ }^{886}$ CORRAL GiJÓN, M.C.: "Las uniones de hecho y sus efectos patrimoniales (parte $2^{\mathrm{a}}$ : efectos patrimoniales)", Revista Crítica de Derecho Inmobiliario, núm. 664, marzoabril 2001.
} 
parecer la jurisprudencia francesa no le reconoce más efectos que los que conllevan al enriquecimiento sin causa ${ }^{887}$.

Los miembros de las uniones o uniones de pareja registrados no tienen la condición de legitimarios. Sólo tienen un derecho de uso de la vivienda de acuerdo con el artículo 763 del CCF. Sólo pueden heredar si han sido instituidos herederos en el testamento.

\subsubsection{La preterición y la desheredación en el Derecho civil francés}

A diferencia de lo que ocurre en el Derecho civil español, el Derecho francés no prevé la preterición. Ello es consecuencia de la configuración de la reserva o legítima francesa. A diferencia del Derecho patrio el Código francés no hace reserva de los bienes destinados a legítima. Simplemente limita la cuantía de los que puede disponer en vida el testador y en consecuencia, el resto son legítimas. De ahí que no se tengan que nombrar legitimarios, sino que se les concede una acción personal de reclamación cuando estimen que su derecho ha sido perjudicado en todo o en parte ${ }^{888}$. La reserva que la Ley hace en Francia a favor de determinados parientes del disponente, no se configura como un límite a la libertad de disposición post mortem. Sino conforme a la tradición germánica se hace en base a la

\footnotetext{
${ }^{887}$ La STS de 12/09/2005 (Tol. 725.211) F. J. $2^{\circ}$ se refiere al PACS como : “ existen dos grandes grupos de ordenamientos jurídicos: los que admiten el pacto formal entre convivientes y a partir de aquí, establecen unos determinados efectos, como ocurre en Francia, después de la Ley de 15 de noviembre de 1999, que introdujo el "pacto civil de solidaridad" (PACS), aunque mantuvo el concubinato como relación puramente de hecho, es decir, sin pacto formal, al que la jurisprudencia francesa ha reconocido sólo efectos cuando concurren los requisitos del enriquecimiento sin causa (sentencia de 15 de octubre de 1996)".

${ }^{888}$ Véase CAROL Rosés, F.: “La preterición...”, op. cit., pág. 438. "Dado que la libertad de testar es escasa, no ofrecen demasiado interés la preterición errónea y la legítima formal".
} 
copropiedad entre los parientes consanguíneos cuyo patrimonio, a priori, ya les pertenece y además de una manera colectiva” ${ }^{, 889}$.

\subsubsection{El artículo 909 del Code francés}

Este precepto tras su modificación en 2007, por la Ley 2007-308, de 5 de marzo de 2007 de reforma de la protección jurídica de las personas mayores refleja en su disposición las nuevas necesidades del testador. Lo hace al respecto de la protección de su libertad de testar. Una libertad condicionada puesto que podrian los cuidadores por las nuevas tendencias en que las personas mayores finalizan su exitencia en un geriátrico. Podrían los cuidadores quebrar la última voluntad del disponente. Un testador vulnerable, no hay duda al respecto que la proximidad de sus cuidadores pueden atraer con facilidad su voluntad. De ahí que el legislador francés haya previsto dicho riesgo para el testador y su familia en el apartado primero del precepto citado ${ }^{890}$. Su vigencia desde el 01/01/2009 prohíbe ser beneficiarios testamentarios a las personas jurídicas que ejercen el cuidado del mayor y a los tutores del mismo. Si bien con algunas excepciones a los parientes de hasta el cuarto grado ${ }^{891}$.

Esta protección del testador vulnerable, también se da en el Derecho español. Concretamente en del Derecho civil catalán el artículo 412-5.2 $\mathrm{CCC}$ establece como requisito imprescindible el testamento notarial abierto o pacto sucesorio para poder favorecer, el disponente, a sus cuidadores

\footnotetext{
${ }^{889}$ PÉREZ EsCOLAR, M.: "El cónyuge supérstite como legitimario" en El cónyuge supérstite en la sucesión intestada, Dykinson, Madrid, 2005.

${ }^{890}$ Artículo 909. 1, del Code francés: Los médicos o cirujanos, los profesionales sanitarios y los farmacéuticos que hubieran cuidado a una persona durante la enfermedad que le causó la muerte, no podrán beneficiarse de las disposiciones entre vivos o testamentarias que se hubieran hecho en su favor durante el curso de dicha enfermedad.

${ }^{891}$ TORRES GARCÍA T. F. Y GARCÍA RuBIO, M.P.: La libertad de testar: El principio de igualdad de la persona y el libre desarrollo de la personalidad en el Derecho de sucesiones, Fundación Coloquio Jurídico Europeo, Madrid, 2014, pág. 182 y 183.
} 
cuya relación sea contractual. Por lo tanto si el testador desea favorecer mortis causa a sus cuidadores o empleados de centros asistenciales necesita el otorgamiento de escritura pública. El legislador catalán considera que el notario valorará la capacidad del testador antes de otorgar el testamento (arts. 417-7; 685 y 707.4 CCC) ${ }^{892}$. El ordenamiento común español exige para la validez del testamento que el testador goce de sus plenas facultades mentales en el momento de testar, ello por mandato imperativo del artículo 663.2 del Código civil. Si bien la jurisprudencia española puede destruir la presunción notarial de capacidad ${ }^{893}$.

Hay poco que comparar entre la desheredación española y lo dispuesto para el mismo fin en el Code francés. Más bien destacar que es precisamente la desheredación una de las instituciones por las cuales durante el periodo Codificador español este, ya se desmarcó de su principal referente, el Code Napoleón. Puesto que a dicha época ya no contaba este, con la institución señalada, y solamente regulaba la indignidad sucesoria. Dándose con ello, en el Código napoleónico, una separación con el Derecho histórico escrito anterior a la codificación francesa y un profundo acercamiento al Derecho consuetudinario de origen germánico. Es precisamente esta tendencia, en la sucesión dispuesta en el Code francés, la que produce la separación, por lo que a sucesiones se refiere, entre dos

\footnotetext{
${ }^{892}$ VAQUER AlOY, A.: "La protección del testador vulnerable", Anuario de Derecho Civil, núm. LXVIII-II, abril 2015, pág. 348.

893 STS de 05/11/2009 (Tol. 1.748.175) F.J. $21^{\circ}$ donde pone de manifiesto el Alto Tribunal, el juicio de capacidad del testador efectuado por el Notario antes de otorgar testamento: "El Notario debe apreciar la capacidad del testador, pero este no es un juicio definitivo, puesto que la jurisprudencia de esta Sala ha venido manteniendo la posibilidad de destruir la presunción de capacidad que se deriva de las afirmaciones notariales, porque se trata de una presunción iuris tantum que admite prueba en contrario (STS de 19 septiembre 1998 , entre otras)".
} 
sistemas como son el francés y el español que únicamente los separa físicamente una línea fronteriza ${ }^{894}$.

\subsection{DERECHO ANGLOSAJÓN}

No cabe duda de la influencia del Derecho romano ejercida sobre el Derecho anglosajón tomando este en préstamo tanto máximas como reglas del citado Derecho romano ${ }^{895}$. Resaltando el dato de que en los siglos XII y XIII, en Inglaterra, la herencia se dividía en tres tercios, de los cuales correspondía un tercio al viudo, otro a los hijos y el restante era libre disposición para el testador. En el supuesto de concurrir a la sucesión sin hijos, le correspondía la mitad de la herencia a la viuda. Entendiendo con ello, que de la otra mitad restante podía disponer libremente el testador ${ }^{896}$. Es destacable también la teoría de la "partes razonables" que no dejaba de ser un mecanismo destinado a proteger a los familiares más íntimos del causante, en que la esposa o descendientes reclamaban judicialmente lo que

894 Más información en RePRESA PolO, M.P.: La desheredación, op. cit., pág. 18. Mantiene la autora que "el Code napoleónico únicamente recoge un solo supuesto en el que podía perder el heredero lo que le correspondía en la herencia". Otra manifestación importante que hace la autora es al respecto de los artículos 834 y ss del Anteproyecto de Código civil de 1882 y 1888, que recogen lo dispuesto para la desheredación en el Proyecto de García Goyena y ello pasará íntegramente al Código civil español vigente de 1889. Lo hará por virtud de la Base $15^{a}$ de la Ley de bases de 1888 , es decir, "la necesidad de mantener en su esencia la legislación vigente sobre los testamentos", en la legislación precedente.

${ }^{895}$ BARrio Gallardo A.: El nacimiento..., op. cit., pág. 188. "De ahí que se haya afirmado que el tratado de bracton no sólo ofrece testimonio de la influencia del derecho romano y de sus exponentes medievales, sino que al mismo tiempo sigue siendo una declaración de genuino derecho inglés (...) tan detallado y preciso que no hay nada comparable en toda la literatura jurídica de la edad media".

${ }^{896}$ Véase en BARRIO GALLARDO, “El nacimiento...”, op. cit., págs. 204 y205. Este autor se ampara en Hale, Spence Y Glanville, para afirmar acerca de los bienes muebles, en el caso de fallecimiento del padre en que un tercio iba a la esposa, otra idéntica parte correspondía a los hijos del causante y del tercio restante disponía libremente el testador. Caso de ser viudo y tener hijos se dividía por mitades la herencia, es decir, la mitad para los hijos y la otra mitad para disponer a su discreción el testador. En el supuesto de carecer de hijos, pero no de esposa, regía el mismo proceder de reparto, es decir, $50 \%$ para la viuda y $50 \%$ para libre disposición. 
se denominaba "reasonable part". Venía a constituir, una vez deducidas las deudas, un tercio del caudal relicto. La pervivencia de esta institución, típica en los siglos XIV y XV se prolongó hasta bien entrado el siglo XIX en algunas regiones de los países regidos por el Common Law.

\subsubsection{La decadencia del Civil law}

La decadencia del Civil Law proveniente del continente europeo se produjo como consecuencia del distanciamiento patente entre Inglaterra y Europa durante el reinado de los Tudor y los Estuardo. Precisamente fueron, dichos reyes, quienes mostraron una ferviente oposición a las ideas jurídicas procedentes del extranjero. Por lo tanto, no se puede decir que Inglaterra rechazó el sistema legitimario como consecuencia de la falta de demanda. Ni que las familias inglesas requerían otro tipo de regulación sucesoria. Ni menos a que su libertad de testar fuera más beneficiosa que la que recoge la existencia de legitimarios. Solamente cabe decir que la legítima se suprimió en el Derecho anglosajón por dos razones:

1. La primera por razones políticas (distanciamiento con EuropaContinental)

2. La segunda por decidir dos dinastías reales oponerse a las ideas jurídicas que provenían de fuera de Inglaterra, es decir, de países continentales como podía ser España, entre otros.

Por lo expuesto, se puede afirmar que la libertad de disposición inglesa no es fruto de un derecho pulido y valorado. Es un fruto político del rechazo al Derecho no cultivado en la propia Inglaterra. La desaparición de la legítima obedecería a una oposición de Enrique VIII a la práctica pontificia que la recomendaba ${ }^{897}$. Incluso existen afirmaciones que acusan a

\footnotetext{
${ }^{897}$ Véase en BARRIO GALLARDO, "Estudio histórico-comparado...", op. cit., pág. 53. Encuentra, este autor, explicación a la desaparición de la legítima en Inglaterra al añadirle "al clima jurídico enrarecido el cisma anglicano y la abierta ruptura de Enrique
} 
la práctica eclesiástica inglesa en constante contradicción con el Derecho canónico y las fuentes pontificias ${ }^{898}$. Otras voces también afirman que se ha implantado, dicha libertad de disposición sin mirar el contenido. Fijándose únicamente en el origen de la procedencia. Es más, se justifica lo expuesto, en la profunda romanización jurídica que sufrió Inglaterra en el siglo XIII. Manteniendo incluso que, ante lagunas en el Derecho propio, se recurríría al Ius Commune ${ }^{899}$.

\subsubsection{Legítimas dentro del Derecho anglosajón}

Escocia, es un referente del Derecho consuetudinario anglosajón, en el cual, queda patente la pervivencia de las legítimas. Así, en el caso del cónyuge supérstite su derecho asciende a un tercio de los bienes muebles de la herencia. En aquellos supuestos, en que la muerte de uno de los cónyuges insta la disolución del matrimonio con la existencia de hijos comunes. Cuando la disolución del matrimonio deviene sin hijos comunes, la cuota legitimaría del viudo asciende a la mitad de los bienes muebles de la herencia. A los hijos y descendientes les corresponde un tercio de los bienes muebles, de concurrir a la sucesión con el cónyuge del causante. La

VIII con el papado de Clemente VII como una desviación de la práctica eclesiástica inglesa respecto de las fuentes pontificales".

898 Mayor información en BARRIO GALlARDO, A.: "El common law de la edad contemporánea", en El largo camino hacia la libertad de testar. De la legítima al derecho sucesorio de alimentos, Dykinson, Madrid 2012, pág. 248. Sostiene este autor citando a Helmholz "que la desaparición de la legítima fue una desviación de la práctica eclesiástica inglesa respecto del Derecho canónico de las fuentes pontificias".

${ }^{899}$ Véase en BARRIO GAllardo, A.: "Estudio histórico-comparado...", op. cit., págs. 45 y 92. Según afirma, este autor, "Charles Phineas sostuvo que el Derecho inglés no atravesaría otra época en la que el Derecho romano fuera igual de decisivo. Mientras gobernó Enrique II de Plantagenet, Inglaterra se impregnó del Civil Law cuyo influjo se prolongaría, cuando menos, hasta el reinado de Enrique III".

Por lo que respecta al tema que, a aquí interesa, es decir, las sucesiones en el citado siglo XIII, Glanville y Bracton, "habían descrito en sus tratados cómo debía procederse a partir la herencia de un hombre, sancionando la que más adelante sería conocida como "teoría de la parte razonable" que se canalizaba en el proceso en virtud de la "writ de rationabili parte bonorum" (recurso de una parte razonable de los bienes). 
mitad de los citados bienes muebles si no concurren con el supérstite ${ }^{900}$. En Escocia los legal rigths son un equivalente de las legítimas continentales, si bien cabe resaltar que no existe allí la protección que se le otorga en el continente a la legítima, ni siquiera existe regulación para la preterición. Solamente se regula la reclamación de la legítima ${ }^{901}$. Si bien existió paridad entre la legítima escocesa y la inglesa entre los siglos XI y XIII luego tuvo lugar el distanciamiento de Inglaterra.

Otro ordenamiento relevante de la existencia de legítimas dentro del Derecho anglosajón es el que regula las sucesiones en Irlanda. Son allí legitimarios los hijos y los descendientes de estos, que los puedan representar en la sucesión. También lo es el cónyuge viudo, a diferencia del caso de Escocia, la cuantía que cubre las legítimas es fijada por el juez para lo que toma como base un tercio de la herencia, en caso de concurrir los hijos o sus representantes con el viudo del causante. La misma cuota (1/3) para el segundo si concurre con los primeros. La mitad de la herencia si los unos concurren sin el otro. Es decir, viudo concurriendo sin los hijos del causante o estos sin el viudo. En todos estos supuestos expuestos la fecha tope para reclamar la legítima son 6 meses desde el fallecimiento del causante $^{902}$. También el Derecho de Jersey o el de la Isla de Man, al igual que se ha visto en el escocés, está muy influenciado por el Civil law. Al referirse al "Derecho inglés" hay que precisar que solamente se está aludiendo al Derecho vigente en Inglaterra y Gales. No recoge este término

\footnotetext{
${ }^{900}$ Véase las legítimas en Irlanda en BARRIO GALLARDO, A.: La evolución de la libertad de testar en el Common law inglés, $1^{\text {a }}$ ed, Aranzadi, Navarra, 2011, págs. 199 y 200.

${ }^{901}$ CAROL RosÉs, F. “LA PRETERICIÓN...”, OP. CIT., PÁG. 437.

${ }^{902}$ RENTERÍA AROCENA, “La libertad de testar...”, op. cit., pág. 2100.
} 
todo el Derecho que impera en las Islas Británicas ya que confluye allí un sistema, más bien, plurilegislativo ${ }^{903}$.

Estas limitaciones se razonan al atribuirse a la ley, el derecho a disponer soberanamente de la herencia a favor de los hijos. Crea con ello un derecho a la sucesión en los hijos que incluso, visto bajo otra perspectiva, se podría decir que crea unos acreedores sobre la herencia. Es decir, se impone la voluntad de la ley sobre la voluntad del titular de los bienes. Estos impedimentos legales al propietario de los bienes desvirtúa la autoridad del padre sobre el hijo. En principio crea un deudor en el causante y un acreedor en el legitimario. Lo que verdaderamente aquí importa es lo aportado, es decir, la libertad de testar de que dispone Inglaterra y Estados Unidos ${ }^{904}$.

Cierto es que se podría debatir la argumentación expuesta en el párrafo anterior simplemente retrotrayéndose a los motivos y situaciones que hicieron necesarias dichas reservas legales. Precisamente para evitar las injusticias y los abusos que acarreaba la libertad de testar. Tal libertad, sólo existió durante el siglo XIX en Inglaterra, Estados Unidos, Australia y Nueva Zelanda, entre otros ${ }^{905}$. Siendo el Derecho anglosajón o Common Law, el que le da mayor acogida, con la promulgación de la Dower Act en

\footnotetext{
${ }^{903}$ Véase en YBARRA Bores, A.: "La sucesión mortis causa de ciudadanos ingleses residentes en España: problemas y nuevas perspectivas", en Cuadernos de Derecho transnacional, Vol 1, núm 1, marzo 2015, pág. 227. El término Derecho inglés "no abarca a todo el Derecho que rige en las Islas Británicas (que incluye al Reino Unido de la Gran Bretaña -Inglaterra, Escocia y Gales-e Irlanda del Norte, a las Islas del Canal Jersey, Guernsey, Alderney y Sark- y a la Isla de Man)"

904 Aguilera y Velasco A.: Colección..., op. cit., pág. 139 y 145. Afirma este autor: "las leyes de Inglaterra y de los Estados-Unidos establecen la libertad de testar, que todavía limitan la mayor parte de los Códigos de otras naciones".

${ }^{905}$ SUAU COT, V. J.: "La libertad de testar y sus límites. Hacia una reforma de las asignaciones forzosas", Universidad de Chile", Facultad de Derecho, Departamento de Derecho privado,repositorio.uchile.cl/.../La-libertad-de-testar-y-sus-límites-haci. 2015, pág. 8.
} 
1833 Ley que dejo total libertad a la asignación de patrimonio al viudo. Si bien eliminó, con ello, la única restricción a la libertad de disposición que vinculaba al testador al redactar su testamento. La doctrina y jurisprudencia de la época dice: "one has the right to make an unjust will, an unreasonable will, or even a cruel will" ["Uno tiene el derecho de hacer una voluntad injusta, una voluntad irracional, o incluso una voluntad cruel] $\mathrm{y}$ "the testator's right to be capricious" [El derecho del testador a ser caprichoso] respectivamente.

\subsubsection{La provisión de la familia y dependientes}

El Derecho anglosajón, como es sabido, comprende casi una cuarta parte de los ordenamientos jurídicos del mundo. Dicho Derecho ha regido o rige, en todos aquellos países que han sido colonias inglesas o en los que el inglés es lengua oficial en la actualidad. Se puede afirmar, de manera generalizada, que en la mayoría de países que pertenecen a la familia jurídica anglosajona no hay legítimas. Hay simplemente unos derechos similares a los que en el Derecho continental se entienden por derecho de alimentos. El Derecho anglosajón califica, los derechos alimenticios, como "family provision" "906. Se trata de una provisión que, a instancia de parte, reconoce o deniega derechos a una atribución económica que entienden tener los familiares que instan la reclamación judicial. Ello procede en el caso de no haberles reconocido en el testamento a los familiares una renta

\footnotetext{
906 BARRIO GALlARDO, A.: El common law en la actualidad: un ejercicio de prospectiva, Dykinson, Madrid, 2012, pág. 291. Citando, este autor, a Richard Oughton, para afimar que la libertad de disposición post mortem inglesa sólo tuvo lugar durante un breve periodo de tiempo de 47 años, entre el año 1891, "cuando la Mortmain and Charitable Uses Act de dicho año suprimió todas las restricciones de donaciones testamentarias a la caridad, hasta 1938 cuando se aprobó la Inheritance Family Provision".
} 
única o periódica, o bien cuando han sido favorecidos con la transmisión patrimonial de bienes del causante ${ }^{907}$.

El juzgador decidirá, teniendo en cuenta la posición de los demandantes y al montante de la herencia, si procede la provisión familiar citada y su contenido. Lo hará en base, no a una cuota fija, sino a una ponderación razonable entre los litigantes. Cabe destacar el corto plazo que existe para demandar la "family provision" "908 . El plazo no puede superar los 6 meses desde el fallecimiento del causante. La Ley británica de 1975, sobre Protección de la Familia (Inheritance Family Provision \& Dependants Act) faculta a los órganos judiciales una serie de competencias limitadas. Lo hace, a fin de establecer alimentos temporales tanto a favor de familiares del causante como a personas no familiares ${ }^{909}$. Si bien hay que destacar que la propia Acta de 1975 dispone que las citadas asignaciones no tengan la consideración de un derecho de alimentos. Ello en base a que la necesidad del solicitante sólo es un requisito, entre otros, a considerar por el Tribunal ${ }^{910}$.

La concesión y la cuantía de la family provision no están ni en la función ni en el grado de necesidad del solicitante. Sino más bien es el llamado "estándar de mantenimiento", como la responsabilidad y obligaciones del causante con el solicitante de la provisión el responsable de la concesión o denegación. También influye la cuantía y composición de

${ }^{907}$ Rentería AROCEnA A.: "La libertad de testar en Derecho Comparado" Revista Crítica de Derecho Inmobiliario, núm. 726, julio 2011, págs. 2095 a 2102.

${ }^{908}$ RenteríA ArocenA, "La libertad de testar...", op. cit., pág. 2099. "Pueden reclamar la family provision las siguientes personas, siempre y cuando ni la ley ni el testamento ordenen a su favor una cuota hereditaria o legado razonable".

909 Véase en RENTERÍA AROCENA, “La libertad de testar...”, op. cit., pág. 2100.

${ }^{910}$ SAU COT, "La libertad de testar...", op. cit., pág. 9. "Estas asignaciones no se consideran propiamente alimenticias pues el estado de necesidad del solicitante no es requisito sino uno de los tantos elementos que deben considerar los tribunales al otorgar una family provision". 
la herencia así como las discapacidades existentes, tanto en el solicitante de la provisión, como en los herederos. Quizá uno de los puntos más relevantes es la conducta tanto del que solicita la provisión como de los herederos. Otro aspecto que tiene muy en cuenta el juez para otorgar o denegar la citada provisión familiar son las razones del testador para no haber efectuado la atribución solicitada en su testamento ${ }^{911}$.

Pueden reclamar la "family provision": el cónyuge, aunque esté divorciado, con la excepción de que no la puede pedir si se ha vuelto a casar. Los hijos y descendientes del causante, incluidos los concebidos fuera del matrimonio, e incluso los concebidos pero no nacidos. También cualquier persona que hubiera convivido con el causante y los dependientes económicamente en vida del difunto. Se advierten rasgos muy parecidos a los citados, de convivencia y dependencia económica, en la legítima rusa. Existen allí, estos mismos derechos, por lo que al cónyuge e hijos se refiere y a las parejas de hecho registradas ${ }^{912}$.

Una sentencia de $2007^{913}$, en que se deniega la family provision a una solicitante supuestamente necesitada. Se le deniega la citada provisión a una hija que la solicitaba de la herencia de su padre. Esta solicitante basaba su derecho en que tenía tres hijos de distintos padres y sólo uno estaba en

${ }^{911}$ VAQUER ALOY, A.: "Reflexiones sobre una eventual reforma de la legítima" InDret, núm. 3, 2007, pag.457. Este autor reafirma lo expuesto y amplia información sobre la figura de la family provision. Manteniendo que no comparte fundamento alguno con el derecho de alimentos que recoge el Derecho español, ni tampoco se aprecia disparidad absoluta entre estas dos instituciones.

${ }^{912}$ Más información en SIMEÓN PÉREZ, "La legítima...", op. cit., pág. 8. "La protección a los parientes desvalidos que se reconoce en esta norma como límite a la estatalización forzosa de la propiedad privada se convertirá en una seña de identidad propia del derecho sucesorio de la Unión Soviética que sobrevivirá en todas las innovaciones legislativas. Este principio constituye el germen de la legítima reconocida en el actual art. 1149 GKRF y en muchos otros Códigos de las Repúblicas ex-soviéticas".

${ }^{913}$ VAQUER ALOY, "Reflexiones...", op. cit., pág. 6. "Garland v Morris and another [2007] All ER (D) 11 (Jan), donde el juez Furness acaba denegando la family provision a la hija desheredada por el testador". 
edad laboral, por lo que tenía que vivir de los subsidios sociales. El Juez inglés se basa:

1. En las escasas relaciones habidas entre padre e hija en los últimos años anteriores a su fallecimiento.

2. En que la hija, con lo que había heredado de su madre, se compró una casa.

3. En que desde hacía años no trabajaba ni buscaba trabajo.

4. La buena relación que mantenía el causante con su otra hija y hermana de la solicitante de la provisión.

5. El hecho de que el padre y causante hubiera ayudado a su otra hija y a los hijos de esta en otros tiempos.

Al comparar la libertad de disponer post mortem con el sistema legitimario siempre salen los sistemas angloamericanos del common law en los que rige el principio de libertad de disposición. En los sistemas continentales europeos se han hecho últimamente modificaciones a la legítima. Todas encaminadas a reducir la reserva legal, sin llegar a suprimir totalmente el sistema legitimario ¿Quizá temor? ¿Quizá prudencia? ¿Quizá inseguridad, a la plena libertad de testar? ${ }^{914}$ Sin ir más lejos en el Derecho belga, la Ley de 28 de marzo de 2007 ha reformado la institución de la legítima en ese país. Ha habido un debilitamiento en lo que respecta a la legítima de los padres, si bien siguen siendo legitimarios, se mejora la situación del cónyugue o de la pareja viuda en la sucesión intestada. Con la relevancia del artículo 203.1 del Código civil belga que obliga a la crianza de los hijos del causante, incluso en el supuesto de concurrir a la sucesión con los ascendientes, le otorga al viudo toda la herencia. Así mismo en el supuesto anterior el artículo 745 del Código civil belga impone a cargo de los bienes recibidos un deber de alimentos para los ascendientes del

\footnotetext{
${ }^{914}$ PARRA LuCÁN, “Legítimas...”, op. cit., pág. 487.
} 
causante, evidentemente a aquellos ascendientes que cumplan los requisitos al tiempo de fallecimiento de su descendiente premuerto. Entonces, si la meta es llegar a la libertad de disposición, los sistemas angloamericanos de la Common Law estarán llegando a la meta de la carrera, en que los continentales europeos acaban de empezar. Lo que es lo mismo estarán llegando a la plena libertad de disposición post mortem $^{915}$.

4.2.4. La provisión para la familia anglosajona y el derecho de alimentos continental

A primera vista se le podría atribuir, a esta institución anglosajona, una semejanza con el derecho de alimentos continental. Si bien no son totales las coincidencias entre ambos instituciones, si que se les puede atribuir cierta analogía, por lo menos, con el Derecho común español. En el Derecho anglosajón el artículo 1, de la referida Acta de 1975 dispone sobre las personas que pueden solicitar tal provisión:

1. El cónyuge del causante o pareja de hecho o el ex cónyuge que no haya contraído nuevas nupcias.

2. Hijo del causante.

3. Personas que, durante la vida del causante, este haya tratado como sus propios hijos.

4. Cualquier persona a la que el causante hubiera mantenido, total o parcialmente, cuando estaba vivo ${ }^{916}$.

\footnotetext{
${ }^{915}$ PARRA LUCÁN, “Legítimas...”, op. cit., pág. 487.

${ }^{916}$ Según FernándeZ-Hierro, M., y FERnÁndeZ-Hierro, M.: "Panorama legislativo actual de la libertad de testar" boletín de la Academia Vasca de Derecho= Zuzenbidearen Euskal Akademiaren aldizkaria, núm. 19, 2010, pág. 20. "Provision for Family and Dependants Act 1975" la Provisión para la Familia y Dependientes Acto 1975) "permite a determinadas personas solicitar al Tribunal una "provisión" (disposición) en el supuesto de que el testador en el testamento (o bien las normas de sucesión intestada) no realice una atribución económica razonable a su favor”.
} 
Hay que traer a colación lo dispuesto en el artículo 3 del Acta de 1975 cuyo precepto regula los criterios a tener en cuenta por el tribunal, para atribuir con equidad lo solicitado por el supuesto necesitado:

1. Las evidentes necesidades del solicitante que tenga o pueda tener.

2. Las mismas necesidades que tengan o puedan tener los destinatarios de los bienes a voluntad del testador.

3. Las obligaciones y responsabilidades del causante tanto con los solicitantes de la provisión como los destinatarios de la herencia.

4. Montante hereditario.

5. Discapacidades físicas tanto del solicitante de la previsión como de los destinatarios de la voluntad del testador.

6. Otras cuestiones relevantes para el juez tanto en las personas solicitantes de la previsión como en los destinatarios de la voluntad del causante.

7. Existen otras circunstancias, con peso y valor, para posicionarse el tribunal a favor o en contra del solicitante de la provisión que no ve el mismo derecho en un viudo de corta que de larga duración marital, así como la edad de dicho viudo. Todo ello son factores a tener en cuenta por el juez ${ }^{917}$.

El Derecho común español regula el derecho de alimentos en los artículos 92, 92 bis y $93 \mathrm{Cc}$ así como también en los artículos 142 a 153 del Código civil como normas de orden público enfocadas a la protección de la familia. Esta normativa recoge además de la protección a los hijos la protección entre parientes necesitados. Con ello ya se ve una cierta similitud en el objetivo común de protección familiar entre el Derecho de

\footnotetext{
${ }^{917}$ FERNÁNDEZ-HIERRO, Y FERNÁNDEZ-HIERRO, "Panorama legislativo actual...”, op. cit., pág. 28. Estos autores se reiteran en las amplias libertades de que dispone el Juez inglés "para valorar las circunstancias del caso, y determinar si procede o no la concesión de esta provisión y cómo articularla en relación con la herencia del causante".
} 
alimentos español y la institución anglosajona ${ }^{918}$. Para mayor certeza sólo hace falta remitirse al artículo $845 \mathrm{Cc}$, antes de la reforma de 1981, en que los hijos ilegítimos que no alcanzaban la condición de naturales solamente les quedaban la posibilidad de reclamar, por virtud del precepto citado, $\operatorname{alimentos}^{919}$.

En el Derecho aragonés el artículo 30 CDFA otorga acción a los legitimarios si tras la distribución de la herencia quedaran en situación legal de pedir alimentos. Lo pueden hacer en contra de los herederos del causante, en proporción con las respectivas participaciones en la herencia forzosa. La permanencia del derecho de alimentos en Aragón, con ligeras variaciones encaminadas a su mejora técnica es el que rige en la actualidad en el artículo 515 CDFA. Como se puede apreciar en ambos sistemas, aragonés y anglosajón, se advierte cierto temor o cierta inquietud a la absoluta libertad de testar. Es decir, a que el testador sin límite o control alguno por parte de la Ley pudiera distribuir su patrimonio desacertadamente para las personas necesitadas. Tal desacierto pudiera enmendarse con una "prestación cercana a un derecho de alimentos como causa de la muerte del disponente ${ }^{920}$.

\footnotetext{
${ }^{918}$ De LA IGLESIA MonJe, M. I.: "Derecho de alimentos versus gastos de crianza y educación de los hijos mayores de edad. los gastos de crianza como indemnización en los supuestos de wrongful conception o wrongful pregnancy", Revista Crítica de Derecho Inmobiliario, núm. 749, mayo 2015, pág. 1539.

${ }^{919}$ Más información en PÉREZ EsCOLAR, M.: "El cónyuge supérstite...”, op. cit., Citando (Cita 80) esta autora a Royo Martínez: officium pietatis, y a la STS de 6 de julio de 1957 (R. J. A. no 2222) para decir que: "el deber de amor se manifiesta en vida a través de la institución de alimentos y post mortem por las legítimas".

${ }^{920}$ BARRIO GALlARDO, A.: "Estudio histórico-comparado...", op.cit., pág.77. "Algunos tribunales norteamericanos recurrieron al color insaniae (resaltaba la inoficiosidad del testamento que se apartaba de las pautas sociales) enmendar testamentos que, si bien con arreglo a derecho eran perfectamente válidos, contrariaban la moral pública imperante en la época; otros en la antigua metrópoli, tras la family provisión, se hallaban revestidos de facultad para rescribir el testamento. En Aragón, a finales del siglo xix, se suceden igualmente pronunciamientos en los que se concede una más que dudosa acción
} 


\subsubsection{Diferencias con el Derecho español}

El Acta 1975 es la que aporta las diferencias existentes con el Derecho español:

1. El heredero, conforme se contempla esta figura en el Derecho patrio, es el encargado de gestionar las obligaciones, voluntades y derechos del causante. Acoge con su aceptación la gestión de la herencia. Adopta la figura del causante y fallecido este ostenta su responsabilidad para con sus deudas. Es decir, subsisten muchas de las relaciones jurídicas que existían en vida del causante. Lo único que ha variado es el sujeto titular de los derechos y de las obligaciones que en definitiva es lo que se transmite ${ }^{921}$.

2. Para el Derecho anglosajón no hay que encontrar a alguien que suceda al difunto en sus deudas. Los bienes del fallecido son destinados al pago de sus deudas ${ }^{922}$. Solamente se convierten en bienes heredables, como ya se ha dicho, los sobrantes de dichas deudas $^{923}$. De ahí la importancia que adquiere en el Derecho anglosajón la figura del executor (albacea) en la sucesión testada. Y el administrador (administrator) en la sucesión intestada. Estas dos

de complemento de legítima a imitación de cuanto acontecía en los territorios donde regía el Código civil, a quienes eran totalmente excluidos de la herencia paterna sin motivo aparente, mediante los diez sueldos jaqueses, cinco por sitios y cinco por muebles: una legítima cuya cuantía, en ocasiones, era proporcional al caudal relicto182 y procuraba al excluido tan solo medios de subsistencia".

${ }^{921}$ GARCÍA PÉREZ, C. G.: “La (in) equivalencia terminológica en la traducción de testamentos estadounidenses al español", Revista de Ciencias Humanas y Sociales, Vol. 74, núm.144, 2016, págs. 177 - 194.

${ }^{922}$ Mingorance GosÁlveZ, "Los principios...", op. cit., pág. 3224. "El sistema anglosajón o common law es diferente y entiende que el fallecimiento de la persona física, causante de la apertura del fenómeno sucesorio, señala el instante para satisfacer las deudas y, en general, se puede decir que para extinguir el pasivo del caudal relicto a base del activo".

923 Más información en MingoranCE Gosálvez, "Los principios...”, op. cit. pág. 3223. "Otros sistemas jurídicos hacen del pago de las deudas del causante una operación previa y fundamental, que precede a la adquisición del activo remanente. No hace falta insistir. Se trata de los dos conocidos sistemas romano y anglosajón". 
figuras se asemejan a la figura del albacea en el Derecho sucesorio español cuyo cometido consiste, entre otros, en la distribución de la herencia ${ }^{924}$.

3. Al no contemplar legítima, propiamente dicha, el Derecho anglosajón no conoce la institución como tal. No la conoce como se pueda entender como una reserva de bienes por la ley, para determinados grados de parentesco. El Derecho anglosajón sólo contempla las family provisions que simplemente permiten que el Juez, a su libre albedrío, pueda disponer a favor de determinados parientes del causante una provisión de bienes suficientes para vivir $^{925}$.

Por lo que respecta a la sucesión abintestato (intestacy), esta se abre en defecto de sucesión testada o bien en defecto de beneficiario o de atribución patrimonial alguna en la testada. Es destacable el hecho de que dependiendo si el testador ha distribuido o no, todos sus bienes, tiene lugar la sucesión totalmente intestada o la parcialmente intestada. Posibilidades, las citadas, que contempla y admite el Derecho anglosajón que no está únicamente formado por decisiones judiciales sino que también dispone de importante legislación ${ }^{926}$.

\footnotetext{
924 ANDERSON, M.: "Una aproximación al derecho de sucesiones inglés", Anuario de derecho civil, núm.59, 2006, pág. 1245.

${ }^{925}$ Véase en ANDERSON, "Una aproximación al derecho...”, op. cit., pág. 1246. "La Ley no destina una cantidad proporcional del patrimonio del causante a sus parientes cercanos ni al cónyuge, sino que simplemente se contemplan las llamadas family provisions, por medio de las cuales la autoridad judicial, discrecionalmente, dispone a favor de los dependientes del causante la provisión de bienes suficientes para sobrevivir o, según los casos, para llevar una vida de nivel parecido a la que llevaban con anterioridad al fallecimiento del causante".

${ }^{926}$ DEL OLMO GARCíA, P.: "Enriquecimiento injusto y pago de un tercero en la tradición del "Common law" PICC, PECL, DCFR, CESL", Anuario de Derecho Civil, núm. 69, enero 2016, pág. 8 .
} 
En los sistemas que hay una mayor libertad de disponer para después de la muerte, como los citados, angloamericanos del common law sólo menos del 1\% de los testamentos son impugnados. Lo más curioso es que frente a la escasez de impugnación por parte de los familiares excluidos de la herencia, los jueces en ocasiones utilizan una serie de herramientas para limitar la libertad de disposición. Poniendo especial énfasis cuando los bienes se han otorgado a extraños o casi extraños. La argumentación utilizada se basa en una falta de libre consentimiento o de vicios de consentimiento. Otras veces sin hacer falta que quede demostrada la existencia de alguna de estas figuras jurídicas, los Jueces Common Law, entienden como testamento inválido el que otorga un testador, en que sin razón, deshereda a sus hijos. La argumentación al respecto es que dicho padre no ha actuado bajo los principios del Derecho natural ${ }^{927}$.

\subsection{LA LEGÍTIMA EN ALEMANIA Y AUSTRIA}

En ambos sistemas alemán y austriaco el testador, en principio, es libre de disponer como quiera de su patrimonio para después de su muerte. Aunque también en ambos sistemas, la libertad de disposición post mortem del testador encuentra su límite más importante en la institución de la legítima. Esta, vincula parte del patrimonio del causante a favor de la sus familiares más cercanos ${ }^{928}$.

El principio de libertad de disponer post mortem, en Alemania, lo protege el artículo 14 de la BV (Constitución alemana) y también se encuentra regulado en el $\mathrm{BGB}^{929}$. El citado principio tropieza con la

\footnotetext{
${ }^{927}$ PARRA LUCÁN, “Legítimas, libertad de testar...”, op. cit. pág. 487.

${ }^{928}$ ChristAnL, G.: "La legítima y la libertad de testar en Alemania y Austria: tendencias actuales", en Congreso Internacional Presente y futuro del Derecho de sucesiones: las legítimas y la libertad de testar,(Dir. F. Capilla Roncero, M. Espejo Lerdo de Tejada, F. J. Aranguren Urriza) Sevilla, noviembre-diciembre, 2017.

${ }^{929}$ Código Civil de Alemania denominado en alemán: Bürgerliches Gesetzbuch o BGB.
} 
Pflichtteil (legítima) que no deja de ser una limitación a la libertad de disponer para después de la muerte. En 2005 el BVerfGE ${ }^{930}$ a través de la sentencias de 19 de abril (BVerfGE 112, 332-Pflichtteil) pone de relieve que el principio de libertad de disposición se encuentra limitado por el derecho a la legítima para los descendientes. Dicha protección es de ámbito constitucional hasta tal extremo que no puede eliminarla la Ley ${ }^{931}$. Cabe resaltar que la protección sucesoria constitucional a los descendientes, al igual que en el Derecho español, ni la altera ni le mengua, las necesidades personales que puedan afectar a los citados descendientes ${ }^{932}$. Por lo tanto en Alemania los hijos tienen un derecho constitucional de participación en la herencia de sus padres, sin que por ello tengan que encontrarse en una situación de necesidad. Sin embargo el Tribunal Constitucional alemán no se pronunció en 2005, acerca de la legítima de los padres ni del cónyuge supérstite ${ }^{933}$.

\footnotetext{
${ }^{930}$ Tribunal Constitucional Federal alemán, en alemán Bundesverfassungsgericht o BVerfG.

931 Señala ARROYO I AMAYUELAS, "La reforma...”, op. cit., pág. 2, la STC alemán, referida en el texto, de 19/04/2005, "considera la legítima de los descendientes como un derecho constitucionalmente protegido y, por tanto, por regla general el testador no puede excluirla ni hacer depender de una situación de necesidad del legitimario. Otras modificaciones afectan a la prescripción de las pretensiones familiares y sucesorias".
}

${ }^{932}$ Véase la protección constitucional de los descendientes en PlANAS BELLVÉ, M.: "Armonización europea del principio de libertad de testar y posición del supérstite" Institut Universitari d'Estudis Europeus, núm. 17, 2011-2012, pág. 20, donde la autora explica un caso real: "Una madre con dos hijos, uno de ellos con problemas de esquizofrenia que sufría la propia madre en sus carnes, debido a que su hijo le ocasionaba maltrato ocasional. La madre, vistos los hechos, decide hacer testamento y instituye heredero universal a su otro hijo, desheredando al esquizofrénico. Al poco tiempo la madre muere asesinada por dicho hijo, al que el Tribunal Nacional no lo declaró culpable, debido a su actuación preso de su psicosis. Este hijo reclamó su parte legítima de la herencia. No conforme con lo acontecido, el otro hijo nombrado por la causante heredera universal interpuso demanda ante el BVerfGE por violación del art. 14 GG3".

${ }^{933}$ Christanl, G.: "La legítima y la libertad de testar..." op. cit. Mantiene el autor citado, que fueron opiniones muy diferentes, acerca de la garantía constitucional de la legítima, hasta la resolución del Tribunal Constitucional en 2005, que aclaró la garantía que la Constitución alemana ofrece a la legítima. 


\subsubsection{Los legitimarios en el BGB}

El BGB entró en vigor el día uno de enero del año 1900, tras 25 años de elaboración. Consta de 5 libros: Parte general, Obligaciones, Derechos Reales, Derecho de Familia y Sucesiones. En el tema que aquí interesa, la legítima del Código alemán, se configura como un derecho de crédito contra la herencia del causante. Por lo tanto se puede decir que la legítima en Alemania es pars valoris. La legítima como tal no otorga ningún derecho a los legitimarios sobre los bienes de la herencia. Dicho derecho nace en el momento del fallecimiento del causante. El derecho que los legitimarios tienen contra los herederos testamentarios del disponente consiste en una parte de lo que les hubiera correspondido en la sucesión intestada ${ }^{934}$.

Como ya se ha apuntado, son legitimarios en Alemania, los hijos y descendientes que tengan representación sucesoria. Estando supeditados al principio de que los parientes más próximos excluyen a los más remotos (parágrafo 2303.1 BGB). La Porción de legítima que corresponde a los legitimarios de conformidad con el mismo parágrafo es la mitad de lo que les hubiera correspondido a los titulares del derecho en la sucesión legal o intestada. Se trata de una cantidad fija, a diferencia de la cuota variable del Derecho romano justinianeo, que no deriva de la institución de heredero. De ser apartados de la sucesión, su reclamación será como acreedores de la herencia y no con otra calidad, excepto que el testador disponga de otra manera $^{935}$.

\footnotetext{
${ }^{934}$ Véase BERNAD MAINAR, “La porción legítima...", op. cit, pág. 1780. Mantiene este autor que "La recepción del Derecho justinianeo en Alemania se produce en calidad de Derecho común con la influencia propia del Iusnaturalismo que se introduce a través del ALR prusiano y el ABGB austriaco".

${ }^{935}$ BERnAD MAINAR, R.: “La porción legítima...”, op. cit., pág. 1780.
} 
Lo que más ha evolucionado ha sido la equiparación con el respecto de los hijos matrimoniales y los no matrimoniales, en 1960 el BGB pasaba a considerar tal equiparación. Con anterioridad a dicha fecha a los hijos habidos fuera del matrimonio se los consideraba como exentos de parentesco con el causante y por lo tanto carecían de todo derecho a legítima. Se les concedía simplemente un derecho de alimentos limitado en el tiempo.Tras la citada reforma de 1960 los hijos extramatrimoniales, por virtud del § $1934^{\mathrm{a}}$ BGB, disponían de un derecho de crédito del doble de la cuota legitimaría si concurrían con parientes o con el cónyuge vivo del causante. Con las reformas de 2009 los hijos ya no tienen distinción hereditaria entre ellos ${ }^{936}$.

\subsubsection{La reforma de 2010 en Alemania}

Con el propósito de suavizar las restricciones impuestas al testador, cabe destacar, la reforma que ha sufrido el Derecho sucesorio que se regula en el Libro Quinto del BGB. Lo ha hecho afectando de manera particular a la legítima en sus preceptos 2305; 2306. 1; 2325. 3; 2331ª ap. 1; 2332,1 y 2; 2334; 2335, todos del (BGB). El día 1 de enero de 2010 entró en vigor la Ley que modifica el Derecho de sucesiones y la prescripción en el Derecho alemán. Esta Ley tiene como objetivo la modificación, entre otros, del Derecho de sucesiones que todavía conservaba, prácticamente, su redacción original, a excepción de alguna reforma de poca trascendencia ${ }^{937}$.

\footnotetext{
936 Equiparación de los hijos matrimoniales con los no matrimoniales en WACKE, A.:"las reformas más importantes del BGB desde su promulgación en 1900, con especial referencia al derecho de obligaciones", Revista chilena de derecho, Vol. 40, núm. 2, 2013, págs., 699 a 710.

${ }^{937}$ Véase la explicación que ofrece la autora ARROYO AMAYUELAS, E.:“'Inheritance Law and Limitation Periods Reform in Germany "(La Reforma del Derecho de Sucesiones y de la Prescripción en Alemania)(Spanish). InDret, 1., 2010, pág. 5, "la explicación que acompaña al proyecto es que era necesaria la reforma del Derecho sucesorio para adecuar esta parte del derecho a la evolución social...".
} 
Es interesante resaltar el Proyecto de Ley que aprobó el Gobierno, justificando su necesidad, en base a adecuar el Derecho sucesorio a la evolución social. Tomando como referentes: el incremento de parejas no casadas e hijos no matrimoniales, aumento de las familias reconstruidas, incremento de la movilidad de la población y el aumento de la esperanza de vida. Estas fueron las argumentaciones con las que el Gobierno alemán motivaba la evolución social para justificar la Ley que reformaba el Derecho de sucesiones en Alemania. Cabe destacar de esta Ley, que las modificaciones más importantes recayeron, como se ha dicho, dentro del sistema legitimario. Concretamente, en las causas de desheredación, es decir, las que impiden el derecho a legítima ${ }^{938}$.

Con esta reforma de 2010 el legislador ha tenido que atender a la realidad social, y a la vez, a lo dispuesto por la referida Sentencia del Tribunal Constitucional de 19 de abril de $2005^{939}$. Esta sentencia ratificaba la legítima de los descendientes como "un valor protegido constitucionalmente del que no se les puede privar y cuya percepción no puede hacerse depender de una previa necesidad". Se entiende con esta expresión del Tribunal Constitucional alemán (TCA en adelante) que una persona no necesitada también tiene derechos. Tiene los mismos derechos

\footnotetext{
${ }^{938}$ ARroyo i AmAYUELAS, E.: “La reforma...”, op. cit. , pág. 5.

${ }^{939}$ Más información sobre la ya referida sentencia del Tribunal Constitucional BVerfGE de 19 de abril de 2005, "(Drucksache 16/8954, pp. 8-9. ) en ARROYO AMAYUELAS, "Inheritance Law and Limitation...", op. cit. pág. 6, "El legislador ha mantenido el equilibrio entre la necesidad de adecuar el valor de la legítima a la realidad social y la obligatoriedad de observar el mandato contenido en la Sentencia del Tribunal Constitucional (BVerfGE) de 19 de abril de 2005. Según el BVerfG, la legítima de los descendientes es un valor protegido constitucionalmente del que aquéllos no pueden verse privados y cuya percepción no puede hacerse depender de una previa situación de necesidad. Lo garantiza el art 14.1, I en relación con el art. 6.1 de la Ley Fundamental de la República Federal Alemana ("Grundgesetz"). A pesar de los progresivos cambios en la evolución de las estructuras familiares, la legítima no pierde vigencia y sus fundamentos aún se explican en virtud del principio de solidaridad familiar y de protección de la familia.
} 
que tiene el necesitado si no desea reclamar alimentos. Ello lo garantiza el artículo 14. 1, en relación con el artículo 6.1 de la Ley Fundamental de la República Federal Alemana (Grundgesetz) ${ }^{940}$. Sólo el tiempo dirá si existía o no demanda social suficiente para el cambio, ya que de ello depende la supervivencia de la modificación. Si bien cabe resaltar que las reformas efectuadas por el Parlamento alemán son menores que inicialmente las propuestas por el Gobierno. Ello, no deja de confirmar el miedo, prudencia, etc., anteriormente expuesto, a manipular las legítimas y su consecuente libertad de disposición ${ }^{941}$

\subsubsection{El principio de solidaridad en el BGB alemán}

Los artículos que contienen el principio de solidaridad en el BGB son $\S \S 1601,1618$ a. Cabe añadir un hecho que se viene reflejando a lo largo de esta investigación. En la mayor parte de las sucesiones, sus beneficiarios, se encuentran dentro de la propia familia y su justificación se encuentra dentro de la propia herencia. Esta, no está únicamente compuesta de bienes adquiridos por el causante, sino que también, en la mayoría de los casos, dentro de su composición, también hay bienes heredados de otros de sus antepasados. Dicho de otra manera, en la conservación e incremento del patrimonio de los padres han colaborado los hijos. En el tipo de patrimonio, expuesto se advierte el principio de solidaridad familiar reflejado en la sentencia, también expuesta, en el párrafo anterior. Junto al principio de protección a la familia que justifica los límites impuestos a la libertad de disposición post mortem. Ambos principios justifican la permanencia de las legítimas en Alemania. Argumenta el TC alemán: “El causante no puede privar de la legítima a sus descendientes por el mero hecho de no tener trato familiar con ellos basta con no instituirlos herederos". Con la legítima

\footnotetext{
940 ARroyo i AMAYUELAS, "La reforma del derecho...", op. cit., pág. 6.

${ }^{941}$ ARROYO I AMAYUELAS, "Inheritance Law and Limitation...”, op. cit., pág. 5.
} 
se evita que los hijos extramatrimoniales con una escasa relación, con el testador, queden excluidos de su derecho ${ }^{942}$.

\subsubsection{El cónyuge viudo en el Derecho alemán}

El derecho a la legítima del cónyuge viudo se regula en el $\S 100^{\circ}$ de Lebenspartnerschaftsgesetz (Ley de Asociación Civil), que establece que: "el conviviente supérstite es heredero legal del otro conviviente". Por ello su derecho asciende a un cuarto o, la mitad del haber hereditario dependiendo de con quién concurra. Si lo hace con hijos o descendientes la octava parte, que supone la mitad de un cuarto que le correspondería en la sucesión legal. Si concurre con los padres o hermanos del causante le corresponde siempre una cuarta parte. Si concurre con parientes de segundo grado o abuelos del causante, su derecho asciende a la mitad del caudal relicto. Si el difunto no tiene parientes hasta segundo grado, ni tampoco abuelos, el viudo, tanto si es casado como si no lo es, tiene derecho a la totalidad de la masa hereditaria. En el supuesto de que el supérstite esté

\footnotetext{
${ }^{942}$ Véanse los principios de solidaridad y de protección a la familia en ARROYO AMAYUELAS, "Inheritance Law and Limitation...",op. cit. pág. 6. "Principio de solidaridad familiar: Cita 13 "(BVerfGE, C, I 3 a i b (JZ, 1004)". "El principio de solidaridad familiar (presente en los $\S \S 1601,1618$ a BGB) demuestra que el patrimonio de padres e hijos se mantiene y/o se incrementa gracias a la ayuda mutua y recíproca entre ellos. Por un lado, mediante los alimentos u otro tipo de atenciones de los hijos a los padres cuando éstos se hacen mayores; por otro lado, a través de la formación que los padres dan a sus hijos para que éstos sean capaces de ganar por si mismos su propio patrimonio. El BVerfG añade que, en la mayoría de sucesiones, y a pesar de la relajación de los vínculos familiares tradicionales, los herederos resultan escogidos dentro de los miembros de la familia, dato que también indica que, gracias a la solidaridad intergeneracional, el patrimonio del testador no se forja con sus únicos e individuales esfuerzos, sino que, en parte, proviene de una riqueza heredada". Principio de solidaridad familiar: Cita 14, "(BVerfGE, C, I 3 c (JZ, 1004) "El principio de protección de la familia justifica que deban imponerse límites a la libertad de testar. El causante no puede privar de la legítima a sus descendientes por el mero hecho de no tener trato familiar con ellos. En ese caso, basta la posibilidad de no instituirles herederos. El derecho a la legítima evita que hijos no matrimoniales, o que han sido fruto de anteriores matrimonios del causante, queden excluidos de una participación material en su herencia por el simple hecho de haber desaparecido o haberse relajado las relaciones entre padres e hijos".
} 
excluido de la herencia, puede exigir, en concepto de legítima, la Pflichtteil que es la porción obligatoria que le corresponde conforme a su concurrencia con otros parientes ${ }^{943}$.

Por lo tanto, el cónyuge viudo, que contempla el Derecho alemán, es legitimario y comparte dicha legalidad hereditaria con los descendientes, los padres y los abuelos del causante. Dispone de un derecho de crédito en aquellos casos en que el testador haya pretendido apartarlo de la herencia. Lo más llamativo es que si los cónyuges estaban casados en régimen de participación de bienes se atribuye, al cónyuge sobreviviente, un aumento de un cuarto en su parte de la herencia. Si estaban casados en separación de bienes se proporciona una partición igual que si el cónyuge compite a la herencia con uno o dos hijos ${ }^{944}$. Vistos los hechos generales se puede manifestar que:

1. El Derecho francés sólo reconoce al viudo supérstite en defecto de descendientes o ascendientes.

2. En el Derecho común español es legitimario, pero sólo se le reconoce al viudo un derecho de usufructo sobre la parte de mejora de los legitimarios y sólo en ausencia de ellos (descendientes o ascendientes) es llamado a la herencia como heredero.

\footnotetext{
${ }^{943}$ ArAUJO DÍAS, C. M.: "Uniones de hecho: la posición sucesoria del conviviente supérstite en Portugal, AFDUC, ( Anuario da Faculta de de Dereito da Universidad de da Coruña,) núm. 18, 2014, pág. 74.

${ }^{944}$ Mientras dure el régimen de participación cada cónyuge conserva su autonomía patrimonial y sólo entra en aplicación la participación cuando el matrimonio se disuelve y se genera un derecho solidario en las ganancias obtenidas. Dicho de otra manera: mientras dura el matrimonio funciona como una separación de bienes y al extinguirse la sociedad actúa con un derecho de participación sobre las ganancias (no sobre sus bienes) del otro cónyuge. El cálculo es sencillo, diferencia entre el patrimonio inicial (casamiento) y final (disolución). Determinadas las ganancias de cada cónyuge el que menor incremento haya tenido tendrá derecho a la mitad de la diferencia entre su incremento y el del otro cónyuge y si el incremento sólo se ha producido en uno de ellos, el otro tiene derecho a la mitad de ellas.
} 
3. En el Derecho italiano, las cosas son diferentes, el cónyuge supérstite es legitimario por derecho propio incluso concurriendo a la sucesión con descendientes ascendientes o hermanos del causante ${ }^{945}$.

4. El Derecho austriaco confiere al cónyuge viudo, además de lo dicho para el supérstite alemán, un derecho personal consistente en un legado. Este legado le confiere derecho a habitar en la vivienda familiar y a coger los muebles necesarios para materializar el citado derecho de carácter legitimario. La cuota del viudo en Austria, cuando concurre con los descendientes del causante, asciende a un sexto, que es la mitad de un tercio que le correspondería en la sucesión legal. Cuando concurre con los padres del causante su cuota asciende a un tercio. En el resto de casos asciende a la mitad del haber hereditario ${ }^{946}$.

\subsubsection{La preterición en el Derecho alemán}

El testador alemán solamente se enfrenta a la preterición errónea que recoge el § 2079 BGB. En este ordenamiento sólo tiene cabida la impugnación de la voluntad del testador si el legitimario existía a la muerte del causante. Omisión producida en su testamento por desconocer su existencia. La impugnación queda excluida para el supuesto en que el disponente hubiera conocido de la existencia del legitimario. La acción es de anulabilidad contra la disposición testamentaria que produce la preterición y no contra el testamento que produciría la sucesión legal ${ }^{947}$.

\footnotetext{
${ }^{945}$ ARAUjo DíAs, Uniones de hecho..., op. cit., pág. 76.

${ }^{946}$ Christanl, G.: "La legítima y la libertad de testar..." op. cit.

${ }^{947}$ Más información en CAROL RosES, F.: "La preterición...”, op. cit., pág. 437. La traducción del precepto por parte de este autor: "Una disposición de última voluntad puede ser impugnada si el causante ha omitido a un legitimario existente al tiempo de la muerte del causante, cuya existencia era desconocida para él al tiempo de otorgarse la disposición, o el cual ha nacido o ha llegado a ser titular de la legítima únicamente después del otorgamiento. La impugnación queda excluida siempre que se entienda que
} 


\subsubsection{La legítima en el Derecho austriaco}

En el Derecho austriaco, al igual que el alemán, el causante goza de libertad de disposición post mortem. Si bien en ambos sistemas la citada libertad de disposición encuentra su límite más importante en la legítima que vincula parte del patrimonio a favor de la familia más allegada. La reforma de 2015, en Austria entró en vigor a partir del 1 de enero de 2017. En Austria, a diferencia de Alemania, la legítima no goza de garantía constitucional. Al igual que en Alemania son legitimarios, en Austria, los hijos tanto matrimoniales como extramatrimoniales y adoptivos. Así como sus descendientes cuando tenga cabida el derecho de representación sucesoria. También es legitimario el cónyuge del causante. Por consiguiente, en el Derecho austriaco tras la reforma de 2015 los ascendientes del causante ya no son legitimarios. La justificación a ello, por parte del legislador, se centró en la edad de los ascendentes. Sobretodo en abuelos y bisabuelos que mueren después de sus descendientes y que por regla general su patrimonio es superior al del causante. ${ }^{948}$.

Argumento muy respetable el del legislador austriaco, pero bajo mi opinión, se aparta completamente del fundamento de la legítima. Como bien dice el Tribunal Constitucional alemán, la legítima no es un derecho que dependa de la necesidad del legitimario ni de la del causante. En este contexto sería totalmente permisible la sustitución del término necesidad por la de patrimonio. Por lo tanto la legítima ni depende del patrimonio que tenga el legitimario ni del tenga el causante ${ }^{949}$. Al igual que en Alemania en

el causante hubiera adoptado la (misma) disposición incluso con conocimiento de la situación fáctica".

${ }^{948}$ Christanl, G.: "La legítima y la libertad de testar..." op. cit.

${ }^{949}$ Véase la ya citada Sentencia del Tribunal Constitucional BVerfGE de 19 de abril de 2005, "(Drucksache 16/8954, pp. 8-9.)" en ARROYO AMAYUELAS, Inheritance Law and Limitation..., op. cit. pág. 6, Según el BVerfG, "la legítima de los descendientes es un valor protegido constitucionalmente del que aquéllos no pueden verse privados y cuya 
Austria la legítima también es un derecho de crédito contra los herederos del causante, es decir, pars valoris. El legitimario austriaco tiene un derecho personal a reclamar su legítima cuando haya sido excluido por el causante en su testamento, sin haber habido motivos de desheredación, indignidad o repudiación a la legítima.

Por lo que respecta a la cuantía de la legítima, ello depende del activo de la herencia, es decir, de la hipotética cuota legal del legitimario. La legítima asciende a la mitad de esta hipotética cuota legal. En primer lugar hay que determinar el número de coherederos legales. Al contrario de lo que ocurre en Alemania, que hay que contar todos los herederos excepto los que han repudiado su legítima. En Austria no se cuentan los coherederos que por indignidad o por desheredación no pueden ser herederos, ni tampoco tienen descendientes. Por lo tanto las cuotas de los otros podrán acrecer su parte.

Con la reforma, antes expuesta de 2015, en Austria desaparece la intangibilidad de la legítima, es decir, la protección de la legítima. El testador tiene la libre facultad de imponer gravámenes condiciones o sustituciones sobre los bienes que asigna a los legitimarios, sin que ello suponga una lesión de la legítima. Caso muy distinto en Alemania, en que el testador no puede imponer gravámenes sobre los bienes que asigna a los legitimarios en pago de su derecho. Cuando esto ocurre, el legitimario puede repudiar la legítima y reclamarla libre de cargas ${ }^{950}$.

\subsubsection{La desheredación en Alemania y Austria}

percepción no puede hacerse depender de una previa situación de necesidad. Lo garantiza el art 14.1, I en relación con el art. 6.1 de la Ley Fundamental de la República Federal Alemana".

${ }^{950}$ Christanl, G.: "La legítima y la libertad de testar..." op. cit. 
Partiendo de la premisa que la legítima es de reparto igualitario entre los legitimarios, por lo tanto, la desheredación es una excepción a dicho reparto. De ahí ya se atisba que la desheredación ha de conllevar causas que se aparten de la normalidad. Causas excepcionales al normal proceder entre legitimario y disponente. La solidaridad entre generaciones es el fundamento actual de la legítima en Alemania. Así lo ha manifestado el Tribunal Constitucional alemán en la citada sentencia de 19 de abril de $2005^{951}$. En Alemania tras la reforma del Derecho de sucesiones llevada a cabo en 2009, con la actual redacción del parágrafo 2333 BGB y la derogación de los $\S 2334$ y 2335 BGB se han unificado las causas de desheredación para todos los legitimarios: descendientes, ascendientes y viudo $^{952}$.

Hasta la modificación, las causas de desheredación eran distintas en función del grado de parentesco. Por ello se eliminó, con la reforma última de Alemania, la causa de llevar vida deshonrosa para el legitimario tipificada en el $\S 2333.5^{953} \mathrm{BGB}$. Esta misma causa también ha sido

\footnotetext{
${ }^{951}$ Para mayor información véase VAQUER ALOY, A.: "Acerca del fundamento de la legítima",Indret, núm. 4, octubre 2017, pág. 8. Este autor cita toda la información sobre la referida Sentencia en la cita (17) de la obra citada: "Neue Juristische Wochenschrift, 2005/32, p. 1561 ss".

${ }^{952}$ Más información en ArRoyo AmAYUElAS, E.: "La reforma...", op. cit., pág. 5. Pone la autora como ejemplo de antes y después de "la uniformización de las causas de privación para todos los legitimarios que, hasta la fecha, eran distintas en función del grado de parentesco (vgr. el $\S 2333$ Nr. 2 y 5 BGB no se aplicaban a los padres: $\S 2334$; ni el § 2333 Nr. 5 se aplicaba al cónyuge, § 2335 BGB) ”.
}

${ }^{953}$ SAP de Baleares, (S. $5^{\text {a }}$ ) de 04/01/2011 (Tol. 2.072.638) F.J. 4 ${ }^{\text {o }}$. Por virtud de los artículos 9.1 y 9.8 del Código civil se aplica el Derecho civil alemán en la presente resolución de la Audiencia Provincial de Las Islas Baleares. En ella, la Sala expone, las causas de desheredación previstas en el parágrafo 233 BGB. Se puede apreciar la causa $5^{\text {a }}$ expuesta en el texto, ya que a fecha de resolución todavía no había tenido lugar la supresión de dicha causa del ordenamiento alemán. "Según el Derecho alemán (parágrafo 2333) son causas de desheredación: 1. Atentar contra la vida del causante o su cónyuge u otro de sus descendientes. 2. Descendiente culpable de ultraje corporal doloso contra el causante o su cónyuge. 3. Descendiente culpable de crimen o delito doloso grave contra el causante o su cónyuge. 4. Incumplimiento malicioso por el descendiente de la obligación de alimentos que legalmente le incumbe frente al 
eliminada en Austria tras la reforma de 2015. También fue ampliado, en este país, el grupo de personas más próximas al causante, incluso sin vínculo familiar, que les puede afectar, el atentado contra su vida. Cabe destacar, de la Ley última citada de modificación del Derecho de sucesiones en Alemania, que no contempla la falta de trato familiar como causa de desheredación ${ }^{954}$.

El actual parágrafo 2333 BGB que recoge las causas de desheredación en Alemania dispone en su número 1 que el causante puede privar de la legítima a los descendientes: (cabe destacar sobre las causas de desheredación recogidas en el parágrafo 2333 BGB su condición de "numerus clausus" siendo una enumeración completa de interpretación restrictiva ${ }^{955}$ ).

1. Por atentar contra la vida del causante, su cónyuge o pareja de hecho o contra sus descendientes o persona de proximidad parecida con el disponente.

2. Por cometer un delito o falta grave y dolosa contra las personas citadas en el punto anterior.

3. Por incumplir de manera intencional el deber legal de alimentos al causante.

4. Como consecuencia de un delito doloso cuya condena por sentencia penal firme sin suspensión de privación de libertad tenga la duración

causante. 5. Llevar el descendiente una vida deshonrosa o inmoral contra la voluntad del causante".

${ }^{954}$ Más información en ARroyo AmAYUELAS, E. Y FARNÓs AMOROS E.: "Entre el testador...", op. cit., pág. 11.

${ }^{955}$ Véase la referida SAP de Baleares, Secc. $5^{\text {a }}$ de 04/01/2011 (Tol. 2.072.638) F.J. $4^{\text {o }}$ apartado $4^{\circ}$, "Las causas 1 a 4 requieren la comisión de un crimen o delito contra el causante previsto en el Código penal y la $5^{\text {a }}$ requiere un comportamiento deshonesto e inmoral continuado, como ejemplo: ludopatía, prodigalidad, adulterio, alcoholismo, prostitución, etc". 
mínima de un año. Por la comisión de un delito doloso que debido a ello fuera inaceptable, para el causante, la participación de los condenados en su sucesión ${ }^{956}$. Ocurre lo mismo cuando se condena por sentencia firme al descendiente a ser internado en un psiquiátrico o centro de rehabilitación como consecuencia de un hecho gravado y doloso. La diferencia entre esta causa y la del punto 2 es, que en esta última, el delito o la falta grave y dolosa se ha de haber cometido contra las personas del punto $1^{957}$.

En Austria el legitimario puede ser privado de su legítima si resulta condenado por delito doloso y punible, con pena privativa de libertad de un año contra el causante o su pareja de hecho. También puede suponer causa de desheredación, el contravenir por parte del legitimario, la voluntad del disponente. Cumple causa de desheredación el haber causado graves sufrimientos mentales al causante, como pueda ser el abandono del mismo en situaciones de emergencia. Sigue la misma suerte el incumplimiento de los deberes familiares, como el abandono en la última enfermedad del disponente. Otra causa de desheredación es la condena al legitimario por una pena de privación de libertad de 20 años o superior. En Alemania el causante tiene un margen más amplio para poder desheredar que en Austria. Se tienen en cuenta los deberes de solidaridad frente al causante con mayor rigor en situaciones que el legitimario viola su deber de solidaridad frente al causante $e^{958}$.

Tanto en Austria como en Alemania el causante puede reducir la legítima frente al peligro de prodigalidad, endeudamiento excesivo del legitimario o la presunción de que la legítima no quede dentro de la familia.

\footnotetext{
${ }^{956}$ Christanl, G.: "La legítima y la libertad de testar..." op. cit.

${ }^{957}$ Arroyo AmAYUELAS, E.: “La reforma del Derecho...” op. cit., pág. 11.

${ }^{958}$ Christanl, G.: "La legítima y la libertad de testar..." op. cit.
} 
En Alemania esta limitación se reduce a que los herederos legales se conviertan en fideicomisarios de los legitimarios, con el fin de privar a los legitimarios del poder de disposición de los bienes ${ }^{959}$. En cambio en Austria el disponente puede privar al legitimario de su legítima en favor de los descendientes de éste. También tiene la facultad de reducir la cuota de legítima a la mitad si el legitimario, nunca o durante mucho tiempo (al menos 20 años), no ha mantenido con el causante una relación familiar, como es habitual entre este tipo de familiares. Siempre que el causante no haya sido el inductor o promotor del distanciamiento o impedimento ${ }^{960}$.

Al contrario que en Alemania, en Austria la causa de desheredación por falta de relación familiar, entre causante y legitimario, sí que ha sido incorporada en 1989 al ordenamiento austriaco. Como se ha dicho, con la posibilidad de reducir la legítima a la mitad, a falta de una relación normalmente llevada a cabo entre padres e hijos (\$733 a ABGB). Cabe citar la crítica sufrida por esta norma debido a la oportunidad que concedía al disponente para poder impedir la relación familiar con el descendiente. Debido a ello hubo en 2001 una reforma del precepto para limitar la desheredación en el supuesto que sea el causante el que hubiera provocado la ruptura de la relación familiar. En tal caso carecía de facultad, el testador, para reducir la legítima. La norma volvió a ser modificada en 2004 para reducir el supuesto de hecho a padres, madres e hijos, puesto que con anterioridad el abuelo podía privar de la legítima a su hijo, por este no mantener relación familiar con su hijo y nieto del causante ${ }^{961}$.

\footnotetext{
${ }^{959}$ Christanl, G.: "La legítima y la libertad de testar..." op. cit.

${ }^{960}$ Christanl, G.: "La legítima y la libertad de testar..." op. cit.

${ }^{961}$ Ver información sobre las distintas Leyes de reforma de 1989, 2001 y 2004 en ARROYo AMAYUELAS, E. Y FARNÓS AMORÓS, "Entre el testador abandonado..., op. cit., pág. 12, en que se modifica el parágrafo773a ABGB.
} 
La nueva tendencia del Tribunal Supremo español es la ampliación de las causas por las que se puede privar al legitimario de su parte legítima. De hecho se ha podido comprobar en la ya citada STS de 03/06/2014 (Roj: 2484) que se sanciona con la privación de la legítima un comportamiento no tipificado por la Ley, como es el maltrato psicológico. No contempla, esta justa causa el Código civil, pero en cambio, otros ordenamientos sí que tipifican tal supuesto, como pueda ser el Derecho catalán, entre otros, que incorpora a su ordenamiento en 2008 una justa causa de desheredación que admite la ausencia de relación familiar entre el disponente y el legitimario (art. 451-17.2, e, Código civil de Cataluña) ${ }^{962}$.

Sin ninguna duda la gran diferencia entre el sistema legitimario español y alemán radica más que en las determinadas causas de desheredación en la intangibilidad de la legítima. En el Derecho común español la legítima es inmutable e inatacable. En cambio el Derecho alemán permite al testador por virtud del parágrafo 2338 BGB disponer a favor de los descendientes del hijo declarado pródigo o bien que haya contraído muchas deudas. Fallecido el causante la legítima que hubiera correspondido al hijo, declarado pródigo o cargado de deudas, pasa a los legitimarios de este. Incluso el testador alemán puede trasmitir a un ejecutor testamentario la administración de la parte de legítima que corresponde al pródigo o, al legitimario endeudado. En el supuesto de no mantener las deudas al tiempo de fallecimiento del disponente la disposición carecería de eficacia ${ }^{963}$.

No todo son diferencias con el Derecho español, respecto del alemán, también este, al igual que aquel, se ocupa de la indignidad para suceder. Si

\footnotetext{
${ }^{963}$ PERIS RIVERA, A.L.: "Desheredación: una visión comparada", Actualidad Jurídica Iberoamericana, núm. 4, febrero 2016, pág. 334.
} 
bien regula cada causa de indignidad en parágrafos separados: §2345.2 BGB dispone que el legitimario que incurra en la falta tipificada en el $\S$ 2339.1 BGB puede ser privado de su legítima. Con ello se entiende que a su vez, también es causa de desheredación, como ocurre con el Derecho español con algunas causas de indignidad. También coincide el §2336 BGB con el criterio del Derecho patrio, al disponer este parágrafo, que solamente por disposición testamentaria, a tiempo de otorgamiento, se puede privar a un legitimario de su derecho a legítima. También son coincidentes ambos Derechos- español y alemán- (art. 856 Cc Y §2373 BGB) en disponer como excepción a la privación de la legítima el perdón del ofendido (causante) careciendo, en consecuencia, de ineficacia la desheredación del perdonado $^{964}$.

\subsubsection{Los cuidadores del testador y la legítima}

El ordenamiento alemán contempla este supuesto en su artículo $§ 14$ de la Hein Gesetz, este precepto impide que los geriátricos, tanto públicos como privados, reciban bienes patrimoniales de los internos. Los Tribunales alemanes lo han considerado aplicable al ámbito sucesorio, por limitar al testador a la hora de otorgar testamento. La citada sí que es una verdadera restricción a la libertad de testar. Este precepto último fue sometido incluso a control constitucional por el $B V \operatorname{erf} G$, en cuya resolución de 1998 se aceptó la constitucionalidad de la norma ${ }^{965}$.

\footnotetext{
${ }^{964}$ Más detalles en RAGEL SÁNCHEZ, L.F.: "El perdón de conductas ofensivas en la donación y en la sucesión mortis causa", Anuario de la Facultad de Derecho, núm. 16, 1998, pág. 187. El autor se refiere a la STS de 24 de octubre de 1972 como refrendo a su argumentación con respecto al perdón del ofendido, ya que según mantiene la citada STS se requieren actos que revelen la reconciliación entre el ofendido y el ofensor, es decir, volver a las amistades. Mientras que el perdón es: "sólo la remisión de la pena merecida, de la ofensa recibida o de alguna deuda u obligación pendiente".

${ }^{965}$ TORRES GARCÍA T. F. Y GARCÍA RUBiO, M.P.: La libertad de testar..., op. cit., pág. 182 y 183.
} 
Puede que España vaya un paso por delante en prevenir la voluntad del testador frente a personas que por su cercanía puedan afectar a su libre voluntad de disposición post mortem. Ello si se tienen en cuenta los artículos $752^{966}$ y $754^{967}$ del Código civil.

Estos dos preceptos últimos del Código español apenas han sufrido modificación alguna desde 1889. Solamente el 754 Cc original se cambió en 1990 en su primer párrafo "esposa" por "cónyuge". Por lo tanto, cabe decir, que el Código civil de España ya previno en su elaboración los peligros que suponían la libre voluntad del testador. De ahí que dejara sin efecto todo testamento que en la última enfermedad del testador (vulnerable para testar) pudiera favorecer al confesor, testigos del testamento, Notario otorgante, entre otros. En que su denominador común es el de ser personas que físicamente están muy cerca del disponente, como ocurre en el caso del \$ 14 BVerfG en Alemania.

\subsubsection{La aceptación de la herencia ipso iure}

Tanto en la sucesión legal como en la testamentaria desde la muerte del causante el designado, aunque de manera provisional, ya es heredero. Facultad, la citada, que se mantiene desde la adquisición hasta la aceptación ( $\$ 1942$ BGB). Por lo tanto es a tenor del precitado precepto por

\footnotetext{
${ }^{966}$ Artículo 752 Cc español: "No producirán efecto las disposiciones testamentarias que haga el testador durante su última enfermedad en favor del sacerdote que en ella le hubiese confesado, de los parientes del mismo dentro del cuarto grado, o de su iglesia, cabildo, comunidad o instituto".

Artículo 754 Cc: "El testador no podrá disponer del todo o parte de su herencia en favor del Notario que autorice su testamento, o del cónyuge, parientes o afines del mismo dentro del cuarto grado, con la excepción establecida en el artículo 682”.

La prohibición dispuesta en el artículo anteriormente citado será aplicable a los testigos del testamento abierto, otorgado con o sin Notario. Las disposiciones de este artículo son también aplicables a los testigos y personas ante quienes se otorguen los testamentos especiales.
} 
el que se le otorga a la aceptación el carácter de ipso iure en Alemania. La herencia pasa al llamado con el derecho de repudiación que le asiste. No deja de ser una adquisición provisional que si bien no requiere, como ocurre en el Derecho español, necesidad de aceptación expresa o tácita. La adquisición de la herencia tiene lugar incluso faltando la voluntad y el conocimiento del llamado. Ello no significa que el titular del derecho esté obligado a aceptar la herencia, ya que este tiene a su disposición el ius renunciandi, que le garantiza la potestad de aceptar o renunciar. También el Derecho francés como se ha visto, adopta la aceptación de la herencia ipso iure $^{968}$.

\subsection{LA SUCESIÓN EN EL DERECHO ITALIANO}

El Código civil italiano es aprobado en 1865 y entra en vigor el 01/01/1886. Este Código toma como modelo el Código de Napoleón ${ }^{969}$. En 1924 diversas Comisiones para reformar el Código vigente, con la publicación de algunos libros que dieron como fruto la promulgación el 16 de marzo de 1942, al definitivo y vigente Código civil italiano (CCi en adelante). El régimen fascista sólo afectó a algunas expresiones formales o retóricas de conceptos de dicho régimen y la Carta de lavoro (carta de trabajo). Sin afección directa alguna a las instituciones civiles digna de mención ${ }^{970}$. Por lo que aquí interesa del Código italiano es la regulación que este hace de los derechos y obligaciones que tienen lugar a la muerte de una persona. Un ejemplo palpable es el artículo $448 \mathrm{CCi}$ cuando exime

\footnotetext{
${ }^{968}$ GARCÍA HerRera, V.: “Herencia yacente....”, op. cit., págs. 23 a 25.

969 PADOVInI, F.: Rapporto Contractuale e successione per causa di morte, Dott. A. Giuffrè Editore, S.p.A., Milano, 1990, pág. 23.

${ }^{970}$ Más detalles en Alessandri RodríGUEZ, A. Y SOMARRIVA UndurRAGA, M.: Los diversos sistemas jurídicos contemporáneos", en Tratado de Derecho Civil. Partes preliminar y general, Editorial Jurídica de Chile, abril 2011, págs. 103 y 104. Pone de manifestó este autor, que el Codice Civile de 1942 ha tenido en "Códigos posteriores cierta apreciable influencia".
} 
de la obligación de alimentos al alimentante, con respecto al alimentista, por la muerte del primero. Es decir, la obligación cesa con la muerte, por lo tanto, el nuevo obligado lo podrá ser por título propio, pero no por seguir con la obligación del causante ${ }^{971}$.

El Código civil italiano, seguidor del sistema romano, requiere para poderse convertir, el llamado, en heredero de su previa aceptación de la herencia. Por lo tanto delación y aceptación no son coincidentes en el mismo acto ya que existe, entre ambos, un periodo de tiempo en que la herencia permanece yacente ${ }^{972}$. También el Código civil español es seguidor del sistema romano. La discusión doctrinal en España sobre el sistema que sigue el Código civil no ha sido pacifica. Un reducido sector, a tenor de los artículos 657 y 661 del Código civil, le otorgan un carácter germánico, pero la mayoría se inclina por admitir el sistema romanista como patrón. Si bien con ligeras muestras del sistema germánico debido a la influencia ejercida por el transcurrir de los años ${ }^{973}$.

Se refiere a la sucesión, tanto testamentaria como sin testamento, el artículo 42 de la Constitución italiana. Es el propio precepto constitucional el que impone a la Ley la regulación en los distintos supuestos de sucesión. En base a ello, recoge el Libro II del Código Civil italiano, las normas que regulan los distintos tipos o maneras de llevar a cabo la sucesión en Italia. Cabe hacer una marcada distinción entre la sucesión y la delación, en lo

\footnotetext{
${ }^{971}$ Galgano, F.: Diritto privado, 3 a ed., CEDAM, Padova 2006, pág. 855.

${ }^{972}$ Véase GARCíA HerRERA, Herencia yacente..., op. cit., pág. 38. "De ello se sigue que, la herencia yacente sólo tiene cabida en aquellas legislaciones que adoptan el sistema de adquisición de la herencia mediante la aceptación, en el cual se patentiza aquel hiato entre la apertura de la sucesión y la aceptación (v. gr. España, Italia, Portugal, etc.)”.

${ }^{973}$ ACEDo PENCO, A.: “Apertura, vocación y delación de la herencia”, en Derecho de Sucesiones. El testamento y la herencia, Dykinson, Madrid 2014, pág. 56.
} 
que a apertura de la sucesión se refiere ${ }^{974}$. Para el primero de los términos empleados (sucesión) es el acto por el que todo lo trasmisible se separa de su titular fallecido. Mientras que la delación se refiere a la puesta de todo lo trasmisible a disposición de los llamados a la sucesión. Por lo tanto, la sucesión tiene lugar con anterioridad a la delación ${ }^{975}$. Hay dos momentos especialmente importantes por lo que respecta a la sucesión:

1. Plazo de apertura de la sucesión. La sucesión en Italia se abre tras el fallecimiento del finado. Ello por virtud del artículo $456 \mathrm{CCi}$. Momento en que el finado ya no puede ser titular de sus bienes y estos quedan a expensas de la aceptación para adquirir nueva titularidad $^{976}$.

2. Lugar en el que se produce la sucesión. En virtud del artículo 456 CCi la sucesión a la muerte del causante se produce en el lugar de su último domicilio ${ }^{977}$.

Cabe tener presente el lugar de la apertura de la sucesión, ya que ello deriva del último domicilio del causante y es determinante para la competencia territorial, en caso de existir controversia hereditaria. Se ha reflejado la muerte de una persona como causa para la apertura de la sucesión, por ser el efecto más común, pero tiene los mismos efectos, a nivel sucesorio, la declaración de fallecimiento del ausente ${ }^{978}$.

\footnotetext{
${ }^{974}$ Conforme al artículo 456 CCi la apertura de la sucesión supone la primera fase de la sucesión iniciándose en el momento del fallecimiento del causante, en el lugar que éste hubiera tenido su último domicilio.

${ }^{975}$ ZaCCARIA Alesio, A.: Perfiles del derecho italiano de sucesiones. Bosch, S.A. Barcelona, 2008, pág. 10.

${ }^{976}$ Galgano, F.: Diritto privado, op. cit., pág. 859.

${ }^{977}$ Galgano, F.: Diritto privado, op. cit., pág. 859. Que puede ser distinto del lugar en que haya muerto el causante.

${ }^{978}$ GuIDO AlPA.: Manuale di diritto privato. settima edicione, casa editrice dott. Antonio Milani (CEDAM), Padua, 2011, pág. 1186. Confirma el autor lo expuesto, al mantener
} 


\subsubsection{La aceptación o repudiacion de la herencia}

El sistema italiano consagra la adquisición de la herencia mediante la aceptación en su artículo 459 CCi. Entre la apertura de la sucesión y la adquisición de la misma existe una separación temporal. Para que el llamado se convierta en heredero es requisito imprescindible que ponga de manifiesto su voluntad de aceptar de manera expresa o tácita la herencia. La adquisición de la posesión de los bienes, que componen el haber hereditario queda subordinada a la aceptación de los mismos. Por lo tanto desde que se abre la sucesión hasta que es aceptada se produce un lapsus en el tiempo en que los bienes y derechos hereditarios quedan sin titular. Lo que es conocido como periodo en que la herencia permanece yacente. El Codice italiano de 1942 regula esta figura jurídica en sus artículos 528 a $532^{979} \mathrm{CCi}$.

La aceptación, en el Derecho italiano, es constitutiva de la adquisición hereditaria, es decir, es requisito necesario de la adquisición. El efecto que conlleva la aceptación hace que se ponga en marcha el mecanismo del artículo $459 \mathrm{CCi}$, el cual retrotrae la adquisición al momento de la apertura de la sucesión. Entendiendo así, que el heredero ha mantenido la posesión desde la apertura de la sucesión. En el supuesto que el llamado repudie la herencia, por virtud del artículo $521 \mathrm{CCi}$, es anulado el llamamiento. Queda como si nunca hubiera sido llamado a la misma. En cambio, otros ordenamientos, se acogen al sistema de adquisición de la herencia ipso iure (por virtud de una disposición legal) son, entre otros, Alemania ( $\$ 1942$ BGB), Francia (artículo 724 del Code civil) y los países pertenecientes al

la apertura de la sucesión en el momento de la muerte del difunto, así como el último domicilio del causante, matizando que el término "domicilio" se expresa en sentido técnico "a menos que se sepa el lugar de la muerte".

979 García Herrera, V.: "Herencia yacente...”, op. cit., págs. 22 y 23. 
Common Law, como se ha visto anterior mente. Son sistemas los citados que a la muerte del causante el heredero adquiere la herencia de manera automática, es decir, ipso iure ${ }^{980}$.

Una importante distinción con el Derecho español es que este, habla en sus artículos 988 a 1009 del Código civil de "repudiación" y no de "renuncia" como lo hace el artículo $521 \mathrm{CCi}$. El significado de "renuncia" comporta desprenderse de algo que se posee, mientras que el rechazo de lo que pudiera tenerse, pero todavía no se tiene, se está refiriendo a la repudiación ${ }^{981}$.

$\mathrm{Al}$ igual que ocurre en España con el artículo 998 Cc la aceptación de la herencia en Italia, en virtud del artículo $470 \mathrm{CCi}$, puede ser pura y simple o bien a beneficio de inventario. La primera comporta que el patrimonio del causante se confunda con el del heredero, con las consecuencias que ello puede acarrear para el heredero con respecto a los acreedores del causante. La segunda manera de aceptación, no comporta la confusión de ambos patrimonios y el heredero solo acepta hasta donde llegue la herencia frente a posibles acreedores y legatarios del difunto. La renuncia se trata de un acto unilateral, por parte del heredero, conforme al artículo 519 CCi. Sin que ello pueda perjudicar al acreedor del renunciante, si el heredero, no puede satisfacer a sus acreedores con su propio patrimonio.

980 Véase más información en GARCíA HERRERA, "Herencia yacente...", op. cit., pág. 23. "Adquiere la herencia sin necesidad de que medie una aceptación por parte del heredero expresa o tácita. Ello no significa que el llamado no disponga de un plazo para renunciar a la herencia o que actúe la indignidad sucesoria".

981 GARCÍA HeRrERA, "Herencia yacente...", op. cit., págs. 22 y 23. Importante aclaración la que hace la autora al referirse al término empleado por el Codice civile en su artículo 521, en el que habla de "renuncia". Su opinión y que comparte quien suscribe es que "no puede renunciarse aquello que todavía no se tiene y, es evidente, que el llamado no tiene la herencia hasta que no la acepta expresa o tácitamente". Por consiguiente, entiendo más jurídico hablar de repudiación que no de renuncia. 
Los acreedores pueden, en tal caso, impugnar la renuncia tal como dispone el artículo $524^{982}$ CCi. También en España, el artículo 1001 Cc, en aquellos supuestos en que la repudiación perjudique al acreedor del repudiante, faculta a que pueda aquél aceptar en nombre de este, hasta cubrir sus deudas. Portugal, junto con España e Italia se caracterizan por ser de aceptación necesaria, es decir, por acogerse al sistema de adquisición de la herencia mediante la aceptación ${ }^{983}$.

En España, a excepción del Derecho navarro, que adopta el sistema de adquisición de la herencia ipso iure, el resto de Derechos forales se acogen al sistema de la adquisición de la herencia mediante la aceptación. Retrotrayéndose sus efectos al momento de la apertura de la sucesión. En estos Derechos, al igual que ocurre en el Derecho común, la aceptación tiene carácter constitutivo de la adquisición hereditaria. Por lo tanto, la aceptación forma parte esencial de la adquisición. En cambio en el Derecho foral navarro no se puede hablar de herencia yacente, puesto que la sucesión se abre a la muerte del causante y tras la pertinente vocación, el heredero adquiere de manera provisional y conjunta la herencia y la facultad de repudiarla (Ley 315 del Fuero de Navarra). Por lo tanto, no existe en este ordenamiento espacio de tiempo en que el patrimonio hereditario carezca de titular, es decir, que la herencia permanezca yacente. En consecuencia se puede afirmar que en Navarra el carácter es afirmativo y no constructivo, de la aceptación hereditaria, para dar lugar a la

\footnotetext{
982 Galgano, F.: Diritto privado, op. cit., pág. 869.

${ }^{983}$ GARcía Herrera, "Herencia yacente...”, op. cit., pág. 20. En Portugal, el sistema de adquisición mediante la aceptación se consagra en la disposición contenida en el artículo 2050 del Código civil portugués". Por consiguiente, el llamado a la herencia sólo adquiere el dominio y la posesión de los bienes y derechos relictos cuando manifiesta su voluntad aceptando de manera expresa o tácita la herencia.
} 
posesión ${ }^{984}$. Conforme a ello, se puede matizar, que el Derecho navarro, el alemán, el francés y el anglosajón, entre otros, siguen el sistema de adquisición de la herencia ipso iure.

\subsubsection{Administración de apoyo en Italia Amministratore di sastengo}

La nueva redacción del artículo 404 del Codice Civile referido a incapacitación e inhabilitación puede recoger tanto a enfermos mentales como a todo aquel que se encuentre en dificultad para ejercer sus derechos. Ello implica a ancianos, disminuidos psíquicos y sensoriales, dependientes y enfermos sujetos a dependencia. Conforme al siguiente precepto $406 \mathrm{CCi}$ la solicitud la puede presentar el propio interesado. Lo verdaderamente importante es que el administrador de apoyo ha de presentarse ante el juez y recabar su consentimiento y autorización para que, entre otros, tenga validez la transacción realizada, la aceptación o repudia de herencia, así como la disposición de bienes. Ello impide que la repetida influencia de los cuidadores sobre el testador, pueda llevar a quebrar su voluntad ${ }^{985}$.

La jurisprudencia mayor española se pronuncia, con cierta tranquilidad, cuando ha intervenido en la transacción un fedatario público. Lo hace ante casos de dudosa voluntad del disponente, a la hora de otorgar testamento, cuando el favorecido en la disposición ha sido la residencia o centro geriátrico bien como persona jurídica o bien sus responsables o trabajadores como personas físicas. En cambio presenta cierto recelo cuando en los casos tasados como el testamento en peligro de muerte, no

\footnotetext{
${ }^{984}$ Mayor información en GARCÍA HERRERA, "Herencia yacente...”, op. cit., págs. 13 a 22. La autora agrupa los ordenamientos de nuestro entorno cultural entre aquellos que se acogen al sistema de adquisición de la herencia mediante la aceptación como son Portugal, Italia y España. En cambio, los países que adoptan el sistema de adquisición ipso iure son Alemania y Francia.

${ }^{985}$ Véase legislación de referencia, La ley núm. 6 de 09.01.2004; arts. 404 y siguientes CCi en Tribunale di Milano, Ministerio della Giustizia.
} 
interviene Notario. Ello se refiere, según doctrina del Alto Tribunal español, "única y exclusivamente a aquellos supuestos en que el estado del testador es de tal gravedad que se pierde toda esperanza de salvación y no

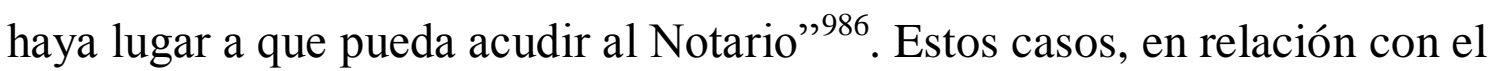
tema que aquí se trata sobre las legítimas, el ordenamiento español las tiene cubiertas con los preceptos que la protegen, es decir, la intangibilidad de la legítima. Incluso el tercio de libre disposición, para el disponente con legitimarios y todo el caudal relicto, para aquellas personas carentes de ellos. En mi opinión, el legislador común español tendría que proveer de contenido el vacío legal al respecto de los cuidadores del testador vulnerable.

\subsubsection{La legítima en el Código civil italiano de 1942}

Tanto en Italia como en España existen las restricciones a la plena libertad de disposición post mortem. Siendo en ambos Derechos precisamente las legítimas las que implican tales restricciones o reservas a los legitimarios. El Código civil italiano de 1942 por virtud de sus artículos 536 y ss CCi concibe la legítima como un valor económico de la herencia, pudiendo recibir su parte los legitimarios en calidad de herederos, legatarios o donatarios. Son legitimarios el cónyuge, los hijos- legítimos,

\footnotetext{
${ }^{986}$ La STS de 451/2005, de 10/06/2005 (Tol. 667.463) F.J. $3^{\text {o }}$ cuyo supuesto de hecho trata acerca de como una entidad dedicada al cuidado de ancianos absorbe por compraventa los inmuebles y por testamento las cuentas bancarias de uno de sus ancianos clientes de 88 años y sin descendientes: “(...)de modo que procedía levantar el velo de esta sociedad para poner coto a los fraudes y abusos que por medio del "manto protector" de la misma, se pudieran cometer, con referencia a la compra del piso por dicha sociedad mediante documento privado de 2 de septiembre de 1992, anterior al testamento de autos, cuando don x xx y su esposa son administradores solidarios de aquella entidad, amén de empleadores de todas las personas que actuaron como testigos en el contrato privado y en el testamento de 11 de septiembre de 1992, y beneficiarios de todos los bienes del difunto-“. Cabe en este punto hacerse dos preguntas reflexivas ¿De tener legitimarios el causante, los responsables del geriátrico hubieran procedido de igual manera? ¿Son un freno o límite las legítimas, a hechos como el casado por el Tribunal Supremo?
} 
adoptivos y los naturales- de los cuales puede operar, si procede, el derecho de representación sucesoria. También son legitimarios los ascendientes del causante en defecto de los anteriores ${ }^{987}$. La cuota correspondiente a cada uno de los legitimarios está en función del número de legitimarios, de ahí, que sea una cuota variable ${ }^{988}$. Muy diferente al planteamiento de la anterior redacción del Código italiano de 1865, cuya cuota de legítima era invariable, es decir, una cuota fija con independencia del número de legitimarios. Es el caso del Derecho común español en que la cuota de legítima es fija e independiente del número de legitimarios.

El artículo 536 y ss. CCi regulan lo que en el Derecho común español se conoce por "legítimas" 989 . La cuota que corresponde a cada legitimario, ascendentes y cónyuge supérstite, en virtud de los artículos $535 \mathrm{CCi}$ es la siguiente:

1. Hijos legítimos y naturales: está en función del número de los mismos.

2. Supuestos de un solo hijo: (legítimo o natural) la mitad de la herencia.

3. Supuestos de dos o más hijos: dos tercios de la herencia.

4. Ascendientes en defecto de descendientes: un tercio dividido por mitades iguales entre ambas líneas, es decir, entre la línea materna y paterna del causante.

${ }^{987}$ Di PIRRO, M.: Istituzioni di Diritto Privato (Diritto Civile), XXII Ed, Simone S.p. A., Napoli, 2016, pág. 717.

${ }^{988}$ BERNAD MAINAR, “La porción...”, op. cit., pág. 1778. Con respecto al Código italiano de 1865, "de concurrir hijos o descendientes, el testador no puede disponer más de la mitad de sus bienes; de no dejar hijos o descendientes, pero sí ascendientes, podía disponer de los dos tercios de la herencia (arts. 805 y 807); además, el cónyuge supérstite contaba con el derecho a una legítima en usufructo (arts. 812-814)".

${ }^{989}$ ZaCCARIA Alessio, Perfiles del Derecho..., op cit., pág. 65, se refiere a la sucesión necesaria como: "aquel fenómeno por el cual la Ley reserva necesariamente a determinados sujetos llamados legitimarios una cuota de la herencia". 
5. Ascendiente concurriendo a la sucesión con el cónyuge: un cuarto del haber hereditario.

6. Cónyuge supérstite no separado por sentencia firme: (con éste legitimario se vuelve a hacer una importante variación)

a. Cónyuge que concurre a la sucesión en solitario: (sin otros legitimarios) la mitad de la herencia ${ }^{990}$.

b. Cónyuge que concurre a la sucesión con un hijo: un tercio para cada uno de ellos.

c. Cónyuge que concurre a la sucesión con dos o más hijos: La mitad de la herencia para los hijos y un cuarto para el viudo.

d. Cónyuge que concurre a la sucesión con ascendientes legítimos del causante: la mitad de la masa hereditaria para el supérstite y un cuarto para repartir entre ambas líneas materna y paterna del causante, es decir, un octavo de la herencia para cada línea.

El Derecho italiano, al igual que hacen otros derechos, también asiste al cónyuge supérstite en la vivienda familiar. Lo hace al amparo del artículo 540.2 y 548 del CCi en que el primero le otorga un derecho de habitación y uso del mobiliario en la casa usada como vivienda familiar. Independientemente de que la vivienda fuera privativa del causante, o en cotitularidad con el cónyuge supérstite ${ }^{991}$.

\subsubsection{La porción disponible}

\footnotetext{
990 STS de 28/04/2014, (Tol. 4.365.031) F.J. $1^{\circ}$ esta resolución pone de manifiesto la diferencia, en cuanto a cuota del viudo/a se refieren, los ordenamientos italianos y español común: "ya que utilizando dicha legislación italiana para determinar los derechos del cónyuge supérstite ésta tendría derecho a la mitad de la herencia en plena propiedad y aplicando la legislación española para determinar los derechos del cónyuge supérstite la viuda tendría derecho exclusivamente al usufructo de $2 / 3$ partes de la herencia ( art. 838 del Código Civil )".

${ }^{991}$ BERNAD MAINAR R. “La porción Legítima...”, op. cit., pág. 1778.
} 
El Código Civil italiano de 1942 dedica el artículo 556 CCi al cálculo de la porción disponible, es decir, de la que el difunto puede disponer. Lo hace este precepto por medio de tres operaciones básicas. Teniendo presente que la legítima es una porción de patrimonio neto y de ahí que se tienda, precisamente, a averiguar el caudal neto de que disponía el causante a su muerte. Tiempo para proceder, entre otros, al pago de las legítimas. Es decisivo el momento en el que se valoran los bienes teniendo en cuenta los gastos y los beneficios que hayan podido producir hasta su adjudicación. La primera operación consiste en agrupar todos los bienes de que disponía el causante a tiempo de su muerte. La segunda operación le sustrae, de la anterior, las deudas que pudiera tener el disponente, entre los que se encuentran los gastos de funeral y entierro, lo que queda es caudal relicto o relictum $^{992}$. La tercera operación es conocida como ficticia ${ }^{993}$, por el hecho de traer a colación las donaciones efectuadas por el finado en vida. De esta manera se sabe con facilidad la parte de la que podía disponer el difunto, para hacer dichas donaciones, y comprobar si se han producido liberalidades ${ }^{994}$.

\footnotetext{
${ }^{992}$ Un término que resulta imprescindible matizar, antes de afrontar el apartado de la porción disponible es el relictum. Si bien es cierto que se refiere a los bienes heredables o pendientes de heredarse, también lo es que, dichos bienes, no son relictum en todos los momentos de la sucesión. Antes de pagarse las deudas del causante, se puede hablar de masa hereditaria, de herencia, etc., pero no de relictum. Cabe hablar, únicamente, de caudal relicto pendiente de ser dividido entre los llamados a la sucesión, del resto que ha quedado de la masa hereditaria, tras haberse deducido las deudas contraídas por el causante en vida de éste. Basta con aceptar que las deudas del difunto no se reparten, sino que se pagan antes del reparto. Por lo tanto, no son heredables. El relictum es heredable y en consecuencia repartido entre herederos y legatarios, por lo que no pueden formar parte de él las deudas.

${ }^{993}$ Señala Di PIERro, Istituzioni...”, op. cit., pág. 719, que el objeto de reunir las donaciones hechas en vida por el causante sólo es bajo el objetivo de la imputación (art. 564 CCi) o bien de la colación (arts. 738 - 751 CCi).

${ }^{994}$ Mengoni, L: Successioni per causa di Morte, A. Giuffrè Editore, S. p. A., Milano, 2000, pág. 43.
} 


\subsubsection{La sucesión universal y la sucesión particular}

En virtud del artículo 588 CCi la sucesión pude ser a título universal o a título particular y por medio de ello se puede distinguir entre herederos y legatarios. La diferencia entre heredero y legatario estriba en la disposición hecha por el testador en su testamento. Si las disposiciones hechas por el testador se componen de la universalidad o una cuota o parte de sus bienes, los favorecidos se convierten en herederos. En cambio el resto de disposiciones a título particular convierten en legatarios a los favorecidos. Con el vigente Código civil de Italia, el heredero es el individuo que el disponente o la Ley, le han atribuido bienes de la herencia. Por lo tanto, no es heredero el llamado a la sucesión, sino el que se le atribuye todos o parte de los bienes del finado ${ }^{995}$.

\subsubsection{Intangibilidad de la legítima}

Como se deduce de los artículos 549, 588, 733 y $734 \mathrm{CCi}$, la intangibilidad de la legítima en Italia se entiende en sentido cuantitativo y no cualitativo. El legitimario tiene derecho a un valor determinado, pero no a una determinada composición de su cuota. La Ley ha establecido excepciones a la viabilidad de la legítima. Así se tiene también en el ordenamiento italiano la cautela socini (art. $550 \mathrm{CCi}$ ), el legado de sustitución de legítima (art. 551CCi), la sustitución fideicomisaria (art. 692CCi) entre otros supuestos que merman la legítima ${ }^{996}$. Cuando ha habido lesión de la legítima, la reintegración de las disposiciones testamentarias o de las donaciones que excedan de la parte disponible para

\footnotetext{
${ }^{995}$ Véase CICU. A.: Succesioni per causa di morte. parte generale, Casa editorial Giuffrè, Milan, (obra distribuida por Librería Boch, Barcelona, 1961, pág. 33, "heredero es aquel que el testador o la Ley le atribuyen la universalidad (todos) o una cuota de bienes del causante".

${ }^{996}$ Di Pirro, M.: Istituzioni..., op. cit., pág. 718.
} 
el testador de la misma tiene lugar, por medio de la acción de reducción de los artículos 553 a $564 \mathrm{CCi}$.

Conforme al artículo 561 D. L. 35/2005 conv. In L. 80/2005, la acción de reducción no tiene naturaleza recuperadora. En cambio, está conectado a la acción de restitución por la cual el legitimario, mediante tal acción, puede pedir la declaración de ineficacia de la disposición testamentaria que lesione su legítima. Hasta obtener la restitución tal como dispone del precitado artículo $561 \mathrm{CCi} \sin$ cargas o hipotecas. Son indignas las ponderaciones e hipotecas si la reducción se exige después de veinte años a partir de la transcripción de la donación. Excepto en el caso de la obligación del donante para compensar al legitimario en dinero por el consiguiente menor valor de los bienes. Siempre que la solicitud se haya propuesto dentro de los diez años desde la apertura de la sucesión ${ }^{997}$.

Prueba lo dicho, sobre las reducciones indignas, la cautela que se debe tomar al adquirir bienes en Italia, cuya procedencia directa o indirecta sean de una donación. Los bancos son reacios a hipotecar tales bienes debido al Decreto-Ley de 14 de marzo de 2005 y de la Ley de 28 de diciembre, también de 2005, que declaran prescrita la acción de reducción de una donación cuando la inscripción de esta, en el Registro de la Propiedad, rebasa los 20 años de antigüedad. Incluso cabe la interrupción judicial de dicho plazo $^{998}$.

\subsubsection{Las causas de desheredación e indignidad}

Tres son los distintos sistemas de desheredación dispersos entre aquellos ordenamientos que mantienen la legítima en su Derecho sucesorio. Como pueda ser el ordenamiento italiano, francés, alemán, austriaco, suizo,

\footnotetext{
${ }^{997}$ Di Pirro, M.: Istituzioni..., op. cit., pág. 721.

${ }^{998}$ Rentería ArocenA, “La libertad de testar...”, op. cit., pág. 2106.
} 
o en los distintos Derechos españoles. Tras comparar estos sistemas sucesorios se advierten las tres formas de desheredar a un legitimario:

1. Simplemente con la voluntad expresa del disponente de privar al legitimario de su correspondiente derecho, como ocurría en el antiguo Derecho romano. O bien dejándole, al legitimario, una porción simbólica, como ocurre en el Derecho de Vizcaya o de Navarra.

2. No queda regulada la institución de la desheredación, sino que se dispone de unas causas tasadas de indignidad que excluyen de su derecho a legítima, a todo legitimario que haya incurrido en alguna de ellas. Sucede de esta manera en ordenamientos como el italiano o el francés. Ello da constancia de que no en todo sistema que admite las legítimas sea inherente la desheredación. Puesto que en los citados sistemas, francés e italiano, únicamente se regula en ellos la indignidad, como única sanción de orden sucesorio que priva al legitimario de su derecho a legítima ${ }^{999}$.

3. Para poder privar a un legitimario de su derecho, la causa ha de ser expresa y fundada en alguna de la fijadas y determinadas por la Ley. Se acogen a ello, entre otros, el Código civil común español, el Código civil alemán (BGB), los Códigos civiles austriaco y suizo ${ }^{1000}$.

Sobre las causas de indignidad se ha de partir que no encuentran acomodo en la voluntad del testador, sino que la encuentran en la Ley y por ello es allí, donde de manera taxativa, se encuentran estas tasadas. Concretamente en el Derecho italiano se encuentran recogidas en el

\footnotetext{
${ }^{999}$ Véase más información en REPRESA POLO, M.P.: La desheredación ..., op. cit., pág. 7. ${ }^{1000}$ O'CAllaghan MuÑOZ, X.: Compendio..., op. cit., pág. 2.
} 
artículo $463{ }^{1001} \mathrm{CCi}$. Conviene aclarar, en este punto, que al hacer referencia a la indisponibilidad de privar de su patrimonio al testador, basado en causas de indignidad, se está aludiendo a los legitimarios. Para el resto, sí que impera la voluntad del testador, para privarles de su patrimonio con posterioridad a su fallecimiento. Le basta al disponente para apartarlos de la sucesión no contar para nada con ellos ${ }^{1002}$. .

En el Derecho italiano, por virtud del artículo 463 CCi se encuentran seis casos por los cuales se puede producir la indignidad para suceder:

1. A quien de manera voluntaria a intentado o, ha matado a la persona que causa la sucesión o bien a su cónyuge, descendiente o a un ascendente del causante. El nuevo Código Civil ha añadido, en el precepto indicado anteriormente, como causas de indignidad lo que se preceptuaba para el propio causante, al descendente, ascendente o cónyuge. Con ello se amplía la cobertura a los familiares más allegados de "Cuius". Excluyendo dicha causa de indignidad, en aquellos supuestos que no la contempla la Ley penal. Es decir, no puede ser causa de indignidad aquella que excluye la punibilidad. Si bien no es respaldada, tal excepción, por la unanimidad de la doctrina al estar frente a una sanción civil y no penal ${ }^{1003}$. No por ello es necesario que se dictamine una sanción penal para que tenga lugar la causa de indignidad citada anteriormente. Ello conforme al artículo $3^{1004}$ del vigente Código de Procedimiento Penal.

\footnotetext{
${ }^{1001}$ Véase en CENDÓN, P.: El diritto privado nella giurisprudenza en la sucesión, unione tipografico-editrice torinense, Torino 2000, pág. 79.

${ }^{1003}$ CiCu, Succesioni per causa di morte..., op. cit., pág. 308.

${ }^{1004}$ Artículo 3 Código de Procedimiento Penal Italiano: “1. Cuando la decisión depende de la resolución de una disputa sobre el estado de la familia o de la ciudadanía, el tribunal, si el caso es grave y si la acción de conformidad con la ley civil ya está en
} 
2. La segunda causa de indignidad conforme al artículo 463. 2 CCi que dispone como indignos los hechos cometidos en perjuicio de alguna de las personas citadas en la primera causa (causante, cónyuge, descendientes o ascendientes) a la que la ley penal declara la aplicación del homicidio.

3. La tercera causa de indignidad trata sobre la denuncia, tanto hecha al propio causante, como a sus más allegados familiares- cónyuge, descendientes o ascendientes-. No se trata de cualquier denuncia, sino, de una acusación que esté penada con reclusión mayor o con un tiempo de privación de libertad no inferior a tres años. Es decir, trata sobre la denuncia falsa o la calumnia en perjuicio del causante o sus allegados.

4. La cuarta causa de indignidad trata sobre la inducción dolosa o violenta de otra persona, para que revoque su testamento o bien deje de revocarlo.

5. La quinta causa trata sobre la alteración del testamento que regula la sucesión, es decir, ocultar por ejemplo un testamento posterior anulando con ello la última voluntad del testador.

6. La sexta causas de indignidad se refiere a falsificado un testamento, o bien ha haberlo usado sabiendo de su falta de veracidad. En ambos casos se produce una violación a la voluntad real del testador.

\subsubsection{La preterición en Italia}

Recoge esta institución el artículo $687 \mathrm{CCi}$ ordenando la revocación ipso iure de las disposiciones testamentarias a título universal o particular realizadas por el disponente. Si a tiempo de otorgarlas carecía de hijos o

marcha, se puede suspender el procedimiento hasta que el pasaje de decisión judicial que define el tema". 
desconocía de su existencia ${ }^{1005}$. Reconociendo que es una disposición más limitada que el artículo $814 \mathrm{Cc}$ cumple una función parcialmente coincidente con el precepto español. El testador italiano puede evitar la revocación testamentaria por ministerio de la ley, de haber prevenido para el caso de que existieran hijos o descendientes no nombrados en el testamento. La provisión en Italia no se refiere a haber hecho una atribución patrimonial concreta, sino a que testador haya previsto el supuesto de preterición, con cierta concreción, en su testamento para que desaparezca el supuesto de hecho de la norma ${ }^{1006}$.

\subsubsection{LA COLACIÓN EN ITALIA}

Es el artículo $731.1^{1007} \mathrm{CCi}$ es el que define la colación en Italia. Entiende este precepto la obligación que tienen ciertos familiares del causante de aportar a la sucesión todo lo que han recibido en concepto de donación directa o indirecta del causante ${ }^{1008}$. A menos que este los haya dispensado de hacerlo dentro de los límites que contiene el artículo 556 CCi. Sólo puede operar de manera legal, el disponente, sí ha respetado la correspondiente "sucesión necesaria" ${ }^{1009}$, con la cuota que la ley le obliga a reservar. Por lo tanto, solamente se puede lograr tal cometido, de dispensa

${ }^{1005}$ CAROL Roses, F.: "La preterición...”, op. cit., pág. 437.

${ }^{1006}$ MiQuel GonZÁLEZ, J.M.: "La legítima material y la legítima formal" Colegío Notarial de Madrid en Academia Matritense del Notariado, Madrid, 2009, pág. 4.

${ }^{1007}$ Artículo737, CCi: "I figli legittimi e naturali e i loro discendenti legittimi e naturali ed il coniuge che concorrono alla successione devono conferire ai coeredi tutto ciò che hanno ricevuto dal defunto per donazione direttamente o indirettamente, salvo che il defunto non li abbia da ciò dispensati'. La dispensa da collazione non produce effetto se non nei limiti della quota disponibile".

${ }^{1008}$ La donación directa se refiere a la que como tal se materializa, es decir, consta en el documento que es una donación. En cambio, la donación indirecta no deja de ser una liberalidad que en realidad disimula una donación.

1009 RAGEl SÁNCHEZ, La Cautela Gualdense..., op. cit., pág. 39, "Los italianos llaman a esta institución sucesión necesaria, no porque sea obligatoria o irrenunciable para el legitimario, sino porque el testador no puede impedirla, no puede evitar que el legitimario la exija". 
de colación, no sobrepasando, por parte del testador, las cuotas de su libre disposición que regula el artículo 536 y ss $\mathrm{CCi}^{1010}$.

La colación en Italia atiende al proceso de división hereditaria y es una institución de probada eficacia, al preservar los derechos del legitimario. Incluso se podría afirmar que la colación es la vía más veloz y segura de hacer valer los derechos hereditarios. Lo es hasta el extremo que no prescribe la acción de división hereditaria ni la acción de reducción ${ }^{1011}$. El artículo 737 CCi establece que los hijos, sus descendientes y el cónyuge supérstite, afectados por la sucesión, han de aportar a la masa hereditaria todo aquello que hayan recibido en vida del causante. A excepción de que este, los haya dispensado de hacerlo ${ }^{1012}$.

El artículo 742 del CCi se refiere a los gastos sujetos a colación, manteniendo que no colacionan las liberalidades previstas en el párrafo segundo del artículo 770 CCi cuya disposición de este precepto dice: "No constituye donación la liberalidad que se suele hacer con ocasión de servicios recibidos o de cualquier modo en conformidad con los usos". Se refiere, el precepto, a las donaciones remuneratorias de regalos de costumbre identificados con las liberalidades de uso, que recoge el artículo 1378 del Código civil español. Es decir, que imponen los usos sociales o los cánones de conducta en el ordenamiento español, que es a los que se refiere el precitado artículo 742 CCI $^{1013}$.

\footnotetext{
${ }^{1010} \mathrm{CICU}$ A, Succesioni per causa di morte..., op. cit., pág. 925, distingue a la colación como fenómeno de aumento de la masa a dividir.

1011 PENE VIDARI, F.: La successione neccessaria en trattato di Diritto Civile, cap. V, (dir. R. Saco), UTET Giuridica, Milano (Italia) 2014, pág. 247.

${ }^{1012}$ GABRIELli COSSELlU, M.: La colación hereditaria: aspectos legales y jurisprudenciales en España y en Italia, Academia Edu, febrero 2017, págs. 27 y 28.

1013 VERDERA IZQUIERDO, B.: "El régimen...", op. cit., de colación de gastos en el código civil", Revista Crítica de Derecho Inmobiliario, núm. 709, octubre 2008.
} 
Dos son las modalidades de colación que permite el Derecho italianoin natura o por imputación- . Siendo la primera la devolución de los bienes a la masa hereditaria con el objetivo de ser posteriormente repartidos entre los coherederos. La colación por imputación supone, no la devolución a la masa hereditaria de los mismos bienes donados, sino su valor al tiempo que se evalúen (no antes) los bienes hereditarios ${ }^{1014}$. Siendo por cuenta del donatario el aumento o la merma de los bienes donados ${ }^{1015}$. También el artículo 1045 Cc español se refiere a la imputación como única modalidad de colación. En este aspecto la Corte di Casacione se ha pronunciado al respecto de la colación hereditaria estableciendo la naturaleza de la colación como: medio de integración de la masa hereditaria dirigida al equilibrio y la equidad entre los coherederos distinguiendo las dos maneras citadas de colacionar que permite el ordenamiento italiano ${ }^{1016}$.

\subsubsection{Parientes afectados por la colación}

Los parientes a los que afecta la colación en el Derecho italiano son, como ya se ha apuntado, los descendientes legítimos y los naturales, así como a sus cónyuges en función de la división hereditaria. Es decir, se reconstruye la herencia como si no se hubieran producido las donaciones. Dentro de los descendientes legítimos, cabe hacer varias distinciones

${ }^{1014}$ Con anterioridad a la Ley 11/1981, de 13 de mayo de modificación del Código civil, el artículo $1045 \mathrm{Cc}$ requería que el valor de los bienes colacionables se evaluaran al tiempo de la muerte del causante. Con la reforma del precepto por la Ley citada la evaluación de los bienes a colacionar tiene lugar a tiempo de evaluo.

${ }^{1015}$ PENE VIDARI, F.: “La successione neccessaria...”, op. cit. pág. 249.

${ }^{1016}$ Más información en GABRIEll Cossellu, La colación hereditaria..., op. cit., págs. 28 y 29. Cita el autor distintas sentencias de la Corte di Casacione, la de 28 de junio de 1976, que establece la naturaleza de la colación, la de 01 de febrero de 1995. que califica la colación de operación necesaria a la apertura de la sucesión y que corresponde la carga de la prueba al que pretenda oponerse a ella. También la Sentencia de 23 de noviembre de 2006, dispone "que el uso y disfrute a título gratuito de un inmueble del causante por parte del heredero no está considerado como una donación colacionable, por tratarse de un comodato y no de una donación, ya que le falta el "animus donandi". 
conforme al precepto de referencia 737 CCi. La misma obligación de colacionar afecta al hijo del causante que al hijo de este, y a su vez nieto del finado, si sucede representando a su padre. En consecuencia tendría que llevar a colación lo que en su día su abuelo donó a su padre y se estaría, ante una colación indirecta por virtud del artículo $740^{1017} \mathrm{CCi}$. Es decir, se ha de colacionar lo donado por el abuelo al padre, incluso en los supuestos, en que el nieto del primero e hijo del segundo, no haya sacado de él, beneficio alguno de la donación y renuncie a la citada herencia ${ }^{1018}$.

De la misma manera que se ha expuesto en el párrafo anterior, el descendiente directo del causante, es decir, su hijo cuando concurre a la sucesión con hijos de sus hermanos, que representan a estos últimos, viene obligado a colacionar las donaciones que en vida le haya otorgado su padre, de la misma manera que si hubiera concurrido con sus propios hermanos ${ }^{1019}$.

No presenta dudas lo dispuesto en el artículo 739.2 CCi ya que, si al matrimonio compuesto por A y B, del que A es hijo de C este, dona 10. 000 $€$ sólo la parte de A está sujeta a colación y en consecuencia se tendrían que aportar a la herencia $5000 €$. Sigue existiendo duda en aquellos supuestos en que el nieto recibe directamente una donación de su abuelo y con posterioridad lo hereda. La duda está en ¿Si debe colacionar dicha donación anterior? En el nuevo Código civil italiano de 1942, los descendientes de más de primer grado suceden siempre por representación, aun en el caso de estirpe única.

\footnotetext{
${ }^{1017}$ Art. 740 Donazioni fatte all'ascendente dell'erede: "Il discendente che succede per rappresentazione deve conferire ciò che è stato donato all'ascendente anche nel caso in cui abbia rinunziato all'eredità di questo".

${ }^{1018}$ GUIDO AlPA.; Manuale di diritto privato..., op. cit., pág. 1208, mantiene al respecto que, "la colación está diseñada para proteger a otros herederos legitimarios, suponiendo que dichas donaciones se han hecho en previsión de la legítima".
}

${ }^{1019}$ Cicu A, Succesioni per causa di morte..., op. cit., pág. 928. 
Todo parece estar muy claro hasta aquí, pero estimo que podría caber otra pregunta ¿Influye a la hora de colacionar, que la donación al nieto por el abuelo, se haya hecho en vida del padre? Hay que partir de la base del espíritu de la colación para interpretar lo dispuesto en el artículo 737 CCi. El espíritu de la colación, no es otro, que procurar que no haya desigualdad entre los hermanos, pero nada dice de la desigualdad entre las estirpes ${ }^{1020}$. Con esta afirmación o principio, coinciden distintos autores al referirse a la colación y manifestar que está destinada a asegurar la igualdad proporcional entre los coherederos del patrimonio del difunto. Es precisamente la colación la que debe aportar la igualdad entre los coherederos, pero no se trata de aportarla a cualesquiera coherederos, sino de aportarla entre los hermanos ${ }^{1021}$.

Sobre la pregunta que se hacía anteriormente- donación del abuelo al nieto en vida del padre-. La respuesta es sencilla, la donación al nieto no perjudica la igualdad entre los hermanos e hijos del causante en la sucesión de este. Véanoslo en un supuesto. El abuelo A dona a su nieto D $1000 €$ de los 11000 de que dispone. Un mes después fallece nombrando herederos a sus dos hijos B y $\mathrm{C}$ del que $\mathrm{C}$ es padre de $\mathrm{D}$. Es evidente que seguirá habiendo una igualdad entre ambos hijos a la hora de heredar, de colacionar D lo donado por su abuelo. Simplemente aumentaría la masa hereditaria pero no contribuiría a facilitar o fomentar la igualdad entre los hermanos.

Si ahora el supuesto se plantea en el sentido que el abuelo A hace la misma donación a $\mathrm{D}$ pero premuere su padre $\mathrm{C}$ a su abuelo y concurre a la

${ }^{1020}$ Véase el espíritu de la colación en CICU ANTONIO, Succesioni per causa di morte..., op. cit., pág. 931, que no es otro, en palabras del autor, "que, facilitar o fomentar la igualdad entre hermanos y no entre estirpes".

${ }^{1021}$ MengOni, Successioni per causa di morte..., op. cit., pág. 44. 
sucesión representando a aquel. Entonces cambia la cosa, si no colaciona se rompe la igualdad entre los hermanos. Se rompe la igualdad entre los hermanos ya que su representado, es decir, C estaría heredando $6000 €$ y su hermano B solamente $5000 €$. Cabe otro supuesto, en que el abuelo A hace la misma donación a su nieto $\mathrm{D}$, pero premueren al causante $\mathrm{A}$ sus dos hijos $\mathrm{B}$ y $\mathrm{C}$ el primero sin descendencia y el segundo con dos hijos del que uno de ellos es D. Llegada la sucesión de A y D concurriendo a ella con su hermano e hijo también de $\mathrm{C}$, si no colaciona los $1000 €$ donados por su abuelo, él hereda $6000 €$ y su hermano $5000 €$. Por lo tanto, es evidente que ha de colacionar la donación para que se produzca la igualdad entre ambos.

\subsubsection{Diferencias con el Derecho común español}

La primera diferencia es acerca de los legitimarios que están llamados a la colación. En el ordenamiento español son llamados a la colación los descendientes y los ascendientes. En cambio en Italia se añade a los anteriores el cónyuge supérstite, al mismo nivel que los descendientes y ascendientes ${ }^{1022}$. Otra diferencia entre ambos países, con respecto a la colación se encuentra en los bienes objeto de la colación, mientras que en España se refiere a las "atribuciones a título gratuito". En cambio en Italia se especifica y concreta más los bienes a colacionar "donaciones que conlleven el empobrecimiento del donante a favor del donatario". Por lo tanto adviértase que quedan, con esta definición, excluidas de la colación la cesión de inmuebles para uso y disfrute en concepto de comodato o precario. Otra diferencia que cabe destacar de ambos ordenamientos son las modalidades de colación ya que el italiano admite la colación in natura y la

${ }^{1022}$ GABRIElli Cossellu, La colación hereditaria..., op. cit., pág. 33. 
colación por imputación, mientras que el español, como se ha apuntado anteriormente, sólo la colación por imputación ${ }^{1023}$.

En el ordenamiento español la colación queda circunscrita al campo de la donación y, por consiguiente, la citada liberalidad de uso es donación. Si bien cabe matizar la inaplicación de determinados preceptos de la donación como es el caso del precitado 1378 del Código civil. Inaplicación por no considerar el legislador español fraude, la adecuación a las normas que impone la propia sociedad ${ }^{1024}$. Dentro de ellas se incluyen todas las que pueden ubicarse dentro de lo normal de la vida cotidiana de una familia, como puedan ser los regalos de cumpleaños, Navidad, celebraciones de acontecimientos, etc. Si bien al tratarse de conceptos indeterminados se tendría que adecuar a cada caso concreto de necesidades y posibilidades de cada familia. ${ }^{1025}$.

Por lo que respecta a la efectividad de la colación, comparando ambos ordenamientos, italiano y español común, se advierte una sustancial diferencia al hacer efectiva la institución citada. El Código civil italiano obliga a que ciertos familiares (descendientes) del causante aporten a la

${ }^{1023}$ GABRIELli COSSELlu, La colación hereditaria ..., op. cit., pág. 34. Mantiene el autor que "en el el Derecho italiano, aunque sea de forma sustancialmente residual para los bienes inmuebles, a elección explicita del obligado a colacionar se mantiene vigente la colación in natura".

${ }^{1024}$ Véase VERDERA IZQUIERDO, "El régimen de colación...", op. cit. La autora manifiesta que: "al tratar las liberalidades de uso, no las considera donación, al no existir un verdadero animus donandi establece que «no se puede decir - tomando la expresión del art. 1.274 infine - que la causa sea "la mera liberalidad del bienhechor", así que no hay, como en la donación, un contrato de "pura beneficencia", sino un acto mediante el que se acata una práctica, que siendo la que verdaderamente lo provoca, puede decirse que es la causa de esa liberalidad".

${ }^{1025}$ VERDERA IZQUIERDO, "El régimen de colación...", op. cit. Cita la autora, la SAP de Vizcaya, de 8 de julio de 2005 (JUR 238005) donde se establece: "Piden los recurrentes que doña Paula colacione dos conceptos: el teléfono móvil y el seguro del coche en los importes correspondientes a los años anteriores al fallecimiento del padre, estimando la sentencia recurrida que son gastos ordinarios que deben quedar incluidos en el artículo 1.041 del Código Civil”. 
sucesión todo lo que han recibido por donación (artículo 731.1 CCi). En cambio, el Código español dispone que el donatario, con obligación de colacionar (cualquier legitimario), reciba de menos lo recibido por donación (artículo $1047 \mathrm{Cc}$ ). Otra diferencia palpable con el Derecho italiano es con arreglo al artículo $1035 \mathrm{Cc}$ que han de concurrir herederos forzosos para tener cabida la colación. No habla el Derecho español de descendientes como lo hace el italiano, sino que se refiere a cualquier legitimario o heredero forzoso. Por lo tanto, la colación en el Derecho común de España se da cuando a la sucesión concurre cualquiera de los legitimarios. Por lo que respecta a lo dispuesto en el artículo $739 \mathrm{CCi}$ son equivalentes, de este precepto en el Código civil español, los artículos 1039 y 1040 Cc. Estos dos artículos eximen el primero al padre de la obligación de colacionar lo que el abuelo donó al nieto y el segundo exime también al hijo de lo que el padre dono a su mujer. Con la salvedad de que si el padre, la donación la hubiera hecho a favor de ambos cónyuges, el hijo tendría que colacionar su parte, que sería la mitad.

No se puede pasar por alto el comprobar si también se cumple en el Derecho español, el principio de la colación en el Derecho italiano, cuyo espíritu es "facilitar o fomentar la igualdad entre hermanos y no entre estirpes". Aporta la prueba de que podría regir el mismo principio en nuestro Derecho, el artículo 1038 Cc. Este precepto hace colacionar al nieto lo que en su día le donó su abuelo. Lo hace colacionar si representa a su padre en la sucesión de su abuelo. Si concurre a ella, con sus tíos o con sus primos. Matiza el citado precepto $1038 \mathrm{Cc}$ que deberá colacionar todo lo que hubiera tenido que colacionar su padre de vivir. Se entiende que se está refiriendo a lo donado por el causante al padre. En el segundo párrafo del precitado artículo se obliga a colacionar lo que los nietos, que heredan representando al padre, hubieran recibido en vida como donación, a menos 
que el testador dispusiese otra cosa. Pero, en caso de disponer el testador en contrario, ha de respetar las legítimas de los coherederos, es decir, se respeta la voluntad del testador hasta que roza la línea fronteriza de las legítimas ${ }^{1026}$.

\section{CONCLUSIONES:}

1. Nuestra legítima es el resultado de una hibridación entre la legítima romana y la reserva germánica en que el objetivo de la primera es totalmente contrapuesto al de la segunda. La legítima romana surge como consecuencia de los abusos efectuados por el testador y precisamente se crea para frenar su libertad de disposición. La reserva germánica, por el contrario, tiene como objetivo la salvaguarda del principio consuetudinario por el que el jefe de familia no podía disponer individualmente de sus

${ }^{1026}$ Si se analiza, detenidamente, los artículos 1038, y 1039, ambos del Código civil español, en el último de los preceptos se exime a los padres de la obligación de colacionar lo donado por los abuelos a sus nietos. Con ello se advierte el principio de igualdad entre hermanos antes señalado, también aplicable al Derecho español. De no ser así, ¿Qué explicación se le puede dar a ambos preceptos? En el primero obliga a colacionar al nieto y en el segundo exime al padre de hacerlo y lo único que varía entre ambos es que premuera o no, el padre al abuelo. En vida el abuelo A dona $1000 €$ de su patrimonio de $21000 €$ al nieto $\mathrm{D}$ y fallecido el abuelo $\mathrm{A}$, el padre de $\mathrm{D}$, concurre a la sucesión con su hermano B. Ambos se repartirán $20000 € / 2=10.000 €$ por cabeza y en aplicación del artículo 1938, del Código civil español, el padre de D, no tendrá que colacionar lo donado por su padre a su hijo D. Adviértase que, no altera la igualdad entre los hermanos el hecho de colacionar los $1000 €$ donados por el abuelo al nieto, es decir, si colaciona se reparten $10.500 €$ por cabeza y si no lo hace 10 . $000 €$ pero la igualdad entre los hermanos, en ambos casos, queda inalterada y garantizada. Variando la premoriencia del padre al abuelo, varía todos los efectos del proceder de la colación que no se ve afectada por el principio de representación, sino que trata de equilibrar la igualdad entre los hermanos. La verdadera diferencia que afecta a dicha igualdad es la premoriencia de alguno de ellos. Con ello se ve como trata de neutralizar, dicha diferencia, la colación en el Derecho español. Si simplemente se supone que premuere el padre de D al abuelo A y a D, no se le aplicaría el artículo 1039 Cc se le seguirá aplicando el $1038 \mathrm{Cc}$. Sería como en el punto anterior, en que no tenía obligación de colacionar el nieto, lo que en vida le donó su abuelo, al concurrir a la sucesión en representación de su padre. $\mathrm{D}$, heredaría $11.000 €$ y su tío $\mathrm{B}, 10.000 €$ y exactamente se repetiría la misma desigualdad en el supuesto de concurrir con sus primos hijos de $\mathrm{B}$, e incluso si se diera el caso de tener que D concurrir a la sucesión de su abuelo con sus propios hermanos representando a su padre. 
bienes. De la fusión de ambas instituciones surgirá una tercera como exponente de la que recogió el Code francés que sirvió de modelo, entre otros, para el Código civil español.

2. La finalidad esencial que persigue la institución de la legítima en general es que al menos una parte de la herencia del causante tenga como destino los familiares más cercanos al difunto. La legítima en particular está orientada a favor de los hijos y descendientes del disponente en previsión del vínculo cercano y directo que les unía en vida de aquel. El legislador, con la legítima establece una presunción legal estimando que de estar en su sano juicio el testador, no hubiera obrado de distinta manera.

3. La naturaleza jurídica de la legítima en el derecho común, de acuerdo con la doctrina mayoritaria, considera su pago como pars bonorum. Si bien este aspecto de la legítima ha sido polémico entre la doctrina, sino también entre la jurisprudencia del Tribunal Supremo, al considerar también la naturaleza de la legítima como una pars hereditatis, como resulta del artículo $806 \mathrm{Cc}$. También ha producido debate este precepto por la confusión que origina entre los conceptos de legitimario y heredero, al que refuerza con el calificativo de forzoso, cuando el legitimario puede renunciar a la legítima.

4. En el conjunto de todo el Derecho español se contienen conceptos de legítima bastante diferenciados, como se ha dicho, el Derecho común la concibe, con alguna excepción, al igual que Aragón como pars bonorum. El Derecho de las Islas Baleares también la concibe como pasr bonorum en Mallorca y Menorca y como pars valoris bonorum en Ibiza y Formentera, así como también en Vizcaya en la parte donde no rige el fuero de Ayala. En el resto del territorio vasco existe plena libertad de disposición post mortem. Para el Derecho catalán y gallego es pars valoris. En Navarra es una legítima simbólica sin contenido patrimonial. En todo caso la 
concepción de la legítima com un derecho de crédito es la que menos conflicto genera a la hora de efectuar la partición.

5. Anteriormente a la promulgación del Código Civil, la legítima, ya dividió en dos grupos a los políticos de la época. Uno de los grupos lo encabezaba D. Manuel Alonso Martínez como defensor de la permanencia de la legítima en el Código y el otro D. Gumersindo Azcarate y Menéndez partidario de suprimir la legítima del Código en debate. Lo verdaderamente sorprendente es que los argumentos parlamentarios que se usaban para defender o detraer la legítima respectivamente eran los mismos con los que ahora, más de un siglo después, se hacen servir para ensalzar o para criticar la figura de la legítima. En consecuencia la permanencia o abolición de la legítima únicamente obedece al interés personal de quien la exalta o trara de la anularla.

6. En los Derechos aragonés y vasco impera la legítima colectiva cuya obligación para el testador con sus legitimarios es el grupo y no el individuo. El disponente tiene facultad para elegir a aquel legitimario que recibirá la legítima. El derecho del resto de legitimarios sólo alcanza a que se les nombre en el testamento o en el pacto sucesorio, siquiera para excluirlos de la sucesión. Por lo tanto la libertad del testador lo único que consigue es poder favorecer a unos en perjuicio de los demás. Es parecido al sistema al que utiliza el Derecho común con la mejora, con la salvedad que el Código civil no desampara a ningún legitimario. La conclusión es que con el sitema de legítimas colectivas puede existir mucha desproporción hereditaria entre los distintos familiares íntimos del causante.

7. La libertad de testar ha sido utilizada para propiciar la unidad patrimonial como sucede con Navarra cuyo Derecho foral es el que más destaca en este aspecto. El testador no vela por el bienestar de sus 
descendientes dentro de sus posibilidades, sino que su preocupación es la de mantener la indivisión de su patrimonio. Lo hace buscando un legitimario, de entre todos, que administre sus bienes, la casa solariega y con ello asegurar su bienestar hasta su muerte. Entonces cabe también concluir que dicha libertad de disposición supone asegurar el futuro de unos (incluido el propio testador) a cambio de la incertidumbre del resto.

8. Es de destacar como en algunos países europeos de nuestro entorno jurídico se haya legislado en previsión de la influencia para testar que pueden ejercer los cuidadores sobre el "testador vulnerable". Son bajo mi punto de vista, las legítimas en su ámbito de actuación, un antídoto que neutraliza a las personas que de una manera poco moral pretenden captar la voluntad del testador en su favor. El testador, en el caso de que esté provisto de legitimarios, la legítima siempre supone un freno para todo aquel que estando físicamente cerca del testador (cuidadores, sanitarios religiosos, etc.) le interese ganarse su confianza. Si bien he de admitir que nuestra legítima, la del Código civil, deja una parte de la herencia del testador vulnerable, a mi juicio, poco controlada. Como sucede con la parte de libre disposición.

9. Dados los dos fenómenos que afectan a la población española, por un lado la mayor esperanza de vida y por otro la incorporación al mundo laboral de la mujer. Estas dos circustancias abocan al anciano testador al geriátrico público o al privado, con los inminentes riesgos que para los titulares, de derechos expectantes de herencia, supone la cercanía de personas con capacidad de influencia al anciano testador. Sería de suma efectividad que España siguiera la tendencia de Europa al respecto. Así el artículo 909, del Code francés, la administración de apoyo italiana, el artículo 14 de la HeinmGesetz en Alemania. En estos ordenamientos se impide que los geriátricos, tanto públicos como privados, reciban bienes 
patrimoniales de los internos, incluso el Derecho catalán ha legislado en este sentido. Por lo tanto, se limita la libertad del testador en este aspecto e incluso lo respalda la Constitución en el caso de Alemania, ya que en 1998 se aceptó la constitucionalidad de la norma que lo respalda. Tales medidas darían una mayor seguridad sobre la parte de libre disposición que todavía hoy queda desprotegida en nuestro ordenamiento común.

10. La conclusión es que de la desaparición de las legítimas convertiría a una gran parte de los testadores en sustanciosas víctimas para los cuidadores desaprensivos, puesto que sin límite dispositivo legal, sería muy fácil ganarse la simpatía del anciano testador y conseguir que este les nombrase herederos únicos.

11. La legítima del Derecho común español hace una importante previsión sobre los hijos que por circunstancias permanecen más alejados del disponente post mortem, con respecto a los que conviven en la época de testar. Este sería el caso de es hijos de anteriores matrimonios o uniones de hecho. Sólo la permanecía de las actuales legítimas pueden evitar una total discriminación testamentaria hacia esos hijos. El fracaso, que bajo mi punto de vista, supondría otorgar en estos momentos la total libertad de disposición al testador sería como volver a regirnos por la Ley de las XII Tablas, con la total desprotección de los hijos y descendientes que ello supone.

12. Si bien todas las medidas relacionadas con la legítima son relevantes hay algunas que personalmente las considero indispensables para el mantenimiento de la legítima individual. La intangibilidad es la principal medida pora garantizar tanto la cantidad como la calidad de la legítima. Tambien son de destacar las tasadas causas de indignidad y desheredación que previnen al legitimario de lo que le puede pasar por incurrir en alguna de ellas. Finalmente en la preterición se advierte al disponente de lo que 
puede suponer la omisión, voluntaria o involuntaria, de un legitimario en el testamento y por último está la repudiación que impide que el legitimario se convierta en un verdadero heredero forzoso.

13. El ordenamiento francés junto con el alemán se acogen al sistema de adquisición de la herencia ipso iure. El llamado a la sucesión adquiere la titularidad de los bienes y derechos simplemente por ser la voluntad del difunto, si bien tiene el llamado la facultad de la renuncia. Por lo tanto el que renuncia es como si nunca hubiera sido heredero, es decir, no hay herencia yacente. La conclusión es que el sistema hereditario español común ahorra un paso innecesario como es el de ser titular de bienes para llegar al mismo destino en caso de repudiación.

14. La única institución que he visto mejorada en los Derechos extranjeros con respecto a nuestro Derecho común ha sido la colación tal como se regula en el Derecho italiano. He de admitir un mayor acierto en la regulación de esta institución en el Derecho italiano que en el Código civil. En el ordenamiento español son llamados a colacionar los descendientes y los ascendientes mientras que en aquel además es llamado el cónyuge viudo. Ocurre lo mismo con los bienes a colacionar, el Derecho italiano los detalla, mientras que el español se limita a utilizar una expresión genérica como es la de "las atribuciones a título gratuito". Otra diferencia es la modalidad de colación puesto que en Italia además de la colación por imputación está la colación in natura, es decir, traer acolación los mismos bienes donados. En cambio el Código civil únicamente admite la colación por imputación, en la que hay que traer a la masa hereditaria únicamente el valor que tienen los bienes donados al momento de evaluarlos.

15. En algunos ordenamientos se excluye a los ascendientes de su condición de legitimarios, en mi opinión esta medida va en contra del principio de la solidaridad familiar que es el que preside la institución de la 
legítima. Por este motivo nos parece, también conveniente, mantener la condición de legitimario al cónyuge viudo en los territorios del Código civil.

16. Como colofón abogo por el mantenimiento del sistema de legítimas tal como cofigura en la actualidad en el Código civil, por mantener el principio de solidaridad familiar de manera más justa y equilibrada que cualquiera de los ordenamientos analizados. Rechazo, por discriminatorio para el resto de legitimarios, el sistema de legítima colectiva por respender a una concepción de mantenimiento de la indivisibilidad de un patrimonio agrario que ha dejado de tener importancia en la España del siglo XXI. Las únicas reformas que me atrevería a hacer son las relativas a una mayor protección del "testador vulnerable" aumentando el número de personas físicas y jurídicas que tendrían que ser incapaces para suceder. Asimismo, incorporar una nueva causa de desheredación: la falta de relación del hijo con el causante siempre que sea imputable al primero. 
- 447 - 


\section{BIBLIOGRAFÍA:}

ACEDO PENCO, A.: “Apertura, vocación y delación de la herencia”, en Derecho de Sucesiones. El testamento y la herencia, Dykinson, Madrid 2014.

ADROHER BioscA, S.: "Hacia la supresión del exequátur en el espacio judicial europeo: el título ejecutivo europeo", Universidad de Sevilla, 2006.

Aguilera y Velasco A.: Colección de Códigos Europeos, anotados y concordados. Código Civil Francés. Tomo I, 1876.

Alascio Carrasco L.: Los pactos sucesorios en el Derecho Civil Catalán, Atelier, Barcelona, 2016.

Albaladejo García, M.: Comentarios al Codigo Civil. Tomo X, Vol 1'º: Artículos 744 a 773 del Código Civi, Artículo 756, Edersa, Madrid, 2004.

Albadalejo García, M.: Comentarios al Código civil y compilaciones forales, Tomo XI, $2^{\mathrm{a}}$ ed, Edersa, Madrid, 1982.

Albaladejo García, M. Curso de Derecho Civil, V, Derecho de sucesiones, Bosch, Barcelona, 1989.

ALEMÁn URIS, J.: “Cautela Socini: análisis a propósito de la STS 17/1/2014”, ROED, núm. 4, 2014.

AlESSANDRI RodRíGUEZ, A. y Somarriva Undurraga, M.:’Los diversos sistemas jurídicos contemporáneos", en Tratado de Derecho Civil. Partes preliminar y general, Editorial Jurídica de Chile, abril 2011.

Algaba Ros, S.: Maltrato de obra y abandono emocional como causa de desheredación, Indret, núm. 2, 2015.

Álvarez Posadilla, J.: Comentarios a las Leyes de Toro, según su espíritu y el de la legislación de España, Imprenta que fue de Fuentenebro, Madrid, 1833.

Alzate Monroy, P.: “El Derecho expectante de viudedad”, Blog de Patricia Alzate Monroy, enero 2010.

ANDERSON, M.: "Una aproximación al derecho de sucesiones inglés". Anuario de derecho civil, Vol. 59, 2006. 
Aragonés Seijo, S.: "Curso de derecho civil de Galicia”, (Director: J. M. Busto Lago) Revista Crítica de Derecho Inmobiliario, núm. 761, mayo 2017.

ARAgOnÉS SEIJO, S.: El beneficio de inventario, de miguel ángel pérez álvarez, Revista Crítica de Derecho Inmobiliario, núm. 762, Julio 2017.

ARAUJO DíAS, C. M.: "Uniones de hecho: la posición sucesoria del conviviente supérstite en Portugal, AFDUC, ( Anuario da Faculta de de Dereito da Universidad de da Coruña,) núm. 18, 2014.

ARIAS RAMOS, J.: y Arias Bonet J.: Derecho romano, Vol. II, $17^{\mathrm{a}}$ ed, Editoriales De Derecho Reunidas, Revista de Derecho Privado, Madrid, 1984, pág. 829.

ARJONA GUAJARDO-FAJARDO, J.L.: "Derecho de representación sucesoria. Estudio sobre la operatividad del derecho de representación en el Código civil español, en caso de repudiación del sujeto llamado a una herencia”, Anuario de Derecho Civil, núm. LXV-I, 2012.

ARnaldo Alcubilla, E.: La noción de orden público en el constitucionalismo español, Dykinson, Madrid, 2011.

Arroyo i AmAÑUelas, E. Y FARNÓs AmOrós, E.: Entre el testador y el legitimario desheredado ¿A quén prefiren los tribunales?, Indret, núm. 2, 2015.

Arroyo Amayuelas, E. "La Reforma del Derecho de Sucesiones y de la Prescripción en Alemania”, InDret, núm. 1, 2010.

Arroyo Amayuelas, E. "Inheritance Law and Limitation Periods Reform in Germany "(La Reforma del Derecho de Sucesiones y de la Prescripción en Alemania) (Spanish). InDret, 1, 2010.

ARTAMENDi GuTIÉRREZ, A.: "Visión integral de la fiscalidad del pacto sucesorio", Actualidad Jurídica (Uría \& Menéndez), núm. 42, enero de 2016.

BAdenas CARPIO, J.M.: Las donaciones colacionables en el Derecho civil balear, Tirant lo Blanch, Valencia, 2006.

BAdoy LóPez, C., Delgado Echevarría, J. y Serrano García, J.A.: Comentarios al Código del Derecho Foral de Aragón. Doctrina y Jurisprudencia, Dykinson, Madrid, 2015. 
BALAREzo ReYes, E.J.: "Los efectos de la ley del adulto mayor sobre el derecho de sucesiones, un replanteamiento respecto a la figura de la indignidad", REDS (Revista de Derecho, Empresa y Sociedad), núm. 11, julio 2017.

BARCELÓ DOMÉNECH, J.: "La desheredación de los hijos y descendientes por maltrato de obra o injuria graves de palabra”, Revista Crítica de Derecho Inmobiliario, núm. 682, marzoabril, 2004.

Baró Pazos, J.: La Codificación del Derecho Civil en España, 1808-1889. Universidad de Cantabria, 1993.

BARÓ PAZOS, J.: "El derecho civil de Cataluña ante el proceso codificador español”, Glossae: European Journal of Legal History, núm. 12, 2015.

BARRIO GALlARDO A.: El nacimiento del common law en el bajo Medievo en El largo camino hacia la libertad de testar. De la legítima al derecho sucesorio de alimentos, Tomo $2^{\circ}$, Dykinson, Madrid, 2012.

BARRIO GALlARDO, A.: "Estudio histórico-comparado de la libertad de testar en Inglaterra y Aragón”, Revista de Derecho Civil Aragonés, núm.17, 2011.

BARrio Gallardo, A.: La evolución de la libertad de testar en el Common law inglés, $1^{\mathrm{a}}$ ed, Aranzadi, Navarra, 2011.

BARRIO GAllardo, A.: El common law en la actualidad: un ejercicio de prospectiva, Dykinson, Madrid, 2012.

Barrio Gallardo, A.: El largo camino hacia la libertad de testar. De la Legítima al Derecho sucesorio de alimentos, Dykinson, Madrid, 2012.

BARrio Gallardo, A.: "El common law de la edad contemporánea", en El largo camino hacia la libertad de testar. De la legítima al derecho sucesorio de alimentos, Dykinson, Madrid 2012.

BEATO DEL PALACIO, E.: "La indignidad para suceder: causas de desheredación” en Raices de lo ilícito y razones de ilicitud (Dir. Isabel Hoyo Sierra y Ángel Sánchez de la Torre), Dykinson, Madrid, 2006.

BERNAD MAINAR, R.: Derecho romano: curso de derecho privado romano, Universidad Catolica Andres Bello, 2001, pág. 582. 
Bernad MAINAR, R.: “La porción legítima en la familia del Derecho romano”, Revista Crítica de Derecho Inmobiliario, núm. 757, 2016., pág. 1766.

Berrocal Lanzarot, A. I.: "El maltrato psicológico como justa causa de desheredación de hijos y descendientes" Revista Crítica de Derecho Inmobiliario, núm. 764, noviembre 2017.

Berrocal LANZAROt, A. I. "El maltrato psicológico como justa causa de desheredación de hijos y descendientes", Revista Crítica de Derecho Inmobiliario, núm. 748, marzo, 2015 .

BerRocal LANZAROT, A. I.: “Cuestiones controvertidas e implicaciones prácticas en torno a la guarda y custodia compartida", Revista Crítica de Derecho Inmobiliario, núm. 756, julio, 2016.

Betancourt Serna, F.: Derecho romano clásico, $3^{\mathrm{a}}$ ed. Universidad de Sevilla, Sevilla, 2007, pág. 105.

Bolas Alonso, J.: La preterición tras la reforma de 13 de mayo de 1981. Conferencia pronunciada en la Academia Matricense del Notariado el día 25 de marzo de 1982, en Anales de la Academia Matritense del Notariado, Tomo XXV, Edersa, Madrid, 2004.

Botello Hermosa, P. I.: "El incomprensible uso como sinónimos de dos figuras jurídicas diferentes: el fideicomiso y la sustitución fideicomisaria.” Revista Crítica de Derecho Inmobiliario, núm. 756, 2016.

Botello Hermosa, P. I.:"Un problema actual de enorme trascendencia jurídica en españa: las personas curateladas como posibles beneficiarias de la sustitución fideicomisaria especial”, Revista Crítica de Derecho Inmobiliario, núm. 762, julio 2017, pág. 1677.

Botello Hermosa, P. I.: "Sustitución del término incapacitado por el de persona con discapacidad necesitada de una especial protección. ¿Acierto o desacierto del legislador de la Ley Orgánica 1/2015?”, Revista Crítica de Derecho Inmobiliario, núm. 754, marzo 2016.

Bueno Delgado, J. A.: "Derecho fiscal" en Hacia un derecho administrativo, fiscal y medioambiental romano III, (coord. A. Fernández Buján y G. Gerez Kraemer), Dykinson, Madrid, 2016. 
Bueno Delgado, J. A.: "El régimen económico y fiscal del estamento clerical, en la legislación justinianea", en Hacia un Derecho administrativo, fiscal y medioambiental romano III, (coords. A. Fernández Buján, G. Jerez Kraemer), Dykinson, Madrid, 2016.

Busto Lago, J. M.: "Los pactos sucesorios en la Ley 2/2006, de 14 de junio, de Derecho Civil de Galicia" Revista Crítica de Derecho Inmobiliario, núm. 706, marzo-abril, 2008 .

CAMACHO ClAVIJO, S.: El testamento revocatorio. La reorganización de la sucesión mediante la revocación testamentaria, Marcial Pons, Madrid, 2015.

CAROl Roses, F.: "La preterición: entre la libertad para testar y los derechos fundamentales. Una revisitación del derecho foral y ordenamientos comparados", Revista Crítica de Derecho Inmobiliario, núm. 759, enero 2017.

CARRANZA TORRES, L.R.: "El peculio castrense y el patrimonio de las personas") Revista en línea: comercio y justicia. info., 2014. Fecha de acceso: 10-01-2017.

Carrau Carbonell, J. M.: "La desheredación por maltrato psicológico y su dificultad de aplicación práctica”, Actualidad jurídica iberoamericana, núm. 3, 2015, pág. 557.

Casinos Mora, F. J.: La prescripción de la hereditatis petitio, Dykinson, Madrid, 2008.

CAStán PÉrez Gómez, S.: "Reflexiones sobre el origen de las sucesiones en Roma. El "testamentum calatis comitiis" y su relación con la sucesión intestada", RIDROM, núm. $11,2013$.

Castán Tobeñas, J.: Derecho Civil Español, Común y Foral, Tomo 4, Reus. 14ª Ed., Madrid, 1.988.

Celaya IbarRa, A.: Curso de derecho civil vasco, Universidad de Deusto, Bilbao, 1998

CENDÓN, P.: El diritto privado nella giurisprudenza en la sucesión, unione tipografico-editrice torinense, Torino, 2000.

Cerdá JiMeno, J.: Costumbres jurídicas en las Pithiusas, Dykinson, Madrid, 2011.

Chamocho Cantudo M.A. y Ramos Vázquez, I.: La herencia de la antigüedad: De las relaciones de trabajo en Roma hasta los sistemas gremiales de cofradías y hermandades medievales, en Introducción jurídica a la historia de las relaciones de trabajo, Dykinson, Madrid, 2013. 
Christanl, G.: "La legítima y la libertad de testar en Alemania y Austria: tendencias actuales", en Congreso Internacional Presente y futuro del Derecho de sucesiones: las legítimas y la libertad de testar,(Dir. F. Capilla Roncero, M. Espejo Lerdo de Tejada, F. J. Aranguren Urriza) Sevilla noviembre-diciembre 2017.

CICU, A.: succesioni per causa di morte. parte generale. Casa editorial Giuffrè, Milan. Obra distribuida en 1964, Boch, Barcelona, 1961.

Corral GarcíA, E.: "El derecho de reversión legal del artículo 812, del Código Civil: cuestiones suscitadas en la jurisprudencia más reciente", Revista Crítica de Derecho Inmobiliario. núm. 667, Septiembre - Octubre 2001.

CORRAL GiJÓN, M.C.: "Las uniones de hecho y sus efectos patrimoniales (parte $2^{\mathrm{a}}$ : efectos patrimoniales)", Revista Crítica de Derecho Inmobiliario, núm. 664, marzo-abril 2001.

CRemades García, P.: "Pactos sucesorios y Derecho foral" en Sucesión mortis causa de la empresa familiar: la alternativa de los pactos sucesorios, Dykinson, Madrid, 2014.

CRemades GarcíA, P.: Sucesión mortis causa de la empresa familiar: la alternativa de los pactos sucesorios, Dykinson, Madrid, 2014.

CuCurull Poblet, T.: Ámbito jurídico del protocolo familiar mortis causa, Dykinson, 2015.

Cucurull PoBlet, T.: El protocolo familiar mortis causa, Dykinson, Madrid, 2015.

De BARRón ARnicheS, P.: "Libertad de testar y desheredación en los Derechos civiles españoles”, Indret, núm. 4, 2016.

De BARRón ARNICHES, P.: El pacto de renuncia a la legítima futura, CEDECS, Barcelona, 2001.

De BARRón ARnicheS, P.: "La renuncia anticipada a la legítima en el derecho foral" en $E l$ pacto de renuncia a la legítima futura, CEDECS, Barcelona 2001.

De BARRÓn ARNiCHES, P.: "La legítima y el pacto de Non Succedendo en el Derecho Foral de Navarra", Revista jurídica de Navarra, núm. 22, 1996.

De Broca i De Monteagut, G. M.: "Historia del Derecho de Cataluña espacialmente del Civil y exposición de las instituciones de las instituciones de Derecho civil del mismo territorio en relación con el Código civil de España y la jurisprudencia”, Generalitat de Catalunya, Departament de Justicia, Barcelona, 1985. 
De la CÁmara Álvarez, M.: Compendio de derecho sucesorio, Wolters Kluwer, Madrid, 1990.

De la IGLESIA Monje, M. I..: "Derecho de alimentos versus gastos de crianza y educación de los hijos mayores de edad. los gastos de crianza como indemnización en los supuestos de wrongful conception o wrongful pregnancy", Revista Crítica de Derecho Inmobiliario, núm. 749, mayo 2015.

DEL Olmo García, P.: "Enriquecimiento injusto y pago de un tercero en la tradición del “Common law” PICC, PECL, DCFR, CESL", Anuario de Derecho Civil, núm. 69, enero 2016.

Delgado EcheverríA, J. y BAyod LóPez, M.C..: Comentarios al Código del Derecho Foral de Aragón. Doctrina y Jurisprudencia, Dykinson, Madrid, 2015

De Pablo Contreras, P.: "Los herederos forzosos y su porción jurídica" en Curso de Derccho civil, (Coord. M. A. Pérez Álvarez), Colex, Madrid, 2008.

De Verda y BeAmonte, J. R.: “Constitución y ususfructo en cuaderno particionalsin asignación coétanea de nuda propiedad”, Aranzadi, núm. 12, 2004.

DíAZ AlABART, S.: La sustitución fideicomisaria sobre el tercio de legítima estricta a favor de hijo o descendiente incapacitado judicialmente, Revista de Derecho privado, núm. 5-6, mayo 2004.

DíAZ GonZÁlez, F, L.: "El derecho de sucesiones en los primeros manuales de Derecho español: el caso de la ilustración del Derecho Real de España de don Juan Salas Bañuls (I)" Anuario de la Facultad de Derecho, núm. 4, 2011.

DíEZ PicAzo, L. y Gullón, A.: Sistema de Derecho civil, Vol. IV, tomo $2^{\circ}$ (Derecho de Sucesiones), $12^{\mathrm{a}}$ ed, Tecnos, Madrid, 2017.

DI PIRro, M.: Istituzioni di Diritto Privato (Diritto Civile), XXII Ed, Simone S.p. A., Napoli, 2016.

DonAT, J.: Las leyes civiles en su orden natural, Imprenta de José Taulo, Tomo III, 1841.

DONATO VARA, A.: “Apuntes sobre la protección de los niños con discapacidad en el sistema de sustituciones hereditarias: la reforma del artículo 782 del Código Civil español. Los derechos de la infancia y de la adolescencia" (Comunicación presentada al Precongreso: Rumbo al Congreso Mundial en Lima-Perú) (págs. 107-120), Ariel. 2006. 
Donato Vara, A.: La Reserva Vidual, Reus, Madrid, 2010.

Donato Vara A.: "Revisión crítica de la reserva vidual en el Derecho Civil Foral: análisis particular de la reserva binupcial en el Derecho y jurisprudencia catalana hasta su definitiva derogación legislativa", Revista Crítica de Derecho Inmobiliario, núm. 729, enero 2012.

DuPlá MARÍN, M. T., El proceso de recepción de la quarta falcidia romana en el Derecho civil catalán, Bosch, 2013.

ESPADA MALLORQUIN, S.: "El impedimento del ejercicio del derecho a una relación directa y regular entre abuelos y nietos como causal de desheredación e indignidad" Revista de Derecho, Vol. 28, núm. 2, 2015.

ESPEJO LERDO DE TEJADA, M.: "El contador-partidor dativo: algunas claves sobre su escaso arraigo práctico y sobre su regulación por la Ley de Jurisdicción Voluntaria”, Anuario de Derecho Civil, núm. LXX-I, enero 2017.

EsPejo LERDO DE TEJADA, M.: La cesión de la herencia en el código civil: ¿cambio personal del heredero?, Anuario de Derecho Civil, núm. LXI-4, Octubre 2008.

ESQUIROL JiMENEZ, V.: "La prohibició de la quarta falcídia: exigència de manifestació expressa per part del testador", Indret, núm. 1, 2011.

EsteVez AbeleiRA, T.: "El pacto de mejora como negocio jurídico mortis causa", Revista Crítica de Derecho Inmobiliario, núm. 758, noviembre 2016.

FAUS I PUjOL, M.: “Testamento legando usufructo poderoso al consorte y nombrando herederos a los hijos. Fuero de Ayala (Alava) En Formularios de Derecho de Sucesiones", vLex, 2010.

FAus i PUjOL, M.: "Escritura de herencia testada a favor de hijos y legítima a la pareja de hecho. Paísvasco", vLex, 2010.

FAUS I PUjOL, M.: "Testamento con legado especial a un hijo y nombrando herederos a los otros. Derecho aragonés", en Formularios de Derecho de sucesiones (2010), vLex, actualizado a octubre de 2017.

FeÁs Costilla, J.: "la renuncia de herencia: problemas y riesgos", Anales de la Academia Sevillana del Notariado, Tomo XXV, Conferencias del curso académico 2013-2014, Sevilla 2014. 
Fernández Costales, J.: “Las Comunidades Autónomas y el Derecho Civil: Derecho Foral y Derecho Consuetudinario Leonés." Tierras de León: Revista de la Diputación Provincial,Vol. 25, núm. 60, 1985.

FERnÁNDEZ Domingo J.I.: Derecho de sucesiones, Reus, Madrid, 2010.

FERNANDEZ EGEA M.A“La aceptación y la repudiación de herencias por las fundaciones" Revista Vasca de Economía Social, núm 13. Fecha de acceso: 22- 07-2018.

FERnÁndeZ-Hierro, M.: Panorama legislativo actual de la libertad de testar, boletín de la Academia Vasca de Derecho, Vol. 8, núm. 19, 2010.

FERRER VANRELl, M.P.: "La legítima en el Derecho civil de la Islas Baleares", en Tratado de legítimas, (coord. F. Torres García), Atelier, Barcelona, 2012.

Francisco PACheCO, J.: Comentario, Critico y Jurídico a las Leyes de Toro, tomo I, Imprenta de Manuel Tello y García, Madrid, 1862.

FuenMAyOR ChAmpín, A.: "Intangibilidad de la legítima", Anuario de Derecho Civil, 1948.

FuRgado ESTEVILL, J. .M.: Regímenes Económicos del matrimonio y de la pareja. Sucesión y prueba de la cualidad de herederos en el Derecho Frances, Bosch, 2011.

GABRIELli COSSELLU, M.: "La colación hereditaria: aspectos legales y jurisprudenciales en España y en Italia", Academia Edu, febrero 2017.

Galgano, F.: Diritto privado, $3^{\mathrm{a}}$ ed, CEDAM, Padova 2006.

Galicia AizPuRuA, G.: "La sucesión forzosa: planteamiento general”, en El Derecho Civil Vasco del Siglo XXI: de la Ley de 2015, a sus desarrollos futuros, Eusko Legebiltzarra / Parlamento Vasco, 2016,

Galván Gallegos, A.: "La indivisibilidad de la aceptación y repudiación de la herencia", Anuario de Derecho Civil, núm. L- 4, octubre, 1997.

GALVEZ CRIADO, A.: "El principio general del libre desarrollo de la personalidad y los pactos entre convivientes tras la STC 93/2013, de 23 de abril”, Revista Crítica de Derecho Inmobiliario, núm. 750, julio 2015.

GAmboa Uribarren, B.: "Mujer y sucesión hereditaria en Roma" en Mujeres y Derecho, pasado y presente: I Congreso multidisciplinar de Centro-Sección de Bizkaia de la Facultad de Derecho, (coord. J. Astola Madariaga) 2008. 
García GarcíA, J. M.: “Asuntos pendientes en el derecho de transmisión: el cónyuge viudo del transmitente y otros supuestos” Revista Crítica de Derecho Inmobiliario, núm. 753, enero 2016.

GARCÍA HERRERA, V.: Herencia yacente y usucapion: generalidades, en la Usucapión a favor de la herencia yacente, Dykinson, Madrid 2008.

GARCÍA-MON Quirós, F.: "Efectos de las adquisiciones onerosas con pacto de supervivencia", en La compraventa con pacto de supervivencia, Dykinson, Madrid, 2016.

GARCía PÉREZ, C. G.: "La (in) equivalencia terminológica en la traducción de testamentos estadounidenses al español”, Revista de Ciencias Humanas y Sociales, núm.144, 2016.

García Rubio M.P., Nieto Alonso, A., Herrero Oviedo, M.: "Las legítimas en la Ley 2/2006 de Derecho Civil de Galicia", en Tratado de legítimas, (coord. Teodora F. Torres García) Atelier, Barcelona, 2012.

GArcía TeJerA, C. y HeRnANDEZ Guerrero J.A.:"Rhetorica ad Herennium", en Retórica y Poética, Biblioteca Virtual Miguel de Cervantes. Fecha de acceso: 12-03-2018. Disponible en: http://www.cervantesvirtual.com/portales/retorica y poetica

GARrido De PAlma, V. M.: "Visión notarial de la legítima". Revista de Derecho Notarial, Madrid, 1971.

GARRIDO de PAlma, V. M.: Régimen matrimonial. Sucesiones mortis causa y Estatutos sociales. Armonización con el Protocolo Familiar, Vol. IX, (coor. M. Garrido Melero y J.M. Furgado Estevill), Consejo General del Notariado, Bosch, Barcelona 2005.

GONZÁLEZ PORRAS, J. M.: Algunas cuestiones sobresalientes en la reforma del código civil sobre la protección de las personas discapacitadas o incapacitadas, ( coord. R. Casado Raigón e I. Gallego Domínguez), Vol. 2, Universidad de Cordoba, Cordoba 2005.

GÓMEZ- CORNEJO TEJEDOR, L.:“El cambio de sesgo en la jurisprudencia en torno a las causas de desheredación en el Derecho común español “, Revista Crítica de Derecho Inmobiliario, mún. 755, Mayo 2016.

GONZALEZ LÓPEZ, R.:" El pulso entre heredero y legatario propiciado por la "voluntas testatotiris" la victoria de la "quarta falcidia", Anuario de la Facultad de Derecho de Universidad de Vigo, núm. 6, 2013. 
GotTlieb Heineccius, J.: Elementos del Derecho Romano según el orden de las instituciones, $3^{\mathrm{a}}$ ed., Imprenta de Pedro Sanz y Sanz (traducción de José de Vicente y Carabantes), Madrid, 1842.

GRANAdOS DE ASENSIO, D.M.: "Preterición de los hijos sobrevenidos (RDGRN de 12/06/2017)", Notaría Abierta, julio, 2017.

GuERro PÉREZ, V.: “Acción de nulidad de las donaciones de inmuebles. aspectos sustantivos y procesales, en Los 25 temas más frecuentes en la vida práctica del derecho de familia, (coord., F. Lledó Yague, y A. Sánchez Sánchez), Dykinson, 2011.

Guido AlPA.: Manuale di diritto privato. Settima edicione, casa editrice dott. Antonio Milani, Cedam Padua, 2011.

HERNÁNDEZ IBAÑEZ, C.: "La causa séptima de indignidad sucesoria: una medida de protección jurídica para personas discapacitadas", RDUNED. Revista de derecho UNED, núm. 1, 2006.

HerRero Oviedo, M.: De un derecho consuetudinario y especial a un derecho civil de Galicia Ius fugit: Revista interdisciplinar de estudios histórico-jurídicos, núm. 16, 2009-2010.

IRIARTE ÁNGEL, J. L.: “Ámbito material y personal y normas conflictuales”, en El Derecho Civil Vasco del Siglo XXI: de la Ley de 2015. Fecha de acceso 18-12-2017.

IRuRzun GoicoA, D.: “¿Qué es la legítima para el Código Civil español? (Búsqueda de su concepto, naturaleza y caracteres)”, Revista Crítica de Derecho Inmobiliario, núm. 759, enero 2017.

JuAn Roca, J.: Comentarios al Código civil, Tomo XIV, Vol 2º: Artículos 1035 a 1087 del Código Civil, EDERSA, Madrid 2004.

JuÁreZ GonZÁLEZ, J. M.: GPS Sucesiones, 2ª ed., Tirant lo Blanch, Valencia, 2017.

KLUGER, V.: "Entre la sombra y la luz. Los hijos ilegítimos en las tesis de la Universidad de Buenos Aires (1871-1888)", Revista de historia del Derecho, núm. 51, 2016.

LaCAlle Serer, E, Sanmartín Escriche F. y Aparicio Urtasum, C.: Sucesiones y Herencias, $1^{\text {a }}$ ed., Tirant Lo Blanch., Valencia, 2008.

Lacruz Berdejo J. L., Sancho Rebullida, F., Luna Serrano, A., AA VV: Elementos de Derecho civil V, nueva edición, Dykinson, Madrid, 2001. 
Lalinde AbADiA, J.: "Precisiones conceptuales sobre la legítima aragonesa", Anuario de Derecho civil ( Ref. ANU-H-1985-10033300388), 1985.

Lasarte Álvarez, C.: Derecho de sucesiones, tomo $7^{\circ}, 10^{\mathrm{a}}$ Ed., Marcial Pons, Barcelona 2015 .

Lasarte Álvarez, C.: Derecho de sucesiones. Principios de derecho civil, $10^{\mathrm{a}}$ ed. Tomo X, Marcial Pons, Madrid, 2015.

LASARTE Álvarez, C.: "La esencial revocabilidad de la dispensa de colación hereditaria", Revista Crítica de Derecho Inmobiliario, núm. 731, mayo 2012.

LASO Gaite, J. F.: "Crónica de la Codificación en España. El procedimiento civil" (Ministerio de justicia, Comisión General de Codificación), Reimpresión, Imprenta Nacional del Boletín Oficial del Estado, Madrid 1999.

LINARES NOCI, R.: "La preterición intencional y no intencional después de la reforma de 13 de mayo de 1981", Revista Crítica de Derecho Inmobiliario, núm. 588, septiembre-octubre 1981.

LÓPEZ Beltrán DE HeREdiA, C. “Aceptación y repudiación de la herencia. El derecho a deliberar", en Cuadernos Prácticos Bolonia (coord. F. Lledó Yagüe), Dykinson, Madrid, 2010.

LóPeZ de la Cruz, L. y PizArro Moreno, E.: "Los efectos de la sucesión", en Derecho de sucesiones (coords J. P. Pérez Velázquez y E. Pizarro Moreno), $2^{\mathrm{a}}$ ed, Tirant lo Blanch, Valencia, 2017.

LÓPEZ LÓPEZ, M. Y HORNERO MÉNDEZ, C.: “La sucesión mortis causa: conceptos generales”, en Derecho de sucesiones (coords J. P. Pérez Velázquez y E. Pizarro Moreno), 2a ed, Tirant lo Blanch Valencia, 2017.

LORA-TAMAYO, I. Y PÉREZ RAMOS, C.: Cuestiones prácticas sobre herencias para especialistas en sucesiones, El Derecho S.A., Madrid, 2016.

LORENZO-REGO, I.: El concepto de familia en Derecho español: un estudio interdisciplinar, Boch, 2014.

Llamas y Molina, S.: Comentario crítico, jurídico, literal, a las Ochenta y tres Leyes de Toro, vol. II, Imprenta y Librería de Gaspar y Roig, 1853.

Lledó Yagüe, F., Monje Balmaseda, O., Herrán Ortiz, A.I., AAVV: Intangibilidad de la legítima, Dykinson, Madrid, 2012. 
Lledó Yagüe, F., Monje Balmaseda, O., Herrán Ortiz, A. I., AAVV: Cuaderno Teórico Bolonia I. La sucesión mortis causa, Dykinson, Madrid, 2012.

Lledó Yague, F., Monje Balmaseda, O., Herrán Ortiz, A. I., AAVV, Examen particular de las causas de indignidad en Cuaderno Teórico Bolonia I. La sucesión mortis causa, Dykinson, Madrid, 2012.

MAdRIÑAN VÁZQUEZ, M.: "La preterición en el Derecho civil de Galicia", Dereito: Revista Xuridica da Universidade de Santiago de Compostela, Vol. 16, núm. 1, 2007.

MAIOFER, W.: “El Derecho natural como Derecho existencial”, Anuario de Filosofía del Derecho, núm. 9, 1962.

MANZANO FERnÁNDEZ, M. M.: "La exclusión del hijo en la herencia del testador. Una visión actualizada de la desheredación en el Código civil", Revista Crítica de Derecho Inmobiliario, núm. 756, julio 2016.

Martín JimÉneZ, C.M.: Teoría y Práctica del Ejercicio de las Acciones Civiles. Comentarios y Formularios, Lex Nova, Valladolid, 2010.

MARTín PÉREZ, J. A.: "La protección de las personas mayores y con discapacidad en el derecho de sucesiones de Cataluña”, en La codificación del derecho civil de Cataluña. Estudios con ocasión del cincuentenario de la compilación, (coord. J.M. Fontanellas Morel), Marcial Pons, Madrid, 2011.

Martínez Atienza, G.: Derecho Civil, Penal Sustantivo y Procesal. Jurisprudencia del Tribunal Supremo, vLex, Madrid, 2015.

MARTÍNEZ MARTÍNEZ, M.: “Avance de la posición y rango y la pareja de hecho en la sucesión intestada vasca: fusión de la tradición y cambio social en la ley 5/2015 de Derecho Civil Vasco, boletín de la Academia Vasca de Derecho, núm. 27, 2015-2016.

MARTÍNEZ VÁZQUEZ DE CASTRO, L.: Hipoteca por bienes reservables en el Código civil, Anuario de Derecho Civil, núm. LIX-1, 2006.

MCClintock, A.: "Un'analisi giuridica della lex Voconia", Teoria e storia del dirito privato, núm. 10, 2017.

Mengoni, L.: Successioni per causa di morte. Quarta ediczione. copyright Dott. A. Giuffrè, Editore Milano SpA. Milano, 2000. 
MenÉndez Mato, J. C.: El Legado de la Legítima Estricta en el Derecho Común Español, Dykinson, Madrid, 2012.

Mingorance GosálveZ, C.: "Los principios de confusión y de separación de patrimonios en el derecho hereditario español”, Revista Crítica de Derecho Inmobiliario, núm. 752, noviembre 2015.

Miquel GonZÁlez, J.M.: "La legítima material y la legítima formal” Colegío Notarial de Madrid en Academia Matritense del Notariado, Madrid, 2009.

Mollá Nebot, M. A. S.: Usufructo de pecunia. Aplicación a los fondos de inversión desde la ley de jurisdicción voluntaria, Dykinson, Madrid, 2015.

Mollá NeBot, S.: "Supuestos de eventual autorización del usufructuario, en derecho común, foral y civil especial en los casos de sucesión legal y voluntaria. Usufructo de pecunia" en Aplicación a los fondos de inversión desde la ley de jurisdicción voluntaria, Dykinson, 2015.

MONASTERIO ASPIRI, I.: “La metodología: prácticas y principios del análisis de documentos, Derecho civil foral (SS. XVII-XIX)", en EL DERECHO CIVIL VASCO DEL SIGLO XXI, de la ley de 2015 a sus desarrollos futuros”, Eusko Legebil tzarra / Parlamento Vasco, Bilbao, 2016.

MONDRAGÓn MARTín, H.: “Ampliación de las causas de desheredación de hijos y descendientes", vLex, núm. 167, abril, 2018.

Montagut Estragues, T.: "El testamento inoficioso en las Partidas y sus fuentes", Anuario de historia del Derecho español, núm. 62, 1992.

MORENO QUeSADA, L.: Las reservas hereditarias en curso de Derecho civil IV Derecho de Familia y sucesiones (coor. F.J. Sánchez Calero), $5^{\mathrm{a}}$ ed, Tirant Lo Blanch, Valencia, 2009.

Moreno Quesada, B., Desheredación y Preterición en Curso de Derecho civil IV. Derecho de familia y sucesiones, $5^{\mathrm{a}}$ ed, Tirant lo Blanch, Valencia, 2009.

MORETÓN SANZ, M. F.: “Cuestiones litigiosas sobre la preterición intencional y errónea: efectos y consecuencias de la tutela de la legítima cuantitativa sobre la sucesión testamentaria", Revista Crítica de Derecho Inmobiliario, núm. 772, noviembrediciembre 2010. 
MORETón SANZ, M. F.: "Vocación hereditaria, personalidad y criaturas abortivas: la reforma del artículo 30 del código civil e incidencia de la eliminación del requisito de la viabilidad en el régimen de la capacidad de suceder por testamento o abintestato", Revista crítica de Derecho Inmobiliario, núm. 728, noviembre 2011.

Moreu BallongA, J. L.: "El apéndice foral aragonés de 1925 y encrucijadas del Derecho civil y de la cuestión territorial en España”, Ius fugit: Revista Interdisciplinar de Estudios Histórico-Jurídicos, núm. 15, 2007-2008.

MuÑOZ GARCíA M.J.: "Limitaciones a la capacidad de obrar de la mujer casada en el Derecho Histórico Español. Especial referencia a las leyes 54 a 61 del ordenamiento de Toro y a su proyección”, Anuario de la Facultad de Derecho de la Un. de Extremadura, núm. 7, 1989.

MunAR Bernat, P. A.: "La legítima en el Derecho civil de la Islas Baleares", en Tratado de legítimas, (Coord.T. F. Torres García), Atelier, Barcelona, 2012.

Munar Bernat, P.A., Verdera Izquierdo, B., Hualde Manso, T., AA VV "Reservas hereditarias" en Tratado de Derecho de Sucesiones (Código Civil y normativa civil autonómica: Aragón, Baleares, Cataluña, Galicia, Navarra, País Vasco), tomo II, Civitas, Pamplona, 2011.

NAGORE YÁRnOZ, J.J.: “Capítulo II. De la legítima Ley 271 Ley 271” en AAVV., Comentarios al Código civil, Edersa, Madrid. 2005.

Nieto PozAnco, M y RoviRA DEL Río.: "Consecuencias legales de la infidelidad en el derecho español: una aproximación jurisprudencial." Revista Via Iuris, 16, 2014.

NúÑEZ MuÑIZ, M. C.: "El usufructo universal y el legado de usufructo universal: análisis particular del ejercicio y titularidad de la acción de desahucio", Revista Crítica de Derecho Inmobiliario, núm. 747, enero, 2015.

NúÑEZ MuÑIZ, M. C.: "De nuevo las legítimas en el código civil español y novedades del Código civil brasileño”, Revista Crítica de Derecho Inmobiliario, núm. 762, julio 2017.

NuÑEZ NuÑEZ, M.: La Sucesión intestada de los parientes colaterales, Dykinson, Madrid 2008.

NUÑEZ NuÑEZ, M.: "Reglas del código civil y legislaciones forales sobre la sucesión intestada de los parientes colaterales", en La sucesión intestada de los parientes colaterales, Dykinson, Madrid, 2008. 
O'Callaghan MuÑoz, X.: "Legitima en los derechos forales" en Compendio de Derecho Civil. Tomo 5 (Derecho de sucesiones), Edersa, Madrid 2004.

O'Callaghan Muñoz, X.: Compendio de Derecho Civil. Tomo 5, Edersa, Madrid, 2004.

O'Callaghan Muñoz, X.: "La reserva lineal" en Compendio de Derecho Civil. (Derecho de sucesiones), Tomo 5, Edesa, Madrid, 2004.

OchoA MARco, R. y Sebastián ChenA, M.S.: La herencia: análisis práctico de los problemas y procesales del Derecho de sucesiones, $7^{\text {a }}$ EDISOFER S.L., Madrid, 2017.

Olis RobledA, S. J.: "La nulidad del acto jurídico" Gregorian Biblical BookShop. Anuario de Filosofía del Derecho (Ref.: ANU-F-1964-10042200424) 1964-1965.

ORRIOls Garcia, S.: Principios y garantías procesales, Bosch, Barcelona, 2013.

Ortega Pardo, G.: "Heredero testamentario y heredero forzoso" Anuario de derecho civil, vol. 3, núm. 2, 1950.

Ortega Pardo, G.: "Heredero testamentario y heredero forzoso ", Anuario de Derecho Civil, Vol. 3, núm. 2, 1950.

OrtuÑo PÉREZ, M. E.: “Limitación de la capacidad de testar", en Contribuciones al Derecho romano de sucesiones y donaciones, Dykinson, Madrid, 2015.

ORTUÑo PÉREZ, M. E.: Contribuciones al derecho romano de sucesiones y donaciones Dykinson, 2015.

Otero VARElA, A.: "la patria potestad en el Derecho histórico español”, Dialnet, núm. 26, 1956.

Otero VARElA. A.: "La mejora del nieto", Anuario de história del Derecho español, núm. 31, 1961.

PAdOVIni, F.: Rapporto Contractuale e successione per causa di morte, Dott. A. Giuffrè Editore, S.p.A., Milano, 1990.

PARRA LUCÁN, M.A, "Legítimas, libertad de testar y transmisión de un patrimonio", Anuario da Facultade de Dereito da Universidade da Coruña, núm. 13, 2009.

PARra lucán, M.A., BARrio GALlardo, A.: "La Legítima en el Derecho aragonés". En Tratado de legítimas, (coord. T. F. Torres García) Atelier, Barcelona, 2012. 
Pene VidARI, F.: La successione neccessaria en trattato di Diritto Civile, cap. V, (dir. R. Saco), UTET Giuridica, Milano (Italia) 2014.

PÉREZ ESCOLAR, M.: "Sucesión intestada y legítima del cónyuge supérstite en el Código civil español. Revisión de fundamentos y planteamiento de futuro", Anuario de Derecho Civil, 2007.

PÉREZ EsCOLAR, M.: "El cónyuge heredero legal”, en El cónyuge supérstite en la sucesión intestada, Dykinson, 2003.

PÉREZ ESCOLAR, M.: "El cónyuge supérstite como legitimario" en El cónyuge supérstite en la sucesión intestada, Dykinson, Madrid, 2005.

PERIS RIVERA, A.L.: "Desheredación: una visión comparada”, Actualidad Jurídica Iberoamericana, núm. 4, febrero 2016.

Peset Reig, M.: “Análisis y Concordancias del Proyecto de Código Civil de 1821”, Anuario de Derecho Civil, Vol. 28, 1975.

PEÑA BeRnAldo De QUIRÓs, M.: "La naturaleza de la legítima", Anuario de Derecho civil, vol. 38, núm. 4, 1985.

Planas Bellvé, M.: “Armonización europea del principio de libertad de testar y posición del supérstite” Institut Universitari d'Estudis Europeus, núm. 17, 2011-2012.

Polo Arévalo E. M.: “Concepto y Naturaleza Jurídica de la Legítima en Derecho Sucesorio Español: precedentes y actualidad”, Ridrom, núm. 10, 2013.

PONS SAlva, M.: "El pacto sucesorio mallorquín: La "diffinitio", Revista Jurídica de les Illes Balears, núm. 11, 2013.

Puig Brutau, J.: Fundamentos de Derecho Civil, III, Bochs, Barcelona, 1964

RAGEL SÁNCHEZ, L. F.: Requisitos comunes para la aplicación de la cautela gualdense o socini y del artículo 820.3. ${ }^{\circ}$ del CódigO civil, Dykinson, Madrid, 2004.

RAGEl SÁnChEZ, L.F.: Desde la Cautela Gualdense o Socini y el artículo 820.3. ${ }^{\circ}$ del Código Civil, Dykinson, 2004.

RAGEL SÁNCHEZ, L.F.: "El perdón de conductas ofensivas en la donación y en la sucesión mortis causa", Anuario de la Facultad de Derecho, núm. 16,1998. 
RAGEL SÁNCHEZ, L.F.: Encuadre de la materia a estudiar en la intangibilidad cualitativa de la legítima, en La Cautela Gualdense o Socini y el artículo 820.3. ${ }^{\circ}$ del Código Civil, Dykinson, Madrid 2004.

Rebolledo Varela, A.L.: "La iniciativa legislativa en el Derecho Civil de Galicia", Boletín de la Academia Vasca de Derecho = Zuzenbidearen Euskal Akademiaren aldizkaria, año 10, núm. 21, 2011.

Rentería Arocena A.: "La libertad de testar en Derecho Comparado" Revista Crítica de Derecho Inmobiliario, núm. 726, 2011.

REPRESA Polo, M.P.: La desheredación en el Código civil, Reus, S.A., Madrid, 2016,

RIVAS MARTíneZ, J.J.: Derecho de sucesiones común y foral, tomo II, Vol. I. $4^{\mathrm{a}}$ ed. Dykinson, Madrid, 2009.

RIVAS MARTíNEZ, J.J.: "La legítima de ascendientes y descendientes en las legislaciones forales", en Derecho de sucesiones común y foral, Tomo II, Dykinson, Cap. XVI, Madrid, 2009.

Rivas Martínez, J.J.: Derecho de sucesiones. Común y foral, tomo III, Dykinson, Madrid, 2009.

RocA- SASTRE MuncuniL, L.: Derecho de sucesiones, Tomo I, Bosch, Barcelona, 1989.

RocA - SASTRE MuncuniLl, L.: Derecho de sucesiones, Tomo II, Boch, Barcelona, 1991.

RÓDENAS GÓMEZ, A.: "El principio nemo pro parte testatus pro parte intestatus decedere potest: estudio sobre el origen, evolución y trascendencia en el ordenamiento jurídico actual", Revista de Derecho UNED, núm. 17, 2015.

Rodríguez Montero, R. P.; El Derecho Civil en Galicia, La Ley de Derecho Civil de Galicia y el Futuro Derecho Civil de Galicia: Apuntes, Ideas y Sugerencias" Anuario da Facultade de Dereito da Universidad de la Coruña, 2001.

Romero Coloma, A. M. "El usufructo universal del cónyuge viudo en el derecho sucesorio español: problemática sobre su admisibilidad", Revista de derecho de familia: Doctrina, Jurisprudencia, Legislación, núm. 58, 2014.

Romero ColOMA, A.M.: "la infidelidad conyugal como causa de separación: análisis y valoración”, Revista Crítica de Derecho Inmobiliario, núm. 670, marzo-abril, 2002. 
Romero Coloma, A. M.: "La prohibición de intervención judicial en los testamentos", $E l$ Notario del Siglo XXI, núm. 58, 2014.

Roncesvalles Barber CÁrCAmo, M.:"LEY 301" en AAVV., Comentarios al Codigo Civil, Tomo XXXVII , Vol. 2º Leyes 253 a 345 de la Compilación o Fuero Nuevo de Navarra, Edersa, Madrid 2005.

RuIZ-Rico RuIZ-Morón, J.: "Lesión de la legítima” en AAVV., Curso de Derecho Civil IV, Derecho de Familia y Sucesiones, 4ª ed., Tiran Lo Blanch, Valencia, 2009.

Sahagún de la Marfa y de Quintana J.: Curso de Ampliación de Derecho Civil Español, Imprenta Hispana de Vicente Castaños, 1857.

SÁnchez Calero, F., Moreno Quesada, B., González Porras J. M., AA VV.: Curso de Derecho civil IV. Derecho de familia y sucesiones, $5^{\text {a }}$ ed, Tirant lo Blanch, Valencia, 2009.

SÁNCHEZ Román, F.: La Codificación Civil en España, Sucesores de Rivadeneira. Impresores de la Real Casa. Madrid, 1820.

SÁNCHEZ-VENTURA MoRER, I.: "Limitación de la responsabilidad a los bienes de la herencia por una de las deudas que conforma el haber hereditario" Revista Crítica de Derecho Inmobiliario, núm. 757, 2016.

SAn Segundo Manuel, T.: "La Legítima los conceptos de computación, atribución, imputación y colación. La acción de suplemento en la jurisprudencia del Tribunal Supremo", Revista Crítica de Derecho Inmobiliario, núm. 707, 2008.

SAn Segundo Manuel, T.: Intangibilidad de la legítima, infracción por acto dispositivo del causante a través de una simulación de compraventa civil, Revista Crítico de Derecho Inmobiliario, núm. 701, mayo 2007.

SARRIÓN GUALDA, J.: "El testamento por comisario en los comentaristas de las Leyes de Toro y en los formularios notariales", Anuario de historia del derecho español, núm. 75, 2005.

SERRANo FERnÁndez, M.: "La sucesión forzosa", en Derecho de sucesiones, (coords J. P. Pérez Velázquez y E. Pizarro Moreno), 2ª ed, Tirant lo Blanch, Valencia, 2017.

SERRANO GARCÍA, J.A.: "La legítima en Aragón”, Revista de derecho civil aragonés, núm. 16, 2010. 
SIMEÓN PÉREZ M.: "La legítima en el Código Civil ruso. Un análisis histórico y comparado", InDret, Barcelona, 2016.

SuAU CoT, V. J.: La libertad de testar y sus límites. Hacia una reforma de las asignaciones forzosas, repositorio.uchile.cl/../La-libertad-de-testar-y-sus-límites-haci.. 2015. Fecha de acceso: 12-12-2015.

Torres García, T. F. y Dominguez Luelmo, A.: "La legítima en el Código civil (II)", en Tratado de légítimas. (coord. T. F. Torres García), Atelier, Barcelona, 2012.

Torres GarcíA, T. F. y Dominguez Luelmo, A.: “La legítima en el Código civil (I)”, en Tratado de légítimas. (coord. T. F. Torres García), Atelier, Barcelona, 2012.

TORRES GARCIA T. F. Y GARCIA RUBIO, M.P.: La libertad de testar: El principio de igualdad de la persona y el libre desarrollo de la personalidad en el Derecho de sucesiones, Fundación Coloquio Jurídico Europeo, Madrid, 2014.

VAliño ARCos, A.: La aemulatio en el Derecho romano, Instituto de História del Derecho, Santiago de Chile, 2002.

VAllet DE Goytisolo J.B.: "Observaciones en torno a la Naturaleza de la Legítima", a propósito de un trabajo de Manuel Peña Bernaldo de Quirós”, Anuario de Derecho civil, 1986.

VAllet De Goytisolo, J.B.: “Apuntes de Derecho Sucesorio III”: Atribución de la legítima a actos intervivos, ”Anuario de Derecho Civil, núm. 4, 1954.

VAllet de Goytisolo, J. B.: “ La legítima en el Derecho Foral de Vizcaya” Estudios de Deusto: revista de la Universidad de Deusto, Vol. 41, núm.1, 1993.

VAllet de Goytisolo, J. B.: Comentarios al código civil y compilaciones forales (dir. M. Albadalejo), Tomo, XI, $2^{\text {a }}$ ed., Edersa, Madrid, 1982.

VAllet DE Goytisolo, J. B.: "Significado Jurídico-Social de las Legítimas y de la Libertad de Testar” Anuario de Derecho Civil, 1966. (Ref.: ANU-C-1966-10000300044 )

VAQUER Aloy, A.: "Libertad de testar y condiciones testamentarias", Indret, núm. 3, julio 2105.

VAQUer Aloy, A.: "Reflexiones sobre una eventual reforma de la legítima” InDret, núm. 3, 2007. 
VAquer, Aloy, A.: "Libertad de disponer y testador vulnerable". Duke Journal of Comparative \& International Law, 2008. Fecha de acceso: 24-10-2015.

VAquer, Aloy, A.: "La legitima en el derecho civil de Cataluña" en tratados de legitimas (Coor. T. F.Torres ), Atelier libros, Barcelona, 2012.

VAQUeR Aloy, A.: "La protección del testador vulnerable", Anuario de Derecho Civil, núm. Lxviii-Ii, abril 2015.

VÁZQuez IRUZuBieTA, C.: “Artículo 806, Cc.”, en Código civil comentado, vLex, Barcelona 2016.

VÁzQuez IruzubietA, C.: Artículo 1009, Cc., en Código civil comentado, vLex, Barcelona 2016.

VÁzQuez IRuZuBIETA, C.: Código civil comentado, vLex, Madrid, 2016.

VERDERA IZQUIERDO, B.:"El régimen de colación de gastos en el código civil”, Revista Crítica de Derecho Inmobiliario, núm. 709, octubre 2008.

VILA RiBES, C.: "La legítima en el Derecho civil de las Islas Baleares", en Tratado de legítimas, (Coord.T. F. Torres García), Atelier, Barcelona, 2012.

VIVAS-TESÓN, I.: “Intangibilidad cuantitativa de la legítima y preterición testamentaria: revisión crítica de las cuestiones controvertidas en materia de preterición, sus clases y efectos”, Revista Crítica de Derecho Inmobiliario, núm. 742, marzo 2014.

VIVAS TESÓN, I.: “Aceptación y repudiación de la herencia tras la ley de jurisdicción voluntaria”, Revista Crítica de Derecho Inmobiliario, núm. 758, noviembre, 2016

YBARRA BORES, A.: "La sucesión mortis causa de ciudadanos ingleses residentes en España: problemas y nuevas perspectivas", en Cuadernos de Derecho transnacional, Vol 1, núm 1, marzo 2015.

ZaCARÍA, Alessio.: Perfiles del Derecho Italiano de Sucesiones, Bosch, Barcelona, 2008. 
TABLA DE JURISPRUDENCIA

\section{Tribunal Supremo:}

STS de 19/12/1903 (Tol. 5.063.049) STS de 04/11/1904 (Tol. 5.854.897) STS de 23/04/1932 (Tol. 5.028.091) STS de 02/01/1946 (Tol. 609/1946) STS de 28/02/1947 (Tol.4.452.460) STS de 27/10/1950 (RJ 1950\1534) STS de 15/05/1955 (Tol. 4.381.440) STS de 23/01/1959 (Tol. 4.348.959) STS de 02/06/1959 (RJ 2922) STS de 31/10/1964 (RJ 1964\4860) STS de 01/07/1969 (RJ 1969\3824) STS de 24/10/1972 (Tol. 4.262.002) STS de 08/09/1973 (Roj. 1973/4111) STS de 07/03 1980 (RJ 1980\1558) STS de 15/06/1982 (Tol. 1.739.290) STS de 18/06/1982 (Tol. 1.739.425) STS de 21/04/1990 (RJ 1990\2762) STS de 23/07/1990 (Tol. 1.730.741) STS de 12/11/1990 (RJ 1990/8698) STS de 20/11/91 (Tol. 1.728.486) STS de 22/11/1991 (Tol. 1.728.561) STS 24/11/1992 (Tol. 5.122.947)

STS de 28/06/1993 (Tol. 5.126.920) STS de 12/07/1996( Tol. 1.658.936) STS de 17/07/1996 (Tol. 216.987). STS de 26/04/1997(Tol. 5.119.575) STS de 25-10/2000 (RJ 2000\8549) STS 17/01/2001 (Tol. 63.745) STS de 23/01/2001 (Tol. 4.964.722) STS de 15/02/2001, (Tol. 4.964.708) STS de 03/12/2001 (Tol. 4.924.412) STS de 09/07/2002, (Tol. 4.975.828) STS de 26/07/2002 (Tol. 595.971) STS de 13/02/2003 (RJ 2003\1017) STS 16/07/2003 (Roj: STS 5087/2003) STS de 07/10/2004 (Tol. 514.224) STS de 12/05/2005 (RJ 2005\3994) STS de 10/06/2005 (Tol. 667.463) 
STS de 13/07/2005 (Tol. 703.303)

STS de 28/08/2005 (RJ 2005\7154)

STS de 12/09/2005 (Tol. 725.211)

STS de 28/09/2005 (RJ 2005\7154)

STS de 22/02/2006 (Tol. 843.360)

STS de 23/02/2006 (RJ 20061909)

STS de 26/02/2006 (Tol. 2.592.138)

STS de 29/05/2006 (RJ 200613343)

STS de $22 / 06 / 2006$ (RJ 200613082)

STS de 07/11/2006 (Tol. 1.022.988)

STS de 13/03/2008 (Tol.1.297.095)

STS de 05/06/2008 (Tol. 1.333.399)

STS de 13/072009 (RJ 2009\4465)

STS de 05/11/2009 (Tol. 1.748.175)

STS de $08 / 10 / 2010$ ( RJ $2010 / 7449$ )

STS de 31/05/2010 (RJ 2010/2653)

STS de 28/01/2011 (RJ 2011।301)

STS de 29/07/2011 (Tol. 2.635.443)

STS e 29/07/2011 (Tol. 2.238.301)

STS de 20/10/2011, (RJ 2012\426)

STS de 21/11/2011 (Tol. 2.299)

STS de 23/12/2011 (RJ 2012l301)

STS 25/9/2012 (RJ 2013\2269)

STS de 18/07/2012 ( RJ 201218364)

STS de 26/06/2012 (Tol. 2.673.860)

STS de 20/07/2012 (Tol. 2.654.655)

STS de 29/07/2013 (RJ 201316395)

STS de 19/02/2014 (RJ 2015\1400)

STS de 28/04/2014, (Tol. 4.365.031)

STS de 03/06/2014 (Roj: 2484/2014)

STS de 10/06/2014 (Tol. 4.374.205)

STS de 03/09/2014 (Tol. 4.521.095)

STS de 28/10/2014 (Tol. 4.561.606)

STS de 10/12/2014 (Tol. 4.748.252)

STS de 30/01/2015 (Roj: STS 565/2015)

STS 21/04/2015 (Tol. 4988.929)

STS de 19/05/2015 (RJ 2015 \2451)

STS de 23/06/2015 (RJ 2015/2547)

STS de 15/09/2015 (Tol. 5.583.589)

STS de $30 / 12 / 2015$ (Tol. 4.748.346)

STS de 09/02/2016, (Roj: STS 407/2016)

STS de 02/03/2016 (Tol.5.656.949)

STS de 08/04/2016 (Tol. 5.687.871)

STS de 16/04/2016 (RJ 20161844) 
STS de 06/06/1016 (RJ 201612337)

STS de 07/07/2016, (Tol. 5.775.242)

STS de 23/04/2018 (RJ 201811753)

\section{Audiencia Provincial}

SAP de Álava (S. $1^{\text {a }}$ ) de 23/08/1992 (AC 1992\1318)

SAP de Oviedo (S. $1^{\text {a }}$ ) de 29/02/1996

SAP de Granada (S. 4) de 27/04/1999 (AC 19991817)

SAP de Málaga, (S. 4a) de 12 /11/1999 (AC 1999\2595)

SAP de Baleares (S 3 $3^{\mathrm{a}}$ ) de 21/02/2001, (AC 2002 446 )

SAP de Les Illes Balears, (S. $3^{\mathrm{a}}$ ) de 21/02/2001(Tol. 69.105)

SAP de Madrid (S. 20a) de 3/12/2001 (JUR 2002\120360)

SAP de Guipúzcoa ( S. 2a) de 15/02/2002 (JUR 2002\219208)

SAP de Vizcaya (S. 4) de 04/12/2002 (JUR 2003192270)

SAP de Cantabria (S. $3^{\circ}$ ) de 25/08/2003 (AC 2003\1949)

SAP de la Coruña (S. 1 $1^{\text {a }}$ ) de 30/08/2003 (AC 2003\1952)

SAP de las Islas Baleares (S.5) de 29/12/2003 (AC 2004/350)

SAP de Murcia (S. $2^{\mathrm{a}}$ ) de 4/02/2005 (JUR 2006/68577)

SAP de Guipúzcoa (S. $3^{\mathrm{a}}$ ) de 10/05/2005 ( JUR 2005\194235)

SAP de Guipúzcoa (S. 3ª) de 07/04/2006 (JUR 2015\57262)

SAP de Barcelona (S. 16) de 04/05/2006 (Tol. 1.009.895).

SAP de Alicante (S. 6 ${ }^{a}$ ) de 04/06/2006 (Tol. 1.274.472)

SAP de Albacete (S. 1a) de 14/06/2006 (Tol. 992.740)

SAP de Valencia (S. 7a) de 19/06/2006 (Tol. 1009.442)

SAP de Burgos (S. 2) de 11/12/2016 (AC 2007\1050)

SAP de Palencia (S. 1 ${ }^{\mathrm{a}}$ ) de 05/11/2007 (AC 20081444)

SAP de Pontevedra (S. 3a) de 13/12/2007(JUR 2008171998)

SAP de Madrid (S. 21) de 27/03/2007 (Tol. 1.907.529)

SAP de Madrid (S. 11) de 27/04/2007 (JUR 2007/210923)

SAP de Murcia (S. 4) de 31/10/2008 (AC 2009/829)

SAP de Cádiz (S. 5) de 28/01/2009 (JUR 2009\156817)

SAP de Zaragoza (S. 4a) de 25/02/2009 (Tol. 1.495.016)

SAP de Las Palmas (S.5) de 28/04/2009 (JUR 2014\147032)

SAP de Madrid (S. 14ª) de 14/07/2009 (Tol. 1.640.320)

SAP de Alicante de (S.6 ${ }^{\mathrm{a}}$ ) de 22/09/2010 (AC 201011868)

SAP de Zaragoza (S. 4 ${ }^{\mathrm{a}}$ ) de 09/11/2010 (Tol. 2.029.598)

SAP de Baleares (S. 5 ${ }^{\text {a }}$ ) de 04/01/2011 (Tol. 2.072.638)

SAP de Zaragoza (S. 4a) de 25/02/2011 (Tol. 2.161.731)

SAP de las Palmas (S. 5) de 28/07/2011 (JUR 2011 \6661)

SAP de Ciudad Real de 03/09/2011 (Tol.2.255.671)

SAP de Santander (S. 2a) de 28/11/2011 (Tol. 2.733.453) 
SAP de Valencia, (S. 11) de 31/05/2012 (AC 2012\1069)

SAP de Baleares (S. 5 ${ }^{\text {a }}$ ) de 09/07/2012 (Tol. 2.617.510)

SAP de Barcelona (S. 13) de 5/12/2012 (AC 2013\2387)

SAP de Jaen (S. 2a) de 08/02/2013 (JUR 2013\188552)

SAP de la Rioja (S. 1 ${ }^{\text {a) }}$ ) de 12/03/2013 (JUR 2013\171765)

SAP de Barcelona (S 1 ${ }^{\text {a }}$ ) de 28/03/2013, (JUR 2003\199937)

SAP de Castellón, (S. ${ }^{\circ}$ ) de 31/05/2013 (JUR 2013 267723)

SAP de La Coruña (S. 6 ${ }^{\text {a }}$ ) de 16/07/2013 (Tol. 3.921.688)

SAP de Baleares (S. 4 ${ }^{\text {a }}$ ) de 15/10/2013 (Tol. 3.990.754)

SAP de Vizcaya (S. 3 ${ }^{\text {a }}$ ) de 19/12/2013 (Tol. 4.315.545)

SAP de Castellón (S. 3 ${ }^{\text {a }}$ de 12/02/2014 (JUR 2014\119873)

SAP de Las Palmas (S. 5) de 31/03/2014 (JUR 2014\147032)

SAP de Barcelona (S. 1 ${ }^{\text {a }}$ ) de 29/04/2014 (Tol. 4.374.667)

SAP de Zaragoza (S. 4 ${ }^{a}$ ) de 27/05/2014 (JUR 2014\180455)

SAP de Zaragoza (S. 5 $5^{\text {) }}$ de 27/06/2014 (AC 2014\1144)

SAP de Málaga (S. 5 ) de 14/10/2014 (AC 2014\2380)

SAP de Barcelona (S. 1 ${ }^{\text {a }}$ ) de 25/11/2014 (JUR 2015\55961)

SAP de la Coruña, de 04/12/2014 (Tol. 4.746.336)

SAP de La Coruña (S. 6 ${ }^{a}$ ) de 31/03/2015 (Tol. 4.948.043)

SAP de Gerona (S. 1 ${ }^{\text {a }}$ ) de 14/05/2015 (Tol. 5.187.109)

SAP de Huesca de 20/11/2015 (AC 2015/1703)

SAP de Madrid (S. 19) de 14/12/2015 (AC 2015\1715)

SAP de Santa Cruz de Tenerife (S. 4 ) de 14/12/2015 (AC 20161383)

SAP de Badajoz (S. 3 ${ }^{\text {a }}$ ) de 04 /02 /2016, (JUR 2016139324)

SAP de Valencia (S.6) de 19/02/2016 (JUR 2016\145993)

SAP de Valencia (S. 8 ${ }^{\text {a }}$ ) de 29/02/2016 (Tol. 5.768.669)

SAP de La Coruña (S. 6 ${ }^{a}$ ) de 31/03/2016 (Tol. 5.733.157)

SAP de La Coruña (S. 6 ${ }^{a}$ ) de 15/04/2016 (Tol. 5.733.055)

SAP de Oviedo (S. 6a) de 09/05/2016 (Tol. 5.737.348)

SAP de Zaragoza, (S. 5 ${ }^{\text {a }}$ de 18/05/2016 (Tol. 6.028.028)

SAP de Barcelona (S.17) de 25/05/2016 (AC 2016\1671)

SAP de A Coruña (S. 4 ${ }^{\mathrm{a}}$ ) de 17/06/2016, (JUR $2016 \backslash 183848$ )

SAP de Álava de 27/06/2016 (JUR 2016\192970)

SAP de Zaragoza (S. 5 ${ }^{\text {a }}$ ) de 12/07/2016 (Tol. 5.825.734)

SAP de Navarra (S. $3^{\text {a }}$ ) de 28/07/2016 (Tol. 5.940.978)

SAP de Orense (S. 1 ${ }^{\text {a }}$ ) de 29/07/2016 (JUR 2016 208447)

SAP de Zaragoza (S. 2 ${ }^{\mathrm{a}}$ ) de 12/07/2016 (Tol. 5.825.734)

SAP de Navarra (S. 3 ${ }^{a}$ ) de 28/07/2016 (Tol. 5.940.978)

SAP de Almería (S. 1 ${ }^{\text {a }}$ ) de 11/10/2016 (JUR 2017\87413)

SAP de las Islas Baleares (S.5) de 12 /12/2016 (AC 2017\164)

SAP de Albacete (S. 1 ${ }^{a}$ ) de 01/02/2017 (JUR 2017\67928)

SAP de Gerona (S. 2a) de 20/02/2017 (Tol. 6.186.103)

SAP de Oviedo (S. 6 ${ }^{\text {a }}$ ) de 24/02/2017 (Tol. 6.026.817)

SAP de Orense (S. ${ }^{\text {a }}$ ) de 02/03/2017 (Tol. 6.086.793) 
SAP de Barcelona (S. 4 ${ }^{\mathrm{a}}$ ) de 25/04/2017 (Tol. 6.414892)

SAP de Barcelona (S. 19ª) de 12/10/2017 (JUR 2017 293914)

SAP de la Coruña (S. 5 ${ }^{\text {a }}$ de 13/10/2017 (AC 2017\1530)

SAP de Barcelona (S. 19) de 6/11/2017 (JUR 2017\292770)

SAP de Baleares (S. 4 ${ }^{\mathrm{a}}$ ) de 16/11/2017 (Tol. 6.493.190)

SAP de Barcelona (S. 17) de 17/11/2017 (Tol. 6.485.599)

SAP de Guipúzcoa (S. 2ª ) de 01/12/2017 (Tol. 6.533.403)

\section{Tribunal Superior de Justicia}

STSJ de Navarra de 25/11/2002 (RJ\2003\2210)

STSJ del País Vasco 02/06/2004, Tol. 48.04.2-01/037363

STSJ de Navarra de 04/04/2006 (Tol. 946.211)

STSJ de Aragón de 30/01/2008 (Roj: STSJ AR 2/2008)

STSJ de Navarra de 01/12/2008 (RJ 2009\1454)

STSJ de Navarra de 29/01/2009 (Tol. 1.509.393)

STSJ de Cataluña de 21/05/2010 (RJ 2010\5129)

STSJ de Aragón de 22/09/2011 (RJ: 2012/3073)

STSJ Illes Balears de 24/10/2012 ( Tol. 2.707.910)

STSJ de Cataluña de 04/03/3013 (Tol. 3.752.625)

STSJ de Baleares de 05/06/2014, (Tol. 4.424.457)

STSJ de Navarra de 09/09/2014 (RJ 2014/5741)

STSJ de Cataluña 18/12/2014 (Roj: STSJ CAT 12148/2014)

STSJ de Cataluña de 13/06/2015; Roj. 4535/2016

STSJ de Cataluña de 25/02/2016 (Tol. 5.685.918)

STSJ de Cataluña de 28/07/2016 (Roj: STSJ CAT 6068:2016)

STSJ de Navarra de 01/09/2016 (RJ 201615499)

STSJ de Galicia de 26/01/2017 (Tol. 5.998.345)

STSJ de Cataluña 02/02/2017 (Roj: STSJ CAT 494:2017)

STSJ de Aragón de 20/02/2017 (RJ 2017\1740)

4. Dirección General de los Registros y del Notariado

RDGRN de 25/02/2008 (RJ 2008, 2791)

RDGRN de 17/10/ 2008 (RJ 2009\637)

RDGRN de 4/09/2012 (RJ 2012\10396)

RDGRN de 21/01/2013 (RJ 2013।8264)

RDGRN de 15/09/2014 (RJ 2014\4742)

RDGRN de 22/06/2015 (RJ 2015\3733) 
RDGRN de 9/06/2015 (RJ 2015 3619)

RDGRN de 13/06/2016 (RJ 201614994)

RDGRN de 18/07/2016 (RJ 201614601)

RDGRN de 04/04/2017 (RJ 2017\1406)

RDGRN de 12/06/2017 (RJ 2017/3257) 